UNIVERSIDADE DE SÃO PAULO

FACULDADE DE FILOSOFIA, LETRAS E CIÊNCIAS HUMANAS

DEPARTAMENTO DE LETRAS MODERNAS

PROGRAMA DE PÓS-GRADUAÇÃO EM ESTUDOS DA TRADUÇÃO

SABRINA MATUDA

Futebóis: uma análise do léxico do futebol em português brasileiro e inglês britânico sob a perspectiva da Linguística de Corpus

São Paulo

2015 


$$
\text { UNIVERSIDADE DE SÃO PAULO }
$$

FACULDADE DE FILOSOFIA, LETRAS E CIÊNCIAS HUMANAS

DEPARTAMENTO DE LETRAS MODERNAS

PROGRAMA DE PÓS-GRADUAÇÃO E EM ESTUDOS DA TRADUÇÃO

\section{Futebóis: Uma análise do léxico do futebol em português brasileiro e inglês britânico sob a perspectiva da Linguística de Corpus}

Sabrina Matuda

Tese apresentada ao Programa de PósGraduação em Estudos da Tradução do Departamento de Letras Modernas da Faculdade de Filosofia, Letras e Ciências Humanas da Universidade de São Paulo, para a obtenção do título de Doutora em Letras.

Orientadora: Profa. Dra. Stella Esther Ortweiler Tagnin

São Paulo

2015 
AUTORIZO A REPRODUÇÃO TOTAL OU PARCIAL DESTE TRABALHO, POR QUALQUER MEIO CONVENCIONAL OU ELETRÔNICO, PARA FINS DE ESTUDO OU PESQUISA, DESDE QUE CITADA A FONTE. 


\section{FOLHA DE APROVAÇÃO}

Sabrina Matuda

Futebóis: uma análise do léxico do futebol em português brasileiro e inglês britânico sob a perspectiva da Linguística de Corpus

Tese submetida ao Programa de Pós-Graduação em Estudos da Tradução do Departamento de Letras Modernas da Faculdade de Filosofia, Letras e Ciências Humanas da Universidade de São Paulo para a obtenção do título de Doutora em Letras.

Aprovada em:

Assinatura:

Prof. Dr.:

Instituição: Assinatura:

Prof. Dr.:

Instituição: Assinatura:

Prof. Dr.:

Instituição: Assinatura:

Prof. Dr.:

Instituição: Assinatura: 
Aos meus pais, Hélio e Rita 


\section{AGRADECIMENTOS}

Um agradecimento mais do que especial a minha orientadora, prof ${ }^{a}$. Stella Tagnin, pelo incentivo constante, pela preciosa orientação, pela prontidão para esclarecer dúvidas de última hora, pelas devidas cobranças e pela confiança em mim depositada. Todas as falhas são de minha inteira responsabilidade.

Aos professores João Azenha Jr. e Paola Giustina Baccin, pelas valiosas contribuições no exame de qualificação.

Ao Professor Flávio de Campos, por me abrir horizontes e inspirações.

Aos companheiros do Grupo COMET, Alva, Carmen, Danilo, Elisa, Helmara, Joacyr, Luciana C., Luciana G., Malila, Marlene, Rodrigo e Sandra. Obrigada pelas discussões sempre proveitosas e, é claro, pelos momentos de descontração e comilança.

À Rozane, companheira fiel de congresso, sempre pronta para mais uma aventura acadêmica.

Ao LUDENS (Núcleo Interdisciplinar de Pesquisas sobre Futebol e Modalidades Lúdicas), pelo apoio à pesquisa.

Aos colegas do LUDENS, pela paciência em responder as inúmeras perguntas, muitas vezes bastante óbvias, sobre futebol.

Em especial, gostaria de agradecer aos colegas "do futebol" Tiago Machado e Vanessa Gonçalves, pela consultoria durante toda a pesquisa. 
Aos amigos, pelo incentivo permanente e por entender a ausência.

A minha irmã, Carina, pela amizade e paciência em meus momentos de crise (que não foram poucos!).

Ao meu avô, Milton Cândido da Silva, que, mesmo sem entender muito bem o que fiz nos últimos três anos, me deu força e estímulo para continuar nos momentos mais difíceis.

Ao meu namorado, John, não só por entender minha ausência, no sentido literal da palavra, mas também pelo constante apoio e incentivo. 


\section{AGRADECIMENTOS ESPECIAIS}

Agradeço especialmente à FAPESP (Fundação de Amparo à Pesquisa do Estado de São Paulo) por acreditar em minha pesquisa e me contemplar com a bolsa de estudos de três anos, permitindo dedicação exclusiva à tese durante esse período. 


\section{Sumário}

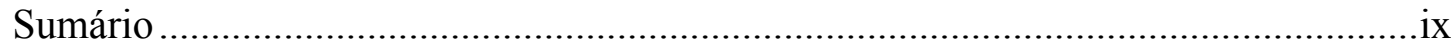

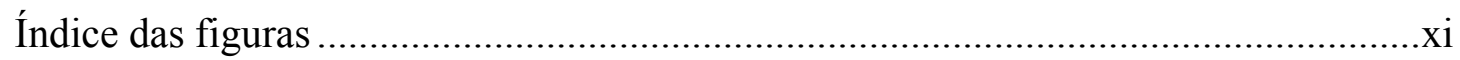

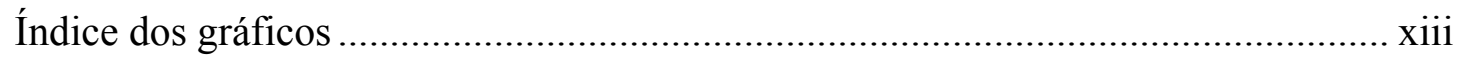

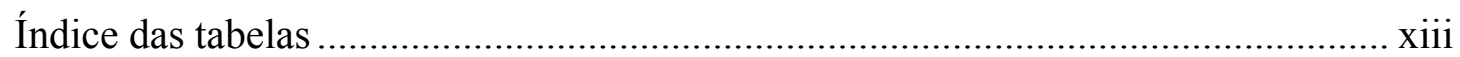

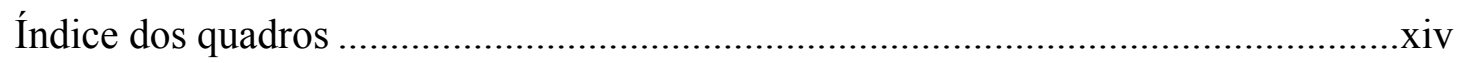

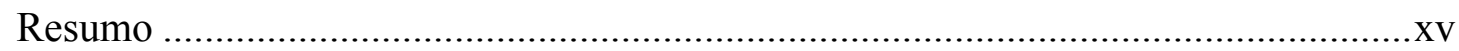

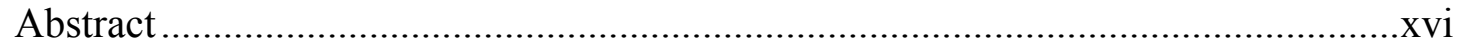

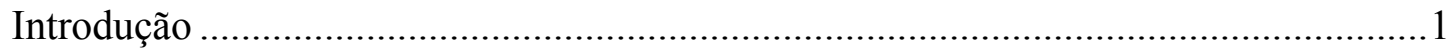

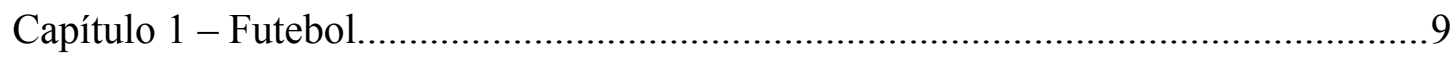

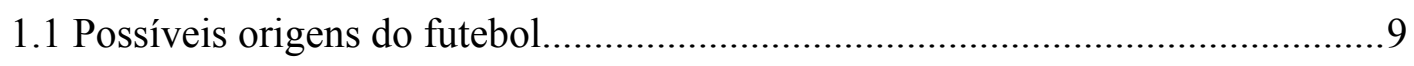

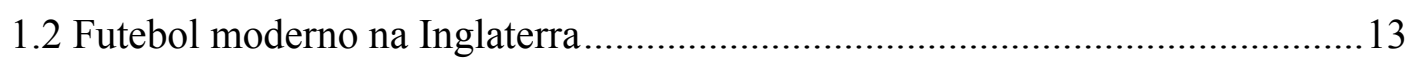

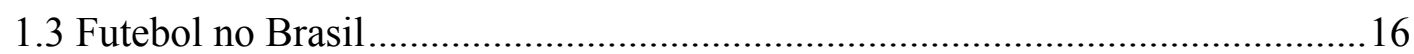

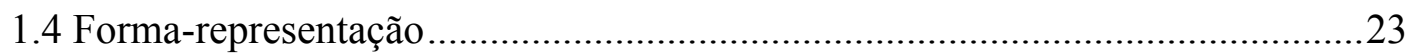

1.4.1 Futebol arte x Futebol força ..................................................................26

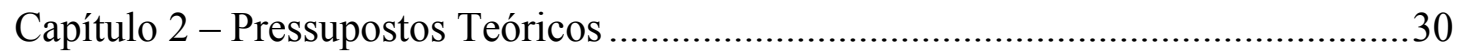

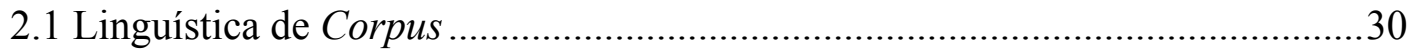

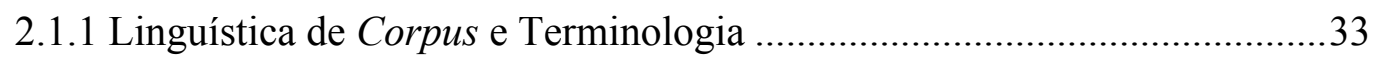

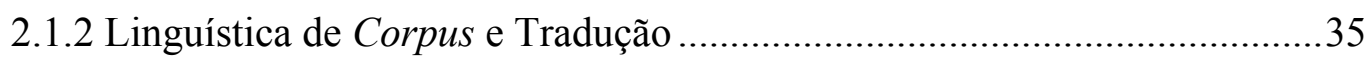

2.1.3 Linguística de Corpus e convencionalidade ..............................................37

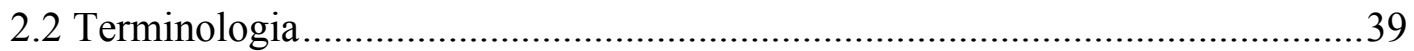

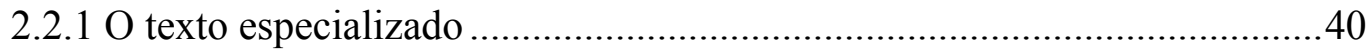

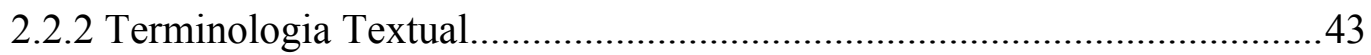

2.2.3 Termos e Combinatórias Léxicas Especializadas .....................................4 44

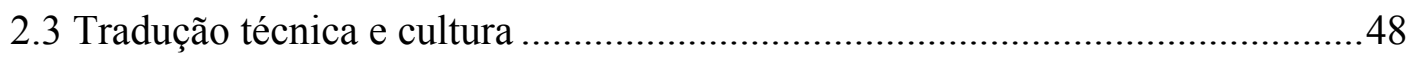

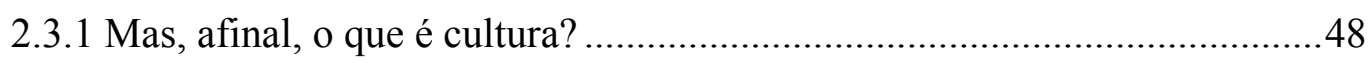

2.3.2 Tradução técnica como condicionante cultural........................................53

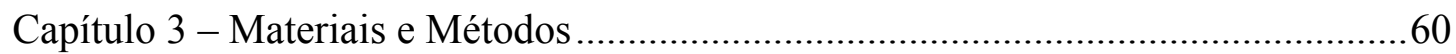

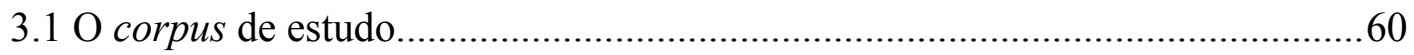

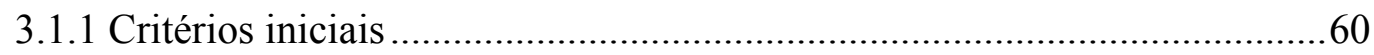

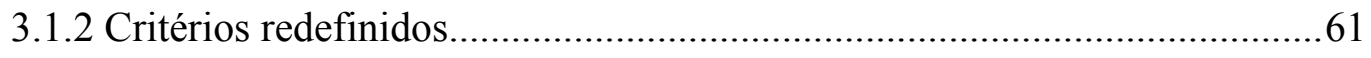

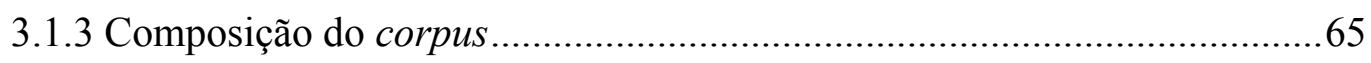

3.1.3.1 Subcorpus em português ................................................................. 71

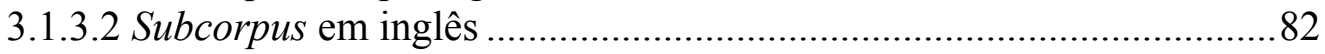

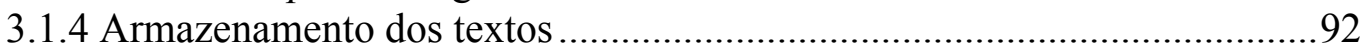

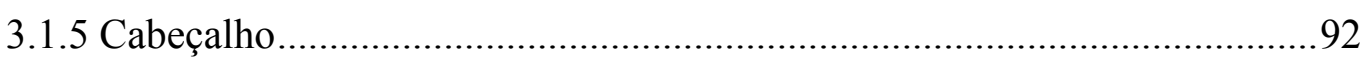

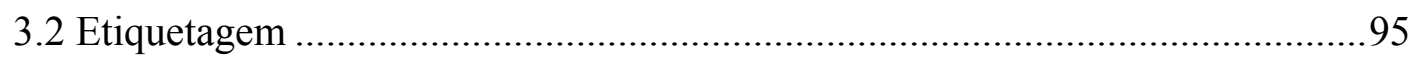




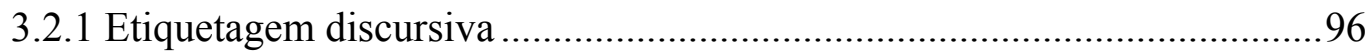

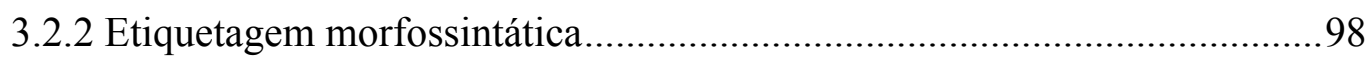

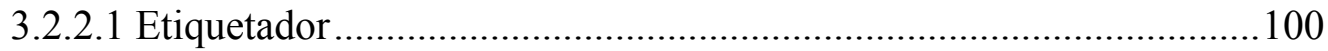

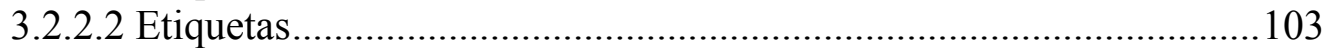

3.2.2.3 Expressões de busca......................................................................104

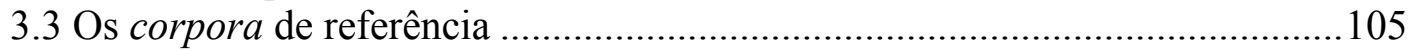

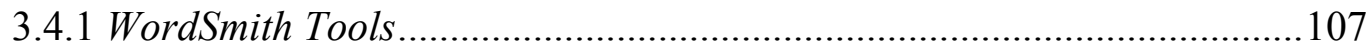

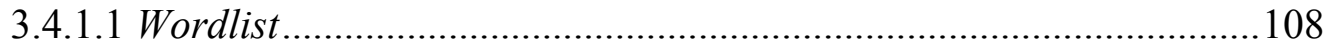

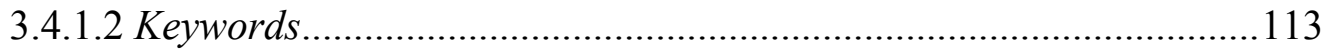

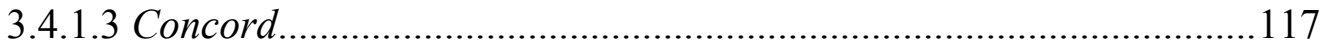

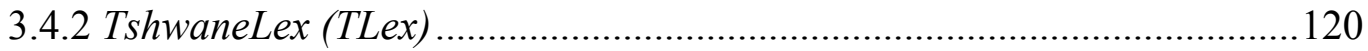

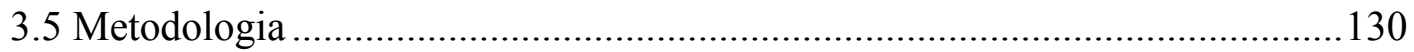

3.5.1 Seleção dos estudos de caso..................................................................131

3.5.2 Compreensão dos significados dos termos ...............................................140

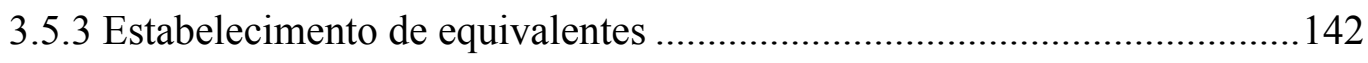

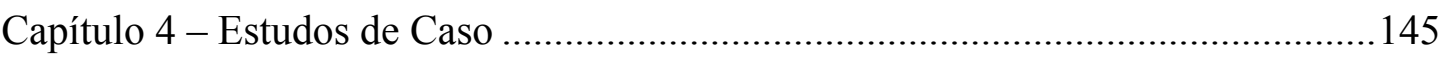

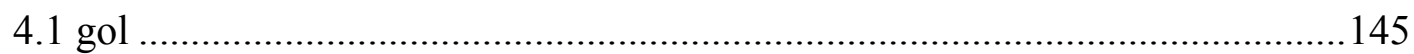

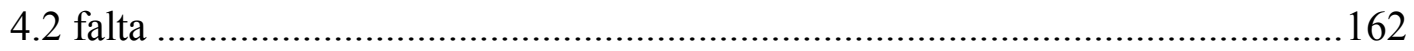

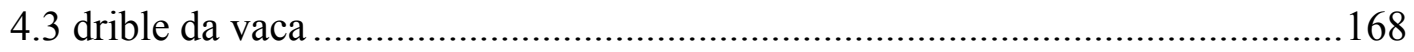

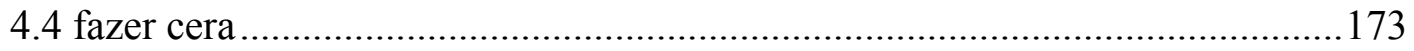

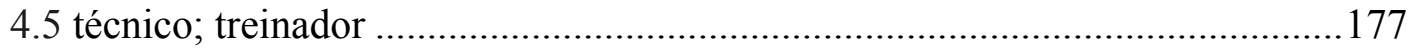

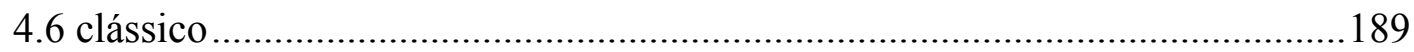

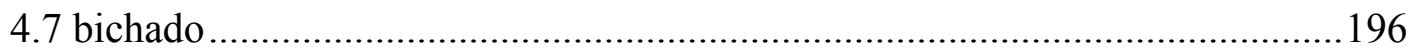

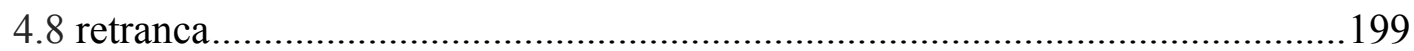

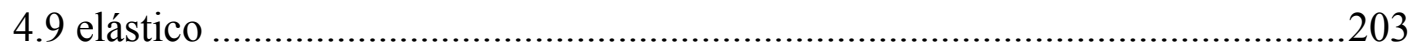

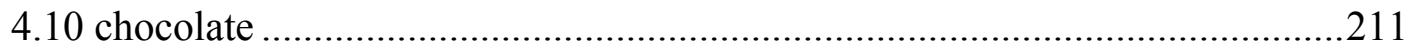

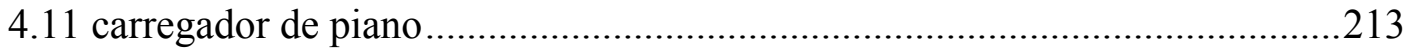

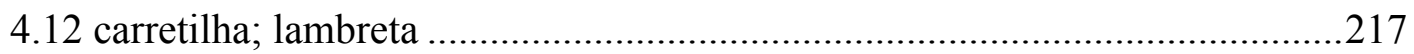

4.13 rolinho; caneta; janelinha; sainha............................................................229

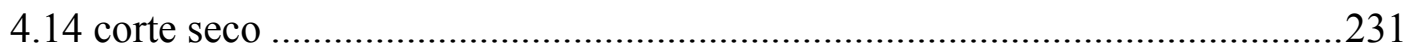

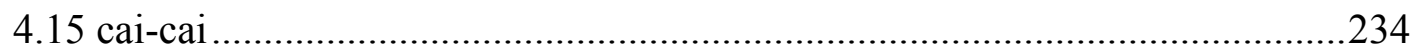

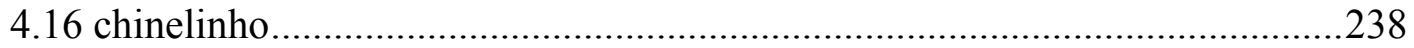

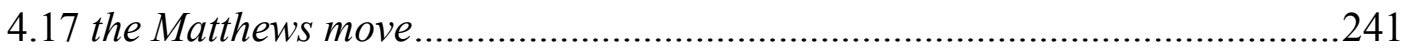

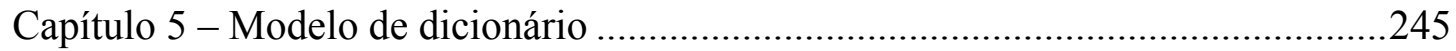

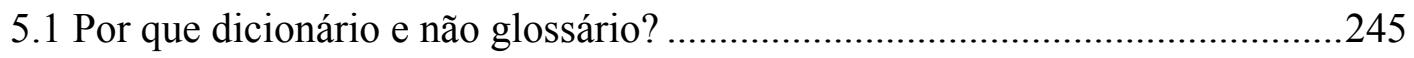

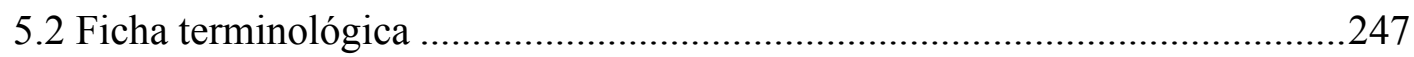

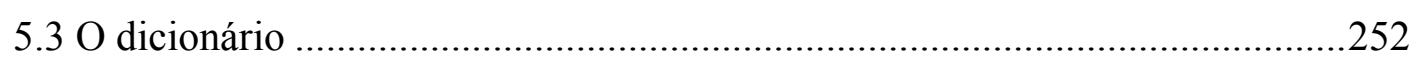

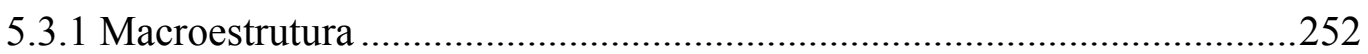




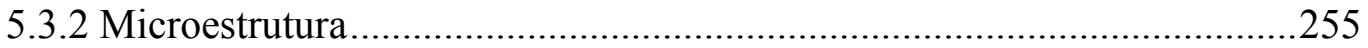

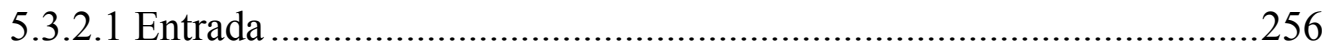

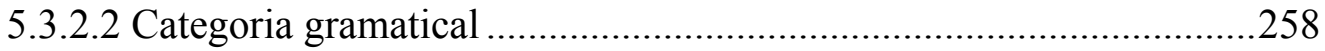

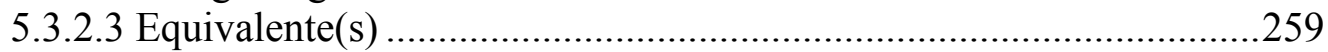

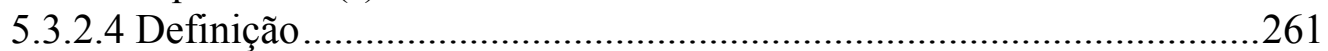

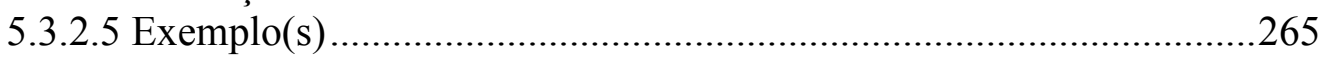

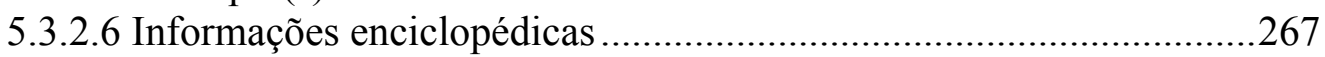

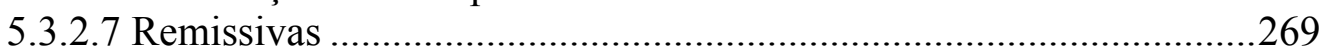

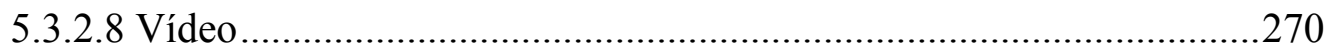

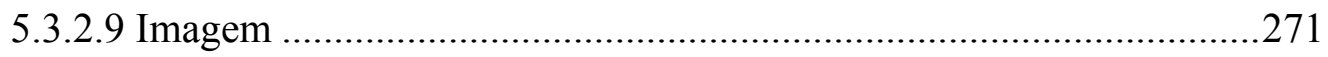

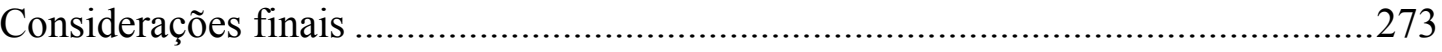

Referências bibliográficas..........................................................................28

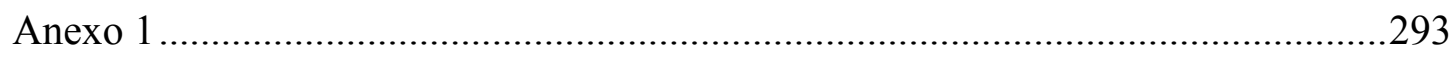

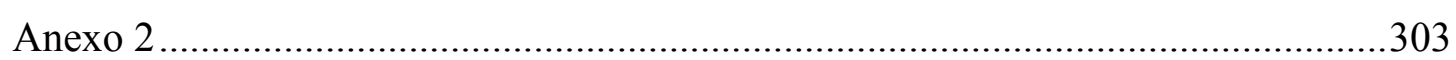

\section{Índice das figuras}

Figura 1: Página do jornal The Guardian sobre o resultado da partida entre o Manchester United e o Liverpool pela Premier League de 2015.

Figura 2: Página do jornal Folha de São Paulo sobre o resultado da partida entre o

Corinthians e o São Paulo pelo campeonato Paulista de 2015.

Figura 3: Página do periódico on-line Lance!Net com resultado de partida (à esquerda) e a descrição da partida (à direita) que ocorreu entre Palmeiras e Corinthians pela $12^{\mathrm{a}}$ rodada do Campeonato Brasileiro de 2014.

Figura 4: Página de RPCIs do jornal Folha de S. Paulo (à direita) e do site do Globo

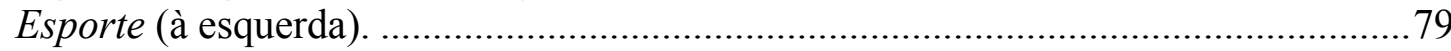

Figura 5: Notícia sobre o resultado de uma partida entre Derby e Nottingham Forest (direita) e a descrição da mesma partida (esquerda); ambas retiradas do site do Jornal

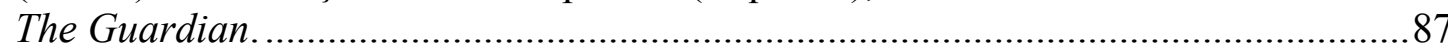

Figura 6: RPCI retirado do jornal The Telegraph (direita) e RPCI retirado do Mail

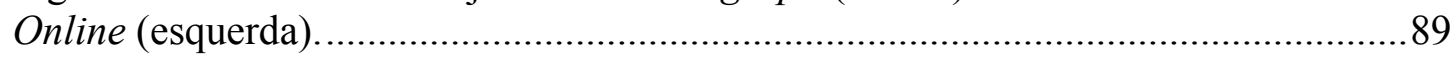

Figura 7: Exemplo de cabeçalho da categoria RP. .................................................94

Figura 8: Etiquetas discursivas criadas para os resultados de partidas, as notícias sobre compra e venda de jogadores e técnicos e as notícias sobre a situação dos times nos

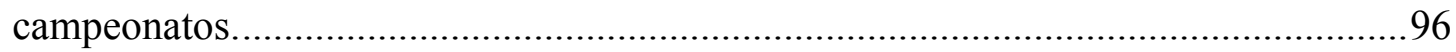

Figura 9: Etiquetas discursivas utilizadas nas descrições de partidas..........................97 Figura 10: Etiquetas discursivas utilizadas nos relatos de partidas com comentários de

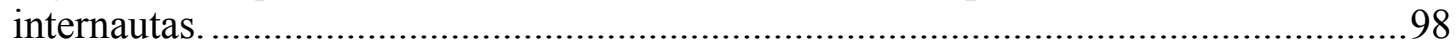
Figura 11: Interface do etiquetador no site web4you (à esquerda) e exemplo de um

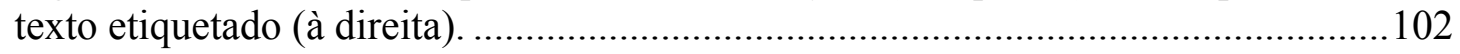

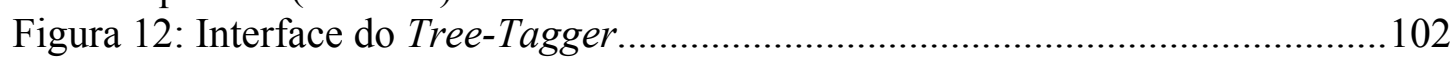

Figura 13: Linhas de concordância da expressão de busca "were VBD be made"....105

Figura 14:Interface do software WordSmith Tools versão 6.0.................................107

Figura 15: Tela de ajuste das funções consideradas para a criação da lista de palavras

do subcorpus de inglês...................................................................................... 109

Figura 16: Ajustes realizados na opção Tags \& Markup das configurações avançadas.

Figura 17: Ajustes realizados para o levantamento das palavras-chave....................116 
Figura 18: Tela de seleção dos corpora.

Figura 19: Seleção das linhas de concordância de goal ordenadas pelas três primeiras

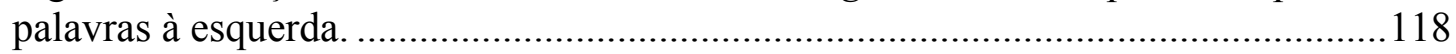

Figura 20: Seleção de clusters de três palavras de goal..........................................120

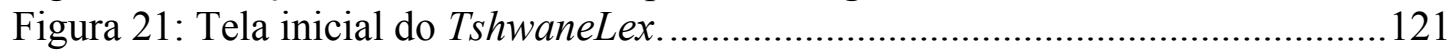

Figura 22: Tela da reversão automática de termos do TLex. ...................................122

Figura 23: Tela da escolha dos elementos que constituirão os verbetes....................123

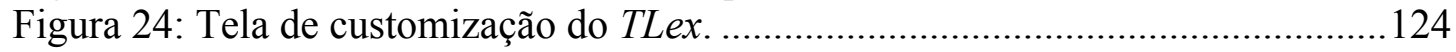

Figura 25: Tela de inclusão de elementos no dicionário.........................................124

Figura 26: Exemplo de verbete que apresenta a referência cruzada same as...........125

Figura 27: Exemplo de verbete que apresenta a referência cruzada SEE .................126

Figura 28: Tela de formatação dos estilos do elemento example. .............................127

Figura 29: Tela de formatação do atributo example do elemento Example................127

Figura 30: Tela de formatação do atributo Source do elemento Example..................128

Figura 31: Tela de visualização hierárquica (Tree View) e janela de preenchimento

das informações do verbete 'drible da vaca' ..........................................................129

Figura 32: Tela de visualização do verbete 'drible da vaca'. ....................................130

Figura 33: Pesquisa no facebook sobre a diferença entre 'drible' e 'jogada'.............142

Figura 34: Número de gols do Campeonato Brasileiro de 2006 a 2013....................146

Figura 35: Número de gols da Premier League nas temporadas de 2011/2012,

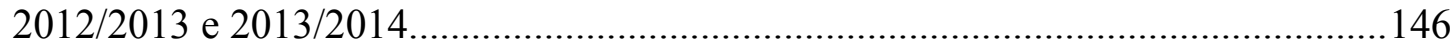

Figura 36: Parte das linhas de concordância da etiqueta VVG.................................148

Figura 37: Parte das linhas de concordância de "fire**"..........................................149

Figura 38: Parte do contexto expandido da linha de concordância 153 de fire*......150

Figura 39: Reportagem sobre o alto número de faltas no Campeonato Brasileiro. ...163

Figura 40: Redução no número de faltas da Série A do Brasileirão........................... 164

Figura 41: Número de faltas de cada time por partida na Premier League de

2013/2014.

Figura 42: Reportagens na imprensa internacional sobre a prática de cavar falta dos

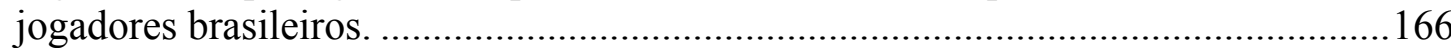

Figura 43: Número de cartões aplicados devido a faltas cavadas no Campeonato

Brasileiro de 2013 e na Premier League 2013/2014.

Figura 44: Resultado parcial da busca no Google por 'Pelé', 'World Cup' e

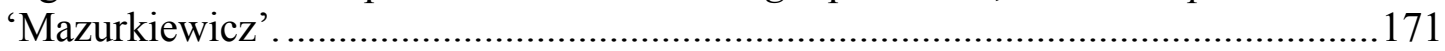

Figura 45: Definição de stall como verbo no freedictionary.com ............................176

Figura 46: Definição de manager apresentada pela Wikipedia. .................................182

Figura 47: Perfil de Louis van Gaal no site do Manchester United...........................183

Figura 48: Perfil dos técnicos do Manchester United ..................................................185

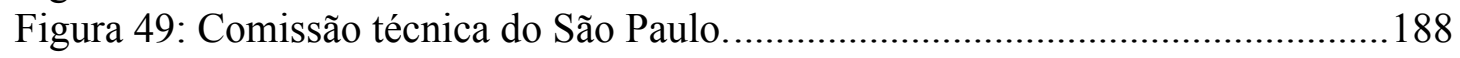

Figura 50: Membros da diretoria e dos conselhos do São Paulo F.C. ........................189

Figura 51: Resultado da busca no Google para as palavras: "Cristiano Ronaldo",

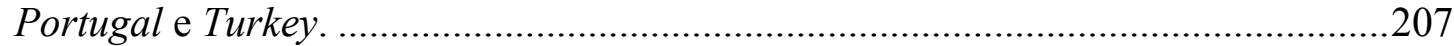

Figura 52: Vídeo tutorial de como dar um 'elástico' ..............................................209

Figura 53: Tutorial do Youtube com uma compilação de 'elásticos' executados por

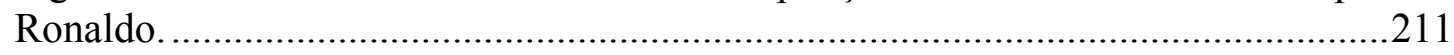

Figura 54: Parte das respostas para a pergunta "O que significa carregar o piano no

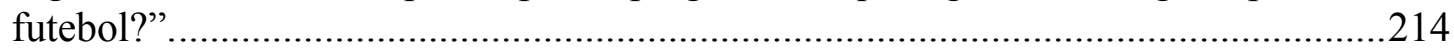

Figura 55: Parte do artigo que descreve o jogador Ramires como carregador de piano. 
Figura 56: Entrada 'Ramires' na Wikipedia .............................................................2216

Figura 57: Definição de box-to-box midfielder na Wikipedia...................................216

Figura 58: Resultado da busca para "rainbow flick" no Google .................................221

Figura 59: Tutorial do drible Jay Jay Okocha no YouTube ......................................224

Figura 60: Instruções de como executar o drible no site Wikihow em inglês............227

Figura 61: Resultado de busca no Google para Johan Cruyff. .................................232

Figura 62: Página do jornal inglês The Guardian descrevendo a origem de um movimento conhecido como "Cruyff turn". ...........................................................23

Figura 63: Resultado da busca no Google.es para as palavras 'Neymar' e 'piscinero'.

Figura 64: Foto do jogador Ashley Young, à esquerda, ponta do Manchester United,

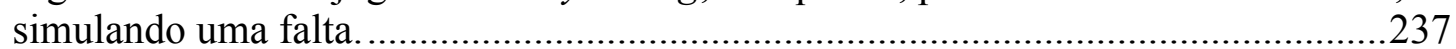

Figura 65: Vídeo com tutorial de como executar o The Matthews move...................242

Figura 66: Tutorial com fotos de como executar The Matthews move......................243

Figura 67: Entrada dos dois verbetes de 'gol' e do verbete 'gol, [FAZER|MARCAR]

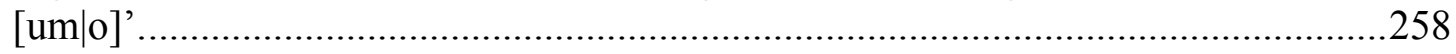

Figura 68: Destaque da categoria gramatical dos dois verbetes de 'falta' e da CLE

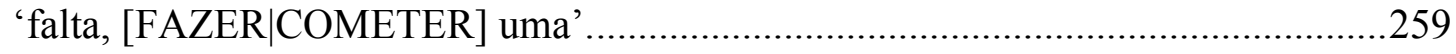

Figura 69: Destaque dos equivalentes de nutmeg em português. ............................259

Figura 70: Destaque dos equivalentes de 'gol, [FAZER|MARCAR] [um|o]'...........260

Figura 71: Destaque para a definição de diver .........................................................2.264

Figura 72: Destaque para os exemplos de 'falta, [FAZER|COMETER]'..................267

Figura 73: Destaque para os exemplos dos equivalentes de nutmeg em português...267

Figura 74: Destaque da informação enciclopédica do termo dummy.......................268

Figura 75: Destaque da informação enciclopédica do termo 'carretilha'..................268

Figura 76: Referência cruzada entre 'lambreta' e 'carretilha' .................................2270

Figura 77: Modo de visualização do elemento ‘vídeo' no TLex..............................271

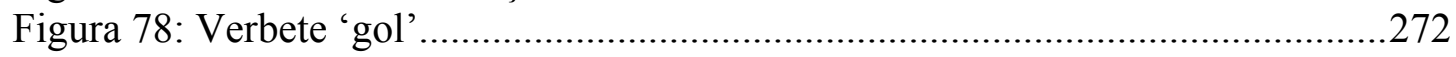

\section{Índice dos gráficos}

Gráfico 1: Tipos de fontes utilizadas na composição da categoria RP do subcorpus em português.

Gráfico 2: Tipos de fontes utilizadas na composição da categoria DR do subcorpus

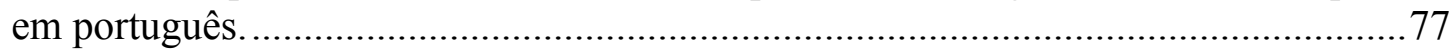

Gráfico 3: Tipos de fontes utilizadas na composição do corpus CV em português. ...80

Gráfico 4: Tipos de fontes utilizadas na composição da categoria ST do subcorpus em

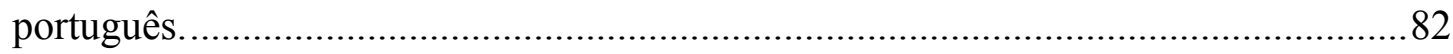

Gráfico 5: Tipos de fontes utilizadas na composição da categoria RP em inglês.........87

Gráfico 6: Tipos de fontes utilizadas na composição da categoria DP do subcorpus em

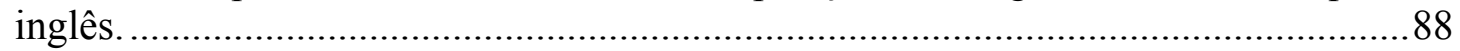

Gráfico 7: Tipos de fontes utilizadas na composição do corpus CV em inglês. ..........90

\section{Índice das tabelas}

Tabela 1: Características do corpus de estudo.

Tabela 2: Vinte palavras mais frequentes, em ordem decrescente, do subcorpus de estudo em inglês. 
Tabela 3: Amostragem da lista de palavras do subcorpus de português ordenada alfabeticamente.

Tabela 4: Visualização parcial dos dados estatísticos do subcorpus de estudo em

inglês.

Tabela 5: Vinte primeiras palavras-chave, em ordem decrescente de chavicidade, do subcorpus em português.

Tabela 6: Palavras-chave do subcorpus de português.

Tabela 7: Número de linhas de concordância para cada etiqueta gramatical de verbo.

\section{Índice dos quadros}

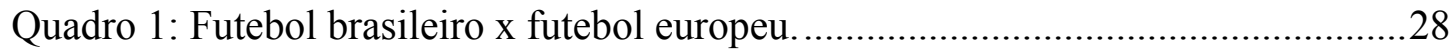

Quadro 2: Composição inicial do corpus de estudo. ....................................................61

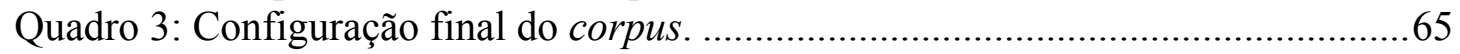

Quadro 4: Contraste de algumas características entre high-context cultures e low-

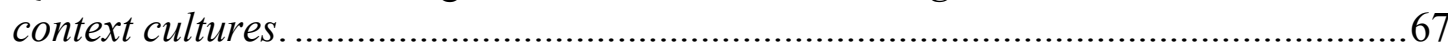

Quadro 5: Fontes utilizadas para a compilação da categoria RP do subcorpus em

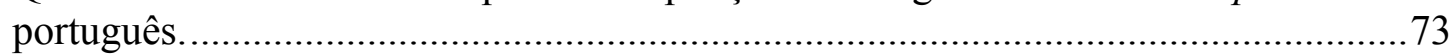

Quadro 6: Fontes utilizadas para a compilação da categoria DP do subcorpus em

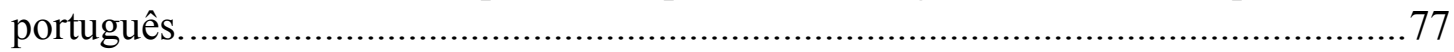

Quadro 7: Fontes utilizadas para a compilação da categoria CV em português...........80

Quadro 8: Fontes utilizadas para a compilação da categoria ST do subcorpus em

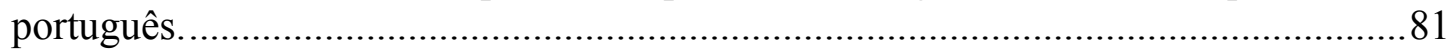

Quadro 9: Fontes utilizadas para a compilação do corpus RP em inglês. .....................85 Quadro 10: Fontes utilizadas para a compilação da categoria DP do subcorpus em

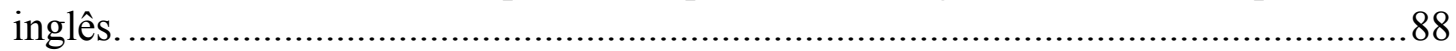

Quadro 11: Fontes utilizadas para a compilação da categoria CV em inglês..............91

Quadro 12: Fontes utilizadas para a compilação da categoria ST do subcorpus em

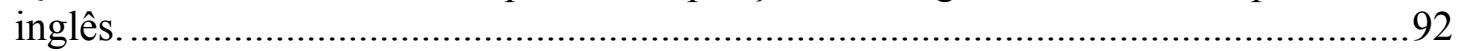

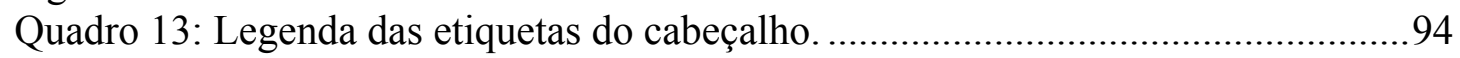

Quadro 14: Etiquetas do Tree-Tagger (inglês)........................................................ 104

Quadro 15: Etiquetas do Tree-Tagger (português).................................................... 104

Quadro 16: Legenda com a classificação das palavras-chave e suas respectivas cores.

Quadro 17: Palavras-chave associadas ao estilo brasileiro e ao estilo inglês.............154

Quadro 18: Colocações verbais e adjetivas de 'falta'...............................................162

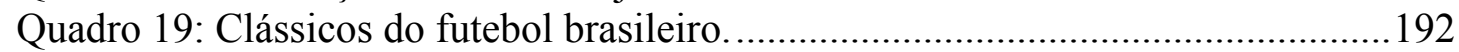

Quadro 20: Categorias gramaticais identificadas entre os termos...............................258

Quadro 21: Definições de 'definição terminológica' encontradas. ............................262 


\title{
Resumo
}

\author{
MATUDA, Sabrina. Futebóis: Uma análise do léxico do futebol em português \\ brasileiro e inglês britânico sob a perspectiva da Linguística de Corpus. 2015. 332 \\ f. Tese (Doutorado em Letras)—Faculdade de Filosofia, Letras e Ciências Humanas, \\ Universidade de São Paulo, São Paulo, 2015.
}

O objetivo desta pesquisa foi criar um modelo de glossário de futebol composto por verbetes marcados por diferenças culturais entre o Brasil e a Inglaterra.

Partimos da hipótese de que os diferentes jeitos de jogar, a história do futebol em cada cultura, a apropriação cultural das regras na Inglaterra e no Brasil e outros fatores de ordem histórico-social contribuíram para a criação do léxico do futebol em português e inglês. Para conduzir a pesquisa, baseamo-nos na Linguística de Corpus, na Terminologia Textual e na Tradução Técnica como ato comunicativo sujeito a condicionantes culturais, áreas que compartilham o interesse de observar a linguagem real em seu contexto de ocorrência. Recorremos ao conceito antropológico formarepresentação para melhor explicar as diferenças entre o futebol brasileiro e o futebol inglês.

O corpus de estudo é comparável e possui 469.765 palavras em português e 600.079 em inglês. Cada subcorpus é composto por cinco categorias de textos: resultados de partidas, descrição de partidas, relatos de partidas com comentários de internautas, notícias sobre compra e venda de jogadores e técnicos e notícias sobre a situação dos times nos campeonatos. O corpus foi submetido à etiquetagem morfossintática por meio do etiquetador Tree Tagger e analisado semi-automaticamente com auxílio do programa WordSmith Tools.

Selecionamos dezessete termos e combinatórias léxicas especializadas (CLEs) que são culturalmente marcados e que deram ensejo aos estudos de caso que compõem o modelo de dicionário proposto. A análise desses casos revelou dois aspectos importantes: 1) o futebol brasileiro é frequentemente associado a palavras como 'drible', 'criatividade', 'espontaneidade', 'habilidade', 'beleza' e 'ginga', ao passo que o futebol inglês é quase que exclusivamente associado a palavras de força e rapidez; 2) os aspectos histórico-culturais e a história do futebol no Brasil e na Inglaterra influenciaram, de forma direta, a terminologia do futebol em português e inglês, confirmando nossa hipótese.

Ao final do trabalho, o modelo de dicionário proposto é apresentado em anexo.

PALAVRAS-CHAVE: Futebol. Termos culturalmente marcados. Linguística de Corpus. Terminologia. Combinatórias léxicas especializadas (CLEs). Tradução 


\section{Abstract}

MATUDA, Sabrina. Footballs: A corpus-driven analysis of football lexicon in Brazilian Portuguese and British English. 2015. 332 p. Dissertation (PhD) Faculty of Philosophy, Languages and Literature, and Human Sciences, University of São Paulo, São Paulo, 2015.

The primary aim of this research is to present a model for a football dictionary consisting of entries marked by cultural differences between Brazil and England.

The central hypothesis of this dissertation is that the different ways of playing, the football history in each culture, the cultural appropriation of rules in England and Brazil and other historical and social factors have contributed to the creation of the football lexicon in Portuguese and English. The theoretical dimensions underlying this study are Corpus Linguistics, Textual Terminology and Technical Translation as a communicative act subject to cultural conditions, areas which share an interest in observing language in its actual context of occurrence. We also highlighted the anthropological form-representation concept to better explain the differences between Brazilian football and English football.

In order to carry out our analysis, we compiled a comparable study corpus which comprises 469,765 words in Portuguese and 600,079 in English. Each subcorpus consists of five categories of texts: match results, match description, match reports with comments from Internet users, news about players' and coaches' purchase and sale and news on the position of the teams in the championships. The corpus was annotated with part-of-speech tags through Tree Tagger and investigated with the linguistic analysis software WordSmith Tools.

Seventeen culturally marked terms and specialized lexical combinations (CLEs) gave rise to the case studies which constitute the dictionary model. The analysis of these cases revealed two important aspects: 1) Brazilian football is often associated with words like 'dribble', 'creativity', 'spontaneity', 'ability', 'beauty' and 'ginga' whereas English football is almost exclusively associated with words of strength and speed;2) the historical and cultural aspects and the history of football in Brazil and England have direct impact on the football terminology in Portuguese and English, a conclusion which confirms our initial hypothesis.

A model of dictionary entries is attached to this dissertation.

KEYWORDS: Football. Culturally marked terms. Corpus Linguistics. Terminology. Specialized lexical combinations. Translation 


\section{Introdução}

Não é sem razão que o campo de problematização do futebol tenha crescido no mundo todo, nos últimos tempos. Como desconhecer que ele se tornou uma espécie de língua geral que coloca em contato as populações de todos os continentes? (WISNIK, 2008)

Ter o futebol como objeto de estudo não é tarefa fácil. A resposta a uma simples pergunta como 'O que é futebol?' poderia, por si só, ser objeto de estudo de uma tese. Nesta pesquisa, observamos o "esporte das multidões" em múltiplas dimensões.

Futebol é esporte. E é o esporte preferido dos brasileiros. Segundo uma pesquisa publicada em 2010 pelo Diário Lance! ${ }^{1}$, cerca de $30 \%$ da população brasileira pratica futebol e aproximadamente $44 \%$ dos brasileiros acima de dezesseis anos se envolve cotidianamente com o esporte, seja de forma ativa ou passiva.

Futebol é paixão. É jogado nos quatro cantos do mundo, por camadas sociais distintas e em diferentes espaços, como campos de várzea, quadras, praias, ruas, escolas, clubes etc. (DAMO, 2005). É um esporte único na habilidade de, ao mesmo tempo, aproximar e separar - é capaz de unir diferentes setores da população de um país em uma partida de Copa do Mundo, ao mesmo tempo em que pode motivar violentos eventos entre torcidas de times rivais.

Futebol é competição. É o jogo mais praticado no mundo. De acordo com o sociólogo John Loy (1969, p. 56), jogo é qualquer forma de competição cujo resultado é determinado por três fatores: habilidade física, estratégia ou sorte, fatores que podem ser observados na preparação física dos jogadores - aspecto que vem ganhando mais evidência nos últimos anos -, nos treinamentos das equipes profissionais e nos resultados inesperados de algumas partidas.

Futebol é lazer. Principalmente no Brasil. Apesar da urbanização das cidades, ainda é comum ver crianças e adultos jogando na rua, em campinhos, na várzea, na praia, em quadras alugadas, enfim, onde houver espaço para improvisar um campo.

\footnotetext{
$1 \quad$ Disponível em: < http://www.bdobrazil.com.br/pt/analises/esporte/Futebol,\%20a\%20maior\%20paixão\%20dos\%20brasil eiros.pdf > . Acesso em: 20 abr. 2015.
} 


\section{Introdução}

Futebol como lazer é sinônimo de 'pelada', modalidade caracterizada por sua espontaneidade, normalmente realizada entre amigos ou moradores de um mesmo bairro. $\mathrm{Na}$ 'pelada' as regras do jogo são frequentemente quebradas: altera-se o número de jogadores - muitas vezes um time tem um jogador a mais que o outro -, e é comum a ausência de árbitros (VILLELA, 1997, p. 69). A pelada normalmente acontece nos fins de semana ou após o expediente de trabalho. Pelada é diversão.

Futebol é mercado da economia. O futebol mundial é um grande negócio. Se considerarmos contratos de jogadores, transferências, direitos de transmissão de partidas, vendas de produtos dos times e outros aspectos, constataremos que o futebol é um dos esportes mais lucrativos do mundo, mobilizando profissionalmente milhões de pessoas. No Brasil, o futebol é uma atividade econômica com grande capacidade de gerar empregos e tem efeito multiplicador maior que muitos setores tradicionais (LEONCINI \& SILVA, 2005).

Futebol é política. Por ora não adentraremos essa dimensão do futebol, dada sua complexidade, mas é inegável que futebol e política sempre andaram juntos, desde os primórdios do esporte, na Inglaterra, até os dias de hoje, como veremos mais adiante.

Futebol é cultura. É reconhecido mundialmente como manifestação cultural. Sociólogos, antropólogos, historiadores, jornalistas, etnólogos, filósofos, pedagogos e psicólogos abordam o futebol sob diferentes ângulos em estudos acadêmicos. É fato que o futebol é considerado elemento importante da nossa cultura. DaMatta (1982) afirma que o futebol expressa a sociedade brasileira, devendo, assim, ter assegurado seu lugar na sociedade. Para o autor, "o futebol praticado, vivido, discutido e teorizado no Brasil seria um modo específico, entre tantos outros, pelo qual a sociedade brasileira fala, apresenta-se, revela-se, deixando-se, portanto, descobrir" (DAMATTA, 1982, p. 21).

Futebol é instrumento de batalha para uma série de conflitos (ANCHIMBE, 2008). Tomemos como exemplo a luta contra o racismo, que acontece em estádios por meio da manifestação de torcedores que carregam faixas com mensagens avessas a essa forma de preconceito. Outro exemplo é a tentativa de amenização de conflitos locais, como uma partida ocorrida em 2006 entre um combinado de Israel e da Palestina contra celebridades. Ou, ainda, na luta contra a pobreza, por meio de 


\section{Introdução}

partidas como, por exemplo, as que estão sendo organizadas pelos ex-jogadores Ronaldo e Zinédine Zidane, embaixadores da Boa Vontade do Programa da ONU para o Desenvolvimento, que tem como objetivo arrecadar verba para trabalhos de recuperação na Guiné, na Libéria e em Serra Leoa e apoiar projetos sociais na cidade de Saint-Étienne.

Enfim, futebol é língua. Como afirma Wisnik (2008), “[Futebol] é a língua geral que coloca em contato as populações de todos os continentes".

Poderíamos continuar, sem muito esforço, apresentando outras dimensões do futebol na sociedade. Contudo, acreditamos que a importância que as dimensões aqui elucidadas conquistou no mundo globalizado já justifica nossa pesquisa. Seja como esporte, paixão, competição, lazer, mercado da economia, política, cultura ou área de pesquisa, o futebol ocupa boa parte das conversas, normalmente com nossos conterrâneos, em nossa língua materna, mas também é tema de diálogos estrangeiros e, na maior parte dos casos, esse segundo tipo de comunicação acontece em inglês.

Levando em conta as particularidades do futebol no Brasil e na Inglaterra como é jogado, por quem é jogado, onde é jogado, o alcance na mídia, o lugar que ocupa na cultura, entre outros fatores -, perguntamo-nos: "Como falar sobre futebol em inglês?", ou melhor, "Como falar sobre o futebol brasileiro em inglês?" A pergunta, que não tem resposta simples, também pode ser feita na ordem inversa: “Como falar sobre o futebol inglês no Brasil?".

A princípio poderíamos responder: "Só depende de uma 'boa' tradução". Mas, então, questionaríamos: "E quais os aspectos que envolvem uma 'boa' tradução?". Essa resposta já é um pouco mais complicada, mas em um primeiro momento mencionaríamos o uso de terminologia apropriada e a consideração do contexto e de fatores culturais, o que nos leva a outra pergunta: "Como garantir a terminologia apropriada e considerar esses fatores que são de suma importância para a tradução?" Uma forma de se fazer isso seria partindo de textos autênticos, analisados por meio de uma metodologia baseada em Linguística de Corpus.

Infelizmente o processo de construção desta tese não foi tão simples quanto aquele idealizado no parágrafo anterior. Em nossa pesquisa de mestrado (MATUDA, 2011), respondemos, em parte, a pergunta sobre as características de uma "boa" tradução técnica, já utilizando a linguagem do futebol como objeto de estudo. 


\section{Introdução}

Investigamos as unidades fraseológicas mais comuns com o termo 'gol' em português e, por meio da análise de corpora comparáveis, propusemos equivalentes tradutórios para essas unidades em inglês. A pesquisa contribuiu para a conscientização de que, embora seja especialmente relacionado ao lazer, o futebol é uma área técnica, pois possui um vocabulário específico organizado em torno de uma temática. Sendo assim, possui uma linguagem própria, utilizada para descrever acontecimentos a ele relacionados. Essa linguagem é padronizada e, justamente por esse motivo, não pode ser utilizada aleatoriamente. Ou seja, devemos respeitar as normas de funcionamento dessa terminologia.

A segunda parte da pergunta, "Como considerar fatores culturais?", infelizmente não foi respondida na dissertação de mestrado por questão de tempo e de objetivos da pesquisa. Mas a ausência de uma resposta foi o pontapé inicial desta pesquisa de doutorado.

Ao concluir o mestrado, tínhamos algumas certezas e várias incertezas sobre a terminologia bilíngue do futebol, e todas essas incertezas estavam relacionadas à influência da dimensão histórica e cultural no funcionamento da linguagem do futebol em português e em inglês. Eis que, dessas incertezas, nasceu a hipótese da presente pesquisa:

Os diferentes jeitos de jogar, a história do futebol em cada cultura, a apropriação cultural das regras na Inglaterra e no Brasil e outros fatores de ordem histórico-social contribuíram para a criação do léxico do futebol em português e inglês.

Sendo assim, propomos observar o léxico do futebol, tendo como pano de fundo a história do esporte em cada cultura, pois partimos da hipótese de que as terminologias são influenciadas por fatores contextuais, que devem ser considerados durante o ato tradutório. O desejo de auxiliar o tradutor deu origem ao objetivo de nosso trabalho:

Criar um modelo de dicionário de futebol composto por verbetes que sejam marcados por diferenças culturais entre Brasil e Inglaterra. 


\section{Introdução}

Com a promessa de auxiliar na comunicação de estrangeiros, turistas e aficionados pelo esporte, surgiram inúmeros glossários e dicionários bilíngues sobre a linguagem do futebol na época da Copa do Mundo de 2014. No entanto, após uma breve análise desse material, constatamos que as obras, em sua maioria disponíveis on-line, foram compiladas sem critério algum. Dos oito sites, glossários e dicionários analisados, destacamos três que podem contribuir, dentro dos objetivos propostos, para a comunicação entre brasileiros e estrangeiros em torno da temática do futebol. Tratemos brevemente de cada um delas.

A primeira é o Global Football Glossary ${ }^{2}$, desenvolvido por um grupo de pesquisa da Pontifícia Universidade Católica do Rio Grande do Sul (PUC). O aplicativo trilíngue (português-espanhol-inglês) contabiliza 300 verbetes, que compreendem termos, definições e exemplos de uso em cada idioma. Os termos são divididos em oito campos semânticos: arbitragem, áreas de campo, equipamentos, ato/ação, posições, termos de jogo, táticas e pessoas. Embora prometa, em sua descrição, abranger expressões comuns do futebolês, a obra não contempla as mais utilizadas $^{3}$ para conversar sobre uma partida, por exemplo. Além disso, os exemplos parecem ter sido criados ${ }^{4}$.

A segunda obra é, na verdade, parte do TECLA SAP ${ }^{5}$, site sobre curiosidades do inglês. Durante a Copa do Mundo e os meses que a antecederam, o autor do site dedicou um espaço ${ }^{6}$ para artigos sobre a linguagem do futebol. Esses artigos, sempre com exemplos e informações completas sobre os termos mais comuns do esporte, são direcionados para curiosos do futebol em geral. No site, o autor dialoga com seus leitores, que, muitas vezes, dão sugestões sobre outros termos que poderiam ser abordados em artigo futuro. Não nos parece, portanto, que o objetivo do autor tenha sido compilar uma obra terminográfica.

A obra mais recente e também a mais completa é o 'Glossário de termos de futebol português-inglês/inglês-português', de Eduardo Araújo. O material é dividido

\footnotetext{
2 Disponível para download em: < https://play.google.com/store/apps/details?id=appinventor.ai ubilab famecos.GloballFootballGlossary $\&$ hl=en >. Acesso em: 26 jul. 2014.

${ }^{3}$ Em contraste com as palavras-chave extraídas de nosso corpus de estudo.

${ }^{4}$ Não encontramos explicações de como os exemplos foram selecionados.

${ }^{5}$ Disponível em: < http://www.teclasap.com.br/ >. Acesso em: 14 abr. 2014.

${ }^{6}$ Disponível em: http://www.inglescomfutebol.com.br/ >. Acesso em: 15 jun. 2014.
} 


\section{Introdução}

em duas partes: a primeira apresenta os elementos estáticos do jogo, como equipamentos, partes do campo, nomes das posições, regras e infrações; e a segunda compreende situações de jogo. Além dessas, um capítulo à parte lista os termos usados na obra, que, bastante completa, contempla, de certa forma, alguns termos marcados por características culturais e históricas. No entanto, trata esses termos e suas particularidades como curiosidades da língua, sem traçar nenhum paralelo com as culturas envolvidas. Constatamos, também, a ausência de sinônimos. Ademais, embora alguns exemplos pareçam autênticos, não é esclarecido para o consulente se foram criados ou extraídos de textos reais. Enfim, não encontramos um dicionário bilíngue inglês-português sobre o futebol formado por verbetes e CLEs culturalmente marcados. Diante dessa lacuna, propomos a elaboração do modelo de dicionário de futebol, cuja construção está detalhada nesta tese.

Para alcançar os dois objetivos propostos, estabelecemos seis passos, a saber:

1) compilar um corpus comparável de futebol no par de línguas inglês e português composto por textos de campeonatos ingleses e brasileiros;

2) explorar o corpus e fazer um levantamento das palavras-chave mais frequentes;

3) selecionar os termos e combinatórias léxicas especializadas (CLEs) culturalmente marcados;

4) estabelecer possíveis equivalentes para os termos e CLEs;

5) criar definições para os termos e CLEs;

6) criar um modelo de glossário composto pelos verbetes marcados por diferenças culturais entre Brasil e Inglaterra.

Para conduzir a análise, utilizamos basicamente três abordagens teóricas: a Linguística de Corpus (LC), a Terminologia Textual, a Tradução Técnica como ato comunicativo sujeito a condicionantes culturais e o conceito forma-representação.

A compilação e a exploração do corpus de estudo foram realizadas por meio dos conceitos subjacentes à LC, que se ocupa da coleta e análise de corpora para a investigação de fenômenos recorrentes na língua.

A Terminologia Textual nos deu o aporte teórico para o estabelecimento dos critérios de identificação, bem como para a definição das CLEs. 


\section{Introdução}

As noções de equivalência de Azenha Jr. (1999) e Tagnin (2007), empregadas na tradução técnica, contribuíram de forma significativa para a busca de equivalentes.

O conceito forma-representação, proposto por Toledo (2002), foi fundamental para entendermos algumas discrepâncias na linguagem utilizada para falar de futebol em inglês e português.

O produto final do trabalho, o Dicionário de termos culturais do futebolês português-inglês e inglês-português, tem como objetivo auxiliar tradutores em geral, estudantes de tradução, comentaristas, colunistas, jornalistas, clubes esportivos etc. na redação de textos sobre futebol em português e inglês, especialmente aqueles que abordam termos culturalmente marcados.

Quanto à divisão, o trabalho estruturou-se em cinco capítulos:

No primeiro capítulo, apresentamos um breve histórico do futebol, com algumas hipóteses sobre as origens do esporte e as circunstâncias que marcaram o surgimento do futebol moderno e sua introdução no Brasil. Ao final, introduzimos o conceito de forma-representação proposto por Toledo (2002) e discutimos a dicotomia "futebol-arte" x "futebol-força".

O segundo capítulo introduz as três abordagens teóricas utilizadas na pesquisa: Linguística de Corpus, Terminologia Textual e Tradução Técnica como ato comunicativo sujeito a condicionantes culturais.

No terceiro capítulo explicamos a metodologia adotada na pesquisa. Apresentamos, inicialmente, o corpus de estudo e os corpora de referência. Em seguida, tratamos dos etiquetadores e das ferramentas computacionais utilizadas na pesquisa, e, ao final desse capítulo, descrevemos os passos seguidos para a análise dos dados.

O capítulo 4 apresenta uma análise detalhada dos estudos de caso selecionados.

As decisões tomadas para a elaboração do modelo de dicionário bilíngue português-inglês de futebol, composto por termos e CLEs culturalmente marcados, são apresentadas no quinto capítulo. Explicamos os elementos que compõem a macro e a microestrutura da obra e discutimos algumas questões teóricas essenciais para a compilação do dicionário. 


\section{Introdução}

Em Considerações Finais recapitulamos os resultados alcançados na pesquisa e discutimos a possibilidade de a metodologia utilizada ser replicada em outros estudos. Após as referências bibliográficas, anexamos o modelo de dicionário construído. 


\title{
Capítulo 1 - Futebol
}

\author{
"Os meios de comunicação têm tentado estender a popularidade do \\ futebol a outros jogos, como o tênis, o voleibol e outros. Em vão: somente \\ o futebol é que verdadeiramente mobiliza a "paixão" do povo \\ brasileiro". (Ariano Suassuna)
}

O presente capítulo apresenta um breve histórico do futebol. Primeiramente, expomos algumas hipóteses sobre as origens do esporte. Em seguida, levantamos alguns pontos que marcaram o surgimento do futebol moderno e discorremos sobre a introdução do futebol no Brasil. Ao final, apresentamos o conceito de formarepresentação proposto por Toledo (2002) e discutimos a dicotomia "futebol arte" x "futebol força".

\subsection{Possíveis origens do futebol}

Voltar às origens do futebol, descrever o surgimento do futebol moderno na Inglaterra e sua chegada e popularização no Brasil seria muita pretensão para uma tese filiada ao programa de Estudos da Tradução e que tem como objetivo verificar como os diferentes tipos de jogar contribuíram para a criação do léxico do futebol em português e inglês. Deixemos, então, esse trabalho para os historiadores e antropólogos, que o têm feito de maneira exemplar.

Desde meados da década de 1990, surgiram inúmeras publicações que têm como tema e objeto o universo futebolístico. Livros, teses, dissertações e artigos sobre o assunto vêm ganhando espaço dentro da produção acadêmica, sobretudo nas faculdades de história e antropologia (TOLEDO, 2002; DAOLIO, 2005; FRANCO JÚNIOR, 2007; MELO, 1997; GIGLIO \& SPAGGIARI, 2010; GUEDES, 2010, HOLANDA et al., 2012, entre outros).

Em nossa pesquisa, utilizamos os trabalhos de historiadores, antropólogos e jornalistas para melhor entender o funcionamento do futebol dentro das sociedades brasileira e inglesa, e, assim, analisar de forma mais ampla a terminologia utilizada 


\section{Capítulo 1}

para tratar desse esporte no Brasil e na Inglaterra. Dessa forma, quando falamos em histórico do futebol não nos referimos a uma história cronológica do futebol, que descreveria todos os acontecimentos que marcaram o esporte desde seu surgimento até a atualidade, mas sim a alguns de seus eventos e características presentes nos dois países mencionados, e que nos levaram a criar uma autorrepresentação sobre nosso futebol e que contribuem para o entendimento de algumas questões culturais.

A escolha de elucidar esses eventos históricos, ainda que de maneira bastante sintética, deu-se pela observação de que parece existir um consenso entre os pesquisadores de que a história do futebol não pode ser isolada da história do mundo. Em The Ball is Round: A Global History of Soccer, Goldblatt (2008) advoga que a história do futebol não pode ser estudada à parte da história, da sociologia e da economia. Para o pesquisador, o caminho contrário também ocorre, ou seja, a história do mundo não é e nem será completa sem a história do futebol. Para Verdú (apud WISNIK, 2008, p. 47), o futebol é entendido como uma mímese, ou seja, uma representação do jogo social, onde o jogo incorpora alguns elementos indicativos de mudança histórica. Em “A dança dos deuses”, Franco Júnior (2007) propõe que o futebol seja entendido como uma metáfora de diferentes planos do viver humano nas condições históricas do último século.

Independentemente das diferenças entre as propostas apresentadas, fica clara a tendência de analisar o futebol considerando-se o contexto histórico-cultural em que está inserido; e uma vez que nos vinculamos a uma vertente da Terminologia e a um modo de entender a tradução que têm como base o contexto de produção do texto, não poderíamos deixar a história do futebol de lado.

Inúmeras são as hipóteses acerca do surgimento do futebol. Acredita-se que na China antiga, entre 2000 e 1500 a.C., guerreiros criaram um passatempo que consistia em chutar o crânio dos inimigos para relaxar após as batalhas. A prática consistia em passar o crânio de pé em pé sem deixá-lo cair no chão, levando-o para dentro de duas varas fincadas no campo. No século III a.C., o passatempo deu origem a uma prática militar chamada tsu-chu, literalmente "chutar a bola" (FRANCO JÚNIOR, 2007, p. 15). Durante o exercício, os participantes - oito ou doze em cada time -, chutavam uma bola de couro recheada de crina de cavalo para dentro dos limites demarcados por duas estacas fincadas no chão. No século II, o tsu-chu foi importado pelo Japão e 


\section{Capítulo 1}

teve seu nome traduzido para kemari. A prática perdeu o caráter de competição e passou a ser mais associada a um ritual: os jogadores, posicionados em um círculo relativamente pequeno, tinham que passar a bola, que representava a terra, sem deixála tocar o chão.

Outro suposto antecessor do futebol é o tlachtli. Jogado no México pelos astecas por volta de 900 a.C., o tlachtli era praticado com uma bola de borracha e os sete jogadores de cada equipe tinham como objetivo arremessá-la para dentro de um aro no campo adversário por meio de toques feitos somente com os joelhos, cotovelos e bacia. Embora o capitão da equipe perdedora fosse decapitado, o tlachtli era um jogo rito, pois, como o próprio nome revela - “o que se dá a ver" (WISNIK, 2008, p. 71) ou, simplesmente, "espetáculo"7 -, a atividade possuía uma relevância simbólica para seus praticantes.

$\mathrm{Na}$ Grécia clássica, pelo menos desde o século IV a.C., o epyskiros era jogado por nove homens que tentavam introduzir uma bola recheada de areia em um alvo determinado. Da prática grega, surgiu, por volta de III a.C. em Roma , o harpastum, jogo inicialmente utilizado como exercício militar com o intuito de aperfeiçoar a capacidade atlética, desenvolver a tática, a lógica e a organização dos soldados, e que se popularizou a partir do século I d.C. Máximo e Porto (1968, p. 11) observam várias afinidades entre o harpastum e o futebol moderno. Essa possível ligação se deve a sua introdução nas ilhas britânicas pelas tropas romanas, o que teria dado origem a diferentes jogos com bola, dentre eles o futebol.

No século XVI, jogava-se em Florença, na Itália, o calcio. O esporte era praticado em um campo retangular no principal espaço público da cidade, a Piazza Santa Croce. Era composto por dois times de 27 homens uniformizados, possuía um conjunto de regras e contava com árbitro. Para Franco Júnior (2007, p. 17), o calcio marcou uma nova etapa na história do jogo devido as suas características e organização. A princípio, era praticado por representantes de todos os segmentos sociais; mas na segunda metade do século XVI, tornou-se exclusividade da nobreza, sem, contudo, deixar de atrair grande público a suas partidas. Devido ao seu caráter nobre, o esporte foi introduzido no treinamento da elite paramilitar local entre os séculos XV e XVIII (FRANCO JÚNIOR, 2007, p. 17). Essa estreita ligação com a

\footnotetext{
${ }^{7}$ Tradução proposta por Franco Júnior (2007, p. 16).
} 


\section{Capítulo 1}

nobreza e sua aplicação no aperfeiçoamento militar levou o jogo ao desaparecimento durante mudanças político-sociais a partir de 1739. Em 1930, o esporte ressurge atrelado ao estado fascista, em comemoração ao quarto centenário de uma partida histórica jogada pelas tropas do imperador austríaco Carlos V (FRANCO JÚNIOR, 2007, p. 17).

De acordo com Franco Júnior (2007, p. 17-18), dada a inegável origem inglesa do futebol moderno, é comum a tentativa de encontrar suas origens em práticas com bolas realizadas no espaço anglo-normando medieval, como na soule. Essa prática tinha um caráter mais ritualístico: assemelhava-se mais a uma festa popular do que a um jogo propriamente dito. Era disputada por grupos muito grandes e descrita por Wisnik (2008, p. 77) como uma "espécie de vale-tudo pela pelota", em que se usavam as mãos, todo e qualquer tipo de choque e até mesmo golpes mais agressivos. A multidão de jogadores percorria campos, bosques e arredores de povoados na disputa pela bola. Ferimentos e fraturas faziam parte da prática e não raras eram as mortes. Os adversários tinham mais um caráter totêmico de clãs - comunidades vizinhas, casados vs. solteiros, cidade vs. campo - do que de equipes esportivas (WISNIK, 2008, p. 77). O objetivo final era conduzir a bola ao território adversário ou subtraí-la do domínio do outro grupo e levá-la até seu próprio território.

$\mathrm{Na}$ Inglaterra, existem registros de diferentes jogos com bola que datam do ano de 1174. O mais popular desses jogos, que ficou conhecido como folk football, era praticado durante a festa popular Schrovetide, que coincide com a terça-feira gorda do calendário cristão. Segundo Franco Júnior (2007, p. 18), os ingleses comemoravam a expulsão dos dinamarqueses praticando uma modalidade em que a bola simbolizava a cabeça do chefe invasor. Não se sabe ao certo como a bola era conduzida, mas alguns registros indicam que se utilizavam os pés. Alguns autores, como Green (1953) e Marples (1954), afirmam que essas práticas eram bastante violentas e as regras eram poucas, se não inexistentes.

Como podemos observar, o homem pratica jogos com bola desde os tempos mais remotos e, como conclui Franco Júnior (2007, p. 19), é impossível traçar uma linha de continuidade entre as práticas antigas de jogos com bola e o futebol moderno. No entanto, chamamos atenção para o fato de que cada uma das práticas expostas acima estava presente em diferentes facetas da vida social: diversão, ritual, esporte, 


\section{Capítulo 1}

condicionamento físico, guerra e política, assim como ocorre com o futebol moderno. Além disso, esses jogos com bola surgiram de condições culturais específicas de determinado povo em determinada época, da mesma forma que o futebol contemporâneo é descrito, jogado e vivido de diversas maneiras em diferentes culturas. Por esse motivo, assim como Dunning (1992), acreditamos que o esporte é uma prática social e, como tal, deve ser contextualizado nas diferentes sociedades nas quais se desenvolveu.

\subsection{Futebol moderno na Inglaterra}

De acordo com Elias e Dunning (1992), o futebol originou-se na Inglaterra e estava vinculado às necessidades e características da sociedade inglesa dos séculos XVIII e XIX, no período de transição entre o regime político monárquico e a constituição do parlamento inglês.

Embora tenha sido praticado nas primeiras décadas do século XIX já com um formato bastante similar ao atual, o esporte só surgiu oficialmente em 1848, durante a Revolução Industrial. Segundo Franco Júnior (2007, p. 25), é praticamente impossível não associar a propagação do futebol à ascensão da Inglaterra durante o Império Britânico, já que os dois se baseiam, sobretudo, em competição, produtividade, quantificação de resultados e fixação de regras.

Após a derrota do imperialismo napoleônico na batalha de Waterloo, a Inglaterra passou por uma época de prosperidade política, econômica e social, em que o futebol foi utilizado como um dos instrumentos para moldar o caráter da elite inglesa e preparar futuros governantes por meio do chamado "cristianismo atlético", descrito por Franco Júnior (2007, p. 25) como “concepção pedagógica que pretendia desenvolver a fibra moral da elite britânica destinada a governar regiões longínquas e inóspitas, plenas de súditos hostis e pouco civilizados". Com esse intuito, o football, até então um jogo de bola sem regras, foi sendo, aos poucos, introduzido nas escolas particulares e nas universidades. No entanto, para que tal política funcionasse, faziase necessário um conjunto de regras capaz de organizar o esporte e, consequentemente, a sociedade. Por esse motivo, em 1848 a Trinity College de Cambridge fixou o primeiro código de regras do esporte. A norma resultante, que 


\section{Capítulo 1}

contava com quatorze regras consideradas "justas" e "coerentes", não teve caráter definitivo, mas foi revisada e alterada inúmeras vezes, por diversos motivos. Anos depois, já em 1863, representantes de colleges de Londres se organizaram e fundaram a Football Association, juntamente com um comitê responsável pela revisão das regras (FRANCO JÚNIOR, 2007, p. 28).

Todas as regras e as mudanças que as sucederam se configuraram como resultado de decisões expressas por grande parte da população. Por esse motivo, o football era considerado, pelos ingleses, um jogo de caráter extremamente britânico. Presentes em diversos lugares do mundo devido ao imperialismo britânico, os ingleses sempre procuravam jogar football entre si, deixando de fora os habitantes locais. Para Elias e Dunning (1992, p. 25), a esportização dos jogos por meio da uniformização das regras pode ser considerada "sintoma de uma transformação mais profunda das sociedades europeias, o que exigia de seus membros individuais uma maior regularidade e diferenciação de comportamento".

Até o fim do século XIX, o futebol era um esporte praticado quase que exclusivamente pela burguesia inglesa entre times locais no esquema 1-10 (um beque e 10 atacantes). Outra característica predominante era o dribbling game, em que o desempenho individual do jogador era mais importante do que o da equipe, prática que mudou por volta de 1876, quando o passing game, forma de jogar que priorizava a importância coletiva do esporte, passou a predominar nas partidas.

As duas últimas décadas do século XIX foram marcadas por diversos acontecimentos no mundo do futebol. Como já dissemos, surge, em 1863, a Federação Inglesa (Football Association), que inspirou associações similares como a irlandesa (1882), a escocesa (1873) e a galesa (1876), contribuindo significativamente para a divulgação do esporte por meio da organização de campeonatos. O público das partidas aumentou consideravelmente e, como consequência dessa difusão, o esporte foi, aos poucos, deixando de ser exclusividade da burguesia e passou a atrair as classes menos abastadas. Em 1870, surgiram clubes de empresas siderúrgicas e, no início da década seguinte, o futebol passou a ser praticado nas escolas públicas. Trabalhadores passaram a administrar os clubes e os melhores jogadores eram convidados a trocar seu time por outro em troca de um emprego mais vantajoso (FRANCO JÚNIOR, 2007, p. 35). 


\section{Capítulo 1}

Parte dessa profissionalização do futebol inglês é frequentemente atribuída à participação de ociosos que dedicavam tempo integral a essa prática, tornando-se mais habilidosos do que os jogadores da nobreza, que frequentemente se negavam a participar de confrontos, receosos de perderem para jogadores pertencentes à classe subalterna. Dessa forma, a nobreza tentava combater esse "profissionalismo" a fim de que o futebol permanecesse como um lazer elitista. No entanto, mesmo com todos os esforços dessa elite, em 1885 a Football Association reconheceu o futebol como atividade profissional.

Todas essas mudanças dentro da esfera futebolística, juntamente com a busca da identidade do esporte, que desde os primórdios passou por diversas mudanças, clamaram por uma revisão no conjunto de regras estabelecido em 1863. Contudo, dessa vez a revisão não aconteceu por meio de uma reunião em que membros da Football Association sugeriam e discutiam alterações. Ao contrário, foi um processo bastante demorado, que se estendeu até as primeiras décadas do século XX. A revisão das regras existentes e a implementação das novas deram-se por meio da aceitação das práticas futebolísticas consagradas nos anos anteriores, refletindo, dessa forma, o conjunto legal inglês, a common law, que é resultante de reiteradas práticas sociais.

A identidade que o jogo acabara de adquirir - mediante a revisão das regras -, sua popularização, a criação de federações e a situação econômica durante a Revolução Industrial, que, dentre inúmeros feitos, ampliou significativamente a rede de ferrovias e impulsionou a melhora nos outros meios de transporte, ligando várias regiões do país, foram essenciais para a difusão do esporte na própria Inglaterra, em especial por meio da ampliação de disputas entre regiões.

A propagação do esporte pela Europa e América foi, acima de tudo, fruto do imperialismo inglês, que exportava não só produtos industrializados como também práticas culturais (FRANCO JÚNIOR, 2007, p. 40). Em grande parte dos casos, o contato dos países com a bola dava-se de dois modos: por meio dos ingleses que residiam no exterior e de estrangeiros que, após estudarem na Inglaterra, voltavam para seus países de origem e introduziam o esporte em diferentes estruturas políticas e sociais (ELIAS \& DUNNING, 1992). Após um período de aceitação e propagação, os países europeus criaram suas próprias federações de futebol, marco importante para a disseminação do futebol moderno. 


\section{Capítulo 1}

Como podemos observar, o futebol, de origem inglesa, disseminou-se em todo o mundo, tornando-se um esporte multicultural devido às características distintas que assumiu nas diferentes culturas em que se implantou.

\subsection{Futebol no Brasil}

Oficialmente, o futebol chegou ao Brasil em 1894 quando Charles Miller, filho de pai escocês que veio ao Brasil para trabalhar na São Paulo Railway Company e de mãe brasileira de ascendência inglesa, trouxe da Inglaterra duas bolas de futebol. Então funcionário da São Paulo Railway Company e sócio do São Paulo Athletic Club, Miller foi responsável pela primeira partida oficial no Brasil, realizada em 14 de abril de 1895 pelas duas entidades ${ }^{8}$.

No entanto, existem registros que comprovam que um esporte muito parecido com o futebol já era praticado no Brasil entre 1880 e 1890, quando jesuítas introduziram no colégio São Luís, em Itu, o "bate bolão". Também era praticado por jovens da elite em outros colégios confessionais e laicos de São Paulo, Rio de Janeiro e Rio Grande do Sul e por marinheiros ingleses no litoral brasileiro (CASTELLANI FILHO, 1982). Existe até mesmo registro de uma partida realizada em 1878 em frente à residência da princesa Isabel, no Rio de Janeiro (FRANCO JÚNIOR, 2007, p. 62). Portanto, para Franco Júnior (2007), atribuir paternidade quase heroica a Charles Miller limita a relação entre o futebol e a sociedade brasileira, uma vez que as significações mais profundas estão no processo de apropriação do esporte pelas diversas camadas sociais que transformaram o futebol em um fenômeno popular.

A história do futebol no Brasil é frequentemente contada a partir de campeonatos e da história dos grandes clubes e até mesmo pela história da torcida brasileira, como constatamos em Holanda et al. (2012).

Como este não é um trabalho de história nem de antropologia, selecionamos alguns marcos históricos do futebol no Brasil, com a intenção de mostrar a ligação entre a linguagem do futebol em português e sua implementação e popularização no país.

\footnotetext{
${ }^{8}$ Franco Júnior (2007, p. 60).
} 


\section{Capítulo 1}

Nos primeiros anos, o esporte era símbolo da modernidade europeia e, portanto, não poderia estar ausente na elite brasileira. Começaram a surgir, então, ligas que representavam o verdadeiro futebol ${ }^{9}$, sempre formadas por jovens brancos e ricos da elite.

Assim como na Inglaterra, no Brasil o esporte também foi sendo, aos poucos, apropriado pelas camadas sociais menos privilegiadas, que o transformaram em um "fenômeno de massas", quebrando as barreiras sociais, dentro e fora do campo, com a criação de times nos subúrbios.

A partir desse momento, evidencia-se uma dupla concepção do futebol dentro da sociedade brasileira. De um lado, o futebol lógico dos sportsmen $^{10}$, reflexo da perspectiva educacional inglesa implantada por meio do cristianismo pedagógico que para preparava os futuros líderes do país. De outro, o futebol dos "canelas negras", praticado pela grande massa detentora da ginga, das improvisações e das influências das danças populares que encantavam o público. Cardoso $(1998$, p. 54) relata que o futebol é uma brincadeira feita sob medida para o pobre, já que pode ser jogado sem nenhum equipamento especial, bastando um objeto que possa ser chutado como bola. Toledo (2000, p. 7) faz referência a um cronista paulistano que, analisando jocosamente a carta de Pero Vaz de Caminha, diz: “A terra é plana e chã. Excelente, portanto para a prática do futebol." A carta, considerada certidão de batismo do Brasil, é utilizada pelo cronista para reforçar seu ufanismo, compartilhado por muitos, de que o Brasil é o país do futebol e possui todas as condições necessárias para a prática do esporte.

Nas primeiras duas décadas do século XX, inicia-se o fenômeno de incorporação das grandes massas à elite na sociedade brasileira e, consequentemente, no futebol. A adesão, em 1912, do Corinthians, o mais popular dos times de várzea, à Associação Paulista de Sports Athléticos (APSA) ${ }^{11}$, foi um dos principais frutos dessa incorporação. Outro fator de suma importância para o afrouxamento das barreiras sociais dentro do esporte foi a decisão de cobrar ingressos para os jogos, atitude

\footnotetext{
${ }^{9}$ Durante muito tempo houve uma divisão entre o futebol da elite e o futebol praticado pelas camadas mais pobres da população, pois a elite era a única classe com acesso aos meios necessários para praticar o esporte: uniformes, bola e conjunto de regras.

${ }_{10}$ Termo utilizado para designar os praticantes de futebol da elite inglesa.

${ }^{11}$ Associação elitista fundada pelo Paulistano, pela A.A. Palmeiras e pelo Mackenzie.
} 


\section{Capítulo 1}

tomada pela APSA em 1913, que aumentou a competitividade entre os times, incentivando a contratação de jogadores que, frequentemente, eram negros ou estrangeiros.

Mesmo já consagrado como esporte nacional e das massas, o futebol ainda enfrentava grande resistência por parte de alguns intelectuais. Em diferentes épocas, Rui Barbosa, Graciliano Ramos e Lima Barreto deixavam clara a antipatia pelo esporte. Vejamos a declaração de Graciliano Ramos:

\footnotetext{
Não seria, porventura, melhor exercitar-se a mocidade em jogos nacionais, sem mescla de estrangeirismo, o murro, o cacete, a faca de ponta, por exemplo? [...] Temos esportes em quantidade. Para que metermos o bedelho em coisas estrangeiras? [...] Desenvolvam os músculos, rapazes, ganhem força, desempenem a coluna vertebral. Mas não é necessário ir longe, em procura de esquisitices que têm nomes que vocês nem sabem pronunciar. (RAMOS, 1990, p. 26-29).
}

Também avesso à introdução do futebol, Lima Barreto atribuía ao football a crescente rivalidade entre Rio e São Paulo, a violência e os atos de preconceito contra os negros (RAMOS, 1990, p. 7-17). Mattos (1997, p. 30) relata que Lima Barreto via no futebol um "jogo bárbaro, degradante e corruptor dos princípios de civilidade", chegando a fundar uma liga contra a prática desse esporte. Rui Barbosa deixa clara sua antipatia pelo esporte, um "elemento estranho incorporado à cultura brasileira", e também pelos seus praticantes, a quem se referia como "corja de malandros e vagabundos" (apud FRANCO JÚNIOR, 2007, p. 69).

Apesar dessa resistência em certos meios intelectuais, o futebol tornou-se o esporte mais praticado no país, tanto pela elite quanto pela massa, atingindo, dessa forma, todos os níveis sociais e refletindo, de forma direta, questões da sociedade brasileira.

As duas primeiras décadas do século XX foram marcadas pelo surgimento de ligas representantes do futebol brasileiro: a Federação Brasileira de Sports (1914) e a Federação Brasileira de Football (1915), unificadas em 1916, dando origem à Confederação Brasileira de Desportos (CBD) (FRANCO JÚNIOR, 2007, p. 73). As mesmas décadas também foram marcadas pelo profissionalismo dissimulado, mais vulgarmente conhecido como amadorismo marrom, prática por meio da qual os 


\section{Capítulo 1}

dirigentes dos clubes recompensavam financeiramente os craques que não tinham contrato ou que recebiam "abaixo do merecido".

Nos anos que se seguem ocorreram as primeiras partidas com times estrangeiros, como o Exeter City, da Inglaterra, e a primeira Copa Roca, na Argentina. Esses jogos despertaram nos brasileiros um sentimento de patriotismo e de unidade, pois pessoas de diferentes camadas sociais se reuniam em torno de um mesmo evento. Essa paixão pelo esporte colaborou significativamente para a construção de uma identidade nacional em torno do esporte (FRANCO JÚNIOR, 2007, p. 80).

Outro fator que impulsionou a popularização do futebol foi o preço cobrado pelas arquibancadas mais baratas dos estádios, as gerais. No início da década de XX o preço cobrado para as gerais dos campeonatos paulista e carioca da primeira divisão era $\$ 500$ (quinhentos réis), metade do preço de uma entrada para o cinema, teatro popular ou circo (HOLLANDA et al., 2012).

Durante a década de 1930, com o reflexo da queda da bolsa de Nova York em 1929 e o tumulto na economia e na política do país, os jogadores brasileiros começaram a migrar para times europeus, fugindo do amadorismo em busca de melhores condições. Com essa migração e com o sonho de modernização do país, em 1931, durante o governo Vargas, ironicamente o futebol foi incluído entre as profissões que seriam regulamentadas pela legislação brasileira, refletindo um passo em direção a sua organização. Segundo Toledo (2002, p. 17), foi também na década de 1930 que aconteceu o primeiro boom na publicação de manuais técnicos, movimento favorável à profissionalização, que coincidiu com o surgimento, no Rio de Janeiro, da Sport Ilustrado, primeira revista brasileira dedicada ao futebol.

Para Rosenfeld (1993), a profissionalização do futebol no Brasil foi uma forma de evitar a emigração de jogadores brasileiros para clubes europeus. Essa profissionalização, acompanhada da crescente admiração pelo esporte, impulsionou a construção do estádio Pacaembu, em São Paulo, e do Maracanã, no Rio de Janeiro.

A Copa de 1938 na França marcou uma nova fase do esporte. Além de a seleção ter sido símbolo de uma unidade nacional, iniciou-se um fenômeno descrito por Franco Júnior (2007) como a "carnavalização do futebol”. Surgem bandeiras, hinos, símbolos, mascotes e outras bugigangas para representar o fanatismo do torcedor. Apesar do terceiro lugar, os jogadores foram reconhecidos como heróis do 


\section{Capítulo 1}

país, dentro e fora do jogo: dentro porque, apesar de um esquema tático precário, conquistou o terceiro lugar, e fora porque a seleção era composta também por negros e membros da classe mais baixa da população, fato que em si sugeria um discurso em torno de uma real possibilidade de ascensão e conquista de um lugar na sociedade pelos menos abastados (FRANCO JÚNIOR, 2007, p. 81).

É nessa época que as torcidas ganham mais força nos estádios brasileiros. No fim da década de 1930, o verbete 'torcida' foi incluído no Grande e Novíssimo Diccionário da Língua Portuguesa ${ }^{12}$ (HOLLANDA et al., 2012). Em 1942 é criada a primeira torcida organizada do Brasil: a charanga rubro-negra ${ }^{13}$. Nos anos seguintes, o profissionalismo avançou e os jogadores passaram, cada vez mais, a trocar de clubes por ofertas melhores.

Para Franco Júnior (2007, p. 83), a política desportiva de Vargas não se consolidou devido à eclosão da Segunda Guerra Mundial, e a consagração da identidade nacional por meio do esporte direcionou-se para as disputas sul-americanas durante os anos sem Copa.

Segundo o autor, durante a guerra o futebol foi utilizado como um instrumento de contestação tanto à política interna quanto à internacional por meio de manifestações, como aquela ocorrida durante a inauguração do Pacaembu em 1940. Na ocasião, a delegação do São Paulo foi ovacionada por todo o estádio que, voltado para a tribuna do ditador, gritava o nome do clube de forma provocativa, identificando-o com o estado em protesto ao sufocamento da Revolução Constitucionalista de 1932, representando, de forma simbólica, o inconformismo de São Paulo em relação à ditadura Vargas (FRANCO JÚNIOR, 2007, p. 84). Ou ainda, com a hostilização a clubes vinculados à colônia italiana, como o Palestra Itália de São Paulo, após a entrada do Brasil na guerra.

Mesmo não tendo sido consolidada, a política esportiva de Vargas contribuiu para que o futebol evocasse um sentimento de identidade nacional. Quando Getúlio Vargas perde a direção do processo de democratização do país e Eurico Gaspar Dutra é escolhido como presidente, um novo jogo político se forma, mas o futebol, assim como nos anos anteriores, continua a ser elemento importante. Com os negros

\footnotetext{
${ }^{12}$ FREIRE, Laudelino. Grande e Novíssimo Dicionário da Língua Portuguesa. 5 v. Rio de Janeiro: A Noite, 1939-1944, p. 4.964 e 4.965.

${ }^{13}$ Torcida do Flamengo.
} 


\section{Capítulo 1}

participando do esporte como legítimos representantes da nação, os estádios tornaram-se espaço frequentado também pelas camadas menos abastadas (FRANCO JÚNIOR, 2007, p. 86).

$\mathrm{Na}$ copa de 1950, a primeira realizada após a guerra, a seleção venceu o México por 4 a 0, empatou com a Suíça em 2 a 2, ganhou de 2 a 0 da Iugoslávia, goleou a Suécia por 7 a 1 e a Espanha por 6 a 1, perdendo na final por 2 a 1 para o Uruguai, na partida que ficou conhecida como Maracanaço.

A derrota de 1950 não se resumiu ao campo, mas se estendeu a outros dois setores. Primeiramente, no que se refere à igualdade racial, pois a derrota despertou um debate racista que questionava a habilidade dos atletas de origem negra. Sobre Barbosa, o goleiro da seleção, recaiu grande parte da culpa da derrota (TOLEDO, 2000, p. 72). Além disso, 1950 era ano de eleições e os candidatos estavam utilizando o futebol como um dos principais instrumentos para aumentar sua popularidade ao lado das massas.

O mundial de 1954, realizado na Suíça, também não traz boas recordações aos brasileiros. Com um time desorganizado e perdido em campo, que refletia o governo de Vargas (FRANCO JÚNIOR, 2007, p. 93), a seleção perdeu para a Hungria por 4 a 2 e se envolveu em uma das maiores briga em campo na história das copas.

Finalmente, após golear a Suécia por 5 a 2 na final da Copa de 1958, os jogadores da seleção ficaram conhecidos como os heróis da pátria (FRANCO JÚNIOR, 2007, p. 135). Em 1962, a vitória se repete, dessa vez na final por 3 a 1 contra a então Tchecoslováquia. Era época de prosperidade; os times nacionais faziam campanha pela Europa, auferindo lucros aos seus clubes e dirigentes. Dessa leva, o Botafogo era, sem dúvida, o melhor representante.

Durante o regime militar (1964-1985), o futebol continuou a prosperar. Usado para desviar a atenção do povo das tensões políticas, simbolizar a identidade da nação e promover o amor à pátria, ficou conhecido como “ópio do povo”. Já em 1970, a seleção conquista o tricampeonato no México, no primeiro mundial transmitido pela televisão.

As décadas de 80 e 90 seguem marcadas por uma série de mudanças na organização do futebol brasileiro. Dentre as muitas modificações, destacam-se a criação do clube dos treze em 1987, entidade organizada para defender os interesses 


\section{Capítulo 1}

políticos e comerciais dos grandes clubes; o desaparecimento das competições locais e menores, cedendo lugar às competições nacionais e internacionais; e a ampliação do processo de profissionalização tanto entre os jogadores, tendo como principal marco a regulamentação da Lei Pelé14 ${ }^{14}$ que estabelece o fim da "lei do passe"15, quanto na forma de administração dos clubes, federações e confederações com participação cada vez maior de empresas privadas (TOLEDO, 2000, p. 10).

Em 1989, após 40 anos sem vencer a Copa América, o Brasil conquista a taça na primeira competição oficial em solo brasileiro desde a Copa do Mundo de 1950. Em 1994 a seleção conquistou o tetracampeonato mundial ao vencer a Itália em uma sofrida decisão por pênaltis. Apesar da vitória, o treinador, Carlos Alberto Parreira, e toda a equipe foram alvos de crítica da população e da imprensa esportiva, pois os brasileiros não conseguiam se reconhecer no estilo de jogo apresentado (HELAL \& MURAD, 1995).

Segundo Daolio (2005), o Brasil tinha a chance de conquistar o pentacampeonato e se reafirmar como potência do futebol-arte no mundial da França de 1998, já que a seleção contava com a melhor safra de jogadores dos últimos tempos. Entretanto, apesar de tudo conspirar a favor, a seleção empolgou a torcida em poucos jogos e foi eliminada pela França em uma final lamentável.

Não há dúvidas de que o século XX foi para o Brasil o século do futebol, desde sua instituição até a consagração como paixão nacional. Contudo, próximo do final desse século, mais precisamente a partir do fim da década de 1970, começa-se a

\footnotetext{
${ }^{14}$ Lei que entrou em vigor no dia 24 de março de 1998, substituía e tentava aperfeiçoar a Lei Zico. Determinou o fim da lei do passe. Em dois anos, os jogadores deixam de ser propriedade dos clubes. A lei também estimula a transformação dos clubes em empresas, incentiva a criação de associações para árbitros e determina que os tribunais de justiça esportiva tenham representantes indicados pela sociedade civil. A lei determina ainda a fiscalização das atividades de clubes e federações pelo Ministério Público. O dinheiro do esporte não pode mais ser usado sem que sejam dadas explicações. Disponível em: <http://www.nominuto.com/esporte/esporte/vinte-perguntas-lei-pele/16997/>. Acesso em: 6 fev. 2015.

${ }^{15}$ Lei $\mathrm{n}^{\mathrm{o}}$ 6.354, de 2 de setembro de 1976, que dispõe sobre as relações de trabalho do jogador de futebol. A lei trata da forma, do conteúdo e dos requisitos do contrato de trabalho do atleta, bem como de suas obrigações para com o clube empregador (arts. $1^{\circ}$ a $10^{\circ}$ ); reserva quatro anos à preparação técnica e atlética do jogador (art. $5^{\circ}$ ); regula a cessão temporária e definitiva do atleta por um clube a outro (arts. $11^{\circ}$ a $14^{\circ}$ ); dispõe sobre as penas que podem ser aplicadas ao atleta pelas entidades (art. $15^{\circ}$ ) e pela Justiça Desportiva (art. $19^{\circ}$ ); cuida dos direitos dos trabalhadores da bola, tais como garantia de salário, férias, duração do trabalho, condições de trabalho (arts. $16^{\circ}, 17^{\circ}, 18^{\circ}$ e $20^{\circ}$ a $27^{\circ}$ ); fixa penas para as entidades desportivas que desconsiderarem os direitos de seus atletas (arts. $30^{\circ}$ e $32^{\circ}$ ), define a competência e abrangência da Justiça Desportiva em matéria de litígios trabalhistas. Disponível em: $<\mathrm{http}$ ://www2.camara.gov.br/documentos-e-pesquisa/publicacoes/estnottec/tema11/pdf/200500.pdf $>$. Acesso em: 06 fev. 2015.
} 


\section{Capítulo 1}

falar de uma "crise" no futebol brasileiro. Crise, essa, que se manifesta de diferentes formas: queda do número de espectadores nos estádios, aumento da violência, emigração de jogadores para o exterior em busca de salários milionários, endividamento financeiro dos clubes, escândalos envolvendo altos dirigentes e acusações de corrupção (HELAL \& GORDON, 2002). Esse cenário caótico causa, de certa forma, um descrédito em relação ao nosso futebol e faz com que, não raramente, os torcedores se distanciem do futebol (HELAL \& GORDON, 2002, p. 38). Para alguns pesquisadores, essa crise no futebol brasileiro parece ter ligação direta com as mudanças ocorridas na sociedade local e com as transformações culturais resultantes do processo de globalização. Soma-se a essa crise a aceleração do impacto televisivo, a revolução digital, o sistema pay-per-view e o crescente número de jornais on-line que colaboraram para que as dimensões de espaço e tempo diminuíssem, de forma a quase deixarem de existir. À medida que várias partidas são transmitidas simultaneamente em países de línguas diferentes, surge uma crescente necessidade de tradução, reescritura, adaptação e transmissão de um fenômeno mundial que é, ao mesmo tempo, muito particular a cada cultura.

Diante desses diferentes, ou cada vez mais parecidos, “jeitos de jogar", encontramo-nos frente ao desafio de descrever, para uma cultura, uma partida ou campeonato que aconteceu em outra cultura, que possui história e visão próprias sobre o esporte e um estilo completamente diferente. É dentro dessa perspectiva terminológica cultural que nosso trabalho pretende se inserir.

\subsection{Forma-representação}

Em Lógicas no futebol, Toledo (2002) aborda o futebol como fenômeno cultural de um ponto de vista bastante amplo e extremamente interessante para os propósitos de nossa pesquisa. Nessa abordagem, são analisados diversos atores, tais como profissionais, especialistas e torcedores, entre os quais se estabelece um sistema de relações. O esporte não deixa de ser tratado como uma questão nacional; no entanto, o autor toma os devidos cuidados para não vinculá-lo única e exclusivamente a um suposto ethos brasileiro.

Toledo parte de três realidades no campo: 


\section{Capítulo 1}

- profissionais: jogadores, técnicos, dirigentes, juízes, preparadores, médicos etc.;

- especialistas: a crônica esportiva, que é composta por comentaristas, locutores e repórteres;

- torcedores.

Segundo o autor (TOLEDO, 2002, p. 27), cada um dos grupos sociais enseja uma partida de maneira distinta. Os profissionais são os responsáveis por viabilizar a partida; os especialistas, por decodificar e ordenar a circularidade e a emoção em uma narrativa linear, estabelecendo uma relação entre profissionais e torcedores; e os torcedores, por articular a magia e a emoção que são transmitidas tanto de forma direta, pelos profissionais, quanto de forma indireta, pelos especialistas.

Em uma pesquisa em que o objeto de estudo é o léxico especializado, é de se esperar que o recorte realizado envolva apenas o segundo grupo de atores sociais - os especialistas -, uma vez que são eles os responsáveis pela criação das notícias. Entretanto, tal recorte não será feito, pois, seguindo a lógica de Toledo, acreditamos que os três grupos desempenham, cada um de uma forma, papel importante para a produção do jornalismo esportivo.

Sendo assim, embora não sejam tratados de forma direta, o primeiro e o terceiro grupo permeiam toda a análise. O primeiro porque sem seus membros jogadores, técnicos, dirigentes etc. - nosso objeto de estudo não existiria, sem contar o fato de que o jornalismo emprega expressões e chavões cunhados por atores desse grupo. Ao grupo dos torcedores, que, a princípio, teria participação menos representativa na produção das notícias, atribuímos dois papeis relevantes para a pesquisa. De acordo com a abordagem da Terminologia com a qual trabalhamos, o fazer terminológico está intrinsecamente ligado ao contexto sociocultural em que é produzido e, por isso, o público-alvo, em nosso caso os torcedores que leem os periódicos, desempenha papel ativo na reprodução do discurso. De forma menos significativa, observamos a participação efetiva dos torcedores nas transmissões sociais, por meio de comentários e interação com os narradores. Atribuímos essa grande importância ao terceiro grupo, pois, no futebol, diferentemente da maioria das áreas especializadas, uma pessoa que acompanha jogos e mesas redondas e conversa 


\section{Capítulo 1}

sobre o resultado de uma partida até mesmo na mesa de um bar é, muitas vezes, considerada especialista no assunto; afinal, "entende" de futebol. Além disso, as expressões criadas pelos atores do primeiro e do segundo grupos tornam-se consagradas na língua quando aceitas e reproduzidas pelo terceiro grupo.

Nesta pesquisa, o conceito forma-representação de Toledo (2002), explicado nos parágrafos que seguem, revelou-se um importante aporte teórico para explicar a diferença no comportamento de alguns termos em português e seus equivalentes em inglês.

Seria impossível falar de um jeito brasileiro ou inglês de jogar futebol sem fazer alusão às regras do jogo, que desempenham papel importante na difusão desse esporte. No Brasil, desde sua introdução há registros de empreendimentos editorais que tinham como objetivo divulgar e universalizar as regras e maneiras de jogar (TOLEDO, 2002, p. 31). Em 1912 já circulavam obras com esse intuito, como a série “Guia de Football”. Segundo Toledo (2002, p. 31), essas obras eram limitadas do ponto de vista social, mas preencheram uma lacuna esportiva na vida das cidades, já que os jornais da época pouca atenção davam aos jogos ocorridos.

Como aponta Hollanda et al. (2012, p. 53):

No início do século XX, o futebol era football. O jogador era player, ou sportsman. Nas posições em campo havia o goalkeeper, o right defender, o left defender, o center-half, havia ainda o right wing e o left wing, além do striker. O árbitro era o referee, e os bandeirinhas, os linesmen. Todos se apresentavam no field, no stadium, em jogos cheios de goals, hands, off-sides e fouls.

Esses termos foram utilizados durante quase toda a Primeira República ${ }^{16} \mathrm{e}$ geraram inúmeros debates. No início de 1919, a Biblioteca Nacional sediou a conferência "Football, Peblóla, Pébol ou Balípodo?", que tinha como objetivo discutir o melhor nome para o esporte.

A década de 1920 foi marcada pela produção de manuais para o público mais elitista, ao passo que a década de 1930, devido ao caminho à profissionalização, à difusão do rádio, à imprensa esportiva e à prática do futebol de várzea, foi marcada pelo consumo de manuais por parte de um público que estava comprometido

\footnotetext{
${ }^{16}$ Período que se estendeu de 1889 (Proclamação da República) até a Revolução de 1930.
} 


\section{Capítulo 1}

diretamente com o esporte. Esses manuais surgiram, sobretudo, com o objetivo de ampliar o conhecimento sobre a prática do futebol, de universalizar e de profissionalizar o esporte:

A manipulação da produção desses manuais técnicos, em diversas camadas da sociedade, gerou diferentes processos de internalização das regras. Essas passaram por interpretações e aclimatações distintas nos lugares em que o futebol se projetou como esporte popular, provocando, consequentemente, uma fragmentação no estilo de jogar. (TOLEDO, 2002, p. 50)

Para Toledo (2002), essa fragmentação está condicionada às variabilidades locais impostas pelos interesses, percepções, leituras e entendimentos das mesmas regras, alterando as padronizações e conferindo plasticidades e emoções variadas à sua função, dentro e fora do jogo.

Cada interpretação que favorece uma forma de jogar resulta de "manejos culturais" $" 17$ das regras e favorece o surgimento de estilos próprios.

Nesse sentido, segundo a proposta de Toledo (2002, p. 61), o conjunto de regras que define a atividade como esporte não delimita as maneiras de jogar. $\mathrm{Na}$ verdade, a apropriação e a interpretação cultural que cada região faz das regras é que determinam as "formas de jogo". Justapostas, as regras e as "formas de jogo" dão origem às "representações", que podem ser entendidas como o ajustamento da observação empírica das "formas de jogo" em um plano simbólico, que, por sua vez, consolida as conhecidas "escolas", "jeitos" e "estilos" de jogar.

O conceito aqui apresentado tem o propósito de dar aporte teórico a nossa premissa: o "jogar à brasileira" e o "futebol inglês" permeiam toda a produção jornalística nas duas culturas.

\subsubsection{Futebol arte x Futebol força}

Eu aprendi a jogar na rua, no quintal, que é como se aprende a jogar.

\footnotetext{
${ }^{17}$ Termo cunhado por Toledo (2005, p. 55).
} 


\section{Capítulo 1}

Dentro dessa perspectiva cultural do futebol, o ensaísta-cineasta Pier Paolo Pasolini descreve o esporte como "linguagem", fazendo uma analogia entre discurso e estilo de jogo ao comparar o futebol prosa europeu ao futebol poesia do Brasil (WISNIK, 2008). O primeiro é linear, esquematizado e centrado em um fim: vencer a partida. O segundo é caracterizado pela não linearidade e improviso, visando um espetáculo. A concepção de que o "Brasil reinventou o futebol"18 não é estranha aos apaixonados e envolvidos pelo esporte, assim como os jargões "futebol arte" e "Brazilian football", que são usados e discutidos mundialmente, como no artigo The riddle of Brazilian Soccer: Reflection on the Emancipatory Dimension of Culture (WISNIK, 2006).

Pasolini não é o único a atribuir ao futebol brasileiro uma aura quase mágica que o diferencia dos outros futebóis. Essa é a forma-representação inscrita no plano simbólico de muitos brasileiros e estrangeiros apaixonados pelo esporte. Na verdade, essa forma-representação parece também estar inserida no plano simbólico de historiadores, antropólogos, jornalistas, cronistas e estudiosos do futebol de forma geral. Ao ler artigos como o de Pasolini e ao analisar o discurso de comentaristas esportivos e de amantes do futebol conversando sobre o estado do futebol brasileiro, perguntamo-nos: De onde surgiu essa dicotomia "futebol brasileiro" e "futebol europeu"?

Da mesma forma que cada país tem seus hábitos e costumes, cada país tem seu estilo próprio de jogar futebol. A identidade do futebol brasileiro foi construída a partir de uma série de oposições, tendo como pano de fundo o futebol europeu. Após realizar várias leituras sobre o assunto, compilamos um quadro com os principais elementos do futebol-arte e do futebol-força baseado na caracterização do futebol brasileiro proposta por Damo (1999):

\begin{tabular}{|l|l|}
\hline \multicolumn{1}{|c|}{ Futebol-arte } & \multicolumn{1}{c|}{ Futebol-força } \\
\hline individual & coletivo \\
\hline artístico & competitivo \\
\hline habilidade & força \\
\hline jogo & esporte \\
\hline
\end{tabular}

\footnotetext{
${ }^{18}$ Tema de uma entrevista realizada com o poeta e antropólogo Antonio Risério pela Terra Magazine em novembro de 2007. Disponível em: <http://terramagazine.terra.com.br/interna/0,,OI2056760EI6608,00- Uma+entrevista+parte+II.html>. Acesso em: 15 abr. 2011.
} 


\section{Capítulo 1}

\begin{tabular}{|l|l|}
\hline rua/clube/escola & clube/escola \\
\hline cultura & aprendizado \\
\hline Quadro 1: Futebol brasileiro x futebol europeu.
\end{tabular}

A comparação poderia ser mais extensa, uma vez que o futebol está vinculado a questões estéticas e a ideias de valor. Ressaltamos, ainda, que não devemos tomar os elementos da tabela como antagônicos, mas reconhecemos que a classificação, embora estereotipada, nos auxilia a entender o cerne da questão.

No Brasil, o futebol de rua e de várzea desempenhou papel extremamente importante na construção do estereótipo "futebol-arte", que sempre foi marcado pela agilidade e pelo improviso, desde o espaço físico, o material utilizado, até mesmo a composição das equipes. Por conta desse improviso, o jogador brasileiro sempre teve a reputação de "intuitivo" e "individualista", e, como o educador físico e estudioso do futebol Jocimar Daolio diria, "de não pensar para jogar”.

No Brasil, o futebol faz parte do universo de brincadeiras infantis e a rua foi, por muito tempo, o seu palco. No entanto, devido à urbanização dos grandes centros, a rua e os campos de várzea foram deixando de ser utilizados como espaço comum para a prática do futebol. Tal fato fez com que o futebol passasse a ser praticado em escolinhas.

Segundo Daolio (2005), é a partir desse momento que o futebol brasileiro, até então conhecido como "futebol-arte", passa por uma série de mudanças, incorporando algumas características mais comuns ao futebol europeu. Isso aconteceu naturalmente, pois esses novos espaços que surgiam tinham - e ainda têm - como objetivo principal formar jogadores profissionais, valorizando o preparo físico das crianças.

Nessa busca constante por um excelente preparo físico, os treinadores muitas vezes acabam desconsiderando a importância do futebol como brincadeira, um futebol que dá mais liberdade às crianças, permitindo que explorem suas habilidades individuais e improvisem o tempo todo, já que uma "pelada" não possui posições fixas. Nela, os jogadores exercem diferentes funções em campo, de forma que um mesmo jogador pode jogar uma partida como atacante e outra como zagueiro. Essa falta de sistematização colaborou para o desenvolvimento da "arte do improviso", que foi, por muitos anos, característica do jogador brasileiro.

Diferentemente do futebol brasileiro, como vimos no item 1.2 o futebol inglês 


\section{Capítulo 1}

foi, desde os primórdios, praticado e organizado por um conjunto de regras com o intuito de moldar o caráter da elite inglesa e preparar futuros governantes para governar regiões longínquas e inóspitas. Ou seja, o estilo ofensivo e o lema de vencer o adversário, em detrimento, muitas vezes, do jogar bonito, são as principais características atribuídas ao futebol inglês.

Nos dias de hoje, jogar o "futebol-arte" ou o "futebol-força" talvez seja mais uma decisão da comissão técnica de cada time do que característica inerente ao futebol brasileiro ou ao futebol inglês, ou seja, é muito mais uma questão de qual estilo deve ser adotado. As opiniões do público se dividem. Para alguns, deve-se jogar bonito, fazer firulas, valorizar os dribles e floreios, utilizar a ginga e a malandragem. Para outros, deve-se adotar um estilo mais ofensivo, fazer gols, vencer o adversário e, se possível, somente se possível, jogar bonito.

Diante desses diferentes “jeitos de jogar", encontramo-nos frente ao desafio de descrever, para determinada cultura, uma partida ou um campeonato que aconteceu em cultura distinta, que possui sua própria história, sua visão do esporte e um estilo completamente diferente. 


\section{Capítulo 2 - Pressupostos Teóricos}

Este capítulo faz, inicialmente, uma introdução à Linguística de Corpus (LC); em seguida, apresenta um breve panorama da Terminologia e expõe a vertente aqui adotada, bem como o conceito de texto especializado e a definição de combinatórias léxicas especializadas. Ao fim, discorre sobre alguns conceitos da tradução técnica.

\subsection{Linguística de Corpus}

São inúmeras as definições para Linguística de Corpus (doravante LC) e não nos cabe aqui apresentar um panorama com todas as definições, que diferem consideravelmente umas das outras. Os teóricos da LC frequentemente discordam quanto a sua caracterização. Berber Sardinha (2000), por exemplo, considera a LC uma abordagem, já McEnery e Hardie (2012) a entendem como metodologia. Existem, ainda, os estudiosos que preferem ser mais neutros em suas definições e não tomam nenhum partido, como, por exemplo, Aijmer e Altenberg (1991, p. 2), que definem a LC como o estudo da língua por meio de corpora. Há, ainda, os que juntam as duas definições, como Bowker e Pearson (2002, p. 20), que afirmam ser a LC "uma abordagem ou metodologia para o estudo da língua em uso ${ }^{19}$ ".

Segundo Berber Sardinha (2004), a LC não constitui somente uma metodologia, um instrumental do qual outras áreas podem se valer para o estudo da linguagem. Para o autor, a LC apresenta também uma nova perspectiva de se chegar à linguagem, possibilitando aos seus seguidores produzir conhecimento novo, que muitas vezes questiona teorias linguísticas tradicionais.

Neste trabalho, adotamos duas definições de LC, que, até o presente momento, nos pareceram as mais abrangentes. Primeiramente, assim como Berber Sardinha (2004, p. 32), acreditamos que a LC constitui uma abordagem empirista que entende a linguagem como sistema probabilístico, refletindo uma nova maneira de enxergar essa linguagem, que, consequentemente, poderá originar uma nova teoria linguística.

\footnotetext{
19 "[...] an approach or a methodology for studying language use".
} 


\section{Capítulo 2}

Adotamos, também, a visão de McEnery e Hardie (2012, p. 1), que definem LC como “[...] área que foca em um conjunto de procedimentos, ou métodos, para o estudo da língua $[\ldots]^{20}$.

As duas definições supracitadas se enquadrariam perfeitamente nos propósitos de nossa pesquisa se utilizássemos a LC unicamente para explorar um fenômeno linguístico. No entanto, o escopo de nossa pesquisa vai além da esfera linguística; estabelecemos, sempre que possível, um paralelo entre língua, cultura e história. Ademais, acreditamos que a LC pode e deve ser utilizada como metodologia, e, sim, unicamente como metodologia em alguns tipos de pesquisas.

A visão de McEnery e Hardie (2012) parte dos estudos da linguagem para estabelecer relações com outras áreas, do mesmo modo que fazemos em nossa pesquisa. No entanto, ressaltamos que existe uma tendência mais atual de utilizar a LC em áreas afins; exemplos dessa tendência foram os três cursos de verão oferecidos pela Lancaster University nos três últimos anos (2013-2015): UCREL Summer School in Corpus Linguistics, ESRC Summer School in GIS in Corpus Approaches for Social Sciences e ERC Summer School in GIS for the Digital Humanities. Como podemos observar pelos títulos, somente um dos cursos - Summer School in Corpus Linguistics - foi direcionado a linguistas.

Enfim, não nos cabe aqui criar uma nova definição de LC, apenas atentamos para o fato de que, embora utilizemos essas duas definições, acreditamos que a LC pode ser aplicada para outros fins, que não se restrinjem a pesquisas linguísticas.

Outro ponto a ser discutido em qualquer pesquisa que trabalhe com LC é a definição de corpus. Novamente, adotamos a definição de Berber Sardinha (2004 p. 18):

Um conjunto de dados linguísticos (pertencentes ao uso oral ou escrito da língua, ou a ambos), sistematizados segundo determinados critérios, suficientemente extensos em amplitude e profundidade, de maneira que sejam representativos da totalidade do uso linguístico ou de algum de seus âmbitos, dispostos de tal modo que possam ser processados por computador, com a finalidade de propiciar resultados vários e úteis para a descrição e análise.

\footnotetext{
20 "[...] area which focuses upon a set of procedures, or methods, for studying language [...]”.
} 


\section{Capítulo 2}

Um dos pontos da definição de corpus proposta por Berber Sardinha (2004) é que todo corpus é compilado com o objetivo de ser representativo da totalidade do uso linguístico ou de algum de seus âmbitos. Tendo esse princípio em mente, encontramos uma das principais vantagens dos corpora: a observação da língua natural, ou seja, da língua em uso. Em nossa pesquisa, observamos os usos do futebolês no Brasil e na Inglaterra em contextos reais, prática que possibilita distanciarmo-nos de teorias da Terminologia que tratam o léxico especializado como um construto teórico idealizado, livre de contaminações contextuais.

As noções de análise quantitativa e qualitativa são de extrema importância no que se refere à caracterização da LC. $\mathrm{O}$ fato de trabalhar com a manipulação de grande quantidade de textos por meio de software evidencia sua natureza quantitativa. No entanto, a LC é muitas vezes caracterizada erroneamente como abordagem não qualitativa (LEECH, 1991, p. 110) dada a importância que atribui à frequência e à probabilidade.

É fato que os estudos baseados em corpus partem de uma análise quantitativa, que constitui o primeiro de vários passos a caminho de uma descrição mais detalhada. Contudo, a tendência de associar o quantitativo como oposto de qualitativo acaba muitas vezes ofuscando outras características da LC.

Um corpus pode ser utilizado de diferentes maneiras: para validar, exemplificar, contestar ou formular teorias linguísticas. Tognini-Bonelli (2001) distingue duas abordagens principais de pesquisas realizadas com corpora: abordagem baseada em corpus (corpus-based) e abordagem direcionada pelo corpus (corpus-driven).

$\mathrm{Na}$ abordagem baseada em corpus, o linguista utiliza o corpus para explicitar, testar e exemplificar teorias e hipóteses pré-existentes, e, principalmente, para extrair exemplos. A vantagem dessa abordagem é que a extração de exemplos autênticos, seja para fins lexicográficos ou para a validação de hipóteses, confere mais autoridade à pesquisa. Por outro lado, utilizar o corpus somente para verificar dados limita a visão do linguista, que acaba por ignorar novos fenômenos, deixando de fazer novas descobertas e de desafiar teorias já existentes.

$\mathrm{Na}$ abordagem direcionada pelo corpus, o linguista analisa o corpus sem hipóteses pré-concebidas. O corpus mostra-lhe o caminho a ser percorrido. As 


\section{Capítulo 2}

descrições são feitas sempre com base nas evidências do corpus, possibilitando, assim, novas descobertas. Por isso, dizemos que nessa abordagem o linguista não busca evidências para classificá-las dentro de categorias pré-definidas. Ao contrário, se no decorrer da pesquisa não forem encontrados padrões linguísticos ou se os padrões encontrados não se encaixarem em alguma categoria, os achados constituirão argumentos de extrema relevância para a descrição da linguagem ou para a descoberta de novos fenômenos. Nessa abordagem, o caminho metodológico percorrido pelo linguista é claro: a observação dos dados conduz à formulação de hipóteses, que, consequentemente, leva à generalização dos resultados, possibilitando, assim, a formulação de novas teorias (TOGNINI-BONELLI, 2001, p. 85).

Apesar de as duas abordagens apresentarem características bem distintas, acreditamos que podem ser utilizadas em conjunto. Neste trabalho, utilizamos a abordagem direcionada pelo corpus para extrair os termos a serem estudados a partir das palavras-chave e de seus agrupamentos (clusters). Por outro lado, lançamos mão da abordagem baseada em corpus quando partimos de uma tradução prima facie para a busca dos equivalentes nas linhas de concordância.

\subsubsection{Linguística de Corpus e Terminologia}

É fato que a Linguística de Corpus vem dialogando com a Terminologia já há algum tempo, sobretudo fora do Brasil. Segundo Finatto (2007, p. 450), isso ocorre porque a Terminologia se aproxima cada vez mais de uma das vocações da LC: análise de grandes corpora com o intuito de identificar usos "reais" da língua.

Uma das principais características da LC é a ênfase na frequência, seja de itens lexicais ou de combinatórias, fato que dá mais confiabilidade à extração terminológica, uma vez que a frequência atesta seu uso mais comum. Como explicado no item anterior, a LC parte da premissa de que, por meio da observação de usos extensivos da língua, podemos identificar traços de sistematicidade como colocações, combinatórias léxicas, explicações sobre fenômenos gramaticais etc.

Visto que um dos principais produtos do estudo terminológico é a produção de dicionários especializados, partimos da análise feita por Bowker (2002) sobre alguns problemas relacionados à produção desse tipo de obra e verificamos em Hunston 


\section{Capítulo 2}

(2002) como a LC pode contribuir para a solução desses problemas.

Cinco principais problemas são identificados por Bowker $\left(2002\right.$, p. 15) ${ }^{21}$ no trabalho de compilação de dicionários, tanto de língua geral quanto especializados:

a) incompletude: uma vez que a língua é dinâmica e os significados dos termos não são estáticos, as definições apresentadas por dicionários tendem a ter "data de validade";

b) tamanho: se, ao compilar um dicionário especializado, o pesquisador inserir todo o tipo de informação que considerar relevante, o produto final será muito extenso;

c) ausência de contexto e informação sobre o uso dos termos: tão importante quanto entender o significado ou saber o equivalente de um termo na língua de chegada é saber como usar o termo. Dicionários mais tradicionais não costumam disponibilizar esse tipo de informação, seja de forma explícita, com comentários sobre o uso, ou de forma implícita, incluindo exemplos que privilegiem os usos mais comuns;

d) ausência de informação sobre a frequência dos termos: esse tipo de informação tende a ser ignorada em dicionários mais tradicionais;

e) ausência de uma diagramação que facilite a busca de informações: muitas vezes um dicionário disponibiliza informações relevantes a respeito de um termo; no entanto, a apresentação dessas informações não é bem organizada.

Em contrapartida, Hunston $(2002 \text {, p. } 96)^{22}$ lista cinco aspectos que a LC vem introduzindo na compilação de dicionários de língua geral e especializados:

a) ênfase na frequência: a LC introduziu a inclusão de informações sobre a frequência dos verbetes que compõem um dicionário. Essa frequência pode ser apresentada de forma explícita, com a introdução do grau de frequência da palavra ou do termo, ou de forma implícita, por meio da decisão, por exemplo,

21 A autora descreve os cinco tópicos detalhadamente. Aqui, apresentamos somente o problema colocado pela autora com uma breve explicação.

22 Assim como Bowker (2002), Hunston (2002) descreve os cinco tópicos detalhadamente. Novamente, apresentamos somente o problema colocado pela autora com uma breve explicação. 


\section{Capítulo 2}

de qual acepção da palavra ou do termo deve ser apresentada primeiro;

b) ênfase em colocações e fraseologias: a apresentação de colocados e fraseologias é uma tendência de dicionários modernos e, assim como a ênfase na frequência, pode ser realizada direta ou indiretamente. Diretamente, quando o verbete lista os colocados e fraseologias mais ocorrentes, e indiretamente, quando seleciona exemplos que contenham esses colocados e fraseologias;

c) ênfase na variação: a compilação de um dicionário por meio da LC permite que o pesquisador tenha acesso, por exemplo, aos tipos e gêneros textuais em que um termo ocorre com maior frequência, a fim de informar o consulente sobre essas peculiaridades;

d) ênfase no aspecto léxico-gramatical: alguns dicionários baseados em LC incluem, por exemplo, listas de verbos seguidos por preposições específicas, como o COBUILD Project: the Grammar Patterns series, que foca a apresentação de padrões gramaticais;

e) ênfase na autenticidade: talvez a maior contribuição da LC para a produção de dicionários, pois os exemplos ilustram o uso "real", disponibilizando, assim, a situação de comunicação em que a palavra ou termo ocorre.

Se observarmos os problemas comuns à construção de dicionários, apresentados por Bowker (2002), e as vantagens que a LC traz à Terminologia, listadas por Hunston (2002), veremos que o uso da LC em pesquisas terminológicas é mais do que justificável.

\subsubsection{Linguística de Corpus e Tradução}

O uso de tecnologia na tradução cresce a cada dia. Baker (1993, 1995, 1996), Tognini-Bonelli (1996, 1991), Bowker (1999), Hunston (2002), Laviosa (2002), Kübler e Aston (2010), Zanettin (2012) e Viana e Tagnin (2015) descrevem pesquisas que exploram a contribuição da Linguística de Corpus para os estudos da Tradução.

Ainda em 1972, Holmes já advogava que a teoria da tradução deveria lançar mão de novos desenvolvimentos em outras disciplinas para sua evolução e que a teoria não deveria ser estudada separadamente da prática. Se tomarmos a divisão dos 


\section{Capítulo 2}

elementos presentes no estudo da tradução proposta por Holmes (1988, p. 71-77), teremos:

a) estudos puros da tradução: são divididos em estudos descritivos e estudos teóricos. Os estudos descritivos têm como objetivo descrever o fenômeno da tradução e os estudos teóricos almejam estabelecer princípios gerais, por meio dos quais o fenômeno da tradução pode ser descrito e explicado;

b) estudos aplicados da tradução: referem-se ao ensino da tradução. Abrangem tanto o estudo de língua estrangeira quanto a educação do tradutor.

Ao considerar a proposta de Holmes, observamos duas vertentes principais de estudos da tradução: a pura e a aplicada; e, segundo alguns estudiosos, como Baker (1992) e Ulrych (1997), a Linguística de Corpus pode ser a chave para unir essas duas vertentes.

Primeiramente, a LC contribui para os estudos descritivos da tradução uma vez que, por meio da análise de corpora paralelos ${ }^{23}$, torna-se possível a observação dos processos de tradução. As ferramentas de análise de corpora e os alinhadores de texto facilitam a manipulação dos corpora, de forma que pesquisadores possam analisar uma grande quantidade de contextos de tradução a fim de estabelecer princípios gerais por meio dos quais o fenômeno da tradução pode ser descrito e explicado, contribuindo, também, para os estudos teóricos. A análise de grande quantidade de traduções é imprescindível para que generalizações acerca do processo sejam feitas e, consequentemente, teorias sejam elaboradas.

A contribuição da LC para os estudos aplicados da tradução nos parece um desdobramento de sua contribuição para os estudos puros, uma vez que, ao introduzir a LC no ensino de tradução, os alunos passarão a observar as normas de tradução colocadas em prática por tradutores profissionais e a seguir ou questionar as teorias existentes com maior embasamento. Além disso, há uma grande tendência no uso de corpora paralelos e comparáveis na educação de tradutores (VIANA \& TAGNIN, 2015). Os corpora paralelos auxiliam aprendizes a encontrar equivalentes de forma

\footnotetext{
${ }^{23}$ Corpora compostos por textos na língua de partida e suas traduções na(s) língua(s) de chegada.
} 


\section{Capítulo 2}

bastante simples, já que são, na grande maioria, alinhados. Dessa forma, basta o pesquisador buscar uma palavra na língua de partida que terá acesso a sua tradução na língua de chegada.

Tal técnica possui vantagens e desvantagens, pois, apesar de a busca ser simples, os equivalentes apresentados são traduções. Sendo assim, não existe garantia da qualidade da tradução, já que os equivalentes encontrados são fruto de decisões tomadas pelo tradutor, tendo em vista seus respectivos contextos na língua de partida e na língua de chegada, seu treinamento e seu conhecimento linguístico e cultural das línguas com as quais trabalha. Essas decisões podem ou não refletir o uso convencional de uma palavra, termo ou expressão. Construídos somente com textos originais, os corpora comparáveis ${ }^{24}$ fornecem a palavra, termo ou expressão efetivamente utilizados em determinada situação de comunicação. Segundo Tagnin (2007), o corpus apresentará o termo mais provável de ocorrer no contexto que o tradutor estiver pesquisando. Em suma, o conhecimento adquirido durante a pesquisa mostra-se enriquecedor e fundamental para a formação do tradutor.

\subsubsection{Linguística de Corpus e convencionalidade}

Convencionalidade é definida por Tagnin (2005, p. 14) como a "forma peculiar de expressão numa dada língua ou comunidade lingüística." "Como dizer" exemplifica a questão da convencionalidade de forma muito clara. Professores e estudantes de línguas estrangeiras, assim como tradutores, frequentemente se veem diante de uma situação em que sabem o que tem de ser dito, mas não estão certos se o que têm em mente reflete a forma mais natural de dizê-lo.

A convencionalidade caminha lado a lado com a LC, pois ambas partilham uma mesma visão de língua: embora muitas combinações e arranjos sejam gramaticalmente possíveis, podem ter baixa probabilidade de ocorrência.

Presente em diversos níveis da língua, nesta seção a convencionalidade será apresentada nos níveis sintático e semântico. "O nível sintático compreende a combinabilidade dos elementos, sua ordem e sua gramaticalidade" (TAGNIN, 2013,

\footnotetext{
${ }^{24}$ Compostos por textos originalmente escritos em duas ou mais línguas e compilados de acordo com os mesmos critérios.
} 


\section{Capítulo 2}

p. 25). A combinabilidade refere-se à propriedade que os elementos linguísticos têm de se combinar entre si, ou seja, algumas palavras atraem a companhia de outras. Por exemplo, em português dizemos 'gol de honra', ao passo que em inglês não se diz honour goal, mas sim consolation goal.

Sabe-se que tanto na língua geral quanto em línguas de especialidade existem construções e expressões que desafiam a gramática normativa, "mas cujo uso é consagrado" (TAGNIN, 2013, p. 126). Em nosso caso, um exemplo a ser elucidado é quando jogadores ingleses conversam entre si ou dão entrevistas a emissoras de TV falando em futebolês. Leith (1998, p. 18) afirma que os jogadores amam o particípio passado, mas nunca o usam na passiva e nem no present perfect. É quase praxe ouvir frases como The boy done good, em vez de The boy did well. Embora a primeira frase esteja gramaticalmente incorreta, é de uso comum entre os jogadores.

É no nível semântico que observamos a relação não motivada de uma expressão e seu significado. Como explicaríamos, por exemplo, a origem da expressão "cavalo paraguaio"? ${ }^{25}$

Tanto os exemplos do nível sintático quanto o exemplo do nível semântico reforçam a ideia de Sinclair (1984, p. 203) de que existe um grande número de frases gramaticalmente corretas que não soam natural ao falante nativo. Em geral essas frases ocorrem em textos produzidos em situações comunicativas específicas, como, por exemplo, na produção oral e escrita de falantes não nativos.

Por fim, uma vez que a Linguística de Corpus se ocupa do reconhecimento de usos concretos da linguagem em amostras extensivas, configura-se como uma abordagem que permite ao linguista descrever os fenômenos linguísticos de forma bem detalhada, mostrando-se essencial para o estudo da convencionalidade, tanto em textos originais quanto em textos traduzidos.

Por fim, encerramos este item com uma citação de Hanks (1996, p. 85), que mostra, de forma bastante clara, a importância do reconhecimento da convencionalidade na língua e como a LC contribui para seu estudo:

O potencial criativo da língua é inegável, mas a análise das linhas de concordância de um corpus nos mostra que somos criaturas de

\footnotetext{
${ }^{25}$ Expressão antiga utilizada para clubes, geralmente sem tradição, que disparam na tabela no início da competição e depois não conseguem manter o ritmo e acabam na classificação intermediária.
} 


\section{Capítulo 2}

hábito, bastante previsíveis, que tendem a repetir os mesmos chavões e clichés nos enunciados. Se assim não fosse, as línguas não funcionariam. Os seres humanos não suportam muita criatividade. ${ }^{26}$

\subsection{Terminologia}

Em nossa pesquisa de mestrado (MATUDA, 2011) realizamos um estudo bastante detalhado sobre as vertentes terminológicas desde a origem da Terminologia, que data do século XVI com estudos na área da química, botânica e zoologia (ALMEIDA, 2003, p. 211), passando pela Teoria Geral da Terminologia (TGT) de Eugen Wüster, até abordagens mais recentes como a Socioterminologia (GAUDIN, 1993), a Teoria Comunicativa da Terminologia (TCT) (CABRÉ, [1999] 2005), a Teoria Sociocognitiva da Terminologia (TEMMERMAN, 2000) e a Terminologia Textual (KRIEGER \& FINATTO, 2004).

Após analisar os pressupostos de cada abordagem, optamos por adotar a Terminologia Textual (TT) como aporte teórico para nossa pesquisa. Quatro anos se passaram desde então. Desenvolvemos um projeto de doutorado baseado em algumas hipóteses levantadas ainda em nossa pesquisa de mestrado, assistimos a disciplinas da pós-graduação, participamos de diversos congressos, apresentamos os resultados parciais da análise de dados em eventos de Tradução, Linguística de Corpus e Terminologia e participamos de cursos e workshops. No entanto, apesar da constante busca por informações e teorias mais atuais sobre Terminologia, cremos que Terminologia Textual continua sendo adequada ao objetivo de nossa pesquisa.

Nos itens que seguem apresentamos a vertente terminológica que orientou nossa análise. Primeiramente, introduzimos o principal objeto de estudo da Terminologia Textual, qual seja o texto especializado; em seguida, explicamos as principais características da TT; ao fim, discutimos o conceito de combinatórias léxicas especializadas (CLEs).

\footnotetext{
26 "The creative potential of language is undeniable, but the concordances to a corpus remind us forcibly that in most of our utterances we are creatures of habit, immensely predictable, rehearsing the same old platitudes and the same old clichés in almost everything we say. If it were not so, language would become unworkable. Humankind cannot bear very much creativity".
} 


\section{Capítulo 2}

\subsubsection{O texto especializado}

Seria inviável falar de Terminologia Textual sem discutir seu objeto de estudo: o texto especializado. Antes de adentrar as características desse tipo de texto, ressaltamos que a importância do texto para a Terminologia não é exclusividade da Terminologia Textual. Já na década de 1980 a linguística do texto (HALLIDAY, 1978; BEAUGRANDE \& DRESSLER, 1981) chamava atenção para o papel do texto na investigação terminológica. Ademais, para teorias mais atuais de terminologia, como a Socioterminologia e a Teoria Comunicativa da Terminologia ${ }^{27}$, existe uma forte relação entre a importância do texto e a característica comunicativa que postulam. No entanto, foi somente com a Terminologia Textual que o texto deixou de ser um aspecto apenas relevante para assumir o papel central na investigação terminológica. Mas, afinal, o que seria o texto especializado?

De acordo com Finatto e Krieger (2004), desde o final do século XX estudiosos têm-se dedicado a pesquisar critérios identificadores de textos especializados motivados pelo princípio de que a caracterização desse tipo de texto não pode ser realizada somente pelo componente temático. Dentre esses pesquisadores, Hoffmann (1998 apud Finatto \& Krieger, 2004, p. 113) empresta a definição de texto técnico utilizada nesta pesquisa:

O texto especializado é o instrumento ou resultado de uma atividade comunicativa socioprodutiva especializada. Compõe uma unidade estrutural e funcional (um todo) e está formado por um conjunto ordenado e finito de orações coerentes pragmática, sintática e semanticamente ou de unidades com valor de oração, que, como signos linguísticos complexos de enunciados complexos do conhecimento humano e das circunstâncias complexas, correspondem à realidade objetiva.

Com base na definição de Hoffmann, podemos observar que o texto especializado, diferentemente do que ocorre nas vertentes mais tradicionais da terminologia, não se limita à presença de termos técnicos, mas é formado pelo conjunto dos vários recursos linguísticos utilizados em determinado âmbito de comunicação.

\footnotetext{
${ }^{27}$ A respeito dessas duas teorias, consultar Matuda, 2011.
} 


\section{Capítulo 2}

Ainda segundo Hoffmann (1998 apud FINATTO \& KRIEGER, 2004, p. 113), o texto técnico possui dois eixos básicos: um horizontal, relacionado ao critério temático, englobando diferentes disciplinas e suas eventuais subdivisões; e um vertical, relacionado ao grau de especialização do texto, ou seja, à densidade terminológica. A classificação de Hoffmann ressalta o fator pragmático no âmbito das comunicações especializadas e enfatiza o papel que as unidades lexicais assumem em diferentes contextos especializados de comunicação especializada.

Alguns tipos de texto possuem maior densidade terminológica do que outros: em nosso caso, as notícias de resultados de partidas possuem densidade terminológica menor do que os relatos de partida minuto a minuto. Um texto sobre resultado de partida publicado por um tabloide inglês pode apresentar uma terminologia bem distinta daquela expressa em um texto do mesmo gênero publicado por um jornal mais tradicional. Essa variação terminológica não se refere apenas à densidade terminológica de um texto, mas também às diferentes terminologias encontradas em periódicos distintos. Por esse motivo, mais do que o tema, o grau de densidade informativa, a forma de se comunicar, a situação em que se comunica e para quem se comunica constituem fatores determinantes do grau de especialização de um texto.

Finatto e Krieger (2004, p. 116) propõem que a variação tipológica no âmbito da comunicação especializada reflete, por exemplo, na distinção entre uma tese, um artigo de periódico altamente especializado em determinada área do conhecimento e um texto de jornal ou de revista informativa redigido com a finalidade de divulgar ao grande público um acontecimento científico. No nosso caso, essa distinção não pode ser aplicada por vários motivos. Primeiramente, devido à grande repercussão que o futebol tem na sociedade moderna, a delimitação de "grande público" e de especialistas se torna um pouco controversa. Em um primeiro momento, poderíamos caracterizar os jornalistas esportivos, jogadores, técnicos e membros da comissão técnica como especialistas e os leitores e fãs de futebol em geral como "grande público". No entanto, acontece que, em se tratando de futebol, todo torcedor pode ser considerado um especialista na área.

Devido a essa grande dificuldade de delimitação de 'grande público' e de especialistas, adotamos, aqui, a classificação de atores sociais do futebol, proposta por Toledo (2002, p. 15): 


\section{Capítulo 2}

Parto de três [atores sociais] dentro do campo esportivo: os profissionais (jogadores, técnicos, dirigentes, juízes, preparadores, médicos, etc.), os especialistas (a crônica esportiva) e o conjunto genérico de torcedores, "comuns" ou nomeados e reunidos em certas coletividades específicas.

Essa classificação é utilizada por Toledo para uma análise das lógicas do futebol, com o propósito de caracterizar os grupos sociais que se expressam por meio do futebolês. Dentro dessa ordem, os profissionais são todos aqueles que interferem diretamente no jogo, quer seja dentro do campo, como os jogadores, ou fora do campo, como os dirigentes e instituições, como as federações. Os especialistas são representados pela crônica esportiva e pelo jornalismo esportivo ${ }^{28}$ e, segundo Toledo, ocupam um lugar simbólico equidistante entre os profissionais e os torcedores, pois não participam efetivamente da partida, mas também não se comprometem em um nível de emoção partidária, pelo menos em teoria. Por fim, o "grande público" é caracterizado pelos torcedores.

É a classe dos especialistas que mais nos interessa neste trabalho, pois é através do produto do fazer jornalístico que observamos o futebol fora de seu locus de ritualização máxima, que é a partida. Ademais, é também por meio dos textos jornalísticos que o futebol alcança o "grande público". Contudo, não podemos deixar de enfatizar a importância que o terceiro grupo, o conjunto genérico de torcedores, desempenha em nossa pesquisa, pois frequentemente recorremos a torcedores e amantes do esporte para melhor entender uma jogada ou drible.

Deve-se somar, ainda, à classificação de Toledo o grau de densidade informativa da notícia, a forma de se comunicar, os traços de impessoalidade do jornalista, o contexto em que a notícia foi produzida ${ }^{29}$ e o propósito da comunicação -

\footnotetext{
${ }^{28}$ Embora a crônica esportiva faça parte do grupo de especialistas dentro da classificação com a qual optamos por trabalhar, é importante ressaltar que não coletamos textos do gênero para a compilação do corpus de estudo. Além disso, há no fazer jornalístico um reivindicado distanciamento entre o jornalista e o fato, que se opõe à condição dos cronistas, que narram e descrevem uma partida expressando opinião pessoal e de forma mais literária, fugindo à linguagem meramente descritiva que é o objeto de estudo desta pesquisa.

${ }^{29}$ Uma notícia sobre o resultado de partida de um jogo do campeonato brasileiro provavelmente é produzida em um contexto mais específico e, portanto, voltada para um público mais específico do que uma notícia, por exemplo, sobre uma partida de Copa do Mundo, pois durante esse acontecimento mais pessoas torcem, inclusive torcedores não habituais.
} 


\section{Capítulo 2}

que pode ser mais informativo, mais descritivo ou mais técnico - para que, assim, seja possível caracterizar o texto técnico propriamente.

Uma vez caracterizado seu principal objeto de estudo, passemos, agora, a uma breve discussão sobre as características da Terminologia Textual.

\subsubsection{Terminologia Textual}

Para Finatto e Krieger (2004, p. 119), essa Terminologia tem como principal característica o fato de considerar o texto como o "habitat natural" das terminologias. Dessa forma, o objeto 'termo' dá lugar ao objeto 'texto'.

A TT possui duas características principais. A primeira refere-se ao reconhecimento do papel do cenário comunicativo e, consequentemente, do texto especializado para a descrição de uma terminologia. A segunda está relacionada ao estudo e à caracterização do texto especializado.

Ao reconhecer o papel do cenário comunicativo, a Terminologia Textual parte do pressuposto de que os termos são utilizados em situação de comunicação e que, portanto, não devem, ou melhor, não podem ser estudados à parte do contexto sociocultural em que ocorrem.

Os termos passaram a ser analisados em funcionamento, ou seja, em textos especializados, permitindo, assim, a verificação de fenômenos até então ignorados ou deixados em segundo plano pelos terminólogos. O contexto discursivo, antes considerado insignificante, passa a representar uma das principais características da Terminologia, contribuindo para um novo tratamento das unidades terminológicas, abandonando o pressuposto de que os termos constituem construtos teóricos idealizados em um sistema linguístico independente.

Enfim, de acordo com essa perspectiva o texto passa a ser o principal objeto de estudo da Terminologia e é justamente esse fato que permite a inclusão de outros objetos, como variações, neologismos, sintagmas terminológicos, colocações, coligações e combinatórias léxicas de um dado cenário de comunicação, levando em conta não somente os aspectos linguísticos, mas também os comunicativos, cognitivos e pragmáticos.

Com base nesses princípios, acreditamos que o estudo terminológico aqui 


\section{Capítulo 2}

proposto vai além da investigação do termo técnico na língua de partida e seu equivalente na língua de chegada. Partindo dos pressupostos teóricos da TT, propomos estudar mais do que o termo; comprometemo-nos com a investigação do texto em que os termos ocorrem e, consequentemente, com um melhor entendimento das diferenças culturais do futebol brasileiro e do futebol inglês.

\subsubsection{Termos e Combinatórias Léxicas Especializadas}

Conforme exposto no item anterior, a vertente de Terminologia adotada confere à Terminologia diferentes objetos de estudo, como termos, variações, neologismos, sintagmas terminológicos, colocações, coligações e combinatórias léxicas especializadas de uma dada língua de especialidade. Com base nos objetivos de nossa pesquisa, optamos por investigar os termos e combinatórias léxicas especializadas (CLEs) do futebol. Temos ciência da importância de neologismos, colocações, coligações e dos outros objetos de estudo presentes no texto especializado. Contudo, trabalhar com todos esses elementos extrapolaria o escopo desta tese.

Em nossa pesquisa, adotamos uma visão de termo proposta por Finatto (2007, p. 223): “[...] condição especial da palavra, um signo linguístico dotado de significado e significante, e atrelado a uma determinada unidade e corpo de conhecimentos historicamente estabelecidos."

De acordo com essa definição, não existem critérios específicos que definam um termo. Uma unidade lexical pode assumir status de termo dependendo do contexto em que ocorre. Por exemplo, a unidade lexical 'cartão' assume status de termo no futebolês, pois possui um significado e um significante que adquirem um estatuto peculiar nesse âmbito de comunicação. Portanto, a situação de uso é fundamental para determinar o significado de um termo.

Embora não seja o objeto de estudo central da Terminologia Textual, o termo é de suma importância no âmbito das línguas de especialidade. Como ter uma conversa sobre futebol sem utilizar os termos 'gol', 'falta' ou 'técnico'? Entretanto, acreditamos que conhecer o significado de um termo e identificar seu equivalente em língua estrangeira é apenas um dos desafios encontrados por redatores técnicos e 


\section{Capítulo 2}

tradutores. Uma lista de termos juntamente com seus significados e equivalentes na língua de chegada é primordial para uma redação técnica bem escrita. No entanto, saber como utilizar esses termos é tão importante quanto conhecer seus significados.

Em nossa pesquisa de mestrado (MATUDA, 2011), partimos do princípio de que um termo raramente ocorre sozinho, ou seja, é muito provável que venha acompanhado de um colocado, formando, assim, uma colocação e, muitas vezes, seja até parte de uma unidade de sentido maior. Portanto, trabalhamos com unidades fraseológicas especializadas (UFEs) do futebol em inglês e português extraídas do corpus de estudo, deixando de lado termos individuais. Dessa forma, na análise abordamos, por exemplo, a UFE 'fazer um gol', mas não abordamos o termo 'gol' individualmente.

Continuemos com o exemplo de 'gol' a fim de exemplificar a mudança em nossa concepção dos objetos de estudo da Terminologia. Em uma conversa, ou na produção de um texto sobre futebol, o interlocutor que deseja utilizar o termo 'gol' em inglês deve estar ciente de que, para se referir ao espaço retangular limitado por uma baliza horizontal e duas balizas verticais, às quais se prende uma rede, e demarcado por uma linha paralela à baliza horizontal, o termo correto é goal. Da mesma forma, para se referir ao ponto que um time faz quando a bola ultrapassa por completo a linha do gol, também deve selecionar o termo goal. No entanto, esse interlocutor deve ser informado sobre os possíveis equivalentes e colocados quando precisar utilizar o termo em expressões, como, por exemplo, 'fazer um gol' em inglês. Nesse caso, o conhecimento dos colocados do termo e das expressões em que ele ocorre é fundamental, uma vez que a escolha por opções equivocadas pode demonstrar desconhecimento das convenções da área e gerar interpretações inadequadas, comprometendo, assim, a qualidade da comunicação.

Reconhecida a importância do estudo do termo e apresentada a definição de 'termo' adotada em nossa pesquisa, demonstramos, no exemplo acima, a relevância do estudo das expressões em que o termo ocorre. Expressões para as quais, em nossa pesquisa de mestrado, utilizamos o conceito de unidades fraseológicas especializadas. A combinação recorrente de itens lexicais tem sido objeto de vários estudos e, dependendo de sua formação, recebem diferentes nomeações, tais como: 


\section{Capítulo 2}

- colocação (HEID, 1992, 1994, 1998; MARTIN, 1992; SCHAETZEN, 1993; DESMET, 1996);

- coocorrência (LAINÉ, PAVEL \& BOILEAU, 1992; PESANT \& THIBAULT, 1993);

- frasema (GRÉCIANO, 1993);

- fraseologismo (BLAIS, 1993; PAVEL, 1993);

- entidade fraseológica (GOUADEC, 1994);

- unidade fraseológica (GOUADEC, 1994; BEVILACQUA, 1996);

- unidade fraseológica especializada (CABRÉ, LORENTE \& ESTOPÀ, 1996).

- colocação de linguagens de especialidade (L'HOMME, 1998);

- combinatória léxica especializada (L'HOMME \& BERTRAND, 2000; BEVILACQUA et al., 2012);

- item lexical multi-palavra (PALUMBO, 2003);

- fraseologia (KRIEGER \& FINATTO, 2004);

- unidade de tradução especializada (TEIXEIRA, 2008).

Essa variedade terminológica não corresponde, necessariamente, a uma mesma variedade conceitual. Ou seja, podem ou não se referir ao mesmo objeto. Discutir todas as definições e seus critérios de delimitações foge do escopo de nossa pesquisa. Por esse motivo, nos parágrafos que seguem apresentaremos o termo, a definição e os critérios de identificação aqui adotados. Ressaltamos que a escolha foi realizada considerando dois fatores principais: 1) o objetivo de nossa pesquisa; e 2) a relação direta que nosso trabalho mantém com a tradução.

No que se refere ao primeiro fator, o objetivo de nossa pesquisa, eliminamos, em um primeiro momento, as abordagens que partem de padrões morfossintáticos pré-estabelecidos para a identificação dessas expressões. A análise de padrões morfossintáticos não se mostra relevante ao dar prioridade a termos e combinatórias culturalmente marcadas, uma vez que a extração de tais padrões, como, por exemplo, substantivo + substantivo ou substantivo + verbo, não garante a identificação dos objetos de nosso interesse.

O segundo fator, a relação com a tradução, desempenhou papel fundamental na escolha da vertente teórica utilizada para descrever combinações recorrentes de 


\section{Capítulo 2}

itens lexicais, da definição e dos critérios de identificação, já que em todo momento discorremos sobre a problemática do estabelecimento de equivalentes tradutórios e também chamamos atenção, ainda que de forma menos incisiva, para a importância de preparar os futuros tradutores para a produção de textos que estejam em conformidade com as convenções da língua de especialidade com a qual trabalham.

Enfim, no âmbito desta pesquisa, adotamos o conceito de 'combinatória léxica especializada' (CLE) para designar as expressões em que os termos ocorrem. Bevilacqua et al. (2012, p. 242) apresentam a seguinte definição de CLE:

Entendemos as CLEs como unidades sintagmáticas recorrentes nas situações de comunicação de áreas temáticas que revelam preferência marcante por especificidades e por convenções próprias do idioma, da área e/ou do gênero textual em que ocorrem. São colocações e fraseologismos que não podem ser explicados unicamente por exigências gramaticais, estilísticas e afinidades semânticas, pois resultam de uma seleção restritiva condicionada ao modo de dizer característico de cada âmbito do conhecimento. Seu uso é justificado somente pela repetição frequente e pelo consenso da comunidade de falantes que compartilha a mesma especialidade.

O primeiro ponto interessante dessa definição é que se baseia na frequência das unidades sintagmáticas em situações de comunicação em áreas técnicas. Situações, essas, que mostram preferências por convenções próprias do idioma, da área e do gênero textual em que ocorrem, ponto que dialoga com a Linguística de Corpus, ao considerar a frequência, e com a Terminologia Textual, ao observar a situação de comunicação.

O fato de que as CLEs são colocações ou fraseologismos que resultam de uma seleção restritiva condicionada ao modo de dizer característico de cada âmbito do conhecimento nos deu a liberdade de trabalhar com combinatórias de duas palavras, como cricket score, e com combinatórias maiores, como stab the ball home. Por fim, seu uso em situação autêntica de comunicação, caracterizado pela repetição frequente e pelo consenso da comunidade de falantes que compartilha a mesma especialidade, justifica os critérios adotados para a validação das CLEs encontradas no corpus $^{30}$.

No que se refere à delimitação de unidades fraseológicas, Tognini-Bonelli (2001, p. 104) resume de forma muito clara essa problemática: “Onde está a fronteira

\footnotetext{
${ }^{30}$ Os critérios de validação das CLEs são apresentados no item 3.5.1.
} 


\section{Capítulo 2}

entre um item relativamente independente, como uma palavra ou um termo técnico, e um item onde o contexto se torna parte de uma expressão, que, conforme defende Sinclair, é, na realidade, um item lexical multipalavra?"31.

Diante da problemática de delimitação das CLEs, optamos por considerar as características presentes na definição de Bevilacqua et al. (2012) e seguir os procedimentos da Linguística de Corpus. Em suma, as CLEs identificadas nesta pesquisa são compostas por um termo e um ou mais itens lexicais. A quantidade de itens lexicais foi delimitada pela análise das linhas de concordância e dos colocados dos termos, procedimentos detalhados no item 3.5.1.

\subsection{Tradução técnica e cultura}

Neste item, apresentamos o modo como entendemos a tradução técnica. Primeiramente, introduzimos o conceito de cultura para, ao final, discutir a relevância de aspectos culturais no âmbito da tradução técnica.

2.3.1 Mas, afinal, o que é cultura?

Os primeiros estudos científicos sobre cultura datam de quase cem anos. No entanto, ainda hoje o fenômeno é muito mais incompreendido do que compreendido (HALL, 1990, p. 183). O décimo volume da Enciclopédia de Línguas e Linguística (Encyclopedia of Language and Linguistics) confirmou, em 1994, que, mesmo após um século de esforços para definir cultura de forma apropriada, ainda não existia um consenso sobre o significado e a origem do termo (KATAN, 2004, p. 24). Os interculturalistas Trompenaars e Hampden-Turner (1997, p. 21) relatam que em seus mais de vinte anos de estudos culturais nunca encontraram duas visões similares sobre o conceito de cultura.

\footnotetext{
31، Where is the boundary between a relatively independent item, such as the word as a technical term, and one where the environment becomes part of a phrase, which, Sinclair argues, is effectively a multiword lexical item.?"
} 


\section{Capítulo 2}

Dada a complexidade do conceito, perguntamo-nos: Existe, realmente, a necessidade de se definir cultura em nosso trabalho ou estaríamos apenas preenchendo uma formalidade teórica em nossa pesquisa?

Após refletir sobre o assunto e a necessidade de definição de 'cultura', que, vale ressaltar, está presente em todos os capítulos de nossa tese, decidimos por definila, ou melhor, explicar ao leitor como a compreendemos. Dessa forma, deixamos claro que não definimos cultura como parte do exercício acadêmico de escrita de uma tese, mas sim porque acreditamos que sua definição delimita o modo como uma cultura é percebida, vivida, passada de geração para geração e, em nosso, caso, de uma língua para outra.

Para grande parte dos antropólogos que abordam o tema, como, por exemplo, Alfred Luis Kroeber e Clyde Kluckhohn, cultura pode ser descrita como o modo de vida de um povo, a somatória dos seus padrões de comportamento adquiridos informalmente e suas atitudes (KROEBER \& KLUCKHOHN, 1952, apud HALL, 1990, p. 20).

Para o linguista Edward Sapir (1994), cultura é um complexo que inclui elementos distintos, como conhecimento, crenças, arte, moral, leis, hábitos e qualquer comportamento adquirido inconscientemente por um homem como membro de dada sociedade.

As definições apresentadas têm em comum o fato de que cultura é assimilada informalmente, ou seja, seguimos suas regras inconscientemente.

Outra abordagem bastante interessante é a do linguista americano George L. Trager, que trata cultura como uma forma de comunicação em que a língua, um dos sistemas mais complexos de mensagens, é utilizada como modelo para análise do 'outro' (HALL, 1990, p. 28). A abordagem de Trager nos parece bastante interessante, uma vez que a grande dificuldade dos seres humanos em lidar com os outros envolve, de uma forma ou de outra, distorções de comunicação.

Como podemos observar, são inúmeras as definições de cultura. Contudo, analisar todas essas definições foge do escopo de nossa pesquisa. Por esse motivo, nos parágrafos que seguem apresentaremos brevemente algumas definições que antecederam o conceito de cultura aqui adotado e que, consequentemente, serviram de suporte a ele. 


\section{Capítulo 2}

Durante as leituras sobre o tema, observamos duas grandes tendências: 1) psicanalistas costumam utilizar a antropologia para entender melhor os seres humanos; e 2) antropólogos fazem uso de conceitos psicanalíticos para criar teorias e definições sobre cultura. Um exemplo da segunda tendência, pertinente à pesquisa, é a teoria proposta por Kroeber e Kluckhohn (1952). Em sua definição, os estudiosos dividem o fenômeno 'cultura' em dois tipos: cultura "explícita” e cultura "implícita". "Cultura explícita" englobaria elementos como leis e assuntos discutidos pelos participantes de uma cultura, já "cultura implícita" refere-se ao que é pressuposto, ou seja, ao que assumimos que o outro já sabe (HALL, 1990, p. 61). Aproximando a teoria de Kluckhohn ao nosso campo de pesquisa, poderíamos dizer que o ato de um árbitro conversar com os assistentes sobre a paralisação de um jogo devido à chuva muito forte seria um exemplo de cultura explícita, já que tal fato está previsto nas regras do jogo. Já a decisão do árbitro de interromper o jogo no Brasil mediante qualquer contato físico, mas de deixar a bola seguir caso o mesmo ocorra na Inglaterra, é um exemplo de cultura implícita, pois tais comportamentos consolidaram-se em suas respectivas culturas de forma natural. De acordo com os especialistas, essas são, de fato, práticas recorrentes nos dois países.

Para Hall (1990), apesar de abrir horizontes para os estudos culturais, a teoria de Kluckhohn apresenta certas limitações, pois trabalha com categorias bipolares que refletem a maneira norte-americana de ver e analisar fenômenos culturais, utilizandose de dicotomias, tais como preto e branco, certo e errado etc.

Ressaltamos que, embora não tenhamos adotado a teoria de Kluckhohn por completo, reconhecemos que a bipolarização de fenômenos acerca do futebol pode ser observada em toda a análise, especialmente quando nós, ou os especialistas consultados, tratamos de "futebol-arte" x "futebol-força", "futebol bonito" x "futebol de resultados", "ginga" x "técnica" etc. Contudo, parece importante salientar que, de acordo com Hall, essa bipolarização limita a análise e o entendimento sobre cultura, e, portanto, propõe um modelo tripartido de cultura, composto pelos seguintes níveis: formal, informal e técnico. Assim, Hall afirma que possuímos não duas, mas sim três formas distintas de comportamento.

A fim de exemplificar as três formas de comportamento utilizadas para definir o conceito de cultura, recorremos aos exemplos que o próprio Hall (1990, p. 64) 


\section{Capítulo 2}

utiliza em The Silent Language e, em seguida, mostramos como o conceito pode ser aplicado para desmistificar a bipolaridade das culturas futebolísticas do Brasil e da Inglaterra criada ao longo dos anos, baseada em nossa forma-representação dos respectivos futebóis.

O antropólogo utiliza o processo de aquisição e aprendizagem da prática do esqui em três situações distintas. Primeiramente, menciona a cidade de Grand Lake, localizada no Colorado, em uma região onde costuma nevar com frequência. Nessa cidade, existe uma tradição de utilizar o esqui para locomoção durante o período de inverno. Professores, trabalhadores, alunos e todos os habitantes da cidade esquiavam para chegar aos seus destinos. As crianças aprendiam as habilidades básicas de esquiar logo após aprenderem a andar. Cada habitante acabava, eventualmente, desenvolvendo seu estilo de esquiar, assim como temos um estilo próprio de andar. Todos esquiavam, ninguém questionava a necessidade de se utilizar os esquis; apenas esquiavam. Esquiar era parte da rotina dessas pessoas; assumia-se que todos sabiam esquiar. Nesse caso, esquiar constituía uma tradição formal.

Enquanto todos os habitantes de Grand Lake esquiavam diariamente, em Denver um grupo de habitantes esquiava no tempo livre, por prazer. Esquiar era um hobby para esse grupo. Alguns eram habilidosos, outros nem tanto. O que importava era a diversão envolvida. Essas pessoas não tinham consciência de como esquiavam e da técnica que utilizavam. Também não sabiam como ensinar, formalmente, outras pessoas a esquiar e, nessa tarefa, utilizavam instruções como: "me observe", "faça assim", "não faça isso" ou "flexione os joelhos e tome impulso". Essa concepção de esquiar é classificada por Hall como informal e pode ser mais bem descrita pela frase "você vai pegar o jeito".

Em outra região, fotógrafos tiravam fotos e faziam filmes de esquiadores profissionais descendo montanhas e fazendo as mais variadas manobras. Os filmes foram analisados, quebrados em partes e os componentes de cada manobra foram isolados com o objetivo de desvendar as técnicas por trás do esporte. Após as análises, constatou-se que esquiar não é um dom e que qualquer pessoa com paciência e vontade de aprender pode esquiar por meio do aprendizado de técnicas. Essa forma de esquiar foi caracterizada por Hall como técnica. 


\section{Capítulo 2}

No que diz respeito às "culturas futebolísticas" do Brasil e da Inglaterra, cremos que o modo como o futebol é aprendido e jogado no Brasil é bastante semelhante ao modo como os habitantes de Denver aprendiam a esquiar em suas viagens às montanhas nos fins de semana. $\mathrm{O}$ aprendizado ocorre de maneira informal, na maioria das vezes pela persistência na prática e pela relação erro e acerto. Tanto o esqui quanto o futebol podem ser caracterizados como atividades de lazer. Assim como não existe uma tradição formal de esquiar em Denver, não existe uma tradição formal de se jogar futebol no Brasil. Existe, sim, como observamos no capítulo 1, a prática do futebol por lazer, passada de pai para filho e de geração para geração em várias camadas da sociedade. Se cairmos na tentação de essencializar e romantizar o futebol brasileiro, diremos que toda criança no Brasil, principalmente do sexo masculino, já "nasce com a bola nós pés". No entanto, tomamos cuidado para não tecer certas generalizações.

Enquanto associamos a cultura futebolística do Brasil ao aspecto informal, enxergamos uma forte ligação entre a cultura futebolística inglesa e o aspecto técnico. A própria forma como o futebol moderno foi difundido na Inglaterra apoia a hipótese de que o futebol inglês é mais técnico do que o brasileiro, já que foi, desde o início, ensinado em escolas e universidades por meio do "cristianismo atlético" (item 1.2). Ademais, como veremos nos estudos de caso (capítulo 4), a tecnicidade do futebol inglês se manifesta de várias formas, como, por exemplo, na explicação da execução de dribles e jogadas e nos termos existentes em inglês que não possuem equivalentes em português.

Como podemos observar, apenas dois elementos da tríade de Hall mostram-se presentes nas culturas futebolísticas do Brasil e da Inglaterra. No entanto, chamamos atenção para o fato de que, embora um dos elementos predomine - o informal no Brasil e o técnico na Inglaterra -, os dois, ou até mesmo os três elementos podem estar presentes em dada situação. Além disso, acrescentamos, ainda, que devido às mudanças que o futebol vem sofrendo nos últimos anos, é cada vez mais complicado elucidar os elementos que diferenciam uma cultura da outra ${ }^{32}$.

\footnotetext{
${ }^{32}$ Apresentamos uma discussão detalhada sobre a forma-representação do futebol brasileiro no item 1.4 .
} 


\section{Capítulo 2}

Enfim, acreditamos que a definição de cultura proposta por Hall pode nos auxiliar na interpretação dos dados do corpus a fim de elucidar as diferenças culturais que refletem na linguagem do futebol em português e inglês. Assim como Hall, não queremos estereotipar a concepção de cultura, pois acreditamos na sua imensa dimensão e no papel que desempenha em nosso dia a dia. Dessa forma, acreditamos que uma cultura e seus três aspectos sejam um molde em que todos, de certa forma, se enquadram. Ela controla nossas vidas de formas diferentes. É parte do comportamento humano que não percebemos, que é obvio, a parte que não pensamos, já que, muitas vezes, assumimos, erroneamente, como universal. Acrescentamos, ao conceito de Hall, a importância da língua, já que a língua é o meio convencional de comunicação e de pensamento de uma cultura.

Enfim, após um melhor entendimento do termo e de alguns questionamentos que não serão respondidos nesta tese, temos uma certeza: nossos padrões culturais são únicos e, portanto, não são universais (HALL, 1990, p. VIII).

\subsubsection{Tradução técnica como condicionante cultural}

O termo 'tradução' possui três referentes principais: a disciplina Estudos da Tradução, o produto final (texto traduzido) e o processo tradutório (MUNDAY, 2001, p. 4). Em nossa pesquisa, tecemos alguns comentários e levantamos algumas questões acerca da disciplina Estudos da Tradução. No entanto, são o segundo e o terceiro significados que nos interessam: o texto traduzido - em nosso caso, termos e CLEs do domínio do futebol em português e seus equivalentes em inglês -, e o processo tradutório pelo qual esses equivalentes foram encontrados.

Ao falar em processo tradutório, não nos referimos aos processos cognitivos envolvidos no ato tradutório e nem às técnicas de tradução, mas sim às escolhas que um tradutor ou terminológo faz durante a busca por um equivalente na língua de chegada. Mais especificamente, preocupamo-nos com o produto final e o processo tradutório da tradução técnica. Mas, afinal, o que seria a tradução técnica?

$\mathrm{Na}$ literatura, existem diversas definições para tradução técnica, que, vale ressaltar, é frequentemente utilizada como sinônimo de tradução especializada. Para alguns teóricos, como Wright e Wright (1993), a tradução técnica ou especializada se 


\section{Capítulo 2}

ocupa da tradução de textos de línguas de especialidade, que abrangem não só disciplinas como engenharia e tecnologia, mas também outras disciplinas como psicologia, direito, economia e etc. (WRIGHT \& WRIGHT JR., 1993, p. 1). Para Byrne (2006), contudo, existe uma grande diferença entre tradução técnica e tradução especializada, pois, de acordo com o autor, um texto só é considerado técnico quando pertence ao domínio da tecnologia (BYRNE, 2006, p. 2). Outros textos que apresentem uma terminologia específica, mas que não fazem parte do domínio da tecnologia, seriam considerados textos especializados.

Para os propósitos de nossa pesquisa, definimos tradução técnica, considerada aqui sinônimo de tradução especializada, como ramo da tradução que se ocupa da tradução de textos de línguas de especialidade. Entendemos língua de especialidade, ou língua especializada, como uma língua que possui um vocabulário específico e que obedece a normas próprias de sua área, caracterizando, dessa forma, uma terminologia e uma padronização.

Zavaglia et al. (2011) atentam para a problemática da definição de uma tradução técnica em si, pois enfatizam que os textos não devem ser caracterizados com base na dicotomia "texto técnico" (ou especializado ou pragmático ou utilitário) x "texto literário". Isso porque essas classificações foram estabelecidas no início dos estudos terminológicos quando Eugen Wüster elaborou a Teoria Geral da Terminologia e propôs que os termos eram, por natureza, monossêmicos. De acordo com Asencio (2007, p. 51), não existe um grupo de elementos específicos que separam a linguagem geral da linguagem especializada. Para o autor, a linguagem geral pode conter elementos mais característicos de linguagens especializadas e viceversa; o que as difere é o grau de especialização. Por esse motivo, a linha que distingue um texto especializado de um texto de linguagem geral pode ser muito tênue. No caso do futebol, observamos que a descrição de uma partida apresenta densidade terminológica maior do que a notícia do resultado da mesma partida. Isso ocorre porque a descrição é muito mais minuciosa, relatando detalhadamente os lances do jogo, com seus dribles e jogadas, ao passo que a notícia reflete uma visão mais geral da partida, utilizando, dessa forma, menos termos e CLEs

Independentemente do grau de especialidade, a importância da tradução técnica no mercado de tradução é inquestionável. No início do milênio, a tradução 


\section{Capítulo 2}

técnica representava 90\% do mercado de tradução (KINGSCOTT, 2002, p. 247) e, uma vez que a tradução técnica se realiza a partir de um texto especializado - habitat natural das terminologias -, o interesse dos tradutores por um bom manejo terminológico a fim de estabelecer equivalentes adequados entre duas línguas de especialidade parece óbvio.

Apesar das inúmeras pesquisas no campo da tradução de textos especializados, ainda existem algumas falácias associadas a essa prática. Byrne (2006, p. 3) aponta que muito comum é a ideia de que a tradução técnica, diferente da literária, constitui um universo à parte, pois sua terminologia não se deixaria contaminar por relações contextuais e pragmáticas, possuindo certa estabilidade que favoreceria e facilitaria o processo tradutório. Nesse caso, bastaria ao tradutor conhecer o termo na língua de partida e procurar por seu equivalente na língua de chegada, partindo do princípio de que a tradução técnica é uma operação de transcodificação em que os conceitos "constituem uma [sic] amálgama indissolúvel e imune aos efeitos do tempo e do espaço, a fim de poderem resistir a uma série de condicionantes a que estão expostos." (AZENHA, 1999, p. 10).

Ligada a essa ideia, acredita-se, ainda, que a tradução técnica não é criativa (BYRNE, 2006, p. 5). Embora seja, em alguns momentos, menos metafórica do que a literatura, as línguas de especialidade também são marcadas por expressões idiomáticas e metáforas. Rebechi (2015) mostra a problemática da tradução de termos e CLEs da culinária brasileira para o inglês. Esses termos, em grande parte culturalmente marcados, muitas vezes apresentam alto grau de idiomaticidade.

Outra crença sobre tradução técnica apontada por Byrne (2006) é de que o único objetivo de uma tradução técnica é transmitir informação especializada utilizando a terminologia correta. Segundo Byrne (2006, p. 6), embora esse seja talvez o principal objetivo da tradução técnica, o tradutor também deve garantir que a informação seja transmitida de forma correta, seguindo os padrões estilísticos e levando em consideração as características culturais da língua de chegada.

Enfim, talvez a crença mais popular no que se refere à tradução técnica seja a ideia de que o tradutor de textos de especialidade deve ser especialista na área em que traduz. No entanto, sabe-se que, além de conhecimento na área de especialidade, o tradutor deve possuir outras habilidades, como, por exemplo, boa escrita, habilidade 


\section{Capítulo 2}

de realizar pesquisas em livros, em dicionários e na internet, conhecimento de gêneros e tipos textuais e da cultura de chegada, dentre outras (BYRNE, 2006, p. 6). Para Azenha (1999, p. 40), a tarefa de administrar todas essas habilidades exige que o tradutor controle um número elevadíssimo de variáveis, que devem ser administradas com base em suas competências e limitações sobre o objeto de trabalho.

Em um artigo intitulado Terminology and Translation - bringing research and professional training together through technology, Maia (2005) enfatiza a necessidade de o tradutor ser preparado para entender as línguas e as culturas com as quais trabalha e utilizar ferramentas computacionais, como software de tradução e ferramentas de corpora, para melhor explorar as diferenças linguísticas e culturais. Acreditamos que, em um cenário ideal, o tradutor de textos especializados seria um especialista com formação em tradução e amplo conhecimento das culturas com as quais trabalha. Entretanto, sabe-se que a realidade é bastante diferente: poucos especialistas estão dispostos a traduzir e a formação em tradução é tradicionalmente para linguistas (MAIA, 2005, p. 1).

Após definir os conceitos 'tradução técnica' e 'línguas de especialidade', debater algumas crenças sobre tradução técnica e expor o que se espera do tradutor desses textos, apresentamos, nos parágrafos seguintes, nossa visão de tradução técnica.

Nesta pesquisa, adotamos a proposta de tradução técnica de Azenha (1999, p. 60), qual seja uma tradução que vai além dos limites do texto e que define o ato tradutório tendo como ponto de partida o ato de comunicação. Em virtude disso, o texto especializado, assim como qualquer outra forma de comunicação, está atrelado a uma realidade sócio-histórico-cultural. Para o autor, não podemos deixar de lado as relações que o texto especializado trava com o contexto em que é produzido durante a tradução.

Considerando os pressupostos sobre tradução técnica mencionados, podemos afirmar que os termos, as CLEs, as definições, os equivalentes e as expressões devem ser empregados de maneira convencional no texto de chegada, respeitando as variáveis ligadas ao emissor, ao receptor, à situação e ao objetivo de comunicação.

Em nossa pesquisa, levamos em consideração o gênero textual, o periódico ou o site em que a notícia foi publicada, o jogo e o campeonato reportado na notícia, o 


\section{Capítulo 2}

autor da notícia e toda e qualquer variável que influencie a escolha terminológica. Também não podemos deixar de considerar, mesmo sem entrar em detalhes, as formas-representações que caracterizam o futebol inglês e o futebol brasileiro. Os jeitos de jogar são diferentes e, consequentemente, as jogadas têm reflexo direto na terminologia usada nas duas línguas. Esses diferentes jeitos de jogar podem causar dificuldade ao tradutor durante a busca de equivalentes, pois, muitas vezes, um termo comumente utilizado em uma língua simplesmente não ocorre na outra, pois caracteriza uma prática não comum na cultura de chegada.

Nessa vertente de tradução técnica, o ponto de partida para uma tradução é a relação entre linguagem e cultura e a tarefa de traduzir um texto especializado vai muito além da transferência de códigos linguísticos, pois envolve a transposição de barreiras culturais, por esse motivo o problema tradutório na está, na maioria das vezes, restrito ao termo, mas sim ao que está ao seu redor.

Explicada nossa visão de tradução técnica e delimitado o ponto de partida de uma tradução, achamos por bem expor nossa concepção de unidade de tradução (UT). Inúmeras são as discussões a respeito da delimitação das UTs. No entanto, para os objetivos de nosso trabalho, não adentraremos nenhuma das definições já propostas e consideraremos como UTs, em nosso caso UTEs (Unidades de Tradução Especializadas), os termos e as CLEs presentes no corpus.

Outro ponto a ser ponderado é a definição de equivalente tradutório. Neste estudo, consideramos "equivalente" uma unidade fraseológica que funcione no texto de chegada como funciona no texto de partida (TAGNIN, 2007, p. 1). O conceito, bastante amplo, permite identificar equivalentes não só no nível da palavra, do texto ou da frase, mas também equivalentes pragmáticos, ou seja, equivalentes que, embora não reflitam uma tradução para a língua de chegada, são utilizados no mesmo contexto e com o mesmo objetivo comunicativo.

Estabelecidas as conexões entre tradução, texto especializado e cultura, discutimos, nos parágrafos a seguir, a relação entre Linguística de Corpus e tradução.

É fato que a LC muito tem a contribuir para os estudos da tradução e para a formação de tradutores. Segundo Tagnin (2011), o estudo da tradução por meio da LC tem-se tornado, nos últimos anos, uma das linhas de pesquisa mais privilegiadas da Linguística de Corpus. 


\section{Capítulo 2}

Estudos de tradução e corpora tendem a se dividir em duas áreas: teórica e prática (HUNSTON, 2002, p. 123). As teorias da tradução podem se beneficiar de corpora paralelos para investigar o processo, as metodologias, as abordagens, as preferências e as normas de tradução. Já em termos práticos, o tradutor pode se beneficiar dos softwares que podem ser aplicados aos corpora, dos corpora monolíngues disponíveis on-line para a busca e verificação de padrões linguísticos e expressões convencionais em determinada língua, dos corpora paralelos para a busca de equivalentes tradutórios, dos corpora comparáveis, principalmente os da língua de especialidade, para busca e confirmação de equivalentes tradutórios. Enfim, a contribuição da LC para a tradução pode ser bastante relevante e variada.

Laviosa (2002, p. 18) cita a contribuição do uso de corpora na tradução para a substituição da noção estática de equivalência, por muito tempo entendida como correspondência formal de estruturas semânticas e sintáticas, pelo conceito dinâmico de equivalência funcional entre o texto de partida e o de chegada.

A identificação de equivalentes tradutórios em corpora pode ser realizada por meio de corpora paralelos e comparáveis, ambos com suas vantagens e desvantagens. Os corpora paralelos fornecem, de forma rápida e prática, equivalentes utilizados por tradutores. No entanto, como nem sempre se pode atestar a qualidade da tradução, alguns desses 'equivalentes' até podem ser gramaticalmente possíveis, porém nem sempre são os mais prováveis, ou seja, os mais consagrados pelo uso naquela área específica. Além disso, a escassez de corpora paralelos em áreas técnicas contribui para que tradutores optem por outras alternativas, como os corpora comparáveis e a própria web. Corpora comparáveis constituem fontes riquíssimas para a busca de equivalentes tradutórios, uma vez que podem fornecer o equivalente mais provável em contexto real de uso, pois são formados somente por textos originais. Deve-se considerar, contudo, que a identificação do equivalente pode ser um pouco mais demorada, já que nem sempre é possível estabelecer uma tradução prima facie entre os termos ${ }^{33}$.

Por fim, ao considerarmos que os termos são empregados em dado cenário histórico-cultural e, portanto, condicionados por normas sociais e linguísticas sempre

\footnotetext{
${ }^{33}$ No item 3.5.3, explicamos a metodologia adotada na identificação dos equivalentes das unidades fraseológicas para as quais não conseguimos estabelecer uma tradução prima facie.
} 


\section{Capítulo 2}

sujeitas a alterações (AZENHA, 1999, p. 22), não vemos outra possibilidade senão o uso de corpora comparáveis para a identificação dos equivalentes das combinatórias léxicas especializadas ${ }^{34}$.

Neste capítulo, apresentamos a fundamentação teórica do trabalho. Primeiro, introduzimos a Linguística de Corpus, bem como a definição e as tipologias de corpus presentes na literatura; em seguida, discutimos a abordagem baseada em corpus e a abordagem direcionada pelo corpus. Na segunda seção, introduzimos a questão do texto especializado; em seguida, discorremos sobre a Terminologia Textual e, ao final, apresentamos o conceito de CLEs. Por fim, na terceira seção, apresentamos nossa visão de tradução técnica. No próximo capítulo, será exposta a metodologia utilizada na pesquisa.

\footnotetext{
${ }^{34}$ Vide capítulo 4 para o detalhamento.
} 


\section{Capítulo 3}

\section{Capítulo 3 - Materiais e Métodos}

Neste capítulo apresentamos, inicialmente, o corpus de estudo. Em seguida, tratamos dos etiquetadores utilizados e do processo de etiquetagem. Após, discorremos sobre as ferramentas computacionais utilizadas para a análise. Ao final, expomos a metodologia subjacente à pesquisa e descrevemos os passos seguidos para a análise dos dados.

\section{$3.1 \mathrm{O}$ corpus de estudo}

Neste item, apresentamos o caminho percorrido para a construção do corpus de estudo, que se divide em dois subcorpora: um em português e outro em inglês. Primeiramente, descrevemos os critérios iniciais utilizados para a compilação do corpus; em seguida, discutimos as modificações realizadas ao longo da pesquisa. Depois, explicamos como os textos foram armazenados para, então, descrever a composição final dos dois subcorpora, o de português e o de inglês. Ao final, apresentamos o cabeçalho criado para a organização dos textos.

\subsubsection{Critérios iniciais}

Dados os objetivos desta pesquisa, expostos na introdução, compilaríamos, a princípio, dois outros subcorpora: um contemporâneo, formado por textos coletados no período de 2006 a 2010, construído durante nossa pesquisa de mestrado, e que foi ampliado com textos da Copa das confederações (2013) e da Copa do Mundo (2014); e outro, histórico, composto por textos sobre resultados de partidas das fases finais das copas de 1930 a 2014. No quadro 1 descrevemos esses dois corpora:

\begin{tabular}{|l|l|l|}
\hline \multicolumn{2}{|l|}{ contemporâneo } & histórico \\
\hline conteúdo & especializado & especializado \\
\hline assunto & futebol & futebol \\
\hline autoria & de língua nativa & de língua nativa \\
\hline língua & $\begin{array}{l}\text { português (BR) e inglês (ING); } \\
\text { comparável }\end{array}$ & $\begin{array}{l}\text { português (BR) e inglês (ING); } \\
\text { comparável }\end{array}$ \\
\hline finalidade & de estudo estudo \\
\hline meio & eletrônico & eletrônico \\
\hline
\end{tabular}




\section{Capítulo 3}

\begin{tabular}{|l|l|l|}
\hline modo & $\begin{array}{l}\text { escrito e falado (porções de falas } \\
\text { transcritas) }\end{array}$ & escrito \\
\hline tipo de texto & $\begin{array}{l}\text { resultados de partidas, regras do jogo, } \\
\text { narrações minuto a minuto e e } \\
\text { transmissão social }\end{array}$ & $\begin{array}{l}\text { resultados de partidas; se possível, } \\
\text { regras do jogo }\end{array}$ \\
\hline período & últimos quatro anos (2010-2014) & 1930 a 2014 \\
\hline seleção & de amostragem ${ }^{35}$; balanceado & de amostragem; balanceado \\
\hline tamanho & $\begin{array}{l}\text { aproximadamente um milhão de } \\
\text { palavras em cada língua a definir }\end{array}$ \\
\hline fontes & $\begin{array}{l}\text { jornais, tabloides, periódicos esportivos, } \\
\text { periódicos especializados em futebol, } \\
\text { uma revista e uma agência de notícias }{ }^{36} \text {. }\end{array}$ & inglês: The Daily Telegraph \\
\hline
\end{tabular}

Quadro 2: Composição inicial do corpus de estudo.

No entanto, ao longo da pesquisa, fizeram-se necessárias alterações, que são discutidas e justificadas no próximo item.

\subsubsection{Critérios redefinidos}

A ideia inicial era ampliar o corpus de estudo já existente, compilado durante nossa pesquisa de mestrado, que conta com aproximadamente um milhão de palavras em cada língua, e, a partir desse corpus ampliado, realizar a extração dos candidatos a termo. No entanto, no decorrer da pesquisa notamos que seriam necessárias algumas alterações na composição do corpus para que pudéssemos atingir os resultados esperados.

Primeiramente, decidimos compilar um novo corpus. O corpus compilado para a nossa pesquisa de mestrado tinha como objetivo servir de base para o levantamento de termos e unidades fraseológicas especializadas (UFEs) do futebol e, uma vez que um corpus deve ser representativo de uma totalidade linguística, coletamos textos de resultados de partidas do campeonato inglês, do campeonato espanhol, do campeonato italiano, da liga dos campeões, do campeonato brasileiro e da Libertadores da América. O corpus foi bastante útil para a pesquisa; no entanto, nossa pesquisa de doutorado almeja verificar como os diferentes jeitos de jogar na Inglaterra e no Brasil, como a história do futebol em cada uma dessas culturas e como a apropriação cultural das regras reflete na terminologia utilizada para falar sobre

\footnotetext{
${ }^{35}$ Corpus composto por porções de textos ou de variedades textuais, planejado para ser uma amostra finita da linguagem como um todo (BERBER SARDINHA, 2004, p. 20).

${ }^{36}$ Uma vez que agências de notícias não publicam periodicamente sobre resultados de partidas, coletamos textos de uma agência de notícias somente em inglês.
} 


\section{Capítulo 3}

futebol em português brasileiro e em inglês britânico.

Assim, os textos de outros campeonatos, que não os de campeonatos Brasileiros e campeonatos Ingleses, não contribuiriam para a identificação das particularidades das duas culturas em estudo. No entanto, não descartamos o corpus existente, pois o utilizamos para validar termos, colocações e CLEs que não apresentam uma ocorrência relativamente alta $^{37}$ no corpus de estudo e, muitas vezes, para extrair exemplos que porventura possam ser mais explicativos do que os presentes no novo corpus.

Ressaltamos, também, que os textos sobre resultados de partidas da Copa das Confederações e da Copa do Mundo das seleções do Brasil e da Inglaterra fazem parte da composição do corpus de estudo e os textos referentes às partidas de outras seleções foram utilizados da mesma forma que o corpus compilado durante o nosso mestrado. Sendo assim, por questão de organização, nomeamos o corpus compilado durante o mestrado e o corpus composto por textos sobre campeonatos europeus “corpus de validação". Composto por textos coletados entre o período de 2006 e 2010, e acrescido de textos coletados da Copa das Confederações de 2013, da Copa do Mundo de 2014, do Campeonato Espanhol, do Campeonato Alemão, do Campeonato Italiano e do Campeonato Francês, esse corpus, que contabiliza aproximadamente um milhão e duzentas mil palavras em cada língua, foi utilizado única e exclusivamente para validação dos termos e busca de exemplos e equivalentes.

O corpus de estudo utilizado na pesquisa é composto por textos de periódicos ingleses sobre partidas da Barclay's Premier League (primeira divisão), do CocaCola Championship (segunda divisão), da Coca-Cola League One (terceira divisão), e da Coca-Cola League Two (quarta divisão) da temporada de 2013/2014 e por textos de periódicos brasileiros sobre partidas da primeira e da segunda divisões do campeonato brasileiro, do Campeonato Paulista, do Campeonato Carioca, do Campeonato Mineiro, do Campeonato Gaúcho e do Campeonato Baiano de 2013.

No que se refere à compilação de um minicorpus histórico, tivemos que rever sua validade para a pesquisa. Iniciamos a compilação do corpus com a coleta de

\footnotetext{
${ }^{37}$ Em nossa pesquisa, trabalhamos com termos que ocorrem, até mesmo, uma única vez no corpus. No entanto, sempre que a frequência de um termo ou CLE foi inferior a três, utilizamos outras fontes para validar o temo ou CLE.
} 


\section{Capítulo 3}

textos do Jornal do Brasil; no entanto, esse processo mostrou-se muito laborioso. Primeiramente, mesmo tendo livre acesso ao arquivo histórico do Jornal do Brasil, não encontramos textos sobre o resultado de diversas partidas de futebol ocorridas no período proposto. Decidimos, então, fazer um recorte e selecionar oito textos por Copa, sem fazer discriminação de fases (fases de grupos, oitavas-de-final, quartas-definal, semifinal, final), com o intuito de facilitar a compilação. Contudo, mesmo com o recorte realizado, não encontramos oito textos sobre partidas jogadas pelas seleções do Brasil e da Inglaterra em todas as copas, mesmo porque a Inglaterra não se classificou para as copas de 1934, 1938, 1974, 1978 e 1994. Além disso, o arquivo do Jornal do Brasil disponibiliza todos os textos em formato PDF, fator que dificulta bastante a compilação do corpus, uma vez que o software utilizado só trabalha com arquivos de texto (.txt).

Ainda no início do projeto, adquirimos o software OmniPage ${ }^{38}$, um dos mais eficientes conversores de PDF disponíveis no mercado, e tentamos converter os textos para o formato TXT, revisar os arquivos convertidos e adicioná-los ao corpus. Todavia, a tentativa não foi bem sucedida, pois o conversor não reconhecia a maior parte dos caracteres dos textos. Em vez de revisar, teríamos de digitar os textos novamente, uma vez que o número de erros e caracteres desconhecidos que o programa retornava era superior ao número de frases inteiras ou mesmo de palavras sem nenhum erro de digitação.

Acreditamos que a inaplicabilidade do conversor para nossa pesquisa deu-se pelo fato de o banco de dados do Jornal do Brasil ser composto por textos escaneados de textos originais que, muitas vezes, não são $100 \%$ legíveis. Tivemos o mesmo problema com o jornal britânico The Daily Telegraph: os textos estavam em formato PDF e o reconhecimento dos caracteres pelo software mostrou-se bastante falho. Ademais, em inglês ainda deparamos com o problema do acesso aos textos. O jornal disponibiliza textos antigos em um banco de dados on-line. Contudo, a disponibilização dos textos não era feita de forma periódica. Dessa forma, não seria possível realizar a busca por meio de jogos da Copa do Mundo, uma vez que não encontramos textos de algumas Copas no banco de dados.

\footnotetext{
$38 \quad$ Disponível em: $\quad<\quad$ http://www.software.com.br/p/omnipageprofessional?gclid=Cj0KEQjwhuqrBRCFuPz4ipOx5JIBEiQAZJ7F-nvbCJ-b xKdewW3KwY4a62aB4v-TUh8j1 GuEc3nkaAuRq8P8HAQ. Acesso em: 13 abr. 2014.
} 


\section{Capítulo 3}

Ante as dificuldades expostas, decidimos não seguir adiante com a compilação do minicorpus histórico, que enriqueceria os achados da pesquisa, mas que não faz parte, e nem é imprescindível, para a concretização de nosso objetivo principal. Dessa forma, para garantir a dimensão cultural e histórica do projeto, contamos com a contribuição de pesquisadores do LUDENS, mestrandos e doutorandos em história ou em antropologia, que estão realizando suas pesquisas sobre futebol. Esses pesquisadores atuaram como consultores, ou seja, sempre que uma dúvida em relação à utilização ou ao surgimento de um termo ocorria, discutíamos com eles seu uso e sua relação com o futebol brasileiro ou inglês. Além disso, a interação com esse grupo de pesquisadores possibilitou um contato muito produtivo com obras sobre a história do futebol. Enfim, as leituras realizadas sobre o surgimento do futebol como esporte, a história do futebol no Brasil e na Inglaterra, a dimensão do futebol na sociedade contemporânea, as formas-representações dos futebóis e a relação entre futebol, cultura e identidade nacional foram bastante proveitosas para o entendimento das particularidades do léxico do futebol em português brasileiro e inglês britânico.

Apresentamos, no quadro abaixo, a configuração final do corpus de estudo:

\begin{tabular}{|l|l|}
\hline Conteúdo & especializado \\
\hline Assunto & futebol \\
\hline Autoria & de língua nativa \\
\hline Línguas & português (BR) e inglês (ING); comparável \\
\hline Finalidade & de estudo \\
\hline Meio & eletrônico \\
\hline Modo & escrito e falado (porções de falas transcritas) \\
\hline $\begin{array}{l}\text { Tipos de } \\
\text { texto }\end{array}$ & $\begin{array}{l}\text { resultados de partidas (RP), descrições de partidas (DP), relatos de } \\
\text { partidas com comentários de internautas (RPCI), notícias sobre compra e } \\
\text { venda de jogadores e técnicos (CV) e notícias sobre a situação dos times } \\
\text { nos campeonatos (ST). }\end{array}$ \\
\hline Período & 2013 - 2014 \\
\hline Seleção & de amostragem; balanceado \\
\hline Tamanho & aproximadamente 500 mil palavras em cada língua \\
\cline { 2 - 3 } & Inglês \\
\hline
\end{tabular}

\footnotetext{
${ }^{39}$ Utilizamos as caracterizações de corpora propostas por Berber Sardinha (2004), segunda as quais um corpus de amostragem representa uma amostra finita da linguagem - é composto por porções de textos ou variedades textuais e um corpus balanceado contém número similar de palavras em todas as categorias (registros, tipos, gêneros textuais etc.) que abrange, fato que nem sempre é possível devido às próprias características intrínsecas a cada gênero, como em nossa pesquisa.
} 


\section{Capítulo 3}

\begin{tabular}{|l|l|l|l|l|}
\hline & No. palavras & No. textos & No. palavras & No. textos \\
\cline { 2 - 5 } & 600.079 & 612 & 469.765 & 864 \\
\hline
\end{tabular}

Quadro 3: Configuração final do corpus.

\subsubsection{Composição do corpus}

Redefinidos os critérios de compilação, construímos um corpus com as seguintes características:

\begin{tabular}{|c|c|c|c|c|c|c|c|c|c|c|c|c|}
\hline & \multicolumn{2}{|c|}{ total } & \multicolumn{2}{|c|}{$\mathrm{RP}$} & \multicolumn{2}{|c|}{ DP } & \multicolumn{2}{|c|}{ RPCI } & \multicolumn{2}{|c|}{$\mathrm{CV}$} & \multicolumn{2}{|c|}{ ST } \\
\hline & 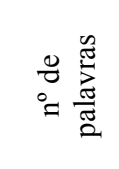 & 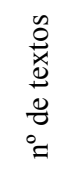 & 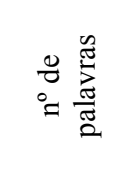 & $\begin{array}{l}0 \\
\stackrel{0}{x} \\
\stackrel{0}{0} \\
0 \\
0 \\
0 \\
0\end{array}$ & 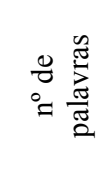 & $\begin{array}{l}0 \\
0 \\
0 \\
0 \\
0 \\
0 \\
0 \\
0\end{array}$ & $\begin{array}{l}\frac{\pi}{5} \\
\stackrel{5}{\frac{\pi}{\pi}} \\
\stackrel{0}{\pi}\end{array}$ & 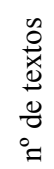 & 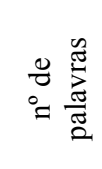 & 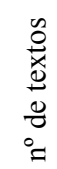 & 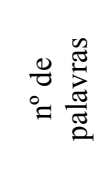 & \begin{tabular}{l}
0 \\
0 \\
\multirow{0}{0}{} \\
0 \\
0 \\
0 \\
0
\end{tabular} \\
\hline ING & 600.079 & 612 & 420.055 & 428 & 68.008 & 55 & 72.328 & 73 & 20.004 & 32 & 18.684 & 24 \\
\hline PT & 469.765 & 864 & 328.835 & 605 & 56.370 & 103 & 42.278 & 74 & 23.488 & 51 & 18.794 & 31 \\
\hline
\end{tabular}

Tabela 1: Características do corpus de estudo.

O número de palavras difere consideravelmente entre os dois subcorpora: 600.079 em inglês e 469.765 em português. Contudo, vale enfatizar que tentamos, na medida do possível, fazer o balanceamento pelo número de palavras em cada categoria e não pelo número de textos. Por meio da tabela 1 , observamos que em todas as categorias o subcorpus em português possui número maior de textos; já em relação ao número de palavras desses textos, o subcorpus em inglês supera o subcorpus em português apenas nas categorias CV e ST. Ressaltamos que encerramos a coleta do subcorpus em português em dezembro de 2013 e a coleta do subcorpus de inglês em julho de 2014 devido à diferença nas datas de início e término dos campeonatos no Brasil e na Inglaterra.

A categoria que apresenta maior diferença no número de palavras em inglês e em português - $42 \%$ - é o de relatos de partidas com comentários de internautas (RPCI). Tal diferença pode ser justificada por dois motivos principais. Primeiramente, é característica intrínseca aos textos em inglês apresentarem mais informações e serem mais detalhados, conforme explicaremos abaixo. Além disso, fazer comentários em um site sobre os lances do jogo parece ser prática comum ao torcedor inglês, que interage durante toda a partida com os comentaristas, opinando sobre os lances, jogadas e atitudes dos jogadores e do juiz, ao passo que o torcedor brasileiro parece 


\section{Capítulo 3}

não ter tal interesse, e, quando participa das narrações, muitas vezes aborda outros tópicos que não a partida em $\mathrm{si}^{40}$.

Outro fator que contribuiu para delimitar o encerramento da coleta do corpus foi a relação type/token ratio $^{41}$ das cinco categorias. Em inglês o type/token ratio continuava a subir à medida que inseríamos mais textos, indicando a incidência de palavras novas (types); já em português essa relação não apresentou alteração, ou seja, o número de formas novas não aumentava significativamente conforme inseríamos mais textos no corpus. Dessa forma, se continuássemos a coletar textos, o subcorpus em inglês teria uma riqueza lexical maior do que o subcorpus em português. Ressaltamos que, se o objetivo dessa pesquisa fosse realizar um levantamento completo dos termos do futebol nas duas línguas, teríamos que continuar a coletar textos em inglês e o balanceamento seria justificado pela type/token ratio nos dois subcorpora, e não pelo número de palavras. No entanto, como pretendemos verificar como os jeitos de jogar influenciam o léxico, acreditamos que, embora as palavraschave levantadas não representem a totalidade da linguagem futebolística em inglês, são suficientes para o estabelecimento de uma ligação entre cultura futebolística e léxico.

Para explicar a diferença no número de palavras dos dois subcorpora, utilizamos o conceito de high and low context cultures do antropólogo Edward Hall (1976). Hall parte do pressuposto de que a quantidade de informação linguística e contextual necessária para transmitir uma mensagem varia de acordo com a cultura e, para descrever as culturas, o autor cria dois grupos: high-context culture e low-context culture.

O primeiro grupo, high-context, é formado por países como Brasil, Itália, Grécia e países da África, Ásia e América Latina. Essas culturas são caracterizadas por utilizarem grande quantidade de elementos contextuais, os quais auxiliam seus integrantes a entenderem as regras, ou seja, o modo como a cultura funciona. Por esse motivo, parte da informação fica implícita, é o dito pelo não dito; informações que

\footnotetext{
${ }^{40}$ Não eliminamos nenhum dos comentários realizados pelos internautas, nem mesmo os que fogem à partida.

${ }^{41}$ Relação entre o número de palavras corridas e palavras distintas. Na frase "O jogador cobrou o pênalti”, há cinco types (palavras corridas) e quatro tokens (palavras distintas), pois o artigo "o" ocorre duas vezes.
} 


\section{Capítulo 3}

estão subentendidas na fala, ou, em nosso caso, em um texto, podem contribuir muito mais para a transmissão do significado do que aparentam. Essas culturas possuem um forte senso de comunidade, fator que implica em diferentes estilos comportamentais (MANCA, 2010, p. 373), que são dados como subentendidos e, raramente, aparecem de forma explícita.

O segundo grupo, low-context, é formado por países como Estados Unidos, Alemanha, Suíça e outros países da Europa Ocidental e do Reino Unido. As culturas que se enquadram nesse grupo são caracterizadas por explicitar os elementos contextuais. Quase nada é subentendido, os assuntos são debatidos exaustivamente de modo que não restem dúvidas ou margem para uma interpretação equivocada. A comunicação é feita da forma mais explícita possível e é realizada por meio da transmissão de fatos, sem a expressão de sentimentos.

A teoria de Hall é bastante complexa e detalhada ${ }^{42}$. Contudo, para nossa pesquisa, selecionamos apenas três elementos que acreditamos desempenharem papel fundamental na produção dos textos sobre futebol: clareza das mensagens, uso da comunicação não verbal e flexibilidade de tempo. O quadro a seguir mostra como esses três elementos se realizam nos dois tipos de cultura:

\begin{tabular}{|c|c|c|}
\hline & high-context cultures & low-context cultures \\
\hline Clareza das mensagens & $\begin{array}{l}\text { informação implícita; o significado } \\
\text { contido nas entrelinhas é tão } \\
\text { importante quanto o que está } \\
\text { explícito. }\end{array}$ & $\begin{array}{l}\text { informação explícita; } \\
\text { transmitida de forma clara e } \\
\text { simples de modo a não deixar } \\
\text { nada subentendido. }\end{array}$ \\
\hline $\begin{array}{l}\text { Uso da comunicação } \\
\text { nãoverbal }\end{array}$ & muita informação não verbal. & $\begin{array}{l}\text { ausência de informação não } \\
\text { verbal; todo o significado deve } \\
\text { estar explícito em forma de } \\
\text { texto. }\end{array}$ \\
\hline Flexibilidade de tempo & $\begin{array}{l}\text { tempo policromático; a noção de } \\
\text { tempo é aberta e flexível; pouca } \\
\text { importância é atribuída a horários } \\
\text { marcados; agendar uma atividade é } \\
\text { tarefa quase impossível, a menos } \\
\text { que o indivíduo tenha aprendido a } \\
\text { se organizar de acordo com o } \\
\text { tempo monocromático (HALL, } \\
1976, \text { p. } 22)^{43} \text {. }\end{array}$ & $\begin{array}{l}\text { tempo monocromático; horários } \\
\text { marcados, segmentação das } \\
\text { atividades } \\
\text { funcionam como prontidão } \\
\text { organização da noção de tempo. }\end{array}$ \\
\hline
\end{tabular}

Quadro 4: Contraste de algumas características entre high-context cultures e low-context cultures.
$42 \quad$ Quadro
completo
disponível
em:
$<$ http://www.changingminds.org/explanations/culture/hall_culture.htm>. Acesso em: 5 maio 2011.
${ }^{43}$ Para Hall, embora a noção de tempo seja cultural, é possível para uma pessoa de high-context culture aprender a lidar com o tempo monocromático. 


\section{Capítulo 3}

O quadro, a partir da visão de Hall, mostra alguns pontos em que a cultura brasileira (high-context culture) e a cultura inglesa (low-context cultute) diferem no que se refere à produção de textos. Nos textos de nosso corpus, a clareza das mensagens fica evidente nos textos jornalísticos sobre o resultado de uma partida em inglês. As informações são apresentadas de forma linear e simples. A própria divisão das páginas das notícias reflete essa organização. Tomemos, por exemplo, a estrutura da notícia de dois jornais brasileiros e de dois jornais ingleses transmitindo o resultado de uma partida:

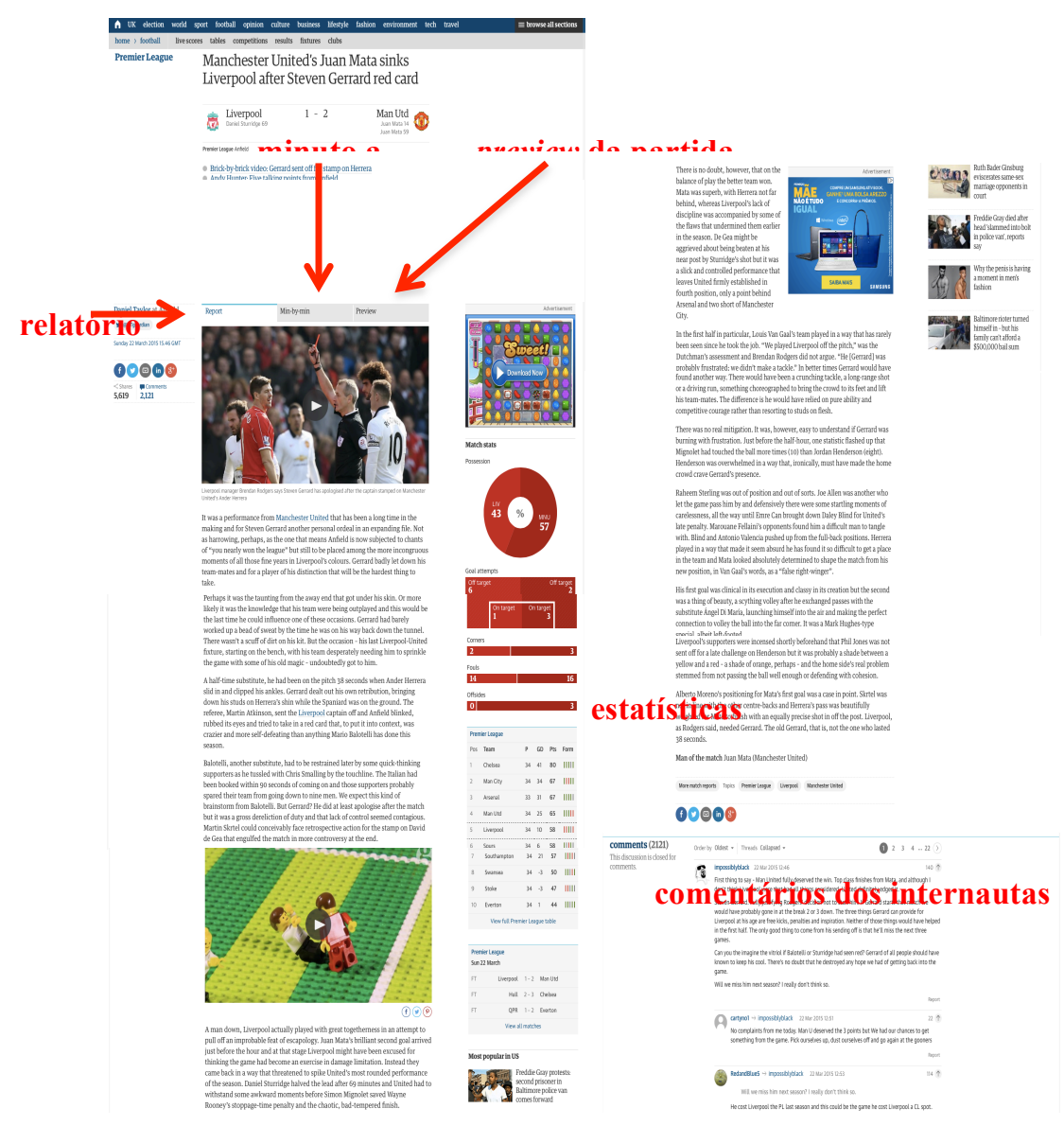

Figura 1: Página do jornal The Guardian sobre o resultado da partida entre o Manchester United e o Liverpool pela Premier League de $2015 .^{44}$

\footnotetext{
${ }^{44}$ A página da notícia foi editada para melhor visualização. Retiramos todas as propagandas presentes entre os parágrafos, mas preservamos todos os elementos que compõem a notícia. Notícia integral
} 


\section{Capítulo 3}

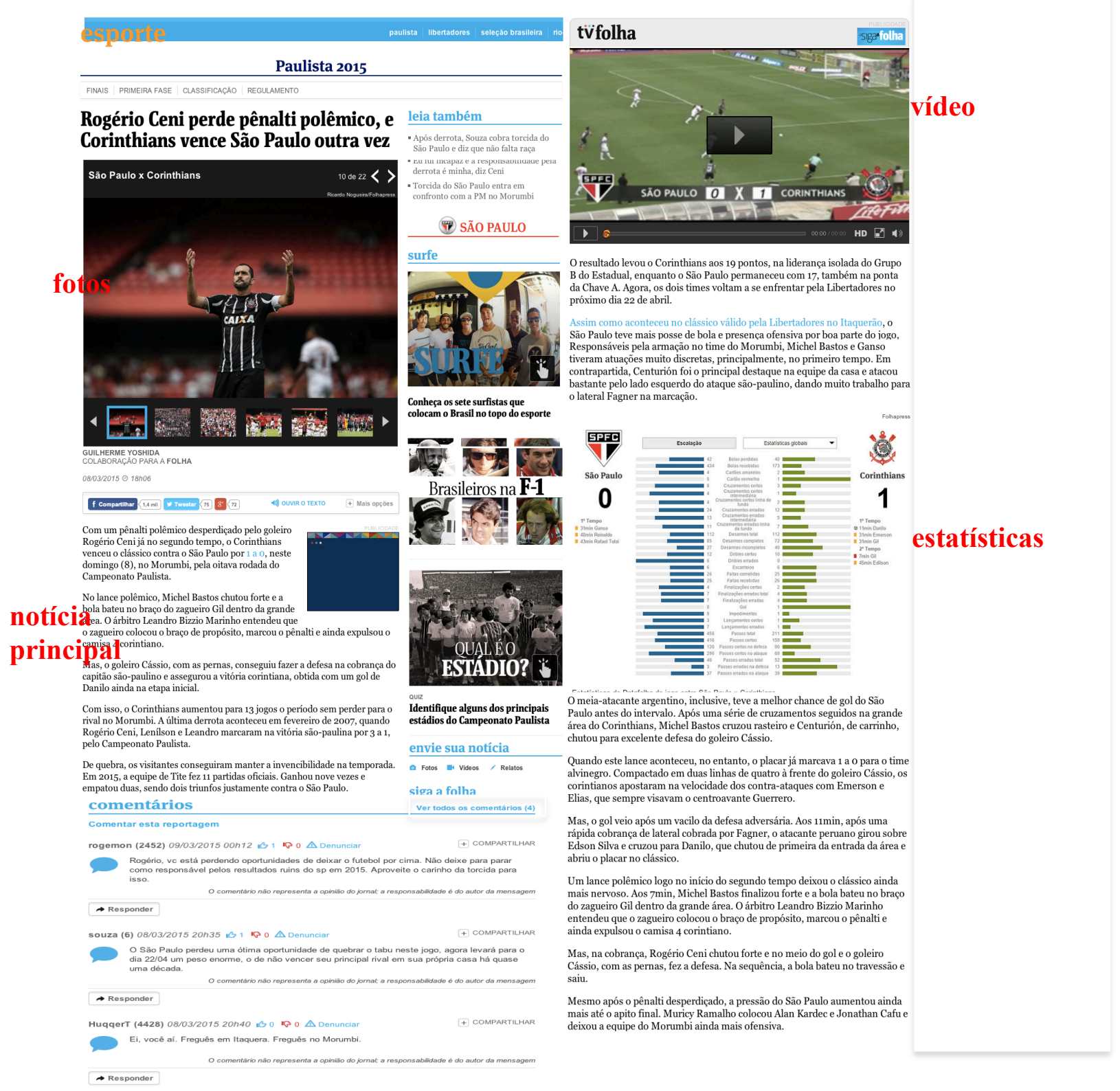

Figura 2: Página do jornal Folha de São Paulo sobre o resultado da partida entre o Corinthians e o São Paulo pelo campeonato Paulista de 2015. ${ }^{45}$

disponível em: < http://www.theguardian.com/football/2015/mar/22/liverpool-manchester-unitedpremier-league-match-report $>$. Acesso em: 29 abr. 2015.

${ }^{45}$ A página da notícia foi editada para melhor visualização. Retiramos todas as propagandas presentes entre os parágrafos, mas preservamos todos os elementos que compõem a notícia. Notícia integral disponível em: <http://www1.folha.uol.com.br/esporte/2015/03/1599967-rogerio-ceni-perde-penaltipolemico-e-corinthians-vence-sao-paulo-outra-vez.shtml >. Acesso: 29 abr. 2015. 


\section{Capítulo 3}

Como podemos notar, a página do jornal brasileiro apresenta uma notícia principal sobre a partida, um quadro com estatísticas, fotos e um vídeo. Por outro lado, ao observarmos a página do The Guardian, notamos uma quantidade considerável de links na página da notícia principal. Observamos que o site apresenta o relatório da partida, a transmissão minuto a minuto, uma notícia que foi publicada antes do início da partida discutindo as expectativas para a partida, bem como a escalação dos times, os números da partida (faltas cometidas, posse de bola de cada time, impedimentos etc.) e ainda comentários feitos pelos internautas sobre a partida, publicados em ordem cronológica. Além dessa diferença na estrutura, o texto é rico em detalhes e os relatos são feitos de forma precisa, evitando, dessa forma, uma interpretação equivocada dos lances da partida. Por outro lado, nos textos em português as informações nem sempre são apresentadas de forma linear e há muita informação implícita, como, por exemplo, a omissão das jogadas que resultaram em um gol, fator que em hipótese alguma compromete o significado do texto para um leitor inserido em nossa cultura.

Outro fato interessante no que se refere às diferenças das notícias em inglês e português é o número de tipos de comentários de internautas nos dois sites: a página do jornal brasileiro apresenta somente quatro comentários, todos eles expressando descontentamento dos torcedores do São Paulo F.C. com o time; já a página do jornal inglês apresenta mais de 2.000 comentários, de razões diferentes, como, por exemplo, comentários sobre os lances da partida, elogios, descontentamentos, expectativas, discussões sobre esquema tático adotado etc. No que se refere ao uso da informação não verbal, constatamos que as notícias em português utilizam mais recursos visuais (fotos e vídeos) do que as notícias em inglês.

Quanto à flexibilidade de tempo, observamos que, durante as descrições de partidas com comentários de internautas, o público inglês tende a comentar lance por lance, ao passo que o público brasileiro, ao opinar, geralmente tece um comentário geral sobre um período da partida, sobre um lance polêmico ou sobre o resultado final.

Enfim, cremos que a teoria de Hall contribui de forma significativa para o nosso entendimento do funcionamento dos textos no Brasil e na Inglaterra, além de 


\section{Capítulo 3}

fornecer subsídios necessários para as decisões sobre os critérios de compilação do corpus.

Nos subitens que seguem, justificamos o recorte de campeonatos nas duas línguas e apresentamos, de forma mais detalhada, as fontes dos textos que compõem os subcorpora de estudo. A caracterização está dividida por língua e é feita em forma de gráficos para melhor visualização e apresentada na seguinte ordem: resultados de partidas (RP), descrição de partidas (DP), relatos de partidas com comentários de internautas (RPCI), notícias sobre compra e venda de jogadores e técnicos (CV) e notícias sobre a situação dos times nos campeonatos (ST).

\subsubsection{Subcorpus em português}

O subcorpus em português é composto por textos de periódicos brasileiros sobre partidas da primeira e da segunda divisões do Campeonato Brasileiro, do Campeonato Paulista, do Campeonato Carioca, do Campeonato Mineiro, do Campeonato Gaúcho e do Campeonato Baiano de 2013. Justificamos o recorte realizado devido à dimensão dos campeonatos selecionados e à disponibilidade de textos sobre as partidas.

Selecionamos a série A do Campeonato Brasileiro, conhecido como "Brasileirão", uma vez que esse é o maior torneio entre clubes do país. A temporada tem início em maio e término em dezembro, totalizando 38 rodadas com dez partidas cada. No final do campeonato, os quatro últimos colocados caem para a série B e os quatro primeiros colocados da série B sobem para a série A.

Decidimos coletar também textos da série B, pois, uma vez que todo ano quatro times da série A caem para a série B, o campeonato conta com a participação de times de tradição no futebol brasileiro. Além disso, é transmitido nas redes aberta e fechada de TV, sendo que grande parte dos sites acessados publica notícias sobre os resultados das partidas do campeonato de forma regular.

Os campeonatos Paulista, Carioca, Mineiro, Gaúcho e Baiano também foram selecionados devido à disponibilidade de notícias sobre suas partidas com regularidade. A princípio estávamos receosos sobre a seleção de campeonatos estaduais, já que nossa pesquisa analisa a linguagem do futebol do Brasil como um 


\section{Capítulo 3}

todo e não tem como objetivo trabalhar com regionalismos. Contudo, o cabeçalho criado para o armazenamento dos textos nos permite verificar se um termo ocorre somente em um campeonato ou em um jornal específico ${ }^{46}$.

Partindo do pressuposto de que os resultados de uma pesquisa com corpus dependem da composição do corpus de estudo, tentamos compilar um corpus que abrangesse os principais veículos de informação sobre futebol. Dessa forma, utilizamos jornais e tabloides, portais de notícias, sites esportivos, sites de clubes, agências de notícias, emissoras, revistas e sites de apostas para compilar o corpus.

$\mathrm{O}$ quadro 5 contém as fontes que configuram a categoria resultados de partidas (RP) em português, composto por textos das séries A e B do Campeonato Brasileiro, do Campeonato Paulista, do Campeonato Carioca, do Campeonato Mineiro, do Campeonato Gaúcho e do Campeonato Baiano de 2013:

\begin{tabular}{|c|c|c|}
\hline fonte & site & sigla \\
\hline \multicolumn{3}{|c|}{ Portais de notícias } \\
\hline 1. BOL notícias & http://noticias.bol.uol.com.br & $\mathrm{BOL}$ \\
\hline 2. IG esportes & http://esporte.ig.com.br & IG \\
\hline 3. Terra esportes & http://esportes.terra.com.br & TER \\
\hline 4. UOL esportes & http://esporte.uol.com.br & UOL \\
\hline \multicolumn{3}{|c|}{ Jornais e Tabloides } \\
\hline 1. Agora & http://www.agora.uol.com.br & $\mathrm{AGO}$ \\
\hline 2. Correio 24 horas & http://www.correio24horas.com.br & COR \\
\hline 3. Diário de São Paulo & http://www.diariosp.com.br & DSP \\
\hline 4. Estado de Minas & http://www.em.com.br & EMI \\
\hline 5. Estado de São Paulo & http://www.estadao.com.br & EST \\
\hline 6. Folha de S. Paulo & http://www.folha.uol.com.br & FOL \\
\hline 7. Gazeta do Povo & http://www.gazetadopovo.com.br & GP \\
\hline 8. Jornal do Brasil & http://jblog.jb.com.br & JB \\
\hline 9. Jornal Extra & http://extra.globo.com & EXT \\
\hline 10. Metrô News & http://www.metronews.com.br & MET \\
\hline 11. O Dia & http://odia.ig.com.br & DIA \\
\hline 12. O Globo & http://oglobo.globo.com & GLB \\
\hline 13. Zero Hora & http://zh.clicrbs.com.br/rs/ & ZER \\
\hline \multicolumn{3}{|c|}{ Sites esportivos } \\
\hline 1. Acervo Santista & http://www.acervosantista.com.br & ASAN \\
\hline 2. Arena FC & http://www.arenafutebolclube.com.br & ARE \\
\hline 3. Canelada & http://canelada.com.br & CAN \\
\hline 4. CBF News & http://www.cbf.com.br/noticias & $\mathrm{CBF}$ \\
\hline 5. ESPN & http://espn.uol.com.br & ESPN \\
\hline 6. Estádio VIP & http://estadiovip.com.br & EVIP \\
\hline 7. Futebol Interior & http://www.futebolinterior.com.br & FINT \\
\hline 8. Futebol na Rede & http://futebolnarede.com & FRED \\
\hline 9. Gazeta Esportiva & http://www.gazetaesportiva.net & GAE \\
\hline
\end{tabular}

\footnotetext{
${ }^{46} \mathrm{O}$ cabeçalho criado será apresentado no item 3.1.5.
} 


\section{Capítulo 3}

\begin{tabular}{|c|c|c|}
\hline 10. Globo Esporte & http://globoesporte.globo.com & GLE \\
\hline 11. Impedimento & http://impedimento.org & IMP \\
\hline 12. Lance!Net & http://www.lancenet.com.br & LAN \\
\hline 13. Olé do Brasil & http://oledobrasil.com.br & OLE \\
\hline 14. Plantão do Futebol & http://www.plantaodofutebol.com.br & PFU \\
\hline 15. SportTV & http://sportv.globo.com/site/ & STV \\
\hline 16. Tempo Real & http://globotv.globo.com/busca/?q=tempo+real & TR \\
\hline 17. Torcedores & http://torcedores.com & TOR \\
\hline 18. Trivela & http://trivela.uol.com.br & TRI \\
\hline \multicolumn{3}{|c|}{ Blogs de futebol } \\
\hline 1. Blog Marcondes Brito & http://blogs.band.com.br/marcondesbrito/ & BMB \\
\hline 2. Blog Fernando Sampaio & http://blog.jovempan.uol.com.br/fernandosampaio/ & BFS \\
\hline 3. Blog do Milton Neves & http://blogmiltonneves.bol.uol.com.br & BMN \\
\hline 4. Blog do Neto & http://blogdoneto.blogosfera.uol.com.br & $\mathrm{BN}$ \\
\hline \multicolumn{3}{|c|}{ Sites de clubes } \\
\hline 1. Corinthians & http://www.corinthians.com.br/site/home/ & $\mathrm{CFC}$ \\
\hline 2. São Paulo Futebol Clube & http://www.saopaulofc.net & SPFC \\
\hline 3. Santos Futebol Clube & http://santosfc.com.br & SFC \\
\hline \multicolumn{3}{|c|}{ Revistas } \\
\hline 1. Area $\mathrm{H}$ & http://www.areah.com.br & AREH \\
\hline
\end{tabular}

Utilizamos, portanto, 47 fontes distintas, com o intuito de abranger os principais veículos de informação da imprensa futebolísica brasileira. Quatro dessas fontes são portais de notícias: BOL notícias, IG sports, Terra sports e UOL esportes. A seleção foi feita tendo em mente a disponibilidade de notícias, a regularidade com que são publicadas e a organização do site, já que, devido à própria natureza desse tipo de publicação - que visa transmitir informações de forma rápida, muitas vezes quase instantânea -, a organização em relação ao modo como as notícias são publicadas pode deixar a desejar. Não raro deparamos com portais de notícias que transmitem notícias de jogos de partidas, mas que não possuem uma página de “esportes" ou "futebol”. Sendo assim, a notícia fica na página inicial quando é publicada, mas depois sai dessa página e fica arquivada em alguma parte do site que não possui uma temática clara, dificultando bastante o trabalho de coleta do corpus.

No que se refere aos jornais e tabloides, utilizamos dois critérios para a seleção. Primeiramente, selecionamos veículos que publicam notícias sobre resultados de partidas das séries A e B do Campeonato Brasileiro regularmente: Estado de São Paulo, Folha de S. Paulo, Jornal do Brasil e O Globo. O segundo critério foi selecionar jornais dos estados onde acontecem os cinco campeonatos com os quais trabalhamos. Assim, a categoria RP conta com cinco jornais de São Paulo (Agora, Diário de São Paulo, Folha de S. Paulo, Estado de São Paulo e Metrô news), quatro 


\section{Capítulo 3}

jornais do Rio de Janeiro (Jornal do Brasil, Jornal Extra, O Dia e O Globo), dois jornais do Rio Grande de Sul (Gazeta do Povo e Zero Hora), um jornal de Minas (Estado de Minas) e um jornal da Bahia (Correio 24 horas).

Estamos cientes da maior presença de jornais paulistas e cariocas na composição dessa categoria. No entanto, acreditamos que, uma vez que nossa pesquisa tem como objetivo estudar a linguagem do futebol no português brasileiro em geral - utilizamos etiquetas que auxiliam na identificação de possíveis regionalismos -, tal fato não prejudique os resultados da pesquisa. Ademais, as páginas dos jornais de São Paulo e do Rio são, de forma geral, mais organizadas do que as páginas dos jornais dos demais estados.

A seleção dos sites esportivos, que abrange tanto sites esportivos em geral quanto sites exclusivos sobre futebol, foi baseada no critério da confiabilidade. Para tanto, consultamos um grupo de especialistas que, como explicado anteriormente, é constituído por estudiosos do futebol, jornalistas esportivos e torcedores em geral. Após a listagem dos sites mencionados, verificamos a viabilidade da coleta. Afinal, alguns sites publicam notícias de forma mais esporádica, sem apresentar certa regularidade, o que não nos interessava muito devido ao tempo que dispenderíamos para verificar se a notícia sobre determinado jogo havia de fato sido publicada em determinado periódico durante todo o processo de coleta do corpus.

Durante as conversas com os especialistas sobre sites esportivos, foram mencionados quatro blogs: Blog Marcondes Brito, Blog Fernando Sampaio, Blog do Milton Neves e Blog do Neto. Dada a popularidade dos blogs entre os especialistas, optamos por incluí-los em nosso corpus. Vale ressaltar que não incluímos essa categoria de site no subcorpus em inglês, pois blogs sobre futebol não parecem ser tão comuns na Inglaterra quanto no Brasil e, além disso, os blogs que encontramos são, em sua maioria, compostos por crônicas esportivas e raramente publicam posts sobre resultados de partidas.

Selecionamos os sites dos clubes Corinthians, São Paulo Futebol Clube e Santos Futebol Clube devido à regularidade com que os três publicam notícias sobre as partidas de seus times e à organização, fator de extrema importância para encontrar uma notícia de um jogo que ocorreu, por exemplo, três dias antes da coleta do texto.

Por fim, decidimos coletar textos da revista area $H$, revista voltada ao público 


\section{Capítulo 3}

masculino e que aborda diversos temas, como, por exemplo, consumo, relacionamento, carreira e futebol. O nome da revista surgiu em uma conversa informal com três fãs de futebol sobre os melhores sites esportivos. Um deles mencionou a revista, o segundo disse que nunca ouvira falar dela e o terceiro afirmou que jamais leria sobre futebol nesse tipo de publicação. Optamos por inserir a revista como fonte para a compilação do corpus uma vez que acreditamos que um corpus deve ser abrangente de uma língua ou variedade linguística.

O gráfico 1 mostra a porcentagem de cada tipo de veículo informativo na composição da categoria RP:

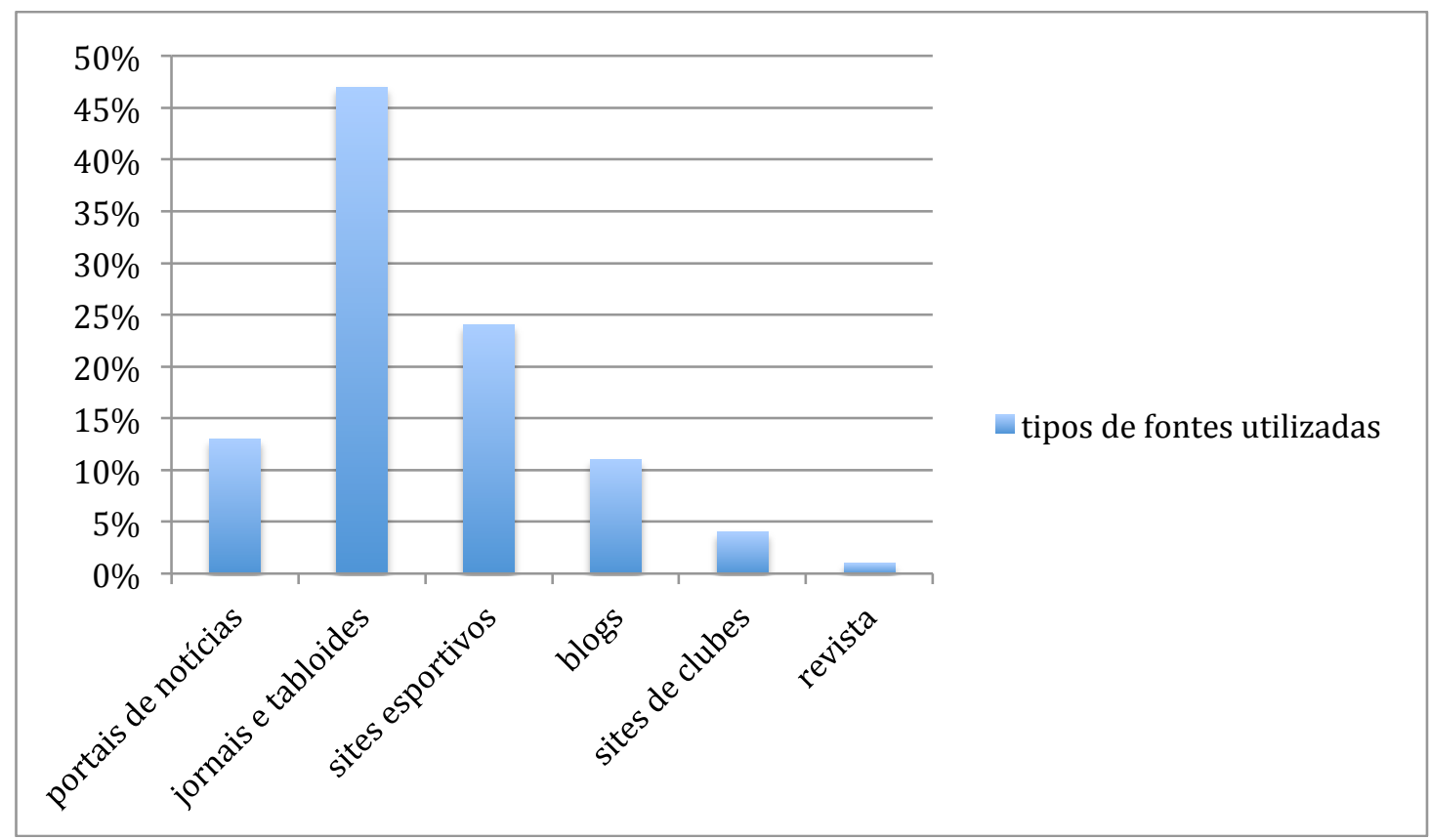

Gráfico 1: Tipos de fontes utilizadas na composição da categoria RP do subcorpus em português.

O segundo subcorpus é o de descrição de partidas (DP), que se diferencia do primeiro por tratar-se de textos que se assemelham muito a narrações, descrevem as partidas por meio de lances e são sempre divididos pelos minutos. A figura 3 mostra os dois gêneros textuais - RP e DP - no periódico Lance!Net: 


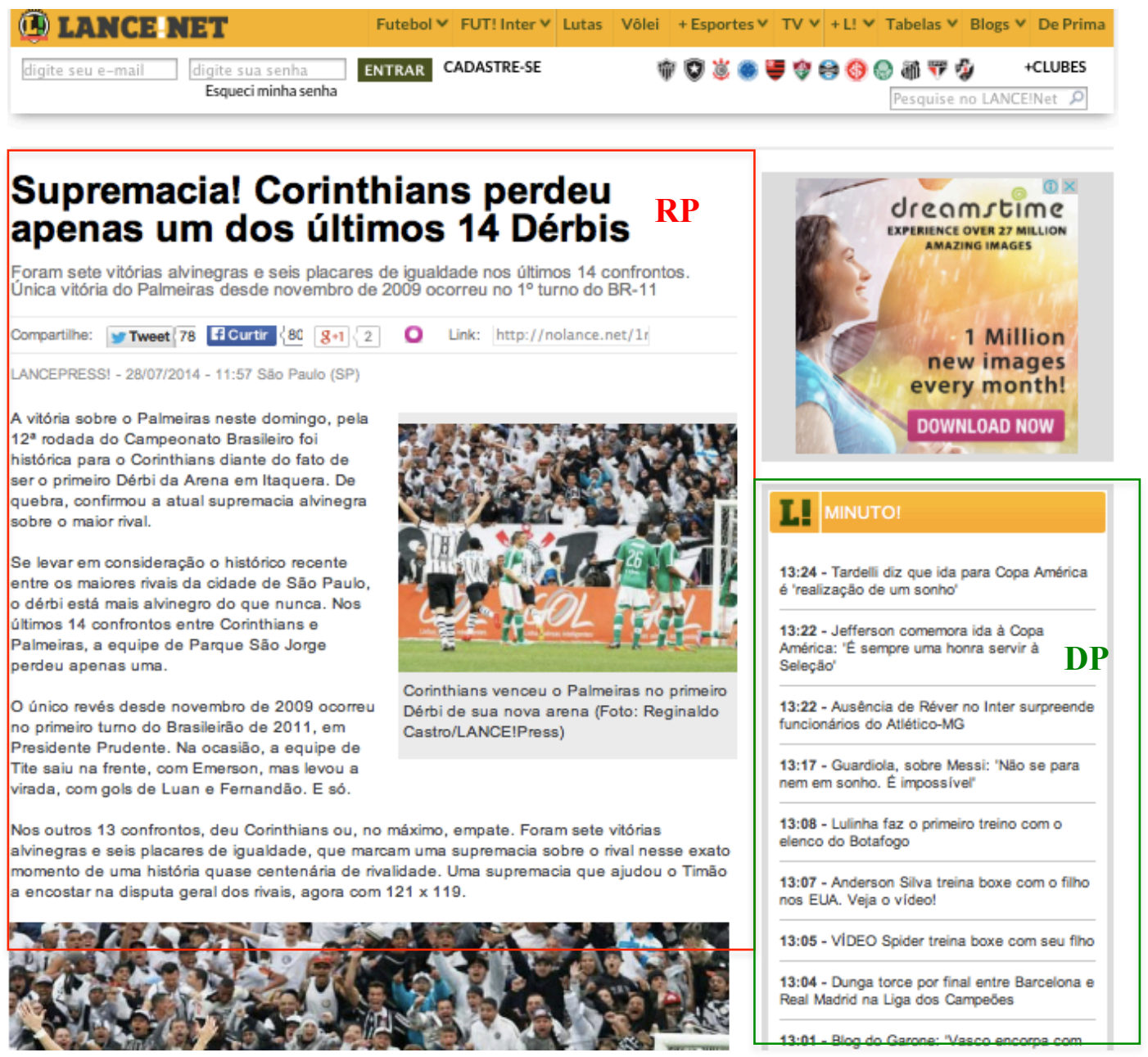

Figura 3: Página do periódico on-line Lance!Net com resultado de partida (à esquerda) e a descrição da partida (à direita) que ocorreu entre Palmeiras e Corinthians pela $12^{\mathrm{a}}$ rodada do Campeonato Brasileiro de 2014. $^{47}$

O quadro 6 mostra as fontes que configuram o corpus de descrições de partidas (DP) composto por textos da série A do Brasileirão:

\begin{tabular}{|c|c|c|}
\hline fonte & site & sigla \\
\hline \multicolumn{3}{|c|}{ portal de notícias } \\
\hline 1. Terra Esporte & http://esportes.terra.com.br & TER \\
\hline \multicolumn{3}{|c|}{ jornais } \\
\hline 1. Estado de São Paulo & http://www.estadao.com.br & ESP \\
\hline
\end{tabular}

\footnotetext{
${ }^{47}$ Como explicado no início deste capítulo, coletamos textos do Campeonato Brasileiro do ano de 2013 para compilar o corpus. Durante a coleta, atentamos somente para o texto e não salvamos figuras e vídeos que, porventura, acompanhassem a notícia. Além disso, vale ressaltar que, embora tenhamos tido o cuidado de salvar o link de todas as notícias, muitas vezes os comentários minuto a minuto são excluídos da página após algum tempo. Por esse motivo, em nossa tese mostramos quase sempre notícias de jogos mais atuais, ainda disponíveis na página do veículo de informação em questão, acompanhadas de figuras e, vídeos e, possivelmente, da descrição da partida.
} 


\section{Capítulo 3}

\begin{tabular}{|c|c|c|}
\hline 2. Folha de S. Paulo & http://www.folha.uol.com.br & FSP \\
\hline \multicolumn{3}{|c|}{ sites esportivos } \\
\hline 1. Lance!Net & http://www.lancenet.com.br & LAN \\
\hline 2. Globo Esporte & http://globoesporte.globo.com & GLE \\
\hline
\end{tabular}

Utilizamos apenas cinco sites para a coleta desse subcorpus, pois a grande maioria dos sites brasileiros ainda não disponibiliza descrições de partidas com regularidade. Alguns jornais e sites esportivos disponibilizam essas descrições esporadicamente, sem explicar aos leitores os critérios utilizados para privilegiar a descrição de algumas partidas em detrimento de outras. Nesses casos, optamos por não trabalhar com tais periódicos porque teríamos de acessar o site para verificar se havia a descrição. Em caso afirmativo, poderíamos coletar o texto, caso contrário, teríamos de procurar outro periódico, fato que tornaria a tarefa ainda mais laboriosa.

O gráfico a seguir mostra a porcentagem de cada tipo de veículo informativo na composição do corpus:

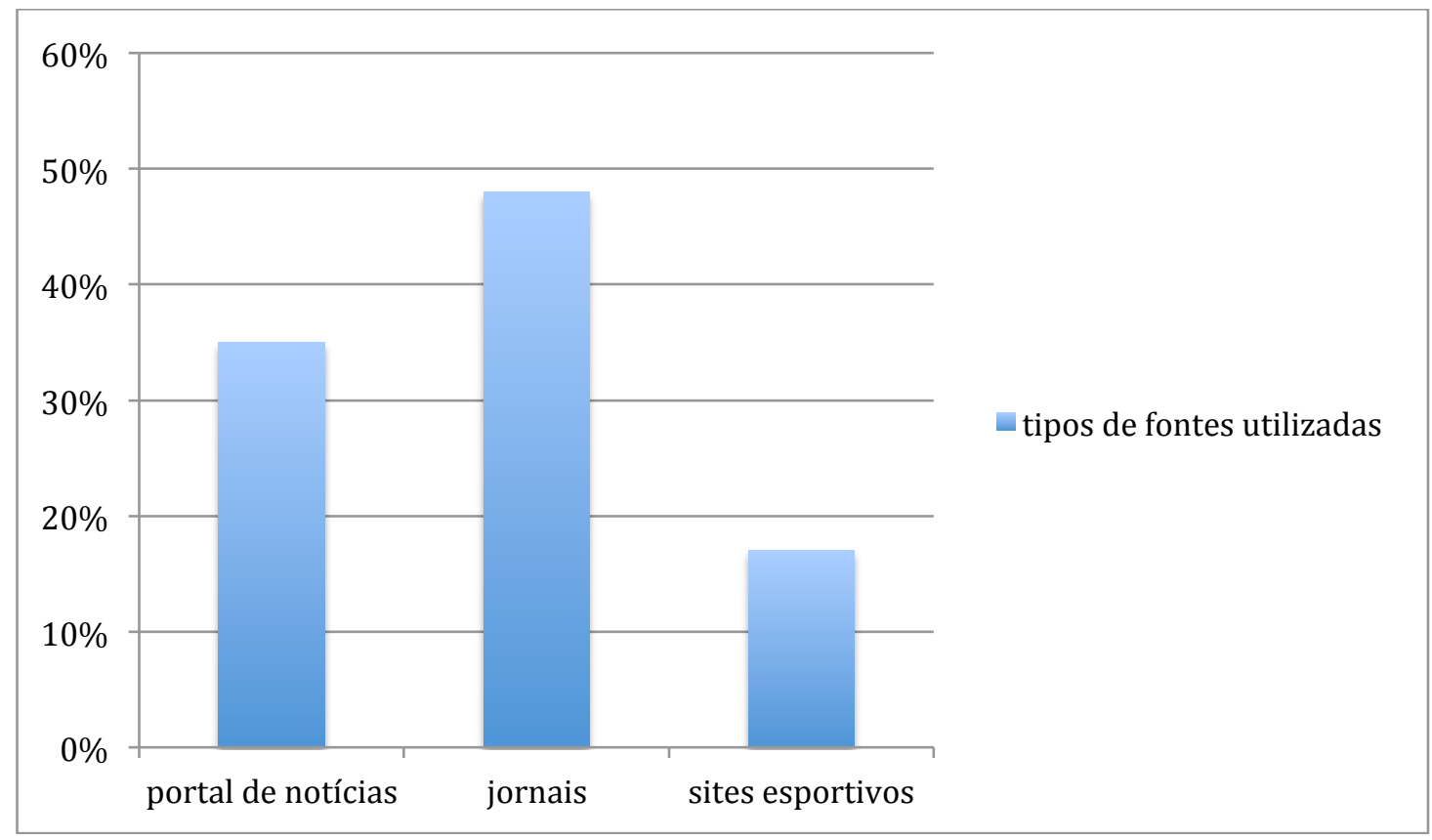

Gráfico 2: Tipos de fontes utilizadas na composição da categoria DR do subcorpus em português.

A maior parte dos textos coletados pertence aos dois jornais supracitados. Tal fato deu-se de forma natural, uma vez que tanto o site do Estado de São Paulo quanto o da Folha de S. Paulo publicam descrições de todos os jogos da série A do 


\section{Capítulo 3}

Brasileirão e nenhum dos sites apresenta problemas, como, por exemplo, congelamento da página durante a transmissão. Além disso, os dois sites mantêm essas descrições disponíveis por vários dias após o término do jogo, fator que facilita o processo de coleta dos textos. $35 \%$ dessa categoria é composto por textos do portal de notícias Terra, que se mostrou bastante eficaz para esse tipo de transmissão. Por fim, $17 \%$ do é composto por DP dos sites esportivos Lance!Net e Globo Esporte que, embora publiquem DP da maioria das partidas do Campeonato Brasileiro, às vezes apresentam problemas de funcionamento.

A terceira categoria que compõe nosso subcorpus de estudo em português é composta por relatos de partidas com comentários de internautas (RPCI) da série A do Campeonato Brasileiro de 2013. Os RPCI diferenciam-se das DP, pois, nos primeiros, os internautas podem comentar juntamente com os narradores. A compilação de textos para essa categoria demandou bastante trabalho. Primeiramente, tivemos muita dificuldade para encontrar sites que disponibilizassem esse tipo de notícia com regularidade. Após observar as transmissões em várias rodadas do Campeonato, selecionamos os dois sites que transmitem as notícias com regularidade: o do jornal Folha de S. Paulo e o site do Globo Esporte. O primeiro transmite os comentários dos jogadores em uma caixa de texto separada dos comentários dos narradores; já o segundo transmite os comentários dos torcedores, que frequentemente estão no estádio assistindo ao jogo, ao lado dos comentários dos narradores. Observemos a figura abaixo: 


\section{Capítulo 3}

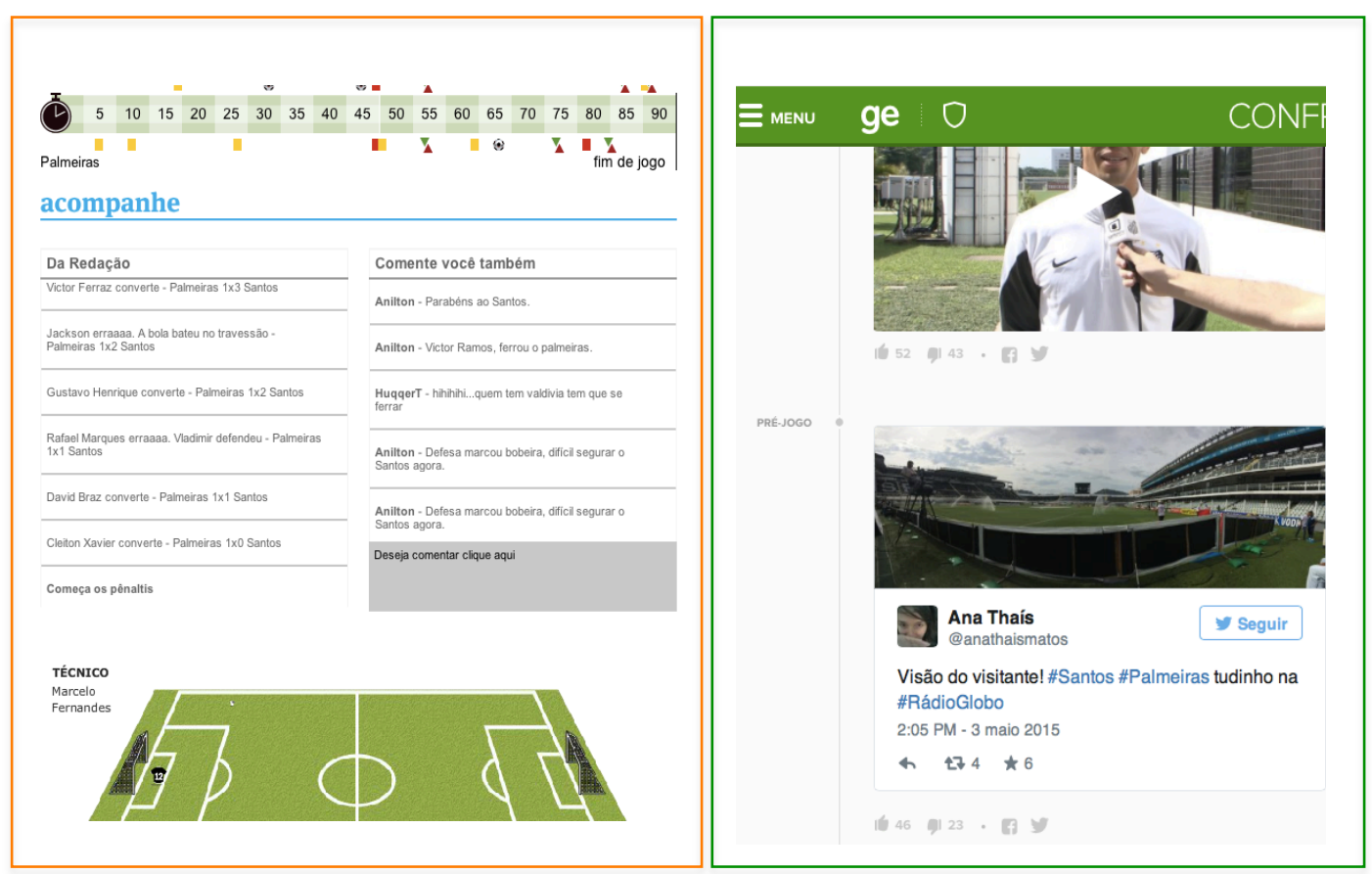

Figura 4: Página de RPCIs do jornal Folha de S. Paulo (à direita) e do site do Globo Esporte (à esquerda).

Como mencionado anteriormente, utilizamos apenas dois veículos de informação para a coleta da categoria RPCI, que possui 74 textos, sendo que 50 foram coletados da Folha de S. Paulo e os outros 24, do Globo Esporte.

Para compor a categoria sobre compra e venda de jogadores e técnicos no Brasil no ano de 2013, utilizamos as seguintes fontes:

\begin{tabular}{|c|c|c|}
\hline fonte & site & sigla \\
\hline \multicolumn{3}{|c|}{ Jornais } \\
\hline 1. Estado de Minas & http://www.em.com.br & EMI \\
\hline 2. Estado de São Paulo & http://www.estadao.com.br & EST \\
\hline 3. Folha de S. Paulo & http://www.folha.uol.com.br & FOL \\
\hline 3. Jornal do Brasil & http://jblog.jb.com.br & JB \\
\hline 5. O Globo & http://oglobo.globo.com & GLB \\
\hline 6. Zero Hora & http://zh.clicrbs.com.br/rs/ & ZER \\
\hline \multicolumn{3}{|c|}{ Sites esportivos } \\
\hline 1. Canelada & http://canelada.com.br & CAN \\
\hline 1. CBF News & http://www.cbf.com.br/noticias & $\mathrm{CBF}$ \\
\hline 3. ESPN & http://espn.uol.com.br & ESPN \\
\hline 4. Estádio VIP & http://estadiovip.com.br & EVIP \\
\hline 5. Gazeta Esportiva & http://www.gazetaesportiva.net & GAE \\
\hline 6. Globo Esporte & http://globoesporte.globo.com & GLE \\
\hline 7. Impedimento & http://impedimento.org & IMP \\
\hline 8. Lance!Net & http://www.lancenet.com.br & LAN \\
\hline 9. Olé do Brasil & http://oledobrasil.com.br & OLE \\
\hline 10. Plantão do Futebol & http://www.plantaodofutebol.com.br & PFU \\
\hline
\end{tabular}




\section{Capítulo 3}

\begin{tabular}{|l|l|l|}
\hline 11. SportTV & http://sportv.globo.com/site/ & STV \\
\hline 12. Tempo Real & http://globotv.globo.com/busca/?q=tempo+real & TR \\
\hline 13. Torcedores & http://torcedores.com & TOR \\
\hline \multicolumn{2}{|c|}{ Blogs de futebol } & \\
\hline 1. Blog do Milton Neves & http://blogmiltonneves.bol.uol.com.br & BMN \\
\hline 2. Blog do Neto & http://blogdoneto.blogosfera.uol.com.br & BN \\
\hline
\end{tabular}

Quadro 7: Fontes utilizadas para a compilação da categoria CV em português

Para compilar a categoria CV do subcorpus de estudo em português, utilizamos 21 fontes distintas. Os sites que mais publicam notícias sobre compra e venda de jogadores são os sites esportivos. Acreditamos que tal fato justifique-se por ser o leitor desses sites geralmente "mais especializado", desejoso de obter outros tipos de informação sobre seu time além dos resultados das partidas. Os blogs de futebol também publicam esse tipo de notícia com certa regularidade, seguidos dos jornais. O gráfico 3 mostra a divisão das fontes utilizadas:

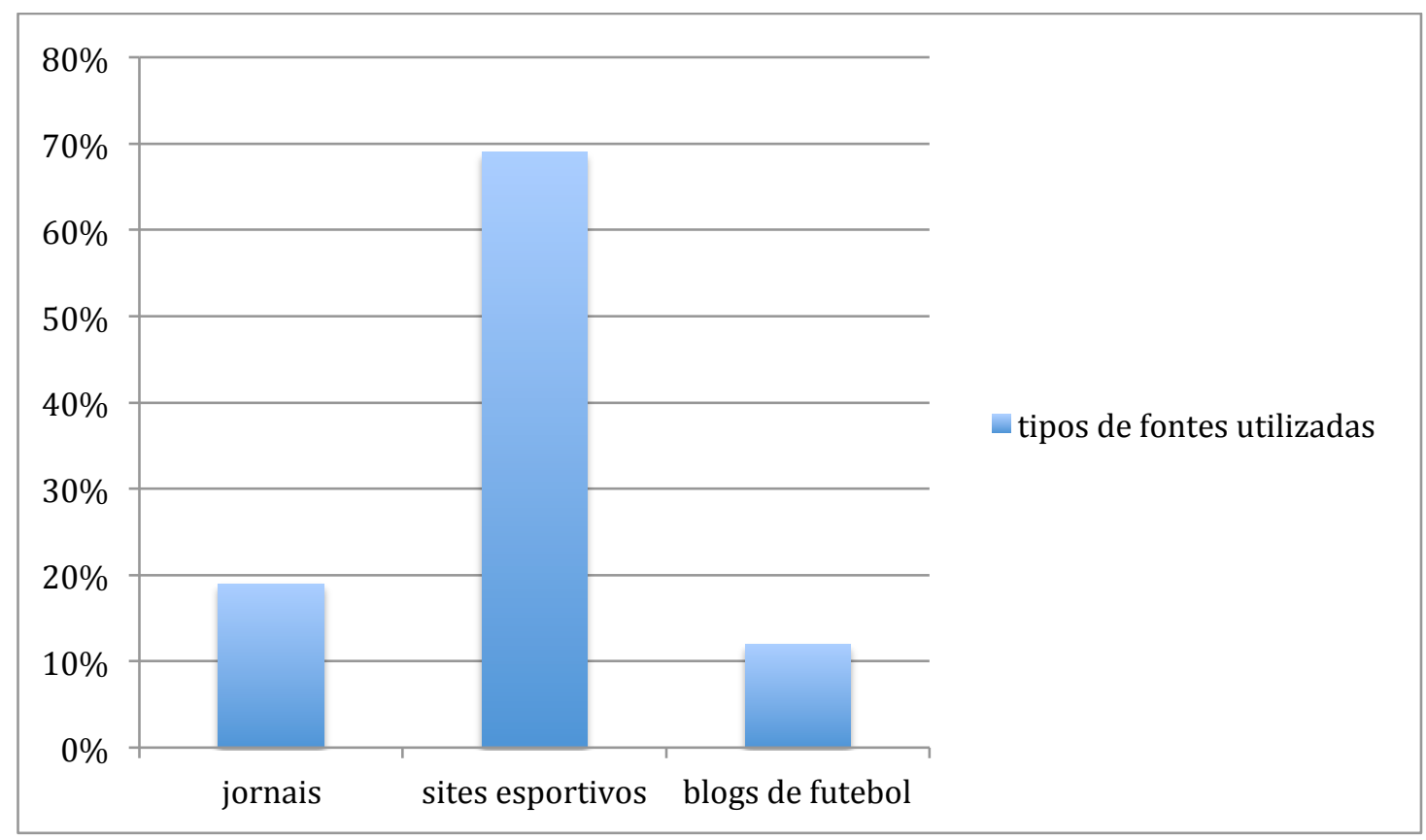

Gráfico 3: Tipos de fontes utilizadas na composição do corpus CV em português.

Para compor a categoria de notícias sobre a situação dos times nos campeonatos (ST), selecionamos textos das seguintes fontes:

\begin{tabular}{|l|l|l|}
\hline \multicolumn{1}{|c|}{ fonte } & \multicolumn{1}{c|}{ site } & \multicolumn{1}{c|}{ sigla } \\
\hline \multicolumn{1}{|c|}{ Portais de notícias } & TER \\
\hline 1. Terra esportes & http://esportes.terra.com.br & $\underline{ }$ \\
\hline
\end{tabular}




\section{Capítulo 3}

\begin{tabular}{|c|c|c|}
\hline 2. UOL esportes & http://esporte.uol.com.br & UOL \\
\hline \multicolumn{3}{|c|}{ Jornais e Tabloides } \\
\hline 1. Correio 24 horas & http://www.correio24horas.com.br & COR \\
\hline 2. Diário de São Paulo & http://www.diariosp.com.br & DSP \\
\hline 3. Estado de Minas & http://www.em.com.br & EMI \\
\hline 4. Estado de São Paulo & http://www.estadao.com.br & EST \\
\hline 5. Folha de S. Paulo & http://www.folha.uol.com.br & FOL \\
\hline 6. Jornal do Brasil & http://jblog.jb.com.br & JB \\
\hline 7. O Dia & http://odia.ig.com.br & DIA \\
\hline 8. O Globo & http://oglobo.globo.com & GLB \\
\hline 9. Zero Hora & http://zh.clicrbs.com.br/rs/ & ZER \\
\hline \multicolumn{3}{|c|}{ Sites esportivos } \\
\hline 1. Acervo Santista & http://www.acervosantista.com.br & ASAN \\
\hline 2. Arena FC & http://www.arenafutebolclube.com.br & ARE \\
\hline 3. Canelada & http://canelada.com.br & CAN \\
\hline 4. CBF News & http://www.cbf.com.br/noticias & CBF \\
\hline 5. ESPN & http://espn.uol.com.br & ESPN \\
\hline 6. Estádio VIP & http://estadiovip.com.br & EVIP \\
\hline 7. Futebol Interior & http://www.futebolinterior.com.br & FINT \\
\hline 8. Futebol na Rede & http://futebolnarede.com & FRED \\
\hline 9. Gazeta Esportiva & http://www.gazetaesportiva.net & GAE \\
\hline 10. Globo Esporte & http://globoesporte.globo.com & GLE \\
\hline 11. Impedimento & http://impedimento.org & IMP \\
\hline 12. Lance!Net & http://www.lancenet.com.br & LAN \\
\hline 13. Olé do Brasil & http://oledobrasil.com.br & OLE \\
\hline 14. Plantão do Futebol & http://www.plantaodofutebol.com.br & PFU \\
\hline 15. SportTV & http://sportv.globo.com/site/ & STV \\
\hline 16. Tempo Real & http://globotv.globo.com/busca/?q=tempo+real & TR \\
\hline 17. Torcedores & http://torcedores.com & TOR \\
\hline
\end{tabular}

Quadro 8: Fontes utilizadas para a compilação da categoria ST do subcorpus em português.

A coleta dos textos da categoria ST em português foi bastante simples: coletamos um texto de cada um dos periódicos selecionados, com exceção dos sites Globo Esporte, Impedimento e Lance!Net, dos quais coletamos dois textos cada. Desse modo, a divisão dos tipos de fonte foi a seguinte: 


\section{Capítulo 3}

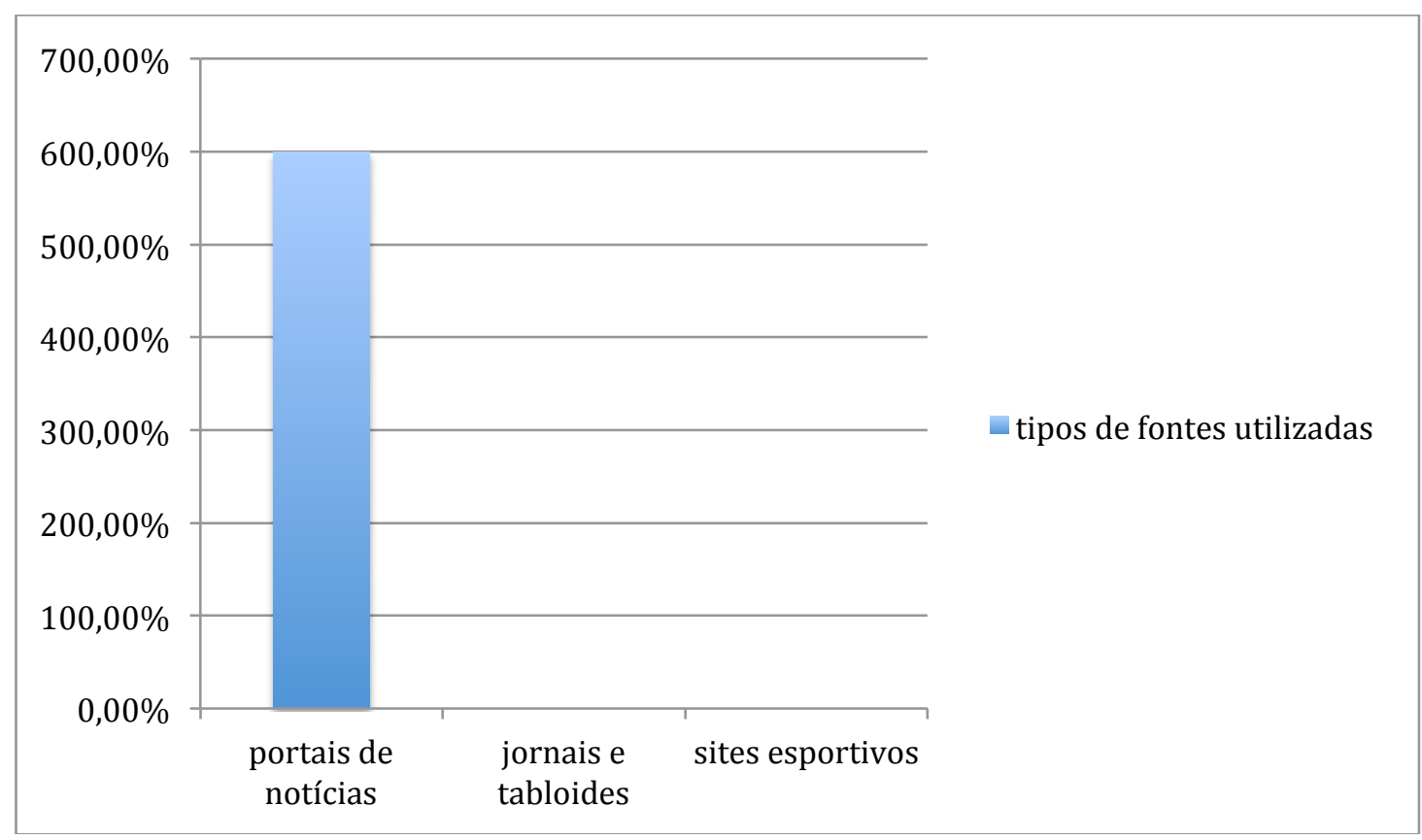

Gráfico 4: Tipos de fontes utilizadas na composição da categoria ST do subcorpus em português.

\subsubsection{Subcorpus em inglês}

Como mencionado no item 3.2, o subcorpus em inglês é composto por textos da Barclay's Premier League, do Coca-Cola Championship, da Coca-Cola League One, e da Coca-Cola League Two da temporada de 2013/2014. Diferentemente do recorte realizado em português, o recorte em inglês não se deu por campeonatos estaduais, mas sim por divisões. Tal escolha pode ser justificada pela própria organização dos campeonatos no Reino Unido.

A primeira divisão do futebol inglês é a Premier League, conhecida atualmente como Barclay's Premier League por questões de patrocínio. É uma liga de uma única divisão e conta com vinte clubes. Abaixo da Premier League, encontramos a Football League, que é dividida em três divisões de 24 clubes, todos profissionais: Coca-Cola Championship (segunda divisão), Coca-Cola League One (terceira divisão), e Coca-Cola League Two (quarta divisão). Os 92 clubes que compõem as quatro primeiras divisões são chamados de league clubs e representam a elite do futebol inglês.

Embora a Premier League não seja associada à Football League desde 1992, o sistema de rebaixamento e promoção entre as duas ligas permanece: todo ano caem 


\section{Capítulo 3}

três clubes da Premier League para o Coca-Cola Championship; três clubes do CocaCola Championship sobem para a Premier League e três clubes caem para a CocaCola League one; três clubes da Coca-Cola League One sobem para o Coca-Cola Championship, ao passo que outros três caem para a Coca-Cola League Two; três clubes da Coca-Cola League Two sobem para a Coca-Cola League One e três caem para a Blue Square Premier (quinta e última divisão nacional), que não faz parte dos "League Clubs". A maioria dos jogadores dessa liga exerce a atividade profissionalmente, mas alguns também desempenham outras atividades remuneradas.

Abaixo da quinta divisão começam a aparecer divisões mais regionais. A sexta divisão é subdividida em Blue Square North e Blue Square South, ou seja, norte e sul. Após o término dos respectivos campeonatos, os melhores times de cada subdivisão disputam uma partida decisiva para estabelecer os clubes que sobem para a Blue Square Premier e os que caem para a sétima divisão, que, por sua vez, é subdividida em Unibond Premier, BGB South Premier e Ryman Premier, sendo que cada uma delas subdivide-se em duas. Esse tipo de subdivisão geográfica ocorre até a $16^{\text {a }}$ divisão.

Enfim, explicar detalhadamente as divisões e os campeonatos do futebol inglês foge ao escopo deste trabalho. Contudo, acreditamos que o breve panorama apresentado é essencial para justificar a escolha de se trabalhar com campeonatos nacionais, e não regionais, como fizemos em português. Isso se deve ao fato de que, como explicado, as divisões regionais só acontecem a partir da sexta divisão, que conta também com jogadores não profissionais, fator que, acreditamos, influencia a dinâmica de uma partida em relação ao saldo de gols, aos tipos de dribles e ao número de faltas. Ademais, o espaço que esses campeonatos ocupam na mídia é significativamente inferior ao das quatro primeiras divisões, razão pela qual não encontramos regularidade na publicação de notícias, dificultando bastante uma coleta sistemática de textos para o corpus.

Assim como na compilação do subcorpus em português, utilizamos jornais e tabloides, portais de notícias, sites esportivos, sites de clubes, agências de notícias, emissoras, revistas e sites de apostas para compilar o subcorpus em inglês.

O quadro 9 contém as fontes que configuram a categoria de resultados de partidas (RP), composto por textos da Barclay's Premier League, do Coca-Cola 


\section{Capítulo 3}

Championship, da Coca-Cola League One, e da Coca-Cola League Two da temporada de 2013/2014:

\begin{tabular}{|c|c|c|}
\hline fonte & site & sigla \\
\hline \multicolumn{3}{|c|}{ Portais de notícias } \\
\hline 1. The Huffington Post & http://www.huffingtonpost.com & HUF \\
\hline 2. International Business Time & http://www.ibtimes.co.uk & IBT \\
\hline 3. Sports Yahoo & http://sports.yahoo.com & YAH \\
\hline \multicolumn{3}{|c|}{ Jornais e Tablóides } \\
\hline 1. Daily Express & http://www.express.co.uk & DAIE \\
\hline 2. Daily Post & http://www.dailypost.co.uk & DAIP \\
\hline 3. Mail Online & http://www.dailymail.co.uk/home/index.html & MAI \\
\hline 4. Metro & http://metro.co.uk & MET \\
\hline 5. Mirror Online & http://www.mirror.co.uk & MIR \\
\hline 6. The Guardian & http://www.theguardian.com/uk & GUA \\
\hline 7. The Independent & http://www.independent.co.uk & IND \\
\hline 8. The Journal & http://www.thejournal.co.uk & JOU \\
\hline 9. The Sun & http://www.thesun.co.uk/sol/homepage/ & SUN \\
\hline 10. The Telegraph & http://www.telegraph.co.uk & TEL \\
\hline 11. The Times & http://www.thetimes.co.uk/tto/news/ & TIM \\
\hline 12. Western Gazette & http://www.westerngazette.co.uk & WGAZ \\
\hline \multicolumn{3}{|c|}{ sites esportivos } \\
\hline 1. Bleacher Report & http://bleacherreport.com & BLE \\
\hline 2. Click Liverpool & http://www.clickliverpool.com & CLI \\
\hline 3. Dirty tackle & http://www.dirtytackle.net & DTA \\
\hline 4. Eye football & http://www.eyefootball.com & EFOO \\
\hline 5. FIFA News & http://www.fifa.com/newscentre/news/ & FFN \\
\hline 6. Football 565 & http://www.football365.com & F565 \\
\hline 7. Four Four Two & http://www.fourfourtwo.com & FFT \\
\hline 8. FOX Sports & http://www.foxsports.com.br & FOX \\
\hline 9. Goal Stage & http://goalstage.com & GS \\
\hline 10. Manchester United Mad & http://www.manchesterunited-mad.co.uk & MUM \\
\hline 11. Midfield Dynamo & http://www.midfielddynamo.com & MDY \\
\hline 12. Premier League & http://www.premierleague.com/en-gb.html & PL \\
\hline 13. SKY Sports & http://www.skysports.com & SSP \\
\hline 14. Sons of Sam horn & http://sonsofsamhorn.net & SSH \\
\hline 15. Sporting Life & http://www.sportinglife.com/football & SP \\
\hline 16. Sport Net & http://www.sport.net & SNET \\
\hline 17. Talk Sports & http://talksport.com & TSP \\
\hline 18.Team Talk & http://www.teamtalk.com & TT \\
\hline 19. The FA & http://www.thefa.com & TFA \\
\hline 20. The Offside & http://www.theoffside.com & TOF \\
\hline 21. The Spoiler & http://www.thespoiler.co.uk & TSP \\
\hline 22. Weloba & http://www.weloba.com & WLB \\
\hline 23. World soccer & http://www.worldsoccer.com & WS \\
\hline 24. 101 Great Goals & http://www.101 greatgoals.com & GRE \\
\hline $25.90 \mathrm{~min}$ & http://www.90min.com/leagues/premier-league & $90 \mathrm{M}$ \\
\hline \multicolumn{3}{|c|}{ Agência de notícias } \\
\hline 1. Reuters & http://thomsonreuters.com/en.html & THO \\
\hline \multicolumn{3}{|c|}{ Sites americanos } \\
\hline 1. News Day & http://www.newsday.com & ND \\
\hline 2. Sports Illustrated & http://www.si.com & SI \\
\hline
\end{tabular}




\section{Capítulo 3}

\begin{tabular}{|c|c|c|}
\hline 1. Manchester United & http://www.manutd.com/Splash-Page.aspx & MAN \\
\hline 2. Tottenham Spur & http://www.tottenhamhotspur.com & TTS \\
\hline \multicolumn{3}{|c|}{ Emissora } \\
\hline 1. BBC & http://www.bbc.co.uk & $\mathrm{BBC}$ \\
\hline \multicolumn{3}{|c|}{ Revista } \\
\hline 1. RWD & http://rwdmag.com & RWD \\
\hline \multicolumn{3}{|c|}{ Sites de apostas } \\
\hline 1. Bet shoot & http://www.betshoot.com & BET \\
\hline
\end{tabular}

Para compor a categoria RP, utilizamos 48 fontes distintas, sempre tentando abranger os principais veículos de informação da imprensa futebolísica Inglesa. Três correspondem a portais de notícias: The Huffington Post, International Business Time e Sports Yahoo. Optamos por coletar textos do The Huffington Post, pois o portal tornou-se um dos mais populares na web nos últimos anos; selecionamos o International Business Time devido à natureza do portal: um portal sobre negócios, mas que diariamente publica textos sobre futebol; e decidimos trabalhar com o Yahoo Sports, pois o portal, além de bastante popular, publica semanalmente notícias sobre resultados de todos os jogos das quatro primeiras divisões do futebol inglês.

No que se refere aos jornais e tabloides, selecionamos os veículos que publicam notícias sobre resultados de partidas das quatro primeiras divisões. Além disso, todos os periódicos selecionados publicam notícias antes, durante e depois da partida, fator que nos ajudou de forma significativa na compilação da categoria, uma vez que ao coletarmos textos para a RP, selecionávamos, também, os textos para compor as categorias DP e RPCI.

A seleção dos sites esportivos, que, assim como em português, abrangem tanto sites esportivos em geral quanto sites sobre futebol, foi feita com base em pesquisas na internet. Antes de iniciar a coleta desses textos pesquisamos quais eram os melhores sites esportivos em geral e os melhores sites sobre futebol. A pesquisa realizada no Google retornou páginas que listavam os melhores sites. Fizemos uma listagem de todos os sites mencionados, visitamos seus domínios a fim de analisar o tipo de notícia publicada e verificamos a viabilidade de coleta.

Optamos por incluir textos da Reuters porque, durante a pesquisa realizada para verificar onde o público inglês lê sobre futebol, a agência foi mencionada em diversos sites.

Embora nosso subcorpus seja representativo do inglês britânico, selecionamos 


\section{Capítulo 3}

dois periódicos americanos para ajudar em sua compilação: a revista Sports Illustrated que, embora americana, publica notícias sobre todos os jogos dos campeonatos ingleses até a quarta divisão; e o jornal Newsday que, apesar de não ser um dos jornais mais conhecidos fora dos Estados Unidos, ocupa a $11^{\mathrm{a}}$ posição no ranking de distribuição dos jornais nesse país. Mas o principal fator para a inclusão desse jornal no corpus, em detrimento de outro com mais prestígio internacional, é que, durante pesquisa realizada no Google, o Newsday foi apontado quatro vezes como melhor jornal on-line para se informar sobre o campeonato inglês nos Estados Unidos

Selecionamos os sites dos clubes Manchester United e Tottenham HotSpur para compor a categoria de sites esportivos devido a sua organização, o que facilita a busca por determinadas notícias. É importante ressaltar que os sites Manchester United Mag e We Love Barça não fazem parte dessa categoria, pois não são vinculados aos times que dão nome aos sites, Manchester United e Barcelona, respectivamente. Ressaltamos, ainda, que o site We Love Barça, embora carregue o nome de um time espanhol, escreve sobre futebol inglês, e seus colaboradores são, em grande maioria, britânicos.

A emissora $B B C$ foi incluída nas fontes do corpus devido a sua popularidade na Inglaterra e ao grande espaço que dedica ao futebol no site BBC Sports.

Durante a pesquisa no Google, constatamos que a revista $R W D$ foi apontada como um dos melhores periódicos para se inteirar sobre futebol de forma clara e objetiva, pois, embora publique notícias sobre todos os jogos dos campeonatos, essas são sempre curtas e mencionam somente os pontos principais das partidas.

Por fim, decidimos coletar notícias publicadas no site de apostas betshoot, devido à cultura de apostas esportivas no Reino Unido. Bastante presente na década de 1920 em São Paulo e no Rio de Janeiro, tal prática desapareceu no Brasil nas décadas seguintes (HOLLANDA et al., 2012).

O gráfico 5 mostra a porcentagem de cada tipo de veículo informativo na composição da categoria RP do subcorpus em inglês: 


\section{Capítulo 3}

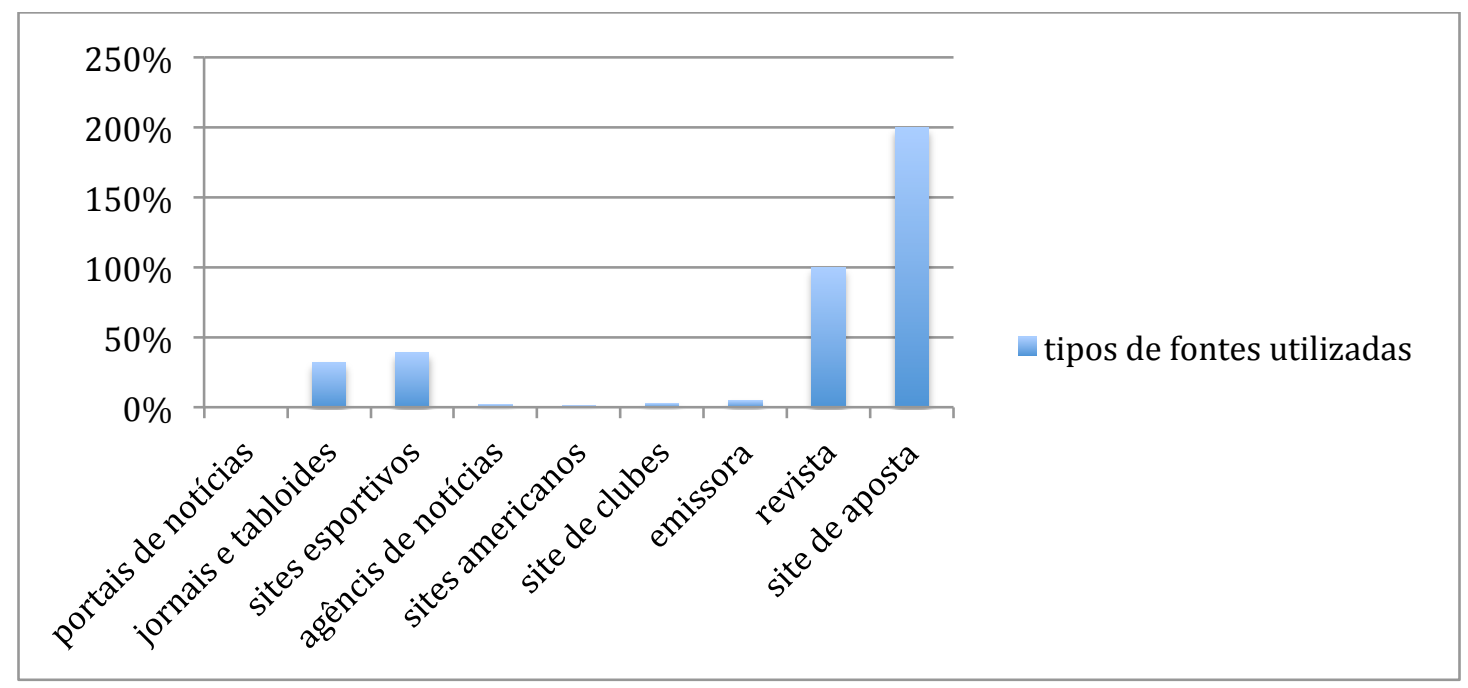

Gráfico 5: Tipos de fontes utilizadas na composição da categoria RP em inglês.

A segunda categoria que compõe o subcorpus em inglês é o de descrição de partidas (DP) e a figura 5 mostra os dois gêneros textuais compreendidos: uma notícia sobre o resultado de uma partida entre Derby e Nottingham Forest (à direita) e a descrição da mesma partida (à esquerda), ambas coletadas do mesmo jornal:
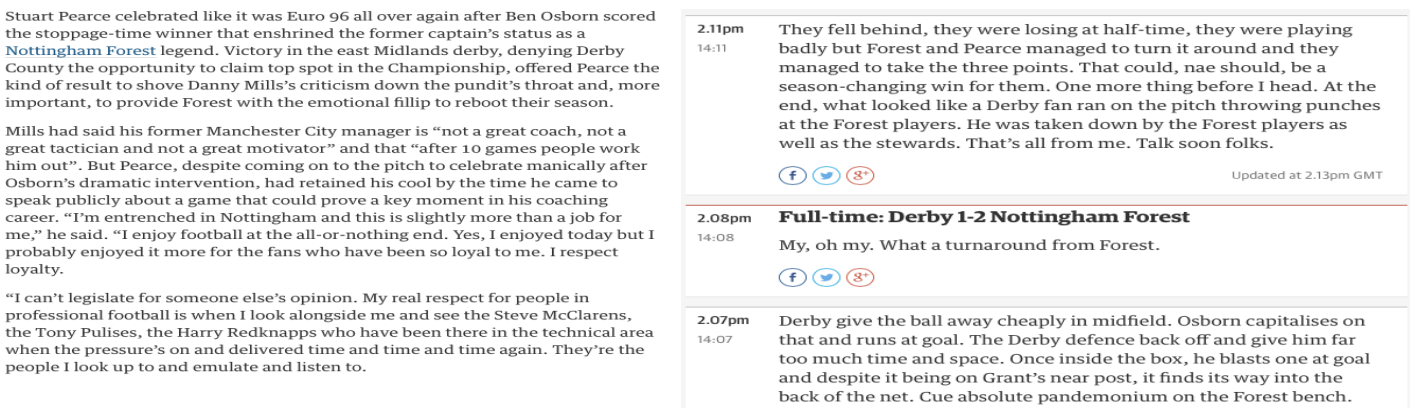

Figura 5: Notícia sobre o resultado de uma partida entre Derby e Nottingham Forest (direita) e a descrição da mesma partida (esquerda); ambas retiradas do site do Jornal The Guardian.

O quadro 10 mostra as fontes que configuram o corpus de descrições de partidas (DP), composto por textos da Barclay's Premier League, do Coca-Cola Championship, da Coca-Cola League One, e da Coca-Cola League Two da temporada de 2013/2014:

\begin{tabular}{|c|c|c|}
\hline fonte & site & sigla \\
\hline \multicolumn{3}{|c|}{ Jornais e Tablóides } \\
\hline 1. Mail Online & http://www.dailymail.co.uk/home/index.html & MAI \\
\hline
\end{tabular}




\section{Capítulo 3}

\begin{tabular}{|c|c|c|}
\hline 2. Mirror Online & http://www.mirror.co.uk & MIR \\
\hline 3. The Guardian & http://www.theguardian.com/uk & GUA \\
\hline 4. The Independent & http://www.independent.co.uk & IND \\
\hline 5. The Journal & http://www.thejournal.co.uk & JOU \\
\hline 6. The Telegraph & http://www.telegraph.co.uk & TEL \\
\hline 7. The Times & http://www.thetimes.co.uk/tto/news/ & TIM \\
\hline \multicolumn{3}{|c|}{ sites esportivos } \\
\hline 1. Bleacher Report & http://bleacherreport.com & BLE \\
\hline 2. Eye football & http://www.eyefootball.com & EFOO \\
\hline 3. FOX Sports & http://www.foxsports.com.br & FOX \\
\hline 4. SKY Sports & http://www.skysports.com & SSP \\
\hline 5. Talk Sports & http://talksport.com & TSP \\
\hline 6. The Offside & http://www.theoffside.com & TOF \\
\hline 7. The Spoiler & http://www.thespoiler.co.uk & TSP \\
\hline $8.90 \mathrm{~min}$ & http://www.90min.com/leagues/premier-league & $90 \mathrm{M}$ \\
\hline \multicolumn{3}{|c|}{ Emissora } \\
\hline 1. BBC & http://www.bbc.co.uk & $\mathrm{BBC}$ \\
\hline
\end{tabular}

Quadro 10: Fontes utilizadas para a compilação da categoria DP do subcorpus em inglês.

O gráfico a seguir mostra a porcentagem de cada tipo de veículo informativo na composição da categoria DP:

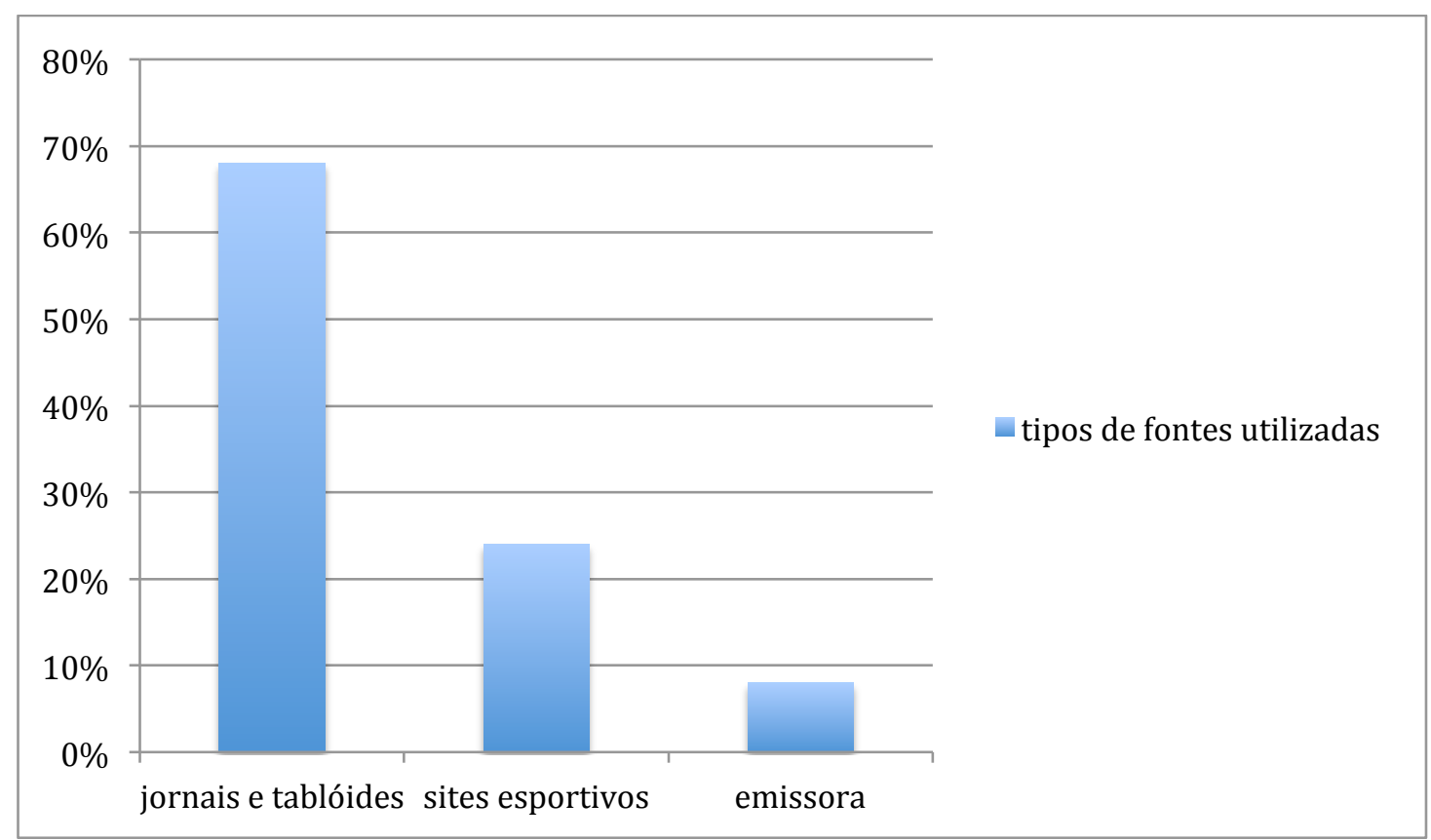

Gráfico 6: Tipos de fontes utilizadas na composição da categoria DP do subcorpus em inglês.

A limitação dos tipos de fontes utilizadas e a redução do número de periódicos em cada categoria devem-se à menor oferta do gênero textual em questão. A princípio acreditávamos que os sites esportivos apresentariam maior oferta de descrições de 


\section{Capítulo 3}

partidas; no entanto, os jornais e tabloides publicam essas descrições com maior regularidade, além de possuir estrutura mais organizada, o que contribui de forma significativa para o trabalho de compilação do corpus.

A terceira categoria é composta por relatos de partidas com comentários de internautas (RPCI) da Barclay's Premier League, do Coca-Cola Championship, da Coca-Cola League One, e da Coca-Cola League Two da temporada de 2013/2014. Em alguns sites os comentários ocorrem no corpo do texto, simultaneamente com a descrição da partida pelo periódico em questão, mas na grande maioria esses comentários ocorrem em uma seção separada, abaixo do texto dos narradores. Não raras vezes um periódico apresenta somente RPCI, deixando de lado as DPs. Em nossa pesquisa, entendemos que os RPCIs complementam as DPs. Contudo, optamos por armazenar esses textos separadamente por questão de organização. A figura 6 mostra dois RPCIs: à esquerda temos um RPCI retirado do jornal The Telegraph, onde o internauta faz comentários no meio do texto do narrador; o RPCI à direita, retirado do Mail Online, mostra os comentários dos internautas em um bloco de texto separado da descrição da partida feita pelo narrador:
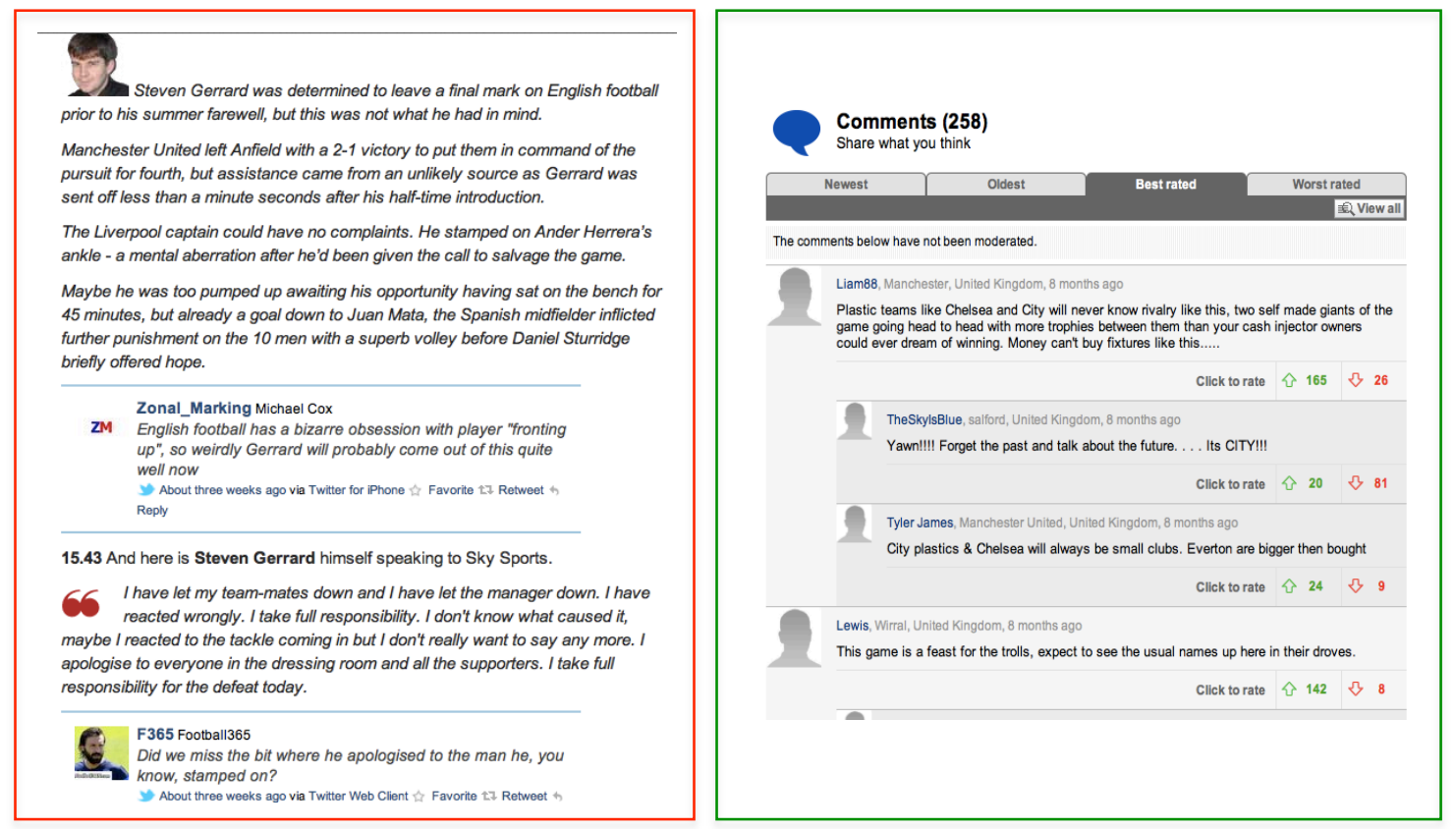

Figura 6: RPCI retirado do jornal The Telegraph (direita) e RPCI retirado do Mail Online (esquerda).

É interessante observar que, além de o jornal Mail Online apresentar os comentários em aba diferente no site, permite, ainda, que esses comentários sejam 


\section{Capítulo 3}

classificados pelas seguintes categorias: mais recentes, mais antigos, melhores comentários e piores comentários.

Esse subcorpus dispensa a listagem de fontes utilizadas uma vez que o recorte realizado foi o mesmo que utilizamos para a coleta das DPs. Ressaltamos, no entanto, que, por vezes, os RPCIs correspondem às DPs acrescidas de comentários. Nesses casos, selecionamos um único subcorpus para armazenar o texto de uma partida. No exemplo da figura 6, o texto foi armazenado somente no subcorpus RPCI. O gráfico abaixo mostra a porcentagem de cada tipo de veículo informativo na composição da categoria:

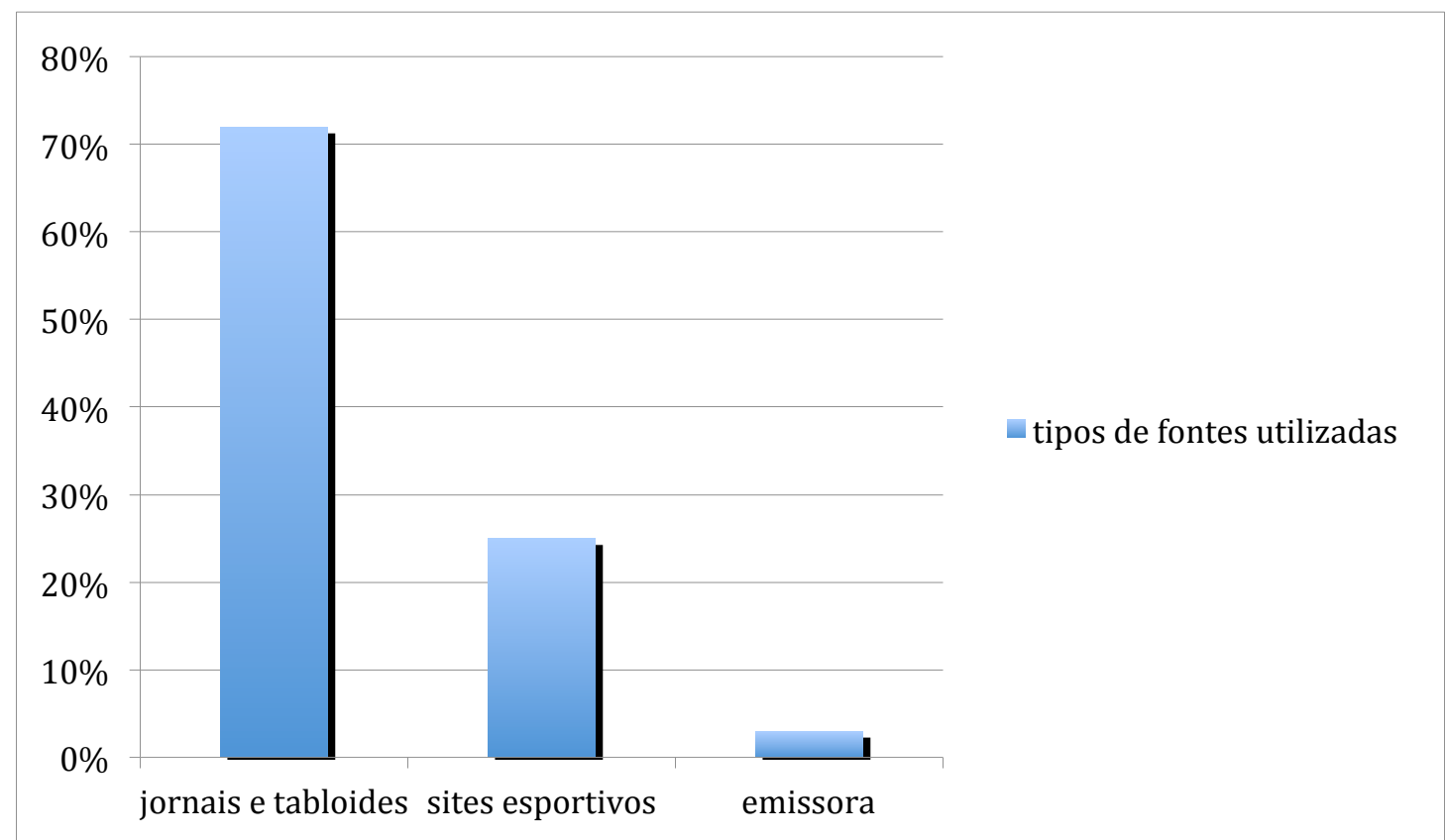

Gráfico 7: Tipos de fontes utilizadas na composição do corpus CV em inglês.

Para compor o subcorpus sobre compra e venda de jogadores e técnicos na Inglaterra e na Europa nos anos de 2013 e 2014, utilizamos as seguintes fontes:

\begin{tabular}{|c|c|c|}
\hline fonte & site & sigla \\
\hline \multicolumn{3}{|c|}{ Jornais e Tabloides } \\
\hline 1. Daily Express & http://www.express.co.uk & DAIE \\
\hline 2. Daily Post & http://www.dailypost.co.uk & DAIP \\
\hline 3. Mail Online & http://www.dailymail.co.uk/home/index.html & MAI \\
\hline 4. Metro & http://metro.co.uk & MET \\
\hline 5. Mirror Online & http://www.mirror.co.uk & MIR \\
\hline 6. The Guardian & http://www.theguardian.com/uk & GUA \\
\hline
\end{tabular}




\section{Capítulo 3}

\begin{tabular}{|c|c|c|}
\hline 7. The Independent & http://www.independent.co.uk & IND \\
\hline 8. The Journal & http://www.thejournal.co.uk & JOU \\
\hline 9. The Sun & http://www.thesun.co.uk/sol/homepage/ & SUN \\
\hline 10. The Telegraph & http://www.telegraph.co.uk & TEL \\
\hline 11. The Times & http://www.thetimes.co.uk/tto/news/ & TIM \\
\hline 12. Western Gazette & http://www.westerngazette.co.uk & WGAZ \\
\hline \multicolumn{3}{|c|}{ sites esportivos } \\
\hline 1. Bleacher Report & http://bleacherreport.com & BLE \\
\hline 2. Click Liverpool & http://www.clickliverpool.com & CLI \\
\hline 3. Dirty tackle & http://www.dirtytackle.net & DTA \\
\hline 4. Eye football & http://www.eyefootball.com & EFOO \\
\hline 5. FIFA News & http://www.fifa.com/newscentre/news/ & FFN \\
\hline 6. Football 565 & http://www.football365.com & F565 \\
\hline 7. Four Four Two & http://www.fourfourtwo.com & FFT \\
\hline 8. FOX Sports & http://www.foxsports.com.br & FOX \\
\hline 9. Goal Stage & http://goalstage.com & GS \\
\hline 10. Manchester United Mad & http://www.manchesterunited-mad.co.uk & MUM \\
\hline 11. Midfield Dynamo & http://www.midfielddynamo.com & MDY \\
\hline 12. Premier League & http://www.premierleague.com/en-gb.html & PL \\
\hline 13. SKY Sports & http://www.skysports.com & SSP \\
\hline 14. Sons of Sam horn & http://sonsofsamhorn.net & SSH \\
\hline 15. Sporting Life & http://www.sportinglife.com/football & SP \\
\hline 16. Sport Net & http://www.sport.net & SNET \\
\hline
\end{tabular}

Por representar uma parte menor do subcorpus, apenas 32 textos, foi possível realizar um balanceamento mais preciso entre os tipos de fontes, de modo que $50 \%$ do categoria é composto por textos extraídos de jornais e tabloides, e os outros $50 \%$, por textos de sites esportivos.

Por fim, para compor a menor categoria, a de notícias sobre a situação dos times nos campeonatos (ST), selecionamos textos das seguintes fontes:

\begin{tabular}{|c|c|c|}
\hline fonte & site & sigla \\
\hline \multicolumn{3}{|c|}{ Jornais e Tabloides } \\
\hline 1. Daily Express & http://www.express.co.uk & DAIE \\
\hline 2. Daily Post & http://www.dailypost.co.uk & DAIP \\
\hline 3. Mail Online & http://www.dailymail.co.uk/home/index.html & MAI \\
\hline 4. Metro & http://metro.co.uk & MET \\
\hline 5. Mirror Online & http://www.mirror.co.uk & MIR \\
\hline 6. The Guardian & http://www.theguardian.com/uk & GUA \\
\hline 7. The Independent & http://www.independent.co.uk & IND \\
\hline 8. The Journal & http://www.thejournal.co.uk & JOU \\
\hline 9. The Sun & http://www.thesun.co.uk/sol/homepage/ & SUN \\
\hline 10. The Telegraph & http://www.telegraph.co.uk & TEL \\
\hline 11. The Times & http://www.thetimes.co.uk/tto/news/ & TIM \\
\hline 12. Western Gazette & http://www.westerngazette.co.uk & WGAZ \\
\hline \multicolumn{3}{|c|}{ sites esportivos } \\
\hline 1. Bleacher Report & http://bleacherreport.com & BLE \\
\hline 2. Click Liverpool & http://www.clickliverpool.com & CLI \\
\hline
\end{tabular}




\section{Capítulo 3}

\begin{tabular}{|l|l|l|}
\hline 3. Dirty tackle & http://www.dirtytackle.net & DTA \\
\hline 4. Eye football & http://www.eyefootball.com & EFOO \\
\hline 5. FIFA News & http://www.fifa.com/newscentre/news/ & FFN \\
\hline 6. Football 565 & $\underline{\text { http://www.football365.com }}$ & F565 \\
\hline 7. Four Four Two & $\underline{\text { http://www.fourfourtwo.com }}$ & FFT \\
\hline 8. FOX Sports & $\underline{\mathrm{http} / / \text { www.foxsports.com.br }}$ & FOX \\
\hline 9. Goal Stage & $\underline{\mathrm{http} / / \text { goalstage.com }}$ & $\mathrm{GS}$ \\
\hline 10. Midfield Dynamo & $\underline{\mathrm{http} / / \text { www.midfielddynamo.com }}$ & $\mathrm{MDY}$ \\
\hline 11. Sky Sports & http://www.skysports.com & SSP \\
\hline 12. Sporting Life & http://www.sportinglife.com/football & SP \\
\hline
\end{tabular}

Por representar a menor parte do subcorpus, com apenas 24 textos, o balanceamento foi bastante simples, pois coletamos um texto de cada um dos periódicos utilizados.

\subsubsection{Armazenamento dos textos}

Os textos foram gravados em extensão ".txt", editor disponível no pacote de programas Microsof Office, e armazenados em subpastas, a fim de ser manipulado com auxílio do software Wordsmith Tools, utilizado no processamento do corpus. Para facilitar essa manipulação, nomeamos os textos de acordo com o padrão utilizado no Cortec (Corpus Técnico-Científico), disponível no Projeto Comet $^{48}$, como, por exemplo, JO-IF-TEL_001, em que JO= texto jornalístico, IF=informativo, $\mathrm{TEL}=\mathrm{The}$ Telegraph, e $001=$ número do arquivo.

\subsubsection{Cabeçalho}

Cabeçalhos são metadados, ou seja, informações sobre o texto, como, por exemplo, sua origem, a data de coleta, o número de palavras e o autor. São utilizados para auxiliar a extração de informações relevantes para a pesquisa.

Para que o computador processe essas informações, elas devem ser codificadas. O método mais comum de codificação é o SGML, um código escrito no formato <etiqueta de abertura> informação </etiqueta de fechamento> (BERBER SARDINHA, 2004, p. 74). Um exemplo da utilização de etiquetas SGML seria: $<$ titleOfText $>$ Sunderland beat Chelsea 2-1 at Stamford Bridge $</$ titleOfText $>$.

\footnotetext{
${ }^{48}$ Disponível em: http://comet.fflch.usp.br. Acesso em: 4 ago. 2015
} 


\section{Capítulo 3}

De acordo com McEnery et al (2006, p. 23), existem três razões principais para a inserção de cabeçalho em um corpus. Primeiramente, uma vez que corpora consistem, basicamente, de trechos da língua em uso que foram retirados do contexto em que ocorrem, resultando em perda de informação contextual, o cabeçalho ajuda o pesquisador a recuperar esse tipo de informação. Em segundo lugar, por mais que seja possível agrupar os textos de um corpus de acordo com suas características principais, como, por exemplo, criando subcorpora, grande parte das informações extratextuais é perdida e, muitas vezes, esse tipo de informação pode influenciar a análise do corpus.

Em nosso caso, utilizamos o cabeçalho para verificar se os termos selecionados ocorrem em mais de uma categoria, já que não queremos trabalhar com jargões de determinado veículo de informação ou jornalista. Por fim, o préprocessamento de textos é parte inerente ao processo de compilação de um corpus. Em nossa pesquisa, todas as notícias que coletamos possuem informações sobre a data e o local de publicação, o nome do jornalista, o campeonato em que o jogo ocorreu etc. Mesmo que não criássemos um cabeçalho teríamos que editar o texto de modo que esse tipo de informação não aparecesse em nossa lista de palavras. Nesse momento, perguntamo-nos: Já que o pré-processamento vai ser realizado, por que não arquivar essas informações de maneira que possamos recuperá-las quando necessário?

O cabeçalho foi compilado com o objetivo de organizar informações que julgamos importantes para a análise terminológica, como, por exemplo, a data de publicação, a fonte e o local em que a notícia foi produzida ou, ainda, o campeonato referente à notícia da partida. Mediante nossos propósitos, criamos o cabeçalho apresentado na figura 7 :

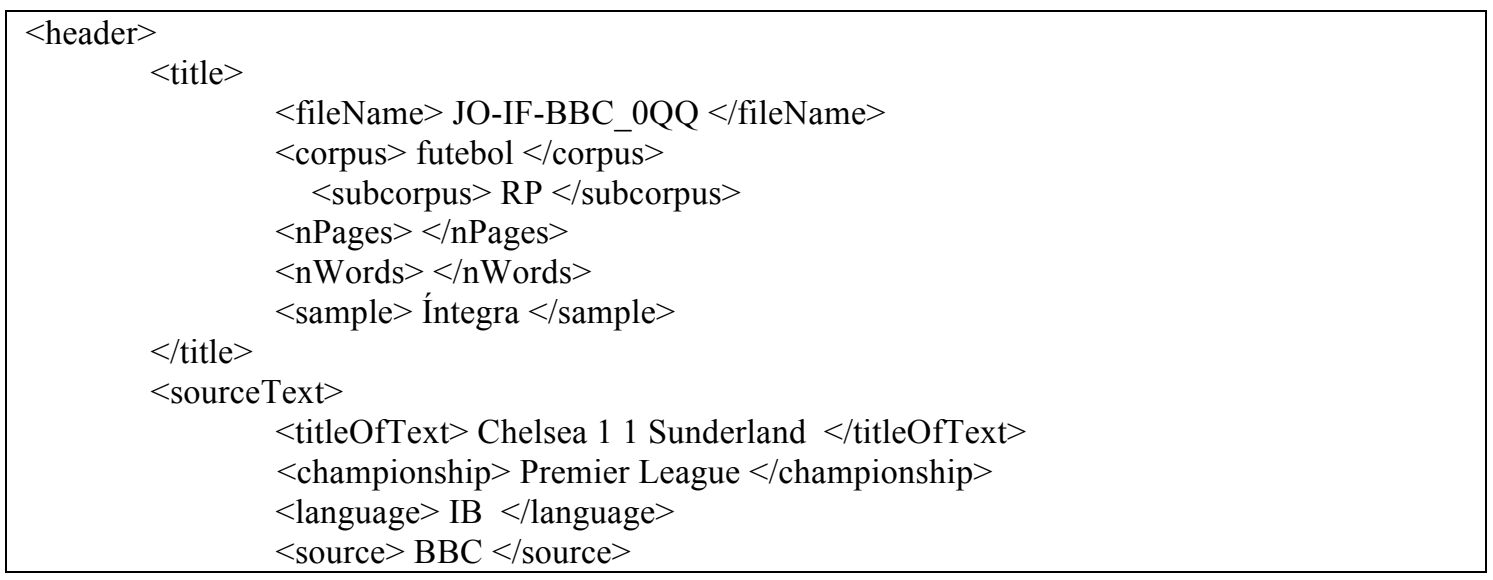




\section{Capítulo 3}

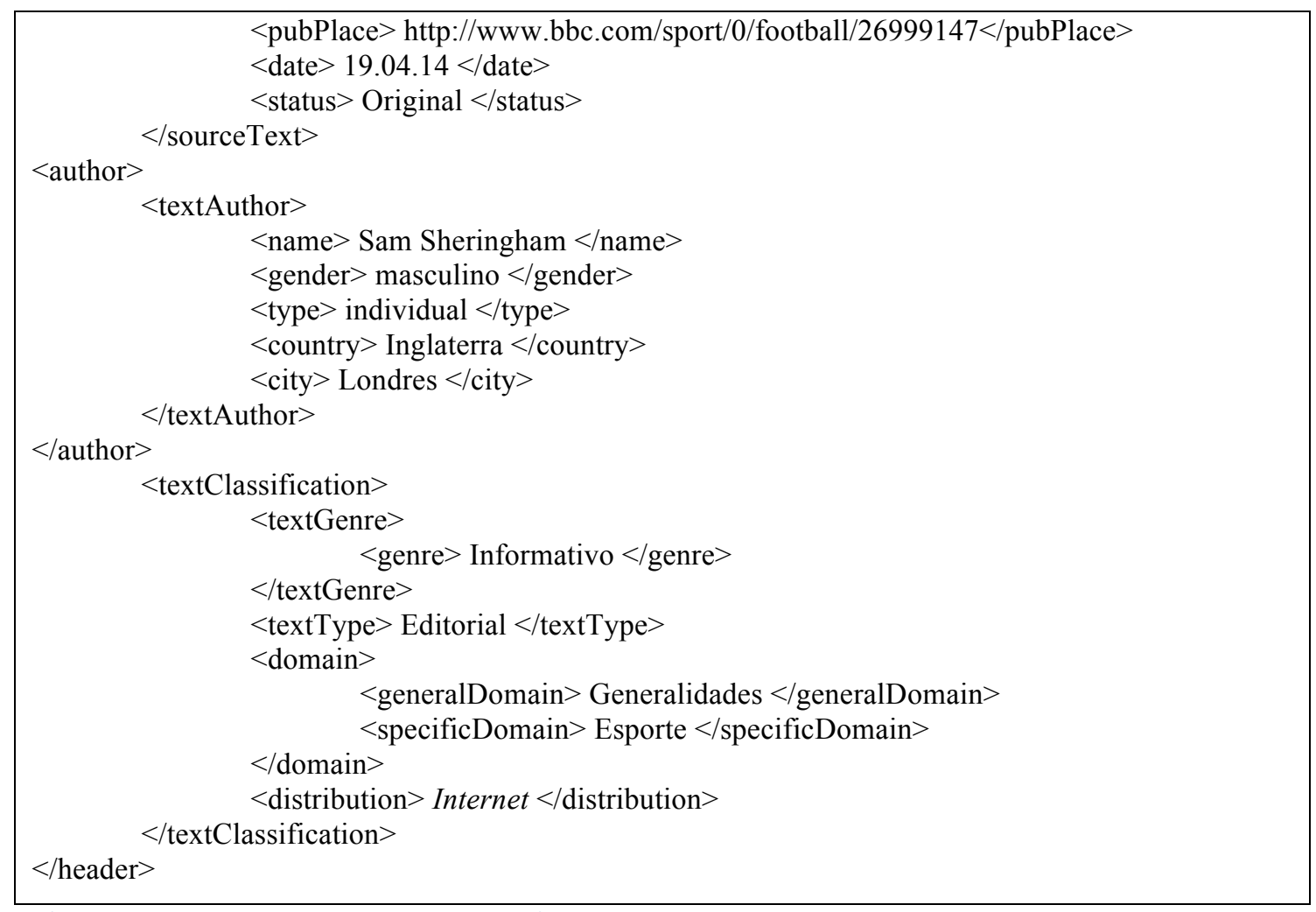

Figura 7: Exemplo de cabeçalho da categoria RP.

O quadro abaixo explica as etiquetas criadas:

\begin{tabular}{|c|c|c|c|c|}
\hline \multirow{5}{*}{$\begin{array}{l}\text { title } \\
\text { título }\end{array}$} & \multicolumn{2}{|l|}{ fileName } & \multicolumn{2}{|c|}{ nomenclatura do arquivo } \\
\hline & \multicolumn{2}{|l|}{$\begin{array}{l}\text { corpus } \\
\text { subcorpus }\end{array}$} & \multicolumn{2}{|c|}{$\begin{array}{l}\text { nome do corpus } \\
\text { nome do subcorpus }\end{array}$} \\
\hline & \multicolumn{2}{|l|}{ nPages } & \multicolumn{2}{|c|}{ número de páginas } \\
\hline & \multicolumn{2}{|l|}{ nWords } & \multicolumn{2}{|c|}{ número de palavras } \\
\hline & \multicolumn{2}{|l|}{ sample } & \multicolumn{2}{|c|}{ íntegra ou parte do texto } \\
\hline \multirow{6}{*}{$\begin{array}{c}\text { sourceText } \\
\text { informações sobre o texto }\end{array}$} & \multicolumn{2}{|c|}{$\begin{array}{l}\text { titleOfText } \\
\text { championship }\end{array}$} & \multicolumn{2}{|c|}{$\begin{array}{l}\text { título do texto } \\
\text { campeonato }\end{array}$} \\
\hline & \multicolumn{2}{|c|}{ language } & \multicolumn{2}{|l|}{ língua } \\
\hline & \multicolumn{2}{|l|}{ source } & \multicolumn{2}{|l|}{ nome do site } \\
\hline & \multicolumn{2}{|l|}{ pubPlace } & \multicolumn{2}{|l|}{ endereço do site } \\
\hline & \multicolumn{2}{|l|}{ date } & \multicolumn{2}{|l|}{ data de coleta } \\
\hline & \multicolumn{2}{|l|}{ status } & \multicolumn{2}{|c|}{ original ou tradução } \\
\hline \multirow{5}{*}{$\begin{array}{c}\text { textAuthor } \\
\text { informações sobre o } \\
\text { autor }\end{array}$} & \multicolumn{2}{|l|}{ name } & \multicolumn{2}{|c|}{ nome } \\
\hline & \multicolumn{2}{|l|}{ gender } & \multicolumn{2}{|l|}{ sexo } \\
\hline & \multicolumn{2}{|l|}{ type } & \multicolumn{2}{|c|}{ individual/ parceria/ grupo } \\
\hline & \multicolumn{2}{|l|}{ country } & \multicolumn{2}{|c|}{ país } \\
\hline & \multicolumn{2}{|l|}{ city } & \multicolumn{2}{|l|}{ cidade } \\
\hline \multirow{5}{*}{$\begin{array}{l}\text { textClassification } \\
\text { classificação do texto }\end{array}$} & textGenre & gênero textual & Genre & gênero textual \\
\hline & textType & & tipo textual & \\
\hline & & & generalDomain & domínio geral \\
\hline & textDomain & domínio & specificDomain & $\begin{array}{l}\text { domínio } \\
\text { específico }\end{array}$ \\
\hline & Distribution & & meio de distribui & \\
\hline
\end{tabular}

Quadro 13: Legenda das etiquetas do cabeçalho. 


\section{Capítulo 3}

Como podemos observar na figura 7 , as etiquetas são hierárquicas, ou seja, estão subordinadas umas às outras. A etiqueta <header $>$ abre o cabeçalho e a $</$ header $>$ o fecha, da mesma forma que a etiqueta $<$ title $>$ abre as informações sobre o título do texto e a etiqueta $</$ title $>$ as fecha.

Embora o procedimento de etiquetagem seja bastante laborioso e demande tempo da pesquisa, é fundamental para arquivar informações relevantes para a análise. Em nosso caso, por exemplo, a etiqueta $<$ source $>$ foi utilizada durante a análise do corpus para verificar o periódico em que a notícia foi publicada, pois estabelecemos que não trabalharíamos com termos que ocorressem em um único periódico. Por esse motivo, ressaltamos que todo cabeçalho deve ser preparado tendo em vista as necessidades da pesquisa a ser realizada.

\subsection{Etiquetagem}

Etiquetar um corpus consiste em adicionar informações que facilitem a análise linguística (HUNSTON, 2002, p. 79). Existem diversas formas de anotação. Leech (2004) cita as principais:

- - fonética: consiste em adicionar informações sobre a pronúncia das palavras em um corpus oral;

- - semântica: insere informações sobre a categoria semântica das palavras;

- - pragmática: inclui informações sobre os tipos de atos discursivos que ocorrem em um diálogo oral;

- - discursiva: adiciona informações sobre marcadores anafóricos e sobre a organização do texto;

- - estilística: insere informações sobre o discurso (discurso direto x discurso indireto); - lexical: inclui o lema de cada palavra em sua ocorrência no corpus (o verbo ‘jogando' estaria sob o lema 'jogar');

- - morfossintática: insere etiquetas gramaticais.

Em nosso estudo, utilizamos a discursiva e a morfossintática. 


\section{Capítulo 3}

De acordo com Leech (1997, p. 2), o processo de etiquetagem de um corpus reflete de forma direta nos resultados da pesquisa, pois o corpus, após ser etiquetado, torna-se um instrumento de pesquisa linguística ainda mais rico. No nosso caso específico, a etiquetagem discursiva nos permitiu omitir informações presentes nos textos que não seriam relevantes para a análise, como, por exemplo, os minutos nas descrições de partidas, e a etiquetagem morfossintática possibilitou a extração de informações culturais importantíssimas por meio da análise de categorias gramaticais.

\subsubsection{Etiquetagem discursiva}

A etiquetagem discursiva consiste em marcar características como referentes anafóricos, tópicos ou marcadores discursivos em um corpus (BERBER SARDINHA, 2004). Para nossa pesquisa, criamos três modelos de anotação discursiva: um para os resultados de partidas, as notícias sobre compra e venda de jogadores e técnicos e as notícias sobre a situação dos times nos campeonatos (Fig. 8); outro para as descrições de partidas (Fig. 9) e um último para os relatos de partidas com comentários de internautas (Fig. 10), cada um de acordo com as partes que os compõem:

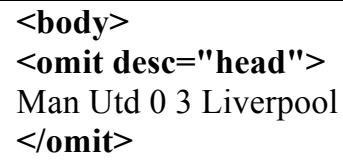

Figura 8: Etiquetas discursivas criadas para os resultados de partidas, as notícias sobre compra e venda de jogadores e técnicos e as notícias sobre a situação dos times nos campeonatos. 


\section{Capítulo 3}

As etiquetas $<$ omit desc $=$ "head" $><$ /omit $>$ marcam o título do texto, as $<$ standfirst $>$ e $<$ /standfirst $>$ delimitam a linha fina, também conhecida como olho ou subtítulo da notícia, e as $<$ body $>$ e $<$ /body $>$ identificam o corpo do texto. O mesmo modelo de etiquetas foi utilizado nas três categorias uma vez que a estrutura das notícias é a mesma: título, linha fina e texto. Ressaltamos que, às vezes, a notícia não possui linha fina; nesses casos o campo é deixado em branco.

Nas descrições de partidas, as etiquetas que marcam o título e o corpo do texto são as mesmas apresentadas acima. Além dessas, criamos uma etiqueta para marcar o minuto da narração: $<$ minute $><$ /minute $>$. Entretanto, para que a lista de palavras gerada pelo WordSmith Tools não incluísse esses números, o programa foi ajustado para ignorar essa última etiqueta:

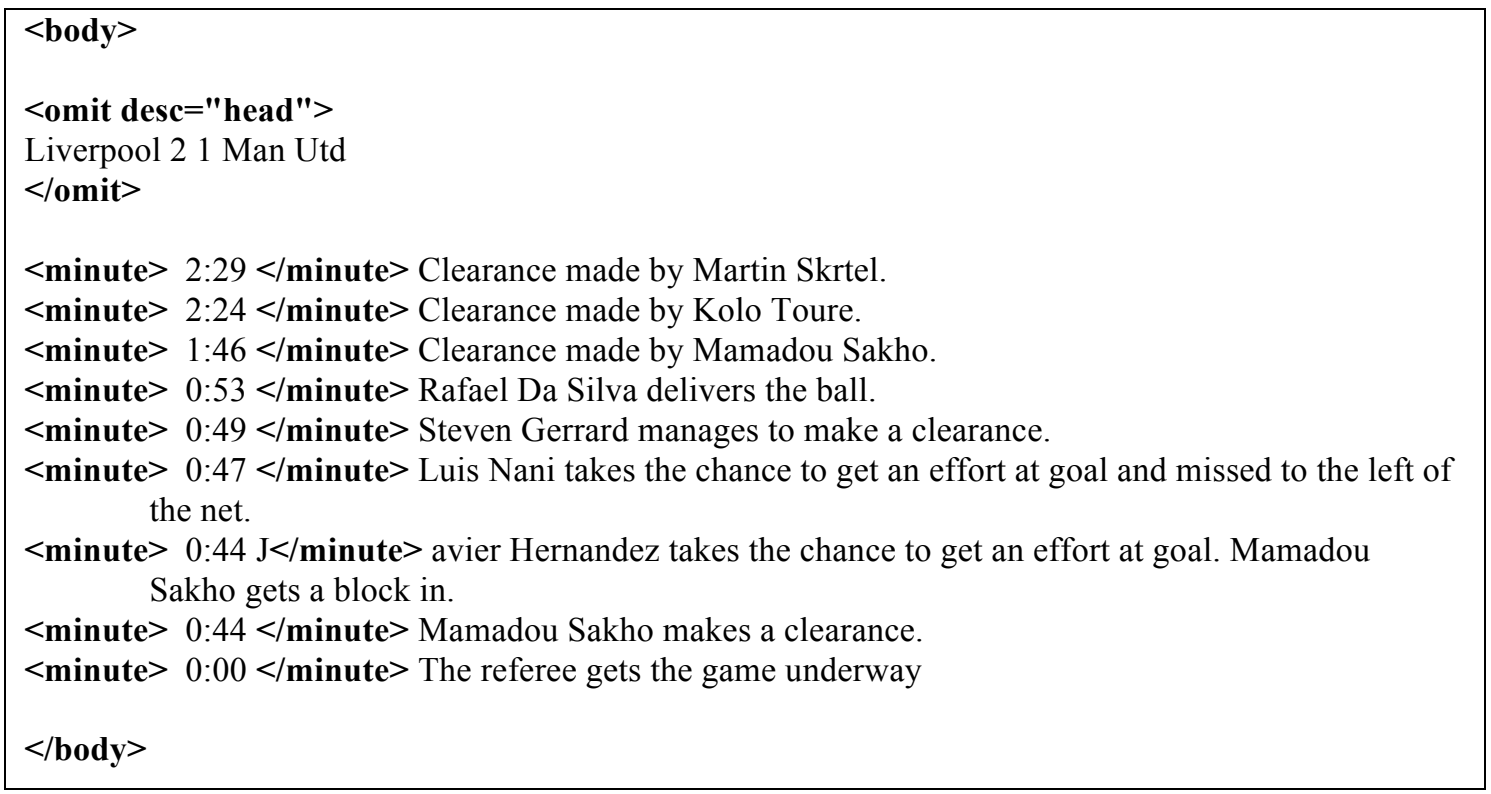

Figura 9: Etiquetas discursivas utilizadas nas descrições de partidas.

Para os relatos de partidas com comentários de internautas utilizamos as mesmas etiquetas das descrições de partidas e criamos duas novas: <commentary $>$ $</$ commentary $>$ e $<$ commentator $></$ commentator $>$; a primeira é utilizada para marcar o comentário e a segunda, para marcar o autor do comentário: 


\section{Capítulo 3}

\begin{tabular}{l}
\hline <body $>$ \\
<omit desc="head"> \\
Liverpool 21 Man Utd \\
$<$ <omit $>$ \\
$<$ minute $>32: 50<$ /minute $>$ \\
$<$ commentary $><$ commentator $>$ Laffalot $</$ commentator $>$ \\
"I share your pain about the lack of leadership in the Liverpool side. In this regard, I was hoping \\
Rooney would develop, but he is gone in the big matches and his decision to take the penalty kick \\
(when he could have been gracious and given it to Mata or shown support and leadership by giving it \\
to Falcao) showed again that he is too feeble minded to rise above the sub-ordinary person that he is. \\
$</$ commentary $>$
\end{tabular}

Figura 10: Etiquetas discursivas utilizadas nos relatos de partidas com comentários de internautas.

\subsubsection{Etiquetagem morfossintática}

A etiquetagem morfossintática, ou part of speech tagging (POS), consiste em atribuir a cada palavra do corpus uma etiqueta que represente sua categoria gramatical (HUNSTON, 2002). Dessa forma, a palavra foul ${ }^{49}$ pode ser etiquetada como substantivo ou como verbo, dependendo da sua função no corpus.

De acordo com McEnery et al. (2006), a POS é o tipo de etiquetagem mais comum em análises linguísticas baseadas em corpus, pois constitui a base para outros tipos de etiquetagem, como, por exemplo, a etiquetagem semântica, e também porque pode ser realizada automaticamente com textos em várias línguas com aproximadamente $97 \%$ de acerto.

É sempre importante lembrar que, como qualquer software, os etiquetadores podem apresentar falhas e etiquetar palavras de forma incorreta. Por esse motivo, o pesquisador pode, muitas vezes, julgar incorretas as etiquetas atribuídas pelo programa.

Não raro, devido à margem de falta de precisão dos etiquetadores $(3 \%)$, alguns corpora são manualmente revisados após a etiquetagem automática. Como em nossa pesquisa não trabalhamos diretamente com análise de categorias gramaticais e utilizamos as etiquetas unicamente para facilitar o processo de estabelecimento de equivalentes entre os termos em inglês e português, não revisamos a etiquetagem.

\footnotetext{
${ }^{49}$ A palavra foul tem como equivalentes "falta" ou "fazer uma falta" em português. No primeiro caso, a palavra é utilizada como substantivo para designar uma infração às regras do jogo, e no segundo, como verbo, descreve o ato da infração.
} 


\section{Capítulo 3}

Além disso, o processo de revisão das etiquetas é bastante laborioso e ofusca as vantagens da etiquetagem automática (KENNEDY, 1998).

Embora o processo de etiquetagem não seja condição sine qua non para pesquisas com corpus, pesquisadores como Kennedy (2008), Hunston (2002) e McEnery et al. (2006) enfatizam as vantagens de se etiquetar um corpus morfossintaticamente, uma vez que essa etiquetagem possibilita buscas mais complexas. Só um corpus etiquetado permitirá ao pesquisador realizar levantamentos de colocações verbais, por exemplo. Além disso, as possibilidades de investigação aumentam, visto que o pesquisador pode fazer generalizações sobre, por exemplo, uma classe gramatical, e não somente sobre uma palavra de busca. Em sua dissertação de mestrado, Carvalho (2007) menciona a importância da etiquetagem morfossintática para pesquisas em tradução e relata que só por meio de buscas de etiquetas gramaticais pôde encontrar alguns equivalentes tradutórios.

Ressaltamos que etiquetar um corpus não implica trabalhar somente com essa versão. Em nossa pesquisa, utilizamos tanto a versão do corpus etiquetado, quanto a versão crua, sem etiquetas.

A versão crua foi utilizada para gerar as listas de palavras e as palavras-chave, assim como para identificar colocações. Poderíamos ter usado o corpus etiquetado para essas etapas, mas não o utilizamos porque a visualização do corpus sem etiquetas é mais clara. O corpus etiquetado possui muita informação, deixando a visualização mais poluída. Além disso, teríamos que ajustar as configurações do software que utilizamos na análise para que ignorasse todas as etiquetas.

A versão etiquetada foi utilizada para aprimorar o processo de identificação dos equivalentes tradutórios. Durante nossa pesquisa de mestrado, em que trabalhamos com unidades fraseológicas (UFs) do futebol quando o corpus ainda não estava etiquetado, partíamos de uma tradução prima facie ou de possíveis colocados para encontrar equivalentes para as UFs em português no subcorpus em inglês. Após a etiquetagem do corpus, já no final da pesquisa, passamos a realizar buscas por classes gramaticais, fato que enriqueceu os achados e ampliou a possibilidade de equivalentes e, muito frequentemente, de equivalentes mais apropriados. 


\section{Capítulo 3}

\subsubsection{Etiquetador}

Utilizamos o software Tree-Tagger para etiquetar o corpus. O Tree-Tagger é um etiquetador automático que apresenta a anotação morfossintática e o lema de cada ocorrência no corpus. Foi desenvolvido por Helmut Schmid no projeto TC (Textual Corpora and tools for their exploration) no Instituto de Linguística Computacional da Universidade de Stuttgart e pode ser utilizado para etiquetar textos em alemão, inglês, francês, italiano, holandês, espanhol, búlgaro, russo, grego, português, chinês, suaíli, latim, estoniano e francês antigo.

O Tree Tagger é um etiquetador bastante popular; algumas universidades, como, por exemplo, a Pontifícia Universidade Católica de São Paulo (PUC-SP), disponibilizam o etiquetador em suas páginas. No entanto, a manutenção da página do site que disponibiliza a ferramenta parece não ser feita regularmente e o etiquetador está frequentemente fora do ar. Enfrentamos esse problema durante nossa pesquisa de mestrado. Na época, baixamos o programa diretamente para nosso computador ${ }^{50}$, tarefa que, vale ressaltar, foi uma das mais laboriosas da pesquisa, visto que baixamos os arquivos necessários para a instalação, sem, no entanto, possuir um manual do usuário com os passos a serem seguidos. Após auxílio via email do professor Tony Berber Sardinha, conseguimos, finalmente, instalar o Tree-Tagger. Realizamos um teste com o etiquetador para as duas línguas e o Tree-Tagger funcionou perfeitamente para a etiquetagem dos textos em inglês. Porém, quando tentávamos etiquetar qualquer texto em português, recebíamos a mensagem de que essa não era uma língua disponível. Entramos novamente em contato com o professor Berber Sardinha e um de seus orientandos nos passou um novo $l i n k^{51}$, dessa vez com a opção de etiquetagem em português.

O programa foi baixado no computador pessoal que utilizamos durante a pesquisa de mestrado e que esteve em nossas mãos até agosto de 2014. No entanto, a máquina, já bastante antiga, parou de funcionar em 2014. Tentamos baixar o programa novamente por meio dos mesmos links e de outros links encontrados online, mas não tivemos sucesso. Tentamos até mesmo o link da página do professor

\footnotetext{
${ }^{50} \mathrm{O}$ programa está disponível para ser baixado no site: <http://corpuslg.org/courses/tree-taggerwindows.zip>. Acesso em: 4 ago. 2015.

${ }^{51}$ Disponível em: <http://corpuslg.org/users/crismayer>. Acesso em: 4 ago. 2015.
} 


\section{Capítulo 3}

Helmut Schmid ${ }^{52}$. No entanto, nosso esforço não foi bem sucedido, pois, embora a página apresente uma série de links para instalação do software, não disponibiliza um manual para o usuário e o link para contato com os desenvolvedores do programa ou com o responsável do site não funciona.

Nossa alternativa para etiquetar os textos do corpus que ainda não estavam etiquetados, uma vez que a etiquetagem foi feita em etapas, foi procurar na internet outra página que disponibilizasse o programa. Poderíamos utilizar outro etiquetador, mas como o conjunto de etiquetas é único para cada programa, insistimos no Tree Tagger, pois se utilizássemos outro etiquetador teríamos que etiquetar todos os textos novamente.

Ao pesquisar no Google sobre páginas que disponibilizavam o etiquetador, encontramos a página web4you ${ }^{53}$. O site disponibiliza o Tree Tagger on-line. Basta colar o texto na caixa de texto e clicar em submit que o texto é etiquetado. $\mathrm{O}$ procedimento funciona para todas as línguas com as quais o etiquetador trabalha; o único problema desse site é que ele está em japonês e não possui tradução para o português ou para o inglês.

Sem meios de quebrar a barreira linguística para ler o site e as instruções a fim de verificar atualizações e obter informações mais detalhadas, decidimos verificar o bom funcionamento do etiquetador etiquetando textos previamente etiquetados pela versão do software que tínhamos em nosso computador e comparando as duas versões. Realizamos o procedimento com 50 textos e as etiquetas atribuídas a cada item do corpus foram exatamente as mesmas. Após validar a eficácia do etiquetador on-line, etiquetamos os textos que não haviam sido etiquetados.

A figura 11 mostra a interface do etiquetador no site web4you e o exemplo de um texto etiquetado:

\footnotetext{
${ }^{52}$ Disponível em: < http://www.cis.uni-muenchen.de/ schmid/tools/TreeTagger/ >. Acesso em: 4 ago. 2015.

${ }_{53}$ Disponível em: < http://web4u.setsunan.ac.jp/Website/TreeOnline.htm >. Acesso em: 4 ago. 2015.
} 


\section{Capítulo 3}

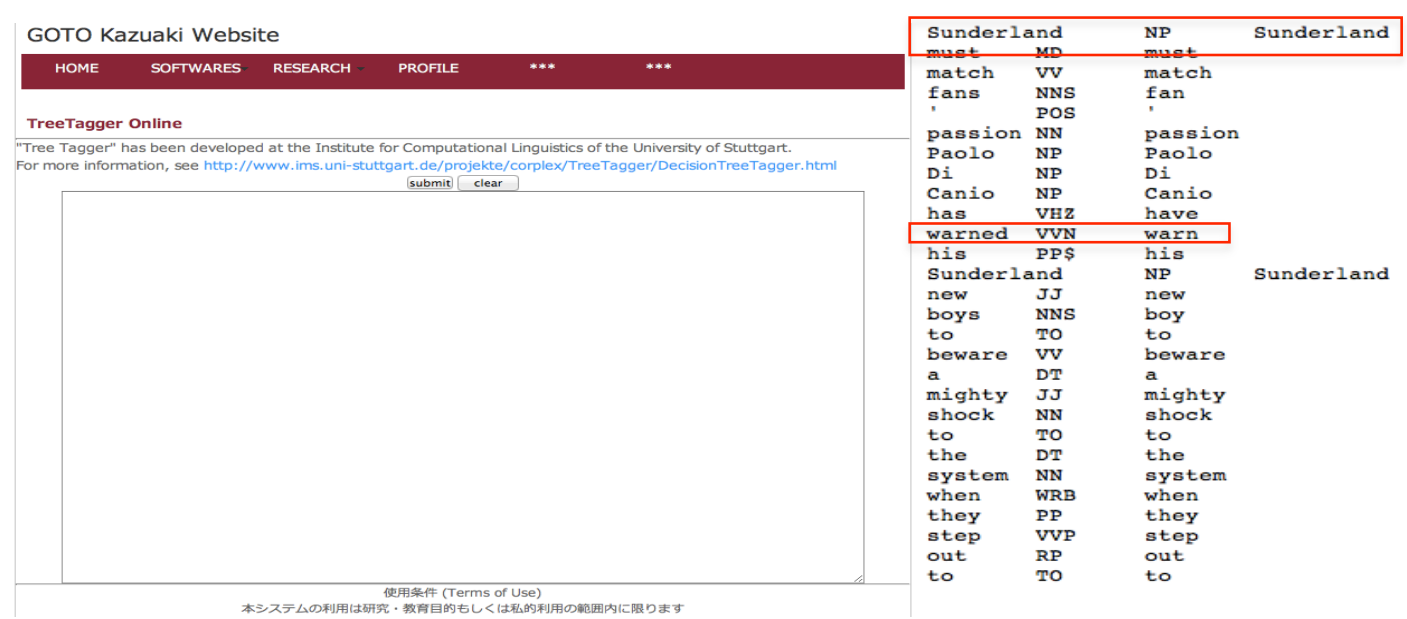

Figura 11: Interface do etiquetador no site web4you (à esquerda) e exemplo de um texto etiquetado (à direita).

A figura 12 mostra a interface do etiquetador que foi baixado em nosso computador e utilizado para etiquetar os textos até agosto de 2014:

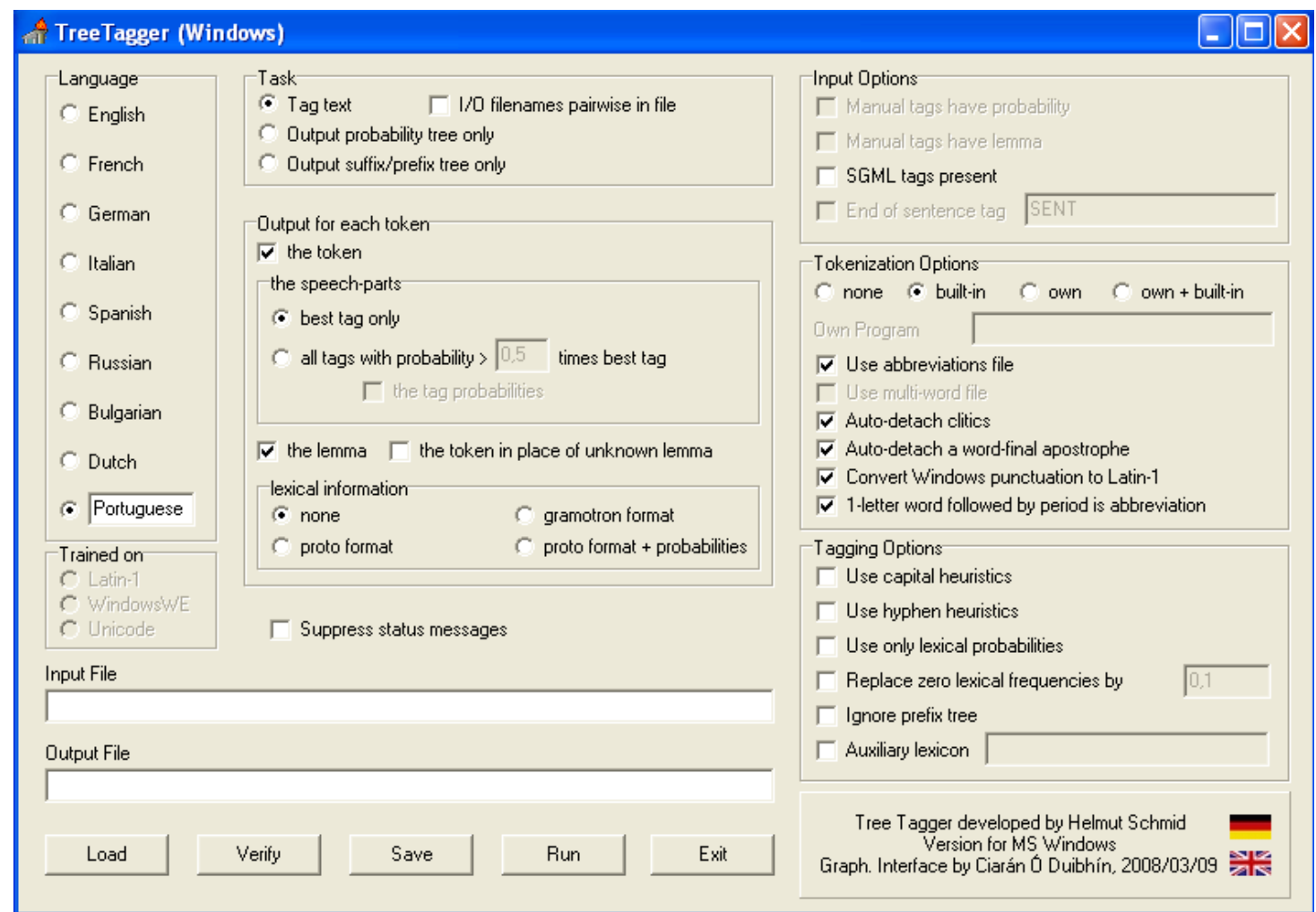

Figura 12: Interface do Tree-Tagger.

O processo de etiquetagem, embora simples, é bastante trabalhoso, pois o programa etiqueta somente um texto de cada vez. O primeiro passo é selecionar a língua do texto a ser etiquetado. Na figura acima, selecionamos a opção em branco e 


\section{Capítulo 3}

digitamos "Portuguese". Após essa seleção, clicamos em "Input File" para selecionar o arquivo a ser etiquetado. Selecionado o arquivo, clicamos em "Output file" e o programa abre uma caixa de diálogo save as (salvar como), onde escolhemos a pasta de destino em que o arquivo seria armazenado. Por fim, nomeamos o arquivo, sempre acrescentando a terminação “.tag” para que o Tree-Tagger funcionasse corretamente.

\subsubsection{Etiquetas}

O Tree-Tagger utiliza um conjunto de etiquetas diferentes para cada língua. Para o inglês, são 36 etiquetas (SANTORINI, 1991, p. 6-7):

\begin{tabular}{|l|l|}
\hline \multicolumn{1}{|c|}{ Etiqueta } & \\
\hline CC & Coordinating Conjunction \\
\hline CD & Cardinal Number \\
\hline DT & Determiner \\
\hline EX & Existentião \\
\hline FW & Foreign Wore \\
\hline IN & Preposition or subordinating conjunction \\
\hline JJ & Adjective \\
\hline JJR & Adjective, comparative \\
\hline JJS & Adjective, superlative \\
\hline LS & List item marker \\
\hline MD & Modal \\
\hline NN & Noun, singular or mass \\
\hline NNS & Noun, plural \\
\hline NP & Proper noun, singular \\
\hline NPS & Porper noun, plural \\
\hline PDT & Predeterminer \\
\hline POS & Possessive ending \\
\hline PP & Personal pronoun \\
\hline PP\$ & Possessive pronoun \\
\hline RB & Adverb \\
\hline RBR & Adverb, comparative \\
\hline RBS & Adverb, superlative \\
\hline RP & Particle \\
\hline SYM & Symbol \\
\hline TO & To \\
\hline UH & Interjection \\
\hline VB & Verb, base form \\
\hline VBD/VVD & Verb, past tense \\
\hline VBG/VVG & Verb, gerund or present participle \\
\hline VBN/VVN & Verb, past participle \\
\hline VBP/VVP & Verb, non-3rd person singular present \\
\hline VBZ/VVZ & Verb, 3rd person singular present \\
\hline & \\
\hline
\end{tabular}

\footnotetext{
${ }^{54}$ A única diferença entre as etiquetas é que o software baixado em nosso computador utiliza a etiqueta VB para os verbos e o etiquetador disponível no site utiliza a etiqueta VV para os verbos. No caso de busca por etiquetas de verbos, sempre realizávamos duas buscas, uma para cada etiqueta.
} 


\section{Capítulo 3}

\begin{tabular}{|l|l|}
\hline WDT & Wh-determiner \\
\hline WP & Wh-pronoun \\
\hline WP\$ & Possessive pronoun \\
\hline WRB & Wh-adverb \\
\hline
\end{tabular}

O conjunto de etiquetas para o português é menos detalhado: são apenas onze as etiquetas disponíveis. Observemos o quadro abaixo:

\begin{tabular}{|l|l|}
\hline \multicolumn{1}{|c|}{ Etiqueta } & \multicolumn{1}{c|}{ Descrição } \\
\hline ADJ & Adjetivo \\
\hline ADV & Advérbio \\
\hline DET & Determinante \\
\hline CARD & Número Cardinal / Ordinal \\
\hline NON & Nome Comum / Próprio \\
\hline P & Pronome \\
\hline PREP & Preposição \\
\hline V & Verbo \\
\hline I & Interjeição \\
\hline VIRG & Separadores dentro da oração \\
\hline SENT & Separadores de orações \\
\hline
\end{tabular}

Quadro 15: Etiquetas do Tree-Tagger (português).

Embora o conjunto de etiquetas para o português seja menos detalhado que para o inglês, as buscas por etiquetas se mostraram bastante úteis nas duas línguas.

\subsubsection{Expressões de busca}

Cada busca realizada no corpus etiquetado será detalhada no "Capítulo 4 Análise e Discussão dos Dados". Nesta seção, apresentamos, brevemente, como conduzimos as buscas pelas etiquetas.

Se observarmos a figura 11, veremos que o texto etiquetado é apresentado em um arquivo ".txt", dividido em três colunas. A exemplo da primeira linha da figura, na primeira coluna visualizamos a ocorrência do corpus, o substantivo Sunderland; na segunda, observamos a etiqueta gramatical MD, que indica um verbo modal; na terceira, visualizamos a forma lematizada da palavra, que nesse caso não muda. Mais abaixo, encontramos a ocorrência do item warned, seguida da etiqueta VVN, que indica verbo no particípio passado, e de sua forma lematizada, warn.

Dada a forma como o Tree-Tagger apresenta o texto etiquetado, é preciso digitar a expressão de busca tal qual aparece no arquivo. Por exemplo, se quiséssemos 


\section{Capítulo 3}

ter acesso às concordâncias do verbo were seguido de made, teríamos que digitar a expressão de busca "were VBD be made". Observemos a figura a seguir:

\begin{tabular}{|c|c|c|c|c|c|c|}
\hline \multicolumn{6}{|c|}{ C Concord } & \multirow[t]{2}{*}{$\square$ 回 } \\
\hline File Edit & jit View Compute Settings Window Help & & & & & \\
\hline & $\mathrm{N}$ Concordance & Set Tag & Word \#|t. \#| os. $\mid$ & An os.l & $\#$ os.l|t. $\#$ os.l| File & \multirow{2}{*}{$\begin{array}{r}\% \\
92 \%\end{array}$} \\
\hline 1 & ... misses $W Z$ miss they PP they were VBD be made $W N$ make to TO to & 940 & $201 \%$ I & $02 \%$ & $02 \%$ ljo-if-uef_004.tag & \\
\hline 2 & Six CD Six changes NNS change were VBD be made $W N$ make from IN & 357 & $121 \% \mathrm{l}$ & $04 \% \mathbf{I}$ & $04 \%$ jo-if-tel_040.tag & $24 \%$ \\
\hline 3 & SENT. Tottenham NP Tottenham were $V B D$ be made $W N$ make to TO to & 1.089 & $248 \%$ & $09 \% \mathbf{I}$ & 0 9\% jo-if-foo_037.tag & $69 \%$ \\
\hline 4 & $\ldots$ as $\mathbb{I N}$ as the $\mathrm{DT}$ the Reds $\mathrm{NNS}$ red were $\mathrm{VBD}$ be made $\mathrm{WN}$ make to TO to & 1.309 & $264 \%$ & $08 \% \mathbf{I}$ & $08 \%$ jo-iff-foo_028.tag & $98 \%$ \\
\hline 5 & $\ldots$ as $I N$ as the DT the Reds NNS red were VBD be made $W N$ make to TO to & 1.309 & $264 \%$ I & $08 \% \mathbf{I}$ & 0 8\% jo-if-foo_001.tag & $98 \%$ \\
\hline 6 & safety. SENT. Liverpool NP Liverpool were VBD be made WN make to TO to & 682 & $145 \%$ & $01 \%$ & 0 1\%lo-if-eye_007.tagl & $52 \%$ \\
\hline 7 & and 12 CD@card@ arrests NNS arrest were VBD be made WN make.SENT . & 1.491 & $604 \% \mathrm{l}$ & $09 \% \mathbf{I}$ & $09 \%$ lo-if-day_005.tagl & $78 \%$ \\
\hline 8 & NP Brad Friedel NP Friedel and CC and were VBD be made $W N$ make to TO to & 245 & $40 \% \mathrm{l}$ & $01 \% \mathbf{I}$ & 0 1\%lo-if-365_064.tagl & $12 \%$ \\
\hline 9 & And CC and Coventry NP Coventry were VBD be made $\mathrm{WN}$ make to TO to & 947 & $239 \%$ & $00 \% \mathbf{l}$ & 0 0\%lo-if-365_056.tagl & $71 \%$ \\
\hline 10 & into IN into goals NNS goal and CC and were VBD be made $W N$ make to TO to & 851 & $164 \% \mathrm{l}$ & $05 \% \mathbf{I}$ & 0 5\%lo-if-365_042.tagl & $66 \%$ \\
\hline 11 & $C C$ but the $D T$ the visitors NNS visitor were VBD be made $W N$ make to TO to & 100 & $24 \% \mathrm{I}$ & $04 \%$ & $04 \%$ o-if-365_032.tagl & $5 \%$ \\
\hline 12 & yard. SENT. Blackburn NP Blackburn were VBD be made $\mathrm{WN}$ make to TO to & 1.486 & $267 \%$ & $01 \% \mathbf{I}$ & 0 1\%lo-if-365_025.tagl & $71 \%$ \\
\hline 13 & WG run but $C C$ but they PP they were $V B D$ be made $W N$ make to TO to & 357 & $122 \%$ l & $04 \%$ & $04 \%$ nar-sky__002.tagl & $4 \%$ \\
\hline 14 & again. SENT. Slovakia NP Slovakia were VBD be made $W N$ make to TO to & 1.184 & $285 \%$ & $02 \%$ & $02 \%$ l jo-if-tfa_006.tag & $92 \%$ \\
\hline 15 & SENT. And CC and they PP they were VBD be made $W N$ make to TO to & 1.002 & $249 \%$ & $07 \%$ & $07 \%$ jo-if-tfa_003.tag & $77 \%$ \\
\hline 16 & Uruguayan JJ Uruguayan fans NNS fan were VBD be made $W N$ make nervous & 905 & $160 \%$ & $05 \% \mathbf{I}$ & 0 5\%lo-if-sky_007.tagl & $25 \%$ \\
\hline 17 & DPR NP but CC but they PP they were $\mathrm{VBD}$ be made $\mathrm{WN}$ make to TO to & 48 & $09 \% \mathbf{l}$ & $02 \%$ & $02 \%$ jo-if-foo_010.tag & $2 \%$ \\
\hline 18 & DPR NP but CC but they PP they were $\mathrm{VBD}$ be made $\mathrm{WN}$ make to TO to & 42 & $06 \% \mathbf{l}$ & $02 \%$ & $02 \%$ jo-if-foo_o09.tag & $2 \%$ \\
\hline 19 & NN occasion , ., England NP England were VBD be made $W N$ make to TO to & 2.073 & $437 \%$ & $09 \%$ & 0 9\%lo-if-day_002.tagl & $49 \%$ \\
\hline 20 & JJ offensive remarks NNS remark were $V B D$ be made $W N$ make. SENT. & 2.151 & $603 \% \mathrm{I}$ & $04 \%$ & $04 \%$ jo-if-wp_066.tag & $75 \%$ \\
\hline 21 & NNS check on IN on tickets NNS ticket were VBD be made $W N$ make at IN at & 450 & $129 \%$ & $06 \% \mathbf{l}$ & 0 6\% jo-if-wp_059.tag & $45 \%$ \\
\hline 22 & other U.S. NP U.S. players NNS player were VBD be made WN make available & 747 & $283 \% \mathrm{l}$ & $04 \%$ & 0 4\% jo-if-wp_034.tag & $25 \%$ \\
\hline
\end{tabular}

Figura 13: Linhas de concordância da expressão de busca "were VBD be made".

Se digitássemos apenas "were warned" o programa identificaria a presença da etiqueta e da forma lematizada entre were e warned e não retornaria nenhum resultado.

\subsection{Os corpora de referência}

Um corpus de referência é utilizado para contraste com o corpus de estudo a fim de evidenciar neste as formas mais frequentes, filtrando os elementos mais genéricos, recorrentes (também) naquele. Por esse motivo, a escolha do corpus de referência é extremamente importante para a análise em qualquer pesquisa com corpus. Ademais, uma vez que a noção de palavras-chave parte do princípio da relevância estatística da comparação entre o corpus de estudo e o corpus de referência, os critérios de compilação de um corpus de estudo e a escolha do corpus de referência influenciam de forma direta o resultado da pesquisa.

Berber Sardinha $(2004$, p. 102) recomenda que o corpus de referência seja entre três e cinco vezes maior que o corpus de estudo. Entretanto, ainda segundo o autor, compilar um corpus muito maior do que o recomendado não retornará, 


\section{Capítulo 3}

necessariamente, maior número de palavras-chave. Não existem, porém, restrições que limitem o tamanho do corpus de referência. Hunston (2002, p. 68), por exemplo, recomenda que o corpus de referencia seja maior e mais genérico que o corpus de estudo; no entanto, não acredita que exista um modelo definitivo para a escolha de um corpus de referência.

Em geral, devem-se incluir nesse material vários gêneros textuais, de modo que o corpus proporcione uma escolha não marcada das palavras-chave, pois suas características influenciam os tipos de palavra que podem ser classificadas como chave (BERBER SARDINHA, 2004, p. 100). Assim como Hunston (2002), Scott e Tribble (2006, p. 65) acreditam que não existe uma regra para a seleção de um corpus de referência e que sua escolha deve ser realizada considerando a tipologia do corpus de estudo e os resultados esperados.

Em nossa pesquisa, utilizamos dois corpora de referência: o BNC (British National Corpus $)^{55}$ e o Lácio-Ref ${ }^{56}$. Ambos são muito maiores que o de estudo. Contudo, foram os que nos retornaram melhores resultados.

O BNC, corpus fechado (1990-1994), possui 100 milhões de palavras e foi desenvolvido com o objetivo de ser representativo das variantes escrita e falada do inglês britânico. O Lácio-Ref é o corpus de referência do português brasileiro que conta com 4.278 arquivos, totalizando 8.291 .818 palavras. É um corpus não anotado, com informações morfossintáticas, sintáticas ou de nível mais elevado, mas possui anotações da existência de elementos gráficos e de cabeçalho. A grande maioria dos textos está disponibilizada na íntegra.

\subsection{Ferramentas Computacionais}

Pesquisas que utilizam a Linguística de Corpus, seja como metodologia ou como abordagem linguística, demandam o uso de ferramentas computacionais para o processamento do corpus. Essas ferramentas fazem o trabalho "braçal" da pesquisa, como contar palavras, classificar a ordem dos itens listados, gerar linhas de concordância e alinhar traduções, de forma automática e eficaz. A partir desses dados,

\footnotetext{
${ }^{55}$ Disponível em: <http://www.natcorp.ox.ac.uk/>. Acesso em: 14 abr. 2010.

${ }^{56}$ Disponível em: < http://www.nilc.icmc.usp.br/nilc/projects/lacio-web.htm>. Acesso em: 15 maio 2015.
} 


\section{Capítulo 3}

o pesquisador procede com a análise qualitativa, manual. Nesta seção, apresentamos duas das três ferramentas computacionais utilizadas na pesquisa: o WordSmith Tools 6.0 e o TshwaneLex. A ferramenta Tree tagger foi apresentada no item 3.2.2, uma vez que a utilizamos na fase de pré-processamento do corpus, e não durante a análise.

\subsubsection{WordSmith Tools}

Utilizamos o software WordSmith Tools para processar o corpus. O programa, de autoria de Mike Scott, da Universidade de Liverpool, é publicado pela Oxford University Press e pela Lexical Analysis Sofware Ltda. ${ }^{57}$ Trabalhamos com a versão mais atual do software, a 6.0, que está disponível para Windows XP e versões mais atuais do Windows.

O software é um conjunto integrado de recursos para análise lexical e possui três ferramentas principais - Wordlist, Keywords e Concord - e uma série de utilitários:

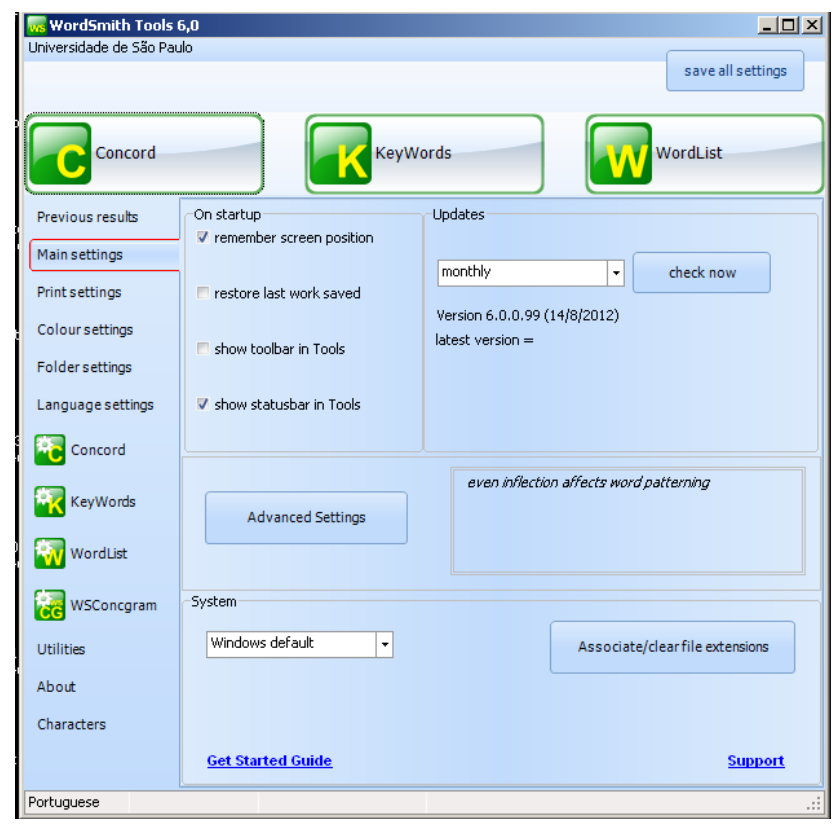

Figura 14:Interface do software WordSmith Tools versão 6.0.

Nos itens que seguem mostraremos as ferramentas e os ajustes utilizados em nossa pesquisa. Os exemplos selecionados foram extraídos do corpus de estudo e dos

\footnotetext{
${ }^{57}$ Disponível em: < http://www.lexically.net/wordsmith/ >. Acesso em: 15 jan. 2015.
} 


\section{Capítulo 3}

corpora de referência, ora em português, ora em inglês, sempre com o objetivo de ilustrar os passos seguidos para a análise.

\subsubsection{Wordlist}

A ferramenta Wordlist permite a criação de listas de palavras ${ }^{58}$. O programa produz, a cada vez, duas listas de palavras, uma em ordem alfabética e outra em ordem de frequência. As listas aparecem em duas abas distintas e, juntamente com as listas, o programa disponibiliza uma terceira aba com informações estatísticas.

Independentemente da área da pesquisa com corpus, seja ela lexicografia, terminologia, tradução, literatura, análise do discurso etc., ou tipo de pesquisa, isto é, baseada em corpus ou direcionada pelo corpus, a lista de palavras funciona como ponto de partida para etapas futuras na análise, como, por exemplo, palavras-chave e linhas de concordância (KENNEDY, 1998, p. 245).

O primeiro passo para a criação de uma lista de palavras é selecionar, em language and settings, a língua da lista a ser criada. Essa etapa é fundamental, pois o programa só compara listas de palavras da mesma língua. A figura a seguir mostra a tela dos ajustes realizados para gerar a lista de palavras do nosso subcorpus em inglês:

\footnotetext{
58 Utilizamos a acepção de palavra de Barnbrook et al. (2013), qual seja uma sequência de letras separada por espaço em branco que, dependendo do interesse do pesquisador, pode ou não conter sinais como apóstrofo e hífen.
} 


\section{Capítulo 3}

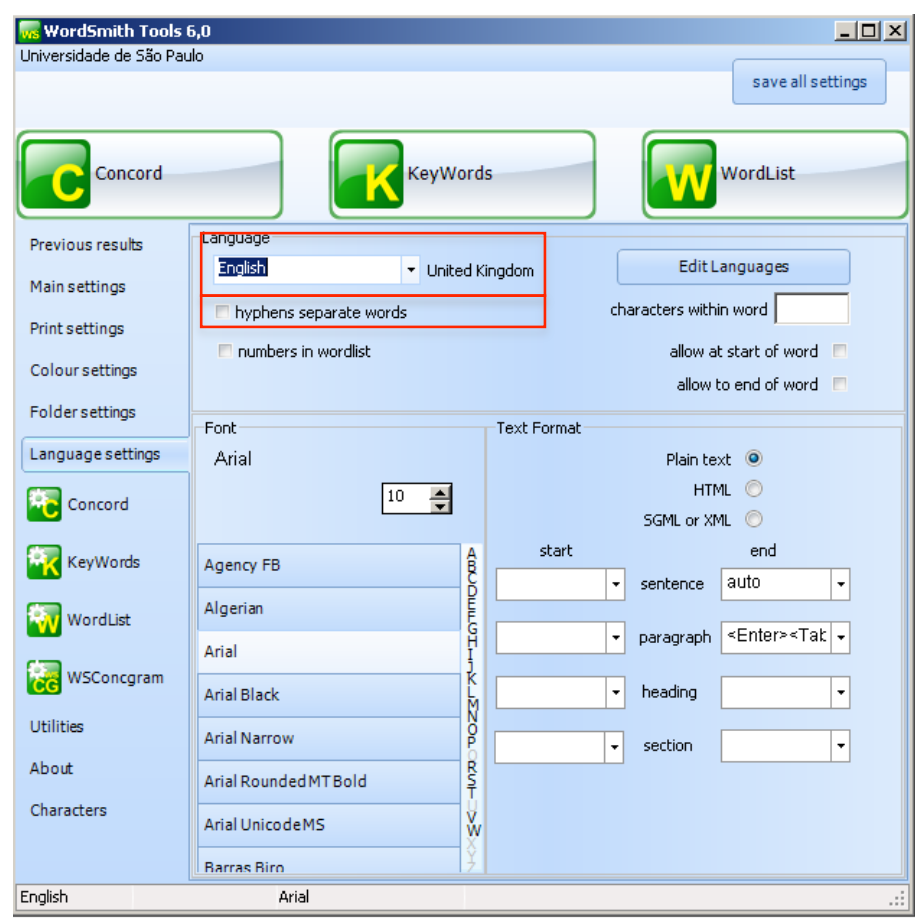

Figura 15: Tela de ajuste das funções consideradas para a criação da lista de palavras do subcorpus de inglês.

Ajustamos a língua para inglês britânico e também deixamos a opção de hyphens separate words em branco, pois a experiência de trabalhar com a linguagem do futebol adquirida durante nossa pesquisa de mestrado nos mostrou alto índice de palavras compostas separadas por hífen. Nesse caso, devido ao ajuste realizado, o programa considera, por exemplo, o termo hat-trick ${ }^{59}$ como uma única palavra.

Quando se trabalha com cabeçalho, o pesquisador deve realizar ajustes específicos na opção Tags \& Markups das configurações avançadas para que o programa não considere as etiquetas na elaboração da lista de palavras. Como mencionado no item 3.1.5, a informação inserida no cabeçalho contribui para melhor interpretação dos dados. No entanto, essas informações são extralinguísticas e não devem ser contabilizadas como ocorrências do corpus. A figura 16 mostra os ajustes realizados para nossa pesquisa:

\footnotetext{
${ }^{59}$ Termo utilizado quando um jogador faz três gols em uma partida.
} 


\section{Capítulo 3}

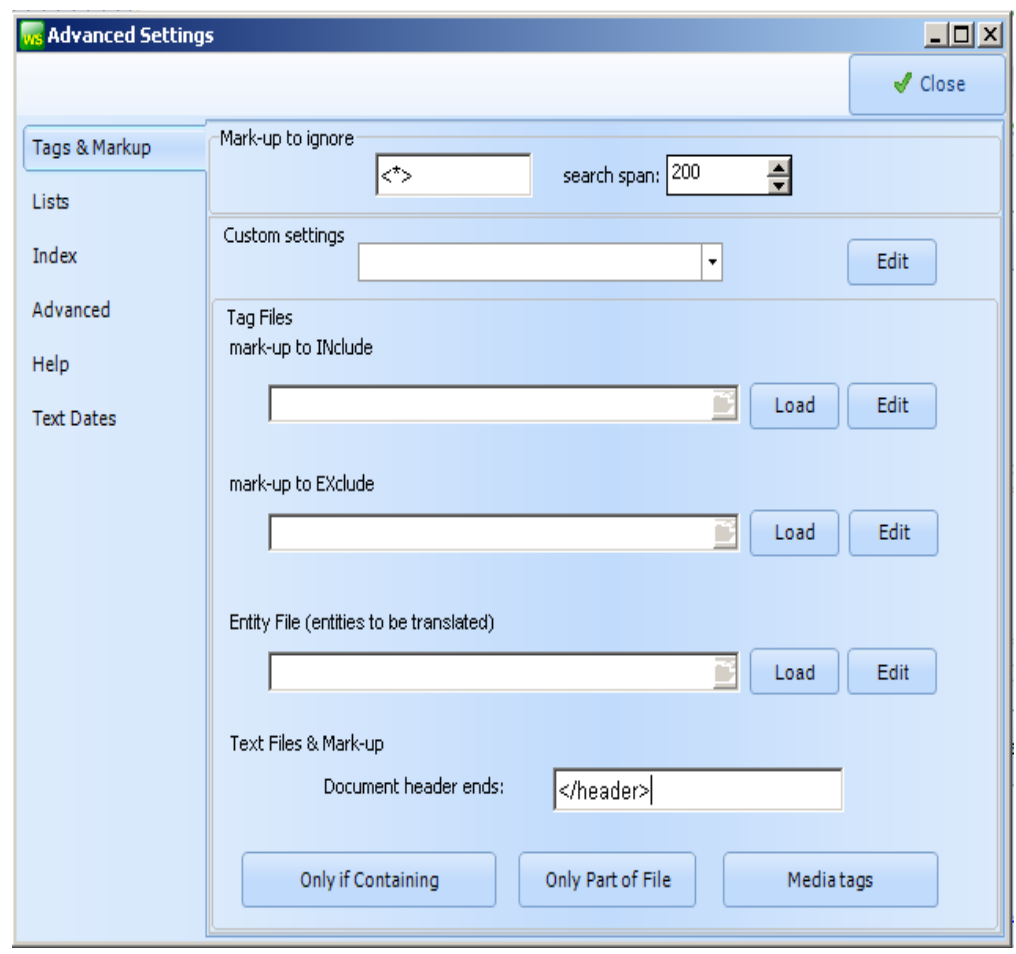

Figura 16: Ajustes realizados na opção Tags \& Markup das configurações avançadas.

Uma vez que nosso cabeçalho segue o modelo SGML, em que todas as etiquetas seguem o formato <etiqueta de abertura> informação </etiqueta de fechamento>, ajustamos o programa para ignorar essa marcação em mark-up to ignore e indicamos a etiqueta que representa o término do cabeçalho na caixa document header ends.

Realizados os ajustes, selecionamos o corpus de estudo e a ferramenta gerou a lista de palavras do corpus selecionado. A tabela abaixo apresenta as vinte palavras mais frequentes do subcorpus de estudo em inglês:

\begin{tabular}{cccccc}
$\mathbf{N}$ & Word & Freq. & $\mathbf{\%}$ & Texts & $\mathbf{\%}$ \\
\hline 1 & THE & 63555 & 5,94 & 612 & 100,00 \\
2 & A & 27939 & 2,61 & 609 & 99,64 \\
3 & TO & 25220 & 2,36 & 605 & 98,91 \\
4 & AND & 21342 & 1,99 & 606 & 99,09 \\
5 & OF & 18517 & 1,73 & 603 & 98,64 \\
6 & IN & 18407 & 1,72 & 608 & 99,46 \\
7 & FOR & 10579 & 0,99 & 599 & 97,91 \\
8 & ON & 9770 & 0,91 & 598 & 97,82 \\
9 & FRM & 8800 & 0,82 & 579 & 94,65 \\
10 & BUT & 8442 & 0,79 & 570 & 93,93 \\
11 & WITH & 8268 & 0,77 & 594 & 97,10 \\
12 & IT & 8155 & 0,76 & 551 & 90,12 \\
13 & HIS & 7797 & 0,73 & 568 & 92,84
\end{tabular}




\section{Capítulo 3}

$\begin{array}{lccccc}14 & \text { IS } & 7771 & 0,73 & 415 & 67,82 \\ 15 & \text { WAS } & 7733 & 0,72 & 558 & 91,30 \\ 16 & \text { THAT } & 7003 & 0,65 & 512 & 83,68 \\ 17 & \text { AS } & 6150 & 0,57 & 552 & 90,30 \\ 18 & \text { HE } & 6141 & 0,57 & 523 & 85,58 \\ 19 & \text { AT } & 6009 & 0,56 & 578 & 94,56 \\ 20 & \text { BY } & 5640 & 0,53 & 503 & 89,21\end{array}$

Tabela 2: Vinte palavras mais frequentes, em ordem decrescente, do subcorpus de estudlo em inglês.

A lista de palavras gerada apresenta cada palavra (word) do corpus seguida da respectiva frequência (Freq.), da porcentagem de ocorrência da palavra no corpus (\%), do número de textos em que ocorre (Texts) e da porcentagem de textos em que ocorre (\%). Por exemplo, the é a palavra mais frequente do subcorpus em inglês. Ocorre 63.555 vezes, soma 5,94\% das ocorrências desse subcorpus, está presente em 612 textos e aparece em $100 \%$ dos textos selecionados.

Ao analisar as vinte palavras mais frequentes do subcorpus, percebemos que a lista é composta somente por palavras gramaticais, como artigos, preposições e pronomes. Segundo Baayen (1998), essa é uma tendência nas listas de palavras, já que elas mostram apenas a frequência dos itens de um corpus. No entanto, para uma pesquisa terminológica, as palavras de conteúdo mostram-se mais interessantes, pois refletem o que é relevante em uma área de especialidade (BAKER, 2006, p. 123). Em nosso subcorpus em inglês, a primeira palavra de conteúdo que aparece é ball, vigésimo segundo item da lista de palavras, com 4.576 ocorrências.

O WordSmith Tools também disponibiliza uma lista de palavras em ordem alfabética que pode ser útil para a visualização das diferentes formas de uma palavra, uma vez que nosso corpus não foi lematizado ${ }^{60}$. A tabela 3 mostra uma parte da lista de palavras em ordem alfabética do subcorpus em português:

\begin{tabular}{|c|c|c|c|c|}
\hline $\mathbf{N}$ & Word & Freq. $\%$ & Texts & $\%$ \\
\hline 3988 & COBRADA & 53 & 51 & 3,11 \\
\hline 3989 & COBRADAS & 4 & 4 & 0,24 \\
\hline 3990 & COBRADO & 45 & 44 & 2,68 \\
\hline 3991 & COBRADOR & 6 & 4 & 0,24 \\
\hline 3992 & COBRADORES & 1 & 1 & 0,06 \\
\hline 3993 & COBRADOS & 1 & 1 & 0,06 \\
\hline 3994 & COBRAM & 3 & 3 & 0,18 \\
\hline
\end{tabular}

\footnotetext{
${ }^{60}$ Não agrupamos as palavras em sua forma canônica. Se agrupássemos as palavras do corpus de estudo, teríamos que realizar o mesmo procedimento com o corpus de referência, o que demandaria muito tempo e não se mostrou necessário ao longo da pesquisa.
} 


\section{Capítulo 3}

$\begin{array}{lrrrrr}3995 & \text { COBRAMOS } & 1 & & 1 & 0,06 \\ 3996 & \text { COBRANÇA } & 3168 & 0,32 & 572 & 34,86 \\ 3997 & \text { COBRANÇAS } & 45 & & 40 & 2,44 \\ 3998 & \text { COBRANDO } & 21 & & 19 & 1,16 \\ 3999 & \text { COBRAR } & 42 & & 39 & 2,38 \\ 4000 & \text { COBRARAM } & 2 & 1 & 0,06 \\ 4001 & \text { COBRARE } & 1 & 1 & 0,06 \\ 4002 & \text { COBRAVAM } & 1 & 1 & 0,06\end{array}$

Tabela 3: Amostragem da lista de palavras do subcorpus de português ordenada alfabeticamente.

Ao observar a lista, constatamos que 'cobrança' é a forma mais comum do lema 'cobrar', por exemplo. Em nossa pesquisa, essa lista foi utilizada para verificar o número total de ocorrências das diferentes formas de uma palavra. Por exemplo, o verbo 'marcar' e suas formas flexionadas: 'marca', 'marcou' etc. Além da lista de frequência e da lista em ordem alfabética, o WordSmith Tools exibe uma lista com informações estatísticas. Observemos a tabela 4:

\begin{tabular}{|c|c|c|c|c|c|c|c|}
\hline $\mathbf{N}$ & text file & file size & tokens 1 & tokens 2 & sum of entries & types & (TTR) \\
\hline 1 & Overall & 4102752 & 600079 & 575066 & & 11914 & 2,13 \\
\hline 2 & JO-IF-AGO_001.txt & 3402 & 385 & 374 & & 195 & 52,14 \\
\hline 3 & JO-IF-AGO_002.txt & 2266 & 201 & 193 & & 121 & 62,69 \\
\hline 4 & JO-IF-AGO_003.txt & 2319 & 200 & 194 & & 129 & 66,49 \\
\hline 5 & JO-IF-AGO_004.txt & 2015 & 167 & 151 & & 93 & 61,59 \\
\hline 6 & JO-IF-AGO_005.txt & 2095 & 161 & 152 & & 92 & 60,53 \\
\hline 7 & JO-IF-AGO_006.txt & 2324 & 205 & 192 & & 121 & 63,02 \\
\hline 8 & JO-IF-ASAN_001.txt & 5055 & 662 & 649 & & 310 & 47,77 \\
\hline 9 & JO-IF-ASAN_002.txt & 2782 & 276 & 267 & & 147 & 55,06 \\
\hline 10 & JO-IF-ASAN_003.txt & 2496 & 226 & 218 & & 121 & 55,50 \\
\hline 11 & JO-IF-ASAN_004.txt & 2631 & 255 & 244 & & 142 & 58,20 \\
\hline 12 & JO-IF-ARE_001.txt & 2943 & 325 & 309 & & 153 & 49,51 \\
\hline
\end{tabular}

Tabela 4: Visualização parcial dos dados estatísticos do subcorpus de estudo em inglês.

A lista mostra os arquivos utilizados no levantamento (text file), o tamanho do arquivo (file size), o total de itens lexicais corridos em cada arquivo (tokens 1), o total de itens lexicais utilizados no levantamento da lista de palavras após eliminação de números e caracteres especiais (tokens 2), a soma de entradas (sum of entries) - que só é preenchida quando a opção Compute | Tokens é ativada -, as formas distintas no corpus (types) e a razão forma/item (TTR - type token ratio).

Observemos a frase abaixo para melhor entender a relação forma/item: 


\section{Capítulo 3}

"Falei para ele, Luis Fabiano, chutar para fora, chutar para cima, porque a vida do São Paulo já está definida". ${ }^{6}$

A frase possui vinte tokens, ou seja, vinte itens lexicais. No entanto, apresenta apenas dezoito types, ou dezoito formas diferentes, já que as palavras 'chutar' e 'para' foram utilizadas duas vezes.

A relação forma/item é obtida dividindo-se o total de formas pelo total de itens. No exemplo acima, dividimos dezoito por vinte e obtivemos a relação forma/item de 0,9. Contudo, o programa apresenta essa relação em forma de porcentagem. Dessa forma, teríamos que dividir o número de formas (dezoito) pelo número de itens (vinte) dividido por cem, ou seja, $18 \div(20 \div 100)$, para obter a relação forma item de $90 \%$. Esse indicador é de extrema importância para pesquisas terminológicas, pois indica a densidade lexical do texto ou do corpus. Quanto maior a relação forma/item, maior a riqueza lexical, ou seja, maior a ocorrência de formas distintas. Em nossa pesquisa, observar a relação forma/item nos ajudou a definir o momento de fechar o corpus, pois uma vez que a relação não aumenta, indicando a ausência de formas novas, a inserção de novos textos no corpus deixa de ser vantajosa.

\subsubsection{Keywords}

A ferramenta Keywords permite a criação de uma lista de palavras-chave do corpus ao comparar nosso corpus de estudo com o corpus de referência selecionado, de modo a verificar as palavras estatisticamente mais frequentes no corpus de estudo. Essas palavras são consideradas palavras-chave, pois possuem, em termos estatísticos, uma frequência relativa de maior importância no corpus de estudo do que no corpus de referência, podendo, assim, ser utilizadas para indicar a temática do corpus.

Enquanto a lista de palavras é o primeiro passo para a maior parte das pesquisas em corpus, a lista de palavras-chave é um procedimento rápido e um instrumento valioso para direcionar o linguista em sua pesquisa (BAKER, 2004). A

\footnotetext{
${ }^{61}$ Disponível em: < http://esporte.ig.com.br/futebol/2012-10-21/vagner-love-revela-ter-pedido-paraluis-fabiano-chutar-penalti-para-fora.html > Acesso em: 19 maio 2015.
} 


\section{Capítulo 3}

importância das palavras-chave em pesquisas com corpus é ressaltada por vários acadêmicos. Tribble (2000) compara um corpus de ficção romântica com um corpus geral e, por meio do estudo de palavras-chave, identifica características da ficção romântica que são mais frequentes na linguagem falada do que na escrita; Gledhill (1995) identifica itens com frequência relativa maior em diferentes seções de um artigo científico; Teixeira (2008) elabora um modelo de dicionário de culinária voltado para a produção textual partindo da lista de palavras-chave. Enfim, há um número significativo de estudos que demonstram a importância das palavras-chave em uma pesquisa com corpus.

Scott (2004) cita três tipos de palavras-chave que resultam da comparação do corpus de estudo com um corpus de referência: 1) nomes próprios; em nosso caso, encontramos nomes de alguns jogadores, times, campeonatos e estádios; 2) palavras que humanos reconheceriam como palavras-chave, já que indicam a temática do corpus; e 3) palavras gramaticais, que normalmente possuem frequência relativa parecida com o corpus de referência, mas que indicam o estilo, a característica ou, até mesmo, as colocações do corpus como, por exemplo, a palavra 'para' em português. No nosso subcorpus em português, a preposição é colocado frequente dos verbos 'chutar' e 'tocar'.

Dada a importância das palavras-chave para os resultados da pesquisa, realizamos alguns ajustes na ferramenta antes de gerar a lista. Primeiramente, escolhemos o teste estatístico a ser utilizado. O programa WST oferece dois testes estatísticos: o log likelihood e o chi-square. Segundo Gerber (2007), a medida estatística log-likelihood é indicada quando o pesquisador tem a intenção de comparar listas de grandes dimensões, enquanto a chi-square tem maior eficácia quando usada para comparar uma amostra da população. Em nosso caso, a segunda medida seria adotada se quiséssemos comparar os diferentes gêneros textuais que compõem o corpus. Apesar da distinção bastante clara entre as duas medidas, nenhum autor lido define 'listas de grandes dimensões'. Apesar de acreditarmos desde o início que a loglikelihood seria indicada para nossa pesquisa, geramos listas de palavras com as duas medidas e analisamos os resultados, que comprovaram nossa hipótese inicial.

Outro ajuste realizado foi no valor de $p$, ou $p$-value em inglês, que é o resultado de um teste de significância aplicado para verificar a hipótese nula, ou seja, 


\section{Capítulo 3}

de que não existe diferença significativa entre dois grupos de dados e as diferenças entre eles ocorrem puramente por acaso (DAYRELL, 2011, p. 147). Em outras palavras, a probabilidade de um evento ocorrer varia entre 0 e 1 . O primeiro número indica que as chances de um evento ocorrer são nulas, ou seja, 0 . O segundo, por outro lado, indica a certeza da ocorrência do evento (OAKES, 1998). Contudo, entre 0 e 1 existem diferentes graus de probabilidade para que um evento ocorra e, em nosso caso, ao determinar o valor de $p$ para elaborar uma lista de palavras-chave, estabelecemos a probabilidade de as palavras serem chave ou não. Dessa forma, quanto maior o valor de $p$ estipulado, mais palavras-chave serão encontradas, e quanto menor o valor estipulado, menos palavras são encontradas, conferindo, assim, maior certeza de um resultado significativo.

Uma vez que sabíamos de antemão que não analisaríamos todas as palavraschave do corpus, ajustamos o valor de $p$ em 0,000001 a fim de obter um número reduzido de palavras-chave. De acordo com esse ajuste, a chance de uma palavra ser considerada chave ao acaso é de um em um milhão. Contudo, para restringir ainda mais o número de keywords, optamos por ter acesso a somente 300 palavras. A frequência mínima selecionada para a palavra ser considerada chave foi 1 , uma vez que os hapax legomena, palavras que ocorrem uma única vez no corpus, podem constituir valioso objeto de análise (BERBER SARDINHA, 2004, p. 24). A figura 17 mostra a tela da ferramenta com os ajustes realizados: 


\section{Capítulo 3}

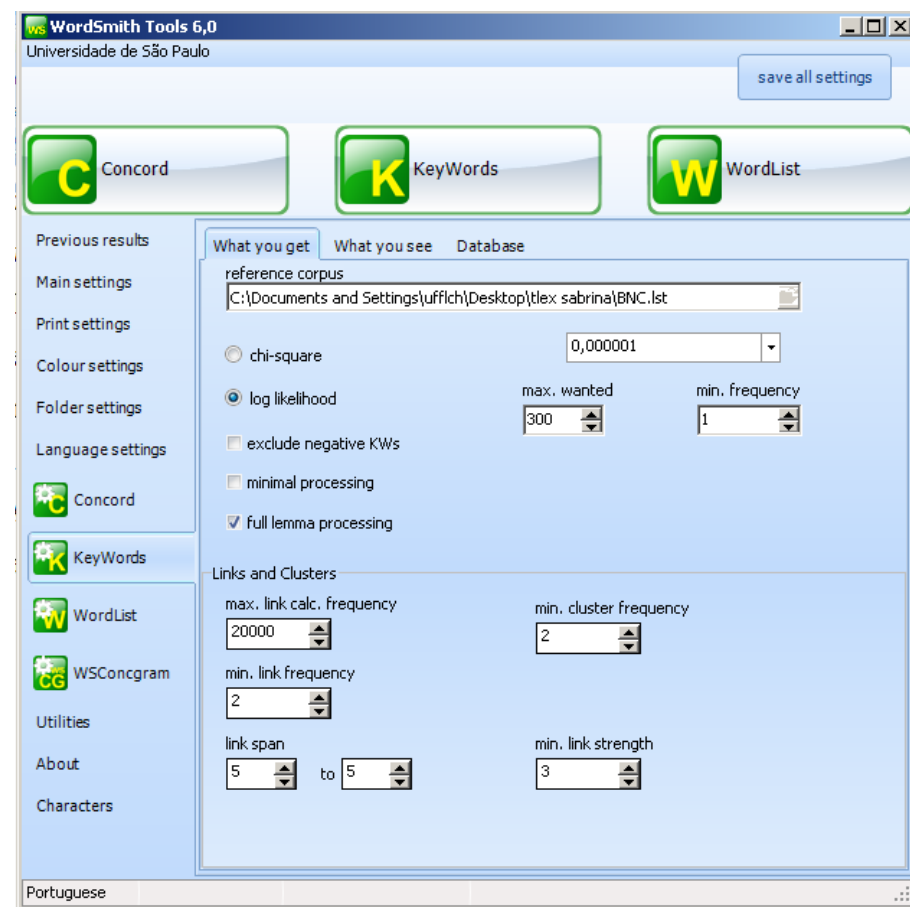

Figura 17: Ajustes realizados para o levantamento das palavras-chave.

Realizados os devidos ajustes, selecionamos os corpora a serem comparados (figura 18) e o programa gerou a lista de palavras chave (tabela 5):

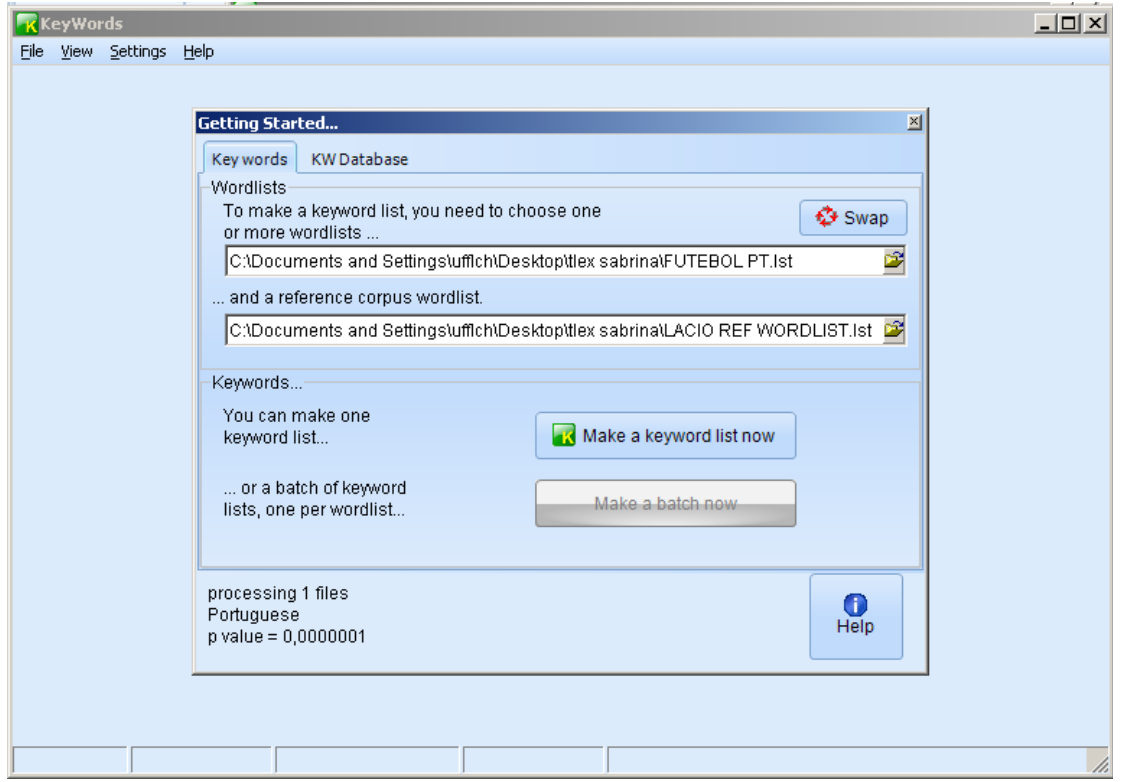

Figura 18: Tela de seleção dos corpora. 


\section{Capítulo 3}

\begin{tabular}{rrrrrrrl}
$\mathbf{N}$ & Key word & Freq. & \% & RC. Freq. & RC. $\%$ & Keyness & P \\
\hline 1 & BOLA & 6857 & 0,64 & 184 & & 26757,29 & 0,00 \\
2 & GOL & 6171 & 0,58 & 236 & & 23608,26 & 0,00 \\
3 & FALTA & 6901 & 0,65 & 1747 & 0,02 & 20360,84 & 0,00 \\
4 & DIREITA & 4844 & 0,45 & 416 & & 17266,00 & 0,00 \\
5 & BATIDO & 3968 & 0,37 & 10 & & 16295,12 & 0,00 \\
6 & MINUTOS & 4102 & 0,38 & 511 & & 13913,16 & 0,00 \\
7 & COBRANÇA & 3168 & 0,30 & 129 & & 12062,80 & 0,00 \\
8 & JOGO & 3942 & 0,37 & 951 & 0,01 & 11760,91 & 0,00 \\
9 & ÁREA & 5920 & 0,56 & 4436 & 0,06 & 11574,28 & 0,00 \\
10 & CHUTE & 2560 & 0,24 & 23 & & 10341,64 & 0,00 \\
11 & ESQUERDA & 3123 & 0,29 & 564 & & 9927,80 & 0,00 \\
12 & GOLEIRO & 2370 & 0,22 & 85 & & 9095,58 & 0,00 \\
13 & TIME & 2884 & 0,27 & 583 & & 8956,83 & 0,00 \\
14 & FUTEBOL & 2597 & 0,24 & 382 & & 8572,63 & 0,00 \\
15 & PARTIDA & 2467 & 0,23 & 471 & & 7753,59 & 0,00 \\
16 & COMETIDA & 1845 & 0,17 & 16 & & 7457,47 & 0,00 \\
17 & TIRO & 1930 & 0,18 & 73 & & 7382,04 & 0,00 \\
18 & ESCANTEIO & 1677 & 0,16 & 6 & & 6863,57 & 0,00 \\
19 & META & 2017 & 0,19 & 384 & & 6342,25 & 0,00 \\
20 & ÁRBITRO & 1573 & 0,15 & 35 & & 6183,24 & 0,00
\end{tabular}

Tabela 5: Vinte primeiras palavras-chave, em ordem decrescente de chavicidade, do subcorpus em português.

Ao observar a lista de palavras-chave do subcorpus de português, constatamos que todos os itens, sem exceção, fazem parte do léxico do futebol. No que se refere aos tipos de palavras-chave identificados por Scott (2004), os vinte primeiros itens pertencem ao grupo de palavras que identificam a temática do corpus.

\subsubsection{Concord}

A ferramenta Concord lista as ocorrências de um item específico, chamado de palavra de busca ou nódulo. Esse item pode ser formado por uma ou mais palavras e é apresentado em linhas de concordância com o cotexto ao seu redor. As concordâncias podem ser geradas de duas maneiras principais: 1) por meio de um batch, em que o programa gera linhas de concordância para cada ocorrência de um corpus; e 2) por meio da seleção de um item do corpus. No primeiro caso, o programa procura a ocorrência de cada item de um corpus e cria um arquivo com todas as ocorrências acompanhadas de uma quantidade previamente selecionada de cotexto. No segundo caso, o pesquisador insere na caixa de busca a palavra para a qual deseja gerar concordâncias e o programa gera linhas de concordância com essa palavra. O primeiro tipo de lista, embora bastante útil em alguns casos, não se mostra 


\section{Capítulo 3}

interessante em nossa pesquisa, uma vez que não analisamos todas as palavras do corpus. Utilizamos, aqui, o segundo tipo, em que geramos linhas de concordância para os termos selecionados para a análise.

As concordâncias podem ser produzidas em diversos formatos, sendo o mais comum o formato KWIC (key word in context) ou, em português, palavra-chave ${ }^{62} \mathrm{em}$ contexto; nesse, a palavra de busca aparece centralizada, acompanhada de uma quantidade determinada de cotexto à direita e à esquerda. A figura 19 apresenta a palavra de busca goal centralizada e em azul, e ressalta as três palavras imediatamente a sua esquerda:

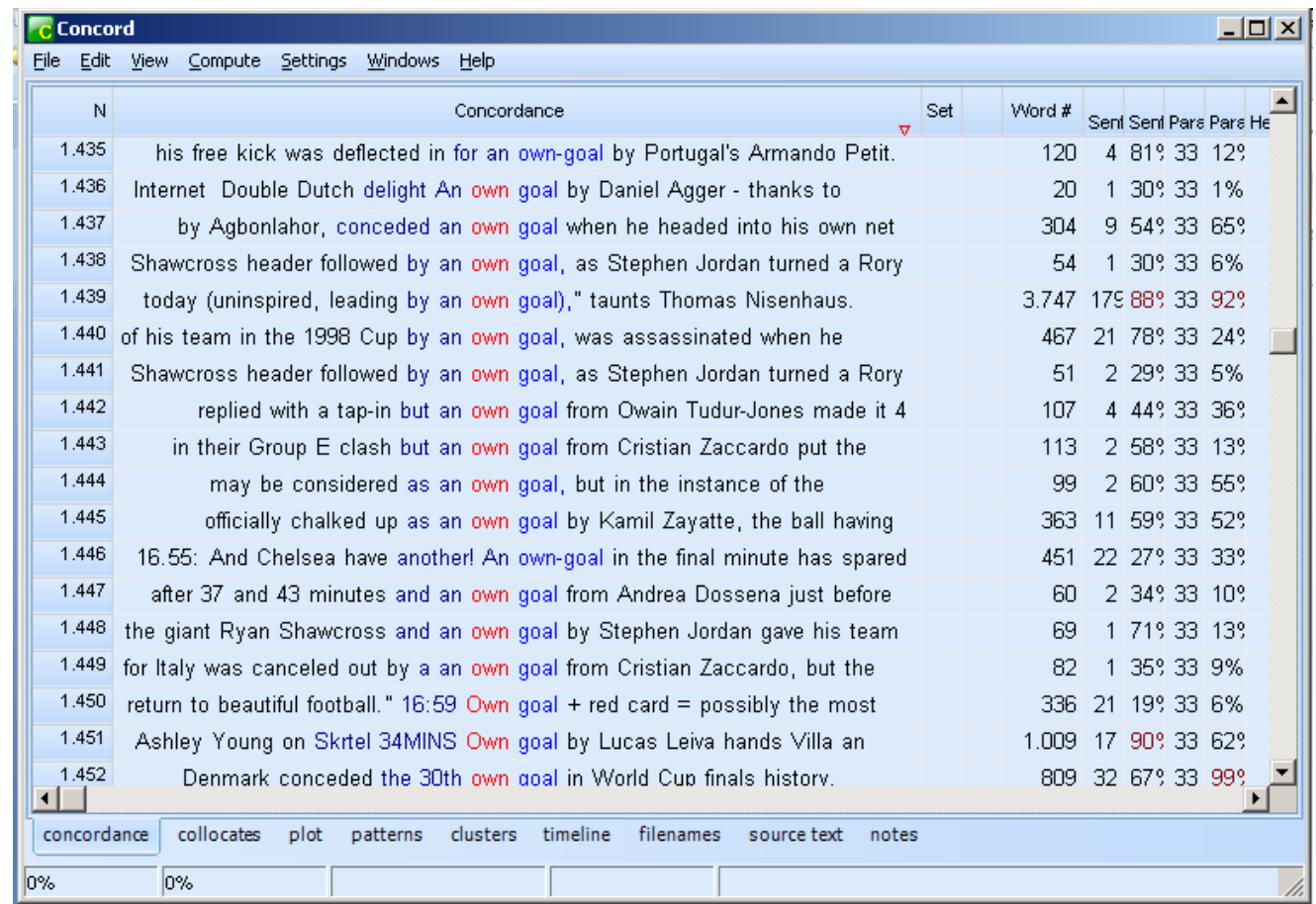

Figura 19: Seleção das linhas de concordância de goal ordenadas pelas três primeiras palavras à esquerda ${ }^{63}$.

\footnotetext{
${ }^{62}$ Kennedy (1998, p. 251) chama atenção para os diversos termos adotados pela literatura para se referir ao nódulo da linha de concordância. Dentre eles, encontramos "target item", "keyword", "node word" e "serch item". Em nossa pesquisa utilizamos os termos "nódulo' e 'palavra de busca' indistintamente.

${ }^{63} \mathrm{O}$ programa permite salvar as listas de palavras, as listas de palavras-chave e as linhas de concordância em arquivo Excel. Todas as listas e tabelas aqui apresentadas são seleções das listas completas importadas para o Excel. Raras vezes mostramos a tela do WST, pois o programa só funciona em ambiente Windows e a pesquisadora trabalha com o sistema operacional padrão do MacBook. Dessa forma, a análise foi realizada na sede do projeto Comet, no prédio de Letras, da Faculdade de Filosofia, Letras e Ciências Humanas da Universidade de São Paulo. As listas foram salvas em formato .xls e a pesquisadora redigiu a tese em seu computador pessoal consultando as listas previamente salvas. Já no caso das linhas de concordância e dos clusters, optamos por mostrá-los na tela do software, pois quando são salvos em .xls, perde-se a formatação.
} 


\section{Capítulo 3}

A observação das linhas facilita a identificação de padrões linguísticos, como colocações e unidades de sentido mais extensas. No entanto, quando o número de linhas disponibilizadas pela ferramenta é muito alto, como no caso de goal, torna-se difícil, para não dizer impossível, estabelecer algum padrão somente observando as concordâncias. Para a identificação de padrões em casos como esse, é possível reordenar as linhas de diversas maneiras. Em pesquisas terminográficas ou lexicográficas, o mais comum é ordenar o resultado pelos colocados à direita ou à esquerda do nódulo.

$\mathrm{Na}$ figura acima, observamos a ocorrência da colocação own goal, que tem 'gol contra' como equivalente em português. O WST permite que o pesquisador clique na linha de concordância para ter acesso ao texto integral, fator que facilita bastante a análise de um item, principalmente durante a busca de equivalentes tradutórios, pois, embora o programa exiba o cotexto, este, muitas vezes, não é suficiente para entender o uso de um termo, colocação ou uma expressão.

A ferramenta Concord conta com o dispositivo Clusters, que permite a identificação de agrupamentos, também conhecidos como n-gramas, que podem ser descritos como associações de palavras que coocorrem com determinada frequência dentro de uma janela de determinado número de palavras à esquerda e à direita de uma palavra de busca.

Os clusters são computados automaticamente e não refletem, necessariamente, colocações ou CLEs. Para obter uma lista de clusters, clicamos na aba clusters que aparece na parte inferior da tela da ferramenta Concord. A figura 20 mostra uma seleção de clusters de 'gol' de três palavras, com frequência mínima de 3: 


\section{Capítulo 3}

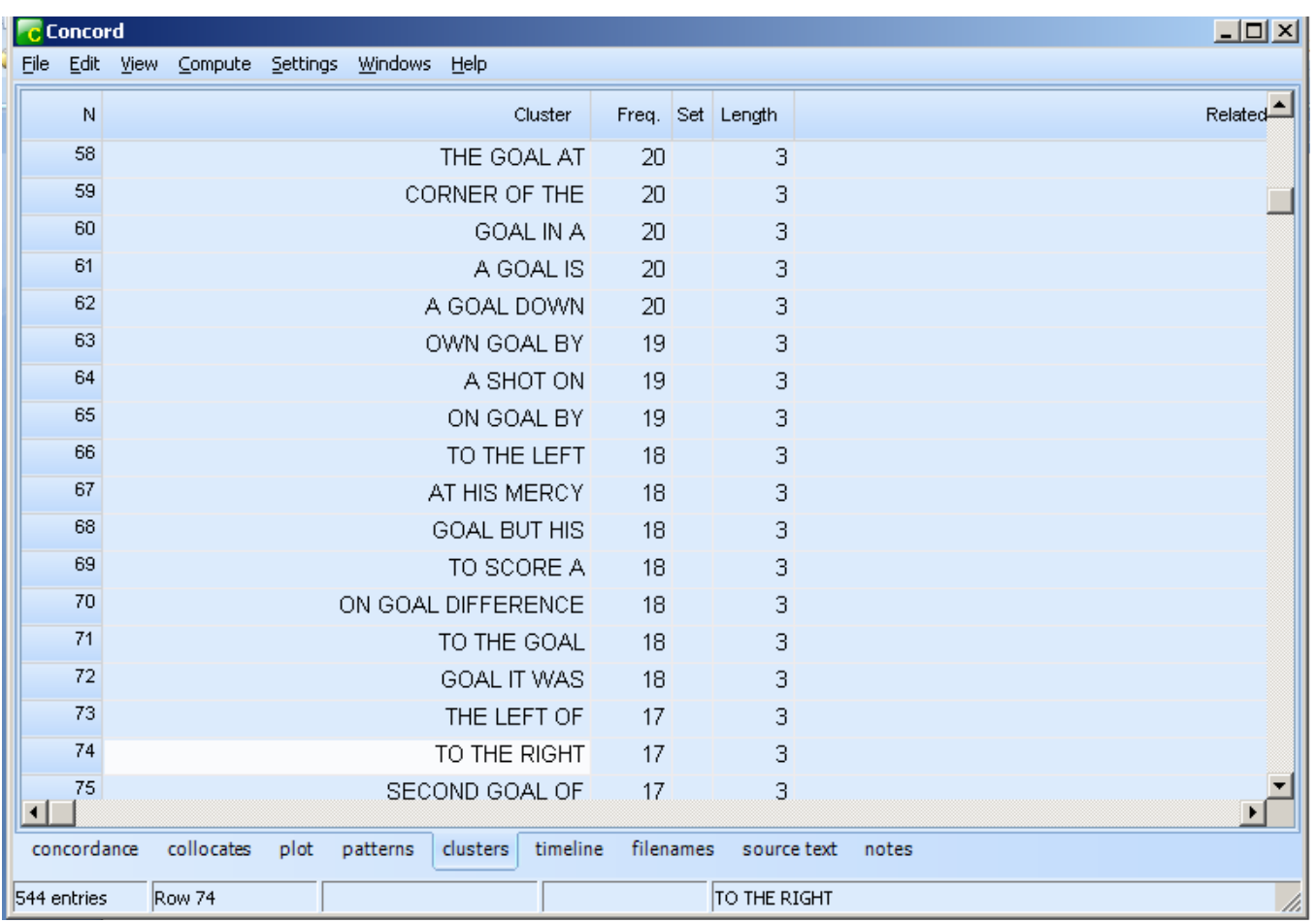

Figura 20: Seleção de clusters de três palavras de goal.

Utilizamos os clusters em alguns momentos de nossa pesquisa unicamente para visualizar, de forma mais sistemática, os colocados de alguns termos. Poderíamos ter utilizado o dispositivo collocates, mas demos preferência ao clusters devido ao modo como essas associações de palavras são disponibilizadas. Ou seja, o dispositivo foi utilizado somente quando procurávamos por uma associação de duas ou mais palavras e havia um grande número de linhas de concordâncias que, embora ordenadas, dificultavam a análise.

\subsubsection{TshwaneLex (TLex)}

O software TshwaneLex, ou TLex, é um software de compilação de dicionários e listas terminológicas que conta com uma série de aplicativos que auxiliam o lexicógrafo ou terminógrafo no processo de compilação. Além disso, pode ser utilizado para todas as línguas e para a criação de diferentes tipos de obras de referência, uma vez que permite a customização dos verbetes.

O software inclui quatro aplicativos: 


\section{Capítulo 3}

1) TLex Dictionary Compilation Software: utilizado para a construção de dicionários e bancos de dados terminológicos;

2) tlTerm Professional Termbase Sofware: compila listas terminológicas;

3) tlCorpus Concordance Software: compila corpus de forma semiautomática e realiza o levantamento de listas de palavras;

4) tlReader: possibilita a visualização de obras lexicográficas e terminológicas criadas pelo TLex.

Nesta pesquisa utilizamos somente o TLex Dictionary Compilation Software, pois a compilação do corpus foi feita de forma manual e a análise do corpus foi feita com o auxílio do software WST. A figura abaixo mostra a tela inicial do software:

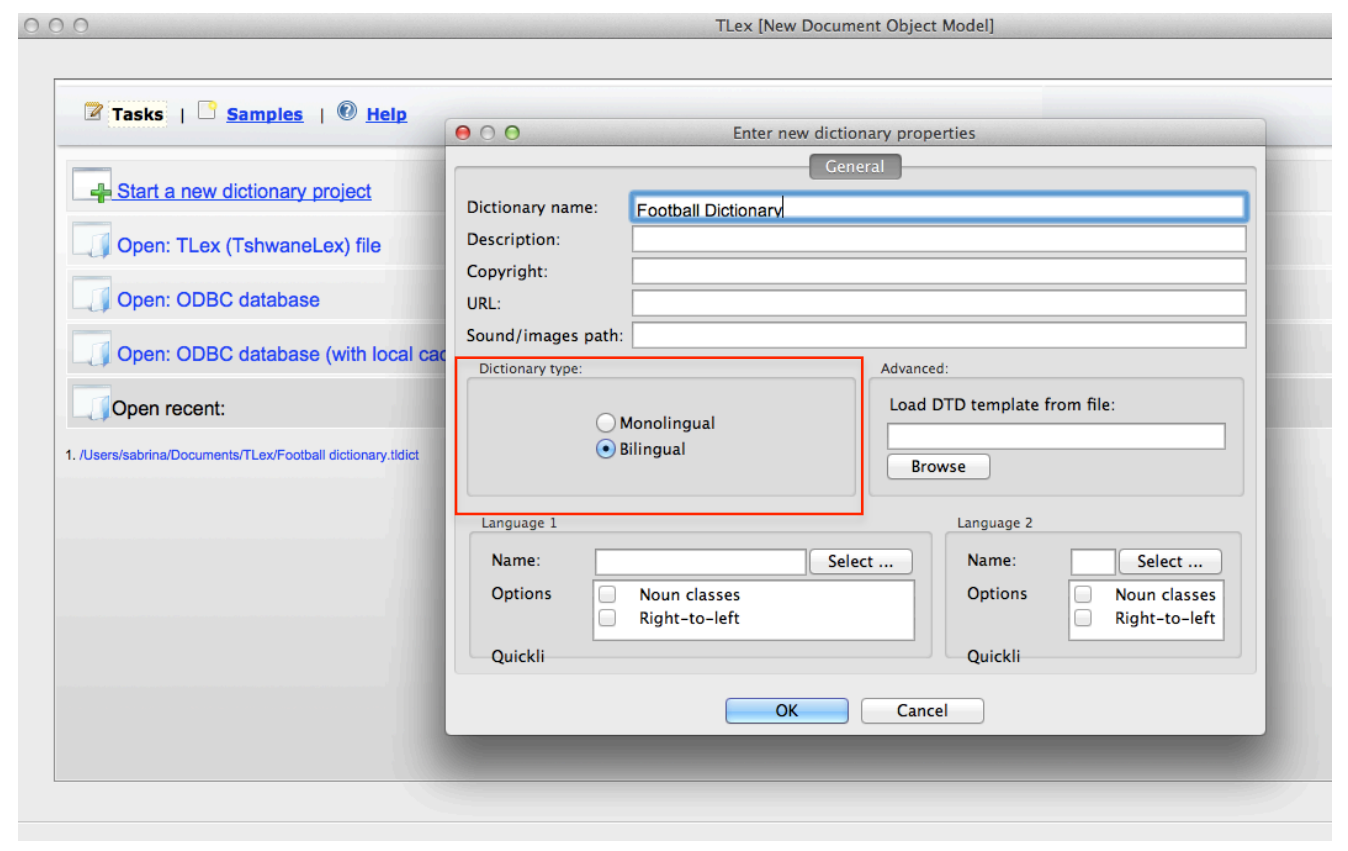

Figura 21: Tela inicial do TshwaneLex.

Ao abrir o aplicativo temos a opção de criar um novo projeto, abrir um arquivo salvo no TLex - quer seja um dicionário, um corpus ou uma lista terminológica - e abrir um banco de dados.

Ao clicar em Start a new dictionary project (iniciar novo projeto de dicionário, no alto, à esquerda), o programa abre uma janela em que o pesquisador deve nomear o dicionário, em nosso caso Football Dictionary, e selecionar a opção monolingual (monolíngue) ou bilingual (bilíngue), onde selecionamos a opção 


\section{Capítulo 3}

'bilíngue'. As outras caixas de informação que o software disponibiliza não são de preenchimento obrigatório. Selecionamos a opção 'bilíngue' uma vez que nosso modelo de dicionário foi elaborado nas duas línguas. Ao selecionar essa opção, é possível criar, de forma automática, verbetes na língua dois (inglês), desde que o campo TE (translation equivalent) esteja preenchido na língua um (português).

Para criar entradas na língua dois de forma automática, clicamos no botão 'reverse' e o programa abre uma janela com o termo em português e o equivalente em inglês, que constituirá o verbete na outra parte do dicionário (figura 22). Essa opção funciona perfeitamente para verbetes que possuem um único equivalente, como, por exemplo, o termo 'bichado, ${ }^{64} \mathrm{em}$ português, que tem como equivalente crock em inglês. No entanto, é muito comum um termo em português possuir mais de um equivalente em inglês, como é o caso de 'lambreta', que apresenta sete equivalentes nesse idioma. Nesse caso, o procedimento realizado é o mesmo, mas, ao criar a entrada para os equivalentes em inglês, o programa cria uma única entrada com todos os termos. Observemos a figura abaixo:

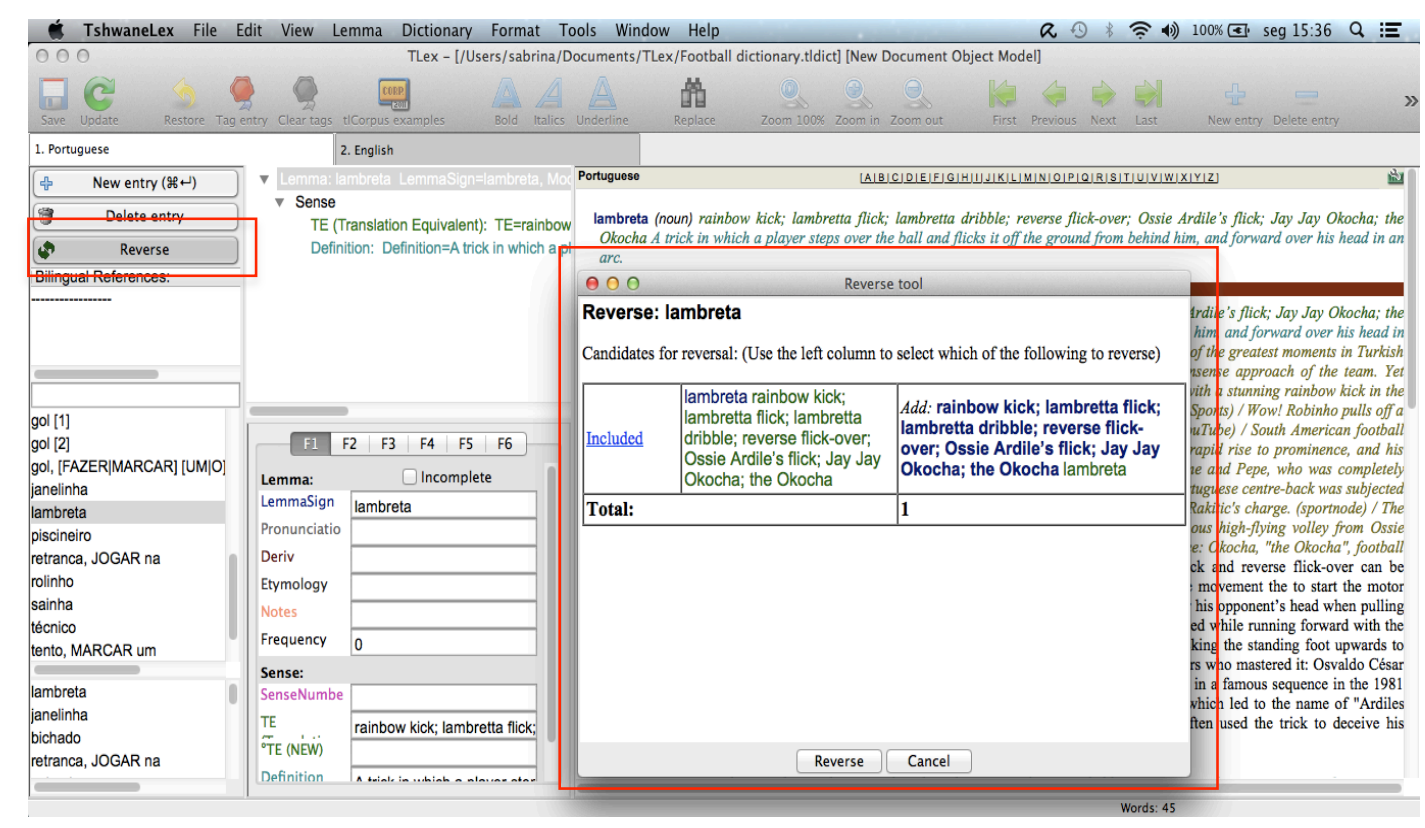

Figura 22: Tela da reversão automática de termos do TLex.

Dada a impossibilidade de o programa criar entradas separadas para os equivalentes em inglês, optamos por inserir os termos manualmente na parte em

\footnotetext{
${ }^{64}$ Jogador que apresenta algum problema físico, geralmente crônico.
} 


\section{Capítulo 3}

inglês. Sendo assim, selecionamos a versão bilíngue de dicionário, mas não utilizamos o que seria a característica mais promissora da ferramenta: versão automática dos verbetes da língua um para a língua dois.

Ao observar a figura 23, vemos que o programa disponibiliza uma série de elementos, como referência (reference), definição (definition) e equivalente tradutório (TE) para a construção dos verbetes:

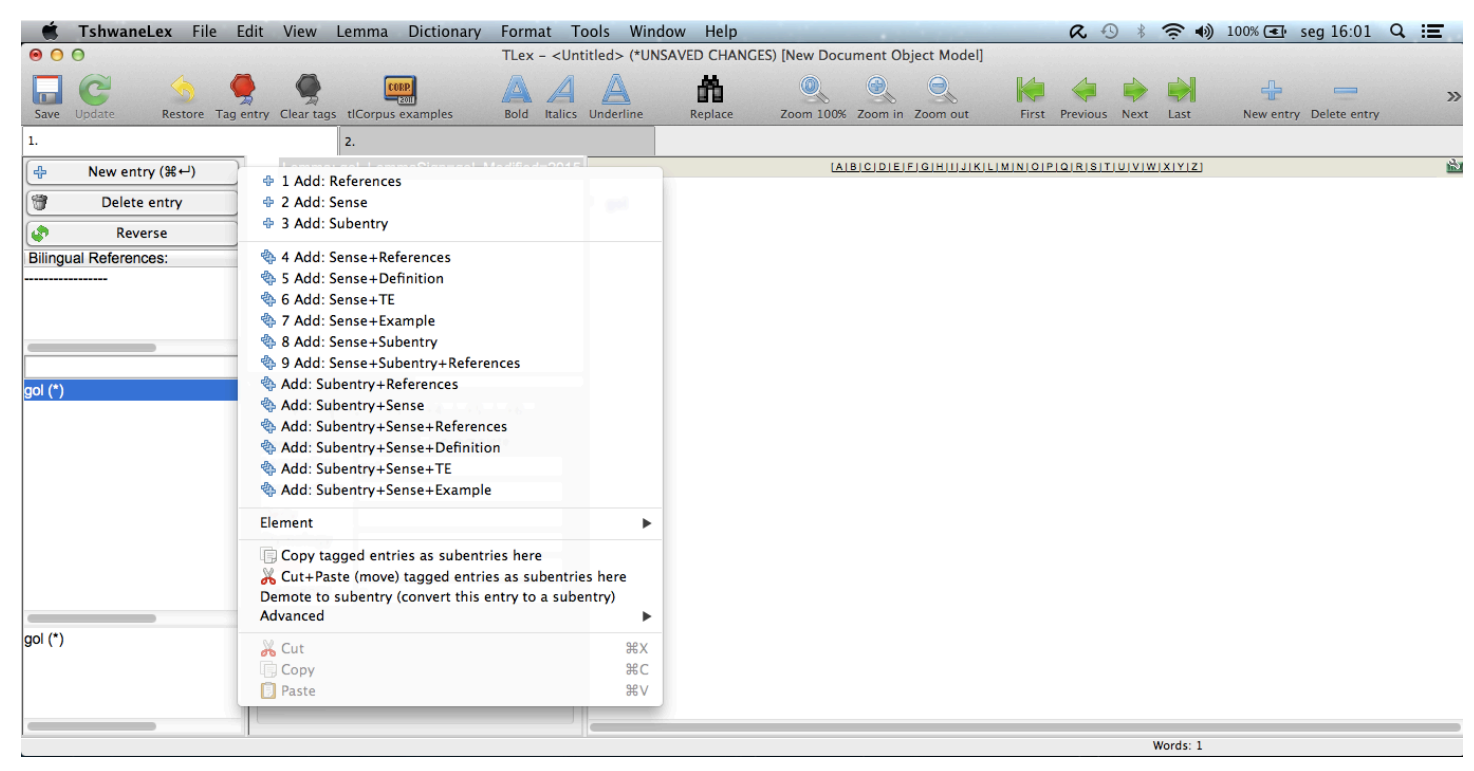

Figura 23: Tela da escolha dos elementos que constituirão os verbetes.

Embora o programa apresente uma lista bastante extensa de elementos, não contempla alguns que fazem parte de nosso verbete, como, por exemplo, os elementos 'ilustração' e 'vídeo'. Dessa forma, tivemos que criar novos elementos. Para tanto, selecionamos a função Customize DTD em Dictionary: 


\section{Capítulo 3}

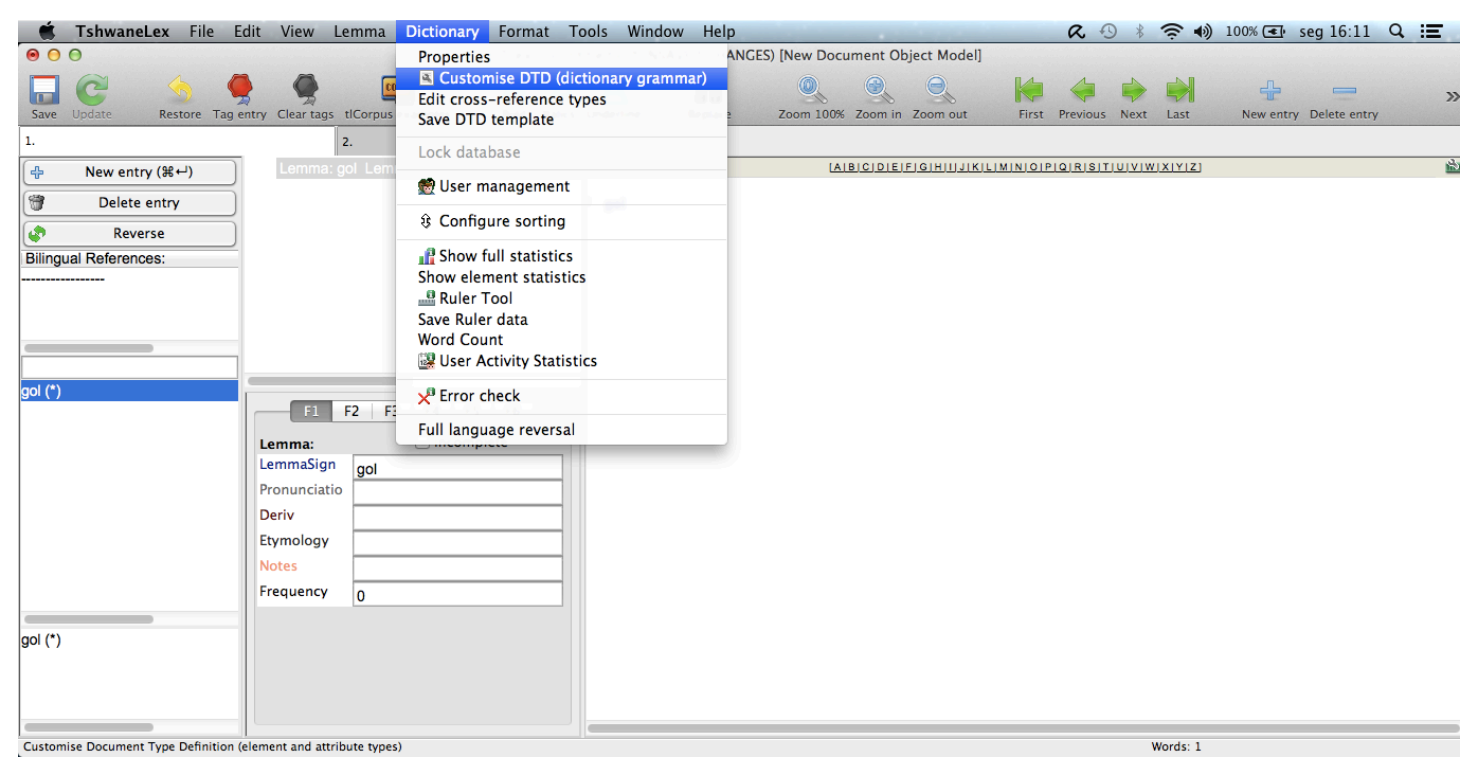

Figura 24: Tela de customização do TLex.

Acrescentamos à lista de elementos disponibilizada pelo TLex os campos comment, onde disponibilizamos informações históricas e culturais sobre alguns termos, image, para inserir uma figura que ajude o consulente a melhor compreender o significado da entrada, e video, para inserir vídeos que contribuam para o entendimento da definição:

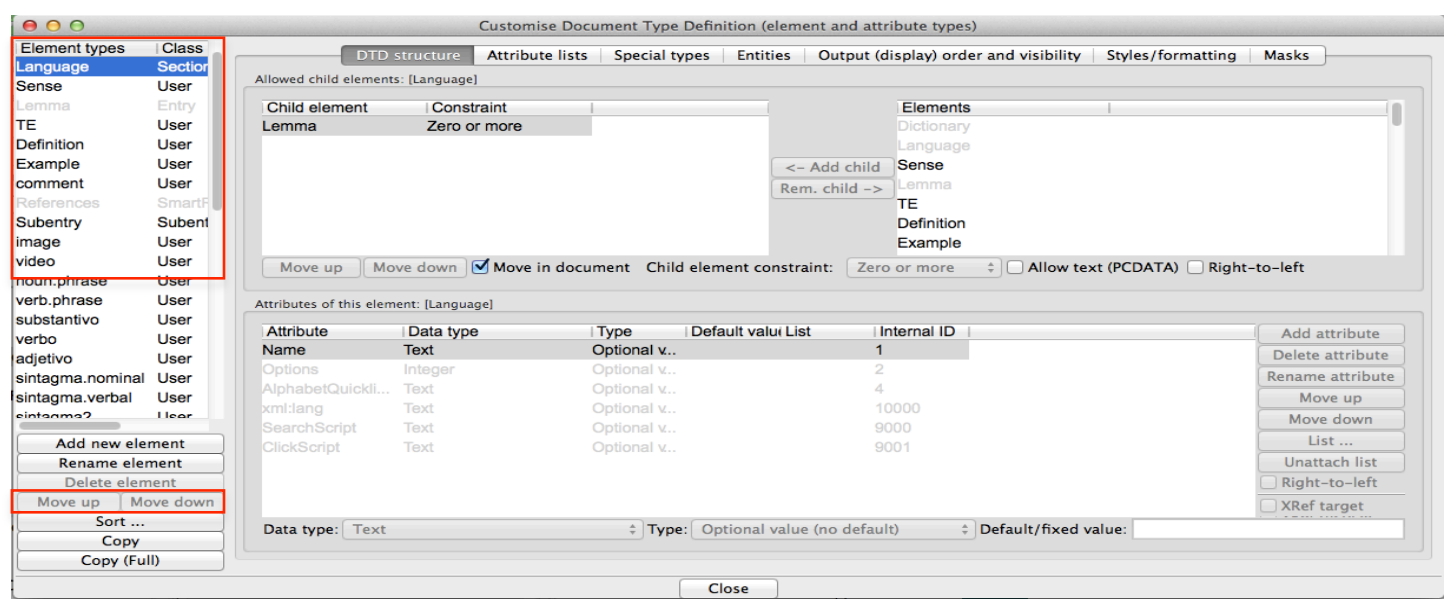

Figura 25: Tela de inclusão de elementos no dicionário.

A partir da inclusão dos elementos supracitados, elaboramos um modelo de verbete com as informações que julgamos importantes para o consulente de nossa obra. Uma característica bastante interessante da ferramenta é a possiblidade de alterar a ordem em que os elementos são apresentados no verbete. Para tanto, basta o 


\section{Capítulo 3}

pesquisador selecionar o elemento desejado e alterar a ordem de exibição utilizando os botões "move up" e "move down" (figura 25). Em nosso dicionário, a ordem escolhida foi: 1) classificação gramatical; 2) equivalente tradutório (TE); 3) definição (Definition); 4) exemplo (Example); 5) comentários (comment); 6) subentrada (subentry); 7) referências (references); 8) imagem (image); e 9) vídeo (video).

Nenhum dos campos é de preenchimento obrigatório. Dessa forma, inserimos figuras ou vídeos somente naqueles verbetes em que o recurso visual auxilia na compreensão do significado do termo. O campo comment, por exemplo, também só é preenchido quando diferenças culturais ou fatores históricos acrescentam ao significado apresentado no campo definition.

No que se refere ao campo references, utilizamos dois tipos de referências: 1) same as, para verbetes considerados sinônimos; nesse caso utilizamos o sistema de remissivas, ou seja, preenchemos as informações na entrada do item mais frequente e o software criou um link entre as entradas; 2) SEE, para direcionar o consulente a outro verbete, a fim de contrastar dois significados de um mesmo termo ou de ter acesso a outra expressão em que o termo é utilizado. A figura 26 mostra um verbete que possui a referência cruzada same as e a figura 27 mostra um verbete que possui a referência cruzada SEE:

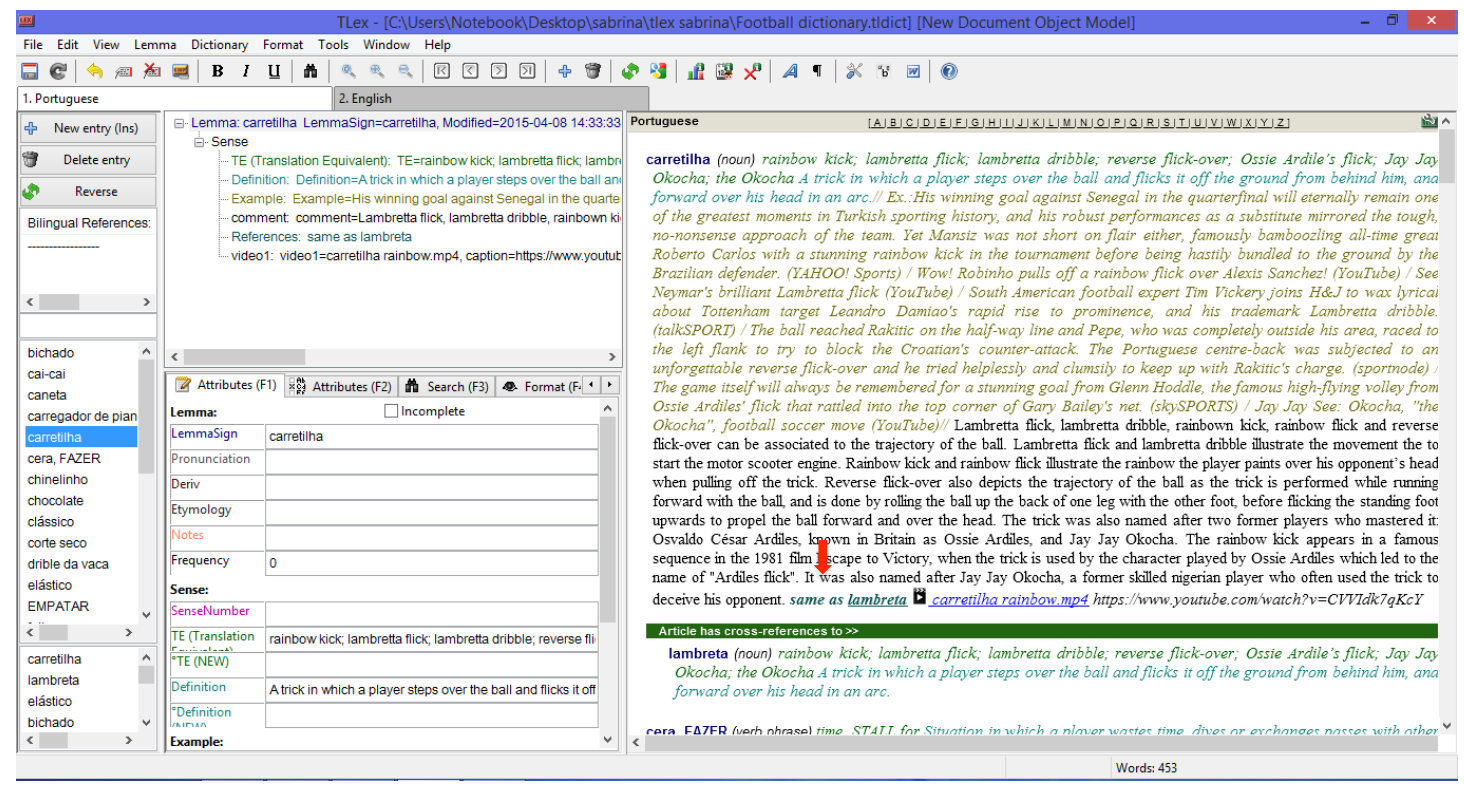

Figura 26: Exemplo de verbete que apresenta a referência cruzada same as. 


\section{Capítulo 3}

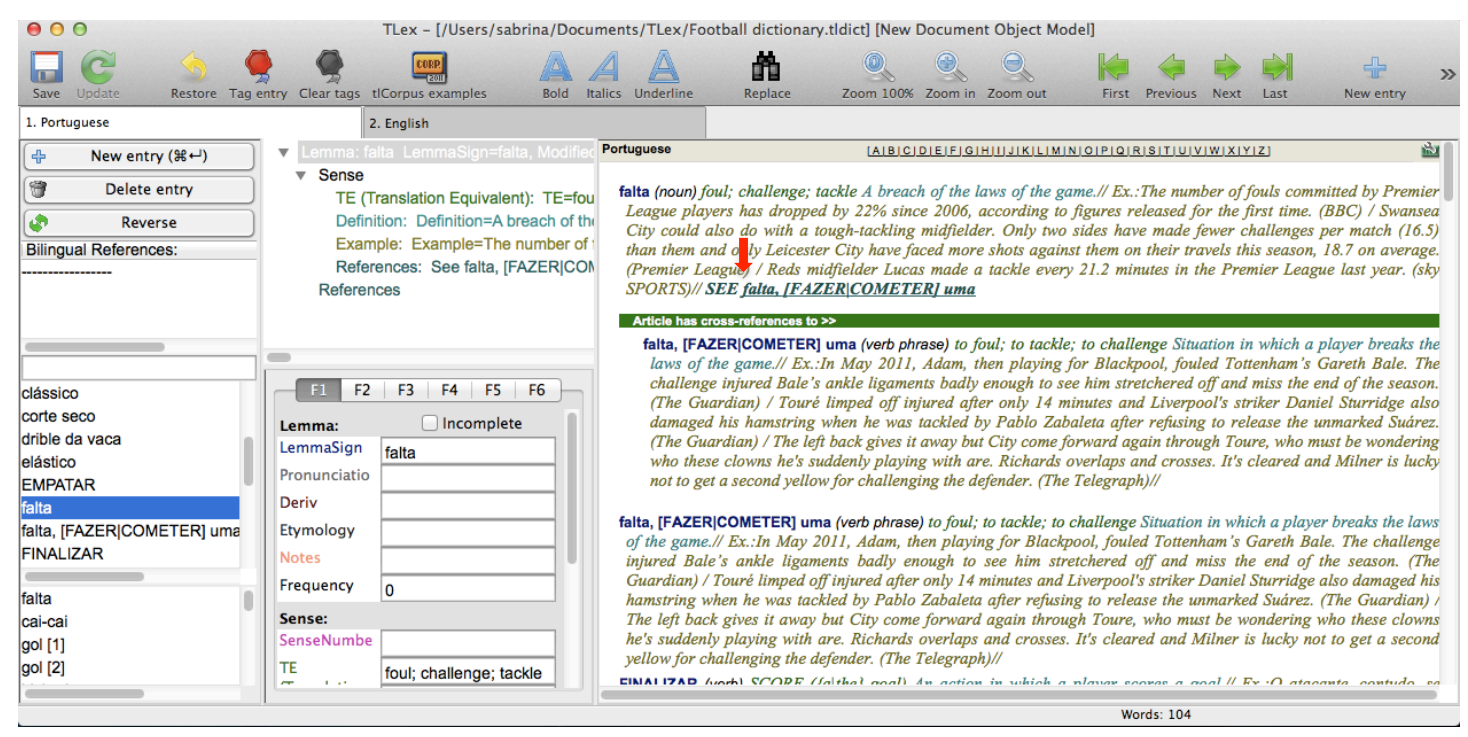

Figura 27: Exemplo de verbete que apresenta a referência cruzada $S E E$.

A figura 26 mostra o verbete 'carretilha', que tem como sinônimo o termo 'lambreta'. 'Carretilha' compõe a entrada principal porque apresenta frequência maior que 'lambreta' no corpus. A figura 27 mostra o verbete 'falta', que apresenta referência cruzada para o verbete 'falta, [FAZER|COMETER], uma'. Em ambos os casos o software indica que o verbete possui referência cruzada por meio da informação article has cross-references to, no caso da entrada principal (mais frequente), ou article is cross-referenced from, no caso da segunda entrada.

O software também permite que o pesquisador altere estilos e fontes de cada elemento, visando uma melhor visualização do produto final. Por exemplo, o elemento $^{65}$ example, que é formado por dois atributos - o exemplo em si (Example) e a fonte de onde o exemplo foi retirado (source) -, aparece em itálico, em verde oliva, precedido de '//EX.:' e seguido de '//'. Para realizar esses ajustes, clicamos, na aba Dictionary, em Customize DTD e em Stlyes/formatting. As figuras abaixo exibem os ajustes:

\footnotetext{
${ }^{65}$ Todo campo (elemento) criado no TLex é formado por, no mínimo, um atributo, que pode ser entendido como informação que estará presente no campo. Por exemplo, o campo TE (equivalente tradutório) é formado por um único atributo - o equivalente tradutório -, pois nesse campo o equivalente na língua dois é a única informação a ser inserida. No entanto, alguns campos apresentam mais de um atributo, como é o caso do campo example, em que exibimos o exemplo em si (atributo Example) e a fonte de onde o exemplo foi coletado (atributo Source).
} 


\section{Capítulo 3}

\begin{tabular}{|l||l|l|l|l|l|}
\hline DTD structure & Attribute lists & Special types & Entities & Output (display) order and visibility & Styles/formatting \\
\hline
\end{tabular}

Figura 28: Tela de formatação dos estilos do elemento example.

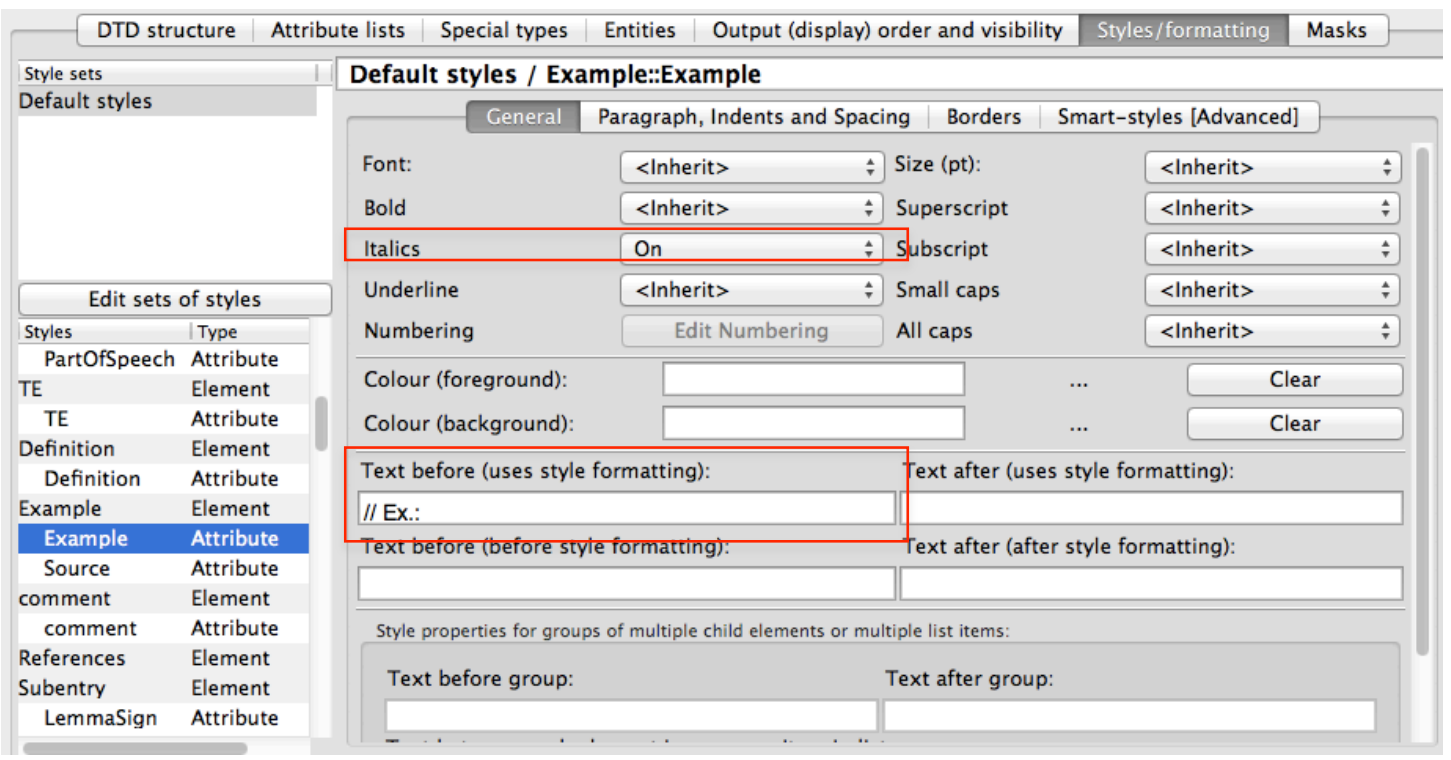

Figura 29: Tela de formatação do atributo example do elemento Example. 


\section{Capítulo 3}

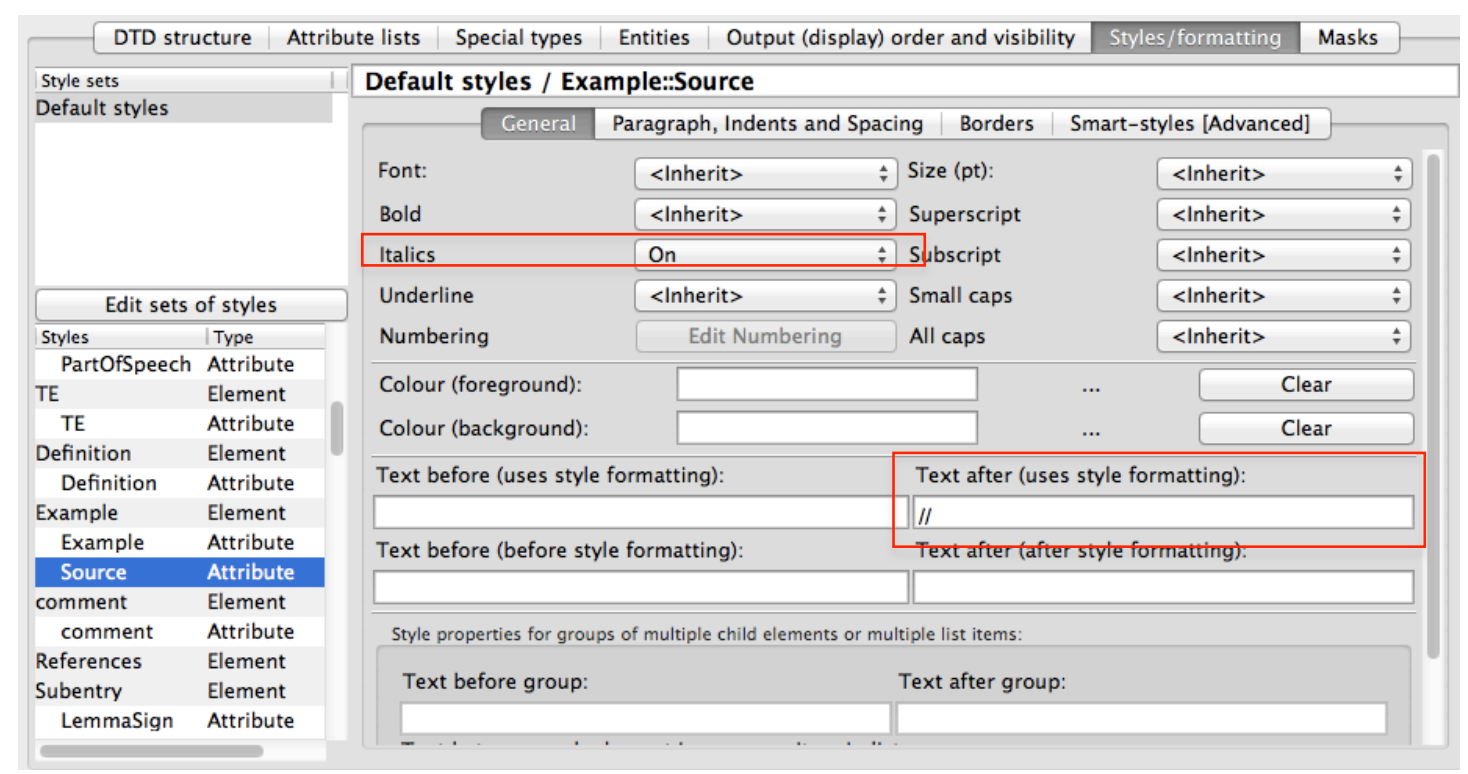

Figura 30: Tela de formatação do atributo Source do elemento Example.

A figura 28 mostra os ajustes realizados para o elemento Example: fonte Times New Roman número 11 e cor verde oliva. A figura 29 exibe os ajustes para o atributo Example: fonte itálico e texto precedido de '//EX.:'. A figura 30 mostra os ajustes para o atribute Source: fonte 'itálico' e texto procedido de '//'.

Após inserir novos elementos e formatá-los, passamos ao preenchimento dos campos. Os verbetes são montados a partir de uma estrutura hierárquica (Tree View), previamente selecionada (figura 31, que fica à esquerda da tela, e sua visualização aparece à direita (Preview). O Tree View apresenta uma janela na parte inferior, onde inserimos as informações que farão parte do verbete: 


\section{Capítulo 3}

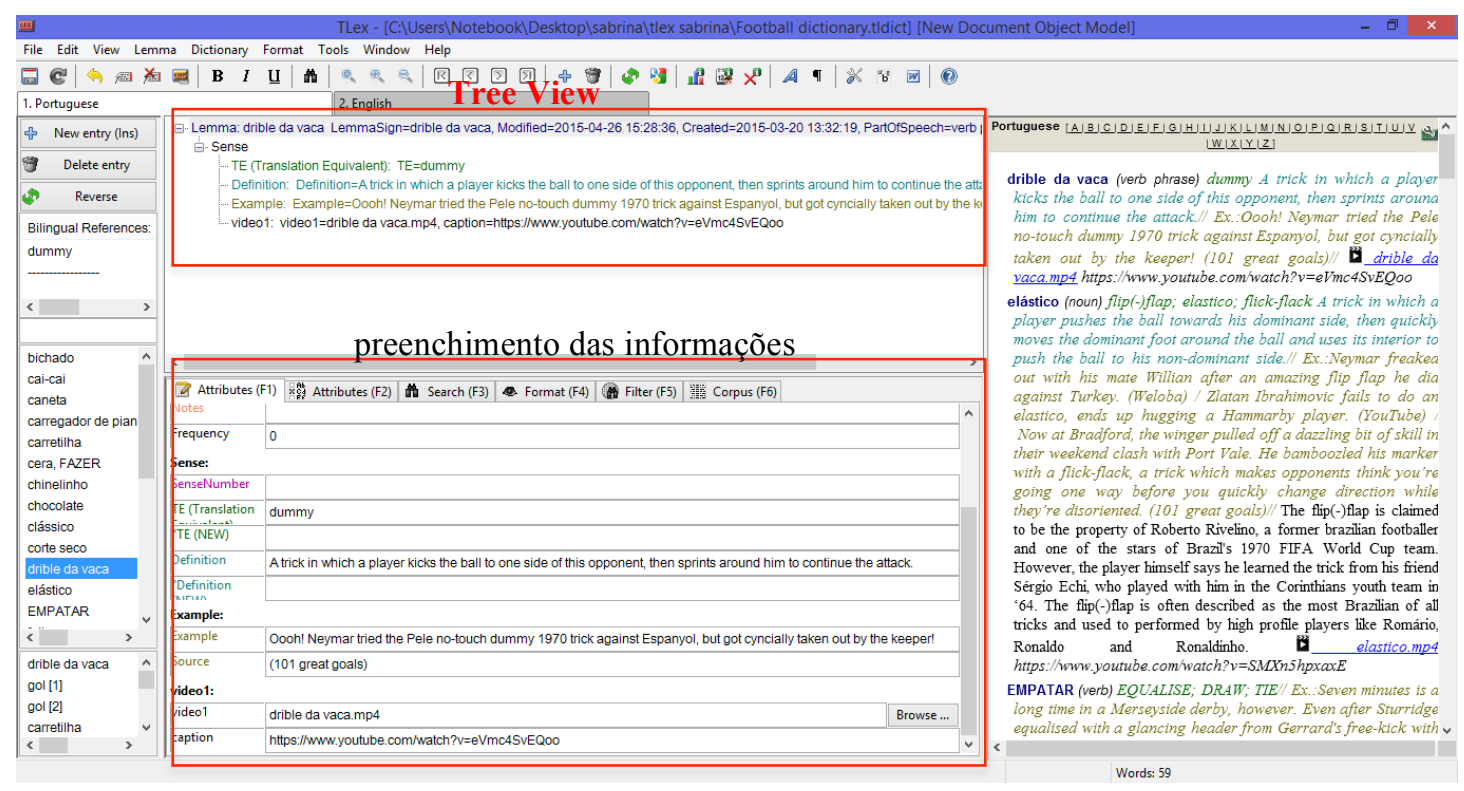

Figura 31: Tela de visualização hierárquica (Tree View) e janela de preenchimento das informações do verbete 'drible da vaca'.

Como podemos observar, na parte superior selecionamos os elementos que fazem parte do verbete; no caso de 'drible da vaca', observamos a classe gramatical, o equivalente tradutório, a definição, o exemplo e um vídeo, pois acreditamos que o recurso audiovisual complementa a definição. $\mathrm{Na}$ parte inferior, preenchemos os campos selecionados com as informações específicas do verbete.

Preenchidos os campos, o programa gera o verbete na janela Preview (figura 32). Ressaltamos que a ordem dos elementos e as fontes selecionadas podem ser alteradas a qualquer momento, e, uma vez alteradas, as modificações são replicadas para todos os verbetes.

Por fim, a janela Preview mostra a interface do verbete: 


\section{Capítulo 3}

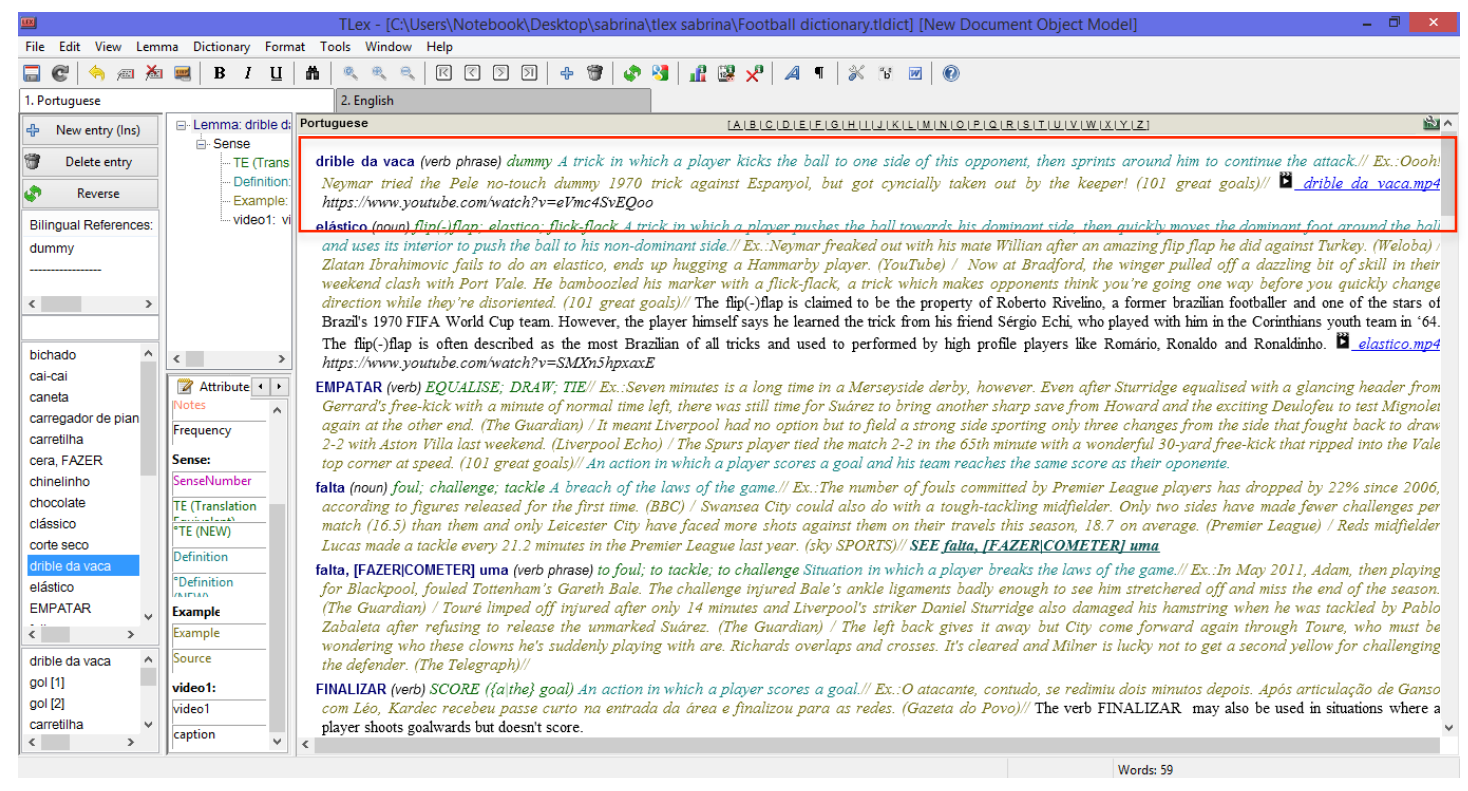

Figura 32: Tela de visualização do verbete 'drible da vaca'.

O software TLex foi de extrema importância para a organização das informações coletadas e para garantir a uniformidade dos verbetes do dicionário. Estamos cientes de que o software possui recursos que não foram explorados em nossa pesquisa por questão de tempo. Vale ressaltar, ainda, que por falta de assistência no manuseio da ferramenta ${ }^{66}$, os caminhos percorridos nem sempre foram os mais simples. Entretanto, salientamos sua praticidade e versatilidade para a compilação de dicionários, quer sejam bilíngues ou monolíngues, de língua geral ou especializados.

\subsection{Metodologia}

Nesta seção, descrevemos a metodologia utilizada em nossa pesquisa. Primeiramente, detalhamos os procedimentos adotados para a escolha dos estudos de caso; após, explicamos os passos seguidos para melhor compreender o significado dos termos selecionados em português; e, ao final, descrevemos os passos seguidos para o estabelecimento dos equivalentes tradutórios.

\footnotetext{
${ }^{66} \mathrm{O}$ software disponibiliza um canal de contato, mas não responde muitas das solicitações ou demora demais para esclarecer as dúvidas dos usuários.
} 


\section{Capítulo 3}

3.5.1 Seleção dos estudos de caso

A partir do levantamento semiautomático das palavras-chave, demos continuidade à pesquisa realizando a análise qualitativa da lista a fim de selecionar os estudos de caso, que foram escolhidos segundo o objetivo deste trabalho: verificar como os diferentes jeitos de jogar, a história do futebol em cada cultura, a apropriação cultural das regras na Inglaterra e no Brasil e outros fatores de ordem histórico-social contribuíram para a criação do léxico do futebol em português e inglês e criar um modelo de dicionário de futebol composto por verbetes que sejam marcados por diferenças culturais entre Brasil e Inglaterra.

Mostramos, abaixo, as 300 primeiras palavras-chave do corpus de português, em ordem decrescente de chavicidade (keyness):

\begin{tabular}{rrrrrrrr}
\multicolumn{1}{r}{$\mathbf{N}$} & Key word & Freq. & \% & RC. Freq. & RC. $\%$ & Keyness & P \\
\hline 1 & BOLA & 6857,00 & 0,64 & 184,00 & & 26757,29 & 0,00 \\
2 & GOL & 6171,00 & 0,58 & 236,00 & & 23608,26 & 0,00 \\
3 & FALTA & 6901,00 & 0,65 & 1747,00 & 0,02 & 20360,84 & 0,00 \\
4 & DIREITA & 4844,00 & 0,45 & 416,00 & & 17266,00 & 0,00 \\
5 & BATIDO & 3968,00 & 0,37 & 10,00 & & 16295,12 & 0,00 \\
6 & MINUTOS & 4102,00 & 0,38 & 511,00 & & 13913,16 & 0,00 \\
7 & COBRANÇA & 3168,00 & 0,30 & 129,00 & & 12062,80 & 0,00 \\
8 & JOGO & 3942,00 & 0,37 & 951,00 & 0,01 & 11760,91 & 0,00 \\
9 & ÁREA & 5920,00 & 0,56 & 4436,00 & 0,06 & 11574,28 & 0,00 \\
10 & CHUTE & 2560,00 & 0,24 & 23,00 & & 10341,64 & 0,00 \\
11 & ESQUERDA & 3123,00 & 0,29 & 564,00 & & 9927,80 & 0,00 \\
12 & GOLEIRO & 2370,00 & 0,22 & 85,00 & & 9095,58 & 0,00 \\
13 & TIME & 2884,00 & 0,27 & 583,00 & & 8956,83 & 0,00 \\
14 & FUTEBOL & 2597,00 & 0,24 & 382,00 & & 8572,63 & 0,00 \\
15 & PARTIDA & 2467,00 & 0,23 & 471,00 & & 7753,59 & 0,00 \\
16 & COMETIDA & 1845,00 & 0,17 & 16,00 & & 7457,47 & 0,00 \\
17 & TIRO & 1930,00 & 0,18 & 73,00 & & 7382,04 & 0,00 \\
18 & ESCANTEIO & 1677,00 & 0,16 & 6,00 & & 6863,57 & 0,00 \\
19 & META & 2017,00 & 0,19 & 384,00 & & 6342,25 & 0,00 \\
20 & ÁRBITRO & 1573,00 & 0,15 & 35,00 & & 6183,24 & 0,00 \\
21 & FORA & 2659,00 & 0,25 & 1419,00 & 0,02 & 6120,64 & 0,00 \\
22 & VITÓRIA & 2051,00 & 0,19 & 496,00 & & 6112,56 & 0,00 \\
23 & AOS & 5134,00 & 0,48 & 7711,00 & 0,10 & 6053,42 & 0,00 \\
24 & ATAQUE & 1854,00 & 0,17 & 345,00 & & 5856,69 & 0,00 \\
25 & TEMPO & 4691,00 & 0,44 & 6732,00 & 0,09 & 5771,42 & 0,00 \\
26 & ATACANTE & 1578,00 & 0,15 & 107,00 & & 5763,52 & 0,00 \\
27 & CRUZA & 1395,00 & 0,13 & 26,00 & & 5521,41 & 0,00 \\
28 & CAMPO & 2595,00 & 0,24 & 1801,00 & 0,02 & 5278,79 & 0,00 \\
29 & JOGADA & 1354,00 & 0,13 & 41,00 & & 5245,28 & 0,00 \\
30 & DEFESA & 2142,00 & 0,20 & 994,00 & 0,01 & 5217,88 & 0,00 \\
31 & SAI & 1653,00 & 0,16 & 311,00 & & 5209,83 & 0,00 \\
32 & 0 & 40835,00 & 3,83 & 188570,00 & 2,56 & 5170,45 & 0,00
\end{tabular}




\begin{tabular}{|c|c|c|c|c|c|c|c|}
\hline 33 & ATLÉTICO & 1333,00 & 0,13 & 47,00 & & 5119,89 & 0,00 \\
\hline 34 & CHUTA & 1236,00 & 0,12 & 14,00 & & 4965,86 & 0,00 \\
\hline 35 & PLACAR & 1234,00 & 0,12 & 14,00 & & 4957,63 & 0,00 \\
\hline 36 & GOLS & 1337,00 & 0,13 & 81,00 & & 4934,68 & 0,00 \\
\hline 37 & RECEBE & 1708,00 & 0,16 & 500,00 & & 4842,43 & 0,00 \\
\hline 38 & BATE & 1322,00 & 0,12 & 88,00 & & 4836,86 & 0,00 \\
\hline 39 & AMARELO & 1389,00 & 0,13 & 157,00 & & 4775,82 & 0,00 \\
\hline 40 & CARTÃO & 1346,00 & 0,13 & 151,00 & & 4632,84 & 0,00 \\
\hline 41 & CIMA & 1537,00 & 0,14 & 376,00 & & 4567,21 & 0,00 \\
\hline 42 & MEIA & 1455,00 & 0,14 & 284,00 & & 4550,86 & 0,00 \\
\hline 43 & NA & 14476,00 & 1,36 & 51402,00 & 0,70 & 4444,08 & 0,00 \\
\hline 44 & PASSE & 1202,00 & 0,11 & 94,00 & & 4326,03 & 0,00 \\
\hline 45 & ENTRA & 1438,00 & 0,13 & 372,00 & & 4213,50 & 0,00 \\
\hline 46 & TENTA & 1311,00 & 0,12 & 248,00 & & 4127,00 & 0,00 \\
\hline 47 & EMPATE & 1084,00 & 0,10 & 62,00 & & 4020,90 & 0,00 \\
\hline 48 & GRÊMIO & 975,00 & 0,09 & 37,00 & & 3727,74 & 0,00 \\
\hline 49 & RODADA & 1003,00 & 0,09 & 60,00 & & 3705,84 & 0,00 \\
\hline 50 & CORINTHIANS & 1001,00 & 0,09 & 69,00 & & 3649,73 & 0,00 \\
\hline 51 & ZAGA & 897,00 & 0,08 & 9,00 & & 3613,86 & 0,00 \\
\hline 52 & ORIGINAL & 1637,00 & 0,15 & 961,00 & 0,01 & 3611,48 & 0,00 \\
\hline 53 & MAS & 5989,00 & 0,56 & 15472,00 & 0,21 & 3559,41 & 0,00 \\
\hline 54 & MINUTOS & 986,00 & 0,09 & 84,00 & & 3514,72 & 0,00 \\
\hline 55 & TRAVE & 841,00 & 0,08 & 13,00 & & 3349,45 & 0,00 \\
\hline 56 & VENCE & 867,00 & 0,08 & 46,00 & & 3236,05 & 0,00 \\
\hline 57 & BATEU & 893,00 & 0,08 & 67,00 & & 3227,93 & 0,00 \\
\hline 58 & ZAGUEIRO & 867,00 & 0,08 & 49,00 & & 3219,11 & 0,00 \\
\hline 59 & CHUTOU & 805,00 & 0,08 & 11,00 & & 3217,92 & 0,00 \\
\hline 60 & IMPEDIMENTO & 835,00 & 0,08 & 43,00 & & 3124,05 & 0,00 \\
\hline 61 & LATERAL & 990,00 & 0,09 & 213,00 & & 3031,44 & 0,00 \\
\hline 62 & DIEGO & 828,00 & 0,08 & 55,00 & & 3029,73 & 0,00 \\
\hline 63 & FLAMENGO & 778,00 & 0,07 & 32,00 & & 2958,90 & 0,00 \\
\hline 64 & POR & 11609,00 & 1,09 & 44250,00 & 0,60 & 2915,36 & 0,00 \\
\hline 65 & CAMPEONATO & 899,00 & 0,08 & 150,00 & & 2900,18 & 0,00 \\
\hline 66 & LANCE & 805,00 & 0,08 & 67,00 & & 2877,05 & 0,00 \\
\hline 67 & PALMEIRAS & 963,00 & 0,09 & 234,00 & & 2865,87 & 0,00 \\
\hline 68 & BOTAFOGO & 771,00 & 0,07 & 58,00 & & 2786,09 & 0,00 \\
\hline 69 & CHANCE & 981,00 & 0,09 & 287,00 & & 2781,22 & 0,00 \\
\hline 70 & PERIGO & 996,00 & 0,09 & 313,00 & & 2766,58 & 0,00 \\
\hline 71 & ENTRADA & 1522,00 & 0,14 & 1292,00 & 0,02 & 2766,08 & 0,00 \\
\hline 72 & CRUZAMENTO & 810,00 & 0,08 & 100,00 & & 2748,99 & 0,00 \\
\hline 73 & PÊNALTI & 666,00 & 0,06 & 17,00 & & 2601,65 & 0,00 \\
\hline 74 & JOGADOR & 918,00 & 0,09 & 302,00 & & 2515,32 & 0,00 \\
\hline 75 & ÉDERSON & 945,00 & 0,09 & 350,00 & & 2494,17 & 0,00 \\
\hline 76 & NO & 13795,00 & 1,29 & 58109,00 & 0,79 & 2492,87 & 0,00 \\
\hline 77 & FLUMINENSE & 719,00 & 0,07 & 89,00 & & 2439,13 & 0,00 \\
\hline 78 & ESTÁDIO & 732,00 & 0,07 & 103,00 & & 2433,35 & 0,00 \\
\hline 79 & PONTOS & 1455,00 & 0,14 & 1432,00 & 0,02 & 2406,63 & 0,00 \\
\hline 80 & CRUZEIRO & 729,00 & 0,07 & 119,00 & & 2361,25 & 0,00 \\
\hline 81 & SANTOS & 1215,00 & 0,11 & 963,00 & 0,01 & 2298,46 & 0,00 \\
\hline 82 & RECEBEU & 1000,00 & 0,09 & 545,00 & & 2279,97 & 0,00 \\
\hline 83 & FELIPE & 629,00 & 0,06 & 46,00 & & 2279,57 & 0,00 \\
\hline 84 & PASSES & 606,00 & 0,06 & 35,00 & & 2245,73 & 0,00 \\
\hline 85 & CABEÇA & 1133,00 & 0,11 & 833,00 & 0,01 & 2234,56 & 0,00 \\
\hline 86 & CONTRA & 2008,00 & 0,19 & 3223,00 & 0,04 & 2214,42 & 0,00 \\
\hline 87 & FEZ & 1339,00 & 0,13 & 1328,00 & 0,02 & 2203,19 & 0,00 \\
\hline
\end{tabular}




\begin{tabular}{|c|c|c|c|c|c|c|c|}
\hline 88 & ESPORTES & 692,00 & 0,06 & 124,00 & & 2201,90 & 0,00 \\
\hline 89 & MARCOU & 667,00 & 0,06 & 98,00 & & 2201,16 & 0,00 \\
\hline 90 & EQUIPE & 1666,00 & 0,16 & 2214,00 & 0,03 & 2192,02 & 0,00 \\
\hline 91 & GOIÁS & 674,00 & 0,06 & 112,00 & & 2175,87 & 0,00 \\
\hline 92 & DOMINGO & 803,00 & 0,08 & 283,00 & & 2153,63 & 0,00 \\
\hline 93 & PORTUGUESA & 518,00 & 0,05 & 0,00 & & 2143,65 & 0,00 \\
\hline 94 & ADVERSÁRIO & 660,00 & 0,06 & 108,00 & & 2136,76 & 0,00 \\
\hline 94 & TRICOLOR & 526,00 & 0,05 & 7,00 & & 2104,09 & 0,00 \\
\hline 96 & TRAVESSÃO & 535,00 & 0,05 & 15,00 & & 2080,42 & 0,00 \\
\hline 97 & PRIMEIRO & 2325,00 & 0,22 & 4547,00 & 0,06 & 2055,87 & 0,00 \\
\hline 98 & PELA & 4763,00 & 0,45 & 14602,00 & 0,20 & 2052,68 & 0,00 \\
\hline 99 & TORCIDA & 605,00 & 0,06 & 76,00 & & 2047,75 & 0,00 \\
\hline 100 & CRUZOU & 528,00 & 0,05 & 24,00 & & 1994,08 & 0,00 \\
\hline 101 & JOGADORES & 798,00 & 0,07 & 349,00 & & 1987,23 & 0,00 \\
\hline 102 & COBRA & 587,00 & 0,06 & 86,00 & & 1938,06 & \\
\hline 103 & ESQUERDO & 591,00 & 0,06 & 94,00 & & 1923,30 & 0,00 \\
\hline 104 & VASCO & 516,00 & 0,05 & 32,00 & & 1900,13 & 0,00 \\
\hline 105 & LONGE & 824,00 & 0,08 & 454,00 & & 1869,70 & 0,00 \\
\hline 106 & GALO & 467,00 & 0,04 & 9,00 & & 1845,75 & 0,00 \\
\hline 107 & CORITIBA & 446,00 & 0,04 & 0,00 & & 1845,67 & 0,00 \\
\hline 108 & CAMISA & 541,00 & 0,05 & 68,00 & & 1830,94 & 0,0 \\
\hline 109 & APÓS & 1619,00 & 0,15 & 2565,00 & 0,03 & 1808,79 & 0,00 \\
\hline 110 & AFASTA & 509,00 & 0,05 & 45,00 & & 1806,37 & 0,00 \\
\hline 111 & DRIBLE & 525,00 & 0,05 & 68,00 & & 1768,56 & 0,00 \\
\hline 112 & CHANCES & 632,00 & 0,06 & 204,00 & & 1741,47 & 0,00 \\
\hline 113 & MANDA & 502,00 & 0,05 & 54,00 & & 1737,60 & 0,00 \\
\hline 114 & CABECEIA & 428,00 & 0,04 & 3,00 & & 1736,20 & 0,0 \\
\hline 115 & MARCAÇÃO & 749,00 & 0,07 & 393,00 & & 1735,52 & 0,0 \\
\hline 116 & COM & 13200,00 & 1,24 & 60335,00 & 0,82 & 1714,44 & 0,00 \\
\hline 117 & DEFENDIDO & 472,00 & 0,04 & 35,00 & & 1708,07 & 0,00 \\
\hline 118 & DOMINA & 553,00 & 0,05 & 121,00 & & 1686,71 & 0,0 \\
\hline 119 & PERDE & 637,00 & 0,06 & 250,00 & & 1648,68 & 0,00 \\
\hline 120 & FORTE & 975,00 & 0,09 & 943,00 & 0,01 & 1631,34 & 0,00 \\
\hline 121 & CANTO & 601,00 & 0,06 & 204,00 & & 1630,89 & 0,0 \\
\hline 122 & INDIVIDUAL & 700,00 & 0,07 & 367,00 & & 1622,50 & 0,00 \\
\hline 123 & REBOTE & 406,00 & 0,04 & 6,00 & & 1619,08 & 0,0 \\
\hline 124 & ETAPA & 1000,00 & 0,09 & 1021,00 & 0,01 & 1612,77 & 0, \\
\hline 125 & ERRA & 410,00 & 0,04 & 11,00 & & 1597,75 & 0,00 \\
\hline 126 & ARRISCA & 428,00 & 0,04 & 29,00 & & 1562,95 & \\
\hline 127 & DESVIA & 404,00 & 0,04 & 13,00 & & 1559,59 & 0, \\
\hline 128 & GRAMADO & 405,00 & 0,04 & 17,00 & & 1538,07 & 0,00 \\
\hline 129 & FEIRA & 994,00 & 0,09 & 1085,00 & 0,01 & 1528,56 & 0,0 \\
\hline 130 & CRUZADO & 456,00 & 0,04 & 61,00 & & 1528,29 & 0,0 \\
\hline 131 & RASTEIRO & 380,00 & 0,04 & 5,00 & & 1520,50 & 0,0 \\
\hline 132 & TOCOU & 420,00 & 0,04 & 33,00 & & 1510,56 & \\
\hline 133 & COBROU & 388,00 & 0,04 & 15,00 & & 1481,52 & \\
\hline 134 & BOA & 1101,00 & 0,10 & 1438,00 & 0,02 & 1469,92 & 0,0 \\
\hline 135 & TOCA & 454,00 & 0,04 & 77,00 & & 1459,95 & 0,0 \\
\hline 136 & CONSEGUIU & 749,00 & 0,07 & 569,00 & & 1450,85 & 0,0 \\
\hline 137 & LUGAR & 1435,00 & 0,13 & 2522,00 & 0,03 & 1436,88 & 0,0 \\
\hline 138 & CASA & 1254,00 & 0,12 & 1937,00 & 0,03 & 1436,51 & \\
\hline 139 & SUL & 1138,00 & 0,11 & 1595,00 & 0,02 & 1428,42 & \\
\hline 140 & JOGADAS & 404,00 & 0,04 & 37,00 & & 1427,65 & 0,0 \\
\hline 141 & FAZ & 1516,00 & 0,14 & 2826,00 & 0,04 & 1419,48 & 0,0 \\
\hline 142 & FUNDO & 851,00 & 0,08 & 830,00 & 0,01 & 1415,86 & 0,0 \\
\hline
\end{tabular}




\begin{tabular}{|c|c|c|c|c|c|c|c|}
\hline 143 & CORTA & 391,00 & 0,04 & 30,00 & & 1409,85 & 0,00 \\
\hline 144 & FAZER & 527,00 & 0,05 & 189,00 & & 1405,42 & 0,00 \\
\hline 145 & TÉCNICO & 896,00 & 0,08 & 953,00 & 0,01 & 1403,92 & 0,00 \\
\hline 146 & LINHA & 985,00 & 0,09 & 1193,00 & 0,02 & 1399,12 & 0,00 \\
\hline 147 & VAGA & 568,00 & 0,05 & 257,00 & & 1396,46 & 0,00 \\
\hline 148 & VENCEU & 451,00 & 0,04 & 102,00 & & 1365,15 & 0,00 \\
\hline 149 & PEGA & 455,00 & 0,04 & 109,00 & & 1358,59 & 0,00 \\
\hline 150 & ACERTA & 351,00 & 0,03 & 13,00 & & 1343,85 & 0,00 \\
\hline 151 & DERROTA & 518,00 & 0,05 & 209,00 & & 1327,85 & 0,00 \\
\hline 152 & VOLANTE & 391,00 & 0,04 & 54,00 & & 1303,68 & 0,00 \\
\hline 152 & SAIU & 567,00 & 0,05 & 304,00 & & 1301,72 & 0,00 \\
\hline 154 & FABIANO & 326,00 & 0,03 & 5,00 & & 1298,54 & 0,00 \\
\hline 155 & THIAGO & 401,00 & 0,04 & 66,00 & & 1296,77 & 0,00 \\
\hline 156 & FINALIZA & 343,00 & 0,03 & 16,00 & & 1292,90 & 0,00 \\
\hline 157 & CABEÇADA & 328,00 & 0,03 & 7,00 & & 1291,20 & 0,00 \\
\hline 158 & ESTREIA & 308,00 & 0,03 & 0,00 & & 1274,55 & 0,00 \\
\hline 159 & SPORT & 366,00 & 0,03 & 40,00 & & 1264,06 & 0,00 \\
\hline 160 & SÁBADO & 489,00 & 0,05 & 194,00 & & 1260,87 & 0,00 \\
\hline 161 & QUARTA & 579,00 & 0,05 & 350,00 & & 1259,77 & 0,00 \\
\hline 162 & VOLTOU & 501,00 & 0,05 & 222,00 & & 1241,45 & 0,00 \\
\hline 163 & MARCAR & 450,00 & 0,04 & 145,00 & & 1240,56 & 0,00 \\
\hline 164 & RIVAL & 343,00 & 0,03 & 26,00 & & 1238,35 & 0,00 \\
\hline 165 & ANDAMENTO & 545,00 & 0,05 & 300,00 & & 1237,03 & 0,00 \\
\hline 166 & ADRIANO & 345,00 & 0,03 & 34,00 & & 1208,04 & 0,00 \\
\hline 167 & CHEGOU & 718,00 & 0,07 & 691,00 & & 1205,18 & 0,00 \\
\hline 168 & FRENTE & 883,00 & 0,08 & 1144,00 & 0,02 & 1186,84 & 0,00 \\
\hline 169 & INTERNACIONAL & 291,00 & 0,03 & 2,00 & & 1180,80 & 0,00 \\
\hline 170 & ACRÉSCIMO & 407,00 & 0,04 & 111,00 & & 1175,95 & 0,00 \\
\hline 171 & PRIMEIRA & 1544,00 & 0,14 & 3415,00 & 0,05 & 1161,21 & 0,00 \\
\hline 172 & DOMINOU & 877,00 & 0,08 & 1168,00 & 0,02 & 1151,38 & 0,00 \\
\hline 173 & AVANÇA & 346,00 & 0,03 & 53,00 & & 1133,52 & 0,00 \\
\hline 174 & JOGOS & 585,00 & 0,05 & 446,00 & & 1130,88 & 0,00 \\
\hline 175 & SOBRA & 344,00 & 0,03 & 52,00 & & 1129,59 & 0,00 \\
\hline 176 & LUIS & 415,00 & 0,04 & 143,00 & & 1120,84 & 0,00 \\
\hline 177 & ACERTOU & 335,00 & 0,03 & 46,00 & & 1118,00 & 0,00 \\
\hline 178 & DINEI & 283,00 & 0,03 & 6,00 & & 1114,34 & 0,00 \\
\hline 179 & MARCA & 656,00 & 0,06 & 621,00 & & 1113,11 & 0,00 \\
\hline 180 & COMPETIÇÃO & 546,00 & 0,05 & 377,00 & & 1112,88 & 0,00 \\
\hline 181 & FINAL & 1364,00 & 0,13 & 2847,00 & 0,04 & 1109,71 & 0,00 \\
\hline 182 & MARCADOR & 380,00 & 0,04 & 101,00 & & 1105,39 & 0,00 \\
\hline 183 & SAÍDA & 697,00 & 0,07 & 735,00 & & 1098,75 & 0,00 \\
\hline 184 & CABECEOU & 277,00 & 0,03 & 7,00 & & 1082,48 & 0,00 \\
\hline 185 & HERNANE & 316,00 & 0,03 & 37,00 & & 1080,76 & 0,00 \\
\hline 186 & EQUIPES & 537,00 & 0,05 & 381,00 & & 1079,16 & 0,00 \\
\hline 187 & EXPULSO & 313,00 & 0,03 & 35,00 & & 1077,56 & 0,00 \\
\hline 188 & MANDOU & 334,00 & 0,03 & 59,00 & & 1065,66 & 0,00 \\
\hline 189 & LEVANTA & 324,00 & 0,03 & 49,00 & & 1063,82 & 0,00 \\
\hline 190 & EMPATOU & 285,00 & 0,03 & 17,00 & & 1053,11 & 0,00 \\
\hline 191 & TENTOU & 376,00 & 0,04 & 115,00 & & 1052,49 & 0,00 \\
\hline 192 & REBAIXAMENTO & 309,00 & 0,03 & 38,00 & & 1049,18 & 0,00 \\
\hline 193 & INTERMEDIÁRIA & 370,00 & 0,03 & 110,00 & & 1044,10 & 0,00 \\
\hline 194 & CRUZEIRO & 339,00 & 0,03 & 73,00 & & 1037,67 & 0,00 \\
\hline 195 & APROVEITOU & 317,00 & 0,03 & 51,00 & & 1029,41 & 0,00 \\
\hline 196 & JOGA & 343,00 & 0,03 & 82,00 & & 1024,65 & 0,00 \\
\hline 197 & CLÁSSICO & 266,00 & 0,02 & 9,00 & & 1023,92 & 0,00 \\
\hline
\end{tabular}




\begin{tabular}{|c|c|c|c|c|c|c|c|}
\hline 198 & RESULTADO & 1123,00 & 0,11 & 2145,00 & 0,03 & 1021,35 & 0,00 \\
\hline 199 & LÉO & 259,00 & 0,02 & 7,00 & & 1008,92 & 0,00 \\
\hline 200 & ENTROU & 439,00 & 0,04 & 242,00 & & 995,78 & 0,00 \\
\hline 201 & DERRUBADO & 260,00 & 0,02 & 10,00 & & 993,07 & 0,00 \\
\hline 202 & FEITO & 1060,00 & 0,10 & 1977,00 & 0,03 & 991,69 & 0,00 \\
\hline 203 & MAICON & 237,00 & 0,02 & 0,00 & & 980,73 & 0,00 \\
\hline 204 & BRASILEIRÃO & 236,00 & 0,02 & 0,00 & & 976,59 & 0,00 \\
\hline 205 & VIRADA & 329,00 & 0,03 & 82,00 & & 972,82 & 0,00 \\
\hline 206 & PERDEU & 458,00 & 0,04 & 295,00 & & 966,66 & 0,00 \\
\hline 207 & RUBRO & 241,00 & 0,02 & 3,00 & & 965,74 & 0,00 \\
\hline 208 & VOLTA & 709,00 & 0,07 & 909,00 & 0,01 & 961,31 & 0,00 \\
\hline 209 & SANTO & 442,00 & 0,04 & 269,00 & & 958,60 & 0,00 \\
\hline 210 & SEGURA & 340,00 & 0,03 & 103,00 & & 954,33 & 0,00 \\
\hline 211 & MEIO & 1666,00 & 0,16 & 4441,00 & 0,06 & 936,31 & 0,00 \\
\hline 212 & SEGUNDA & 996,00 & 0,09 & 1863,00 & 0,03 & 928,63 & 0,00 \\
\hline 213 & POSSE & 469,00 & 0,04 & 346,00 & & 923,07 & 0,00 \\
\hline 214 & OITAVAS & 264,00 & 0,02 & 27,00 & & 919,96 & 0,00 \\
\hline 215 & DAGOBERTO & 240,00 & 0,02 & 9,00 & & 918,14 & 0,00 \\
\hline 216 & LOGO & 713,00 & 0,07 & 972,00 & 0,01 & 917,17 & 0,0 \\
\hline 217 & JOGANDO & 306,00 & 0,03 & 74,00 & & 911,56 & 0,00 \\
\hline 218 & DESVIOU & 235,00 & 0,02 & 7,00 & & 910,94 & 0,00 \\
\hline 219 & MARCELINHO & 253,00 & 0,02 & 20,00 & & 909,29 & 0,0 \\
\hline 220 & DEU & 684,00 & 0,06 & 903,00 & 0,01 & 904,73 & 0,00 \\
\hline 221 & LIDERANÇA & 434,00 & 0,04 & 287,00 & & 904,15 & 0,00 \\
\hline 222 & COXA & 249,00 & 0,02 & 18,00 & & 903,40 & 0,00 \\
\hline 223 & DEIXA & 546,00 & 0,05 & 538,00 & & 902,09 & 0,00 \\
\hline 224 & LIBERTADORES & 259,00 & 0,02 & 27,00 & & 900,25 & 0,00 \\
\hline 225 & ARRISCOU & 238,00 & 0,02 & 12,00 & & 891,82 & 0,0 \\
\hline 226 & COLOCAÇÃO & 380,00 & 0,04 & 195,00 & & 888,64 & 0,00 \\
\hline 227 & TEVE & 856,00 & 0,08 & 1458,00 & 0,02 & 886,70 & 0,0 \\
\hline 228 & VANTAGEM & 486,00 & 0,05 & 414,00 & & 881,08 & 0,00 \\
\hline 229 & CONSEGUE & 546,00 & 0,05 & 561,00 & & 876,56 & 0,00 \\
\hline 230 & EMPATA & 218,00 & 0,02 & 3,00 & & 871,16 & 0,00 \\
\hline 231 & ARENA & 272,00 & 0,03 & 48,00 & & 868,00 & 0,00 \\
\hline 232 & ABRIU & 394,00 & 0,04 & 232,00 & & 867,68 & 0,00 \\
\hline 233 & DESARMADO & 212,00 & 0,02 & 1,00 & & 864,82 & 0,0 \\
\hline 234 & ADVERSÁRIA & 231,00 & 0,02 & 12,00 & & 863,55 & 0,00 \\
\hline 235 & PONTA & 432,00 & 0,04 & 310,00 & & 862,94 & 0,0 \\
\hline 236 & DUELO & 237,00 & 0,02 & 17,00 & & 860,54 & 0,0 \\
\hline 237 & QUARTAS & 278,00 & 0,03 & 57,00 & & 860,19 & 0,00 \\
\hline 238 & CHEGA & 539,00 & 0,05 & 562,00 & & 856,46 & 0,0 \\
\hline 239 & VENCER & 358,00 & 0,03 & 177,00 & & 850,06 & 0,0 \\
\hline 240 & COMETE & 244,00 & 0,02 & 27,00 & & 841,23 & 0,00 \\
\hline 241 & DEPOIS & 1494,00 & 0,14 & 3983,00 & 0,05 & 839,38 & 0,0 \\
\hline 242 & PASSOU & 715,00 & 0,07 & 1078,00 & 0,01 & 838,38 & 0,0 \\
\hline 243 & TRAVADO & 209,00 & 0,02 & 3,00 & & 834,16 & 0,00 \\
\hline 244 & ZÉ & 273,00 & 0,03 & 64,00 & & 819,36 & 0,0 \\
\hline 245 & MASCULINO & 360,00 & 0,03 & 197,00 & & 819,18 & 0,00 \\
\hline 246 & MARCADO & 363,00 & 0,03 & 207,00 & & 811,11 & 0,0 \\
\hline 247 & MG & 374,00 & 0,04 & 231,00 & & 805,47 & 0,0 \\
\hline 248 & CARIOCA & 303,00 & 0,03 & 113,00 & & 797,75 & 0,0 \\
\hline 249 & INTER & 367,00 & 0,03 & 234,00 & & 778,41 & 0,0 \\
\hline 250 & ESTICA & 199,00 & 0,02 & 5,00 & & 777,86 & 0,0 \\
\hline 251 & BICHADO & 194,00 & 0,02 & 3,00 & & 772,53 & 0,00 \\
\hline 252 & ESPALMA & 185,00 & 0,02 & 0,00 & & 765,54 & 0,0 \\
\hline
\end{tabular}




\begin{tabular}{|c|c|c|c|c|c|c|c|}
\hline 253 & GOLEADA & 203,00 & 0,02 & 11,00 & & 756,28 & 0,00 \\
\hline 254 & ALEX & 208,00 & 0,02 & 16,00 & & 749,76 & 0,00 \\
\hline 255 & ALVINEGRO & 186,00 & 0,02 & 3,00 & & 739,68 & 0,00 \\
\hline 256 & CÍCERO & 448,00 & 0,04 & 445,00 & & 736,14 & 0,00 \\
\hline 257 & LANÇAMENTO & 434,00 & 0,04 & 418,00 & & 728,03 & 0,00 \\
\hline 258 & MARACANÃ & 196,00 & 0,02 & 13,00 & & 717,18 & 0,00 \\
\hline 259 & AJEITA & 190,00 & 0,02 & 10,00 & & 709,53 & 0,00 \\
\hline 260 & TORCEDORES & 223,00 & 0,02 & 40,00 & & 709,35 & 0,00 \\
\hline 261 & CENI & 170,00 & 0,02 & 0,00 & & 703,47 & 0,00 \\
\hline 262 & WILLIAM & 397,00 & 0,04 & 352,00 & & 702,28 & 0,00 \\
\hline 263 & WALTER & 232,00 & 0,02 & 53,00 & & 700,57 & 0,00 \\
\hline 264 & TIMÃO & 174,00 & 0,02 & 2,00 & & 698,67 & 0,00 \\
\hline 265 & FICA & 710,00 & 0,07 & 1268,00 & 0,02 & 698,08 & 0,00 \\
\hline 266 & EMPATAR & 184,00 & 0,02 & 8,00 & & 697,05 & 0,00 \\
\hline 267 & TREINADOR & 239,00 & 0,02 & 63,00 & & 696,70 & 0,00 \\
\hline 268 & MÁRCIO & 277,00 & 0,03 & 119,00 & & 694,25 & 0,00 \\
\hline 269 & MINEIRÃO & 178,00 & 0,02 & 5,00 & & 692,06 & 0,00 \\
\hline 270 & ALÇA & 178,00 & 0,02 & 6,00 & & 685,31 & 0,00 \\
\hline 271 & ARTILHEIRO & 189,00 & 0,02 & 14,00 & & 683,99 & 0,00 \\
\hline 272 & ACIONADO & 211,00 & 0,02 & 35,00 & & 681,32 & 0,00 \\
\hline 273 & PAULO & 364,00 & 0,03 & 295,00 & & 679,62 & 0,00 \\
\hline 274 & LADO & 1048,00 & 0,10 & 2562,00 & 0,03 & 679,34 & 0,00 \\
\hline 275 & RETRANCA & 120,00 & 0,02 & 90,00 & & 676,42 & 0,00 \\
\hline 276 & DEU & 279,00 & 0,03 & 132,00 & & 674,17 & 0,00 \\
\hline 277 & CHUTAR & 168,00 & 0,02 & 2,00 & & 673,98 & 0,00 \\
\hline 278 & BRASILEIRO & 924,00 & 0,09 & 2094,00 & 0,03 & 671,13 & 0,00 \\
\hline 279 & SUBSTITUIÇÃO & 444,00 & 0,04 & 500,00 & & 667,04 & 0,00 \\
\hline 280 & PERTO & 409,00 & 0,04 & 411,00 & & 666,75 & 0,00 \\
\hline 281 & CHOCOLATE & 161,00 & 0,02 & 0,00 & & 666,22 & 0,00 \\
\hline 282 & GOLEIA & 193,00 & 0,02 & 22,00 & & 662,62 & 0,00 \\
\hline 283 & FERNANDO & 515,00 & 0,05 & 711,00 & & 655,06 & 0,00 \\
\hline 284 & PARA & 14614,00 & 1,37 & 79934,00 & 1,08 & 652,22 & 0,00 \\
\hline 285 & TORNEIO & 217,00 & 0,02 & 52,00 & & 647,85 & 0,00 \\
\hline 286 & CARREGADOR & 175,00 & 0,02 & 11,00 & & 643,58 & 0,00 \\
\hline 287 & LANTERNA & 206,00 & 0,02 & 41,00 & & 641,47 & 0,00 \\
\hline 288 & LIVRE & 504,00 & 0,05 & 698,00 & & 639,27 & 0,00 \\
\hline 289 & FIM & 919,00 & 0,09 & 2149,00 & 0,03 & 637,55 & 0,00 \\
\hline 290 & DEIXOU & 408,00 & 0,04 & 440,00 & & 632,83 & 0,00 \\
\hline 291 & MAL & 519,00 & 0,05 & 751,00 & 0,01 & 632,56 & 0,00 \\
\hline 292 & LINDA & 182,00 & 0,02 & 20,00 & & 628,07 & 0,00 \\
\hline 293 & EDUARDO & 402,00 & 0,04 & 432,00 & & 625,11 & 0,00 \\
\hline 294 & ROLINHO & 157,00 & 0,01 & 3,00 & & 620,68 & 0,00 \\
\hline 295 & ZAGUEIRO & 310,00 & 0,03 & 222,00 & & 619,89 & 0,00 \\
\hline 296 & SEGUE & 402,00 & 0,04 & 439,00 & & 617,85 & 0,00 \\
\hline 297 & CORTE & 154,00 & 0,01 & 2,00 & & 616,40 & 0,00 \\
\hline 298 & COMEÇA & 508,00 & 0,05 & 740,00 & 0,01 & 615,33 & 0,00 \\
\hline 299 & FRACO & 215,00 & 0,02 & 61,00 & & 614,60 & 0,00 \\
\hline 300 & ACABOU & 403,00 & 0,04 & 446,00 & & 613,34 & 0,00 \\
\hline
\end{tabular}

O primeiro passo nessa etapa da pesquisa foi classificar as palavras-chave em grupos. O quadro 16 mostra a classificação realizada e as cores escolhidas para realce: 


\section{Capítulo 3}

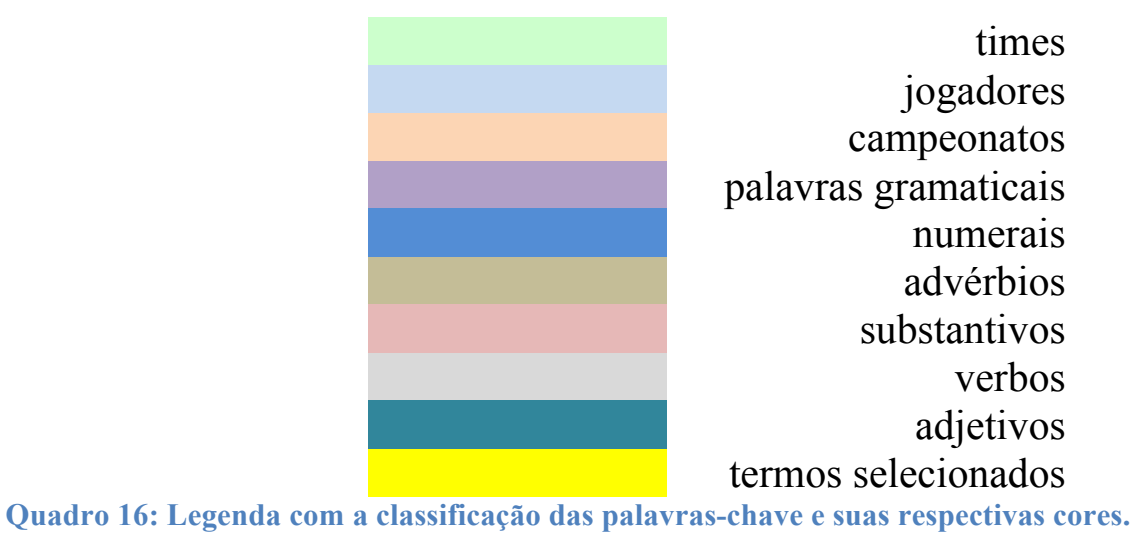

Primeiramente, eliminamos os nomes de times e de jogadores, assim como as palavras que fazem referência a campeonatos (ex.: torneio, brasileiro, brasileirão), pois refletem a realidade futebolística brasileira e não possuem equivalentes em inglês. Também excluímos palavras gramaticais, numerais e advérbios, pois, embora possam servir a pesquisas linguísticas, não revelam termos e fraseologias culturalmente marcados, objetos de estudo desta pesquisa.

Após a exclusão das palavras que não se mostraram relevantes para nossa pesquisa, analisamos todos os substantivos, verbos e adjetivos da lista. Essa análise constituiu a parte mais laboriosa da pesquisa, uma vez que não procurávamos somente por termos ou CLEs de dada terminologia, mas sim por termos ou CLEs culturalmente marcados, que representassem um desafio ao tradutor, já que só compreendemos seus significados quando consideramos o contexto histórico, social e cultural em que ocorrem ou em que foram criados. Assim, para chegar a esses termos, geramos linhas de concordâncias para cada uma das palavras. Reordenamos as linhas diversas vezes, pelas palavras à direita, pelas palavras à esquerda e pelo centro, sempre procurando palavras culturalmente marcadas ${ }^{67}$.

Os dois primeiros termos selecionados foram 'gol' $\mathrm{e}$ 'falta'. Uma breve análise das linhas de concordância dos dois termos mostrou características que consideramos representar um desafio no ato tradutório. Ademais, a complexidade do termo 'gol', mais precisamente da CLE 'fazer um gol', foi descoberta ainda em nossa

\footnotetext{
${ }^{67} \mathrm{O}$ caminho percorrido para chegar aos termos selecionados é apresentado com detalhes no capítulo "Estudos de caso".
} 


\section{Capítulo 3}

pesquisa de mestrado (MATUDA, 2011), e nos instigou a realizar um estudo terminológico de termos culturalmente marcados.

Outro termo selecionado foi 'drible', que ocupa a posição de número 111 na lista de palavras-chave, com 525 ocorrências. Além de as linhas de concordância mostrarem CLEs bastante interessantes para nossa análise, não poderíamos deixar esse termo de fora, uma vez que 'drible' faz parte da forma-representação que temos do nosso futebol. Para esta pesquisa, optamos por trabalhar com o termo 'drible da vaca', um dos mais conhecidos do jogo e que foi criado por um jogador brasileiro.

Ao analisar as linhas de concordância do verbo 'fazer' em busca de uma CLE que não fosse 'fazer um gol' ou 'fazer uma falta', identificamos a CLE 'fazer cera', que, por se tratar de uma expressão idiomática, ou seja, que não tem seu significado alcançado pela soma do significado dos itens que a compõem, confere certa dificuldade ao tradutor.

O próximo termo selecionado foi 'técnico', palavra-chave número 145, e seu sinônimo, 'treinador', palavra-chave número 267. Embora, em um primeiro momento, não sejam caracterizados como termos culturalmente marcados, já tínhamos nos questionado sobre seus equivalentes em inglês ainda no processo de compilação do corpus, pois estávamos cientes das diferenças na estrutura dos times no Brasil e na Inglaterra.

O próprio significado do termo ‘clássico' em português ( $\left.n^{\circ} 197\right)$ justifica sua seleção para compor os estudos de caso. O termo, que é utilizado para designar um confronto de grande rivalidade, frequentemente confronto estadual, é o ápice da rivalidade e da emoção no futebol. Por trás dos clássicos existem diversas histórias, mitos e especulações que refletem, em sua maioria, narrativas locais, ocorridas em dado contexto histórico e cultural.

'Bichado' ( $\mathrm{n}^{\mathrm{o}}$ 251) e 'retranca' $\left(\mathrm{n}^{\mathrm{o}}\right.$ 275) foram selecionados devido à dificuldade que impõem à tradução e aos contextos específicos em que são utilizados em português.

Por meio da análise das linhas de concordância de 'deu' (n² 276), chegamos ao termo 'elástico', um dos dribles mais fascinantes do futebol, que foi incluído em nossa análise por ser um drible popular, de difícil execução e, frequentemente, associado a Rivelino, ex-futebolista brasileiro. 


\section{Capítulo 3}

O termo 'chocolate' ( $n^{\circ}$ 281) nos intrigou ainda em nossa pesquisa de mestrado e, por esse motivo, decidimos dar continuidade à análise realizada, que, na época, restringiu-se à busca de um equivalente para o termo em inglês.

A palavra-chave número 286, 'carregador', chamou a atenção, pois, inicialmente, não a associamos a nenhum termo do domínio do futebol. No entanto, a análise de suas linhas de concordância levou ao termo 'carregador de piano'. Dada a sua idiomaticidade, o contexto particular em que ocorre e a prosódia semântica que adquire na língua portuguesa, elegemos esse termo a constar da nossa lista.

As linhas de concordância de 'linda' revelaram os termos 'lambreta' e 'carretilha' e, assim como outros dribles, têm sua origem vinculada a um contexto específico.

'Rolinho', ocorrência de número 294, também foi selecionado, pois, desde o início da pesquisa, observamos que o significado e a origem dos dribles estão, quase sempre, ligados a determinado contexto histórico-social.

Ao analisar 'corte', ocorrência de número 297, encontramos o termo 'corte seco', que, assim como os outros dribles encontrados, foi acrescentado aos estudos de caso.

Além dos termos selecionados durante a análise das palavras-chave, incluímos, ainda, outros três para nossa análise: 'cai-cai', 'chinelinho' $\mathrm{e}$ 'the Matthews move'. Deparamos com 'cai-cai', utilizado para descrever um jogador que simula faltas, durante a investigação do termo 'falta'. A princípio, não incluiríamos o termo em nossa análise. Entretanto, durante uma discussão com alguns membros do LUDENS sobre a problemática da tradução da CLE 'fazer uma falta', um pesquisador nos perguntou se conhecíamos o equivalente de 'cai-cai' em inglês. Como nosso modelo de dicionário tem como objetivo as necessidades de consulentes que precisem redigir textos sobre futebol em inglês, achamos por bem inserir o termo em nossa análise.

Durante a análise das linhas de concordância de 'bichado' encontramos o termo 'chinelinho', utilizado para descrever um jogador que faz corpo mole, que simula contusões e que passa mais tempo no banco, calçando um chinelo, do que em jogo. Assim como outros termos que possuem significado abstrato, 'chinelinho' foi incluído nos estudos de caso. 


\section{Capítulo 3}

Por fim, selecionamos o termo "the Matthews move" para fechar os estudos de caso. Como explicado anteriormente, nossa pesquisa parte do português para o inglês, mas estamos cientes de que para compilar um dicionário completo sobre futebol teríamos de incluir a análise na direção inglês-português. Ante o exposto, acreditamos ser relevante informar que, embora a análise não tenha sido realizada nas duas direções, utilizamos a lista de palavras-chave do subcorpus de inglês a todo momento. Durante a pesquisa sobre um candidato a equivalente no subcorpus de inglês, analisamos as linhas de concordância de move e chegamos ao termo the Matthews move. Após ler os textos em que o termo ocorre, constatamos que o nome próprio Matthew não fazia referência a um jogador em campo, mas sim a um movimento específico. Dada essa especificidade, que, muito provavelmente, constituiria um desafio à tradução, resolvemos buscar um equivalente em português.

Dessa forma, encerramos a seleção dos dezessete estudos de caso que serão apresentados detalhadamente no capítulo 4. Contudo, achamos importante enfatizar que a análise qualitativa das palavras-chave e a seleção dos estudos de caso foram realizadas com base nos objetivos da pesquisa e na definição de cultura por nós adotada. Ressaltamos, ainda, nossa ciência de que alguns termos marcados culturalmente tiveram de ser deixados de fora da pesquisa, uma vez que nosso objetivo não é compilar uma obra completa sobre o vocabulário do futebol, mas sim mostrar a importância de fatores sociais, históricos e culturais na construção de uma terminologia, e registrar esses fatores em um modelo de dicionário.

\subsubsection{Compreensão dos significados dos termos}

Selecionados os dezessete estudos de caso, o passo seguinte de nossa pesquisa foi entender o significado e a origem dos termos em português para, posteriormente, buscar seus equivalentes tradutórios em inglês.

Após os três anos de nossa pesquisa de mestrado e os quase três anos de doutorado, período durante o qual debruçamo-nos sobre a temática do futebol, nossa familiaridade com o assunto aumentou substancialmente. O significado da maior parte dos termos já era conhecido. Entretanto, a história por trás de cada termo, seus usos, sinônimos e outras peculiaridades ainda eram desconhecidos. Assim, pesquisamos 


\section{Capítulo 3}

sobre os termos e CLEs em quatro fontes distintas: internet, especialistas, redes sociais e um Thesaurus. Destacamos que sempre cruzamos os dados obtidos nas pesquisas com o aporte teórico apresentado no capítulo dois e com o conceito formarepresentação.

A pesquisa on-line no Google foi, quase sempre, o primeiro passo realizado. Por exemplo, para compreender melhor o significado de 'drible da vaca', buscamos esse termo no Google $e^{68}$. A pesquisa retornou aproximadamente 50.000 ocorrências, sendo as primeiras figuras e vídeos do YouTube em que o drible ocorria. Após essas ocorrências, encontramos alguns blogs que discutiam o drible e que narravam sua história. Nesse caso, lemos os textos de todos os blogs a fim de construir nossa própria interpretação. Sabemos da complexidade de traçar a história do surgimento de um drible e, por esse motivo, utilizamos as informações encontradas, mas sempre cientes de que as histórias ali presentes eram apenas narrativas e que sua veracidade dificilmente pode ser comprovada.

Muitas vezes, mesmo após ler toda a informação obtida on-line, ainda tínhamos dúvidas sobre um termo. Nesse caso, recorríamos aos especialistas que, como mencionado anteriormente, são acadêmicos do futebol, jornalistas, educadores físicos e aficionados pelo esporte. O fruto do diálogo com esses grupos rendeu descobertas inéditas tanto para o entendimento do termo em questão, quanto para outros termos e futuros estudos de caso.

O fazer acadêmico sempre foi conhecido por um fazer solitário; não o foi em nosso caso. Muitas vezes, quando surgia alguma dúvida a respeito de um termo e não encontrávamos respostas on-line, ou não estávamos na presença de nossos especialistas, e tínhamos que dar continuidade à pesquisa, utilizamos o facebook para esclarecer nossas dúvidas. Contamos inúmeras vezes com a gentileza da amiga jornalista e acadêmica do futebol Vanessa Gonçalves para esclarecer o significado de um termo. Por exemplo, em determinado momento da pesquisa tivemos que estabelecer a diferença entre 'drible' e 'jogada'. Na ocasião, Vanessa nos deu sua opinião e colocou a pergunta em seu status do facebook, marcando seus amigos futeboleiros. Observemos a figura abaixo:

\footnotetext{
${ }^{68}$ Pesquisa realizada em 15 jan. de 2015.
} 


\section{Capítulo 3}

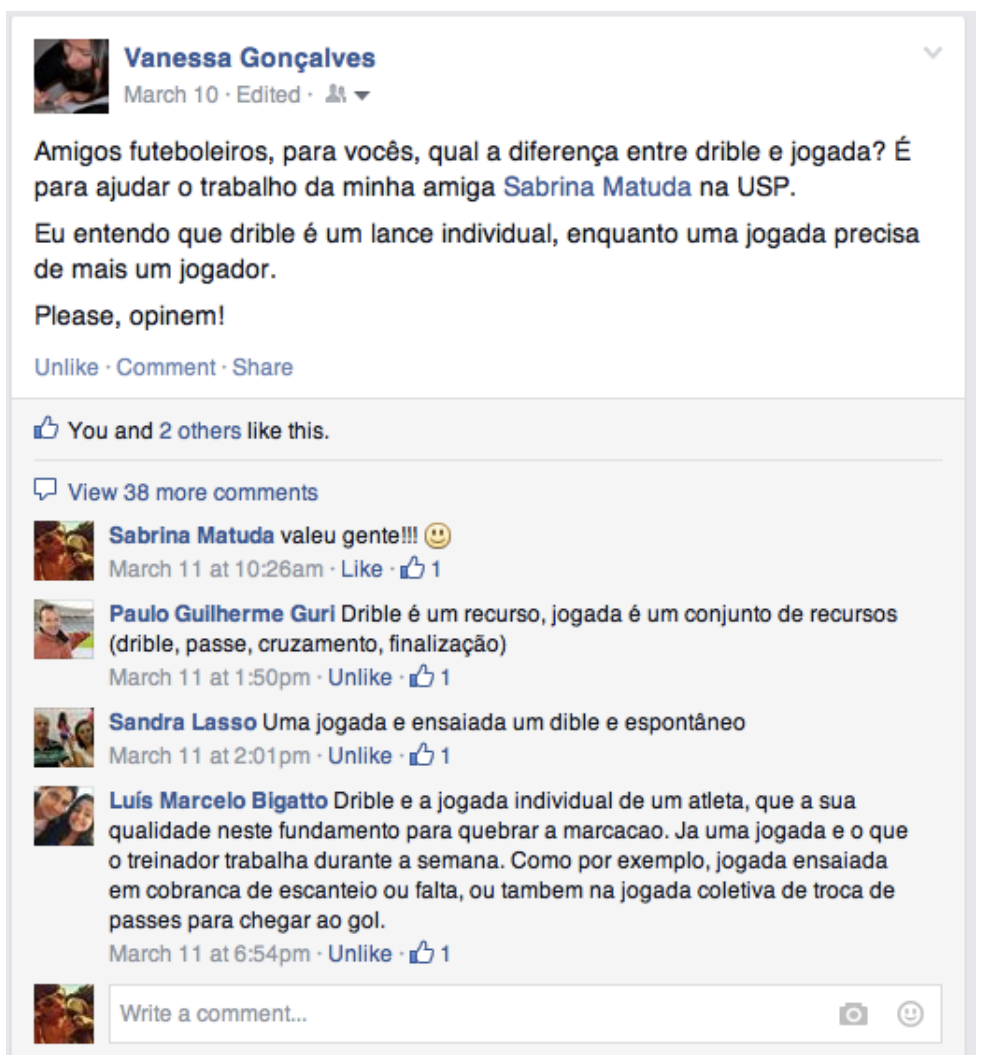

Figura 33: Pesquisa no facebook sobre a diferença entre 'drible' e ‘jogada'.

A pergunta rendeu 42 comentários com diferentes opiniões e duas mensagens inbox de dois jornalistas esportivos com explicações bastante detalhadas sobre a distinção. Consideramos todas as informações e opiniões e elaboramos nossa própria definição de 'drible' e de 'jogada' 69 .

Por fim, para compreender a complexidade dos equivalentes da CLE 'fazer um gol' em inglês, utilizamos um Thesaurus e classificamos todas as CLEs por campo semântico. Esse procedimento teve início em nosso trabalho de mestrado e foi expandido durante a presente pesquisa.

\subsubsection{Estabelecimento de equivalentes}

Diferentemente da seleção dos estudos de caso, em que estabelecemos os passos a serem seguidos para, posteriormente, iniciar a análise, não estipulamos um procedimento padrão para a busca de equivalentes. A decisão deu-se pelo fato de que

\footnotetext{
${ }^{69}$ Os termos ‘drible' e 'jogada' não fazem parte de nossos estudos de caso. Contudo, são utilizados nas definições de alguns verbetes e, para que os termos não sejam utilizados indiscriminadamente, criamos nossa definição, que é apresentada no item 4.3.
} 
cada termo representou um desafio diferente para a tradução. Em suma, utilizamos sete procedimentos, que foram adotados durante a análise, conforme os desafios encontrados, a saber:

a) análise das linhas de concordância da tradução prima facie ou de um possível colocado em inglês: utilizada para o estabelecimento dos equivalentes tradutórios de 'fazer cera', 'bichado', 'chinelinho' e 'retranca';

b) análise das linhas de concordância de um sinônimo do termo em português: utilizada para encontrar o equivalente tradutório de 'clássico';

c) análise de etiquetas gramaticais: utilizada para o estabelecimento dos equivalentes tradutórios de 'fazer um gol' e 'falta';

d) pesquisa no Google: utilizada para o estabelecimento dos equivalentes tradutórios de 'drible da vaca', 'elástico', 'chocolate', 'rolinho', ‘carregador de piano’ e ‘cai-cai';

e) análise da lista de palavras-chave do subcorpus em inglês: utilizada para o estabelecimento dos equivalentes tradutórios de 'carretilha' e 'lambreta';

d) análise das linhas de concordância para validar uma hipótese de equivalente: utilizada para o estabelecimento dos equivalentes de 'técnico' e ‘treinador';

g) conversa com especialista: utilizada para o estabelecimento do equivalente de 'corte seco'.

Os procedimentos acima são apresentados, discutidos e detalhados no capítulo 4 - Estudos de caso".

Nesta seção descrevemos a metodologia utilizada em nossa pesquisa. Inicialmente, apresentamos o corpus de estudo. Em seguida, mostramos os 


\section{Capítulo 3}

etiquetadores utilizados e o processo de etiquetagem. Após, apresentamos as ferramentas computacionais utilizadas para a análise. Ao final, expomos a metodologia utilizada na pesquisa e descrevemos os passos seguidos para a análise dos dados. No próximo capítulo apresentaremos a análise e a discussão dos estudos de caso. 
Capítulo 4

\section{Capítulo 4 - Estudos de Caso}

O objetivo do presente capítulo é apresentar a análise dos estudos de caso selecionados. Cada estudo de caso será apresentado individualmente, em ordem decrescente de frequência no corpus.

4.1 gol

Ao analisar as linhas de concordância de 'gol' em nosso subcorpus em português, encontramos, no total, 870 ocorrências de FAZER|MARCAR [o|um] gol / MARCAR o tento / FINALIZAR / EMPATAR, termos e CLEs utilizadas para descrever um gol.

Ao buscar possíveis equivalentes em inglês, gerando linhas de concordância de goal, encontramos 213 ocorrências de:

- SCORE $[\{\mathrm{a} \mid$ the $\}$ goal $]$

- SNATCH [a goal]

- DELIVER a goal

- ADD \{a|the\} ORDINAL (goal)

- BLAST in ([a goal] $)$

A primeira pergunta que nos ocorreu foi: por que há mais ocorrências de 'gol' em português do que de goal em inglês, já que o número de gols da Série A do Campeonato Brasileiro é bastante próximo daquele da Premier League? A figura 34 mostra o número total de gols do Campeonato Brasileiro de 2006 a 2013 e a figura 35 mostra o número de gols das temporadas 2011/2012, 2012/2013 e 2013/2014 da Premier League: 


\section{Capítulo 4}

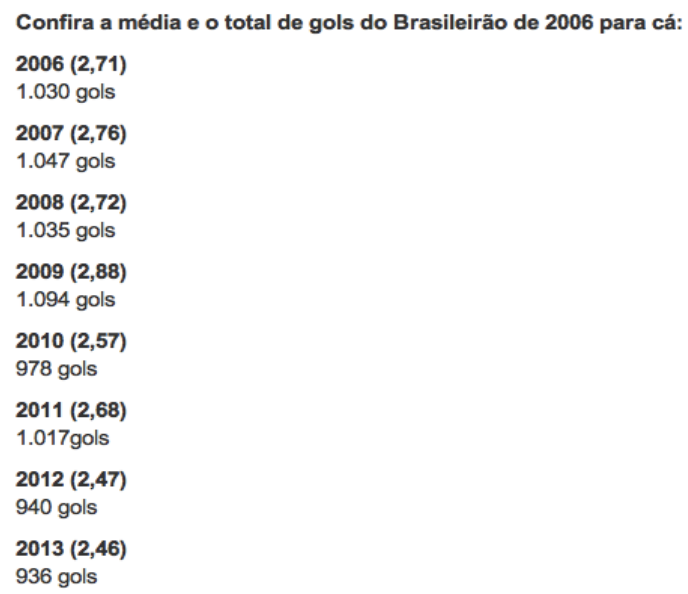

Figura 34: Número de gols do Campeonato Brasileiro de 2006 a $2013^{70}$.

\begin{tabular}{|lll|}
\hline 58 & $1948 / 1949$ & 1303 \\
\hline 59 & $2011 / 2012$ & 1066 \\
\hline 60 & $1899 / 1900$ & 856 \\
61 & $2010 / 2011$ & 1063 \\
\hline 62 & $2012 / 2013$ & 1063 \\
\hline 63 & $1900 / 1901$ & 855 \\
64 & $1999 / 2000$ & 1060 \\
65 & $1984 / 1985$ & 1288 \\
66 & $1985 / 1986$ & 1288 \\
67 & $1911 / 1912$ & 1057 \\
68 & $2009 / 2010$ & 1053 \\
\hline 69 & $2013 / 2014$ & 1052 \\
\hline 70 & $1920 / 1921$ & 1276 \\
\hline
\end{tabular}

Figura 35: Número de gols da Premier League nas temporadas de 2011/2012, 2012/2013 e 2013/2014 ${ }^{71}$.

Como podemos observar, o Campeonato Brasileiro de 2013 teve 936 gols e a Premier League de 2013/2014, 1052 gols. Portanto, o saldo de gols foi bastante semelhante nos dois campeonatos.

Nosso segundo questionamento foi: se goal não descreve os gols marcados, como esses gols estão sendo narrados? Nesse momento, percebemos que o verbo score, presente na CLE SCORE [\{a|the\} goal], muitas vezes ocorria sozinho.

\footnotetext{
${ }^{70}$ Os números entre parênteses indicam a média do número de gols por partida. Disponível em: < http://www.srgoool.com.br/Noticia/Brasileirao-2013-teve-o-menor-numero-de-gols-e-a-pior-media-detentos-dos-pontos-corridos > Acesso em: 16 jun. 2014.

${ }^{71}$ Disponível em: http://www.worldfootball.net/stats/eng-premier-league/1/. Acesso em: 16 jun. 2014.
} 


\section{Capítulo 4}

Observemos os exemplos:

Another corner resulted and, from it, Liverpool scored. ${ }^{72}$

The deputy manager, David Kelly, lauded the new signing Rafik Djebbour after the Algerian striker scored on his debut in the 3-1 win over Yeovil. ${ }^{73}$

Mais adiante, ao ler os textos que coletávamos para compilar o corpus, percebemos que a língua inglesa utiliza outros verbos que, muito frequentemente, não coocorrem com o termo 'gol', como sinônimos de SCORE [\{a|the $\}$ goal]. Sendo assim, geramos linhas de concordância para as etiquetas de verbo do subcorpus em inglês e analisamos todas as ocorrências à procura de verbos que descrevessem um gol. A tabela 7 mostra o número de linhas de concordância para cada etiqueta do subcorpus:

\begin{tabular}{|l|c|}
\hline \multicolumn{1}{|c|}{ etiqueta } & número de ocorrências \\
\hline VB/VV - Verb, base form & 26.032 \\
\hline VBD/VVD - Verb, past tense & 28.993 \\
\hline VBG/VVG - Verb, gerund or present participle & 18.076 \\
\hline VBN/VVN - verb, past participle & 21.118 \\
\hline VBZ/VVZ - Verb, 3rd person singular present & 12.994 \\
\hline
\end{tabular}

Tabela 7: Número de linhas de concordância para cada etiqueta gramatical de verbo.

Aplicamos o dispositivo Re-sort, que permite ordenar as linhas de concordância pelo nódulo de busca, e ajustamos as configurações para que as linhas fossem ordenadas pela etiqueta gramatical e pela primeira palavra à direita e à esquerda. Desse modo, a visualização das etiquetas e dos verbos ficou mais clara:

\footnotetext{
72 Disponível em: <http://www.dailymail.co.uk/sport/football/article-2603602/Liverpool-3-2Manchester-City-match-report-Philippe-Coutinho-scores-winner-Premier-Leagueshowdown.html\#ixzz3bdSbAJjW >. Acesso em: 20 jul. 2014.

73 Disponível em: < http://www.theguardian.com/football/2014/feb/02/nottingham-forest-yeovilchampionship-match-report $>$. Acesso em: 20 jul. 2014.
} 


\begin{tabular}{|c|c|c|c|c|c|c|}
\hline \multicolumn{5}{|l|}{ C VVG.cne } & \multicolumn{2}{|c|}{ - } \\
\hline \multicolumn{7}{|c|}{ File Edt View Compute Settings Window Heb } \\
\hline \multicolumn{2}{|r|}{ N Concordance } & Set Tag $\mid$ Word \# t. H os.| & \# 0 . 1 . & A os. It t H os.| & $\%$ & ^ \\
\hline 1 & with IN with Mexico NP Mexico zipping $\quad$ zip the DT the ball NN ball around & $8.3493408 \%$ & $01 \%$ & 0 1\%lnar-gua_001.tagl & $71 \%$ & \\
\hline 2 & with IN with Klose NP Klose zipping WG zip a DT a shot NN shot just RB & $8.0293768 \%$ & $01 \%$ & 0 1\%lnar-gua_038.tagl & $80 \%$ & \\
\hline 3 & NP South Korea NP Korea zipping WG zip forward RB forward with IN with & $4.5271773 \%$ & $05 \%$ & 0 5\%Inar-gua_025.tagl & $45 \%$ & \\
\hline 4 & with IN with Mexico NP Mexico zipping WG zip the DT the ball NN ball around & $9.7173808 \%$ & $04 \%$ & 0 4\%Inar-gua_019.tagl & $74 \%$ & \\
\hline 5 & DT the ball NN ball is VBZ be zipping WG zip around RP around at IN at a DT & $1.992642 \%$ & $04 \%$ & $04 \%$ Inar-gua_032.tagl & $24 \%$ & \\
\hline 6 & say that IN/that that the DT the zinging WG zing was VBD be quite RB quite & $6.9922667 \%$ & $00 \% \mathbf{I}$ & 0 0\%Inar-gua_029.tagl & $69 \%$ & \\
\hline 7 & NN attempt at IN at " "'" zinging WG zing " '" someone NN someone & $5.4212029 \% 1$ & $04 \%$ & 0 4\%Inar-gua_029.tagl & $54 \%$ & \\
\hline 8 & dribbles NNS dribble , . , zigzagging WG zigzag through IN through the DT & $4.3801873 \%$ & $05 \% 1$ & 0 5\%Inar-gua_027.tagl & $45 \%$ & \\
\hline 9 & glisten turf NN turf and $C C$ and yelling WG yell his PPS his joy NN joy. SENT & $2.951921 \%$ & $05 \% 1$ & 0 5\% jo-iftel__009.tag & $95 \%$ & \\
\hline 10 & pointing WG point and $C C$ and yelling WG yell at IN at each DT each other J & $3.5291597 \%$ & $07 \%$ & $07 \%$ Inar.gua_028.tagl & $27 \%$ & \\
\hline 11 & the DT the field NN field . . . yelling WG yell constant $\mathrm{W}$ constant & $930289 \%$ & $02 \% 1$ & 0 2\%l jo-if-wp_043.tag & $33 \%$ & \\
\hline 12 & $\cdots$ We PP we were VBD be yelling WG yell in IN in front NN front of IN of & $1.939684 \%$ & $05 \% 1$ & $05 \%$-inf-mn_001.tagl & $65 \%$ & \\
\hline 13 & EX there was VBD be a DT a yawning WG yawn gulf NN gulf. SENT. Just RB & $466 \quad 124 \%$ & $02 \% 1$ & 0 2\%ljo-ifftim_010.tag & $22 \%$ & \\
\hline 14 & WZ say " " " Stop NP Stop yawning WG yawn Richard NP Richard. SENT. & $10.4434379 \%$ & $09 \% 1$ & 0 9\%Inar-gua_007.tagl & $79 \%$ & \\
\hline 15 & $C C$ and he PP he 's VBZ be yawning WG yawn. SENT. Jon NP Jon & $10.4094352 \%$ & $09 \% \mathbf{I}$ & 0 9\%Inar-gua_007.tagl & $79 \%$ & \\
\hline 16 & $\ldots$ growling $W G$ grow $\ldots$, yapping $W G$ yap and $C C$ and nipping $W G$ nip . & $1.680346 \% \mathbf{I}$ & $01 \%$ & 0 1\%Inar-gua_003.tagl & $11 \%$ & \\
\hline 17 & $\ldots$ growling $W G$ grow $\ldots$, yapping $W G$ yap and $C C$ and nipping $W G$ nip . & $1.602346 \% 1$ & $01 \%$ & 0 1\%Inar-gua_031.tagl & $10 \%$ & \\
\hline 18 & \multirow{2}{*}{$\begin{array}{l}\ldots \text { growling } W G \text { grow } \ldots . . \text { yapping } W G \text { yap and } C C \text { and nipping } W G \text { nip , } \\
\text { NN deflection.... wrong-footing } W G \text { wrong-foot Argentina NP Argentina }\end{array}$} & $1.680346 \%$ & $01 \% \mathbf{I}$ & 0 1\%Inar-gua_008.tagl & $11 \%$ & \\
\hline 19 & & $55789 \%$ & $07 \%$ & $07 \%$ jo-iffftt_@07.tag & $48 \%$ & \\
\hline 20 & wide J wide after IN after wrong-footing WG wrong-foot Madjid NP Bougherra & $1.790503 \%$ & $06 \% 1$ & 0 6\% jo-if-tel_018.tag & $76 \%$ & \\
\hline 21 & \multirow{2}{*}{$\begin{array}{l}\text { WP hear people NNS people writing WG write and } C C \text { and saying WG say } \\
\text { but } C C \text { but I PP I' } m \text { VBP be writing WG write this DT this from IN from a DT }\end{array}$} & $374 \quad 92 \%$ & $05 \% 1$ & 0 5\%lo-if-gua_094.tagl & $25 \%$ & \\
\hline 22 & & $7.7442408 \%$ & $01 \% \mathbf{l}$ & 0 1\%Inar-gua_009.tagl & $70 \%$ & \\
\hline 23 & than IN than I PP I am VBP be writing WG write this DT this from IN from the & $12.0394862 \%$ & $07 \% 1$ & $07 \%$ Inar-gua_035.tagl & $78 \%$ & \\
\hline 24 & PP\$ his pocket NN pocket , ., writing WG write the DT the correct JJ correct & $5.0801410 \%$ & $09 \% \mathbf{1}$ & 0 9\%Inar-gua_020.tagl & $40 \%$ & \\
\hline 25 & with IN with people NNS people writing WG write us PP us off RP off after IN & $541 \quad 182 \%$ & $03 \%$ & 0 3\%lo-if.gua_084.tagl & $24 \%$ & \\
\hline 26 & just as IN as I PP I was VBD be writing WG write about IN about an DT an & $8.7113857 \%$ & $04 \%$ & $04 \%$ Inar-gua_047.tagl & $84 \%$ & \\
\hline 27 & the DT the critics NNS critic writing WG write them PP them off RP off. & $11504 \%$ & $08 \%$ & $08 \%$ jo-if-foo_032.tag & $9 \%$ & \\
\hline 28 & People NNS people are VBP be writing WG write us PP us off RP off after IN & $2.625735 \%$ & $08 \%$ & $08 \%$ o-if-gua_078.tagl & $98 \%$ & \\
\hline 29 & SENT , laquinta NP is VBZ be writhing WG writhe around RP around in IN in & $1.212767 \%$ & $04 \%$ & $04 \% 1$ jo-if-ny_d032.tag & $24 \%$ & \\
\hline 30 & IN with a DT a player NN player writhing WG writhe on IN on the DT the ground & $1.607384 \%$ & $05 \%$ & 0 5\%l jo-if-wp_057.tag & $46 \%$ & \\
\hline 311 & Torres NP Torres was VBD be writhina WG writhe about RB about on IN on the & $39.941 .39 .3 \%$ & $n \cap \%$ & n ก\%Inar-hhr. n11 tanl & $30 \%$ & \\
\hline concordance & potterns clusters flenanes folow up source text notes & & & & & \\
\hline
\end{tabular}

Figura 36: Parte das linhas de concordância da etiqueta $\mathrm{VVG}^{74}$.

Observamos todas as linhas de concordância e identificamos 39 verbos que poderiam fazer parte de CLEs utilizadas para relatar um gol. Depois, geramos concordâncias no corpus sem etiquetas gramaticais para esses verbos a fim de verificar como ocorrem nos textos, ou seja, os padrões em que ocorrem.

Nessa parte da análise, também eliminamos as estruturas que não funcionavam como equivalentes de 'fazer um gol'. Observemos o exemplo, a seguir, da busca realizada para fire*, um dos 39 verbos identificados a partir das etiquetas:

\footnotetext{
${ }^{74}$ A palavra à esquerda representa a ocorrência no corpus e a palavra à direita é a forma lematizada do verbo. Utilizamos a versão 6.0 do WordSmith Tools para a elaboração das listas de palavras e das palavras-chave, bem como para o restante da análise. No entanto, quando a versão 6.0 não estava disponível, uma vez que o software está instalado nos computadores na sede do Projeto Comet, utilizamos a versão 5.0 que possuímos em nosso antigo computador para consultar o corpus e gerar linhas de concordância. Por esse motivo, as telas das linhas de concordância podem apresentar cores diferentes.
} 


\section{Capítulo 4}

\begin{tabular}{|c|c|c|c|c|c|c|c|}
\hline \multicolumn{2}{|c|}{ Cencord } & & & & & \multicolumn{2}{|c|}{-10} \\
\hline Fib Edt & Wew Comoute Settings Whidow Helo & & & & & & \\
\hline \multicolumn{2}{|r|}{ N Concordance } & Set fag Word $\mathrm{E}$ & t. 1 os & Aosi 1 & $4 \cos |t-4 \cos |$ & $\%$ & A \\
\hline 150 & \multirow{2}{*}{$\begin{array}{l}\text { call El Pistolero defied the elements to fire his side into their first quarter-final for } \\
\text { in the fourth minute when Greg Halford fired home a free-kick ater Kewin Doyle }\end{array}$} & 134 & $19 \%$ & 090 & 0 9xd jo-lf-mir_009.txt & $32 \%$ & \\
\hline 151 & & 118 & $16 \%$ & 0 0Na & 0 0x/jo-1-1365_083.txt & $74 \%$ & \\
\hline 152 & superbly on his chest, set himself and fired home a glorious half volley. Great & 859 & $331 \%$ & $06 \times 1$ & 0 6\%a -nar-tel_003.txtl & $28 \%$ & \\
\hline 153 & on their confusion as Damien Duff fired home a second from outside the & 186 & $44 \%$ & $04 \times 1$ & 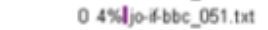 & $33 \%$ & \\
\hline 154 & new-boy. Stephen Ireland popped up to fire home afer a mazy solo burst. In & 163 & 3190 & $02 \times 1$ & 0 20N jo-dispi_003.tat & $32 \%$ & \\
\hline 155 & new-boy. Stephen Ireland popped up to fire home after a mazy solo burst. In & 153 & $21 \%$ & 0 19: & 0 19/jo-1-365_004 tut & $31 \%$ & \\
\hline 156 & \multirow{2}{*}{ the score 10 minutes later when he fired home an angled shot after a clever } & 379 & $134 \%$ & 9 9x: & 0 0xdjo-ifsun_011.txt & $65 \%$ & \\
\hline 157 & & 449 & $154 \%$ & $04 \times 1$ & 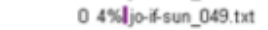 & $78 \%$ & \\
\hline 158 & gobble up Dele Adebola's flick-on and fire home. Both clubs are still waiting for & 274 & $105 \%$ & $05 \% 1$ & 0 5:1jo-f-sun_042.txt & $70 \%$ & \\
\hline 159 & passed inside for unmarked Deco to fire home. Deco had missed the team's & 836 & $436 \%$ & $190 \times 4$ & 0 6\%1 joifwp_026.tnt & $86 \%$ & \\
\hline 160 & to be heading for a draw, Lampard fired home deep into injury-time to send & 781 & $372 \times 1$ & $280 \times 4$ & $08 \times 1$ jo-if-mir_002.txt & $98 \%$ & \\
\hline 161 & \multirow{2}{*}{$\begin{array}{l}\text { Gunners ahead on } 19 \text { minutes when he fired home from a central position on the } \\
\text { proved equally clinical as Defoe as he fired home from a similar angle. The only }\end{array}$} & 202 & $59 \%$ & $00 \times 4$ & 0 0xA jo-ffoo_029.txt & $49 \%$ & \\
\hline 162 & & 337 & $102 \times 1$ & $01 \times 1$ & 0 1 $12 / j 0-1365 \_014 . t x t$ & $46 \%$ & \\
\hline 163 & proved equally clinical as Defoe as he fired home from a similar angle. The only & 338 & $102 \%$ & 0 1थ & 0 12:/jo-4365_013.txt & $46 \%$ & \\
\hline 164 & froe minutes from the end when he fired home from Chris Wood's pass. & 643 & $207 \%$ & $05 \%$ & 0 5\%/jo-4365_044.txt & $96 \%$ & \\
\hline 165 & 18 minutes from time as he turned and fired home from eight yards ater being & 454 & $166 \%$ & $08 \times 1$ & 0 8ะajo-ifbbc_020.txt & $90 \%$ & \\
\hline 166 & \multirow{2}{*}{$\begin{array}{l}\text { through Stefan Maierhofer, who fired home from six yards following a } \\
\text { who also hit the post twice for Ghana, fired home from the spot in 84th minute }\end{array}$} & 462 & $156 \%$ & $08 \times 1$ & 0 8x/ jo-1foo_012.txt & $98 \%$ & \\
\hline 167 & & 172 & $59 \%$ & $07 \times 1$ & 0 7\%al-i-espn_007.txtI & $24 \%$ & \\
\hline 168 & Madrid last night, as Steven Gerrard fired home from the penalty spot in injury & 95 & $02 \%$ & $02 \% 1$ & 0 920jo-fieye_007.txt & $32 \%$ & \\
\hline 169 & King and Bassong, swivels and fires home left-footed past Cudicini, who & 1.071 & $568 \%$ & $04 \%$ & 0 4\%9-nar-foo_025.txtl & $45 \%$ & \\
\hline 170 & 1- Newcastle United 1 Damien Duff fires home Newcastle United's & 82 & $01 \%$ & $03 \% 1$ & 0 3\%/jo-figua_037.txt & $27 \%$ & \\
\hline 171 & fed Zalayeta and the Uruguayan forward fired home on 73 minutes. $\langle/ p\rangle\langle p\rangle$ Milan & 263 & $57 x$ & $37 \% 1$ & 0 2\%/jo-f-gua_010.txt & $58 \%$ & \\
\hline 172 & \multirow{2}{*}{$\begin{array}{l}\text { before Alan set up Luis Aguiar to fire home six minutes from time, putting } \\
\text { to escape Stoke's attentions and fire home. The home side provided }\end{array}$} & 359 & $112 \%$ & $47 \% 1$ & 0 7\%/ jo-fuef_002.txt & $97 \%$ & \\
\hline 173 & & 448 & $98 \% 1$ & $00 \% 1$ & 0 0:4 jo-dind_035.txt & $83 \%$ & \\
\hline 174 & \multirow{2}{*}{$\begin{array}{l}\text { the edge of the area and the full-back fired home through a crowd of players for } \\
\text { with a cross that Tom Cleverley fired home to make it 2-1. Jay }\end{array}$} & 191 & $36 \%$ & $09 \%$ & 0 9:4 jo-1600_022.txt & $60 \%$ & \\
\hline 175 & & 292 & $135 \%$ & $02 \times 1$ & 0 220/jo-i-sun_040.txt & $93 \%$ & \\
\hline 176 & sway from Demichelis and Otamendi to fire home. Too little, too late. In the dying & 881 & $316 \%$ & $04 \%$ & 0 4\%: joriftel_005.txt & $95 \%$ & \\
\hline 177 & Lacazette, who cut it back for Novillo to fire home via a deflection. The goal & 621 & $198 \%$ & $07 \%$ & 0 7\%/ joiftel_049.txt & $79 \%$ & \\
\hline
\end{tabular}

Figura 37: Parte das linhas de concordância de "fire**".

O verbo fire ocorre 445 vezes no corpus. No entanto, em apenas 54 ocorrências ele é utilizado para narrar um gol. Ademais, muitas vezes uma estrutura que é utilizada para descrever um gol, como fire home, pode ser utilizada em outras situações. Na figura 37 fire home só é equivalente de 'fazer um gol' nas ocorrências sublinhadas. Em todas as outras, é utilizado para descrever uma tentativa que não resultou em gol.

O passo seguinte foi validar essas combinatórias léxicas especializadas por meio da análise das concordâncias e do contexto expandido. Ainda no caso de fire, ampliamos os contextos das linhas em que fire home era um possível equivalente de 'fazer um gol'. Observemos, por exemplo, o contexto expandido da linha número 153: 


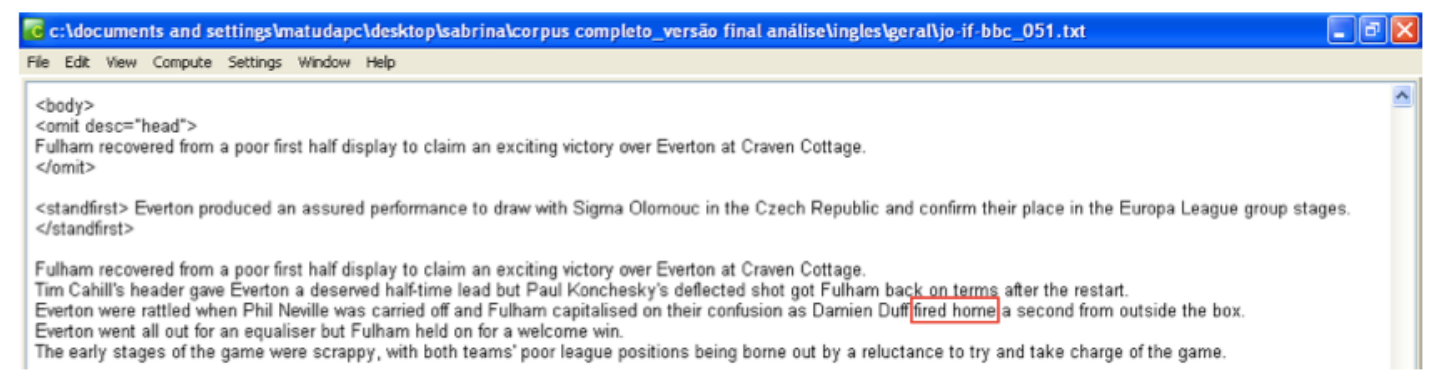

Figura 38: Parte do contexto expandido da linha de concordância 153 de fire*.

Após a validação das CLEs, agrupamos as 39 CLEs por categoria semântica, tendo como base o Roget's International Thesaurus. Optamos por esse tipo de classificação porque, durante a análise, notamos que o significado de algumas CLEs é bastante similar e que o sentido que carregam está relacionado à determinada característica que o verbo expressa.

Apresentamos, nos parágrafos seguintes, os equivalentes por categoria semântica. Embora intercambiáveis, todos apresentam características particulares que denotam categoria semântica, prosódia semântica e lexical priming ${ }^{75}$ distintos, causando, dessa forma, reações diferentes no leitor.

As CLES SCORE (\{a|the $\}$ goal) e NOTCH \{his ORDINAL|CARDINAL\}(goal) compõem a categoria semântica de pontuação. Ambas são utilizadas para pontuar os gols e seus significados recaem sobre o ato de adicionar gols ao placar de uma partida.

Os exemplos abaixo ilustram o uso de notch e score seguido do número de gols, enfatizando a ideia de soma de pontos:

Rooney notched his fifth goal of the season and showed that United are serious contenders to retain their Premier League crown despite the loss of Cristiano Ronaldo during the summer. ${ }^{76}$

\footnotetext{
${ }^{75}$ Teoria linguística desenvolvida por Michael Hoey que parte do princípio de que, à medida que temos contato com uma nova unidade lexical, seja verbo, substantivo, adjetivo etc., essa nova unidade é adquirida juntamente com os contextos linguísticos, sociais e culturais em que frequentemente ocorre. Dessa forma, ao reproduzir a unidade lexical tendemos a utilizá-la nos mesmos contextos em que a encontramos. Toda a informação adquirida por meio da unidade lexical em questão é considerada o lexical priming da palavra.

$76 \quad$ Disponível em: $\quad<\quad$ http://www.manchesterunitedmad.co.uk/rprt/mtch/tottenham hotspur 1 manchester united 3 462846/index.shtml >. Acesso em: 21 set. 2014.
} 
But Eduardo still had time to score the sixth, netting from close in after Andrey Arshavin's shot had come back off a post with two minutes to go. ${ }^{77}$

Durante o agrupamento semântico, identificamos treze CLEs que transmitem a ideia de uma ação violenta. São elas:

a) FIRE \{home | in (a goal) | (the ball) past [goalkeeper]| into the net\}

b) HAMMER \{in $\mid$ home $\}$

c) SLAM \{(the ball) past [goalkeeper] | in | into the roof of the net\}

d) BLAST IN (a goal)

e) LASH home \{(a goal) | into an empty net $\}$

f) SMASH home

g) STAB the ball \{home $\mid$ past [goalkeeper]\}

h) POKE \{the ball home | home past [goalkeeper]\}

i) KNOCK \{the ball \{into the net | in | home\}\} / NUMBER goals

j) THUMP \{home | past [goalkeeper]\}

k) CLIP the ball into the net

l) SNATCH [a goal]

m) THUNDER a goal home

A alta ocorrência de verbos que transmitem a ideia de ação violenta em inglês nos levou à seguinte pergunta: será que o uso de verbos dessa categoria semântica também é comum em português?

Para responder a pergunta, geramos linhas de concordância para a etiqueta gramatical $\mathrm{V}^{78}$, que indica um verbo, no subcorpus de português e observamos as ocorrências.

As concordâncias confirmaram nossa hipótese: em português não utilizamos verbos de ação violenta com a mesma frequência que em inglês. Encontramos 222 ocorrências do verbo "empurrar", sendo 87 sinônimas de 'fazer um gol'. No entanto, em grande parte das ocorrências o verbo "empurrar" estava relacionado à facilidade

\footnotetext{
${ }^{77}$ Disponível em: < http://www.independent.co.uk/sport/football/premier-league/arsenal-sink-evertonwith-six-of-the-best-1772766.html >. Acesso em: 12 out. 2014.

${ }^{78}$ As etiquetas gramaticais em português não distinguem entre os tempos verbais.
} 


\section{Capítulo 4}

com que o gol foi feito, e não à intensidade do chute dado. Observemos o exemplo abaixo:

Em desvantagem o Corinthians tentou pressionar, enquanto o Santos tentava concluir os bons contra-ataques que estava conseguindo. Mas aos 34 minutos Bill aproveitou bola rebatida na trave e empurrou para o gol, empatando o jogo no Pacaembu. ${ }^{79}$

Também encontramos 6.000 ocorrências do verbo 'bater', das quais apenas 28 são utilizadas para descrever um gol. Ao analisar as linhas de concordância, constatamos que das 28 CLEs com o verbo 'bater', somente dezesseis narram um gol feito. As outras representam tentativas que não deram certo:

Jorge Wagner domina e bate para o gol. Mas a bola vai fraca e sem direção. MUCHA SALVA!! Robben faz bela jogada pela esquerda e cruza rasteiro. Mathijsen bate para o gol e bola explode no rosto de Mucha. ${ }^{80}$

Após analisar cuidadosamente as linhas de concordância, expandindo o contexto e visitando o texto integral, concluímos que a diferença na frequência dos verbos de ação violenta é resultado da própria forma de jogar futebol no Brasil e na Inglaterra. Em suma, se os corpora são realmente representativos, eles devem refletir, por meio do léxico, a forma como o futebol é jogado em diferentes culturas.

Se perguntarmos a qualquer pessoa - que goste ou entenda ao menos um pouco de futebol - sobre as diferenças entre o futebol brasileiro e o futebol inglês, as respostas serão muito parecidas: o futebol inglês é mais rápido e mais "pegado", mais "forte". Observemos os depoimentos de jogadores, técnicos e jornalistas brasileiros sobre o futebol inglês:

Ramirez, volante do Chelsea, em entrevista ao site da FIFA em outubro de 2010, sobre sua adaptação ao futebol inglês: "O futebol inglês é muito físico e rápido. Aqui você não tem muito tempo para ficar com a bola no pé e tem que definir logo a jogada. Além de procurar as jogadas quando tenho a bola, eu sempre marquei forte. Por isso, não estou encontrando muitas dificuldades. Já estou me acostumando ao ritmo das partidas aqui. ${ }^{81}$,"

\footnotetext{
${ }^{79}$ Disponível em: < http://temporeal.lancenet.com.br/2014/campeonato-brasileiro/30-nov/fluminensecorinthians/ >. Acesso em: 6 jan. 2015.

${ }^{80}$ Disponível em: < http://oglobo.globo.com/esportes/tempoReal/2014/1024/LanceALance 7010.asp $>$. Acesso em: 15 jan. 2015.

${ }^{81}$ Disponível em: < http://www.guiame.com.br/v4/70368-1663-Destaque-no-site-da-Fifa-Ramires-dizestar-adaptado-ao-futebol-ingl-s.html>. Acesso em: 12 abr. 2011.
} 


\section{Capítulo 4}

Maurício Duarte, repórter do $R 7^{82}$, em agosto de 2010, sobre possivel transferência do atacante Neymar para o Chelsea: "O futebol inglês privilegia a força e há muito contato físico. Exatamente por isso, Robinho não se adaptou no Manchester City. Tanto que o atacante de mais sucesso atualmente no futebol inglês é Wayne Rooney, do Manchester United. $O$ artilheiro pode não ter muita técnica, mas compensa de sobra na vitalidade e na força física. ${ }^{83}$,

Se tomarmos os depoimentos acima, podemos caracterizar o futebol inglês como um futebol que tem a força como um de seus elementos centrais. Por esse motivo, tratamos a discrepância da frequência de verbos de ação violenta em inglês e português por meio do conceito forma-representação de Toledo (2002). Segundo Toledo (2002), o conjunto de regras não determina nem influencia as maneiras de jogar. Na verdade, a interpretação e a apropriação cultural que cada região faz das regras é que revelam as "formas de jogo". Justapostas, as regras e as "formas de jogo" dão origem a um terceiro aspecto identificado nas representações, qual seja o ajustamento da observação empírica das "formas de jogo" em um plano simbólico, que, por sua vez, consolidam as "escolas", “jeitos” ou "estilos" próprios que se traduzem no código linguístico.

Investigar a apropriação cultural das regras no Brasil e na Inglaterra foge ao escopo de nossa pesquisa. Contudo, reconhecer que essa interpretação influencia o "estilo" de jogo e, por conseguinte, a terminologia utilizada nas duas culturas é essencial para entendermos algumas discrepâncias linguísticas. Assim, o fato de o futebol inglês ser mais "pegado" transparece na grande quantidade de verbos de ação violenta.

Para comprovar nossa hipótese de que o futebol inglês é mais 'pegado' e 'rápido' que o futebol brasileiro, compilamos um minicorpus composto por quinze textos sobre o estilo do futebol brasileiro e quinze textos sobre o estilo do futebol inglês, totalizando aproximadamente 20.000 palavras. Esse minicorpus é monolíngue. Coletamos textos somente em inglês por dois motivos: 1) esse material foi compilado para a investigação de um estudo de caso apresentado em um congresso na Inglaterra; assim, achamos pertinente que o corpus estivesse em língua inglesa; 2) não

\footnotetext{
${ }^{82}$ Portal de notícias e entretenimento do conglomerado Record.

${ }^{83}$ Disponível em: <http://esportes.r7.com/futebol/times/santos/area-publica/noticias/estilo-do-futebolingles-desfavorece-talento-de-neymar-20100812.html>. Acesso em: 12 abr. 2011.
} 


\section{Capítulo 4}

encontramos textos descritivos em português que analisassem o futebol inglês, somente alguns trechos de entrevistas e citações.

A análise foi feita de forma bastante simples. Primeiramente, geramos listas de palavras dos minicorpora. Em seguida, comparamos essas listas com listas de palavras de corpora de referência a fim de obter as palavras-chave. Como referência, utilizamos um corpus jornalístico, com aproximadamente 100.000 palavras. Em seguida, analisamos as palavras-chave e selecionamos aquelas utilizadas para descrever as características dos dois futebóis. O quadro 17 mostra as keywords associadas às duas escolas:

\begin{tabular}{|l|l|}
\hline $\begin{array}{c}\text { Palavras-chave associadas } \\
\text { ao estilo brasileiro }\end{array}$ & $\begin{array}{c}\text { Palavras-chave associadas } \\
\text { ao estilo inglês }\end{array}$ \\
\hline - [good] dribblers & - physical [prowess/strength] \\
- creative & - fast \\
- spontaneous & - athleticism \\
- improvisational & - rough \\
- free-flowing & - [long] shoots \\
- possession & - quick \\
- samba [beat] & - [direct] passes \\
- control [of the ball] & $-[$ no] risk \\
- [highly] skilled & - courageous \\
- [flowing] passing [game] & - hard \\
- beautiful & - [break-neck] speed \\
- flair & \\
- invention & \\
\hline Quadro 17: Palavras-chave associadas ao estilo brasileiro e ao estilo inglês.
\end{tabular}

Ao fim da análise, questionamo-nos se a frequência de verbos que denotam ação violenta tende a aumentar em português, uma vez que a prática e o aprendizado do futebol mudaram bastante no Brasil. Antigamente as crianças jogavam futebol na rua, no pátio da escola e em "campinhos". Hoje em dia, as crianças frequentam, desde muito cedo, as chamadas escolinhas de futebol, ambientes em que meninos e meninas são treinados por meio de acompanhamento tático, prática de jogadas e, muitas vezes, condicionamento físico. Levantamos a questão uma vez que é comum ouvir de comentaristas e jornalistas esportivos que o "estilo" do futebol brasileiro, sempre caracterizado por jogadas de habilidade, está passando por um processo de transformação: a troca do "futebol arte" pelo "futebol força" ou, até mesmo, a junção 


\section{Capítulo 4}

desses dois futebóis. De qualquer forma, cremos que essas mudanças, futuramente, terão reflexo na constituição do léxico do futebol em português, incorporando neologismos. No entanto, embora as mudanças venham acontecendo há um tempo, seu reflexo no sistema linguístico muito provavelmente ocorrerá de forma mais lenta, e, até o momento, o "futebol força" não é a "forma de jogo" que temos em nosso plano simbólico ao pensar no futebol brasileiro, e, por esse motivo, não é traduzido em nosso código linguístico.

Outro campo semântico bastante comum em inglês, e que não foi encontrado em português, pelo menos não com frequência significativa, é o de "facilidade". Observemos as CLEs abaixo:

\section{a) SLIDE \{home his ORDINAL (goal) | the ball home\} \\ b) SWEEP \{home | the ball into the net \\ c) DINK in [a goal] \\ d) TUCK home (a goal) \\ e) STROKE a shot past [goalkeeper]}

Aqui, o sentido principal recai sobre a facilidade com que o gol foi feito. $\mathrm{Na}$ realidade, a facilidade não caracteriza o gol, mas sim a trajetória da bola, a posição do jogador ou o toque que o jogador dá na bola.

As CLEs TAP \{in|home\} e FIZZ [the ball past goalkeeper|a sidefooter at goal] compõem a categoria semântica de velocidade. Ambas enfatizam a velocidade do gol; não somente a velocidade com que o jogador recebe e chuta ao gol, mas também a rapidez dos toques até o momento do gol:

Scott Carson, oh Scott Carson. Drogba lines up the shot, fizzes a sidefooter at goal, but it's straight at the keeper. Who proceeds to let the ball squirm from his grasp, drop to Mikel who dinks it square for Malouda to tap in. ${ }^{84}$

Stones were under too much self imposed pressure during a distinctly dodgy period of play but turned the game around 10 minutes later; skipper Wes Parker had seen enough and charged down the flank, crossed expertly for McGleish who was well placed to fizz the ball

84 Disponível em: < http://www.theguardian.com/football/2010/aug/14/chelsea-west-brom-livepremier-league $>$ Acesso em: 16 jan. 2015. 


\section{Capítulo 4}

past Borough keeper Erbil Bozkurt to break the deadlock. ${ }^{85}$

Novamente, se considerarmos os depoimentos dos jogadores, jornalistas e técnicos sobre o futebol inglês, veremos que a alta ocorrência desses verbos de velocidade nos periódicos ingleses reflete o "estilo" do futebol inglês. Tomemos o depoimento de Ramirez: "O futebol inglês é muito físico e rápido. Aqui você não tem muito tempo para ficar com a bola no pé e tem que definir logo a jogada..."86.

Sabemos que o português, assim como o inglês, utiliza palavras de outras categorias gramaticais para indicar a rapidez e a velocidade de uma jogada como, por exemplo, os termos "rápido" e "de primeira". No entanto, chamamos a atenção para o fato de que, pelo menos em nosso corpus, o jogo rápido se mostra tão característico no futebol inglês que existe uma necessidade de expressá-lo por meio de verbos específicos.

Algumas CLEs não descrevem nenhuma particularidade do futebol inglês, mas refletem, de certa forma, uma característica da cultura e, consequentemente, da língua inglesa: alto grau de detalhamento das informações. Para entender essa particularidade cultural, utilizamos os conceitos de high-context culture e low-context culture do antropólogo Edward Hall (1976), apresentado no capítulo 2. A teoria de Hall parte do pressuposto de que a quantidade de informação linguística e contextual necessária para transmitir o significado varia de acordo com a cultura. A teoria de Hall é bastante complexa e detalhada. Contudo, pode ser utilizada para entender o processo de produção de textos sobre futebol nas duas culturas.

As CLEs que apresentamos nos próximos parágrafos transmitem um detalhamento que não encontramos nos verbos e CLEs utilizados para descrever um gol em português. As CLEs do primeiro grupo expressam o movimento que a bola faz para dentro do gol:

a) SLOT \{home([agoal)]|(theball)into\{an|the\} empty net|past[goalkeeper]| in\} Robinho, who was the game's outstanding player, then provided one of the assists of the championship so far as he threaded a delightful ball to Elano in the 72nd minute before the

\footnotetext{
${ }^{85}$ Disponível em: < http://wealdstone-fc.com/2013/posts/wealdstone-4-1-haringey-borough/ > Acesso em: 14 maio 2014.

${ }^{86}$ Disponível em: <http://www.guiame.com.br/v4/70368-1663-Destaque-no-site-da-Fifa-Ramires-dizestar-adaptado-ao-futebol-ingl-s.html>. Acesso em: 16 abr. 2014.
} 


\section{Capítulo 4}

midfielder slotted home a second. ${ }^{87}$

\section{b) DRILL home}

The defender, 25 yesterday, settled a tight game and embarked on a celebration that would have looked more at home on Strictly Come Dancing than Match of the Day. He drilled home Swansea's 69th-minute winner after Leon Britton had rattled the home side's bar with a stunning overhead kick. ${ }^{88}$

\section{c) BURY the ball past [goalkeeper]}

For good measure, Fabregas popped in a peach for his second and Arsenal's fifth as he ran up field, picked his spot and buried the ball past Howard. ${ }^{89}$

Sabemos que muitas vezes o sentido de uma palavra na língua geral e em uma língua de especialidade difere. Mas, no caso desses verbos, só entendemos o funcionamento das CLEs que utilizam drill, bury e slot de forma figurada por meio dos seus significados na língua geral. Drill nos remete ao ato de perfurar, bury, de enterrar e slot, de preencher um espaço, sentidos evidenciados nos exemplos acima.

As CLEs FINISH (off) (a goal) e DELIVER a goal carregam o sentido de completar, realizar uma tarefa, assim como o verbo "finalizar" em português:

O goleiro Felipe nem se mexeu. Novamente impaciente com o atacante Souza, a torcida do Corinthians passou a pedir a entrada de Dentinho. Só parou quando Elias, aos 42, finalizou de fora da área no ângulo: 2 a $1 .^{90}$

And 43 minutes into his full debut, Stanislas finished off a great end-to-end move by tapping in Luis Boa Morte's cross. ${ }^{91}$

It's been 25 years since a match between these two teams delivered a goal and it doesn't look like we're going to get one tonight. ${ }^{92}$

Também detectamos a presença de duas CLEs que descrevem o movimento da bola ou seu controle por um jogador:

\footnotetext{
${ }^{87}$ Disponível em: < http://www1.skysports.com/football/live/match/211263/report $>$. Acesso em: 15 maio 2014.

88 Disponível em: < http://www.thesun.co.uk/sol/homepage/sport/football/2602527/Coventry-0Swansea-1.html $>$. Acesso em: 15 maio 2014.

${ }^{89}$ Disponível em< http://www.clickliverpool.com/sport/everton-fc/125755-everton-destroyed-byarsenal.html >. Acesso em: 15 maio 2014.

${ }^{90}$ Disponível em: < http://www.gazetaesportiva.net/nota/2009/02/21/563360.html > Acesso em: 15 maio 2014.

91 Disponível em: < https:/www.thesun.co.uk/sol/homepage/sport/football/2361096/West-Ham-2Sunderland-0.html $>$. Acesso em: 15 maio 2014.

${ }_{92}$ Disponível em: < http://www.theguardian.com/football/2010/jun/11/world-cup-2010-uruguayfrance-live $>$. Acesso em: 15 maio 2014.
} 


\section{a) HOOK in ([a goal])}

When defender Marius Zaliukas hooked in the second shortly after the break, belief they were capable of a sensational result coursed through the home ranks.

\section{b) STEER the ball past [goalkeeper]}

His pass picks out the run of Osman who steers the ball past Schwarzer.

Analisamos as ocorrências de HOOK in ([a goal]) no corpus e chegamos a duas possibilidades do uso. Primeiramente, pensamos que a CLE poderia descrever o tipo de jogada realizada para fazer o gol, já que hook in descreve uma jogada feita com o pé no ar, a meia altura, conhecida como "voleio" em português, fato que foi confirmado após a observação de outras ocorrências no Google.uk. Nossa segunda hipótese era que a CLE seria utilizada como o termo hook de uso corrente no cricket $\mathrm{e}$ no golfe, cujo significado indica um modo de bater na bola que faz com que ela desenhe uma curva em vez de seguir em linha reta. Confirmar essa segunda hipótese foi um pouco mais complicado do que a primeira, pois se o verbo hook designa, em seu significado, o movimento da bola, o texto, muito provavelmente, não usa nenhum outro recurso linguístico que possamos analisar para validar nossa hipótese. O detalhamento das notícias em inglês foi de grande valia para confirmar essa ideia. Acessamos o site Football.co.uk, do qual um dos textos que contém a CLE foi coletado, vimos as fotos dos gols do jogo e clicamos em um link do YouTube que direcionava para um vídeo que mostrava os gols da partida: constatamos que a bola fez um movimento irregular no seu percurso para o gol.

A última CLE, STEER the ball past [goalkeeper], não descreve o movimento da bola, como a anterior. Seu significado recai sobre o controle da direção que a bola toma, como no exemplo citado, em que o jogador direciona a bola e chuta para o gol.

Identificamos três CLEs utilizadas para narrar gols de cabeça:

a) NOD \{home (into an empty goal) | in | into the net\};

b) HEAD (the ball) \{home|past (goalkeeper)|into the (roof of the) net\}; c) \{HAMMER | POUND $\}$ a header into the net.

A alta frequência dos verbos que narram gols de cabeça em inglês chamou a atenção quando comparada à frequência dos mesmos verbos em português: $1037 \mathrm{e}$ 


\section{Capítulo 4}

387 ocorrências em cada língua, respectivamente.

Recorremos ao conceito forma-representação de Toledo para entender essa discrepância. Tomemos os depoimentos abaixo:

Robinho, em sua apresentação ao Milan, sobre o futebol inglês:

"Não tive nenhum problema com o Roberto Mancini. O que acontece é que o futebol inglês não é muito bom para jogador brasileiro, muita bola alta e a gente gosta de jogar com ela no chão ${ }^{93} . "$

Guilherme Esteves, fanático por futebol, para o site "Futebol no Cotidiano":

"Hoje, tive a oportunidade de assistir a Chelsea x Blackburn, no estádio do Blues, o Stamford Bridge, em Londres. O jogo em si, francamente... não foi bom. Aquele típico futebol inglês tomou conta do gramado. Muitas divididas, eficiência, objetividade e, principalmente, muitas jogadas aéreas. ${ }^{94,}$

Jogadas aéreas, principalmente de bola na área, definem um estilo bem inglês, uma vez que exigem a força, a impulsão e a altura características dos jogadores ingleses. Desse estilo, e também das condições climáticas da Inglaterra - devido à chuva constante as equipes eram forçadas a mandar a bola para o alto, já que era quase impossível fazê-la correr na grama encharcada - surgiu a expressão "chuveirinho" para designar a grande quantidade de jogadas aéreas na área, que caracterizou, por muitos anos, a escola inglesa.

O cabeceio, que definia o "estilo" inglês, era considerado como a melhor forma de atacar e de concluir uma jogada, levando a seleção da Inglaterra à conquista da Copa do Mundo de 1966.

Não cabe aqui discutir a origem e a eficácia do "estilo" inglês, mas sim reconhecer que o papel das jogadas aéreas no futebol inglês é fundamental para entender a divergência entre a frequência de CLEs que narram gols de cabeça em inglês e em português.

A estrutura de ADD $\{\boldsymbol{a} \mid$ the $\}$ ORDINAL (goal) pode ser enquadrada na categoria semântica de adição, pois a referência ao número do gol que foi marcado é parte integrante da CLE.

Rumblings of discontent were just beginning to emerge as Arsenal took the lead

\footnotetext{
${ }^{93}$ Disponível em: http://opiodopovo.wordpress.com.tab/chuveirinho/. Acesso em: 21 maio 2011.

${ }^{94}$ Disponível em: <http://futebolnocotidiano.com.br/?tag=futebol-ingles $>$. Acesso em: 21 maio 2011
} 


\section{Capítulo 4}

through Abou Diaby in the 18th minute and the midfielder added a second three minutes later, prompting Wenger to compare his midfielder with a Highbury great. ${ }^{95}$

Identificamos os verbos $\boldsymbol{E} \boldsymbol{Q} \boldsymbol{U} \boldsymbol{A L I S E}, \boldsymbol{D R} \boldsymbol{A} \boldsymbol{W}$ e $\boldsymbol{T I E}$ como equivalentes de EMPATAR. Entretanto, cada um apresenta suas particularidades. O verbo EQUALISE é o mais comum para narrar um gol de empate. Os trechos que seguem exemplificam seus principais usos:

The keeper keeps hold of the ball, then gets the trainer on to look at his trousers. Meanwhile in the other game, Nigeria have equalised! ${ }^{96}$

Birmingham almost equalised three minutes later when Patrice Evra headed Franck Queudrue's header off the line, but Hart was called back into action early in the second-half when he saved well from another long-range Rooney effort. ${ }^{97}$

Martinez's lads were 13 minutes from victory until Clint Dempsey equalised with a diving header and Zamora had the last word with his bonce on 81 minutes in this gripping fifthround replay. ${ }^{98}$

The South Americans took the lead for the first time early in the second half through the impressive Diego Forlan but Marcell Jansen equalised for Germany within five minutes.

$\mathrm{O}$ primeiro exemplo exemplifica o uso de equalise em uma narração. $\mathrm{O}$ segundo mostra o verbo seguido de uma referência ao tempo. O terceiro explicita o tipo de gol que foi feito e o último indica o time que empatou.

Os verbos $\boldsymbol{T I E}$ e $\boldsymbol{D} \boldsymbol{R} \boldsymbol{A} \boldsymbol{W}$, outros possíveis equivalentes do verbo 'empatar' em português, também ocorrem no corpus. Entretanto, o primeiro ocorre majoritariamente em revistas e jornais americanos e o segundo ocorre para narrar o resultado de um jogo que terminou empatado, e não para narrar um gol de empate:

The Cottagers beat Arsenal 1-0 in August, drew 2-2 with Chelsea over Christmas and stunned United 2-0 last month.

\footnotetext{
${ }^{95}$ Disponível em: < http://www.dailymail.co.uk/sport/football/article-1208528/Arsenal-4-Portsmouth1-Wengers-masterplan-beginning-bear-fruit.html > . Acesso em: 16 maio 2014.

96 Disponível em: < http://www.theguardian.com/football/2010/jun/22/world-cup-2010-greeceargentina-live $>$ Acesso em: 16 maio 2014.

${ }_{97}$ Disponível em: < http://www.telegraph.co.uk/sport/football/teams/manchesterunited/6029372/Manchester-United-v-Birmingham-City-match-report.html?mobile=basic $>$. Acesso em: 16 maio 2014.

${ }^{98}$ Disponível em: < http://www.premierleague.com/en-gb/news/features/man-united-2012-13-seasonat-a-glance.html $>$. Acesso em: 16 maio 2014.
} 


\section{Capítulo 4}

A CLE NESTLE \{in | into\} the (back of the) net remete à ideia de 'aninhar' a bola no gol:

Not a brilliant penalty-struck low and only a few feet to the left of the centre of the goal, but Julio Cesar went the other way and the ball nestled in the back of the net.

Como podemos observar, o exemplo ilustra a posição da bola após o gol.

Identificamos três CLEs que pertencem à categoria de realização, entendida aqui como consecução, ou seja, o ato de alcançar um objetivo. Observemos os exemplos:

\section{a) NET [a goal]}

Liverpool's season is firmly back on track after Yossi Benayoun netted a hat-trick in Saturday's 4-0 Premier League home win over Burnley. Substitute Stefan Maierhofer netted a late consolation for Wolves.

\section{b) $B A G$ [a goal]}

Dave Kitson is finally beginning to find his feet at Stoke as he bagged the winner in a 1-0 victory over Sunderland at the Britannia Stadium. Drogba was a real menace throughout, heading just over from a Jose Bosingwa cross before bagging the all-important goal. ${ }^{99}$

\section{c) NICK [a goal]}

Birmingham City had the early Premier League leaders begging for the final whistle before Aaron Lennon nicked a winner for Tottenham deep into stoppage time. Lions fans were already leaving the Den when Paul Shaw nicked a consolation goal on 79 minutes but the roar that went up when Tim Cahill (right) made it 3-2 within seconds brought many back. ${ }^{100}$

Independentemente do significado de seus verbos na linguagem geral, as três CLEs descrevem um ato de realização. Quando utilizadas, enfatizam a conquista de um gol que é necessário ou importante. Se tomarmos os colocados da CLE nos exemplos acima, hat-trick (três gols marcados por um jogador na mesma partida), consolation (gol de honra), the winner (gol da vitória) e the-all-important goal (gol importante, que pode ser decisivo para a vitória ou para a permanência de um time em um campeonato), veremos que além de descrever um gol feito, a CLE realça a importância do gol tanto pelos colocados quanto pelo uso em detrimento de algum

\footnotetext{
${ }^{99}$ Disponível em: < http://www.teamtalk.com/match/report/978/5522798/Kitson-bags-winner-to-downCats >. Acesso em: 20 maio 2014.

$\frac{\text { Disponível }}{100}$

em:

$<$ http://www.tottenhamhotspurmad.co.uk/rprt/mtch/tottenham hotspur 2 birmingham city 1 460760/index.shtml $>$. Acesso em: 8 jan. 2015.
} 


\section{Capítulo 4}

outro equivalente.

Ao final de nosso primeiro estudo de caso, podemos concluir que a existência de CLEs que expressam o sentido de violência, explosão, rapidez, facilidade e gols de cabeça em inglês e a ausência do mesmo tipo de CLE em português pode ser explicada pelo conceito forma-representação, do mesmo modo que a maior variação de CLEs que descrevem a trajetória da bola tanto em um gol quanto em uma tentativa pode ser explicada pelo conceito de high e low-context culture. O torcedor brasileiro (high-context) espera um relato mais breve da partida, com ênfase no produto final, o gol. Já o torcedor inglês (low-context) espera que os lances sejam narrados de forma precisa, com ênfase nos meios, ou seja, nas jogadas que levaram ao gol.

\section{2 falta}

Um segundo exemplo que pode ser utilizado para evidenciar como o estilo de jogo influencia o funcionamento da linguagem do futebol em português e inglês é o termo 'falta', que ocorre 6.901 vezes no corpus de português. O quadro 18 mostra as colocações verbais e adjetivas de 'falta'encontradas por meio das seguintes buscas no corpus etiquetado: "v * falta" $" 101$ e "falta * adj",

\begin{tabular}{|l|l|l|}
\hline \multicolumn{1}{|c|}{ Colocações verbais } & \multicolumn{2}{c|}{ Colocações adjetivas } \\
\hline - COMETER * falta & - falta dura & - falta grosseira \\
- FAZER * falta & - falta perigosa & - falta infantil \\
- GANHAR * falta & - falta violenta & - falta venenosa \\
- RECEBER * falta & - falta boba & - falta casual \\
- SOFRER * falta & - falta forte & - falta certeira \\
\hline
\end{tabular}

Quadro 18: Colocações verbais e adjetivas de 'falta'.

Ao realizar uma busca para o termo foul no subcorpus em inglês, encontramos apenas 926 ocorrências. Destas, 546 são verbos e 40 substantivos. Esse número é relativamente baixo se comparado às 6.901 ocorrências de 'falta' em português. Nesse caso, assim como no caso de "fazer/marcar um gol", analisamos todas as ocorrências de verbos no corpus em busca de outro(s) possível(is) equivalente(s) para 'falta' e

\footnotetext{
101 "v" representa a etiqueta utilizada para verbos e * indica uma possível palavra entre o verbo e o termo "falta". Com esse tipo de busca, obtemos resultados, como, por exemplo, "cometeu (uma) falta". 102 "adj" representa a etiqueta utilizada para adjetivos e * indica uma possível palavra entre "falta" e um adjetivo.
} 


\section{Capítulo 4}

identificamos 272 ocorrências de tackle - 223 como substantivo e 49 como verbo - e 76 ocorrências de challenge - 60 como substantivo e 16 como verbo -, utilizadas para descrever uma falta. Analisamos as colocações adjetivas e verbais, mas, mesmo assim, a grande diferença de frequência dos termos nas duas línguas parecia não se justificar. Novamente, recorremos ao conceito forma-representação para explicar o uso de 'falta' em português e foul, challenge e tackle em inglês.

Primeiramente, o fato de o número de faltas do campeonato brasileiro ser superior ao número de faltas do campeonato europeu ajuda a entender a grande diferença no número de ocorrências. A figura 39 esclarece essa discrepância:

\section{Brasileiro tem média de faltas maior que dos campeonatos europeus}

Futebol - 28/09/2012 - 13:04

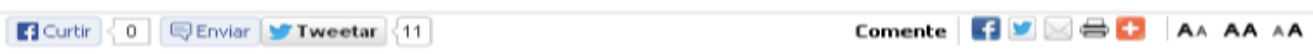

Jogo franco, baixo número de faltas e muitos gols deveriam ser características da liga de um pais que se vangloria pelo futebol arte e pelos cinco títulos da copa do Mundo, mas năo é essa a realidade do Campeonato Brasileiro de 2012 .

- Brasileirão deste ano pode ter sido recheado por estrelas internacionais como Diego Forlán e Clarence Seedorf. Ainda assim, o que esses jogadores encontraram nos campos verde-amarelos é bem diferente daquilo com que eles estavam acostumados na Europa.

Por enquanto o colorado Forlán e o botafoguense Seedorf năo reclamaram do estilo de jogo do futebol do Brasil pelo menos nắo publicamente -, mas seus companheiros de trabalho têm protestado contra um aparente vilắ nacional: o excesso de faltas marcadas pela arbitragem.

"Não pode encostar que é falta. Acho que eles - árbitros - têm de assistir um pouco de futebol europeu", reclamou Iateral escuerdo flamenguista Ramon depois de jogo contra a Ponte Preta, em 5 de setembro.

Getty

City e Stoke só empatam pela quarta rodada da Premier League Manchester City e Stoke, duelo da Premier League

"O Neymar simula bastante durante o jogo. Ponto. Todo mundo tem acesso aos vídeos, é só ver. Esse é o antijogo e temisso emintudos us times. Na Europa, o publico e contra isso, reclamou a zagueiro Paulo Andre, do Corinthians ao final do clássico de 19 de agosto, com Santos. O alvo do corintiano era Neymar, jogador vaiado em jogos recentes da seleção brasileira em campos europeus pelo famoso icai-ca."

A indignaçăo com a simulaçăo de faltas é compreensivel: os europeus nåo eståo acostumados a ver juizes parando $\$$ jogo com tanta frequência. Nenhum dos grandes campeonatos do Velho Continente tem tantas infraçóes quanto Brasileiro.

Até a 23a rodada, a média do atual Brasileirão era de 37,2 faltas por partida, segundo dados do Footstats. Número bem mais alto que a média de 27,48 do Espanhol ou que a de 29,55 do Italiano em suas primeiras rodadas da temporada 2012/2013. A comparaçăo com o Campeonato Inglês é ainda mais impressionante. Na Premier League a média é de 20,75 infrações por jogo, quase a metade do Brasil.

Figura 39: Reportagem sobre o alto número de faltas no Campeonato Brasileiro ${ }^{103}$.

Como podemos observar, além de o número de faltas ser maior no Brasileirão do que na Premier League, os juízes brasileiros tendem a interromper o jogo após todo e qualquer lance de encontro corporal, o que não acontece na Inglaterra.

De acordo com Leonardo Gaciba, árbitro de futebol por 21 anos e pertencente ao quadro da CBF por dezoito anos e da FIFA por cinco, existe, há alguns anos, uma

\footnotetext{
${ }^{103}$ Disponível em: < http://on1.com.br/site/noticia.php?id noticias=3321 > Acesso em: 15 abr. 2014.
} 


\section{Capítulo 4}

luta pela diminuição da média de faltas no Brasileirão; de fato, essa média diminuiu $10 \%$ em cinco anos. Observemos a figura 40:

\begin{tabular}{|c|c|c|c|}
\multicolumn{4}{|c|}{ MÉDIA DE FALTAS BRASILEIRÃO "A" } \\
\hline ANO & № DE JOGOS & № DE FALTAS & MÉDIA PO JOGO \\
\hline 2008 & 380 & 14729 & 38,76 \\
\hline 2009 & 380 & 14142 & 37,22 \\
\hline 2010 & 380 & 13460 & 35,42 \\
\hline 2011 & 380 & 13655 & 35,93 \\
\hline 2012 & 380 & 13156 & 34,62 \\
\hline 2013 & 89 & 3031 & 34,06 \\
\hline
\end{tabular}

Figura 40: Redução no número de faltas da Série A do Brasileirão ${ }^{104}$.

No entanto, mesmo com essa redução o número de faltas no campeonato inglês ainda é bastante inferior, conforme mostrado na figura 41:

${ }^{104}$ Disponível em: < http://sportv.globo.com/platb/blog-do-gaciba/category/sem-categoria/estatisticasdo-apito/ > . Acesso em: 15 abr. 2014. 


\section{Capítulo 4}

\begin{tabular}{|c|c|c|c|c|c|c|c|c|c|}
\hline \multicolumn{3}{|c|}{ League: English Premier } & \multicolumn{2}{|c|}{ † Venue: Al } & \multicolumn{3}{|c|}{ I Season: 2013/2014 } & \multirow[t]{2}{*}{$19 / 06 / 2014$} & \multirow[t]{2}{*}{ 埥 } \\
\hline League & Tables & & iorners & Goals & Shots & Cards & Dashboard & & \\
\hline \multicolumn{10}{|c|}{ Division: English Premier } \\
\hline \multicolumn{10}{|c|}{ Venue: All games } \\
\hline \multicolumn{10}{|c|}{ Analysis Date: $19 / 06 / 2014$} \\
\hline Pos & Team & $P$ & $\begin{array}{l}\text { Fouls } \\
{[\mathrm{F}]}\end{array}$ & $\begin{array}{l}\text { Fouls } \\
\text { [A] }\end{array}$ & Profile & & & & \\
\hline 15 & Aston Villa & 38 & 12.74 & 9.58 & 132.97 & & & & \\
\hline 9 & Stoke & 38 & 12.76 & 10.05 & 126.96 & & & & \\
\hline 10 & Newcastle & 38 & 10.84 & 9.63 & 112.57 & & & & \\
\hline 1 & Man City & 38 & 10.37 & 9.24 & 112.25 & & & & \\
\hline 8 & Southampton & 38 & 11.66 & 10.55 & 110.47 & & & & \\
\hline 11 & Crystal Palace & 38 & 10.63 & 10.16 & 104.66 & & & & \\
\hline 18 & Norwich & 38 & 11.16 & 10.68 & 104.43 & & & & \\
\hline 13 & West Ham & 38 & 10.58 & 10.18 & 103.88 & & & & \\
\hline 16 & Hull & 38 & 11.08 & 10.92 & 101.45 & & & & \\
\hline 6 & Tottenham & 38 & 10.61 & 10.74 & 98.77 & & & & \\
\hline 19 & Fulham & 38 & 10.08 & 10.58 & 95.27 & & & & \\
\hline 14 & Sunderland & 38 & 11.68 & 12.29 & 95.07 & & & & \\
\hline 2 & Liverpool & 38 & 10.79 & 11.37 & 94.91 & & & & \\
\hline 12 & Swansea & 38 & 9.82 & 10.34 & 94.91 & & & & \\
\hline 17 & West Brom & 38 & 11.21 & 11.95 & 93.83 & & & & \\
\hline 3 & Chelsea & 38 & 11.05 & 12.16 & 90.91 & & & & \\
\hline 20 & Cardiff & 38 & 9 & 10.03 & 89.76 & & & & \\
\hline 7 & Man United & 38 & 10.5 & 12.11 & 86.74 & & & & \\
\hline 4 & Arsenal & 38 & 9.16 & 10.76 & 85.09 & & & & \\
\hline 5 & Everton & 38 & 9.61 & 12 & 80.04 & & & & \\
\hline
\end{tabular}

Figura 41: Número de faltas de cada time por partida na Premier League de 2013/2014.

A tabela apresenta a média do número de faltas de cada time por partida na temporada de 2013/2014 da Premier League. A coluna "Fouls [F]" indica o número de faltas que o time fez e a coluna "Fouls [A]" indica o número de faltas feitas contra o time. Tomemos a primeira linha como exemplo: o Aston Villa cometeu 12.74 faltas e sofreu 9.58 faltas por partida.

Outra curiosidade pode ser observada no sétimo parágrafo da figura 39 (destacado na cor verde). O jogador Neymar foi vaiado pelos europeus devido a sua atitude de "cai-cai", ou seja, de cavar, ou simular, faltas. A reputação de "cai-cai" tem sido frequentemente atribuída a jogadores brasileiros e tem tido destaque e repercussão maiores desde o primeiro jogo da seleção Brasileira na Copa do Mundo de 2014 em que o jogador Fred simulou uma falta para conseguir um pênalti a favor do Brasil. As duas figuras abaixo, trechos de reportagens publicadas pela imprensa internacional naquele ano, ressaltam o hábito de cavar falta dos nossos jogadores e a reação de técnicos, jogadores e da própria imprensa internacional diante dessa prática: 


\section{Capítulo 4}

France's Loïc Rémy thinks Brazil striker Fred should be punished for diving

- Striker criticises former Lyon team-mate after Croatia game

Striker criticises forsimo Busacca backs Yuichi Nishimu

Press Association
The Guardian, Friday 13 June 201419.19 BST

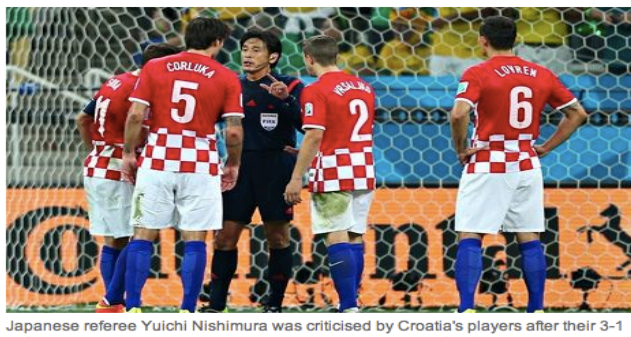

defeat to Brazil on Thursday. Phora was chtised by Croatuas playe

France's Loïc Rémy has no empathy with his former club-mate Fred and thinks he should be "punished" for the way he won a controversial

penalty in Brazi's $3-1$ win against Croatia.

Fred went down in the penalty area under light contact from defender Dejan Lovren in the 71st minute, allowing Neymar to convert a spot kick
World Cup Moments IRivaldo's sive: An 'early' instance of simulation

By OOTB Editoron on June 5, 2004 @oorB_footbal

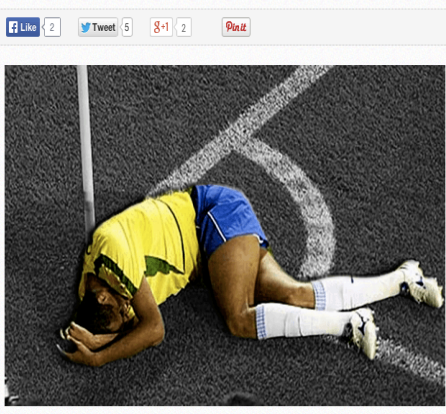

Rivaldo's headrical dive in the Group Stage of the 2002 World Cup is one of the most

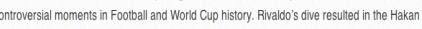
Unsal being red carded by South Korean referere Kim Young.Joo. In this article I will evaluate the ncident belore and the reacion, which sent shockwaves throughout the footbaling world and ie the Turkish fans in everassinina acoomy

Figura 42: Reportagens na imprensa internacional sobre a prática de cavar falta dos jogadores brasileiros $^{105}$.

Não se trata aqui de afirmar que somente jogadores brasileiros cavam faltas. No entanto, chamamos a atenção para a reputação que esses jogadores adquirem. Reputação, essa, que é construída pela forma-representação criada em torno do nosso futebol, de que nossos jogadores, cheios de "malandragem" e "ginga", tentam, sempre que possível, criar situações que favorecem seus times. Infelizmente, não existem estatísticas sobre o número de faltas cavadas no Brasileirão e na Premier League. Contudo, conseguimos encontrar estatísticas com os números de cartões amarelos e vermelhos atribuídos a jogadores que cavaram faltas na última temporada dos dois campeonatos. Observemos a figura 43:

\footnotetext{
${ }^{105}$ Reportagens disponíveis em: < http://www.theguardian.com/football/2014/jun/13/fifa-defendreferees-brazil-croatia $>$ e $<$ http://outsideoftheboot.com/2014/06/05/world-cup-moments-rivaldosdive-an-early-instance-of-simulation/ > . Acesso em: 19 jun. 2014.
} 
Serie A Situational Statistics

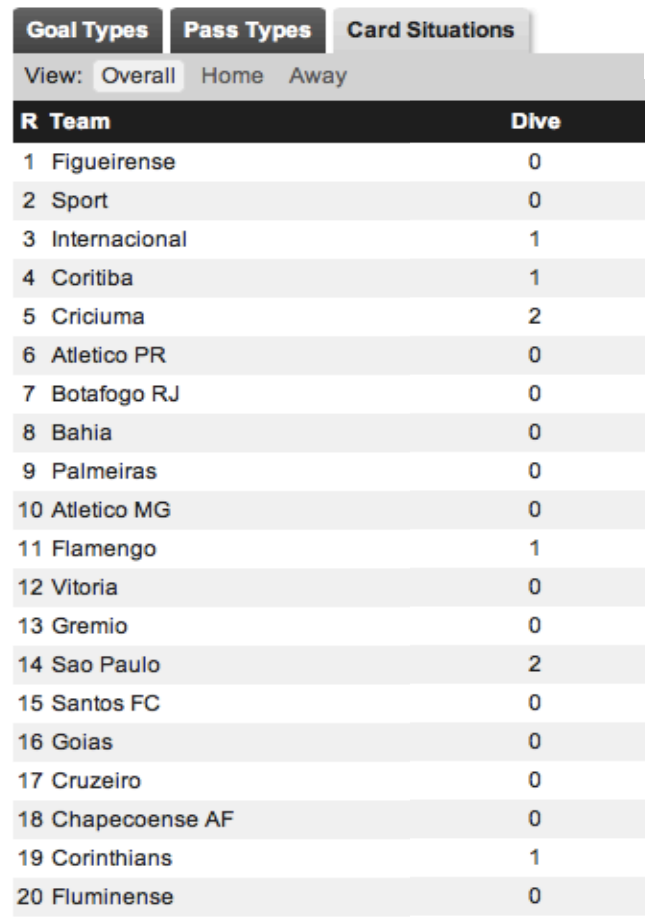

Premier League Situational Statistics

\begin{tabular}{|c|c|}
\hline Goal Types & \multirow[t]{2}{*}{ Card Situations } \\
\hline View: Overall Home Away & \\
\hline R Team & Dive \\
\hline 1 Aston Villa & 1 \\
\hline 2 West Ham & 0 \\
\hline 3 Stoke & 1 \\
\hline 4 Manchester United & 4 \\
\hline 5 Manchester City & 1 \\
\hline 6 Tottenham & 2 \\
\hline 7 Southampton & 0 \\
\hline 8 Sunderland & 1 \\
\hline 9 Norwich & 0 \\
\hline 10 Hull & 2 \\
\hline 11 Arsenal & 0 \\
\hline 12 West Bromwich Albion & 0 \\
\hline 13 Crystal Palace & 2 \\
\hline 14 Liverpool & 0 \\
\hline 15 Fulham & 1 \\
\hline 16 Chelsea & 2 \\
\hline 17 Newcastle United & 0 \\
\hline 18 Swansea & 0 \\
\hline 19 Everton & 3 \\
\hline 20 Cardiff & 1 \\
\hline
\end{tabular}

Figura 43: Número de cartões aplicados devido a faltas cavadas no Campeonato Brasileiro de 2013 e na Premier League 2013/2014.

Pode-se observar que durante o Campeonato Brasileiro de 2013 foram aplicados oito cartões devido a faltas cavadas, ao passo que na Premier League foram 21 cartões. Em um primeiro momento, surpreendemo-nos com o baixo número de aplicações no Brasileirão, dada a fama de nossos jogadores. No entanto, após ler mais reportagens, principalmente em jornais ingleses, sobre o ato de cavar faltas, percebemos que tal atitude é vista de forma muito mais negativa na Inglaterra do que no Brasil, fato que podemos comprovar pelos adjetivos que frequentemente coocorrem com dive em inglês: blatant [espalhafatoso], dodgy [suspeito], shocking [escandaloso], terrible [terrível] e clear [claro]. Em português, não encontramos nenhum colocado significativo para o verbo 'cavar'; identificamos, no entanto, alta ocorrência do adjetivo 'duvidoso', tanto com 'falta' quanto com 'pênalti'. Esses achados e inúmeros 'bate-papos' com os membros do LUDENS nos levam a concluir que, apesar de os juízes apitarem faltas mais frequentemente no Brasil do que na Inglaterra, a tolerância de simulações em campo é maior em nosso país.

Por fim, uma última especulação para o maior número de faltas no 


\section{Capítulo 4}

Campeonato Brasileiro está intrinsecamente ligada ao processo histórico do futebol no Brasil. Em nossas conversas com historiadores do grupo Ludens, foi levantada a hipótese de que a tradição autoritária da sociedade brasileira influenciou de forma direta o papel atribuído à figura da autoridade no futebol - o árbitro -, e o revestiu de mais poder do que em outros países. Além disso, a importância dada a faltas e pênaltis no futebol brasileiro parece ser maior do que no futebol inglês. Tomemos, por exemplo, o pênalti cavado pelo jogador Fred na partida Brasil 3 x 0 Croácia pela fase de grupos da Copa do Mundo de 2014. Na transmissão da rede Globo, o lance foi reprisado sete vezes até o final do jogo, ao passo que na transmissão realizada pelo site football.uk o lance foi reprisado somente uma vez. Ou seja, embora a atitude seja menos aceita na Inglaterra e, digamos, mais tolerada no Brasil, a TV brasileira reprisou o lance exaustivamente. $\mathrm{O}$ mesmo aconteceu nas transmissões minuto a minuto nos jornais brasileiros, que discutiram, durante toda a transmissão, a atitude do jogador, enquanto os jornais ingleses que mencionaram o lance teceram alguns comentários e não retomaram o assunto até o final da transmissão.

A prática de discutir exaustivamente esse tipo de lance interfere, de forma direta, na ocorrência do termo em questão nas duas línguas. Para finalizar, atentamos para o fato de que o chamado comentarista de arbitragem, que tece comentários sobre o desempenho do juiz, parece ser uma figura típica brasileira. Segundo os historiadores do LUDENS, tal constatação sustenta a ideia de que o autoritarismo, que está presente em vários capítulos da história do Brasil, também se manifesta no futebol, já que não encontramos a presença desse tipo de comentarista nas transmissões inglesas, ao menos no que tange às on-line.

Enfim, o estudo de caso do termo 'falta' em português e seus equivalentes em inglês, assim como o estudo de 'fazer/marcar um gol', demonstrou como os jeitos de jogar são frutos de adaptações culturais que cada país faz das regras do jogo. O próximo estudo de caso mostra a problemática da tradução dos diversos tipos de passes.

\section{3 drible da vaca}

É fato que a arte do drible encanta os apaixonados por futebol e, como diria 


\section{Capítulo 4}

Dener, ex-jogador do Vasco e da Portuguesa, falecido em 1994, “[...] o drible é mais bonito que o gol". Também é fato que jogadores brasileiros são conhecidos pela ginga e pela excelente habilidade de driblar. Não queremos entrar, aqui, no mérito desse reconhecimento, mas acreditamos importante ressaltar essa "forma-representação" do jogador e, consequentemente, do futebol brasileiro no plano imaginário dos amantes do futebol.

Mas, afinal, como e onde surgiu o drible? Estaria ele presente desde os primórdios do jogo? Ou teria sido criado posteriormente?

Infelizmente, nesta pesquisa não responderemos as perguntas acima, pois foge do escopo deste trabalho. No entanto, trazemos para nossa discussão uma hipótese compartilhada por alguns estudiosos do futebol: a de que o drible, na forma como é conhecido hoje, é invenção brasileira. Para melhor compreender essa hipótese, retomamos um importante aspecto da história do futebol no Brasil: o negro no futebol.

No Brasil, os jogadores negros foram alvo de preconceito desde o início e não tiveram espaço nos times até a década de 1930 (FILHO, 1964), quando começaram a ganhar espaço no esporte. Contudo, o tratamento despendido aos "canelas negras" pelos juízes era diferente daquele empregado com os jogadores brancos. Segundo Soares (1999, p. 134-135), os negros não podiam derrubar, empurrar e nem mesmo esbarrar em jogadores brancos sem serem punidos severamente. Há registros de casos em que policiais podiam bater no infrator. Dada essa situação, uma hipótese bastante popular é a de que os jogadores negros tiveram que criar meios alternativos para se movimentar em campo sem que fossem punidos. Para tanto, passaram a fazer uso de movimentos corporais que até então não eram populares no futebol. Segundo Mário Prata $^{106}$, o drible é uma forma de transposição dos passes e ginga do samba para o jogo.

Discutir a validade da hipótese apresentada acima foge do escopo desta pesquisa. Contudo cremos que possa ser utilizada como uma possível justificativa para o maior número de ocorrências de dribles no subcorpus de português. Estamos cientes do fato de que essa é apenas uma justificativa e de que outros fatores, como a própria forma-representação que os narradores e jornalistas esportivos constroem do

${ }^{106}$ Mário Prata é escritor, dramaturgo, jornalista e cronista. 


\section{Capítulo 4}

nosso futebol, podem influenciar o número de ocorrências no corpus, já que os textos produzidos por esses sujeitos tendem a refletir a forma-representação em seus imaginários. Na verdade, acreditamos que a hipótese de o drible ter sido inventado no Brasil só contribui para compreender o porquê do maior número de ocorrências no subcorpus em português, pois, ao ler sobre a história do futebol na Inglaterra, constatamos narrativas e descrições de dribles em diversas obras que retratam períodos que antecedem a década de 1930. Ou seja, a maior frequência no subcorpus em português pode ser justificada pela importância que nossos jornalistas esportivos dão aos dribles, sempre enfatizando as "firulas" dos jogadores com a bola.

Um ponto a ser feito em nossa pesquisa é a diferença entre 'drible' e 'jogada'. Distinguir os dois termos foi mais difícil do que prevíamos. Nos dicionários existentes, a definição dos dois termos é muito parecida e os especialistas com quem conversamos não entraram em consenso sobre as características que definem uma jogada ou um drible. A maior parte dos especialistas consultados considera o "corte seco" um drible. Em nossa pesquisa, definimos jogada como um ato que tem um objetivo, geralmente o gol ou o ato de impedir o gol (por exemplo, uma bola cruzada para o atacante marcar); e drible como um ato que tem o fim em si mesmo, ou seja, seu único objetivo é driblar o adversário, ainda que possa fazer parte de uma jogada. Nesse sentido, um corte seco pode ser um drible com fim em si mesmo ou pode fazer parte de uma jogada.

Exposta a definição de 'drible', passemos ao estudo de caso de um drible que chamou atenção: o 'drible da vaca'. Esse drible, em que o jogador toca ou chuta a bola para um lado do adversário e corre para buscá-la pelo outro, possui 27 ocorrências em nosso corpus em português. Também conhecido como 'meia-lua'107 e 'gaúcha'108, o 'drible da vaca' é um dos mais populares do futebol. Talvez sua ocorrência não seja muito alta devido à própria dificuldade de execução, pois exige bastante desenvoltura por parte do jogador.

Parece importante enfatizar que 'drible da vaca' não faz parte das palavraschave do corpus. Chegamos ao termo por meio da análise das linhas de concordâncias

\footnotetext{
${ }^{107}$ Encontramos uma ocorrência de "meia-lua" em nosso corpus.

108 "Gaúcha" não apresenta nenhuma ocorrência em nosso corpus. Validamos o termo como sinônimo de "drible da vaca" após ler artigos sobre a origem do nome do drible que mencionavam o termo "gaúcha" como sinônimo menos frequente.
} 


\section{Capítulo 4}

de 'drible'. Portanto, para encontrar o equivalente de 'drible da vaca', realizamos um procedimento diferente. Imaginamos que a tradução prima facie de 'vaca' não nos ajudaria, e já tínhamos analisado previamente os colocados de dribble sem encontrar um possível equivalente. Sabíamos também que o 'drible da vaca' mais famoso da história foi o que Pelé aplicou no goleiro Mazurkiewicz, do Uruguai, na Copa do Mundo de 1970. Decidimos, então, realizar uma pesquisa no Google com as seguintes palavras: Pelé, “World Cup” e Mazurkiewicz. A figura 44 mostra o resultado parcial da busca:

Web Imagens Videos Notícias Shopping Mais $~$
Aproximadamente 35.800 resultados $(0,71$ segundos $)$

Dica: Pesquisar apenas resultados em português (Brasil). Especifique seu idioma de pesquisa em Preferências

Drible de Pelé - Wikipédia, a enciclopédia livre pt.wikipedia.org/wiki/Drible_de_Pelé -

Drible de Pelé, ou Drible do Pelé foi um histórico drible de corpo que Pelé aplicou no ... Este drible também é alvo de análise no livro "Scientific Soccer in the ... ex-goleiro Mazurkiewicz morre no Uruguai; $\uparrow$ World Championship - Jules Rimet ...

Ladislao Mazurkiewicz - Wikipedia, the free encyclopedia en.wikipedia.org/wiki/Ladislao_Mazurkiewicz - Traduzir esta página Full name, Ladislao Mazurkiewicz Iglesias ... He was elected the best goalkeeper of that tournament. He also ... 1970 FIFA World Cup Team of the Tournament.

Remembering Ladislao Mazurkiewicz - Pele's Uruguayan ... sabotagetimes.com/football/remembering-ladislao-m... - Traduzir esta página 03/01/2013 - Mazurkiewicz had no problem talking about being Pele's dummy in that World Cup semi final. ... The Six Greatest Sides To Never Win A World Cup ... the best goalie of that World Cup (Gordon Banks was a close second).

World Cup moments: Pele's dummy - BBC

www.bbc.co.uk/sport/0/football/26444573 - Traduzir esta página 04/04/2014 - BBC Sport counts down 100 of the greatest World Cup moments, as the ... when he sells Uruguay goalkeeper Ladislao Mazurkiewicz a clever ...

Former Uruguay goalkeeper Mazurkiewicz dies at 67 uk.mobile.reuters.com/.../idUKBRE9010IT2013010... - Traduzir esta página 02/01/2013 - (Reuters) - Former Uruguay goalkeeper Ladislao Mazurkiewicz, once ... Mazurkiewicz also played at the 1966 World Cup in England, where he ... stroke of genius by Pele at the 1970 World Cup when he came out towards the ...

Figura 44: Resultado parcial da busca no Google por 'Pelé', 'World Cup' e 'Mazurkiewicz'.

A terceira e a quarta ocorrências chamaram a atenção, pois utilizam a palavra dummy para descrever o drible que Pelé deu no goleiro do Uruguai. A palavra em 


\section{Capítulo 4}

inglês, que pode ser utilizada para se referir a uma pessoa pouco inteligente ${ }^{109}$, é utilizada, no futebol, para descrever dribles de forma geral. Entramos nos sites das duas ocorrências e constatamos que dummy foi o termo utilizado para descrever o drible requintado de Pelé. Para validar dummy como equivalente de 'drible da vaca', realizamos uma busca com 'Pelé' e 'dummy' no YouTube, que nos retornou o momento histórico da 'meia-lua' de Pelé em cima do uruguaio. Além disso, utilizamos 'campeonato inglês' e 'drible da vaca' como palavras-chave no Google a fim de encontrar jogos do campeonato inglês em que tivesse ocorrido um 'drible da vaca'. Selecionados alguns jogos (6), buscamos no site Football.com e no jornal The Guardian o relatório das partidas, lemos as notícias procurando pela descrição do drible e, para nossa satisfação, o termo dummy foi utilizado como equivalente de 'drible da vaca' nos quatro relatórios em que o drible foi descrito. Sendo assim, validamos dummy como equivalente de 'drible da vaca'.

Oooh! Neymar tried the Pele no-touch dummy 1970 trick against Espanyol, but got cynically taken out by the keeper! $!^{110}$

Esse é um clássico caso em que um termo ou CLE tem um significado idiomático, ou seja, um significado que não pode ser inferido a partir da língua geral, em somente uma das línguas, nesse caso, no português.

Desvendar a origem de expressões idiomáticas é sempre um desafio; no entanto, encontramos inúmeras narrativas de que nos primórdios do futebol brasileiro as partidas eram jogadas em campos improvisados, muitas vezes em pastos. Por esse motivo, os jogadores frequentemente precisavam driblar as vacas que invadiam o campo para comer.

No dia 14 de abril de 1885, Charles Miller reuniu um grupo de ingleses radicados em São Paulo, funcionários da São Paulo Railway e da Companhia de Gás, em um terreno na chamada Várzea do Carmo, para jogar a primeira partida de futebol de que se tem registro no Brasil. Segundo o historiador John Mills, autor da biografia

\footnotetext{
${ }^{109}$ Seleção da acepção da definição de dummy aqui utilizada retirada do Collins Dictonary: (slang) a stupid person; fool. Disponível em: http:/www.collinsdictionary.com/dictionary/english/dummy?showCookiePolicy=true $>$. Acesso em: 4 ago. 2015.

110 Disponível em: < http:/www.101greatgoals.com/blog/oooh-neymar-tried-the-pele-no-touchdummy-1970-trick-against-espanyol-but-gets-taken-out-by-keeper/ >. Acesso em: 8 jan. 2015.
} 


\section{Capítulo 4}

de Charles Miller, o campo era improvisado, os jogadores delimitaram um retângulo e tiraram as vacas que pastavam no lugar. No entanto, a partida foi continuamente interrompida pelos animais à procura de grama. Dessa forma, os jogadores deviam driblar não só seus adversários, mas também as vacas que invadiam o campo.

O drible, praticado desde a introdução do futebol no Brasil, popularizou-se com o ídolo do futebol, Mané Garrincha, que dizia ter perdido a conta das vezes que teve que driblar vacas nos campos improvisados em Pau Grande, sua terra natal no estado do Rio de Janeiro.

Como mencionado anteriormente, desvendar a origem de termos e CLEs é tarefa bastante complexa. No entanto, os relatos apresentados contribuem de forma significativa para nossa premissa de que a terminologia do futebol foi influenciada por fatores históricos e culturais. O 'drible da vaca' é um bom exemplo. Após estudar a história do futebol na Inglaterra, acreditamos que fato semelhante - driblar vacas em um campo - não acontecia nas escolas públicas, onde o esporte era praticado. Por esse motivo, sua tradução literal não teria sentido em inglês.

\section{4 fazer cera}

Analisando a lista de palavras-chave do subcorpus de português encontramos o verbo 'fazer', com 527 ocorrências, e nos perguntamos se esse verbo poderia fazer parte de uma CLE que não 'fazer um gol'. Levantamos, então, as linhas de concordância desse lema e chegamos à CLE 'fazer cera':

Fluminense joga na retranca, consegue fazer um gol no contra-ataque, passa o jogo todo fazendo cera, mas não consegue ganhar do Botafogo. ${ }^{111}$

Após achar que o goleiro estava fazendo cera, o atacante do Arsenal discutiu asperamente com ele. ${ }^{112}$

Visivelmente exaustos, os chilenos tentaram ganhar tempo, fazendo cera para forçar a

\footnotetext{
${ }^{111}$ Disponível em: < http://jblog.jb.com.br/botafogo/2013/01/ > Acesso em: 12 set. 2014.

${ }^{112}$ Disponível em: $<$ http://esportes.terra.com.br/futebol/goleiro-que-classificou-a-holanda-a-semifinalestreou-profissionalmente-pela-selecao-contra-obrasil,be05b5f9db807410VgnCLD200000b2bf46d0RCRD.html > Acesso em: 2 fev. 2015.
} 


\section{Capítulo 4}

decisão nos pênaltis. A torcida percebeu e soltou gritos de "timinho!"113

A expressão, que significa demorar de forma proposital para fazer algo, é utilizada no futebol quando o goleiro ou um jogador retarda a reposição da bola, simula contusões ou troca passes estéreis fazendo passar o tempo.

A ideia de que a expressão tenha surgido como referência à falta de produtividade dos vereadores, que sempre tiveram uma reputação de trabalhar pouco, é compartilhada por muitos. Isso porque quando o cargo de vereador foi instituído no Brasil, os vereadores eram remunerados com cera, produto de alto valor na época. Como apresentavam baixa produtividade e frequentemente protelavam decisões, o povo dizia que os vereadores não trabalhavam, mas apenas se apresentavam ao local de trabalho para 'fazer cera', ou seja, ganhar o pagamento. Quando o futebol foi instituído no Brasil, a expressão passou a ser utilizada com frequência para descrever um momento da partida em que um dos times tentava praticar o antijogo, ou seja, impedir ou retardar o andamento da partida.

A hipótese acima parece bastante plausível; no entanto, assim como em relação às outras expressões, não podemos confirmar sua veracidade com base em relatos. Ainda assim, ressaltamos a importância dessas hipóteses para a construção do significado de alguns termos.

Ao ler textos na internet sobre o possível surgimento da expressão, descobrimos que o termo 'cozinhar' ${ }^{114}$ pode ser utilizado como sinônimo de 'fazer cera':

Com os minutos se passando e o Corinthians "cozinhando" a partida, os nervos dos jogadores foram à flor da pele. E ai a partida ganhou verdadeiro ar de Libertadores. Neymar fez falta feia e levou amarelo. Emerson revidou na mesma moeda e foi expulso. $O$ Corinthians aproveitou a queda de luz para segurar o jogo e contou com mais uma ótima partida de Cássio para segurar o placar e levar a vantagem para o Pacaembu.

O dicionário Caldas Aulete on-line apresenta sete definições para o verbo

\footnotetext{
113 Disponível em: < http://esportes.terra.com.br/futebol/copa-2014/nas-maos-de-julio-cesar-brasilavanca-as-quartas-em-jogo-dramatico,b6f86aa6ff3e6410VgnCLD200000b2bf46d0RCRD.html

Acesso em: 2 fev. 2015.

${ }^{114}$ Não encontramos no corpus nenhuma ocorrência do termo. No entanto, decidimos incluí-lo em nosso dicionário uma vez que a pesquisa com 'cozinhar' ou 'cozinhando' e 'futebol' que realizamos no Google retornou um número relativamente alto de ocorrências em que o verbo era utilizado com o sentido de retardar o jogo.
} 


\section{Capítulo 4}

cozinhar $^{115}$, sendo uma delas:

- Pop. Ir levando (alguém, algo) na conversa, protelando ou evitando ação decisiva; EMBROMAR; ENROLAR [td. : O locatário ia cozinhando o proprietário para adiar o pagamento.: Cozinhavam o jogo, esperando o apito final.] [int. : Os jogadores cozinhavam, prendiam a bola, para garantir o placar.]

Assim como 'fazer cera', 'cozinhar', expressão utilizada na língua geral, passou a ser utilizada no futebol e manteve o mesmo sentido que a primeira.

Cientes do contexto histórico em que 'fazer cera' possivelmente surgiu, inferimos, de antemão, que a tradução prima facie não funcionaria em inglês. Por esse motivo, geramos linhas de concordância para time (tempo), aplicamos o recurso resort para ordenar as ocorrências pelas três palavras à esquerda e encontramos três ocorrências de stall for time. Observemos os exemplos:

17 min: The Nou Camp is a cauldron of whistles, as though this is an attempt to stall for time. As though Arsene Wenger's grand plan was "let's all pretend to be hurt until we're allowed into the next round." And here's some cheery news... ${ }^{116}$

No they didn't! Croatia can thank the ref for allowing Pletikosa to stall for time again and again and again and again and again! $!^{117}$

Even the fucking ball boys are helping the stall for time. ${ }^{118}$

Após analisar a CLE em contexto e conduzir uma busca no Google para 'stall* for time', validamos a expressão como equivalente de 'fazer cera'. A figura 45 mostra a definição do verbo stall no freedictionary.com:

\section{stall 1 (stôl)}

\section{$v$. stalled, stall $\cdot$ ing, stalls}

v.tr.

1. To put or lodge in a stall.

2. To maintain in a stall for fattening: to stall cattle.

\footnotetext{
${ }_{115}^{115}$ Disponível em: http://www.aulete.com.br/cozinhar >. Acesso em: 22 jul. 2014.

116 Disponível em: < http:/www.telegraph.co.uk/sport/football/competitions/championsleague/8369085/Barcelona-v-Arsenal-as-it-happened.html?service=artBody $>$. Acesso em: 11 jan. 2014.

${ }^{117}$ Disponível em: < http://www.fifa.com/worldcup/news/y=2012/m=9/news=belgium-croatia-sharespoils-1699888.html $>$. Acesso em: 6 jan. 2015.

118 Disponível em: < http://sonsofsamhorn.net/topic/84284-world-cup-quarterfinals-day-1francegermany-brazilcolombia/page-9 >. Acesso em: 6 jan. 2015.
} 
3. To halt the motion or progress of; bring to a standstill.

4. To cause (a motor or motor vehicle) accidentally to stop running.

5. To cause (an aircraft) to go into a stall.

v.intr.

1. To live or be lodged in a stall. Used of an animal.

2. To stick fast in mud or snow.

3. To come to a standstill

4. To stop running as a result of mechanical failure: The car stalled on the freeway.

5. To lose forward flying speed, causing a stall. Used of an aircraft.

Figura 45: Definição de stall como verbo no freedictionary.com ${ }^{119}$.

Se observarmos os significados apresentados para stall como verbo intransitivo, conseguimos inferir, sem grandes dificuldades, o significado de stall for time em uma partida de futebol. Estamos diante de mais um caso de expressão idiomática em português que apresenta um equivalente não idiomático em inglês.

Além da idiomaticidade da CLE em português e da transparência do seu significado em inglês, o número de ocorrências das CLEs difere bastante nas duas línguas: 38 em português e apenas três em inglês. Novamente, recorremos ao conceito forma-representação para entender essa diferença. Partimos do pressuposto de que talvez os jogadores brasileiros façam mais cera do que os jogadores europeus, sobretudo os ingleses. Decidimos, então, fazer uma busca no Google para 'fazer cera' a fim de encontrar algum texto explicativo que discuta essa prática e encontramos vários posts de blogs sobre futebol. Dentre eles, destacamos um post ${ }^{120}$ do blog “Olhar Crônico Esportivo”, do GloboEsporte.com, escrito por Emerson Gonçalves, cronista e amante do futebol:

Todo time faz cera, todo ou quase todo jogador faz cera, assim como todos os treinadores, ou quase todos, mandam seus atletas fazerem cera. É uma tremenda falta de fair play, que aliás é outro procedimento hoje deturpado: a gentileza humanitária é transformada em retardo do jogo e da jogada, na quase totalidade das vezes.

Há outro fator que deve ser associado a essas duas práticas: a encenação de tragédia em que é mestre o boleiro brasileiro, a simulação, a atitude deliberada de levar a arbitragem ao erro. Se um adversário encosta o braço no peito de outro, esse

\footnotetext{
${ }^{119}$ Disponível em: http://www.thefreedictionary.com/stall Acesso: 22 jul. 2014

120 Texto integral disponível em: http://globoesporte.globo.com/platb/olharcronicoesportivo/2011/08/17/a-irritante-e-aetica-cera/ $>$. Acesso em: 10 maio 2014.
} 


\section{Capítulo 4}

imediatamente se faz de vítima, levando as mãos ao rosto e protagonizando cena digna de Hollywood naqueles filmes meio bestas de pancadaria solta.

A bola, coitada... Fica esquecida no gramado.

[…].

Tudo isso até existe na Europa, mas num grau muito menor que aqui. E sempre que há um desrespeito desse tipo, seu autor é vaiado pelo público e criticado pelos companheiros de profissão. Quem deve ser enganado num jogo é o adversário através da finta, do drible, do olhar malandro, não a arbitragem e o público.

Como podemos observar, a forma-representação influencia os termos presentes no corpus bem como sua frequência. Por exemplo, se partirmos do princípio de que a apropriação e a interpretação cultural que cada região faz das regras que determinam as 'formas de jogo', e que, quando justapostas, as regras e as 'formas de jogo' dão origem às “representações”, ou seja, nossa observação das formas de jogo, entenderemos o motivo pelo qual 'fazer cera' é muito mais frequente no corpus de português do que stall for time no subcorpus em inglês. O jogador brasileiro sempre foi conhecido como jogador "malandro" e "cheio de malícia" desde os primórdios do futebol no Brasil. Dessa forma, ao interpretar as regras, inseriu, no jogo, a malandragem a ser utilizada a seu favor quando necessário; nesse caso, para atrasar o jogo quando lhe convém.

Por outro lado, o jogador inglês, que aprendeu o futebol nas escolas como parte do cristianismo atlético, que, como mencionado anteriormente, tinha como objetivo principal moldar o caráter da nova elite inglesa por meio de práticas esportivas, não se mostra adepto do antijogo e valoriza mais o fair-play (jogo limpo).

\section{5 técnico; treinador}

Uma análise do léxico do futebol, que compreende termos culturais, não poderia deixar de fora dois termos bastante frequentes em nosso corpus: técnico (896) e treinador (239). Analisamos as ocorrências e constatamos que os dois termos são utilizados como sinônimos. Tomemos os exemplos abaixo: 


\section{Capítulo 4}

Com a partida se encaminhando para seus minutos finais, o técnico Muricy Ramalho sacou Felipe Anderson e "Patito" Rodríguez, lesionado, para as entradas de Bernardo e João Pedro, respectivamente. ${ }^{121}$

Na volta para a etapa complementar, o treinador Muricy Ramalho trocou Giva por André, no Santos. No São Caetano, Martine sacou Pirão, que havia recebido cartão amarelo no primeiro tempo, para a entrada de Rogério. ${ }^{122}$

Os dois exemplos foram retirados do mesmo site, que utiliza os dois termos para fazer referência ao profissional responsável pelo treinamento da equipe. O dicionário on-line Caldas Aulete não apresenta uma definição no domínio esportivo para 'técnico', termo mais frequente no corpus, mas apresenta uma definição para ‘treinador' e apresenta ‘técnico’ como sinônimo:

(trei.na.dor) [ô]

a.

1. Diz-se de profissional que treina, que ensina; ADESTRADOR: profissional treinador de cavalos.

sm.

2. Esse profissional; TÉCNICO: O treinador exigiu o máximo do time.

[F.: De treinar + -dor. Sin.ger.: instrutor] 123

Dada a ausência de paradigma definicional para o termo nessa obra, consultamos o dicionário on-line Michaelis ${ }^{124}$, que apresenta a seguinte definição:

técnico

téc.ni.co

adj (gr tekhnikós, de tekhné) 1 Relativo a uma arte ou ramo especifico de atividade. 2 Que tem técnica. sm 1 Aquele que é perito ou versado numa atividade: $O$ parecer dos técnicos. 2 Esp Treinador de um conjunto esportivo. T. de rádio: $V$ radiotécnico.

Após analisar as ocorrências no corpus e as definições apresentadas pelos dois dicionários, validamos 'técnico' e 'treinador' como sinônimos; passamos, então, à busca de seus equivalentes em inglês. Nesse caso específico, utilizamos 'validar', e não 'estabelecer', uma vez que já tínhamos dois candidatos a equivalentes.

A tarefa de compilar um corpus é, em geral, bastante laboriosa e demanda um

121 Disponível em: < http://www.acervosantista.com.br/tag/flamengo/ > . Acesso em: 21 jan. 2015.

122 Disponível em: < http://www.acervosantista.com.br/tag/neymar/ > . Acesso em: 21 jan. 2015.

123 Disponível em: < http://www.aulete.com.br/treinador\#ixzz3PQ7hJMyw > Acesso em: 21 jan. 2015.

124 Disponível em: < http://michaelis.uol.com.br/moderno/portugues >. Acesso em: 21 jan. 2015. 


\section{Capítulo 4}

período significativo da pesquisa. No entanto, além de ser essencial para a extração terminológica, contribui de forma significativa para que o pesquisador aprofunde seu conhecimento no tema de pesquisa. Durante a seleção dos textos do corpus fizemos também a leitura das notícias. Às vezes, lemos o texto integral, outras, somente alguns trechos. Essa prática ajuda, indiretamente, na identificação de equivalentes, pois o pesquisador familiariza-se mais com a língua de especialidade com a qual trabalha à medida que coleta os textos. No caso de 'técnico' e 'treinador', utilizamos o corpus somente para validar a hipótese levantada durante a compilação do corpus. Após um ano coletando textos de resultados de partidas do Campeonato Inglês, que frequentemente discutem a importância e as atitudes dos 'técnicos' para o resultado de uma partida, chegamos aos termos manager e coach como possíveis equivalentes tradutórios.

No corpus, encontramos 96 ocorrências de manager e quatro de coach, todas fazendo referência ao treinador de uma equipe. A primeira pergunta que nos ocorreu foi: será o número de ocorrências a única diferença entre os dois termos?

Para responder à pergunta, ampliamos as linhas de concordância de modo a ter acesso ao texto integral e melhor entender o contexto em que os termos são utilizados. Abaixo apresentamos três ocorrências de manager e uma ocorrência de coach referindo-se a David Moyes, técnico do clube Manchester United na temporada de 2013-2014:

Manchester United manager David Moyes: "To be two down and come back to win is a great result. I thought it would be a long road back but these players have done this in the past and we did well to get back in the game. For us to get in at half-time 2-2 was great but when we were at 3-2 Hull gave us a few scary moments. However, I'd take that after being 2-0 down after 10 minutes. ${ }^{125}$

It was another sobering and thoroughly miserable night for United manager David Moyes as, for the second home league game in succession, the current gap in quality and strength between the reigning champions and their rivals was emphasised as City followed Liverpool by winning 3-0 and with plenty to spare. ${ }^{126}$

After this latest stumble at home, United manager David Moyes presented his own

\footnotetext{
${ }^{125}$ Disponível em: < http://www.premierleague.com/en-gb/matchday/matches/2013-2014/epl.html/hullvs-man-utd >. Acesso em: 21 jan. 2015.

${ }^{126}$ Disponível em: < http://www.bbc.com/sport/0/football/26624110 >. Acesso em: 21 jan. 2015.
} 


\section{Capítulo 4}

assessment: 'We played well,' he said. ${ }^{127}$

'Dinoasaur coach' David Moyes reveals Robin van Persie is fit and ready to go - despite criticism of 'Jurassic' training methods ${ }^{128}$

Os três primeiros exemplos utilizam manager para descrever a função ${ }^{129} \mathrm{de}$ David Moyes no clube. O quarto exemplo utiliza o termo coach para avaliar uma decisão de Moyes e questionar seus métodos de treinamento e táticas. Observemos um trecho maior do texto:

'Dinoasaur coach' David Moyes reveals Robin van Persie is fit and ready to go - despite criticism of 'Jurassic' training methods

David Moyes today confirmed Robin van Persie is fit to play some part in tomorrow's friendly with Cerezo Osaka - the ideal riposte to criticism that his training methods are out of "Jurassic Park".

Van Persie was taken off as a precaution during Tuesday's defeat in Yokohama after feeling a tightness in his thigh". ${ }^{130}$

Lendo o trecho acima, observamos que coach é utilizado para enfatizar a função do técnico de preparar e treinar os jogadores para as partidas, bem como de desenvolver a tática de jogo. Em seguida, geramos linhas de concordância para as outras três ocorrências de coach no corpus. Vejamos os contextos em que o termo ocorre:

Coach Steve Bruce will use his strikers Jelavic and Long once again, after being out for the Cup game, while the team continues to miss goalkeeper McGregor (25/0), defender McShane (9/0) and offensive midfielder Brady (18/3). ${ }^{131}$

Sunderland coach Gustavo Poyet will do some soul-searching to ensure there is no repeat of Saturday's sloppy start at Old Trafford on Wednesday ${ }^{132}$

\footnotetext{
${ }^{127}$ Disponível em: < http://www.dailymail.co.uk/sport/football/article-2531800/Manchester-United-1Tottenham-2-Adebayor-Eriksen-target-halt-Moyes-revival.html >. Acesso em: 21 jan. 2015.

${ }^{128}$ Disponível em: < http://www.independent.co.uk/sport/football/premier-league/dinoasaur-coachdavid-moyes-reveals-robin-van-persie-is-fit-and-ready-to-go--despite-criticism-of-jurassic-trainingmethods-8731465.html >. Acesso em: 21 jan. 2015.

${ }^{129}$ As responsabilidades do manager são apresentadas na figura 46.

${ }^{130}$ Disponível em: < http://www.independent.co.uk/sport/football/premier-league/dinoasaur-coachdavid-moyes-reveals-robin-van-persie-is-fit-and-ready-to-go--despite-criticism-of-jurassic-trainingmethods-8731465.html >. Acesso em: 21 jan. 2015.

${ }^{131}$ Disponível em: < http://www.betshoot.com/betting-previews/hull-vs-arsenal/ >. Acesso em: 21 jan. 2015.

${ }^{132}$ Disponível em: < http:/www.thejournal.co.uk/sport/football/football-news/gus-poyet-repeatsaturday-non-starter-6528056 > . Acesso em: 21 jan. 2015.
} 


\section{Capítulo 4}

Similarly, the approach adopted by both Mourinho and Ancelotti could easily be seen as a derivative of the now discredited philosophy advocated by the much-maligned and despised British coach Charles Hughes, whose long-ball theories dominated the English game in the 1980s. ${ }^{133}$

Ao analisar os trechos acima, nossa hipótese pôde ser comprovada. Ainda assim, recorremos ao Google para buscar definições de manager e coach. Analisamos as definições apresentadas por vários dicionários on-line, dentre eles Collins Cobuild $^{134}$, Macmillan Dictionary ${ }^{135}$ e The Free Dictionary ${ }^{136}$. Apesar de serem dicionários renomados, foi a Wikipedia.com que apresentou a definição mais completa:

\footnotetext{
${ }^{133}$ Disponível em: $<$ http://www.dailypost.co.uk/sport/sport-opinion/barry-horne-jose-mourinhotactics-7052954 >. Acesso em: 21 jan. 2015.

${ }^{134}$ Disponível em: < http://www.collinsdictionary.com/dictionary/english $>$. Acesso em: 21 jan. 2015.

${ }^{135}$ Disponível em: $<$ http://www.macmillandictionary.com >. Acesso em: 21 jan. 2015.

${ }^{136}$ Disponível em: $<$ http://www.thefreedictionary.com $>$. Acesso em: 21 jan. 2015.
} 


\section{Manager (association football)}

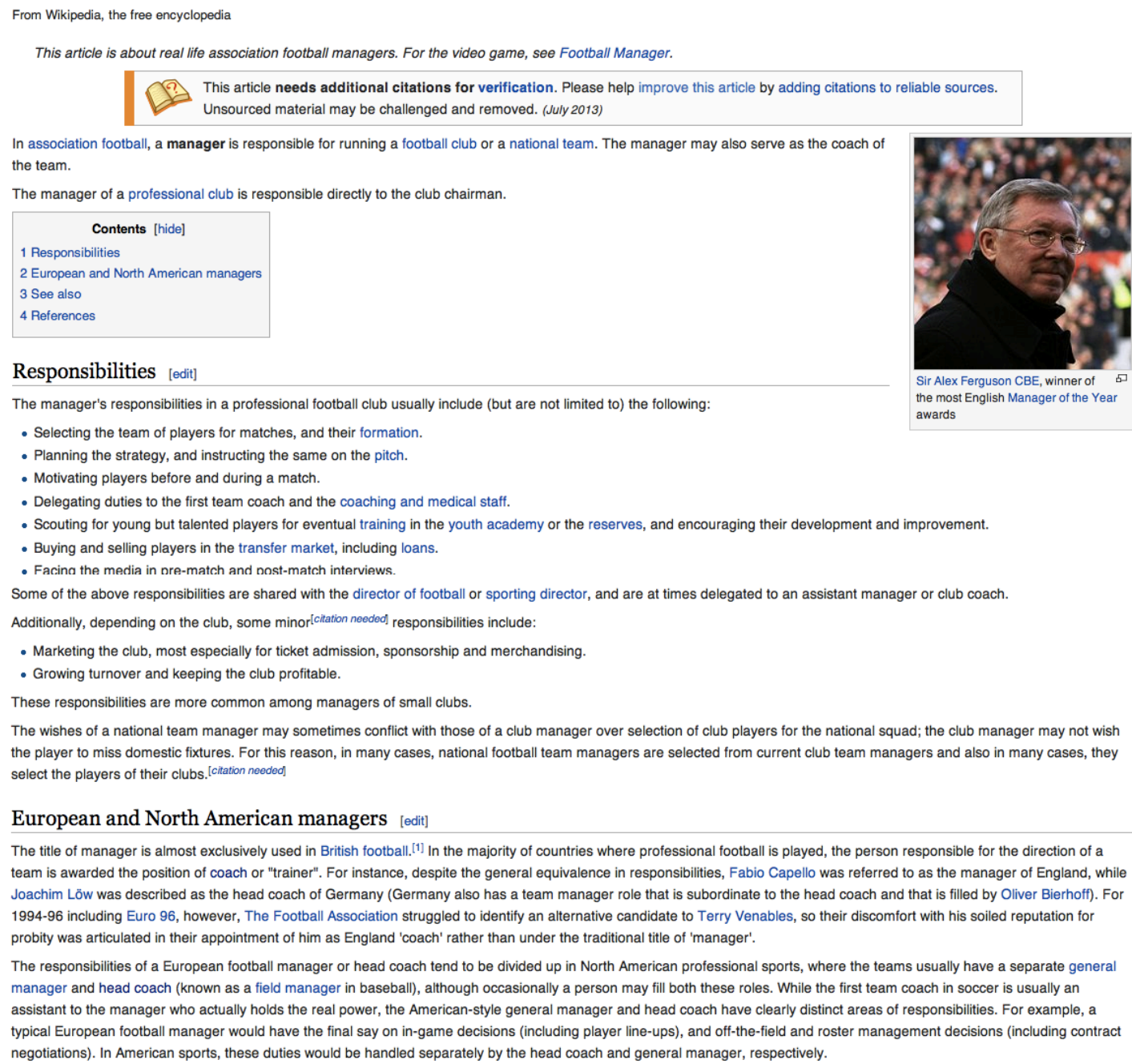

Figura 46: Definição de manager apresentada pela Wikipedia ${ }^{137}$.

A definição da Wikipedia elenca as principais responsabilidades de um manager, que incluem: montar o time para as partidas; planejar a estratégia e a tática de jogo; instruir os jogadores em campo; motivar os jogadores antes e durante a partida; delegar as tarefas para os outros membros da comissão técnica; selecionar novos talentos para jogar nas categorias de base do time; comprar e vender jogadores; e lidar com a mídia nas entrevistas antes e depois das partidas. Dependendo do clube, o manager pode assumir outras responsabilidades, como, por exemplo, fazer o marketing do clube, lidando com patrocínios e propagandas e, até mesmo, gerenciar as vendas e garantir a lucratividade do time.

${ }^{137}$ Disponível em: $<$ http://en.wikipedia.org/wiki/Manager_(association_football) $>$. Acesso em: 21 jan. 2015. 


\section{Capítulo 4}

Um fato interessante da definição apresentada pela Wikipedia é a distinção entre managers europeus e norte-americanos. De acordo com o site, o título de manager é quase que exclusivo do futebol britânico, embora uma busca em nosso corpus de validação tenha mostrado que o termo manager (84) é significativamente mais frequente do que coach (27) em textos do Campeonato Europeu. Enfim, o ponto a ser ressaltado aqui é que na Inglaterra o manager é responsável tanto por treinar os jogadores quanto por funções mais burocráticas. Já no Brasil a função do manager é dividida entre o 'técnico', responsável por treinar a equipe, e o 'presidente' e os 'dirigentes esportivos', que desempenham as funções burocráticas. A figura 47 mostra o manager do Manchester United, e a figura 48 mostra os coaches, que corresponderiam ao que denominamos no Brasil auxiliar técnico e coordenador técnico:

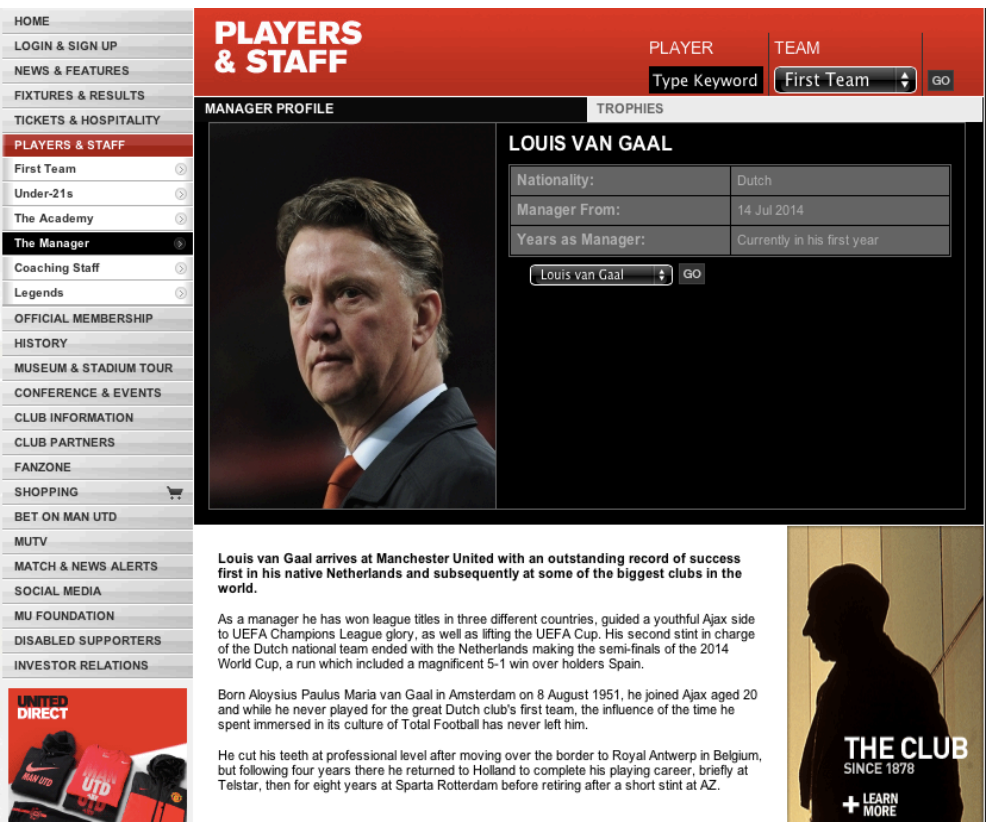

Figura 47: Perfil de Louis van Gaal no site do Manchester United ${ }^{138}$.

\footnotetext{
${ }^{138}$ Disponível em: < http://www.manutd.com/en/Players-And-Staff/Managers/Louis-van-Gaal.aspx >. Acesso em: 22 jan. 2015.
} 
Capítulo 4

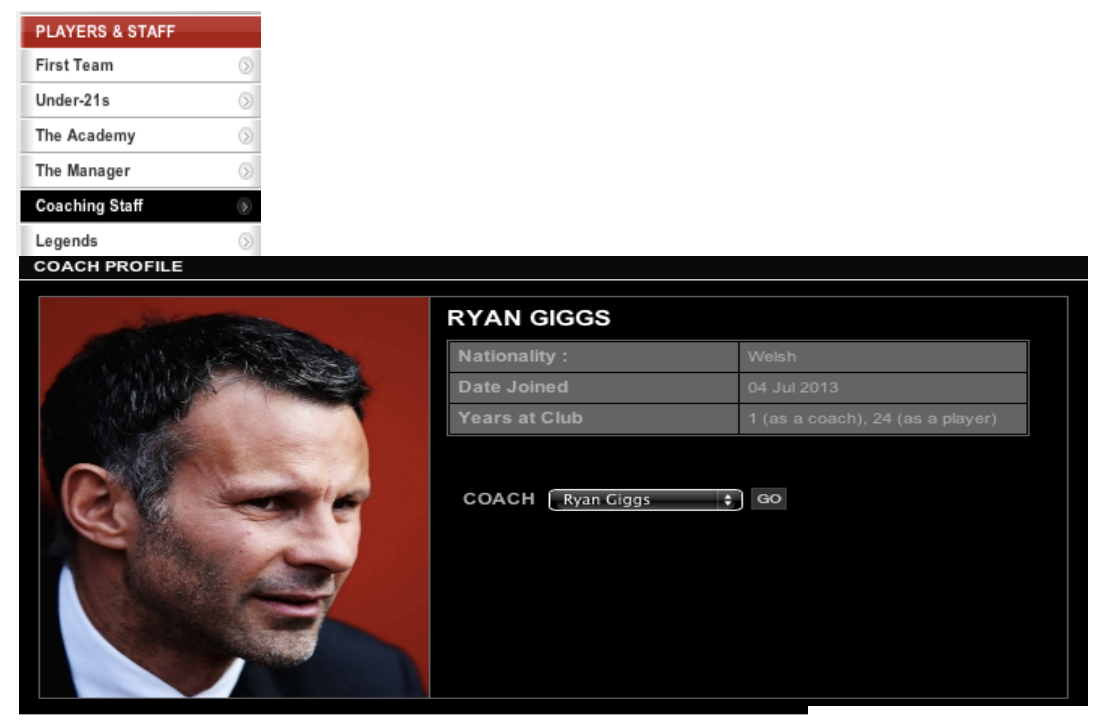

Ryan Giggs was confirmed as assistant manager to new Manchester United boss
Louis van Gaal on 19 May 2014 , the day the Welshman announced that the was

britg verain on his glorious playing career at Old Trafford.

\begin{tabular}{l} 
COACH PROFILE \\
\hline \\
\hline ALBERT STUIVENBERG
\end{tabular}

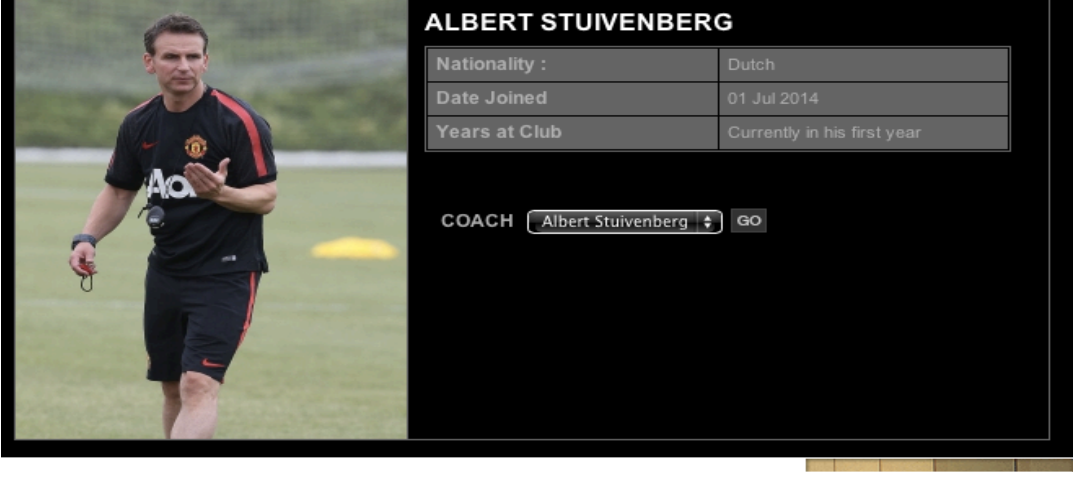

Albert Stuivenberg earned his role as United's assistant coach during his time in
charge of Netherlands Under-21s, which impressed Louis van Gaal.

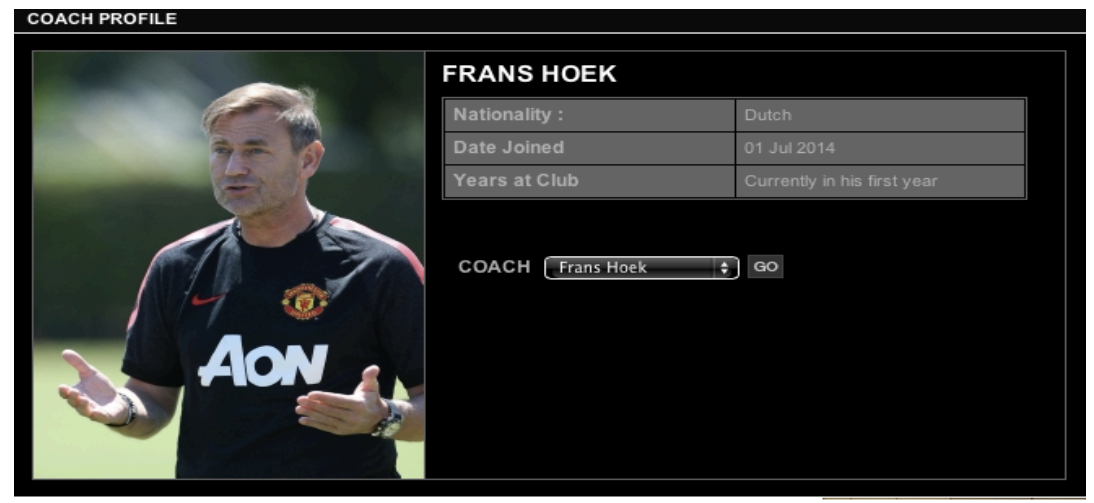
Widely acknowledged as one of the best goalkeeping coaches in the game, with a
proven track record of developing talent, Frans Hook has a fascinating philosophy for 


\section{Capítulo 4}

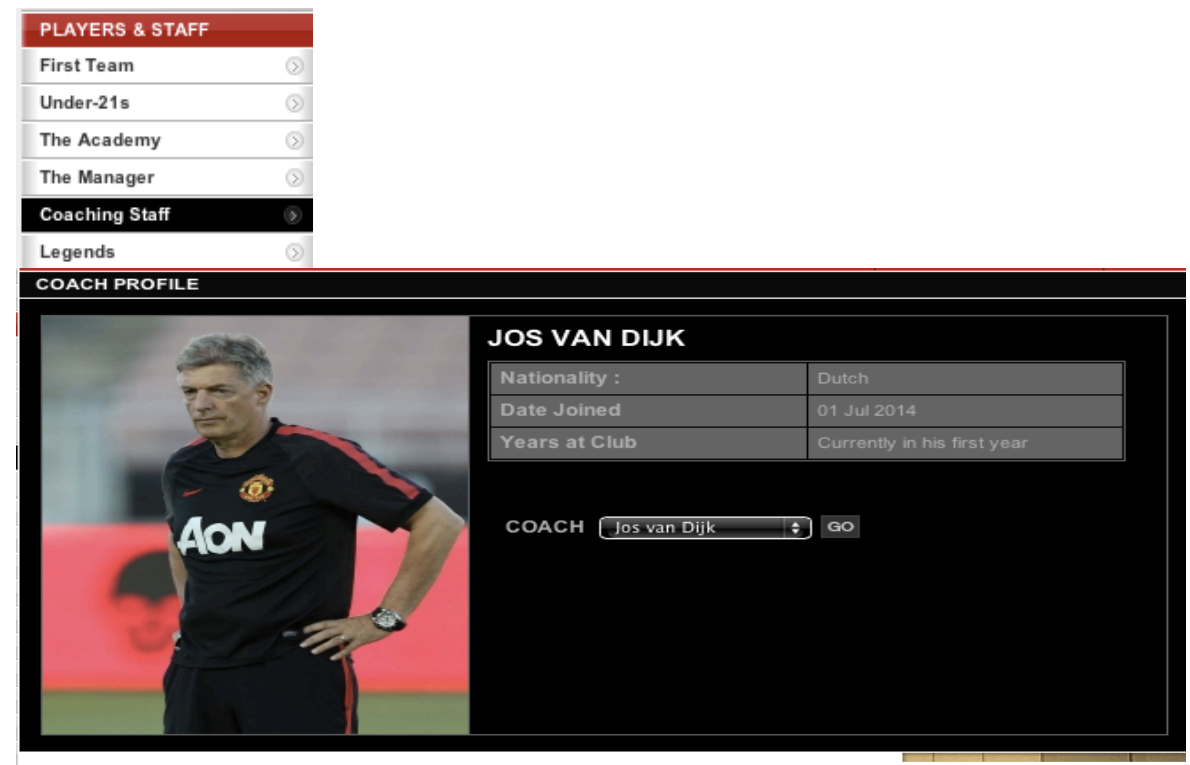

Jos van Dijk has worked with Louis van Gaal since his time at AZ Alkmaar and joined
United as a training physiologist in the summer of 2014.

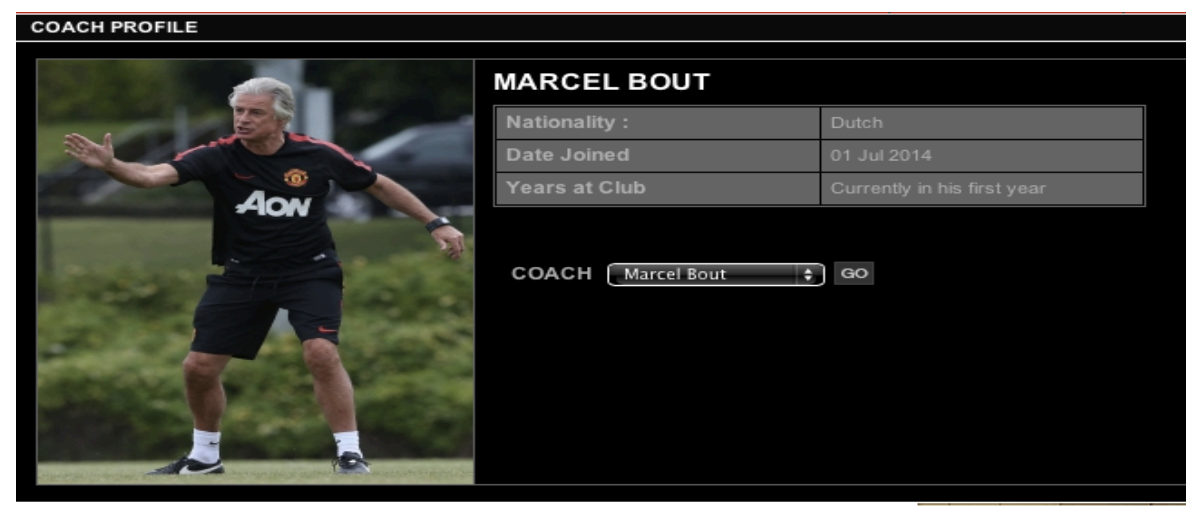

An assistant coach who specialises in opposition scouting, Marcel Bout joined
Manchester United with a reputation for achieving success with various top-flight clubs around Europe.

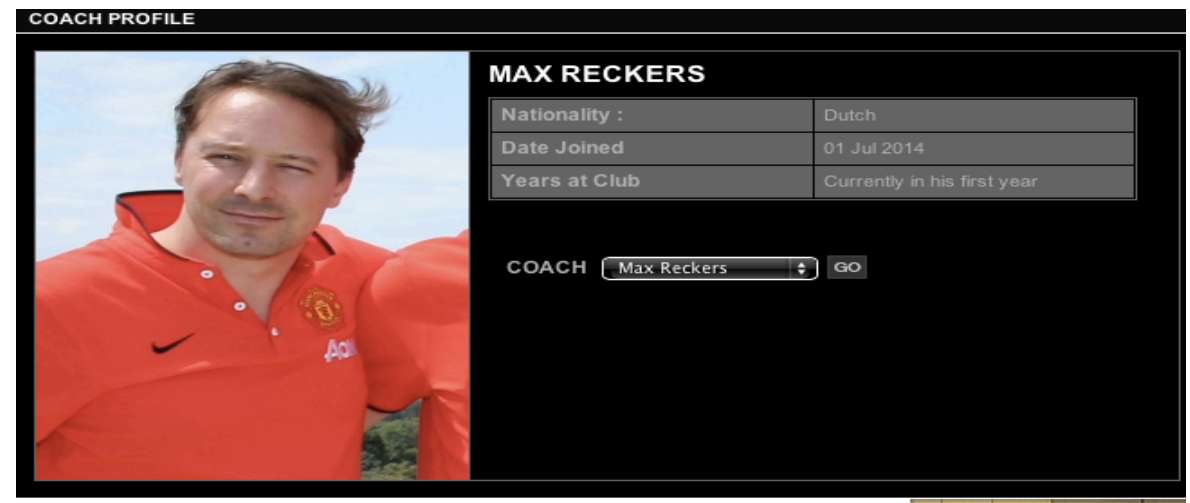
Max Reckers' role as United's performance analyst - collecting and analysing player
data -illustrates the technological advances that have been made in the modern
game.

Figura 48: Perfil dos técnicos do Manchester United ${ }^{139}$.

${ }^{139}$ Disponível em: $<$ http://www.manutd.com/en/Players-And-Staff/Coaching-Staff/Ryan-Giggs.aspx >. Acesso em: 22 jan. 2015. 


\section{Capítulo 4}

Ao analisar a divisão de membros da equipe proposta pelo Manchester United, constatamos que o 'manager' é, conforme definição da Wikipedia, responsável por funções burocráticas, e também pelo treinamento dos jogadores, e conta com coaches, técnicos que atuam em partes específicas do treinamento dos atletas, como, por exemplo, o técnico assistente, o treinador de goleiros, o psicólogo e o analista de performance.

Podemos observar as obrigações de um manager no discurso de Joey Barton, meia do Queens Park Rangers, na Leaders in Football Conference, ao falar sobre o jogo moderno:

'We rate managers but we don't rate coaches in this country,' said Barton, capped once by the senior national team in 2007.

'I am not here to disrespect Fergie. He is a great manager, the icon, the pinnacle of British management.

'But he couldn't put on a coaching session to save his life. I've spoken to people about him and he can barely lay out cones. This is not a coach, this is a manager.

'This is the difference - there is a big, big difference between a coach and a manager.'

When critiquing the current Three Lions squad, the 31-year-old said: 'The England team are $s^{* * *}$ at the minute.

'We haven't won anything. We haven't got great players - they are told they are great. Players are playing to get the flash car and Page 3 bird, rather than for the love of the game. ${ }^{140}$

No discurso, Barton critica Alex Ferguson, técnico do Manchester United entre 1986 e 2013, pela falta de habilidade em treinar os jogadores, sendo mais conhecido por sua notória capacidade de gerenciamento do clube. A crítica de Barton também foi publicada no site FOXSPORTS:

Barton ataca de novo! 'Ferguson é um bom gerente, não um técnico', diz o meia O polêmico meia Joey Barton, do Olympique de Marselha, atacou novamente. Dessa vez os alvos das críticas do jogador foram o ex-treinador do Manchester United Alex Ferguson e a Seleção Inglesa. Barton afirmou que Alex Ferguson era um bom gerente, mas não era um treinador de futebol. O jogador ainda brincou dizendo que o lendário técnico não conseguia colocar cones no gramado durante os treinamentos. ${ }^{141}$

\footnotetext{
${ }^{140}$ Disponível em: < http://metro.co.uk/2013/10/10/joey-barton-sir-alex-ferguson-couldnt-coach-tosave-his-life-4142133/ > . Acesso em: 22 jan. 2015.

${ }^{141}$ Disponível em: < http://www.foxsports.com.br/videos/53647939730-barton-ataca-de-novoferguson-e-um-bom-gerente-nao-um-tecnico-diz-o-meia >. Acesso em: 22 jan. 2015.
} 


\section{Capítulo 4}

A divisão proposta pelos times brasileiros difere bastante daquela dos times ingleses. Tomemos o caso do São Paulo Futebol Clube como exemplo:

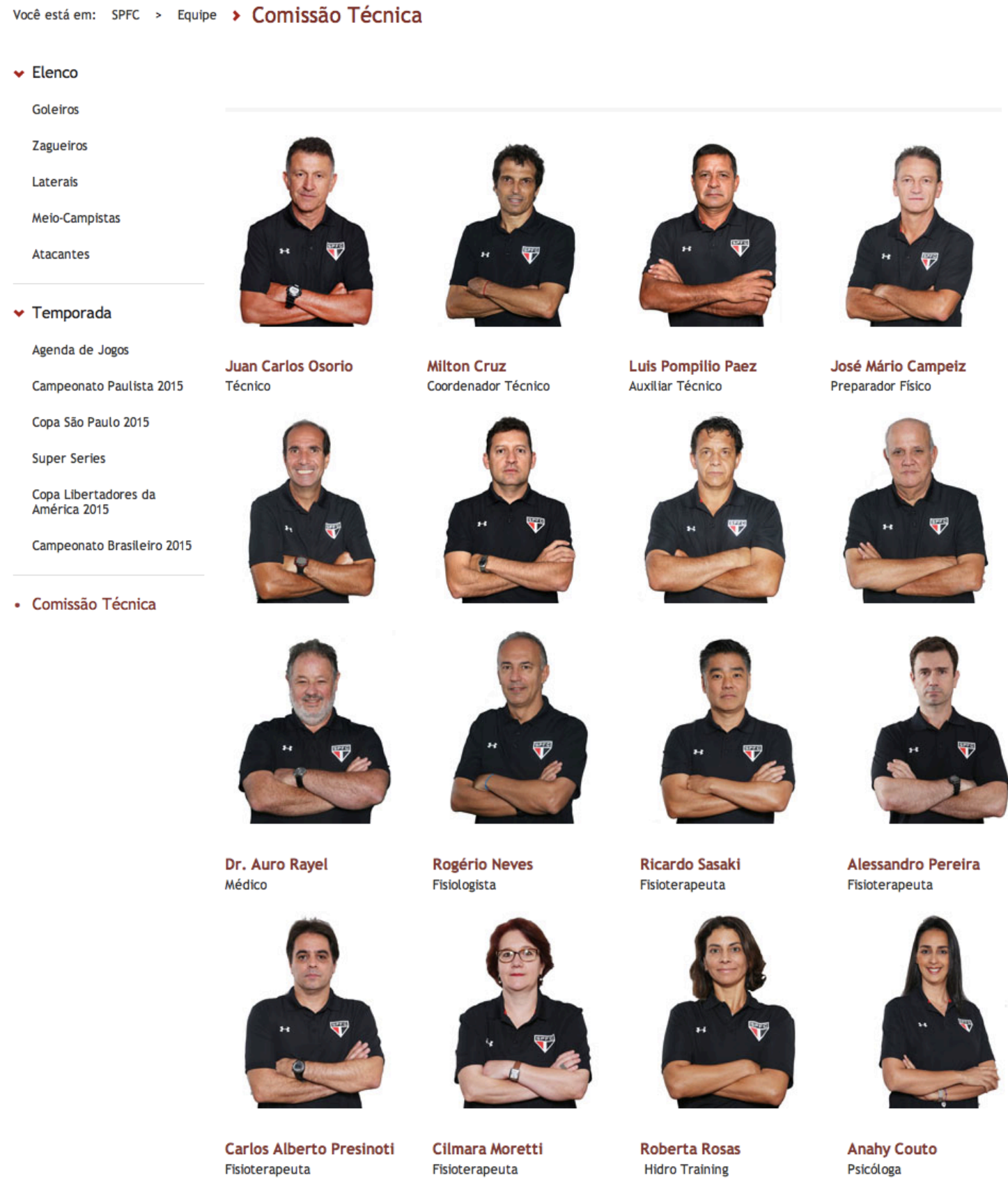




\section{Capítulo 4}
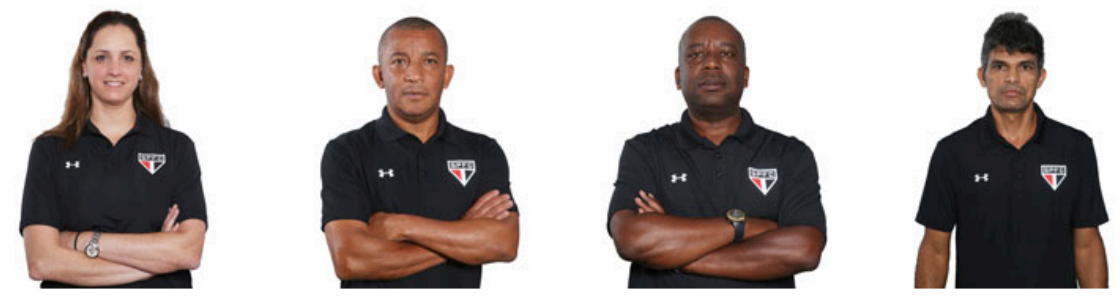

Cristina Soares

Nutricionista

Ailton Rodrigues

Massagista

Almir Lima

Massagista / Podólogo

Valdeci Nascimento
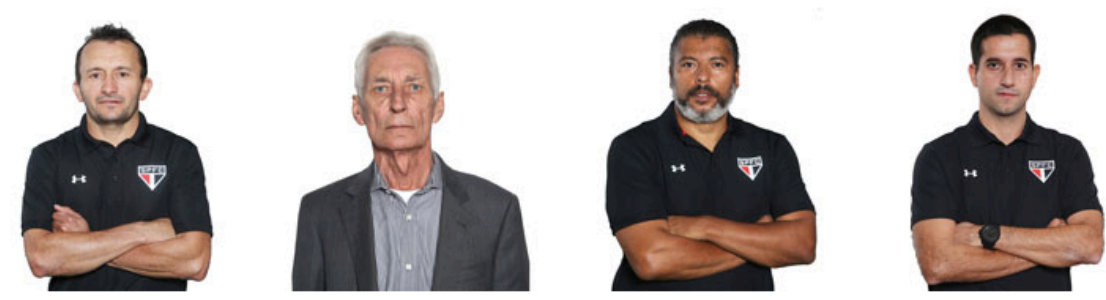

Cícero Feitosa

José Eduardo Chimello Gerente de Futebol

José Carlos dos Santos Gerente de Futebol

Juca Pacheco Assessor de Imprensa

Figura 49: Comissão técnica do São Paulo ${ }^{142}$.

A figura mostra o técnico Muricy Ramalho e toda a equipe técnica do time. A figura 50 mostra a divisão de cargos da diretoria do clube:

${ }^{142}$ Disponível em: < http://www.saopaulofc.net/equipe/comissao-tecnica/ >. Acesso em: 22 jan. 2015. 


\section{Capítulo 4}
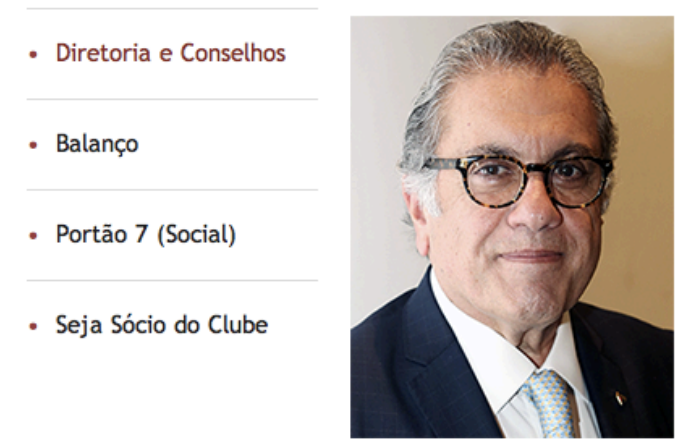

Carlos Miguel Aidar

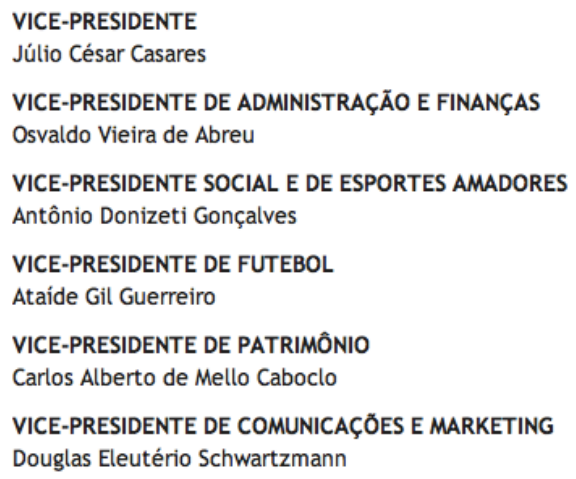

Figura 50: Membros da diretoria e dos conselhos do São Paulo F.C.

Como podemos observar, os times brasileiros fazem uma divisão entre o treinamento físico e os cargos burocráticos. Além disso, as obrigações burocráticas atribuídas ao manager também são divididas nos clubes brasileiros, ou seja, existe um especialista em marketing, um em patrimônio etc.

Após todas as diferenças constatadas, validamos manager como equivalente de 'técnico' e 'treinador'; quando em português existe uma referência a algum membro da comissão técnica, como, por exemplo, o auxiliar técnico ou preparador físico, coach é a melhor opção de equivalente tradutório em inglês. Enfim, ressaltamos aqui como diferenças culturais, nesse caso a forma de administração dos clubes, influencia diretamente os termos de uma área de especialidade.

\section{6 clássico}

O termo 'clássico', utilizado para dar nome a um duelo futebolístico de grande rivalidade, apresenta 266 ocorrências no corpus. Observemos alguns exemplos: 


\section{Capítulo 4}

O Estádio do Morumbi, sem dúvida, é motivo de orgulho para o torcedor são-paulino. Porém, em clássicos contra o Corinthians, o maior estádio particular do Brasil virou uma pedra no sapato do São Paulo. Nos últimos nove jogos disputados no Morumbi, a equipe do Parque São Jorge conquistou quatro vitórias e cinco empates. ${ }^{143}$

No Morumbi, a última vitória do São Paulo contra o Corinthians foi em 11 de fevereiro de 2007, pela primeira fase do Campeonato Paulista. Na ocasião, o time que era comandado por Muricy Ramalho venceu o clássico por 3 a $1 .^{144}$

Barcos e Damião definem o resultado do clássico deste domingo, disputado em clima tenso; Jorge Henrique deixa Colorado com um a menos ${ }^{145}$

Fla domina o clássico, faz gol de letra e vence o Flu no Maracanã: 3 a $2^{146}$

O termo, utilizado mais frequentemente para confrontos estaduais (254), também pode ser utilizado para designar confrontos interestaduais (12):

Em clássico esvaziado, Flamengo bate Corinthians e ganha ânimo para decisão ${ }^{147}$

Uma bomba de $113 \mathrm{~km}$ por hora decidiu um clássico sempre cercado de rivalidade. Atlético$M G$ e Flamengo suaram a camisa, ainda que tenha faltado muita inspiração. Com tantos desfalques, os dois entraram com times praticamente mistos no estádio Independência. $O$ elenco melhor fez o Galo cantar mais alto. ${ }^{148}$

Apenas doze das 266 ocorrências no corpus descrevem clássicos interestaduais. Contudo, uma pesquisa no Google confirmou que o termo também é utilizado para descrever duelos de times de cidades diferentes, como, por exemplo, Corinthians e Fluminense, mas essa probabilidade é baixa, pois 'clássico' ocorre frequentemente dentro de um mesmo contexto situacional: jogos de times de um mesmo estado.

Ao analisar as ocorrências do corpus, sempre ampliamos as linhas de concordância e, quando necessário, acessamos o texto integral. Esses dois

\footnotetext{
${ }^{143}$ Disponível em: < http://esporte.ig.com.br/futebol/2013-07-02/sao-paulo-nao-vence-o-corinthiansno-morumbi-ha-nove-jogos.html $>$. Acesso em: 5 jan. 2015.

${ }^{144}$ Disponível em: < http://esporte.ig.com.br/futebol/2013-07-02/sao-paulo-nao-vence-o-corinthiansno-morumbi-ha-nove-jogos.html >. Acesso em: 5 jan. 2015.

${ }^{145}$ Disponível em: < http://globoesporte.globo.com/futebol/brasileirao-serie-a/noticia/2013/08/barcose-damiao-marcam-e-primeiro-gre-nal-da-arena-termina-empatado.html > . Acesso em: 5 jan. 2015.

${ }^{146}$ Disponível em: < http://globoesporte.globo.com/futebol/brasileirao-seriea/noticia/2013/08/flamengo-domina-fluminense-e-vence-de-virada-no-maracana.html > Acesso em: 5 jan. 2015.

${ }^{147}$ Disponível em: < http://esportes.terra.com.br/corinthians/em-classico-esvaziado-flamengo-batecorinthians-e-ganha-animo-para-decisao,4cf8d91b4db82410VgnVCM10000098cceb0aRCRD.html $>$ Acesso em: 5 jan. 2015.

${ }^{148}$ Disponível em: < http://www.portalodia.com/esporte/esporte/atletico-mineiro-faz-um-gol-e-venceo-flamengo-183670.html $>$. Acesso em: 5 jan. 2015.
} 


\section{Capítulo 4}

procedimentos permitem entender melhor o contexto em que o termo ocorre e, não raras vezes, possibilitam novas descobertas. Ao acessar o texto integral de uma ocorrência de 'clássico', o título da notícia chamou a atenção:

Gre-Nal estreia na Arena com empate, três expulsos e gols dos matadores ${ }^{149}$

'Gre-Nal', o termo utilizado para designar o clássico disputado pelo Grêmio e pelo Sport Club Internacional, levantou uma dúvida: existiria nome para outros clássicos do futebol brasileiro? Para descobrir a resposta, acessamos os textos integrais das ocorrências de 'clássico', lemos os textos e encontramos mais dois termos:

Comandado por Elias e Hernane, o Flamengo dominou o Fluminense e venceu por 3 a 2, de virada, neste domingo, o primeiro Fla-Flu do reformado Maracanã. ${ }^{150}$

Ninguém gosta de perder, mas o Coritiba enxergou a derrota deste domingo (21) por 3 a 1 no clássico Atletiba como algo positivo. ${ }^{151}$

O primeiro termo é utilizado para o confronto entre Flamengo e Fluminense, um dos maiores clássicos do futebol brasileiro, e o segundo é utilizado para o clássico entre Atlético Paranaense e Coritiba. Diante dos achados, perguntamo-nos se outros clássicos também teriam nomes específicos, e, como não encontramos outros nomes em nosso corpus, realizamos uma busca no Google para as palavras 'clássico', 'futebol' e 'brasileiro' e obtivemos uma lista bastante extensa, das quais destacamos os confrontos mais importantes:

\footnotetext{
${ }^{149}$ Disponível em: < http://globoesporte.globo.com/futebol/brasileirao-serie-a/noticia/2013/08/barcose-damiao-marcam-e-primeiro-gre-nal-da-arena-termina-empatado.html >. Acesso em: 5 fev. 2015.

${ }^{150}$ Disponível em: < http://oglobo.globo.com/esportes/campeonato-brasileiro-2013/flamengo-vencefluminense-de-virada-no-maracana-9468228 >. Acesso em: 5 fev. 2015.

${ }_{151}$ Disponível em: $<$ http://www.gazetadopovo.com.br/esportes/campeonatoparanaense $/$ conteudo.phtml?id=1365393 >. Acesso: 5 fev. 2015
} 


\section{Capítulo 4}

\begin{tabular}{|l|l|}
\hline \multicolumn{1}{|c|}{ confronto } & \multicolumn{1}{c|}{ nome do clássico } \\
\hline São Paulo vs. Corinthians & Majestoso \\
\hline Palmeiras vs. Corinthians & Derby Paulista \\
\hline São Paulo vs. Santos & San-São \\
\hline Ponte Preta vs. Guarani & Dérbi Campineiro \\
\hline Juventus x Portuguesa & Dérbi dos Imigrantes \\
\hline Atlético Mineiro vs. Cruzeiro & Galo contra Raposa \\
\hline América Mineiro vs. Atlético Mineiro & Clássico das multidões \\
\hline Bahia vs. Vitória & Ba-Vi \\
\hline Ceará vs. Fortaleza & Clássico-Rei \\
\hline Remo vs. Paysandu & Re-Pa \\
\hline Rio Negro vs. Nacional-AM & Rio-Nal \\
\hline
\end{tabular}

Quadro 19: Clássicos do futebol brasileiro ${ }^{152}$.

O cruzamento de dados da pesquisa no corpus com a pesquisa no Google mostrou que embora existam termos específicos para designar vários clássicos do futebol brasileiro, esses termos não são utilizados frequentemente em notícias sobre resultados de partidas, mas sim para descrever a trajetória dos clássicos, geralmente em blogs que narram a história de um time.

Ao ler os nomes dos clássicos, o termo derby ou 'dérbi', utilizado para descrever os clássicos entre Palmeiras e Corinthians (Derby Paulista), Ponte Preta e Guarani (Dérbi Campineiro) e Juventos e Portuguesa (Dérbi dos Imigrantes), chamou a atenção, uma vez que a palavra em inglês - derby - é utilizada para designar diferentes tipos de corridas de cavalo e de motocicleta. Com exceção do 'Derby Paulista' e do 'Dérbi dos imigrantes', o termo é utilizado somente para descrever rivalidades entre times de cidades menores, pois mobilizam toda a cidade; por ser pequena, a cidade geralmente possui somente dois times grandes, como é o caso do 'Dérbi Campineiro' ou do 'Dérbi de Ribeirão Preto' entre o Botafogo Futebol Clube e o Comercial Futebol Clube.

Diante do achado, perguntamo-nos se, em inglês, derby seria o equivalente de 'clássico'. Para responder a pergunta, geramos linhas de concordância para derby no corpus de inglês e encontramos 34 ocorrências. Apresentamos alguns exemplos abaixo:

Tottenham 0 - Arsenal 1: Rosicky rocket seals derby win as Spurs come up short ${ }^{153}$

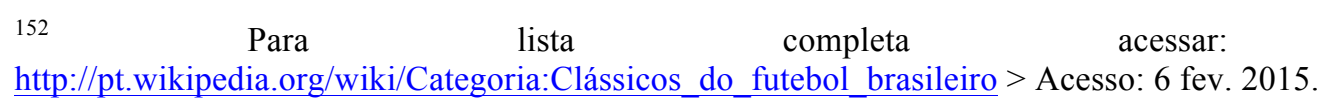




\section{Capítulo 4}

Manchester City 4 Manchester United 1: Demolition derby! Aguero strikes twice while Yaya and Nasri rub salt into Moyes' wounds as new boss endures embarrassment at the Etihad ${ }^{154}$

Both Bristol clubs have united to condemn the violence and pitch invasion which marred last night's derby clash. $^{155}$

"It's a massive game between two title contenders. It's not going to define the season, but it's a big game, a local derby."

The west Lancashire derby has been played in all four tiers of the Football League and the clubs' stadiums are only 17 miles apart. ${ }^{157}$

TOMAS ROSICKY'S stunning second-minute strike was enough to settle the north London derby in Arsenal's favour. ${ }^{158}$

Merseyside derby: Luis Suarez hit by moment of madness as Kevin Mirallas lucky to escape red card after horrific tackle ${ }^{159}$

Scott McDonald's deflected effort gave Millwall a deserved win over Charlton in a cagey south London derby. ${ }^{160}$

Analisando as ocorrências, observamos dois fatores. Primeiramente, encontramos quatro ocorrências da colocação local derby, o que nos fez questionar se local seria utilizado para rivalidades locais e o termo derby seria utilizado para rivalidades entre dois times independentemente da localização geográfica. Observando os contextos em que os dois termos ocorrem, constatamos que ambos são utilizados exclusivamente para confrontos de times da mesma região; portanto, os dois termos são sinônimos. Já o termo rivalry é utilizado para designar confrontos

\footnotetext{
${ }^{153}$ Disponível em: <http://www.express.co.uk/sport/football/465214/Tottenham-0-Arsenal-1-Rosickyrocket-seals-derby-win-as-Spurs-come-up-short >. Acesso em: 6 fev. 2015.

${ }^{154}$ Disponível em: < http://www.dailymail.co.uk/sport/football/article-2426897/Manchester-City-4Manchester-United-1--Match-report-Sergio-Aguero-scores-twice-derby-win.html\#ixzz3Qv3QKbFX $>$. Acesso em: 6 fev. 2015.

155 Disponível em: <http://www.independent.co.uk/sport/football/football-league/bristol-city-andbristol-rovers-unite-to-condemn-violence-at-derby-8799461.html >. Acesso em: 6 fev. 2015.

156 Disponível em: $<$ http://www.telegraph.co.uk/sport/football/teams/manchesterunited/10324862/Manchester-derby-against-Man-City-not-Uniteds-biggest-game-of-the-seasonLiverpool-is-says-Wayne-Rooney.html >. Acesso em: 6 fev. 2015.

157 Disponível em: < $\underline{\text { http://www.huffingtonpost.co.uk/2013/08/06/steward-horse-blackpool- }}$ preston n 3711157.html >. Acesso em: 6 fev. 2015.

${ }^{158}$ Disponível em: <http://www.express.co.uk/sport/football/465214/Tottenham-0-Arsenal-1-Rosickyrocket-seals-derby-win-as-Spurs-come-up-short >. Acesso em: 6 fev. 2015.

159 Disponível em: <http://www.independent.co.uk/sport/football/news-and-comment/merseysidederby-luis-suarez-hit-by-moment-of-madness-as-kevin-mirallas-lucky-to-escape-red-card-afterhorrific-tackle-8959359.html>. Acesso: 6 fev. 2015.

${ }^{160}$ Disponível em: < http://www.bbc.com/sport/0/football/24089964 >. Acesso em: 6 fev. 2015.
} 


\section{Capítulo 4}

entre grandes times de cidades diferentes, como, por exemplo, Liverpool F.C. and Manchester United F.C. rivalry. No entanto, o termo não é utilizado em notícias de resultados de partidas, mas somente em sites que discutem a rivalidade entre os times. Por esse motivo, não encontramos nenhuma ocorrência em nosso corpus.

O segundo fator que chamou a atenção é que, em inglês, diferentemente do que foi observado em português, as notícias utilizam os nomes dos derbies: West Lancashire derby (confronto entre Blackpool F.C. e Preston North End F.C, ambos do condado de Lancashire), North London derby (entre os times Arsenal e Tottenham Hotspur, ambos da região norte de Londres), Mereyside derby (entre Everton e Liverpool, ambos da cidade de Liverpool) e South London derby (confronto entre dois dos quatro times do sul de Londres: Charlton Athletic, Crystal Palace, Millwall e AFC Wimbledon).

Das 34 ocorrências do termo, quatro fazem parte da colocação local derby e nove fazem parte de uma CLE que dá nome a um clássico específico, como os exemplos apresentados acima ${ }^{161}$.

Realizamos, então, uma pesquisa no Google com as palavras derby, football, meaning e history a fim de verificar a origem do termo. Encontramos inúmeros blogs, artigos e fóruns discutindo o assunto e observamos que a origem do termo é bastante controversa. Contudo, uma hipótese é compartilhada por vários autores. O termo teria derivado de uma partida anual disputada em Derby, Inglaterra, pelas paróquias St. Peter's e All Saints na terça-feira de carnaval. A competição, disputada pela última vez em 1946, mobilizava não só os membros da paróquia, mas também toda a população da cidade, e era caracterizada por grande rivalidade entre os torcedores, que, não raro, usavam de violência para manifestar suas preferências clubísticas. Segundo Franco Júnior (2007), mais do que rivalidade esportiva, esses derbies simbolizavam rivalidades ancestrais, oposições políticas, religiosas e étnicas. De acordo com o historiador, ainda hoje essas partidas são caracterizadas por enfrentamentos entre clubes ao mesmo tempo próximos e distantes. Próximos na localização geográfica: são divididos por bairros, algumas vezes ruas; e distantes devido à origem, aos discursos e às idealizações bastante distintas. Ademais, os

161 A lista completa dos clássicos do futebol inglês está disponível em: < http://en.wikipedia.org/wiki/Category:England football derbies >. Acesso em: 6 fev. 2015. 


\section{Capítulo 4}

derbies ingleses são muitas vezes caracterizados por eventos violentos. Tal fato pode ser constatado durante a leitura dos textos em que o termo ocorre. Observemos trechos de uma notícia sobre um jogo entre Bristol City e Bristol Rovers:

Another night of shame for British football: A dozen fans arrested and three officers injured as violence breaks out at Bristol

A fierce local derby was marred by violence and a pitch invasion last night as about 12 people were arrested and three police officers were injured.

'We warned before the match that we would not tolerate any form of anti-social behaviour or violence.

Police said known hooligans attached to both clubs were identified and so far around a dozen people had been arrested.

Mounted police were called in to clear the pitch at Ashton Gate after Bristol City fans celebrated their victory over rivals Bristol Rovers. Avon and Somerset Police said about 12 people were arrested and three officers received medical treatment for non-serious injuries. ${ }^{162}$

Como podemos observar, a rivalidade entre os times ultrapassa o tempo de jogo. Contudo, a fim de não generalizar resultados e estereotipar o futebol inglês como mais violento do que o futebol brasileiro, juntamos todos os textos em que o termo derby ocorre em uma pasta, de modo que esses textos passaram a constituir um minicorpus, e geramos uma wordlist para verificar as palavras recorrentes nesses textos. Poderíamos ter gerado keywords, mas optamos por trabalhar somente com a wordlist, uma vez que o minicorpus é composto somente por 21 textos, de forma que a análise da lista de palavras não demandou muito tempo.

Lendo a lista de palavras encontramos outros itens lexicais que também podem ser relacionados à violência: injured (10), police (9), fight (7), violence (6), drunk (4), arrested (4), hooligans (3), antisocial (1) e injury (1). Como podemos observar, o lexical priming do termo derby é muito frequentemente relacionado à violência, já que o contexto linguístico, social e situacional em que o termo ocorre evoca eventos como brigas, enfrentamentos entre torcidas e polícia. Realizamos o mesmo procedimento para os textos em que o termo 'clássico' ocorre no subcorpus

162 Disponível em: < http://www.dailymail.co.uk/news/article-2412066/Bristol-Derby-footballviolence-sees-12-fans-arrested-3-officers-injured.html\#ixzz3QwOREnyh >. Acesso em: 6 fev. 2015. 


\section{Capítulo 4}

em português e não encontramos um grupo semântico específico como em inglês, mas apenas quatro ocorrências de 'briga', três de 'torcida' e duas de 'polícia'.

Abordar o tema futebol e violência foge do escopo desta pesquisa. No entanto, ao pesquisar sobre a história do futebol, observamos que futebol e violência sempre caminharam juntos: um de seus antepassados mais antigos, o tsu-chu era praticado na China antiga como exercício militar; o Rei Eduardo II teve que decretar uma lei proibindo o esporte em 1314 devido ao barulho, à desorganização e, sobretudo, à violência gerada pela sua prática; o estádio do time inglês Millwall teve de ser fechado três vezes entre as décadas de 1920 e 1950 devido ao confronto entre grupos de hooligans. Esses são alguns exemplos que evidenciam a violência presente no esporte.

No livro 'Sociologia do futebol', o professor Richard Giulianotti aventou uma série de possíveis causas para a violência no futebol inglês e para o surgimento do hooliganismo ${ }^{163}$ na Inglaterra. As causas são inúmeras e vão desde o conflito de classes marxista até uma especulação de que os hooligans inicialmente não eram violentos, e que a violência seria fruto de uma criação da mídia para vender mais jornais e lotar os estádios.

Enfim, como mencionado anteriormente, não nos cabe, neste trabalho, pesquisar sobre a violência no futebol inglês. Contudo, seguindo a teoria de lexical priming de Hoey (2004), acreditamos que, ao aprender um termo, o consulente de um dicionário deve aprender também seus colocados e o contexto situacional em que o termo ocorre. Nesse sentido, ao escrever sobre um derby em inglês, devemos ter consciência da rede de itens lexicais que o termo atrai, que é diferente daquela observada na utilização do termo no contexto brasileiro.

\section{7 bichado}

Ao analisar as keywords, chamou a atenção o termo 'bichado', com 194 ocorrências:

\footnotetext{
${ }^{163} \mathrm{O}$ termo refere-se a um comportamento destrutivo e desregrado. Tal comportamento é comumente associado a fãs de futebol. Para definição completa acessar: $<\underline{\text { http://pt.wikipedia.org/wiki/Hooliganismo> }}$. Acesso em: 11 fev. 2015.
} 


\section{Capítulo 4}

A imprensa soltou que Dagoberto,[sic] está machucado e que vai continuar no Cruzeiro sendo aquele jogador bichado que jogava no Internacional, mas vim aqui para esclarecer que é o contrario. ${ }^{164}$

"Vou disputar a Série B de novo? Posso estar bichado, bêbado, qualquer coisa, mas garanto que não estou louco. Chega de Série B. Estou fora!". ${ }^{165}$

Tem gente que fala que o Paulo Henrique Ganso está de má vontade, outros que ele está 'bichado' e tem até algumas pessoas que dizem que ele tem sérios problemas psicológicos. ${ }^{166}$

"Péssima contratação! jogador chinelinho, joelho bichado...." 167

Nesse caso em particular, o conhecimento da área nos ajudou a inferir o significado do termo, que é utilizado para descrever um jogador que apresenta algum problema físico. Ainda assim, para confirmar a hipótese consultamos o dicionário Aulete Digital e o blog "A bela e a bola"168, que apresentam definições para alguns termos do futebol. Observemos as definições:

\section{Que foi atacado por bicho (2) (lentilha bichada); BICHOSO}

2. Pop. Diz-se de quem tem a saúde arruinada, tem problemas crônicos, está envelhecido e debilitado etc.

3. Pop. Esp. Diz-se de atleta que vive se machucando ou que tem problemas físicos permanentes

4. Pop. Diz-se do que apresenta defeito ou está estragado

[F.: Part. de bichar. $]^{169}$

Bichado: jogador que tem uma contusão ou moléstia crônica. ${ }^{170}$

Uma vez que as duas definições comprovaram nossa hipótese, passamos à busca por um equivalente para 'bichado' em inglês. Para tanto, geramos uma concordância para injur*171, tradução direta para 'machuc*', a fim de encontrar um

\footnotetext{
164 Disponível em: < http://www.plantaodofutebol.com.br/2013/02/explicacao-da-contusao-dedagoberto.html >. Acesso em: 14 jan. 2015.

${ }^{165}$ Disponível em: $<$ http://oledobrasil.com.br/valdivia-sobre-interesse-do-flamengo-disputar-a-serie-bde-novo-em-2014-estou-fora/ >. Acesso em: 14 jan. 2015.

${ }^{166}$ Disponível em: < http://blogdoneto.blogosfera.uol.com.br/2013/02/08/o-que-realmente-acontececom-o-ganso/ > . Acesso em: 14 jan. 2015.

${ }^{167}$ Disponível em: < http://globoesporte.globo.com/mg/sul-de-minas/noticia/2013/08/com-estrela-alexsilva-boa-esporte-anuncia-pacotao-para-serie-b.html >. Acesso em: 14 jan. 2015.

${ }^{168}$ Disponível em: $<$ http://abelaeabola.blogspot.com.au $>$. Acesso em: 15 jan. 2015.

${ }^{169}$ Disponível em: $<$ http://www.aulete.com.br/bichado\#ixzz3OksPcTQE $>$. Acesso em: 15 jan. 2015.

${ }^{170}$ Disponível em: $<$ http://abelaeabola.blogspot.com.au/2009/08/dicionario-futeboles-ii.html $>$. Acesso em: 15 jan. 2015.

${ }^{171}$ Utilizamos a busca "injur*" com o objetivo de obter ocorrências para injury e injured.
} 


\section{Capítulo 4}

possível equivalente. A busca retornou 68 ocorrências. Analisamos as linhas de concordância, mas não encontramos nenhum possível equivalente. Encontramos, no entanto, o nome do jogador Gareth Bale $e^{172}$, que no ano de 2013 adquiriu reputação de 'bichado' devido às várias contusões que sofreu durante a temporada. Expandimos a linha de concordância e lemos o parágrafo que descrevia a situação de Bale no campeonato:

Real say they detected the back injury during the player's medical. Bale then appeared in the starting line-up against Villarreal just three days later, but has yet to start a second game ${ }^{173}$.

O jogador sofreu uma lesão, jogou uma partida, mas ainda não participara de outro jogo. Ler o parágrafo não contribuiu para encontrarmos o equivalente. Mas ao clicar na ocorrência para ter acesso ao texto integral, acessamos também o título da notícia:

He's not a crock ... Real knew about Bale's back woes and deny he needs surgery as angry agent defends £86m star

A palavra crock, que significa 'cerâmica quebrada' ou, em linguagem mais informal, 'bobeira' ou 'asneira', chamou a atenção, pois no contexto da notícia pode fazer referência a um jogador que está sempre 'quebrado'. Geramos, então, linhas de concordância para crock e encontramos mais uma ocorrência:

He has had messages on social media telling him he is a -"permanent crock with an average record". ${ }^{174}$

A notícia, com o título "Miserable Andy Carroll hits rock bottom following latest injury and abuse from West Ham fans", discute a condição física do jogador Andy Carroll, atacante do West Ham United, que sofreu consecutivas lesões e ficou fora durante os quatro primeiros meses da temporada de 2001/2012 do campeonato

\footnotetext{
172 Ressaltamos que sempre que não encontramos o equivalente procurado em nosso corpus (campeonato inglês), utilizamos o corpus de validação a fim de expandir o horizonte de busca. Neste caso, a ocorrência está presente em uma notícia sobre a compra do jogador Gareth Bale pelo Real Madrid publicada pelo jornal Daily Mail.

${ }^{173}$ Disponível em: < http://www.dailymail.co.uk/sport/football/article-2455654/Gareth-Bale-needsurgery-hernia.html\#ixzz3OliItUOy >. Acesso em: 14 jan. 2015

174 Disponível em: < http://www.mirror.co.uk/sport/football/news/miserable-andy-carroll-hits-rock3991758. Acesso em: 15 jan. 2015.
} 


\section{Capítulo 4}

inglês. Na época, o jogador recebeu ameaças dos torcedores do West Ham via mídias sociais.

Após ler as duas notícias que apresentam a ocorrência de crock no corpus, realizar pesquisas no Google a fim de entender a situação dos jogadores - ambos com reputação de estarem sempre contundidos - e procurar no Google por mais ocorrências de crock, validamos o termo como equivalente de 'bichado'.

\section{8 retranca}

Uma das ocorrências que observamos na lista de keywords foi o termo 'retranca' (102), utilizado para descrever um sistema de jogo em que o time se fecha na defesa com a maioria dos seus jogadores. Observemos os exemplos que seguem:

O pior de tudo não é ver o Sheik perder um gol por completa incompetência. O pior foi ver o Corinthians completamente na retranca, apenas se defendendo contra os Bambis. Mais um 0 X 0 e graças ao Cássio. Lamentável. ${ }^{175}$

Time do ano passado jogava com dez jogadores na retranca, jogava no erro dos adversários, a maioria dos jogos ganhou com gols de bola parada e no sufoco. Esse ano vai provar do próprio veneno. A libertadores do ano passado foi um acaso que caiu do céu. ${ }^{176}$

Se usar o que conhecia vai conseguir o que já sabe, jogar na retranca fora de casa quando deveria atacar. Vai conseguir uns 2 a 0 no máximo e falar que não deu, isso se não perder!!!!! É tudo ou nada!!! e já temos nada!!!!!77

No Morumbi, há uma semana, o São Paulo conquistou o direito de avançar no Copa SulAmericana com um empate. Nesta quarta-feira, fora de casa, o time se agarrou a essa vantagem, ficou na retranca e garantiu a igualdade por 0 a 0 com o Atlético Nacional. $O$ resultado basta para colocar o atual campeão na semifinal da Copa Sul-Americana. ${ }^{178}$

No Olímpico, o Grêmio ainda sonhava com altos voos no Brasileiro, mas um empate sem gols com o Coritiba diminuiu as esperanças. O time paranaense armou uma forte retranca, $e$ a rede não balançou em Porto Alegre. ${ }^{179}$

\footnotetext{
${ }^{175}$ Disponível em: < http://www.corinthians.com.br/site/noticias/2013/10/13/18h14-id20728-cassiopega-penalti-no-fim-e-corinthians-empata-com-sao-paulo-no-morumbi.shtml >. Acesso em: 3 fev. 2015.

${ }^{176}$ Disponível em: < http://blog.jovempan.uol.com.br/fernandosampaio/corinthians-aposta-na-retranca contra-o-boca-e-leva-castigo-no-la-bombonera/ > . Acesso em 21 jan. 2015.

${ }^{177}$ Disponível em: < http://spfc.terra.com.br/forum2.asp?nID=246334 >. Acesso em: 3 fev. 2015.

${ }^{178}$ Disponível em: $<$ http://esportes.terra.com.br/sao-paulo/sao-paulo-fica-na-retranca-e-avanca-aposempate-com-atletico-nacional,7039843e51032410VgnVCM4000009bcceb0aRCRD.html >. Acesso em: 3 fev. 2015.

${ }^{179}$ Disponível em: < http://mais.uol.com.br/view/t2pjn3videvl/gremio-recebe-coritiba-e-fica-naretranca-em-empate-sem-gols-0402CD9A366EE4993326?types=V,F\& >. Acesso em: 3 fev. 2015.
} 


\section{Capítulo 4}

Ao analisar os exemplos acima e as outras ocorrências no corpus, constatamos que o termo tem sempre uma prosódia semântica negativa e um mesmo lexical priming. Nos três primeiros exemplos, torcedores do Corinthians e do São Paulo F.C. reclamam da retranca adotada pelos técnicos. Nos dois últimos exemplos, os jogos terminaram sem gol. Os contextos linguísticos e situacionais em que ocorrem são sempre os mesmos. No que se refere ao contexto linguístico, o termo sempre ocorre acompanhado da descrição de um jogo sem gols ou de comentários de torcedores que manifestam suas opiniões contra essa tática. Os contextos situacionais também são sempre os mesmos. Em ordem decrescente de frequência, o termo ocorre quando (1) um time já tem sua vaga garantida na fase seguinte de um campeonato e, por esse motivo, opta por "jogar na retranca"; (2) o time só precisa de um empate para avançar no campeonato; ou (3) o time não pode perder o jogo, pois a derrota o tiraria do campeonato.

Sem um ponto de partida para encontrar o equivalente de 'retranca' em inglês, geramos linhas de concordância para os termos defender (zagueiro), defense (defesa) e back (zagueiro, e também usado para descrever a área de defesa). A busca para os dois primeiros termos não retornou nenhum candidato a equivalente. Já a busca por back retornou oito ocorrências:

Once they were 2-0 up, Liverpool sat back, although they could have scored a third just before the break, Sterling breaking through the middle before Coutinho curled a shot just over and beyond the far post. ${ }^{180}$

It has been all Swansea in this opening 20 minutes as the home side relentlessly press the opposition at every opportunity. Ole Gunnar Solskjaer appears content to sit back and absorb the pressure with the pace of Kim, Zaha and Bellamy likely to be their biggest threat on the counter. ${ }^{181}$

City seem happy to sit back and allow Hull the ball, which is no surprise given Hull's lack of an attacking threat today. ${ }^{182}$

Villa's gameplan is clearly to sit back, frustrate City and pick them off on the counter attackbut only one part of that is working so far. ${ }^{183}$

\footnotetext{
${ }^{180}$ Disponível em: < http://www.independent.co.uk/sport/football/premier-league/norwich-2-liverpool3-match-report-liverpool-go-five-points-clear-of-chelsea-at-top-of-premier-league-table-on-day-luissuarez-hits-goal-number-30-9272130.html >. Acesso em: 3 fev. 2015.

${ }^{181}$ Disponível em: < http://www.ibtimes.co.uk/live-premier-league-scores-updates-liverpool-0-0arsenal-1435660 >. Acesso em: 3 fev. 2015.

${ }_{182}$ Disponível em: $<$ http://www.dailymail.co.uk/sport/football/article-2580887/Hull-vs-ManchesterCity-live-Premier-League.html >. Acesso em: 3 fev. 2015.
} 


\section{Capítulo 4}

Gary Cahill says Chelsea won't sit back against Manchester City ${ }^{184}$

It's very important to be an entertaining team but I would prefer we won 6-0 rather than 6-3. Every manager can think the way they want to think, maybe some managers prefer to score one and sit back but we will continue to keep trying to score goals because that's how we want to win. ${ }^{185}$

This could be one of Liverpool's hardest games tonight, teams like Sunderland who go to Anfield will sit back and defend as deep as possible. Cardiff were fantastic on the break but conceded six, Sunderland will say tonight 'we don't care how much of the ball you have you're not going to break us down. ${ }^{186}$

Nobody was under orders to sit back," said Mel. "Spurs played well in this period and without meaning to, we kept falling back. ${ }^{187}$

Como podemos observar, em todos os exemplos os times se fecharam na defesa e não atacaram, ou seja, jogaram na 'retranca'. Nos primeiros seis exemplos os times optaram por jogar na retranca uma vez que ocupavam uma boa posição na tabela do campeonato ou não precisavam da vitória. No sétimo exemplo, Sunderland, time que vai jogar "fora de casa", nesse caso em Anfield, estádio do Liverpool, joga na retranca muito provavelmente devido à famosa "vantagem de jogar em casa" de que usufrui o time do Liverpool ${ }^{188}$. No último exemplo, o jogador do Tottenham Hotspur diz que o time teve um bom desempenho, sem intenção de jogar na retranca, mas acabou atuando mais na defesa. Ao ler o parágrafo completo, observamos que o time empatou uma partida que poderia ter ganhado, já que, segundo o jornalista que escreveu a notícia, o adversário do Tottenham Hotspur tinha dificuldade para ganhar uma partida.

Em português o termo frequentemente ocorre com o verbo 'jogar', formando, assim, a CLE 'jogar na retranca'. No entanto, é comum que o termo ocorra

\footnotetext{
${ }^{183}$ Disponível em: < http://www.dailymail.co.uk/sport/football/article-2621571/Manchester-City-vsAston-Villa-Sunderland-vs-West-Brom-live-Premier-League.html >. Acesso em: 3 fev. 2015.

${ }^{184}$ Disponível em: < http://www1.skysports.com/football/news/11668/9142800/premier-league-garycahill-says-chelsea-wont-sit-back-against-manchester-city >. Acesso em: 3 fev. 2015.

${ }^{185}$ Disponível em: < http://www.premierleague.com/en-gb/matchday/matches/20132014/epl.html/man-city-vs-arsenal >. Acesso em: 3 fev. 2015.

${ }^{186}$ Disponível em: $<$ http://www.bbc.com/sport/0/football/26755523 >. Acesso em: 3 fev. 2015.

187 Disponível em: < http://www.independent.co.uk/sport/football/premier-league/west-bromwichalbion-3-tottenham-hotspur-3-match-report-baggies-throw-away-threegoal-lead-9256512.html $>$. Acesso em: 3 fev. 2015.

${ }^{188}$ A vantagem de jogar em casa tem sido um importante objeto de estudo no futebol mundial. Estudos como o de Almeida, Oliveira e Silva (2011) analisam partidas e, por meio de métodos estatísticos, calculam o número de vitórias dos times quando jogam em casa e quando jogam fora de casa. Os resultados mostram que existe uma chance maior de vitória dos times que jogam em casa.
} 


\section{Capítulo 4}

acompanhado de outras palavras, como, por exemplo, 'ficar na retranca'. Já em inglês, não encontramos ocorrências de back com o significado de 'retranca' sem o verbo to sit. Então nos perguntamos se o verbo poderia ocorrer com outro colocado. A fim de responder a essa pergunta, geramos linhas de concordância para sit e sat e ordenamos as linhas pelo primeiro colocado à direita. Esse levantamento apontou três ocorrências do termo SIT deep:

The first half started as expected; Tottenham dominating possession looking to thread a pass through the Sheriff defence. However the visitors sat deep and stifled Spurs by giving them no space to create. Tottenham were forced into shooting from distance with Moussa Dembele and Etienne Capoue coming the closest. ${ }^{189}$

West Ham sat deep and were proving difficult to break down, but showed little attacking threat of their own and rarely got out of their own half..$^{190}$

Fulham's intention was obvious from the initial stages, as they sat deep and invited their opponents to attack, but they took a shock lead on a rare foray forward through Sidwell. ${ }^{191}$

Como podemos observar, SIT deep foi usado como sinônimo de SIT back nos três exemplos acima.

Embora o termo em inglês possua um sinônimo, o número de ocorrências nesse idioma é significativamente inferior ao número de ocorrências em português. Sendo assim, para não generalizar nossa análise sobre a prosódia semântica e lexical priming, recorremos ao Google. Realizamos uma busca para "s*t back" e football e também para " $s * t$ deep" e football e analisamos os exemplos das cinco primeiras páginas de resultados, que confirmaram os achados do corpus. Assim, concluímos que (1) a prosódia semântica do termo em inglês é mais neutra do que em português; e (2) o lexical priming é o mesmo do termo em português, já que os contextos situacionais em que o termo é encontrado são quase sempre os mesmos: quando o time ocupa uma posição privilegiada na tabela do campeonato, e quando o time só precisa de um empate para avançar no campeonato. Um contexto situacional não encontrado em português refere-se à situação em que um time opta por "jogar na

\footnotetext{
${ }^{189}$ Disponível em: < http://www.90min.com/posts/485858-tottenham-2-1-sheriff-lamela-finally-showshis-class $>$. Acesso em: 4 fev. 2015.

${ }^{190}$ Disponível em: < http://www.premierleague.com/en-gb/matchday/matches/2013-2014/epl.matchreport.html/man-city-vs-west-ham $>$. Acesso em: 4 fev. 2015.

$191 \quad$ Disponível em: < http://www.premierleague.com/en-gb/matchday/matches/20132014/epl.html/man-utd-vs-fulham >. Acesso em: 4 fev. 2015.
} 


\section{Capítulo 4}

retranca" ao realizar uma partida fora de casa. Além disso, não encontramos nem no corpus e nem nos resultados do Google torcedores ingleses reclamando da decisão do técnico por jogar na defesa.

Como mencionado acima, a prosódia semântica do termo é sempre negativa em português, ao passo que em inglês a prosódia pode ser negativa ou neutra. Das 37 ocorrências de 'retranca' em português, 21 são de comentários de torcedores criticando o sistema adotado pelo técnico. Já em inglês, somente uma das onze ocorrências é parte do comentário de um torcedor criticando essa tática. Sendo assim, parece que os torcedores ingleses aceitam melhor esse sistema de jogo do que os brasileiros.

Retomar o conceito forma-representação que o brasileiro tem de nosso futebol, aquele futebol bonito, alegre e cheio de dribles e gols, ajuda a entender a frustração do torcedor brasileiro ao ver seu time jogar somente no campo de defesa. Acreditamos que talvez esse seja o principal motivo da manifestação de indignação do torcedor nos comentários. O torcedor inglês, por sua vez, mais acostumado com um futebol de resultados, que conduza seu time à conquista do campeonato, raramente reclama quando o técnico adota um sistema mais fechado para garantir a posição na tabela.

\section{9 elástico}

Ao selecionar dribles para os estudos de caso, não poderíamos deixar de fora o famoso 'elástico', drible em que o jogador, com a bola grudada no pé e parado na frente do marcador, toca duas vezes com o mesmo pé na bola, mudando seu movimento de forma a enganar o adversário.

Apesar de ser um dos dribles mais bonitos do futebol, o número de ocorrências no corpus é relativamente baixo (7) e, portanto, não faz parte das palavras-chave. Só tivemos acesso a ele por meio da análise das linhas de concordância de 'deu', que ocorre 279 vezes no corpus e corresponde à palavra-chave número 276.

Geramos linhas de concordância de 'elástico' no corpus e constatamos que apenas duas ocorrências se referem ao drible 'elástico', enquanto as outras cinco fazem referência a um 'placar elástico': 


\section{Capítulo 4}

Com placar elástico, atleticanos não perdoam rivais: 'Ah... é jogo-treino ${ }^{192}$

O que chamou a atenção no placar elástico diante dos nordestinos foi a atitude da equipe paulista. Superior desde o apito inicial, o time do Morumbi comandou o jogo e contou com ótima exibição de Paulo Henrique Ganso, que marcou um golaço no segundo tempo. ${ }^{193}$

O placar elástico tirou o ímpeto da equipe catarinense, que assustou pouco o Palmeiras ao longo da partida. Nas melhores chances, em lances sequenciais aos 34min e aos 35min, Pablo ficou perto de diminuir o marcador, mas o Figueirense teve que se contentar em sofrer mais um aos 38min: em contra-ataque, Juninho saiu na grande área e tocou para Serginho só empurrar para as redes. ${ }^{194}$

O Flamengo foi superior e soube explorar bem as jogadas pelo lado ... Ninguém esperava esse placar elástico, não fizemos um jogo para tomar de 4 a $0 .{ }^{195}$

Com placar elástico, torcida Atleticana não perdoa rivais: 'Ah, é jogo-treino, 196

Como podemos observar, um 'placar elástico' é um placar que apresenta uma grande diferença no saldo de gols. O termo é sinônimo de 'chocolate'. Ressaltamos, aqui, uma das maiores vantagens da pesquisa com corpus: o fenômeno da serendipidade, ou seja, fazer descobertas inesperadas, por acaso, ao investigar outro assunto.

Retomando o termo em questão, as únicas duas ocorrências no corpus em que o termo 'elástico' se refere ao drible ressaltam a dificuldade e a beleza nele envolvidas. Observemos os exemplos abaixo:

Depois, Fred, já num estádio às escuras devido à iluminação precária, ainda deu elástico e quase fez um golaço. Foi uma pena a bola não ter entrado. Mas o torcedor tricolor que se aventurou a torcer debaixo de chuva já estava feliz. ${ }^{197}$

Ilsinho deu caneta de elástico no Roberto Carlos... Pra mim tem mais moral que qualquer $u m !^{198}$

192 Disponível em: < http://globoesporte.globo.com/futebol/times/atletico-mg/noticia/2013/05/complacar-elastico-torcida-atleticana-nao-perdoa-rivais-ah-e-jogo-treino.html > . Acesso em: 28 jan. 2015.

${ }^{193}$ Disponível em: < http://torcedores.com/noticias/4819-sao-paulo-vence-ultrapassa-corinthians-erespira-no-brasileirao $>$ : Acesso em: 28 jan. 2015.

${ }^{194}$ Disponível em: < http://esportes.terra.com.br/figueirense/palmeiras-goleia-figueirense-em-estreiaem-londrina-e-reencontra-vitoria,ac07407e58a91410VgnVCM4000009bcceb0aRCRD.html >. Acesso em: 28 jan. 2015.

${ }^{195}$ Disponível em: < http://globoesporte.globo.com/jogo/copa-do-brasil-2013/23-10-2013/flamengobotafogo.html >. Acesso em: 28 jan. 2015.

${ }^{196}$ Disponível em: < http://spfc.terra.com.br/news.asp?nID=99390 >. Acesso em: 28 jan. 2015.

197 Disponível em: < http://globoesporte.globo.com/jogo/carioca-2013/30-03-2013/fluminenseboavista.html >. Acesso em: 28 jan. 2015. 


\title{
Capítulo 4
}

No primeiro trecho, apesar de o estádio estar às escuras, o atacante Fred conseguiu dar um 'elástico' e quase marcou o gol. Embora não o tenha marcado, o jogador agradou os torcedores ao executar o drible. No segundo, trecho de um comentário de um torcedor, Ilsinho tem mais moral do que qualquer outro jogador por ter dado 'caneta de elástico' em Roberto Carlos. Nesse último exemplo, elástico não se refere ao drible em si, mas sim ao estilo ${ }^{199}$ que Ilsinho aplicou a outro drible, a 'caneta' ${ }^{200}$.

Ao questionar os especialistas sobre um possível motivo para a baixa frequência desse drible, obtivemos uma resposta bastante interessante: "Falar é fácil, fazer é difícil. Faz um tempão que não vejo um elástico no Brasileirão”.

Pesquisando sobre a história do drible na internet, encontramos um depoimento similar:

\begin{abstract}
Não sei se acontece com vocês também, mas quando vejo um lance desses, ainda que o drible não tenha sido concluído, fico feliz. Parece que o lado lúdico e mágico do futebol de alguma forma se renova. Cá entre nós, em nome de um jogo moderno, objetivo, tático, onde o que importa é exclusivamente a vitória, jogadas assim estão cada vez mais raras. ${ }^{201}$
\end{abstract}

O trecho acima, extraído do "Canelada F.B", site sobre futebol que discute a rodada final dos campeonatos, o desempenho dos jogadores, da comissão técnica e da diretoria de clubes brasileiros e internacionais, segue a mesma linha de argumentação de Damo (1999) no que se refere ao antagonismo 'futebol arte' x 'futebol força'. Segundo o autor, o futebol "bonito", "com ginga" e "alegre" está gradativamente sendo ofuscado por um futebol de resultados, ou seja, que tem a vitória como objetivo exclusivo. Sendo assim, belas jogadas como o 'elástico', consideradas arriscadas devido ao alto grau de dificuldade que envolvem, são cada vez mais raras.

\footnotetext{
${ }^{198}$ Disponível em: < http://estadiovip.com.br/47468/ilsinho-pode-voltar-ao-sao-paulo $>$. Acesso em: 28 jan. 2015.

${ }^{199}$ Para executar a 'caneta', Islinho tocou duas vezes com o mesmo pé na bola, mudando seu movimento.

${ }^{200}$ Vide item 4.13.

${ }^{201}$ Disponível em: < http://canelada.com.br/futebolnomundo/rivelino-ronaldinhos-e-agora-cr7-a-artedo-elastico-nao-pode-parar/ >. Acesso em: 28 jan. 2015.
} 


\section{Capítulo 4}

O elástico, considerado um dos dribles mais espetaculares do futebol, exige técnica apurada e habilidade com a bola, e permite que o jogador crie uma superioridade perante o rival. Afinal, ao superar o defensor, o autor da manobra fica em posição vantajosa para continuar o ataque. De acordo com os especialistas e sites consultados, são poucos os jogadores que dominam o 'elástico'; Rivelino, Romário, Ronaldinho Gaúcho, Ronaldo Fenômeno e Robinho são sempre citados entre os que executam o drible com perfeição.

Em grande parte dos sites, Rivelino é citado como inventor do 'elástico'. No entanto, em entrevista o jogador esclarece que aprendeu a jogada com Sérgio Echi, seu companheiro no grupo de aspirantes do Corinthians. Rivelino diz ter apenas aperfeiçoado a criação de Echi.

Chamou a atenção o fato de Rivelino ter ficado famoso pelo 'elástico' e passar a ser conhecido como "rei do Corinthians" e "reizinho do parque" em tempos difíceis para o time, que não conseguia conquistar títulos. O único momento de glória que o Corinthians alcançou com Rivelino foi a conquista do Torneio Rio-São Paulo de 1966. Contudo, o primeiro lugar foi dividido com outros três times: Botafogo, Santos e Vasco. Enfim, o ponto a ser levantado aqui é que, embora o Corinthians estivesse passando por uma fase ruim, sem conseguir vitórias, muito menos títulos, seus jogadores arriscavam jogadas e dribles de risco. Ou seja, naquela época, diferentemente dos dias de hoje, prevalecia o futebol arte. Isso justifica a baixa ocorrência do termo no corpus em português, uma vez que nosso corpus de estudo é composto somente por textos atuais.

O próximo passo de nossa pesquisa foi identificar o equivalente de 'elástico' em inglês. Como não tínhamos um ponto de partida, analisamos todos os verbos desse subcorpus, uma vez que, em inglês, muitas vezes o substantivo que designa o drible é o mesmo que o verbo. A análise, bastante laboriosa, não retornou nenhum candidato a equivalente. Nossa segunda opção seria analisar os substantivos do corpus, mas a análise demandaria mais tempo do que a análise dos verbos. Como durante a análise em português constatamos que o drible exige muita habilidade e que pouquíssimos jogadores o executam, dentre eles Neymar e Cristiano Ronaldo na atualidade, e Ronaldinho Gaúcho há alguns anos, pesquisamos, no Google, jogos do Campeonato Europeu em que esses jogadores deram um 'elástico'. 


\section{Capítulo 4}

A pesquisa em português mostrou que Cristiano Ronaldo deu um elástico no turco Hamit Altintop durante uma partida Portugal x Turquia. Assim, realizamos uma busca no Google com as seguintes palavras de busca: "Cristiano Ronaldo", Portugal e Turkey e obtivemos o seguinte resultado:

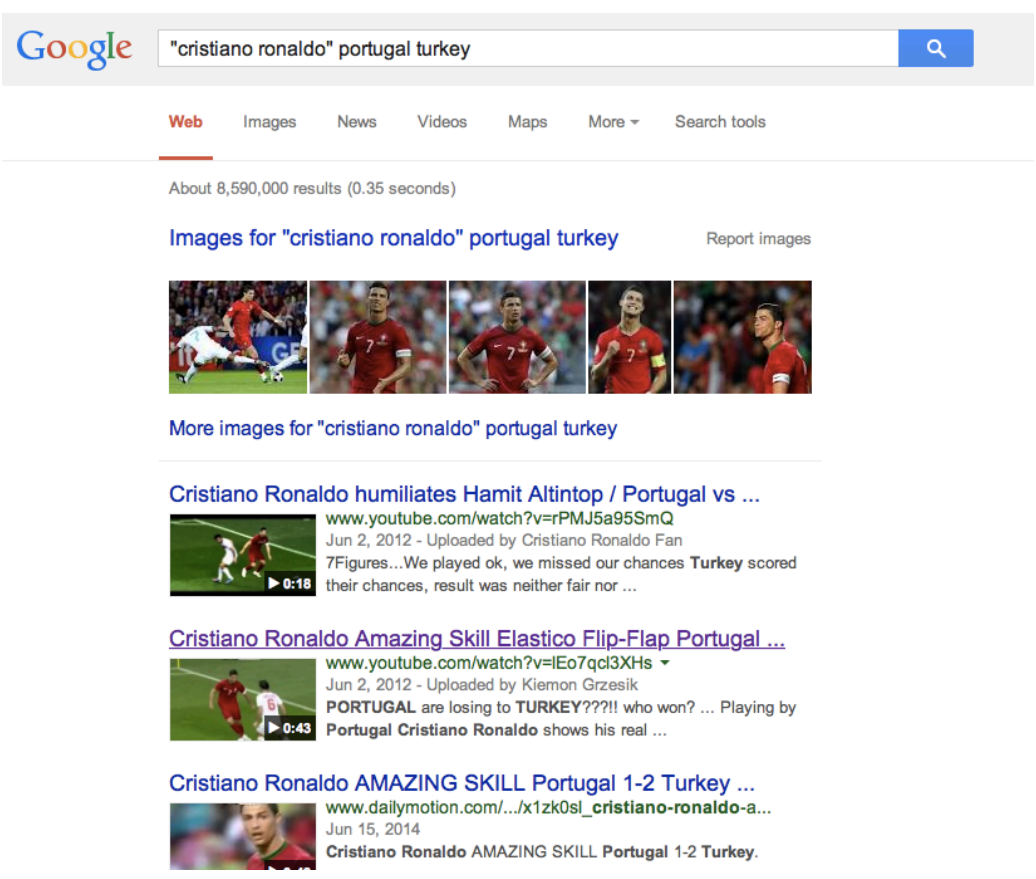

Figura 51: Resultado da busca no Google para as palavras: "Cristiano Ronaldo", Portugal e Turkey.

O segundo link disponibilizado pelo Google chamou a atenção, pois continha o termo 'elástico' seguido de uma palavra, até então, por nós desconhecida: flipflap $^{202}$. Clicamos no link, assistimos ao vídeo ${ }^{203}$ e verificamos que o drible dado por Cristiano Ronaldo era, de fato, o 'elástico'. Para validar flip-flap como equivalente de 'elástico' realizamos outra pesquisa no Google, dessa vez para as palavras de busca "flip-flap" e football. A busca retornou 131.000 resultados, a grande maioria em forma de tutoriais de como executar o drible e vídeos do YouTube que registram o drible em uma partida. Fato interessante é que apesar do alto número de páginas que a pesquisa retornou, os tutorais e, principalmente, os vídeos do YouTube, referem-se, na grande maioria, ao mesmo jogo. Isso comprova que o drible não é executado com

\footnotetext{
${ }^{202}$ Em uma das ocorrências do Google a palavra skill antecede o termo flip-flap, formando uma CLE. No entanto, por termos encontrado apenas uma ocorrência no Google, não incluímos a CLE em nosso dicionário.

${ }^{203}$ Disponível em: < https://www.youtube.com/watch?v=1Eo7qcl3XHs $>$. Acesso em: 29 jan. 2015.
} 


\section{Capítulo 4}

frequência em partidas oficiais e, quando o é, a mídia, os torcedores e os blogueiros se voltam para o acontecimento e registram o momento mágico. Observemos os exemplos abaixo:

Paul Pogba pulled off a glorious flip flap skill for Juventus v Inter [GIF + Video $]^{204}$

Isco (Spain U21) produces an outrageous flip flap and a perfect nuts $v$ Russia U21 (GIF \& Video $)^{205}$

Neymar freaked out with his mate Willian after an amazing flip flap he did against Turkey. ${ }^{206}$

Playing on the inherent connection between Brazil and the home country of their mothertongue Portugal, as well as the global brand of players like Ronaldinho and Luis Figo. This advert changed football more than most people would care to admit. Ronaldinho's legendary flip-flap was rife in world football in the aftermath of this ad. ${ }^{207}$

Como mencionado algumas vezes no decorrer desta pesquisa, temos ciência das limitações de trabalhar com o Google para a busca de equivalentes e, principalmente, para a validação de CLEs das quais o termo faz parte. No entanto, não podemos deixar de mencionar que em todas as ocorrências do Google analisadas o termo é sempre acompanhado por um adjetivo de prosódia semântica positiva. Nos exemplos acima, glorious, outrageous, amazing e legendary. Também interessante é observar que o termo é grafado de duas formas: flip flap e flip-flap, sendo a primeira mais frequente.

$\mathrm{Na}$ busca que realizamos para "Cristiano Ronaldo", Turkey e Portugal, observamos que o primeiro link na página de resultados também utiliza o termo 'elastico', cuja grafia foi adaptada para a língua inglesa, omitindo-se o acento agudo:

Cristiano Ronaldo Amazing Skill Elastico Flip-Flap Portugal Vs Turkey ${ }^{208}$

\footnotetext{
204 Disponível em: < http://www.101 greatgoals.com/gvideos/paul-pogba-pulled-off-a-glorious-flipflap-skill-for-juventus-v-inter-gif-video/ > . Acesso em: 29 jan. 2015.

205 Disponível em: < http://www.101greatgoals.com/blog/manchester-city-target-isco-spain-u21produces-an-outrageous-flip-flap-v-russia-u21-gif-video/ > . Acesso em: 29 jan. 2015.

${ }^{206}$ Disponível em: < http://www.weloba.com/article/neymars-top-skills-in-some-videos-collection $>$. Acesso em: 29 jan. 2015.

${ }^{207}$ Disponível em: < http://rwdmag.com/blog-the-top-10-world-cup-adverts-ever/ >. Acesso em: 29 jan. 2015.

${ }^{208}$ Disponível em: < https://www.youtube.com/watch?v=1Eo7qcl3XHs >. Acesso em: 29 jan. 2015.
} 


\section{Capítulo 4}

Por esse motivo, o passo seguinte foi confirmar se 'elastico' é, de fato, utilizado com frequência em inglês e se o termo possui outros sinônimos. Realizamos uma busca para 'elastico' e football no Google.uk e obtivemos mais de 35.000 ocorrências. Apresentamos alguns exemplos abaixo:

Check out a video next in that Portuguese luminary Cristiano Ronaldo performs a 'Elastico' opposite Spain in their new accessible match. Portugal went upon to win a compare 4-0. ${ }^{209}$

How to do a elastico - Football skills tutorial ${ }^{210}$

Zlatan Ibrahimovic fails to do an elastico, ends up hugging a Hammarby player ${ }^{211}$

Após analisar 40 ocorrências de 'elastico' no Google, validamos o termo como sinônimo de flip flap. A análise dos vídeos do YouTube nos levou a outro possível equivalente: flick-flack. Observemos a figura 52:

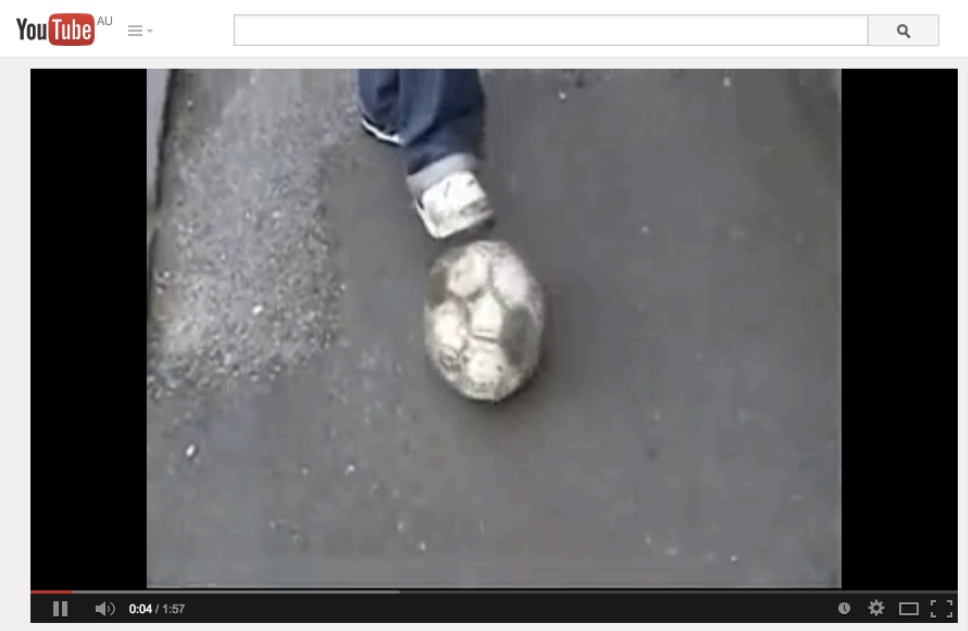

the flick-flack (elastico) skill slow motion

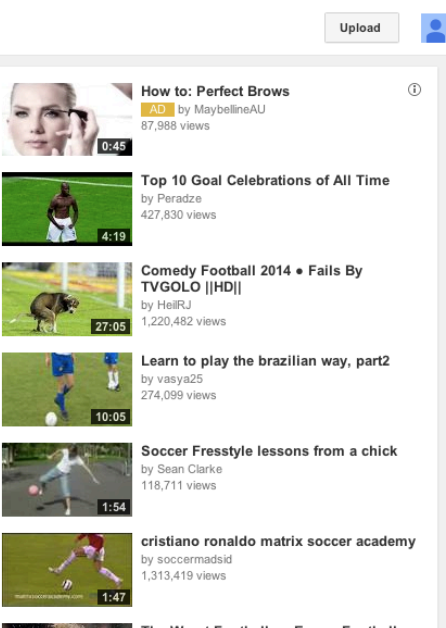

282 2

Figura 52: Vídeo tutorial de como dar um 'elástico,212.

Encontramos um site em que o termo flick-flack é apresentado como sinônimo de 'elástico'. Para validar o candidato a equivalente, realizamos nova busca no

\footnotetext{
${ }^{209}$ Disponível em: < http://goalstage.com/cristiano-ronaldo-'elastico'-against-spain---video/ >. Acesso em: 29 jan. 2015.

${ }^{210}$ Disponível em: $<$ https://www.youtube.com/watch?v=U2 8G6PFuKg >. Acesso em: 29 jan. 2015.

${ }^{211}$ Disponível em: < http://www.101greatgoals.com/gvideos/gif-zlatan-ibrahimovic-fails-to-execute-aelastico-ends-up-hugging-a-hammarby-player/ > . Acesso em: 29 jan. 2015.

${ }^{212}$ Disponível em: $<$ https://www.youtube.com/watch?v=I6vad40xckI > . Acesso em: 29 jan. 2015.
} 


\section{Capítulo 4}

Google. Dessa vez para "flick-flack" e football. Analisamos 50 dos 55.700 resultados e validamos o termo como sinônimo de flip flap.

Encontrados os equivalentes, retornamos ao corpus e geramos linhas de concordância para flip flap, flip-flap, elastico e flick-flack, na esperança de encontrar alguma ocorrência. Entretanto, não obtivemos nenhuma linha de concordância para essas palavras de busca.

Poderíamos interpretar o resultado da busca de forma negativa e entender que o corpus não está balanceado ou que não é representativo da terminologia do futebol em inglês. Contudo, dadas as raízes interdisciplinares de nossa pesquisa, acreditamos que a ausência do termo em inglês no corpus é resultado de dois fatores principais: 1) o estilo do futebol inglês, que prioriza resultados em detrimento de belas jogadas. Ademais, nenhum dos jogadores contemporâneos que executam o drible - Neymar, Cristiano Ronaldo ${ }^{213}$ e Ronaldinho Gaúcho - joga na Inglaterra. Por esse motivo, a probabilidade de encontrar alguma ocorrência no corpus é, por natureza, bastante baixa; e 2) a forma-representação do futebol brasileiro. Embora a frequência de 'elástico' seja baixa no corpus e as ocorrências encontradas no Google descrevam quase sempre o mesmo 'elástico', não é raro encontrar ocorrências em inglês que estabelecem ligação entre a dificuldade e a plasticidade do drible com o futebol brasileiro. Observemos o exemplo abaixo:

A short history of the flip flap, by way of Japan and Algeria

The elastico, or flip flap, is the property of Roberto Rivelino: that's how the old story goes. That mustachioed Corinthians and Fluminense trickster-star of three World Cups for Brazil-is lauded as its flair-filled inventor; he was a player who loved (perhaps even lived) to tease and torment defenders, first with a tentative, deft little leftward flick, and then next with the obligatory darting switch back inside. It was a move full of purpose, and one that almost invariably resulted in the beating of a man, the setting up of a teammate, or the rifled shot at goal. Sometimes, just sometimes, he would even score. ${ }^{214}$

Apesar de o título mencionar Japão e Argélia, o exemplo foi retirado de um artigo sobre a origem do drible e relata a história de Rivelino, fazendo, em todo o

\footnotetext{
${ }^{213}$ O jogador Cristiano Ronaldo jogou no Manchester United de 2003 a 2009, e nosso corpus de estudo foi compilado nos anos de 2013 e 2014. Além disso, o jogador atingiu sua melhor fase a partir de 2009, quando conquistou títulos e prêmios, e ficou conhecido como jogador extremamente técnico e habilidoso.

${ }^{214}$ Disponível em: < http://inbedwithmaradona.com/journal/2013/4/22/a-short-history-of-the-flip-flapby-way-of-japan-and-algeria >. Acesso em: 29 jan. 2015.
} 


\section{Capítulo 4}

texto, inúmeras referências à genialidade do jogador. A figura que segue é a capa de uma compilação de 'elásticos' em um vídeo do YouTube:

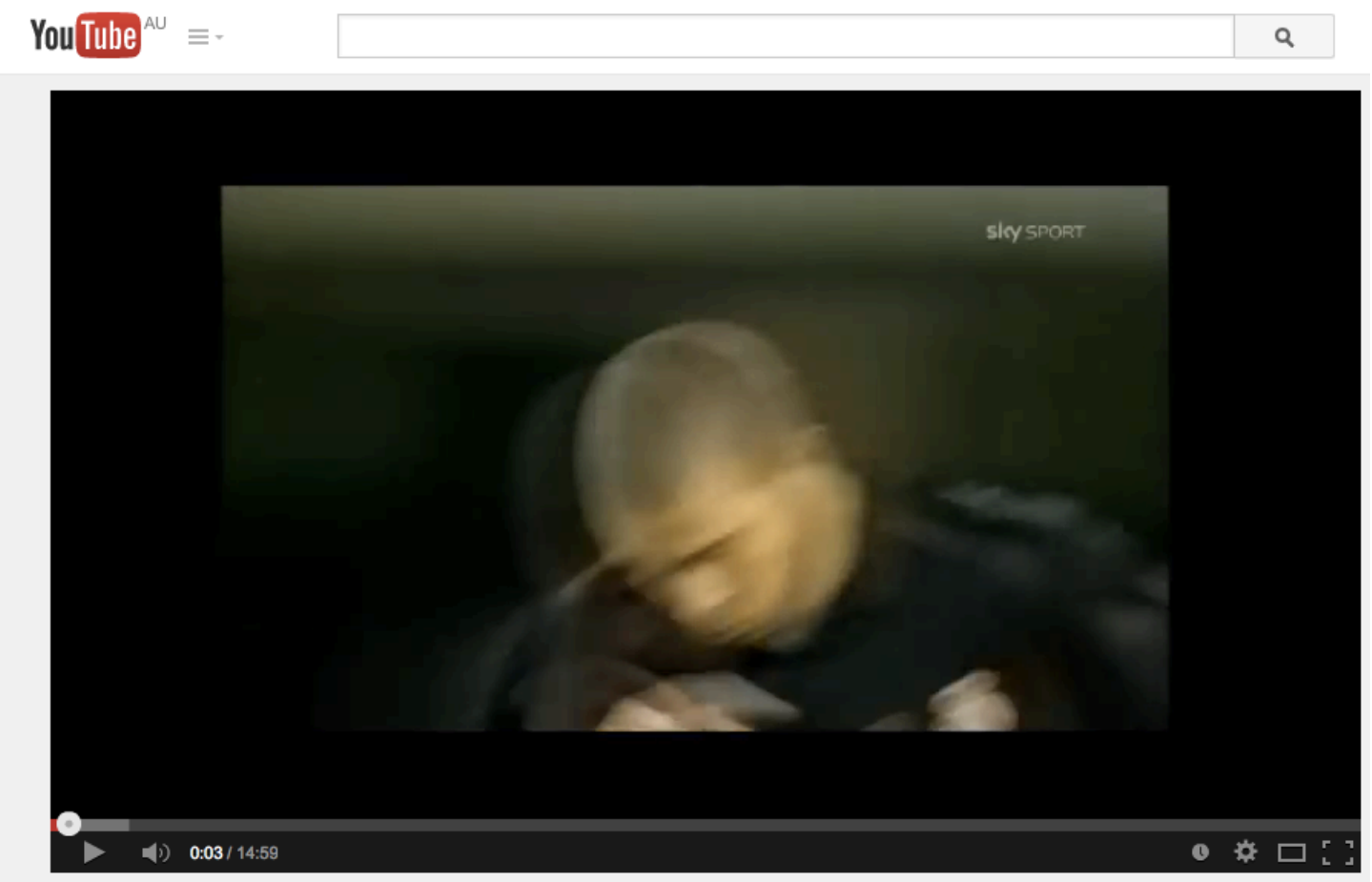

Ronaldo Brazil Impossible Technique And Dribbling Ever

Figura 53: Tutorial do Youtube com uma compilação de 'elásticos' executados por Ronaldo. ${ }^{215}$

O exemplo, título de um tutorial do YouTube que demonstra como executar o drible por meio de uma compilação de 'elásticos' dados por Ronaldo, descreve o drible como uma "técnica impossível” executada por um jogador brasileiro.

Ao fim da análise, concluímos que 'elástico', um dos dribles mais respeitados do futebol, possui três equivalentes em inglês: flip(-)flap, elastico e flick-flack. Também constatamos que o drible raramente acontece em partidas oficiais e, quando algum jogador consegue executá-lo com perfeição, ganha espaço significativo na mídia, tanto profissional (jornais e periódicos esportivos), quanto amadora (vídeos do YouTube que são postados por fãs de futebol).

\subsection{0 chocolate}

${ }^{215}$ Disponível em: < $\underline{\text { https://www.youtube.com/watch?v=uVueW6X7TM0 }}>$. Acesso em: 29 jan. 2015. 


\section{Capítulo 4}

Um exemplo de termo que surgiu em um momento histórico específico é o termo "chocolate", utilizado quando um time vence o outro com grande diferença de gols. Observemos o exemplo que segue:

Gol da Alemanha! Chocolate sobre o Brasil vira piada na internet Internautas fizeram de uma partida de video-game uma simulação do fatídico 7 a 1 da Alemanha no Brasil, inspirado no Barcelona x Fluminense, clássico da internet. ${ }^{216}$

A origem da expressão, que ocorre 161 vezes no corpus, é incerta; no entanto, a ideia de que tenha surgido em uma partida do Campeonato Brasileiro em 1981, em que o Vasco goleou o Internacional por 4 - 0, é compartilhada por muitos. Na época, o resultado foi considerado uma vingança pela derrota da final do Campeonato Brasileiro de 1979, em que o Internacional derrotara o Vasco. Na final de 1981, durante a derrota do Internacional, o narrador Washington Rodrigues teria tocado a música "El bodeguero", do cubano Richard Egües, cujo refrão é "Toma chocolate / Paga lo que debes".

Não encontramos, em nosso corpus, o equivalente em inglês para o termo. Decidimos, então, recorrer ao Google e procurar por partidas em que um time tivesse vencido por uma grande diferença de gols. Para tanto, observamos a tabela de resultados do campeonato inglês, selecionamos alguns jogos, lemos as notícias que descrevem as partidas e validamos o termo cricket score como equivalente de "chocolate". Assim como o termo em português, cricket score foi utilizado para descrever goleadas:

As a result, World Cup watchers could be excused for expecting Holland to wrack up a cricket score in tonight's 5 pm kick-off against Australia, who were beaten by Chile in their opener. $^{217}$

\section{6:31am: $5-0$}

Khedira scores Germany's fifth in the first half. An easy shot on target past Cesar.

We joke about a cricket score, but sadly, that's the way it's headed.

Incredible scenes, I think everyone is stunned we're still 15 minutes from half time. ${ }^{218}$

\footnotetext{
${ }^{216}$ Disponível em: < http://www.foxsports.com.br/videos/302603331928-gol-da-alemanha-chocolatesobre-o-brasil-vira-piada-na-internet $>$ Acesso: 15 ago. 2014.

${ }^{217}$ Disponível em: < http://www.westerngazette.co.uk/World-Cup-2014-preview-Manchester-UnitedHolland/story-21254978-detail/story.html $>$ Acesso: 8 jan. 2015.

${ }^{218}$ Disponível em: < http://www.smh.com.au/fifa-world-cup-2014/world-cup-match-centre/world-cup2014-germany-v-brazil-live-blog-20140708-3bjld.html > Acesso: 8 jan. 2015.
} 


\section{Capítulo 4}

O significado do termo é claro para qualquer inglês com um mínimo de conhecimento sobre críquete e sabe que um placar como 517 x 1 é comum nesse jogo. No entanto, para o brasileiro comum, que pouco ou nada entende de críquete, o termo não faz o menor sentido, já que seu significado só é alcançado por meio da análise do contexto sociocultural em que está inserido.

Os exemplos acima foram retirados de notícias sobre a partida que perdemos por 7x1 para a Alemanha na semifinal da Copa do Mundo de 2014. Em situações como essa, observamos a importância do corpus de validação da Copa do Mundo para a identificação de equivalentes não encontrados no corpus de estudo.

\subsection{1 carregador de piano}

Ao analisar os últimos itens das palavras-chave, a ocorrência 'carregador' chamou a atenção. Geramos, então, linhas de concordância para a palavra e observamos cinco ocorrências de 'carregador de piano'. Vejamos o contexto de uma dessas ocorrências:

Juvenal troca estrela por 'carregador de piano' e diz que Lucas é só sonho ${ }^{219}$

Como desconhecíamos o termo, recorremos ao Google para entender seu significado. Na busca, um dos links disponibilizados foi o do dicionário Aulete digital $^{220}$, que apresenta as seguintes definições:

1 Fig. Pessoa trabalhadora, que recebe bem tarefas pesadas ou dificeis.

2 Esp. Jogador que se dedica com afinco a suas funções, sem estrelismo. ${ }^{221}$

O dicionário, além de apresentar uma definição para o termo na língua geral, apresenta, também, uma definição para o termo dentro do domínio esportivo.

\footnotetext{
${ }^{219}$ Disponível em: < http://globoesporte.globo.com/futebol/times/sao-paulo/noticia/2013/12/juvenaltroca-estrela-por-carregador-de-piano-e-diz-que-lucas-e-so-sonho.html >. Acesso em: 15 abr. 2014.

${ }^{220}$ Disponível em: $<$ http://www.aulete.com.br $>$. Acesso em: 13 jan. 2015.

${ }^{221}$ Disponível em: < http://www.aulete.com.br/carregador $>$. Acesso em: 13 jan. 2015.
} 


\section{Capítulo 4}

Também encontramos uma definição mais detalhada no livro Cabeça-de-bagre: Termos, expressões e gírias do futebol (RIBOLDI, 2008):

Carregador de piano: com pouca habilidade, mas tem muito fôlego e é eficiente para desarmar, tirar a bola do adversário e para realizar tarefas pesadas de seguir o oponente.

Consultamos, ainda, o Yahoo!Respostas ${ }^{222}$, site em que os internautas fazem perguntas sobre diferentes assuntos e recebem respostas ao compartilhar fatos, opiniões e experiências pessoais, e analisamos as respostas para a pergunta: $O$ que significa carregar o piano no futebol ? $^{223}$. Observemos as respostas:

\section{Oque significa carregar o piano no futebol?}

Atualização : deem exemplos de jogadores que "carregam o piano" tbm

Respostas (6)

Classificada como mais alta $\checkmark$

Galvão Bueno O Mais Clubista e Fanático respondido 2 meses atrás

É o jogador que corre igual louco na marcação e se mata para os jogadores talentosos aparecerem.

Normalmente é um primeiro volante, grosso, sem técnica, que só chega na base da bicuda na cara. Um bom exemplo é o Ralf do cúrintia.

\section{It 1 | \\ Comentário}

GALVÃO respondido 1 mês atrás

JOAGR PELOS OUTROS

It 0 P 0

Comentário

WallaceTds respondido 2 meses atrás

Jogar pelo time inteiro,sacrificar-se pelos outros jogadores.Um exemplo era o Ralf do corinthians, teve um tempo que se abola não chegasse nele o resto do time não funcionava,e o cara também se arricava na defesa e no ataque.

H 0 Comentário

Wit Ricio SCCP respondido 2 meses atrás

O "carregador de piano" é assim o centrocampista cuja função maior é estar em todo o lado e carregar a equipa, por assim dizer o piano, para a frente. Este carregar não é só o mero recuperar de bola para lançar a jogada.

Figura 54: Parte das respostas para a pergunta "O que significa carregar o piano no futebol?".

${ }^{222}$ Disponível em: $<$ https://br.answers.yahoo.com $>$. Acesso em: 13 jan. 2015.

${ }^{223}$ Disponível em: $<$ https://br.answers.yahoo.com/question/index?qid=20141102152715AASTYPO $>$. Acesso em: 13 jan. 2015 


\section{Capítulo 4}

Com base nas definições dos dois dicionários e nas respostas do Yahoo!Respostas, podemos concluir que 'carregador de piano' é um jogador, na maioria das vezes um meia ou um centroavante, sem muita técnica, e que normalmente atua na marcação, mas que também ajuda no ataque. Ou seja, o jogador desempenha mais de uma função em campo, mas não tem a mesma fama de alguns de seus colegas de equipe. Entendido o significado e o uso do termo em português, o próximo passo foi tentar encontrar em nosso corpus um possível equivalente em inglês.

Primeiramente, por curiosidade levantamos linhas de concordância para a palavra piano em inglês e, como já esperávamos, não obtivemos nenhum resultado. Como sabíamos que um 'carregador de piano' é, frequentemente, um meia ou um centroavante, pedimos linhas de concordância para os termos midfielder [volante], striker [atacante] e centre forward [centroavante] alinhadas pelas três primeiras palavras à esquerda, devido à ordem dos adjetivos em inglês, e analisamos todas as ocorrências. Mais uma vez, não encontramos candidato(s) a equivalente(s). Por esse motivo, recorremos ao Google e, sem muitas alternativas de busca, pesquisamos pelo nome do jogador Ramires meio-campo do Chelsea, pois, enquanto conduzíamos a análise em português, deparamos com um artigo que descrevia Ramires como um carregador de piano:

\footnotetext{
Não é preciso entender de astrologia para constatar que Felipe

Melo está longe de ser um astro, uma estrela, algo mais que um carregador de piano. Dá pena dele

Mas carregadores de piano são peças fundamentais na cabeça de quem pensa no futebol como Dunga, razão pela qual nada indica que Ramires deixará de ser só uma arma para o segundo tempo.

A vida é assim: começamos pedindo Hernanes, Ganso, Ronaldinho. Mas, diante da dureza da realidade, passamos a nos contentar com um jogador como Ramires.

E com a absoluta convicção de que nem assim seremos atendidos.
}

\section{blogdojuca@uol.com.br}

Figura 55: Parte do artigo que descreve o jogador Ramires como carregador de piano. ${ }^{224}$

\footnotetext{
${ }^{224}$ Disponível em: < http://www1.folha.uol.com.br/fsp/esporte/fk0906201014.htm >. Acesso em: 06 jan. 2015.
} 


\section{Capítulo 4}

Em inglês, a busca retornou vários links com a biografia ou descrições do jogador. O primeiro link direcionou para a entrada 'Ramires' na Wikipedia e, ao ler o primeiro parágrafo, deparamos com um termo que chamou a atenção: box-to-box midfielder. Observemos a descrição nesse site:

\section{Ramires}

From Wikipedia, the free encyclopedia

This name uses Portuguese naming customs. The first or maternal family name is Santos and the second or paternal family name is do Nascimento.

Ramires Santos do Nascimento (Brazilian Portuguese: [ra'mires 'sẽtus du nasìmētu]); born 24 March 1987), known as Ramires, is a Brazilian professional footballer who plays for English club Chelsea and the Brazil national team. A midfielder, he is comfortable playing in either the centre or right midfielder position. He normally plays as a box-to-box midfielder role because of his energy in supporting defensive and offensive play. His attacking and defensive mentality have led to comparisons to former Chelsea teammate Michael Essien.

Ramires began his career playing for Royal Sport Club. In 2005, he signed for Joinville, before joining Cruzeiro, whom he spent just over two seasons with, appearing in 61 league matches and scoring 10 times. In 2009, Ramires moved to Portugal and signed for Benfica from Cruzeiro. He spent one season with Benfica in which he helped them to the Primeira Liga title, five points clear of second-placed Braga. He then joined English club Chelsea in the summer of 2010 on a fouryear contract. He made his Chelsea debut in a 2-0 win against Stoke City in late August 2010 and scored his first goal in a $4-0$ victory against Bolton Wanderers. ${ }^{[5]}$

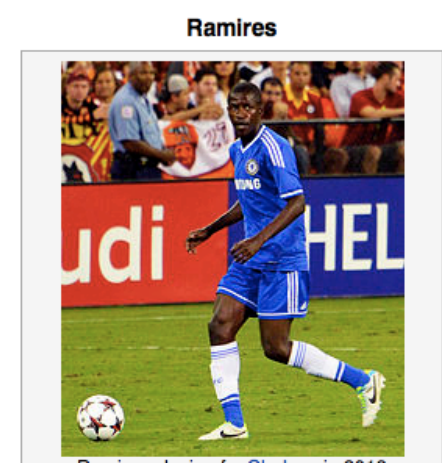

Figura 56: Entrada 'Ramires' na Wikipedia.

Clicamos no hiperlink de box-to-box midfielder e encontramos a seguinte definição:

\section{Box-to-box midfielder [edit]}

The term box-to-box midfielder refers to central midfielders who have good mobility and are skilled at both defending and attacking. ${ }^{[5]}$ These players can therefore track back to their own penalty box to make tackles and block shots, and also run to the opponents' box to try and score. ${ }^{[6]}$

Figura 57: Definição de box-to-box midfielder na Wikipedia.

Como podemos observar, a definição é bastante parecida com as definições de ‘carregador de piano' em português. A única diferença é que a definição da Wikipedia não faz menção ao estrelato. Diferente do português, que usa um termo da língua geral no domínio do futebol, o termo em inglês faz referência às duas áreas do campo. Dessa forma, o box-to-box midfielder "carrega a bola" de uma área (defesa) até a outra (ataque). 


\section{Capítulo 4}

Antes de validar box-to-box midfielder como equivalente de 'carregador de piano', realizamos uma busca no Google para "box-to-box midfielder" no ano de 2014 a fim de verificar quais jogadores são descritos como box-to-box midfielders. Apesar de ter filtrado os resultados para o ano de 2014, a busca retornou um artigo de 2012 intitulado 15 Best Box-to-Box Midfielders in the World Right Now ${ }^{225}$. O artigo menciona jogadores como o próprio Ramires, além de Asturo Vidal, do Juventos, e Daniele De Rossi, do Roma, ambos com reputação de 'carregadores de piano'. Sendo assim, validamos box-to-box midfielder como equivalente de 'carregador de piano'.

Um achado interessante durante a pesquisa do equivalente em inglês foi o possível motivo pelo qual o termo possui baixa frequência tanto no subcorpus em português quanto no subcorpus em inglês: a função do meia, que atua tanto na defesa quanto no ataque, parece estar em declínio. Observemos os seguintes trechos:

By contrast, Kroos is dynamic and hardworking. He can play at the back of midfield or at the front, in the centre or on the flank. He could almost certainly play as a box-to-box midfielder in a 4-4-2 if he ever were asked to do something so archaic. He is creative without being flash, breaks up play without being violent. He is physically robust without being a monster and astute in possession without over-reaching226.

The Question: is the box-to-box midfielder dead? ${ }^{227}$

Nos dois trechos, a discussão do papel do 'carregador de piano' no futebol atual aponta para um possível fim desse tipo de jogador, que parece não encontrar lugar nos esquemas táticos adotados mais recentemente. Seguindo essa lógica, a baixa ocorrência dos termos nos dois corpora é perfeitamente justificada, uma vez que a presença desse tipo de jogador em campo é cada vez mais rara.

4.12 carretilha; lambreta

\footnotetext{
${ }^{225}$ Disponível em: < http://bleacherreport.com/articles/1005399-15-best-box-to-box-midfielders-in-theworld-right-now $>$. Acesso em: 13 jan. 2015.

${ }^{226}$ Trecho retirado de um artigo intitulado The Question: How is interpretation of the playmaker role changing? (Como a interpretação do papel dos jogadores está mudando?). Disponível em: $<$ http://www.theguardian.com/football/blog/2013/apr/04/playmaker-toni-kroos-mesut-ozil $>$. Acesso em: 13 jan. 2015.

${ }^{227}$ Título de um artigo que discute se a função 'carregador de piano' está morta. Disponível em: $<$ http://www.theguardian.com/sport/blog/2009/apr/22/where-have-box-to-box-midfielders-gone $>$. Acesso em: 13 jan. 2015.
} 


\section{Capítulo 4}

Uma ocorrência que nos instigou a pesquisar mais sobre seus colocados foi o adjetivo 'linda', com 182 ocorrências. Geramos linhas de concordância para 'linda' a fim de encontrar padrões linguísticos e deparamos com a colocação 'linda carretilha', com duas ocorrências. Geramos, então, linhas de concordância para 'carretilha' e obtivemos um total de três ocorrências. Sabíamos de antemão que 'carretilha' é um drible em que o jogador puxa a bola com um calcanhar e a levanta com o outro, fazendo com que passe por cima do oponente, e a domina do outro lado, de modo a dar sequência à partida ${ }^{228 .}$

Pesquisamos sobre o drible na internet e conversamos com especialistas da área. Tanto os sites quanto os especialistas definem o drible como um movimento de difícil execução, que exige alto grau de habilidade do jogador e seu uso é comumente associado à depreciação do adversário.

Durante a pesquisa realizada, deparamos com o termo 'lambreta', utilizado como sinônimo ${ }^{229}$ de 'carretilha'. O termo não faz parte da lista de palavras-chave e ocorre uma única vez no corpus. Nesse caso, o nome do drible pode ser associado ao movimento que a linha de pesca faz quando o pescador solta a carretilha e joga a isca na água; no caso de 'lambreta', o nome pode ser associado à pedalada necessária para dar partida no motor do veículo.

No que se refere ao surgimento do drible, Kaneko, ex-ponta-direita do Santos, é conhecido como pai da 'lambreta' no Brasil. Em um jogo entre Santos e BotafogoSP pelo campeonato Paulista de 1968, Kaneko, na linha de fundo, diante do lateral Carlucci, colocou a bola entre as duas chuteiras e, de calcanhar, a lançou sobre a cabeça do lateral. Em seguida, cruzou para a pequena área e Toninho Guerreiro, centroavante dotado de muita habilidade, balançou as redes do goleiro Dirceu Hugo da Roz. O Santos venceu e o jogo permaneceu na memória dos torcedores devido à jogada de Kaneko.

\footnotetext{
228 Para visualizar um vídeo com a execução do drible acesse: < http://www.dailymail.co.uk/video/football/video-1054304/6-year-old-boy-shows-rainbow-flick.html >. Acesso em: 6 jan. 2015.

${ }^{229}$ Conforme discutido no item 1.4 uma das grandes vantagens de se trabalhar com a terminologia do futebol no Brasil é que nossa categoria de especialistas abrange desde acadêmicos de várias áreas que têm o futebol como objeto de estudo de suas pesquisas, até avôs, tios e conhecidos que são apaixonados pelo esporte. No caso de 'lambreta' e 'carretilha', utilizamos nosso conhecimento da área, assim como conversas com especialistas, para validar os dois termos como sinônimos.
} 


\section{Capítulo 4}

Ao ler sites sobre futebol e blogs de aficionados pelo esporte, encontramos menções de 'lambretas' mais antigas. As mais populares são as de Carlinhos Ramos Leal, ponta do Esporte, sobre o lateral Jaiminho, do Náutico, no Campeonato Pernambucano de 1950, e a de Maurinho, ponta do Fluminense, sobre Barbozinha, do Vasco, em um clássico no Maracanã em 1960.

Dado bastante curioso é que, ao pesquisar o drible na internet, confirmamos as informações dadas pelos especialistas: 'carretilha' ou 'lambreta' é um movimento de difícil execução e é cada vez mais raro em partidas oficiais. Por esse motivo, o número de ocorrências no corpus é bastante baixo. Grande parte das ocorrências ressalta a dificuldade e a beleza da jogada e, além disso, a maioria dos links faz referência a uma mesma partida, fato também confirmado nas ocorrências encontradas no corpus:

Alguém ainda vai quebrá-lo.

Eu pensei dez vezes, ia quebrá-lo todo. No lance que ele ia tentar dar a carretilha, eu ia grudá-lo na tela. Uma coisa que eu não admito é falta de respeito, e Neymar estava faltando com respeito. Ele não precisa disso, não precisa fazer graça. Por isso, admiro o Ronaldinho Gaúcho e o Ronaldo Fenômeno. Sempre jogaram o futebol que jogaram sem menosprezar ninguém - declarou Nunes. ${ }^{230}$

Que bonito! Cicinho dá uma lambreta e encobre Zizão aos 12 do $1^{\circ}$ tempo. ${ }^{231}$

Na primeira ocorrência, o drible não chegou a ser executado. Neymar ia dar a carretilha, mas desistiu e não executou o drible. Na segunda, retirada de uma narração em tempo real, o narrador embeleza a jogada de Cicinho, do Corinthians, sobre Zizão, da Ponte Preta. Observamos que todas as páginas da internet que mencionam o drible enfatizam a plasticidade da jogada. Notamos que adjetivos como 'fantástico(a)', 'lindo(a)' e 'belo(a)', e a locução adjetiva 'de encher os olhos' coocorrem frequentemente com 'lambreta' e 'carretilha'. Ademais, encontramos também outros

230 Disponível em: <http://blogs.band.com.br/marcondesbrito/2013/01/24/palmeiras-e-flamengoadmitem-publicamente-que-estao-na-pindaiba $>$. Acesso em: 6 jan. 2015.

231 Disponível em: <http:/globotv.globo.com/globocom/tempo-real/v/que-bonito-cicinho-da-umalambreta-e-encobre-zizao-aos-12-do-1o-tempo/2363145/>. Acesso em: 6 jan. 2015. 


\section{Capítulo 4}

dois sinônimos: 'lençol psicodélico', utilizado pelos jornalistas ${ }^{232}$, e 'rodoblê', como ficou conhecido entre os jogadores ${ }^{233}$.

Após entender a dinâmica do drible em português, o próximo passo foi procurar seu equivalente em inglês. Como sabíamos de antemão que o drible raramente ocorre em partidas oficiais e que, por esse motivo, o número de ocorrências provavelmente não seria alto, o primeiro passo foi analisar os hapax legomena na wordlist do corpus em inglês. Após descartar alguns candidatos a equivalente, chegamos ao termo rainbow flick. Observemos a ocorrência no corpus:

Wow! Robinho pulls off a rainbow flick over Alexis Sanchez! $!^{234}$

Após assistir ao vídeo que demonstra esse drible, validamos rainbow flick como equivalente de 'lambreta' e 'carretilha'. Contudo, uma dúvida nos ocorreu: será que, assim como em português, o termo possui sinônimos em inglês?

Não foi possível responder à pergunta por meio da análise do corpus dada a baixa probabilidade de ocorrência do drible em uma partida. Além disso, já tínhamos descartado os outros possíveis equivalentes. Realizamos, então, uma busca no Google para "rainbow flick" e a primeira ocorrência da primeira página de resultados esclareceu nossa dúvida:

\footnotetext{
${ }^{232}$ Para informações mais detalhadas, acessar: < http://santosfc.com.br/2010/03/ha-42-anos-ex-pontakaneko-dava-lencol-psicodelico-em-jogo-na-vila/ > . Acesso em: 6 jan. 2015.

${ }^{233}$ Para informações mais detalhadas, acessar: < http://www.novomilenio.inf.br/santos/h0299t.htm> Acesso em: 6 jan. 2015.

${ }^{234}$ Vídeo do drible disponível em: < http://www.101 greatgoals.com/gvideos/wow-robinho-pulls-off-arainbow-flick-over-alexis-sanchez/ >. Acesso em: 6 jan. 2015.
} 


\section{Capítulo 4}

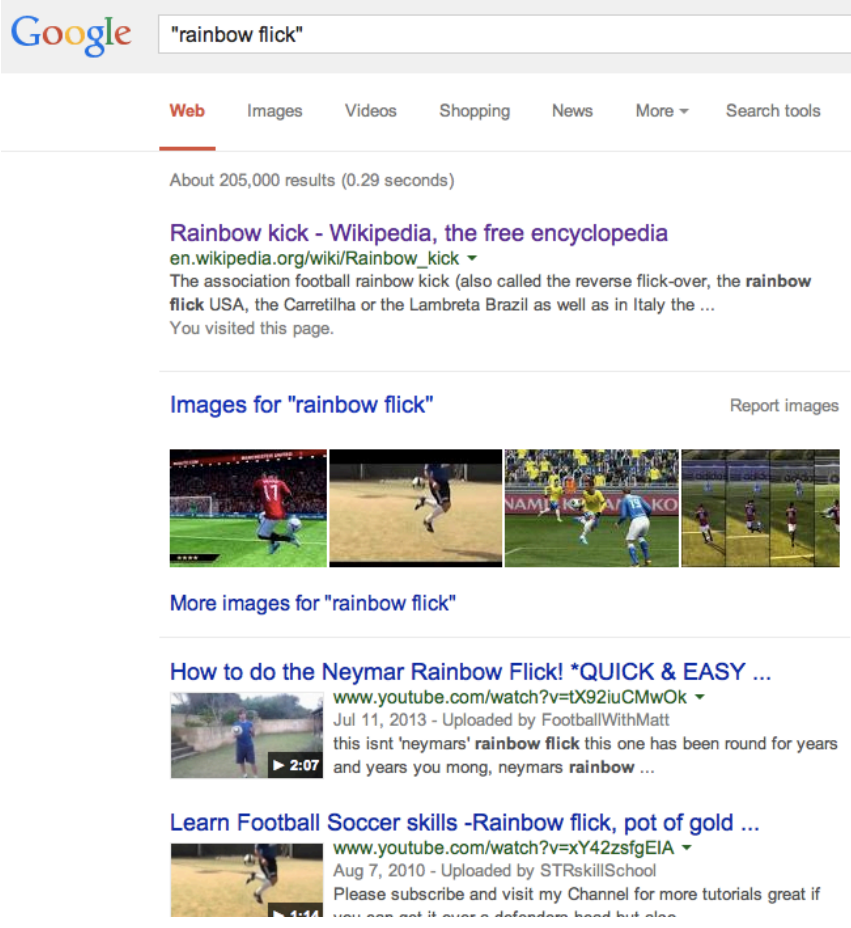

Figura 58: Resultado da busca para "rainbow flick" no Google.

Clicamos no link da Wikipedia ${ }^{235}$ e lemos os sinônimos apresentados pelo site. Verificamos se algum deles estava presente em nosso corpus e não encontramos nenhuma ocorrência.

Conforme discutido anteriormente, sabemos que dificilmente encontraremos respostas para todas as perguntas de uma pesquisa em um corpus. Por esse motivo, realizamos buscas individuais no Google para cada um dos termos apresentados. Utilizamos a busca avançada, restringimos a pesquisa para sites de domínio .uk e validamos rainbow kick, lambretta flick, lambretta dribble, reverse flick-over, (Ossie) Ardiles' flick e Jay Jay Okocha e the Okocha como sinônimos de rainbow flick ${ }^{236}$.

His winning goal against Senegal in the quarterfinal will eternally remain one of the greatest moments in Turkish sporting history, and his robust performances as a substitute mirrored the tough, no-nonsense approach of the team. Yet Mansiz was not short on flair either, famously bamboozling all-time great Roberto Carlos with a stunning rainbow kick in the tournament before being hastily bundled to the ground by the Brazilian defender. ${ }^{237}$

\footnotetext{
${ }^{235}$ Disponível em: < http://en.wikipedia.org/wiki/Main_Page > . Acesso em: 6 jan. 2015 .

${ }^{236}$ Não validamos alguns termos apresentados pela Wikipedia, pois não encontramos nenhuma ocorrência no Google com exceção da ocorrência na própria Wikipedia.

237 Disponível em: <http://sports.yahoo.com/news/olympics-from-the-world-cup-to-the-olympics-ilhan-mansiz-s-unlikely-journey-152423720.html >. Acesso em: 7 jan. 2015.
} 


\section{Capítulo 4}

Video: Neymar's brilliant Lambretta flick ${ }^{238}$

South American football expert Tim Vickery joins H\&J to wax lyrical about Tottenham target Leandro Damiao's rapid rise to prominence, and his trademark Lambretta dribble. ${ }^{239}$

The ball reached Rakitic on the half-way line and Pepe, who was completely outside his area, raced to the left flank to try to block the Croatian's counter-attack. The Portuguese centreback was subjected to an unforgettable reverse flick-over and he tried helplessly and clumsily to keep up with Rakitic's charge. ${ }^{240}$

The game itself will always be remembered for a stunning goal from Glenn Hoddle, the famous high-flying volley from Ossie Ardiles' flick that rattled into the top corner of Gary Bailey's net. ${ }^{241}$

Jay Jay Okocha, "the Okocha", football soccer move $e^{242}$

Lambretta flick, lambrettta dribble e reverse flick-over descrevem o percurso realizado pela bola durante a execução do drible. Infelizmente, para validar os termos em inglês não contamos com a ajuda de especialistas, como foi possível proceder em relação aos termos em português. Contudo, nossas hipóteses puderam ser comprovadas ou não por meio de blogs, fóruns e livros disponíveis no Google Books $^{243}$. Associamos lambretta flick e lambretta dribble ao movimento da bola, uma vez que o referencial é o mesmo em português. No caso de rainbow flick, encontramos uma explicação bastante interessante no livro The Global Art of Soccer $^{244}$. Segundo Witzig (2006, p. 93), autor da obra, o drible é tão fantástico que sua execução, sobre o oponente, pode ser associada a um pintor que pinta um arcoíris. Novamente, devido à alusão ao movimento da bola, essa explicação se aplica também ao termo rainbow kick. Por fim, reverse flick-over descreve o percurso da

\footnotetext{
${ }^{238}$ Disponível em: <https://uk.eurosport.yahoo.com/video/15092011/58/neymar-brilliant-lambrettaflick.html>. Acesso em: 7 jan. 2015.

239 Disponível em: <http://talksport.com/radio/hawksbee-and-jacobs/blog/2011-09-21/tim-vickerytottenham-target-leandro-damiaos-lambretta-dribble\#SPsh8QYxSV7Gy0jY.99>. Acesso em: 7 jan. 2015.

${ }^{240}$ Disponível em: <http://www.sport.net/what-bale-did-is-criminal_158342 >. Acesso em: 7 jan. 2015.

241 Disponível em: <http://www.tottenhamhotspur.com/news/view-froma-legend3-110909/>. Acesso em: 7 jan. 2015.

${ }^{242}$ Disponível em: <https://www.youtube.com/watch? $v=X p 5 k M T m 6 w n Q>$. Acesso em: 7 jan. 2015.

${ }^{243}$ Disponível em: < http://google.com.au/books >. Acesso em: 7 jan. 2015.

$244 \quad$ Disponível em:

http://books.google.co.uk/books?id=H2T0ZD5S86QC\&pg=PA25\&vq=rainbow\&dq=turkey+brazil+rai nbow + carlos\&source $=$ gbs_search_s\&cad $=5 \&$ sig $=$ ACfU3U1vKMi8u4NpTNCWK7IEWE3LR0ws$\mathrm{g} \# \mathrm{v}=$ onepage $\& \mathrm{q}=$ rainbow $\& \mathrm{f}=$ false $>$. Acesso em: 7 jan. 2015.
} 


\section{Capítulo 4}

bola na jogada. Já (Ossie) Ardiles' flick e Jay Jay Okocha ou the Okocha fazem referência a jogadores que executavam o drible com maestria.

O drible aparece no filme 'Fuga para a vitória' (Escape to Victory), que relata a vida de prisioneiros de guerra em um campo nazista na Alemanha durante a segunda Guerra Mundial. Na narrativa, o major Karl von Steiner, que fora jogador da seleção alemã, decide realizar um jogo entre um time alemão e um combinado composto por prisioneiros. O ex-jogador argentino Osvaldo César Ardiles, conhecido na Inglaterra como Ossie Ardile, interpreta Carlos Rey, prisioneiro que 'dá uma lambreta' espetacular em um dos jogadores alemães.

O drible também ficou conhecido com Jay Jay Okocha ou The Okocha devido à desenvoltura com que o jogador nigeriano Augustine Azuka Okocha, mais conhecido como Jay-Jay Okocha, o executava. Okocha, maior craque da Nigéria, mudou-se para a Alemanha em 1993 para defender o Borussia Neukirchen e, mais tarde, o Eintracht Frankfurt, popularizando, em terras alemãs, o drible que, com o tempo, passou a levar seu nome. Okocha passou por outros cinco clubes ao longo de sua carreira. Jogou pelo Fenerbahçe, da Turquia, pelo Paris Saint-Germain, da França, pelo Bolton Wanderers, da Inglaterra, pelo Qatar FC e pelo Hull City, também na Inglaterra, onde, assim como na Alemanha, popularizou o drible.

Um achado interessante sobre o rainbow flick e seus sinônimos é que, assim como no Brasil, o drible é considerado de alta dificuldade e, embora existam várias ocorrências no Google, grande parte delas faz referência a uma mesma partida. Por exemplo, encontramos 25 ocorrências descrevendo a 'lambreta' que Roberto Carlos tomou do jogador Ilhan Mansız da Turquia na Copa de 2002. Ademais, a maioria das ocorrências não foi encontrada nas mesmas tipologias textuais que compõem nosso corpus de estudo (textos jornalísticos sobre resultados de partidas, narrações minuto a minuto, transmissão social e textos sobre compra e venda de jogadores), mas sim em tutoriais sobre como dar o drible ou em sites que tem o futebol como temática, mas que não possuem textos sobre resultados de partidas. Observemos os exemplos que seguem: 
Capítulo 4

You Tubse ${ }^{\text {Au }} \equiv \cdot$

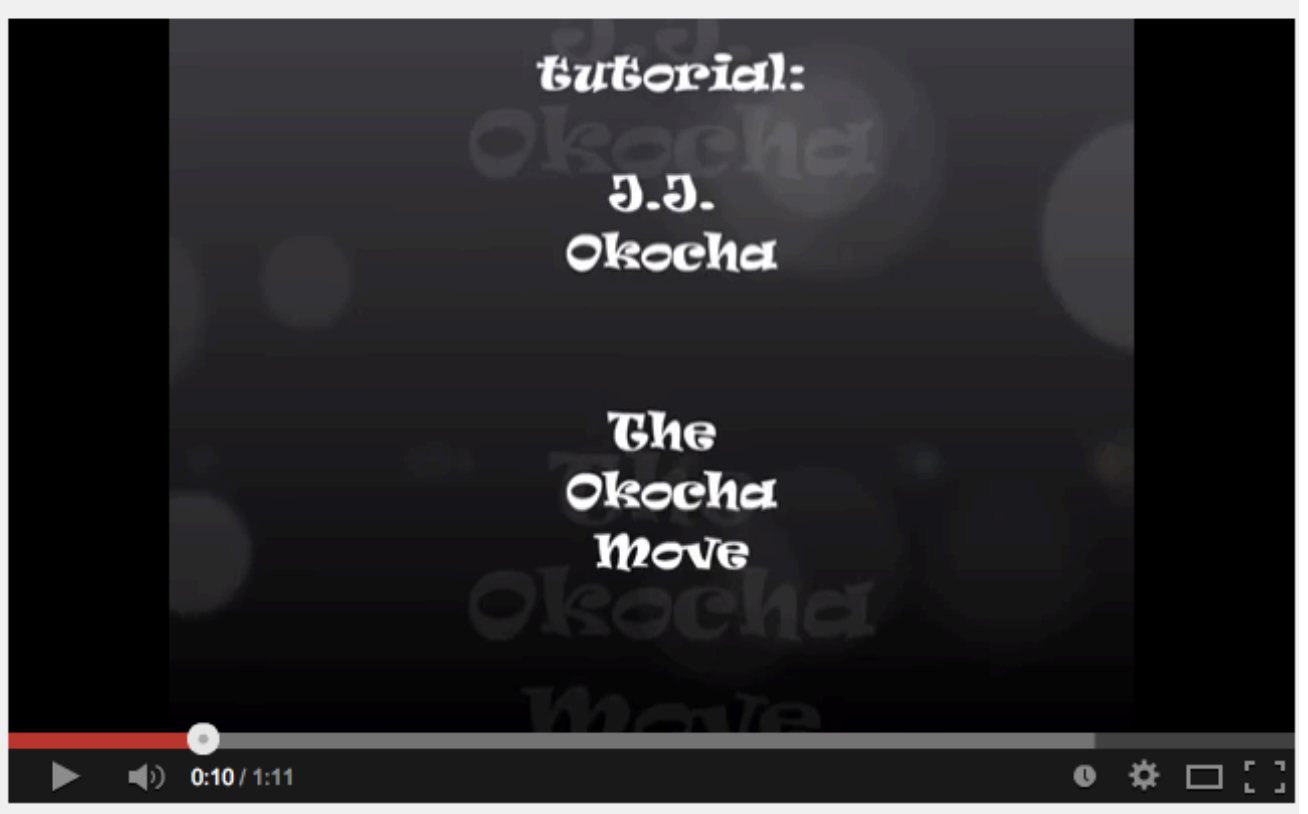

Jay Jay Okocha "the Okocha" football soccer move

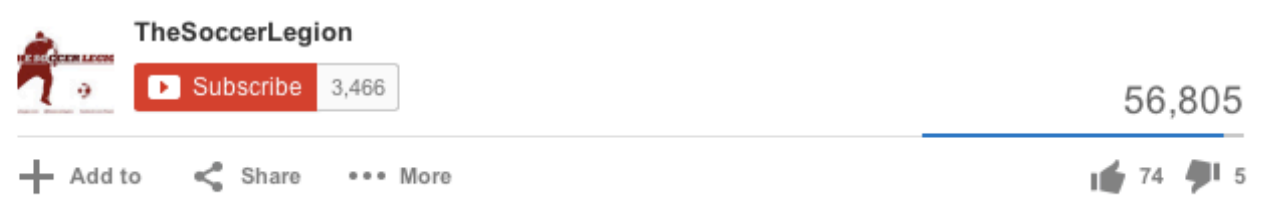

Figura 59: Tutorial do drible Jay Jay Okocha no YouTube 


\section{Capítulo 4}

Article Edit Discuss
Two Methods: Eracticing the Rainbow while Stationary 1 Using the Rainbow on the Field
The soccer rainbow is a flashy move that amazes the crowd and can double as an offensive
tool to push the ball forward. It's a slightly tricky technique that involves using your foot to scoot
the ball up your leg, then kicking it with your opposite heel so that it arcs neatly over your head.
Read on to learn more about how to do a rainbow.

\section{Method 2 of 2: Using the Rainbow on the Field}

1 Dribble the ball fairly quickly towards a defender. You can use the rainbow to switch the direction of the ball right when a defender is trying to steal it.

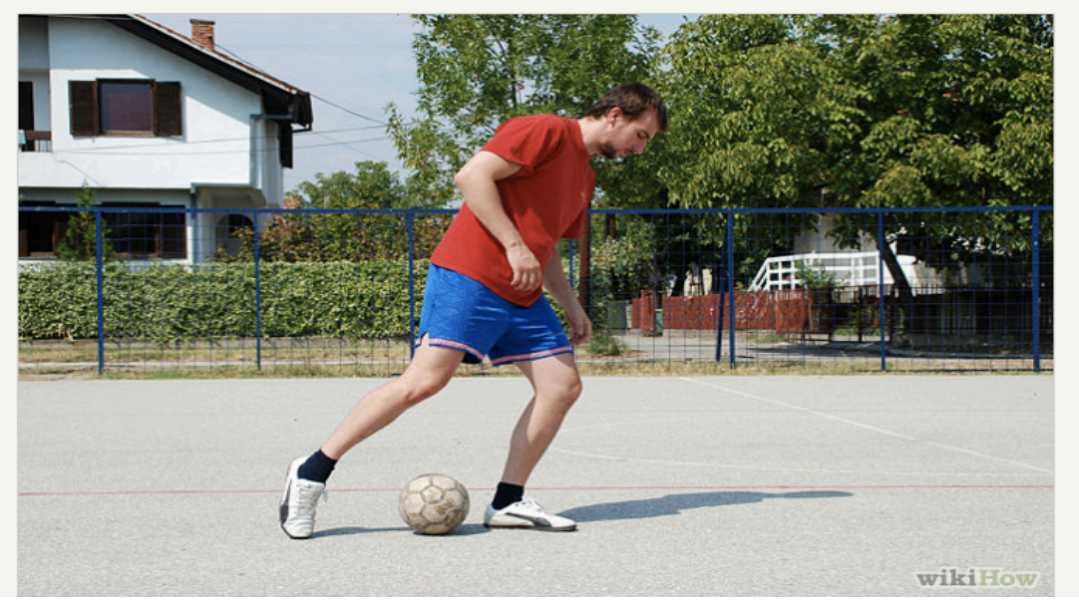

2 Place your dominant foot's heel in front of the ball while leaning forward a bit. 2 This is important because if you don't lean forward, the ball will go backwards.

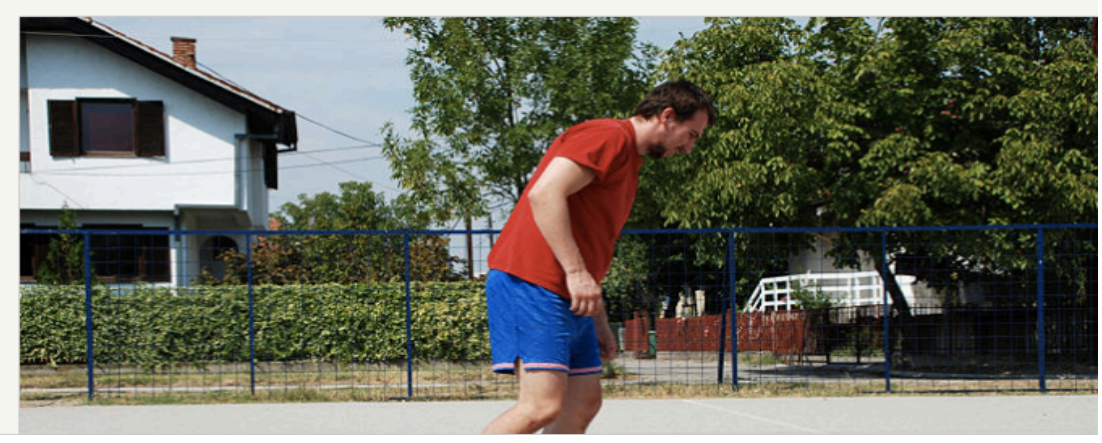

3 Follow through with your foot. Once the ball rolls up to knee level, follow through with your foot so that the ball gets some air as it rolls off of your leg. You want the ball to be positioned just over your heel. So if you used your right foot to roll the ball up your left leg, guide the ball off of your leg once it reaches the knee; it should float down just behind your left heel. 


\section{Capítulo 4}

4 Land on your dominant foot as you kick the ball with your heel. Now the foot you used to roll the ball should land on the ground. At the same time, use the heel of your other foot to kick the ball upward with your heel. For right-handers, that means your right foot will hit the ground as your left heel kicks the ball, arcing it over your head.

- This process must happen very quickly in order to work properly. Practice rolling and kicking over and over until you're able to move your legs fast enough to get it right.

- You want to strike the underside of the ball in an upward motion to get it to arc up and over your head. Practice until the ball lands right in front of your body.

- Lean forward a bit as you land and kick. This will help the ball move in the right direction.

\section{Method 2 of 2: Using the Rainbow on the Field}

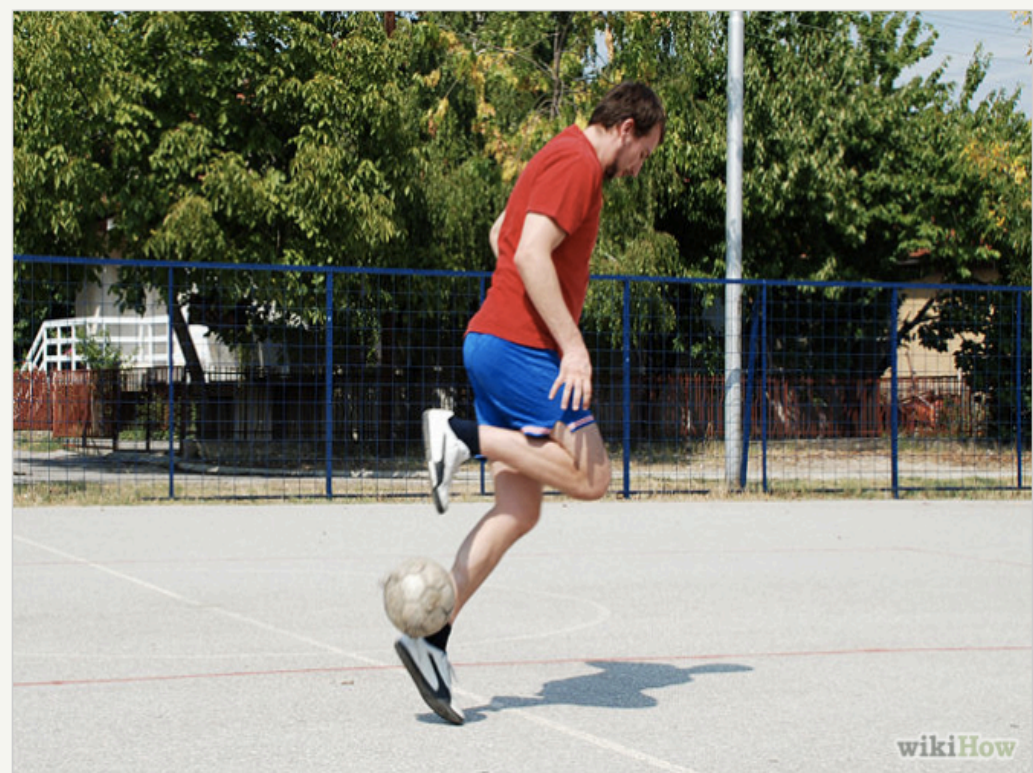

5 Lean forward and kick the ball with your heel. Do this as you land on your dominant foot. The ball should arc up and over the defender, and they will likely be confused about where it went, and you can run around the defender and continue moving with the ball.

\section{Tips}

- This is done while running, so don't stray too far from your natural step. It will just happen. Don't worry too much about where the ball will go. But don't run to fast or it will be difficult to roll the ball up.

- If, after a while, the ball just ends up being kicked in the air by the heel and lands behind you, try running at the ball to gain more momentum, but remember to keep the move as one motion. If you can easily get the ball to go over your head, a cool trick is to incorporate that with juggling, or if you run at the ball diagonally, you can sometimes get the ball to go over your shoulder or in a specific direction.

- The last step will take a long time to get right, the entire step should be one motion, and with practice, you will naturally do the step with ease. 


\title{
Capítulo 4
}

\section{Warnings}

- Some better defenders will know what you are doing as soon as they see your feet. Make the move quick enough so that they don't beat you to the ball. Jog while doing the trick

- Don't do this move too many times in one game, because the other players will start to catch on to what you're doing and be able to stop it. You will also look foolish, as rainbows are just for being able to be a good player - they are hardly ever used in games.

- Do not try to do the trick standing still; it is much easier if you run at the ball and try to get it over your head. But if you get good you can stand still and still do it.

- As soon as you heel the ball, make sure to keep running so you keep on your feet; sometimes you can stumble and land on your face which isn't all that impressive.

\section{Things You'll Need}

\author{
Soccer Ball \\ 7 Some Open Space \\ Running Shoes or Soccer cleats.
}

Figura 60: Instruções de como executar o drible no site Wikihow em inglês.

The story is utter nonsense - revolving around the Nazis taking on a POW team in a bizarre exhibition match - but against the odds the finale is both entertaining and exhilarating, featuring the Ardiles' flick, the Pele bicycle kick, and a truly great escape ${ }^{245}$.

O primeiro exemplo (figura 59) é um vídeo que ensina, passo a passo, como realizar o drible. Como discutido anteriormente, esse tipo de tutorial é muito comum em inglês devido ao modo como o futebol foi implementado na Inglaterra, sempre privilegiando o didatismo. Didatismo, esse, que só surgiu no futebol brasileiro mais recentemente por meio das escolinhas de futebol e que ainda não se manifestou na criação de tutoriais on-line.

\footnotetext{
${ }^{245}$ Disponível em: < http://au.ign.com/articles/2014/06/12/the-greatest-football-movies-ever-made $>$. Acesso em: 7 jan. 2015.
} 


\section{Capítulo 4}

Assim como o primeiro, o segundo exemplo (figura 60), extraído do site WikiHow, reflete a didática do futebol na Inglaterra. A WikeHow é uma comunidade da Wikipedia com guias de "how-to" (como fazer). No site, é possível encontrar diversos tipos de tutoriais, desde como dar um determinado drible no futebol, trocar o pneu de um carro e, até mesmo, treinar para ser um ninja ou dar um nó na haste da cereja com a língua. Assim como a Wikipedia, o site está disponível em diversas línguas e não faz distinção entre inglês britânico e inglês americano e nem entre português do Brasil e de Portugal ${ }^{246}$. Contudo, por ser um dos sites de pesquisa mais acessados do mundo, levamos em consideração as informações presentes na Wikipedia e na WikiHow em nossa análise. Na verdade, mais do que disponibilizar informações linguísticas, os dois sites são ótimas fontes para um melhor entendimento de como falantes nativos do inglês e do português vivem, relatam e entendem o futebol. A primeira diferença significativa entre a WikiHow em português e a WikiHow em inglês é que encontramos um artigo para a maioria dos dribles que procuramos em inglês, mas raramente para aqueles em português. Não encontramos dados exatos, mas acreditamos que a WikiHow em inglês possui um número de artigos bastante superior à versão em português, comprovando, de certa forma, o interesse das culturas inglesas em geral em aprender por meio de tutoriais, pois, nesse sentido, não podemos considerar somente a Inglaterra. Além disso, as instruções dadas em inglês para a execução dos dribles são sempre bem detalhadas, ao passo que as instruções em português são bem sucintas, demonstrando, novamente, como o conceito high and low context cultures ajuda a melhor compreender as diferenças nos gêneros textuais entre duas línguas ou culturas.

O terceiro exemplo foi retirado de um artigo intitulado The greatest football movies ever made ${ }^{247}$, que lista os melhores filmes de futebol existentes e os mais belos passes e dribles.

\footnotetext{
${ }^{246}$ A Wikipedia utiliza o termo soccer (inglês americano) para se referir ao futebol a fim de diferenciálo do futebol americano, conhecido nos Estados Unidos como football. No entanto, sempre que uma busca pelo termo football é realizada, o internauta é direcionado para uma página de desambiguação onde clica no esporte que está procurando: football (futebol americano) ou soccer (Association football).

${ }^{247} \mathrm{O}$ artigo foi publicado em um site australiano, mas o autor morou na Inglaterra por sete anos e se descreve como aficionado pelo esporte, o que o enquadra em nossa categoria de especialistas.
} 


\section{Capítulo 4}

Embora o número de ocorrências seja baixo nas duas línguas, o drible é frequentemente associado a jogadores brasileiros, que, por sua vez, são descritos como habilidosos. Observemos os exemplos abaixo:

It is rarely used in modern professional football, as it has a relatively low success rate, but players with high confidence and skill may attempt it from time to time. Brazilian players such as Neymar, Djalminha, Ronaldinho, Ronaldo and are among those who have used this trick ... ${ }^{248}$

Wow! Barcelona star Neymar scores outrageous rainbow flick goal ${ }^{249}$

Tal fato pode ser explicado pelo conceito forma-representação. Sendo assim, a alta incidência da ocorrência de nomes de jogadores brasileiros seguidos de suas aptidões com o drible pode ser resultado da imagem de futebol-arte, alegre e habilidoso que o inglês construiu ao longo dos anos sobre o futebol brasileiro.

\subsection{3 rolinho; caneta; janelinha; sainha}

São inúmeros os dribles no futebol: 'da vaca' (item 4.3), 'rolinho', 'chapéu', 'pedalada', 'lambreta', 'elástico' (item 4.9), ‘da foquinha', entre muitos outros. Com 157 ocorrências, palavra-chave no corpus que chamou a atenção foi 'rolinho', termo que se refere a um drible em que um jogador rola a bola por baixo das pernas do adversário e corre pelo lado para buscá-la.

Após uma primeira classificação dos dribles encontrados, validamos 'caneta' (22 ocorrências), 'janelinha' (duas ocorrências), 'sainha' (duas ocorrências) e 'saiote' (uma ocorrência) como sinônimos de 'rolinho'. Além das ocorrências no corpus, durante discussão com um dos pesquisadores do LUDENS, surgiram os termos 'janela' e 'cana'.

Antes de tentar encontrar o equivalente de 'rolinho' em inglês, tentamos, sem muito sucesso, descobrir a origem do termo em português. Nossas pesquisas e conversas com historiadores não renderam nada além do óbvio: 'rolinho' descreve a trajetória da bola, que rola por baixo das pernas do adversário; o significado de

\footnotetext{
${ }^{248}$ Disponível em: <http://en.wikipedia.org/wiki/Rainbow_kick>. Acesso em: 8 jan. 2015.

${ }^{249}$ Disponível em: < https://uk.eurosport.yahoo.com/blogs/pitchside-europe/barcelona-star-neymarscores-outrageous-rainbow-flick-in-charity-match-091149816.html >. Acesso em: 8 jan. 2015.
} 


\section{Capítulo 4}

'janelinha' e 'janela' pode estar associado às pernas abertas do adversário, que podem ser comparadas a uma janela aberta, onde a passagem está livre; 'sainha', 'saia' e 'saiote' podem, de alguma forma, fazer alusão ao ato de a bola passar por baixo das pernas do marcador, assim como 'rolinho'; os termos 'cana' e 'caneta' permaneceram sem explicação. Como podemos observar, em alguns casos a história do surgimento de um termo se perde no tempo.

O próximo passo foi a busca do equivalente em inglês. Uma primeira análise da lista de palavras-chave do subcorpus em inglês não contribuiu para a identificação do equivalente. Resolvemos, então, buscar textos em português que se referem a partidas dos campeonatos inglês e europeu em que um jogador tivesse 'dado um rolinho', para, posteriormente, procurar pelas mesmas partidas em inglês e ler os textos em busca do equivalente.

Nossa pesquisa foi bem sucedida e encontramos a palavra nutmeg descrevendo o 'rolinho'. Mesmo não conseguindo descobrir as raízes do termo em português, resolvemos tentar entender o motivo pelo qual nutmeg, palavra em inglês para 'noz-moscada', é utilizada para descrever o drible.

Segundo Peter Seddon, autor do livro The Language and Folklore of the World's Greatest Game, o uso figurado de nutmeg surgiu na Inglaterra Vitoriana. $\mathrm{Na}$ época, era uma gíria utilizada para descrever uma situação em que alguém que fora trapaceado ficou com fama de estúpido, sem ação, assim como o jogador que "toma um rolinho". Isso porque a noz-moscada era um importante produto de exportação para o país e, devido ao seu alto valor, alguns exportadores que queriam se dar bem misturavam a especiaria com pó de madeira a fim de lucrar mais. Dessa forma, nutmeg implicava um ato de habilidade e malícia por parte de um dos comerciantes e de estupidez por parte do outro. Ainda segundo o autor, o termo passou, em algum momento da história, a ser utilizado na linguagem do futebol para designar um drible que exige destreza e astúcia de um jogador e inocência, ou estupidez, do marcador.

Enfim, concluímos a análise de nutmeg levantando dois pontos: 1) o surgimento de alguns termos está atrelado a momentos históricos específicos; e 2) por mais atraente que seja a hipótese de que o drible é invenção brasileira, alguns relatos parecem contradizê-la. No entanto, em nosso trabalho não devemos e nem podemos ignorá-la, pois é uma hipótese bastante difundida entre pesquisadores, narradores, 


\section{Capítulo 4}

jornalistas e apaixonados por futebol, sujeitos que reproduzem suas formasrepresentações para o grande público, tendo reflexo direto nos termos presentes em nosso corpus.

\subsection{4 corte seco}

Este estudo de caso analisa a problemática da identificação de equivalentes em inglês para alguns passes, toques e movimentos executados pelos jogadores.

O termo selecionado é 'corte seco', que apresenta 47 ocorrências em nosso corpus de português, número relativamente alto, pois, dada a variedade de dribles existentes no futebol, o número de ocorrências de cada drible tende a ser mais baixo. A maior parte dos dribles apresenta entre dezessete e 50 ocorrências. Chegamos ao termo 'corte seco' por meio da análise das linhas de concordâncias de 'corte' (154), última palavra-chave de nossa lista.

Corte seco é um drible em que o jogador finge que vai passar ou cruzar a bola, mas, em vez de chutá-la, arrasta a bola por trás do pé que está no chão com a parte de dentro do pé que realizaria o chute. Assim, corta para o outro lado e arranca, com o objetivo de despistar seu marcador.

Analisamos as palavras-chave e até mesmo a lista de palavras do subcorpus em inglês, mas não encontramos nenhuma ocorrência que, em um primeiro momento, pudesse ser considerada como possível equivalente de 'corte seco'. Nesse caso, a alternativa foi selecionar os poucos vídeos do YouTube encontrados a partir da palavra de busca 'corte seco' seguida pela palavra 'futebol' e mostrá-los aos pesquisadores do LUDENS a fim de entender melhor a execução do drible que, até aquele momento, não estava muito clara. Um dos pesquisadores presentes na sala em que o grupo de estudos se reúne fez um comentário que, posteriormente, nos levou ao equivalente de 'corte seco': “Tinha um jogador holandês, que jogou no Ajax e no Barça, se não me engano na década de 70, que era conhecido por dar corte seco. Só que não lembro o nome do cara." Sem muitas opções, entramos na internet e buscamos os jogadores dos times do Ajax na década de 70. Ao ler os nomes dos jogadores, outro pesquisador ali presente disse: "Cruyff! Ele é o cara do corte seco!"

Decidimos, então, por curiosidade, se não por falta de opção, realizar uma 


\section{Capítulo 4}

busca para Johan Cruyff no Google e, ao ler os resultados retornados, uma ocorrência chamou a atenção. Observemos a figura 61:

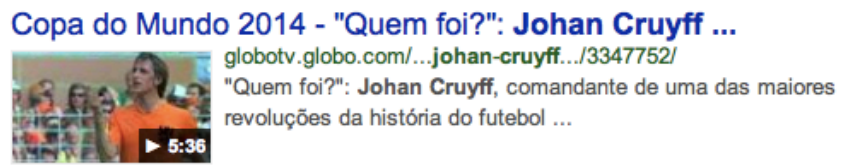

Os $30+$ das Copas: $8^{\circ}$ Johan Cruyff | Esporte Fino

esportefino.cartacapital.com.br/30-melhores-jogadores-copas-johan-cruy... .

Os 30+ das Copas: $8^{\circ}$ Johan Cruyff. Postado por Esporte Fino em 04/06/2014. 8

Cruyff. O maior jogador holandês de todos os tempos certamente se ...

O problema do Barcelona é Neymar, diz Johan Cruyff ...

diariodonordeste.verdesmares.com.br/.../o-problema-do-barcelona-e-ney... .

25/03/2014 - Um dos maiores ídolos da história do Barcelona, o holandês Johan Cruyff,

66, voltou a criticar Neymar, 22. Ex-jogador e ex-técnico do clube ...

\section{Johan Cruyff - Zero Zero}

www.zerozero.pt/treinador.php?id=609

Johan Cruyff. Médio. Percurso: Ajax, Barcelona, New York Cosmos [NASL], LA

Aztecs, Washington Diplomats, Levante, Milan, Feyenoord...

\section{Planet World Cup - Legends - Johan Cruijff} www.planetworldcup.com/LEGENDS/cruyff.html - Traduzir esta página

Johan Cruijff (Netherlands). Hendrik Johannes Cruijff, born in Amsterdam 1947, began

his career at local club Ajax in 1964 where he quickly blossomed into a ..

World Cup: 25 stunning moments ... No25: the Cruyff Turn is .

www.theguardian.com/.../world-cup-stunning-meme... - Traduzir esta página

11/06/2014 - Cruyff At World Cup Johan Cruyff's exhibition of athletic, aesthetic,

balletic brilliance in the 23rd minute against Sweden is one of football's most ...

Figura 61: Resultado de busca no Google para Johan Cruyff.

Clicamos no link para entender Cruyff turn e fomos direcionados para a seguinte página: 
Capítulo 4

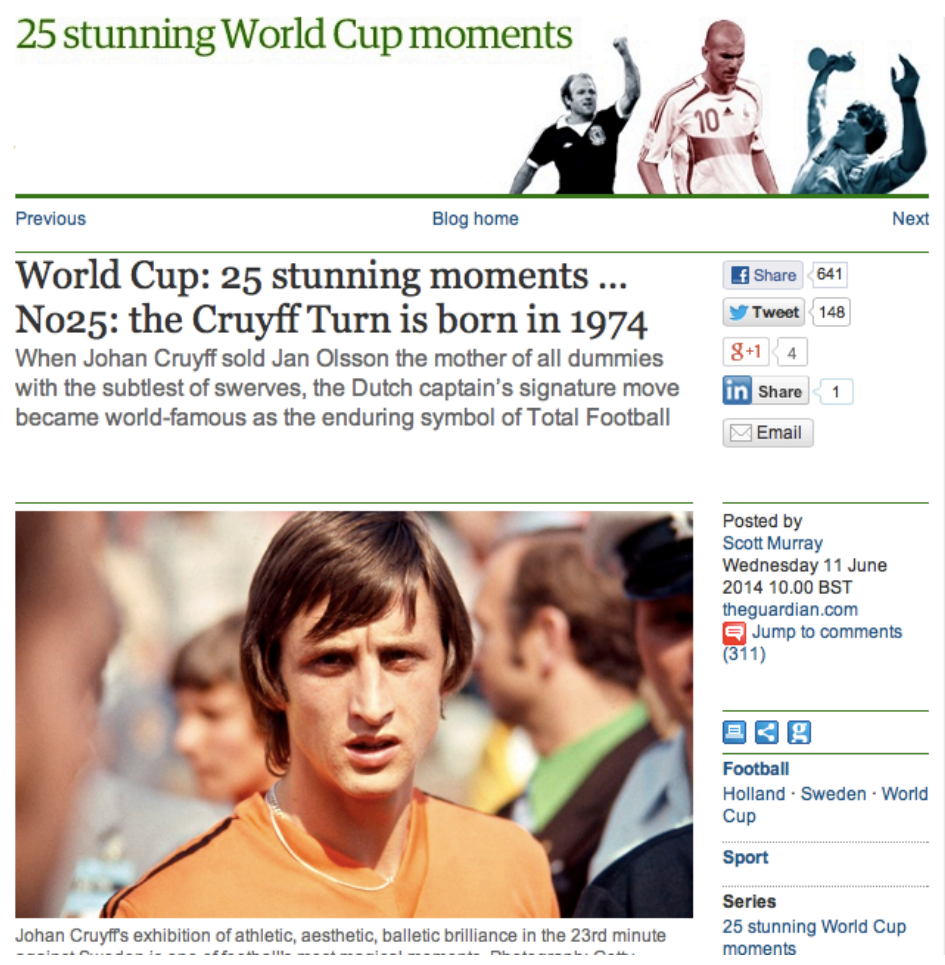

Figura 62: Página do jornal inglês The Guardian descrevendo a origem de um movimento conhecido como "Cruyff turn"250.

Lemos a reportagem do jornal inglês e realizamos uma busca no YouTube para "Cruyff turn” e, após assistir a vários vídeos que exibiam o movimento, validamos Cruyff turn como equivalente de "corte seco".

Em inglês, o movimento foi nomeado em homenagem ao jogador holandês que o executava com perfeição. Existem hipóteses que defendem a ideia de que Cruyff teria executado o movimento pela primeira vez na Copa do Mundo de 1974, em um jogo da Holanda contra a Suécia, em cima do zagueiro Jan Olsson. Investigar a origem do drible foge do escopo desta pesquisa; contudo, acreditamos que esse tipo de informação, histórica e contextual, é fundamental para o entendimento do futebolês. Além disso, o achado comprovou uma hipótese levantada durante a análise dos textos: em inglês, existe uma tendência muita grande de nomear dribles, passes e movimentos em homenagem a jogadores como, por exemplo, Zidane Roulette ${ }^{251}$, The

250 Disponível em: < http://www.theguardian.com/football/blog/2014/jun/11/world-cup-stunningmoments-johan-cruyff-turn-1974 >. Acesso em: 13 jun. 2014.

251 “360” em português. 


\section{Capítulo 4}

Ronaldo Chop ${ }^{252}$, Rivelino's elastico ${ }^{253}$, dentre outros.

\subsection{5 cai-cai}

Durante a análise do termo 'falta' (item 4.2), observamos que o número de faltas no Campeonato Brasileiro é bem maior do que no Campeonato Inglês e discutimos a reputação de 'cai-cai', frequentemente atribuída aos jogadores brasileiros. Como exposto anteriormente, não pretendemos estereotipar nossos jogadores afirmando que eles "cavam" mais faltas do que os ingleses. Contudo, acreditamos que a reputação a eles atribuída pode ser interpretada como resultado da forma-representação criada em torno de nosso futebol ${ }^{254}$. Enfim, essa diferença chamou bastante a atenção e, por esse motivo, decidimos verificar se o termo ocorria no corpus, já que não faz parte da lista de palavras-chave. Para tanto, geramos uma lista de concordâncias para o termo. A pesquisa retornou doze ocorrências e ao ler as notícias a fim de melhor entender a reputação do jogador brasileiro, um termo se destacou:

Galliani deu entrevista sobre as criticas de José Mourinho, técnico do Chelsea, a Neymar e Balotelli. O português disse que simulações e o fato de os atacantes forçarem as expulsões de rivais são meios antiéticos de se jogar. O brasileiro, inclusive, já foi chamado de "piscineiro" por parte da imprensa e da torcida espanhola. ${ }^{255}$

O trecho acima discute a polêmica atuação do jogador Neymar, atacante do clube catalão Barcelona F.C., que possui reputação de simular faltas, e utiliza o termo 'piscineiro' como sinônimo de 'cai-cai'. Diante da possibilidade de um termo sinônimo, geramos linhas de concordância para 'piscineiro' a fim de encontrar mais ocorrências do termo, mas nenhuma outra foi encontrada. Realizamos, então, uma busca para 'piscineiro' acompanhada da palavra 'futebol' no Google, que retornou 43.000 ocorrências. Observemos alguns exemplos:

\footnotetext{
${ }^{252}$ Não possui um termo específico em português. Apresentaremos um exemplo de termo que não possui equivalente em português no próximo item.

${ }^{253}$ Rivelino's elastico é apenas um dos diversos nomes dado ao famoso "elastic" em inglês. Seus sinônimos são apresentados no item 4.9.

${ }^{254}$ Vide item 1.4.1 para discussão completa.

255 Disponível em: < http://noticias.bol.uol.com.br/ultimas-noticias/esporte/2013/10/09/cartola-do-

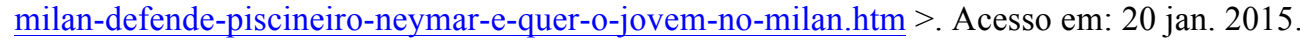




\section{Capítulo 4}

Outra estatística mostra que agora Neymar, quando sofre uma falta, ela realmente aconteceu, derrubando a fama de "piscineiro" que ganhou no seu primeiro ano na Europa. ${ }^{256}$

Nesta terça-feira, os dois maiores jornais esportivos da Catalunha compraram a briga e, para defender o brasileiro, apontaram o galês Gareth Bale, do Real Madrid, como o verdadeiro "piscineiro" do futebol mundial. ${ }^{257}$

Devido ao grande número de páginas encontradas, não foi possível analisar todas as ocorrências. No entanto, a leitura das primeiras páginas de resultado do Google nos permitiu validar 'piscineiro' como sinônimo de 'cai-cai'.

Lendo as páginas de resultado do Google, descobrimos que o termo 'piscineiro' é um empréstimo do termo 'piscinero' da língua espanhola. Observemos o seguinte trecho:

Neymar anotou seu primeiro gol no Campeonato Espanhol, deu uma assistência e participou da maior parte das jogadas ofensivas do Barcelona na contundente vitória por 4 a 1.

Apesar disto, foi lembrado pela imprensa espanhola por ter reclamado de dois pênaltis, em lances nos quais desabou dentro da grande área, e a arbitragem mandou o jogo seguir. O exatacante do Santos terá que lutar, agora na Espanha, contra o rótulo ou como eles dizem por lá, um 'piscineiro'.(nossa ênfase) $)^{258}$

Para confirmar a hipótese, realizamos uma busca no Google Espanha (Google.es) com as palavras 'Neymar' e 'piscinero' e obtivemos resultados como:

\footnotetext{
256 Disponível em: < http://espn.uol.com.br/noticia/450547 menos-piscineiro-mais-forte-edisciplinado-o-neymar-1415 >. Acesso em: 20 jan. 2015.

${ }^{257}$ Disponível em: < http://espn.uol.com.br/noticia/364157 catalaes-rebatem-polemica-sobre-neymarcom-ataques-a-piscineiro-bale $>$. Acesso: 20 jan. 2015.

${ }^{258}$ Disponível em: < http://esporte.ig.com.br/futebol/2013-10-07/criticado-por-mourinho-cai-cai-deneymar-ganha-destaque-na-espanha.html $>$. Acesso em: 20 jan. 2015.
} 


\section{Capítulo 4}

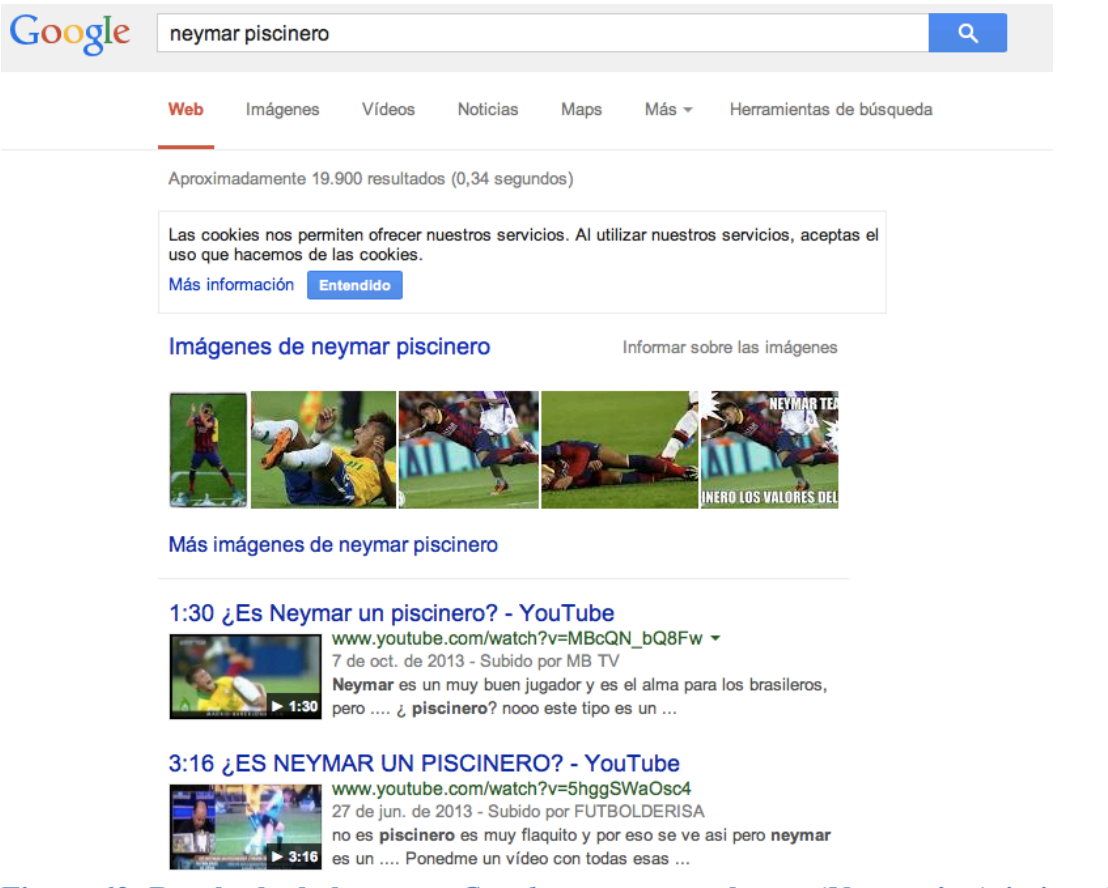

Figura 63: Resultado da busca no Google.es para as palavras 'Neymar' e 'piscinero'.

Após entender o uso de 'cai-cai' e encontrar 'piscineiro', seu sinônimo em português, o próximo passo foi encontrar o equivalente em inglês. Sem saber como iniciar a busca, já que analisar todas as ocorrências de foul, tackle e challenge demandaria muito tempo, mas cientes de que uma tradução literal de 'cai-cai' dificilmente funcionaria na língua inglesa, geramos linhas de concordância para duas palavras de busca, 'Bale' e 'Gareth', pois sabíamos que o jogador Gareth Bale, ponta do Tottenham Hotspur na época em que o corpus foi compilado, é conhecido por simular faltas. A busca retornou cinco ocorrências para Bale e sete para Gareth. Expandimos as linhas de concordância de modo a ter acesso ao texto integral que, muito mais do que relatar a partida, discute a ética do comportamento de Bale, e a palavra diver, presente no relatório de partida de um jogo entre Norwich City e Tottehnham Hotspur pela Premier League de 2013/2014, chamou a atenção:

Norwich commit hard tackles and, had the boy got on to Gareth's ankle, it's an injury that takes him out for six months and you have a player who has a reputation as a diver, which is extremely disrespectful. ${ }^{259}$

259 Disponível em: < http://www.telegraph.co.uk/sport/football/competitions/premierleague/9837678/Norwich-City-1-Tottenham-Hotspur-1-match-report.html >. Acesso em: 20 jan. 2015. 


\section{Capítulo 4}

Lemos o texto integral, geramos as linhas de concordância para diver e, após analisar as seis ocorrências encontradas, validamos diver como equivalente de 'caicai' e 'piscineiro'. Assim como o número de ocorrências de 'falta' é bem superior ao de seus equivalentes em inglês, o número de ocorrências de 'cai-cai' é o dobro do número de ocorrências de diver. Essa diferença já foi discutida detalhadamente na seção 3.1.3. Contudo, ao ler uma das notícias deparamos com uma informação que chamou a atenção:

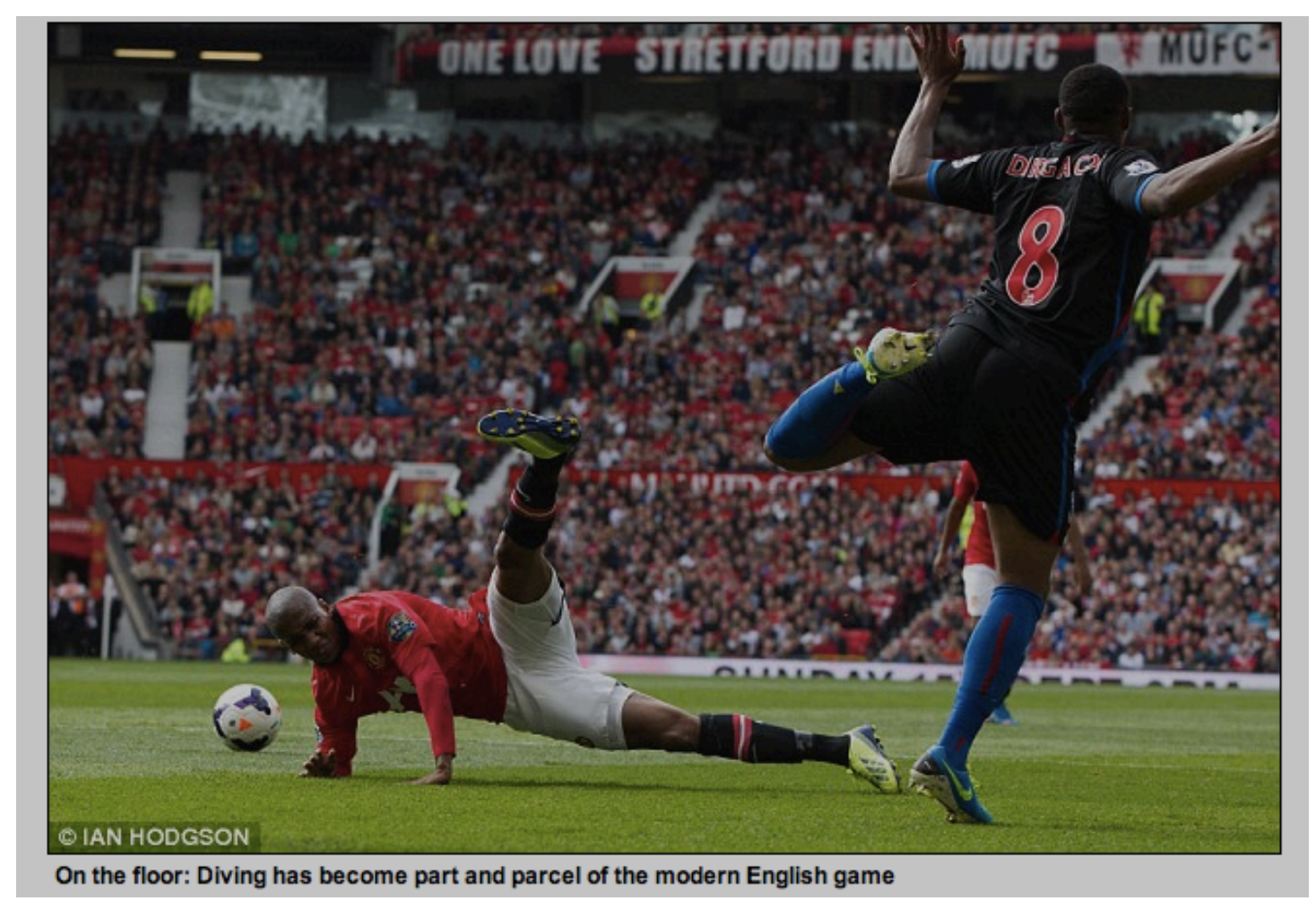

Figura 64: Foto do jogador Ashley Young, à esquerda, ponta do Manchester United, simulando uma falta.

A legenda da foto ressalta o fato de a simulação de falta ter se tornado parte do futebol inglês moderno. Ou seja, se retomarmos o conceito forma-representação, existe a possibilidade de o número de ocorrências de diver, ou do verbo que descreve a ação (to dive), e até mesmo de faltas no Campeonato Inglês aumentar nos próximos anos. Não temos uma explicação científica para esse fato, mas acreditamos que a globalização do futebol, ou seja, a compra pelo futebol inglês e europeu de jogadores sul-americanos com a reputação de 'cai-cai', a convivência dos jogadores europeus com os sul-americanos e as próprias mudanças que o futebol inglês vem sofrendo nos 


\section{Capítulo 4}

últimos anos podem contribuir para uma mudança significativa no estilo do futebol e, consequentemente, no número de ocorrências de alguns termos.

\subsection{6 chinelinho}

Ao analisar as linhas de concordância de 'bichado', observamos a palavra 'chinelinho':

\section{[...] péssima contratação! jogador chinelinho, joelho bichado [...]. ${ }^{260}$}

A princípio, pensamos que 'chinelinho' seria um possível sinônimo de 'bichado'. Para verificar nossa hipótese, geramos linhas de concordância para 'chinelinho' em nosso corpus de português e encontramos mais três ocorrências:

Mais uma vez, nós santistas queremos agradecer ao São Paulo por ter comprado esta mala do Ganso. Estão vendo? Não jogou nada no São Paulo e já está começando a mesma palhaçada que fazia no Santos. Acredite no que estou falando, daqui a pouco vai pro Departamento Médico de novo. Esse é o verdadeiro chinelinho. Chupa Sãopaulinada, vocês queriam o cara? Agora aguenta. ${ }^{261}$

Para Cereto, 'mago' Valdivia tem que fazer sumir o 'chinelinho' no Palmeiras ${ }^{262}$

A maior mágica do Valdivia vai ser fazer desaparecer o "chinelinho". O Valdivia não consegue uma sequência de jogos no Palmeiras, apesar de ter conseguido agora, de seis jogos. O departamento médico está tendo um cuidado especial com ele, por isso será poupado, para não machucar de novo. ${ }^{263}$

Ao ler os contextos, poderíamos concluir que 'chinelinho' seria sinônimo de 'bichado', pois todos fazem referência a um jogador contundido que não jogou um número significativo de partidas por seu time. Contudo, ao procurar no Google uma definição para o termo, descartamos a hipótese. Observemos as três definições abaixo:

\footnotetext{
${ }^{260}$ Disponível em: < http://globoesporte.globo.com/mg/sul-de-minas/noticia/2013/08/com-estrela-alexsilva-boa-esporte-anuncia-pacotao-para-serie-b.html > Acesso em: 19 jan. 2015

261 Disponível em: < http://www.lancenet.com.br/sao-paulo/Ganso-desmente-especulacoes-descartaTricolor 0 932906924.html $>$ Acesso em: 19 jan. 2015

${ }_{262}$ Disponível em: < http://sportv.globo.com/site/programas/redacao-sportv/noticia/2013/08/paracereto-valdivia-precisa-fazer-sumir-o-chinelinho-no-palmeiras.html >. Acesso em: 19 jan. 2015.

263 Disponível em: < http://sportv.globo.com/site/programas/redacao-sportv/noticia/2013/08/paracereto-valdivia-precisa-fazer-sumir-o-chinelinho-no-palmeiras.html $>$. Acesso em: 19 jan. 2015.
} 


\section{Capítulo 4}

a)

Significado de Chinelinho:

Jogador de futebol que faz corpo mole, simulando estar contundido.

Exemplo do uso da palavra Chinelinho:

O cara é o maior chinelinho, pô! Se não quer mais jogar no time, pede pra ser vendido. ${ }^{264}$

b)

O que é um jogador "chinelinho"?

Jogador chinelinho, é aquele jogador que vive entregue ao departamento médico, como não joga, não usa chuteira, por isso nome de chinelinho.

Caso típico do Roger, que na temporada passada jogava no Flamengo, quando o time estava na pior sempre disse que tinha uma distensão, fato jamais comprovado por exames $e$ avaliação médica. ${ }^{265}$

c)

Os "Chinelinhos" do futebol

Corpo mole, simulação de contusões e o famoso "migué": veja a lista dos maiores "chinelinhos" da história do futebol brasileiro ${ }^{266}$

A primeira definição, do Dicionário Informal ${ }^{267}$, explica que 'chinelinho' é o termo utilizado para se referir a um jogador que faz corpo mole e que simula contusões. A segunda definição, do site YahooRespostas ${ }^{268}$, descreve um jogador que está sempre contundido, mas que não apresenta provas médicas de suas contusões e ainda explica a referência ao ato de o jogador usar mais chinelo do que chuteira. A terceira definição, manchete de uma notícia, é bastante parecida com a primeira: jogador que faz corpo mole, que simula contusões e que faz o possível para não jogar. Dessa forma, entendemos que, diferentemente do jogador 'bichado', que não joga porque está contundido, o jogador 'chinelinho’ não joga porque simula contusões.

Entendido o significado do termo e seu uso em português, passamos à busca de um equivalente em inglês. Como em português encontramos as duas ocorrências no mesmo texto, tentamos procurar o equivalente nos textos em que encontramos o termo crock. No entanto, não encontramos nenhum possível equivalente. Decidimos, então, analisar, novamente as linhas de concordância de "injur*", mas nelas também

\footnotetext{
${ }^{264}$ Disponível em: < http://www.dicionarioinformal.com.br/significado/chinelinho/943 > Acesso em: 19 jan. 2015.

265 Disponível em: < https://br.answers.yahoo.com/question/index?qid=20080118133117AAtfr0G $>$. Acesso em: 19 jan. 2015.

266 Disponível em: < http://www.areah.com.br/cool/futebol/materia/77806/1/pagina $1 /$ os"chinelinhos"-do-futebol.aspx $>$. Acesso em: 19 jan. 2015.

${ }^{267}$ Disponível em: $<$ http://www.dicionarioinformal.com.br $>$. Acesso em: 19 jan. 2015.

${ }^{268}$ Disponível em: $<$ https://br.answers.yahoo.com $>$. Acesso em: 19 jan. 2015.
} 


\section{Capítulo 4}

não conseguimos encontrar um equivalente do termo. Contudo, ao expandir as linhas, encontramos um termo que chamou a atenção:

Gourcuff's new injury scare is just a latest in a long history of physical setbacks for the playaker. With a salary of $£ 80,000-a$-week combined with his sicknote reputation, it would be reasonable to argue that while Gourcuff may want to move to Arsenal, Arsenal wouldn't want to sign him $^{269}$

No parágrafo acima, o termo sicknote reputation foi utilizado para descrever o jogador Gourcuff, meia-atacante do Lyon, que mostrava interesse em ser transferido para o Arsenal, da Inglaterra. Lemos algumas outras notícias sobre Gourcuff e constatamos que o jogador está frequentemente contundido, não participa de um número significativo das partidas de seu time e, muitas vezes, os jornalistas esportivos e torcedores questionam sua condição física debilitada.

Para validar sicknote reputation como equivalente de 'chinelinho', realizamos uma busca no corpus para sicknote, mas não encontramos nenhuma outra ocorrência do termo. Recorremos, então, ao Google e buscamos a expressão "sicknote reputation" seguida da palavra football e restringimos a pesquisa a sites do Reino Unido. Encontramos 862 ocorrências e, após ler algumas notícias e analisar os contextos em que a expressão ocorre, validamos sicknote reputation como equivalente de 'chinelinho'.

O número de ocorrências dos termos no corpus é baixo nas duas línguas. No entanto, ao fazer uma pesquisa no Google por 'chinelinho' seguido da palavra 'futebol' no Google Brasil encontramos 56.800 ocorrências. Por razões óbvias, não lemos todas as ocorrências. Contudo, ao ler o contexto em que 'chinelinho' ocorre na página de resultados do Google, constatamos que a maioria tem o mesmo significado da ocorrência encontrada em nosso corpus. Acreditamos que o número de ocorrências seja baixo nos dois subcorpora, pois, como explicado na seção 3.1.3, apenas uma pequena parcela do corpus de estudo é composta por notícias que tratam da compra e da transferência de jogadores e é nesse tipo de notícias que jornalistas falam sobre a fama de 'chinelinho' dos jogadores.

Sabemos das limitações de se utilizar o Google para identificação de

\footnotetext{
${ }^{269}$ Disponível em: < http://www.101 greatgoals.com/blog/lyon-president-aulas-gourcuff-would-takepay-cut-for-arsenal-newcastle-end-gomis-chase/ > . Acesso em: 19 jan. 2015.
} 


\section{Capítulo 4}

equivalentes tradutórios, mas, nesta pesquisa, somente utilizamos a ferramenta para confirmar hipóteses encontradas no corpus e para melhor entender o significado e uso de alguns termos. Nesse caso em particular, o Google contribuiu para a confirmação de uma hipótese prévia que levantamos ao conversar com especialistas: de que o jogador 'chinelinho' é mais comum no Brasil. Não pretendemos, de forma alguma, estereotipar jogadores brasileiros e ingleses. Entretanto, acreditamos que o estereótipo de "malandro" do jogador brasileiro justifique, de certa forma, o maior número de ocorrências de 'chinelinho' em sites em português. Além disso, evidenciou-se que o comportamento desses jogadores ocupa um espaço maior na mídia brasileira do que na mídia inglesa.

\subsection{7 the Matthews move}

Como já mencionado anteriormente, nossa pesquisa parte do português para o inglês. Entretanto, no decorrer da análise observamos que os tópicos abordados pelos textos são diferentes nas duas línguas. Por esse motivo, acreditamos que, em uma pesquisa futura, deveremos realizar a análise também do inglês para o português a fim de identificar termos, colocações e CLEs que nos auxiliem a identificar os tópicos mais comuns nos textos em inglês. Esse processo ainda não está sendo realizado formalmente, mas a todo momento analisamos a lista de palavras-chave do subcorpus em inglês no processo de identificação de equivalentes. Durante uma de nossas análises, deparamos com a colocação the Matthew's move, que apresenta 22 ocorrências no subcorpus em inglês e, como no momento estávamos trabalhando com a categoria de passes, consideramos importante investigar o uso do termo em inglês e tentar estabelecer um equivalente em português. Observemos uma das linhas de concordância de "the Matthews move" expandida:

"My dad made me watch old Betamax video tapes that focused on skill and technique. It involved a Dutch coach called Wiel Coerver. He was in charge of Feyenoord in the 1970s and he created the Coerver coaching technique. In terms of dribbling, it focused on misdirection - so the defender moved one way and you could go the other. It's things like the 


\section{Capítulo 4}

Matthews move, the Rivelino move and the Maradona move - I used to practise it all in the front garden. ",270

Lemos todas as linhas de concordância da ocorrência, expandimos os contextos e acessamos os textos integrais, mas não entendemos o funcionamento do termo, pois, como no exemplo acima, as ocorrências não são explicativas. Em todos os casos a menção ocorre em depoimento de algum jogador, sem descrever o movimento em si. Por esse motivo, mais uma vez recorremos ao YouTube para entender o drible. A busca retornou vários vídeos com um tutorial de como executar o The Matthews move. A figura 65 mostra um dos vídeos:

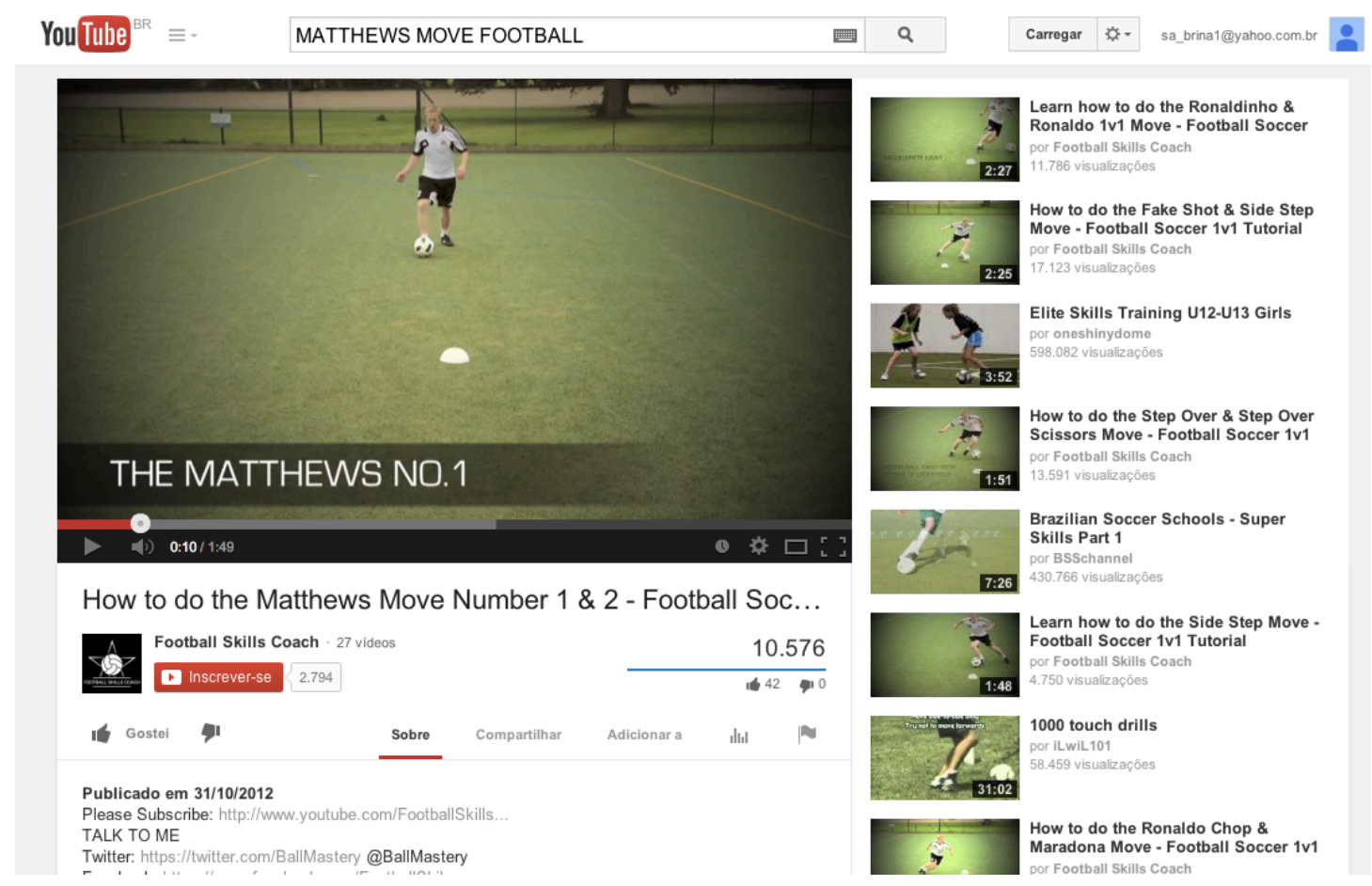

Figura 65: Vídeo com tutorial de como executar o The Matthews move.

O vídeo, representado pela foto acima, descreve a jogada em detalhes, enumerando os movimentos que o jogador deve realizar para executar o drible ${ }^{271}$. Além de assistir a alguns dos vídeos que a busca retornou, realizamos uma pesquisa no Google a fim de encontrar mais informações sobre o drible. A figura 66 mostra um

\footnotetext{
${ }^{270}$ Disponível em: < http://www.coerver.co.uk/blog/2014/02/20/sturridge-hails-the-coerver-influenceon-skills-development/ >.Acesso em: 15 jan. 2015.

${ }^{271}$ Disponível em: $<$ https://www.youtube.com/watch?v=7UVm3kAfSdM $>$. Acesso em: 20 jun. 2014.
} 


\section{Capítulo 4}

tutorial com fotos da execução do drible e também apresenta uma explicação do movimento:

Matthews move
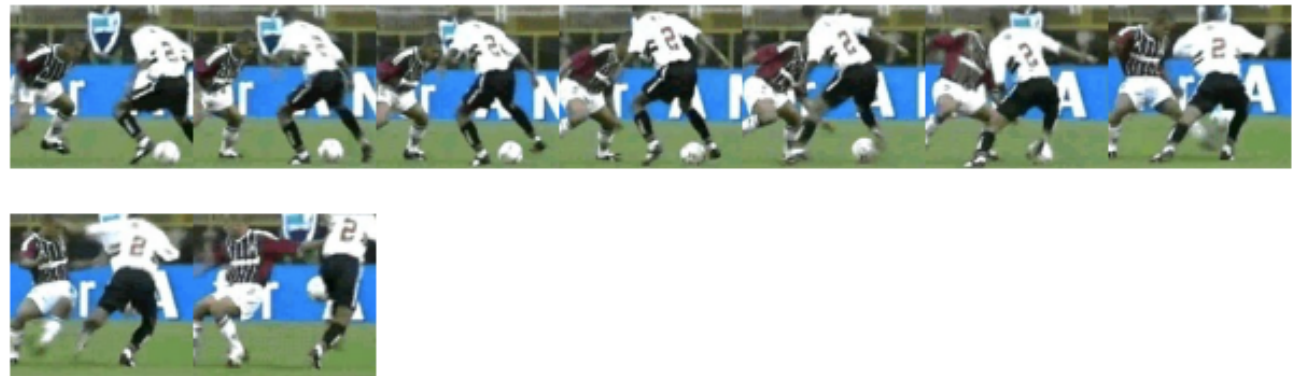

The Matthews is a very effective move, especially when the defender is jockeying. Initially, the attacker pushes the ball with his instep, then he suddenly cuts to the outside. It's important to combine these two steps together without pausing in between.

Figura 66: Tutorial com fotos de como executar The Matthews move.

Após ler diversas explicações e assistir aos vídeos, entendemos o drible: movimento em que um jogador, frequentemente um atacante ou armador, dá um ou dois toquinhos com a parte de dentro do pé na bola, corta e conduz a bola na direção oposta com a parte de fora do pé e arranca. Entendido o drible, o próximo passo foi buscar seu equivalente em português. Analisamos as palavras-chave, mas não encontramos nenhum equivalente. Verificamos os jogos em que The Matthews move ocorre no subcorpus em inglês e procuramos reportagens sobre os mesmos jogos em português, tanto em nosso corpus quanto no Google, e, ainda assim, não chegamos a nenhum possível equivalente. Reunimo-nos, então, com os pesquisadores do LUDENS na esperança de que pudessem nos auxiliar de alguma forma, já que, como descrito anteriormente, de uma forma ou de outra todos estudam futebol e são apaixonados pelo esporte. No entanto, dessa vez não chegamos a um equivalente. Ao contrário, a resposta dada por todos os presentes foi unânime: "Isso não tem nome em português". Um dos pesquisadores continuou: "Se você quiser, pode dizer que é conduzir ou carregar a bola, mas não tem nome específico". Naquele momento, um dos pesquisadores sugeriu que entrássemos em contato com o professor da escolinha 


\section{Capítulo 4}

de futebol do PRODHE 272 para agendar uma visita ao projeto e exibir vídeos de movimentos e dribles para os quais não encontrávamos equivalentes em português.

No dia 17 de abril de 2014, visitamos o projeto e exibimos dez vídeos para uma turma de dezesseis crianças entre sete e quatorze anos. As crianças reagiram de forma bastante similar aos pesquisadores quando assistiram ao vídeo de "The Matthews move”. Disseram que não tinha nome, ou que não sabiam o nome; uma das crianças deu uma resposta bastante peculiar: "Sei lá, carregar, conduzir, levar, chamamos do que queremos, isso não tem nome não!”.

Em inglês, o drible foi nomeado em homenagem ao ex-jogador Sir Stanley Matthews, conhecido como mago do drible. Stanley foi o primeiro jogador de futebol profissional a ser nomeado Cavaleiro do Império Britânico por serviços prestados ao esporte e jogou sua última partida em 1965, aos 50 anos. Stanley era muito rápido e habilidoso e frequentemente realizava o movimento acima descrito para driblar seus oponentes; daí a homenagem a ele prestada.

Outra característica interessante sobre o futebol inglês que observamos durante a análise dos dribles, passes e movimentos é a didática. Em inglês, encontramos tutoriais on-line de como executar vários movimentos e dribles, quer sejam populares ou pouco conhecidos. Fizemos várias buscas com nomes de dribles em português no YouTube e no Google a fim de tentar encontrar algo parecido, mas não encontramos tutoriais e pouquíssimas são as explicações sobre os dribles.

Como vimos no item 1.2, a didática do futebol inglês reflete a forma como o futebol foi implementado na Inglaterra, da mesma forma que a "falta de didática" no futebol brasileiro é resultado da importação do futebol para o Brasil. Enfim, o modo pelo qual a implementação e a propagação do futebol se deram na Inglaterra e no Brasil nos auxiliou a entender a existência de alguns termos em inglês, dada a necessidade de nomeação devido a sua característica didática, e a ausência da nomenclatura para alguns movimentos e dribles em português.

\footnotetext{
${ }^{272}$ Programa de Desenvolvimento Humano pelo Esporte. Disponível em: < http://educandopeloesporte.blogspot.com.br/p/o-prodhe.html\#.U6Sb0BZpuOM>. Acesso em: 16 jan. 2015.
} 


\section{Capítulo 5 - Modelo de dicionário}

Apresentamos, neste capítulo, o modelo de dicionário elaborado durante a pesquisa. Primeiramente, justificamos a escolha do termo 'dicionário' em detrimento de 'glossário' ou 'vocabulário'. Em seguida, apresentamos a organização dos dados e, ao final, mostramos a micro e a macroestrutura do dicionário.

5.1 Por que dicionário e não glossário?

A problemática da classificação de obras lexicográficas é abordada por vários estudiosos, dentre eles, Rey-Debove (1971), Haensh (1982), Pais (1984), BoutinQuesnel et al. (1985), Rivera Dominguez (1985), Barbosa (2001) e Barros (2004).

Durante o doutorado, embora não tenhamos cursado uma disciplina específica sobre Terminografia ou Lexicografia, lemos, exaustivamente, sobre o assunto a fim de denominar, da maneira mais apropriada possível, o produto final de nossa tese. Durante as leituras, deparamos com diversas possibilidades de nomeação, entre elas: 'vocabulário', ‘dicionário terminológico', 'dicionário técnico', 'glossário', ‘dicionário especial', 'vocabulário técnico-científico', 'dicionário de língua de especialidade', 'dicionário de língua científica' e 'dicionário de língua técnica'.

Para Barbosa (2001, p. 26), não existe clareza quanto às fronteiras conceptuais, denominativas e definicionais dos termos 'dicionário terminológico', 'vocabulário' e 'glossário'. Segundo Haensch (1982), o uso arbitrário dessas denominações por parte de diferentes autores contribui para o uso indiscriminado dos termos.

A Norma ISO (International Standardization Organization) ${ }^{273} 1087$, "Terminology/Vocabulary", "Terminologie/Vocabulaire" apresenta a seguinte definição para os três tipos de obra:

dicionário: Coleção estruturada de unidades lexicais com informações linguísticas sobre cada uma delas;

\footnotetext{
${ }^{273}$ Organização Internacional para Padronização.
} 
dicionário terminológico (termo tolerado: dicionário técnico): Dicionário que contém dados terminológicos de um ou mais domínios específicos; vocabulário (termo tolerado: glossário): Dicionário terminológico que contém a terminologia de um domínio específico ou de domínios afins e baseado no trabalho terminológico. (BARBOSA, 2001, p. 24-25). ${ }^{274}$

Observando as definições de 'dicionário terminológico' e 'vocabulário', podemos constatar que a norma apresenta dois termos para obras de mesma natureza e função. Não fica clara a distinção, se é que ela existe, entre os termos. Lemos, também, o texto original em inglês da norma, que, apesar de esclarecer algumas ambiguidades provenientes da tradução, não se mostrou conclusivo para distinguir os termos.

Ao analisar as definições da ISO, Barros (2004, p. 140) relata que a única diferença entre ‘dicionário técnico' e ‘vocabulário' é que este é organizado com base em um trabalho terminológico, definido pela ISO como "atividade relativa à sistematização e à representação dos conceitos, assim como à apresentação das terminologias, de acordo com princípios e métodos estabelecidos" (ISO 1087, 1990: 13 apud BARROS, 2004, p. 140).

Embora não exista uma terminologia uniforme e consensual da Terminologia, encontramos dois pontos em comum entre a maior parte das definições existentes. Primeiramente, parece existir um consenso na definição de 'dicionário': esse tipo de obra reúne lexemas e apresenta, para cada um deles, verbetes que descrevem suas diferentes significações. Entretanto, o mesmo consenso não existe para a caracterização de obras lexicográficas específicas, como os 'dicionários técnicos' e os 'vocabulários'. Outro ponto em comum entre alguns teóricos é o entendimento de que o termo 'glossário' se refere a uma obra que tem como objetivo representar a situação

\footnotetext{
${ }^{274}$ No original: "dictionary: Structured collection of lexical units with linguistic information about each of them / dictionnaire: répertoire structuré d'unités lexicales comportant des informations linguistics sur chacune d'entre elles;

terminological dictionary: (admitted term: technical dictionary): Dictionary containing terminological data from one or more specific subject fields / dictionnaire terminologique (terme toléré: dictionnaire technique): Dictionnaire qui comprend des données terminologiques relatives à un ou plusieurs domaines particuliers;

vocabulary (admitted term: glossary): Terminological dictionary containing the terminology of a specific subject field or of related subject fields and based on terminology work / vocabulaire: Dictionnaire terminologique basé sur un travail terminologique, qui presente la terminologie d'un domaine particulier ou de domaines associés".
} 


\section{Capítulo 5}

lexical de um único texto manifestado, sendo, dessa forma, sincrônica, sintópica ${ }^{275}$ e sinfásica $^{276}$.

Estabelecer uma distinção para os termos acima discutidos foge do escopo de nossa pesquisa. Contudo, achamos importante nos posicionar diante da problemática em prol de um futuro consenso conceptual e denominativo das obras lexicográficas em questão.

Ante o exposto, com o objetivo de não utilizar os termos indiscriminadamente e conferir clareza a nossa pesquisa, adotamos os termos 'dicionário terminológico' e 'dicionário técnico' como sinônimos para designar nossa obra terminográfica, composta por dados terminológicos de uma área específica (futebol) e que tem como base o trabalho terminológico.

\subsection{Ficha terminológica}

Em pesquisas terminológicas, as informações relevantes e pertinentes sobre as unidades terminológicas levantadas são armazenadas em fichas, que são preenchidas de acordo com um protocolo criado pelo pesquisador ou grupo de pesquisa (BOUTIN-QUESNEL et al., 1985, p. 28). Essas fichas, que antigamente eram feitas em papel, hoje são, em sua maioria, elaboradas em formato eletrônico.

O modelo varia de acordo com os dados que estarão presentes no verbete. Dessa forma, sua composição é sempre dinâmica e, embora alguns teóricos, como Dubuc (1978) e Barros (2004), apresentem modelos de ficha bastante completos que podem ser replicados em outras pesquisas, os campos selecionados sempre variam de acordo com a necessidade do registro de informações.

Barros (2004) aponta dois modelos de ficha: o de referências bibliográficas e o de referências terminológicas. No primeiro devem ser registradas as fontes dos dados em que o termo ocorre, como, por exemplo, autor e título da obra, local de

\footnotetext{
${ }^{275}$ Diz-se de relativa uniformidade de dialetos dentro de um mesmo espaço ou região geográfica. Disponível em: <http://www.aulete.com.br/sint\%C3\%B3pico\#ixzz3fnZcT8LD>. Acesso em: 13 jul. 2015.

276 Diz-se de uniformidade no estilo ou na expressão linguística. Disponível em:

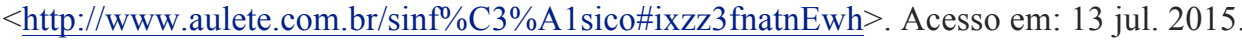




\section{Capítulo 5}

publicação, editora, ano de publicação, número de páginas etc. No segundo devem ser registrados os dados terminológicos.

Vale ressaltar que em nossa pesquisa não foi preenchida a ficha de referências bibliográficas, pois todas essas informações estão presentes no cabeçalho criado para o corpus e são de fácil acesso para consulta.

Com base no modelo de obra terminográfica que construímos, qual seja um dicionário de futebol bilíngue e bidirecional, selecionamos onze componentes para nossa ficha terminológica.

Em uma obra bilíngue, os termos são apresentados na língua de partida - no nosso caso, em português -, e equivalente(s), exemplos e outras informações são apresentados na língua de chegada (inglês). E assim o fizemos em nossa obra que, por ser bidirecional, teve o mesmo tratamento na outra direção, isto é, do inglês para o português.

Durante o preenchimento das fichas terminográficas, por questão de organização optamos por seguir o mesmo procedimento utilizado nos estudos de caso: primeiro, esmiuçávamos o significado e o uso do termo em português para, posteriormente, trabalhar com seu(s) equivalente(s) em inglês. Dessa forma, primeiramente preenchemos as fichas em português e, em um segundo momento, dedicamo-nos ao preenchimento das fichas em inglês. Os campos selecionados para a composição da ficha terminográfica são:

1) Unidade terminológica na língua de partida (LP): a unidade terminológica de nosso dicionário pode ser formada por um termo ou por uma combinatória léxica especializada (CLE) que tenha sido extraída do corpus de estudo em português;

2) Número de ocorrências no corpus: o número de ocorrências de um termo é determinante em qualquer pesquisa com corpus, desde o momento da extração de termos até a organização dos verbetes. Nos casos de termos sinônimos, a escolha do termo principal e de suas remissivas deu-se pelo número de ocorrências dos termos; daí a importância do registro do número de ocorrências na ficha terminográfica; 


\section{Capítulo 5}

3) Classe gramatical: visto que trabalhamos com um modelo de dicionário que possui dezessete verbetes e não com a obra completa, as categorias gramaticais restringiramse àquelas dos termos que compõem os estudos de caso: substantivo, adjetivo, verbo, sintagma adjetivo e sintagma verbal. Temos ciência de que, uma vez expandida, a obra contará com outras categorias gramaticais;

4) Definições do termo encontradas na web: para o preenchimento das fichas em português, coletávamos definições em português, e para o preenchimento das fichas em inglês, coletávamos definições em inglês. Essas definições serviram de base para a construção das definições presentes em nosso dicionário;

5) Exemplos: Preenchemos nossa ficha terminográfica com até três exemplos de cada verbete extraídos do corpus de estudo;

6) CLEs: Em nosso modelo de dicionário há dois tipos de entradas: 1) entradas formadas por um termo - simples ou composto (ex.: 'rolinho' e 'carregador de piano'); e 2) entradas formadas por uma CLE (ex.: gol, [FAZER|MARCAR] [um|o]). Nos verbetes formados por um termo, não apresentamos, formalmente, as CLEs em que o termo ocorre. No entanto, sempre que possível registramos essas CLEs nas fichas e selecionamos exemplos em que aparecem. Acreditamos que um levantamento formal das CLEs de cada termo deve ser realizado posteriormente;

7) Informações Enciclopédicas: Esse campo compreende informações históricas e culturais que não são imprescindíveis para a compreensão do significado do termo, mas que retratam seu surgimento ou sua história, contribuindo, dessa forma, para o entendimento de diferenças no uso do termo nas duas línguas;

8) Remissivas: campo que contém referências a outros termos do dicionário. Trabalhamos com dois tipos de remissivas: 1) mesmo que (same as), utilizada para sinônimos; e 2) ver também (see also), utilizada para ligar um termo a uma CLE composta pelo mesmo termo; 


\section{Capítulo 5}

9) Figura: nesse campo, inserimos uma figura que contribui para o entendimento do significado de um termo;

10) Vídeo: esse campo contém o link de um vídeo que auxilia na compreensão do significado de um termo, geralmente de um drible ou de uma jogada;

11) Equivalente tradutório: campo composto pelos equivalentes tradutórios encontrados durante a análise dos dados.

Salientamos que nem todos os campos da ficha terminológica são utilizados na composição da obra final, mas que todos contribuíram para a organização e construção dos verbetes. Ademais, os elementos não utilizados podem ser úteis caso desejemos inserir mais informações nos verbetes futuramente.

Segue o modelo da ficha terminológica criada para a presente pesquisa, preenchida com o termo 'rolinho':

\begin{tabular}{|c|c|}
\hline \begin{tabular}{l|l} 
1. Termo LP & rolinho \\
\end{tabular} & \begin{tabular}{l|l|} 
2. No. oc. corpus \\
\end{tabular} \\
\hline 3. Classe gramatical & substantivo \\
\hline 4. Definições & $\begin{array}{l}\text { "este drible é quando o jogador rola a bola por debaixo das } \\
\text { pernas de quem o está marcando e corre pelo lado para } \\
\text { buscar a bola." } \\
\text { "Esse drible tem como característica desmoralizar o } \\
\text { adversário e levantar a torcida!" } \\
\text { "Jogar a bola entre as pernas do jogador adversário." } \\
\text { "O drible feito pelos jogadores que faz a bola passar pelo vão } \\
\text { da perna do adversário." }\end{array}$ \\
\hline 5. Exemplos & $\begin{array}{l}\text { "Romelu Lukaku created the second just before half-time } \\
\text { with a powerful run leaving Arsenal's defence - and midfield } \\
\text { - entirely in his wake. He set up Steven Naismith, who } \\
\text { looked suspiciously offside, but nevertheless finished neatly } \\
\text { with a nutmeg through the goalkeeper's legs." } \\
\text { "Deu uma pedalada e passou por Diogo Goiano, fez que ia } \\
\text { para cima de Luccas Claro, mas deu um rolinho e o evitou." } \\
\text { "O Maestro envolveu os adversários dentro da área, deu um } \\
\text { rolinho no último antes de encobrir o goleiro Jefferson." } \\
\text { "Bem marcado, ainda tomou um rolinho do jovem Ganso, } \\
\text { para delírio do olimpo." }\end{array}$ \\
\hline 6. CLEs & $\begin{array}{l}\text { rolinho, DAR um } \\
\text { rolinho, TOMAR um }\end{array}$ \\
\hline \multicolumn{2}{|l|}{ 7. Informações Enciclopédicas } \\
\hline 8. Remissivas & mesmo que 'sainha', 'caneta' e 'janelinha' \\
\hline \multicolumn{2}{|l|}{ 9. Figura } \\
\hline 10. Vídeo & https://www.youtube.com/watch?v=Zld4FmhP8sA \\
\hline 11. Equivalente tradutório & nutmeg \\
\hline
\end{tabular}




\section{Capítulo 5}

Abaixo, apresentamos o modelo de ficha terminológica preenchida com nutmeg, equivalente de 'rolinho':

\begin{tabular}{|c|c|}
\hline 1. Termo LP & 2. No. oc. corpus \\
\hline 3. Classe gramatical & noun \\
\hline 4. Definições & $\begin{array}{l}\text { "A nutmeg (or tunnel, sometimes just meg in British English } \\
\text { slang) is a technique used in association football, field } \\
\text { hockey or basketball, in which a player kicks, rolls or throws } \\
\text { the ball between an opponent's legs (feet). This can be done } \\
\text { in order to pass to another player, to shoot on goal, or to } \\
\text { carry on and retrieve it." } \\
\text { "In football/soccer when you dribble the ball between the } \\
\text { defender's legs." } \\
\text { "an occasion when a player kicks the ball through an } \\
\text { opponent's legs." }\end{array}$ \\
\hline 5. Exemplos & $\begin{array}{l}\text { "Romelu Lukaku created the second just before half-time } \\
\text { with a powerful run leaving Arsenal's defence-and midfield } \\
\text { - entirely in his wake. He set up Steven Naismith, who looked } \\
\text { suspiciously offside, but nevertheless finished neatly with a } \\
\text { nutmeg through the goalkeeper's legs." }\end{array}$ \\
\hline \multicolumn{2}{|r|}{ F } \\
\hline 7. Informações Enciclopédicas & $\begin{array}{l}\text { The Oxford English Dictionary defines 'nutmeg' as a } \\
\text { Victorian slang that means "to be tricked or deceived, } \\
\text { especially in a manner which makes the victim lookfoolish'." } \\
\text { In his book "The Language And Folklore Of The World's } \\
\text { Greatest Game", Peter Seddon points out that the term } \\
\text { 'nutmeg' comes from duplicitous practice in the nutmeg } \\
\text { trade. He states: "Nutmegs were such a valuable commodity } \\
\text { that unscrupulous exporters were to pull a fast one by mixing } \\
\text { a helping of wooden replicas into the sacks being shipped to } \\
\text { England" and "being nutmegged soon came to imply } \\
\text { stupidity on the part of the duped victim and cleverness on } \\
\text { the part of the trickster." The term soon started to be used in } \\
\text { football, implying that the player whose legs the ball had } \\
\text { been played through had been nutmegged. }\end{array}$ \\
\hline \multicolumn{2}{|l|}{ 8. Remissivas } \\
\hline \multicolumn{2}{|l|}{ 9. Figura } \\
\hline 10. Vídeo & https://www.youtube.com/watch?v=g I8CdKZ5Vo \\
\hline 11. Equivalente tradutório & 'rolinho', 'sainha', 'caneta' and 'janelinha' \\
\hline
\end{tabular}

Sempre que possível, as fichas terminográficas foram preenchidas com dados extraídos do corpus de estudo. Entretanto, recorremos à web nas ocasiões em que o corpus não disponibilizava as informações que procurávamos, caso dos exemplos de um termo em inglês que não apresenta nenhuma ocorrência no corpus e das definições desses termos.

No próximo item, explicamos detalhadamente cada elemento que compõe o verbete do dicionário. 


\section{Capítulo 5}

\section{$5.3 \mathrm{O}$ dicionário}

Apresentamos, a seguir, a estruturação do dicionário. Primeiramente, apresentamos a macroestrutura da obra e, em seguida, discorremos detalhadamente sobre cada elemento que compõe o verbete.

\subsubsection{Macroestrutura}

A macroestrutura pode ser entendida como a organização interna de uma obra (BARROS, 2004). O tipo de organização adotada depende diretamente da natureza do projeto e da estruturação das informações presentes no verbete.

De modo geral, os dicionários costumam apresentar uma introdução com as características gerais da obra, os critérios adotados para sua elaboração, seus objetivos e outras informações julgadas relevantes para o consulente. Além desses elementos, é de praxe a apresentação de abreviaturas e símbolos utilizados na obra.

Em nosso modelo de dicionário, elaboramos um texto introdutório com as principais características da obra:

\section{INTRODUÇÃ̃O}

É fato que o futebol é o esporte mais praticado do mundo. É jogado em todo o Brasil por camadas sociais distintas e em diferentes espaços: campos de várzea, quadras, praias, ruas, escolas, clubes etc. Enfim, é parte do cotidiano de muitos brasileiros.

Embora muitos o associem somente com lazer, o futebol é uma área de especialidade, tanto no Brasil quanto em outros países. Portanto, possui uma linguagem própria para descrever o universo a ele relacionado. Essa linguagem é específica e repleta de referências históricas e culturais, que não podem ser desconsiderados na tradução.

A fim de auxiliar tradutores, jornalistas, acadêmicos, curiosos e fãs do futebol a compreender e produzir um texto sobre futebol em português e inglês, criamos o Dicionário de termos culturais do futebolês. A obra, fruto dos três anos de nossa pesquisa de doutorado, conta com termos e fraseologias ${ }^{277}$ culturalmente marcadas do domínio do futebol.

\footnotetext{
${ }^{277}$ Ulizamos o conceito de CLE para a pesquisa, no entanto achamos mais conveniente utilizar o termo 'fraseologia', que é mais conhecido, na introdução da obra terminográfica. Dessa forma, entendemos
} 


\section{Capítulo 5}

Compilamos o maior número possível de verbetes. No entanto, face à amplitude de tal empreitada, entendemos que este é um trabalho que será constantemente aprimorado e ampliado. Assim, o material aqui apresentado não reflete a versão final do projeto, uma vez que um de nossos objetivos foi criar uma obra que estivesse sempre aberta a novas intervenções.

O dicionário foi compilado de acordo com os princípios da Linguística de Corpus, ou seja, os termos e fraseologias foram extraídos de um corpus eletrônico sobre futebol.

Um corpus é um conjunto de textos pertencentes ao uso oral ou escrito da língua, compilado segundo critérios específicos e que possa ser considerado representativo de uma língua ou variedade linguística. Em nosso caso, o corpus é composto por cinco categorias, ou seja, cinco conjuntos de textos: resultados de partidas, descrição de partidas minuto a minuto, relatos de partidas com comentários de internautas, notícias sobre compra e venda de jogadores e técnicos e notícias sobre a situação dos times nos campeonatos.

Para que o corpus fosse representativo, compilamos aproximadamente um milhão de palavras em cada língua a partir de textos em português brasileiro e inglês britânico extraídos de jornais nacionais, revistas esportivas, jornais esportivos, revistas sobre futebol, sites sobre futebol e tabloides.

Diante da impossibilidade de descrever toda a terminologia do futebol nesta obra, termos característicos da linguagem oral podem estar ausentes, assim como outros, mais comuns, que possuem uma tradução direta para o inglês ou que não são culturalmente marcados.

A seleção dos termos foi feita por meio da análise da lista das palavras-chave do corpus, que resulta da comparação do corpus de estudo com um corpus de referência (corpus de língua geral e bem maior do que o corpus de estudo). Nessa comparação, as palavras que possuem frequência relativa estatisticamente mais relevante no corpus de estudo sobressaem revelando a temática do corpus. Assim, em uma lista de palavras-chave de um corpus de futebol, itens como gol, bola e goleiro estarão presentes.

Trabalhar com as palavras-chave nos permite selecionar os termos significativamente mais recorrentes, fator de extrema importância para qualquer compilação terminológica. No entanto, trabalhar com termos frequentes e fornecer seus equivalentes na língua de chegada não garantem a utilidade da obra, já que uma das maiores preocupações dos tradutores e de qualquer pessoa que produz um texto em uma língua de especialidade é utilizar o termo de forma adequada. Ou seja, muitas vezes o produtor do texto conhece o termo na língua-alvo, mas não sabe como utilizá-lo. Tomemos como exemplo a fraseologia 'FAZER um gol', que tem 'MARCAR um gol' como um de seus sinônimos. O equivalente mais frequente em inglês, como o leitor deve imaginar, é 'SCORE a goal'. Contudo, a língua inglesa apresenta outras 39 formas equivalentes para 'fazer um gol'.

O principal objetivo desta obra é proporcionar ao usuário o máximo possível de informações, que levem a um melhor entendimento do texto especializado sobre futebol. $\mathrm{O}$ resultado de anos de investigação é um dicionário bilígue bidirecional com as seguintes características:

fraseologias como expressões que contém um termo e que são formadas por mais de uma palavra, como, por exemplo, 'FAZER uma falta'. 


\section{Capítulo 5}

$\checkmark$ termo em português/inglês

$\checkmark$ classe gramatical

$\checkmark$ equivalente em inglês/português

$\checkmark$ definição

$\checkmark$ exemplo

$\checkmark$ explicações históricas e culturais

$\checkmark$ sinônimos

$\checkmark$ figuras

$\checkmark$ vídeos

De modo geral, o consulente de um dicionário especializado bilíngue almeja encontrar informações sobre o significado de um termo, seu equivalente na outra língua e como ele é utilizado. Esperamos responder a essas questões com este dicionário.

Ainda no que se refere à macroestrutura, a lista de entrada dos verbetes foi elaborada em ordem alfabética contínua, ou seja, apóstrofos e hifens presentes em alguns termos foram ignorados.

Os verbetes, que reúnem as informações sobre os itens terminológicos, são compostos por duas partes: a entrada e o enunciado terminográfico. A entrada corresponde a um item lexical que pode corresponder a um termo simples, composto ou mesmo a uma CLE, e o enunciado terminográfico reflete as informações sobre o item lexical em questão.

Para Barros (2004, p. 55), os elementos do enunciado terminográfico deveriam fornecer informações suficientes para a total compreensão do significado de uma entrada. No entanto, ao definir um termo, muitas vezes o dicionário utiliza unidades lexicais ou terminológicas não familiares ao leitor. Nesses casos, o consulente necessita de informações adicionais para compreender o conteúdo semântico da entrada. Em nossa pesquisa, optamos por utilizar o sistema aberto de cadeia interpretante, ou seja, as acepções dos termos presentes nos enunciados definitórios 


\section{Capítulo 5}

restringem-se ao domínio do futebol. Por exemplo, os termos 'drible' e 'jogada', embora não sejam entradas, são utilizados em alguns enunciados definitórios, e, em nosso dicionário, seus significados limitam-se às suas acepções no domínio do futebol.

\subsubsection{Microestrutura}

De acordo Barros (2004), a microestrutura de um dicionário refere-se à organização dos dados presentes em um verbete. Para a autora, o lexicógrafo ou terminológo deve considerar três elementos principais durante a elaboração da microestrutura da obra, a saber:

a) o número de informações transmitidas pelo enunciado terminográfico;

b) a característica das informações nos verbetes de uma mesma obra;

c) a ordem em que essas informações estarão dispostas.

No que se refere ao número de informações, Rey-Debove (1971, p. 155) estipula que todo verbete deve ser composto por no mínimo três tipos de informações: a entrada, a classe gramatical e uma definição. Naturalmente, o programa de informações do verbete pode compreender outros tipos de informações, como, por exemplo, equivalente em outra língua, no caso de dicionários bilíngues, colocações, notas informativas, exemplos etc. A inclusão desses e de outros elementos depende da natureza da obra.

A fim de garantir homogeneidade e linearidade à obra, as informações presentes nos verbetes devem ser uniformes. Dessa forma, os campos para os elementos que compõem o enunciado definitório devem ser os mesmos em todos os verbetes. Entretanto, o lexicógrafo ou terminológo tem a liberdade de não preencher um ou mais campos. Por exemplo, em nosso caso o campo para o elemento 'vídeo' está disponível para preenchimento em todos os verbetes. Contudo, só o utilizamos quando julgamos que o recurso audiovisual contribui para o entendimento da definição do termo, como no caso dos dribles, pois, para um consulente que não está familiarizado com o futebol, entender o significado de um drible lendo apenas a 


\section{Capítulo 5}

definição, que narra o movimento que o jogador faz com o corpo e o percurso da bola, pode não ser suficiente para a total compreensão do conteúdo semântico da entrada.

A ordem em que os elementos são apresentados também é de extrema importância para garantir a homogeneidade da obra. Em nosso caso, o software utilizado nos permite alterar essa ordem a qualquer momento (vide item 3.4.2).

Vários lexicógrafos abordam a temática e a composição da microestrutura de um verbete. Dentre eles, Bugueño Miranda e Farias (2006), Barros (2004), Welker (2004), Hausmann e Wiegand (1989) e Rey-Debove (1971). Para a construção de nosso modelo de dicionário, utilizamos as três premissas de Barros (2004) mencionadas acima e compartilhamos a mesma ideia de Welker (2004, p. 109) no que diz respeito à composição da microestrutura: desde que estabeleça um padrão, o lexicógrafo ou terminólogo tem a liberdade de elaborar o tipo de microestrutura que melhor se ajuste à obra. Caso essa padronização não ocorra, a leitura dos verbetes poderá tornar-se uma tarefa árdua.

Nos itens que seguem apresentamos os elementos que compõem a microestrutura do dicionário.

\subsubsection{Entrada}

Em Terminologia, 'entrada' é a unidade linguística que recebe o tratamento terminológico. As entradas que compõem nosso dicionário foram extraídas a partir da lista de palavras-chave do corpus de estudo em português. Diferentemente da maioria dos dicionários, onde as entradas são formadas por um único signo linguístico, no modelo de dicionário aqui apresentado as entradas são formadas (1) por um termo, como, por exemplo, 'gol' e 'drible da vaca', ou (2) por uma CLE, como, por exemplo, 'FAZER um gol'.

No primeiro caso, temos entradas formadas por termos simples ('gol') e por termos compostos ('drible da vaca'), que constituem, em sua maioria, sintagmas nominais, verbais ou adjetivos. No segundo caso, incluímos CLEs como entradas e não como subentradas de verbetes formados por um único termo, pois, não raras vezes, a CLE apresenta uma ocorrência tão alta em determinada língua de especialidade que seu significado não constitui a soma de todos seus componentes, 


\section{Capítulo 5}

isto é, a CLE adquire um sentido como um todo. Nesses casos, Barros (2004, p. 158) recomenda que se conserve a ordem sintagmática normal, ou seja, a ordem na qual a CLE foi encontrada no discurso no momento da recolha do termo. Seguindo essa lógica, a entrada da CLE 'fazer um gol', ordem sintagmática encontrada nos textos, seria 'FAZER um gol'. Entretanto, acreditamos que, na maioria dos casos, ao procurar pela CLE em um dicionário, o consulente guia-se pelo termo 'gol', pois 'gol' é a palavra de conteúdo que o consulente conhece. Por esse motivo, decidimos alterar a ordem sintagmática na elaboração dos verbetes de modo que a entrada da CLE 'fazer um gol' seja 'gol, FAZER um'. Ressaltamos, ainda, que criamos referências cruzadas em nosso dicionário. Dessa forma, ao consultar o verbete 'gol' o consulente encontrará uma referência cruzada para 'gol, FAZER um'. Além disso, também incluímos verbos sinônimos e artigos definidos ou indefinidos que também coocorrem com o termo na composição das CLEs. Tomada essa decisão, a entrada da CLE em questão passa a ser 'gol, [FAZER|MARCAR] [um|o]'. Nesses casos, o verbo ou o artigo mais frequente sempre aparece primeiro, seguido do(s) item(ns) menos frequente(s).

Em casos de polissemia, isto é, quando um termo possui mais de uma acepção, optamos por construir duas entradas distintas. No caso de 'gol', abrimos uma entrada para o termo 'gol' que se refere à estrutura física e uma entrada para o termo 'gol' que se refere aos pontos marcados por uma equipe durante o jogo. Por fim, abrimos outra entrada para a CLE 'gol, [FAZER|MARCAR] [um|o]'.

Em casos de sinonímia, como em 'rolinho', 'caneta', 'janelinha' e 'sainha', a entrada principal é a que apresenta a maior chavicidade no corpus. Nesse caso, o termo 'rolinho' constitui a entrada principal e os demais termos são a eles direcionados por meio de uma referência cruzada (item 4.13).

Uma das grandes vantagens de trabalhar com o software TLex é que ele permite a customização das fontes e dos estilos de todos os elementos do verbete. Desse modo, realizamos os devidos ajustes para que as entradas estejam em negrito, na cor azul e separadas do enunciado terminográfico por um espaço. Todas são apresentadas em letra minúscula e em suas formas não marcadas, ou seja, no infinitivo para os verbos e no masculino singular para substantivos e adjetivos. 


\section{Capítulo 5}

A figura 67 mostra as entradas dos dois verbetes de 'gol' e do verbete 'gol, [FAZER|MARCAR] [um|o]':

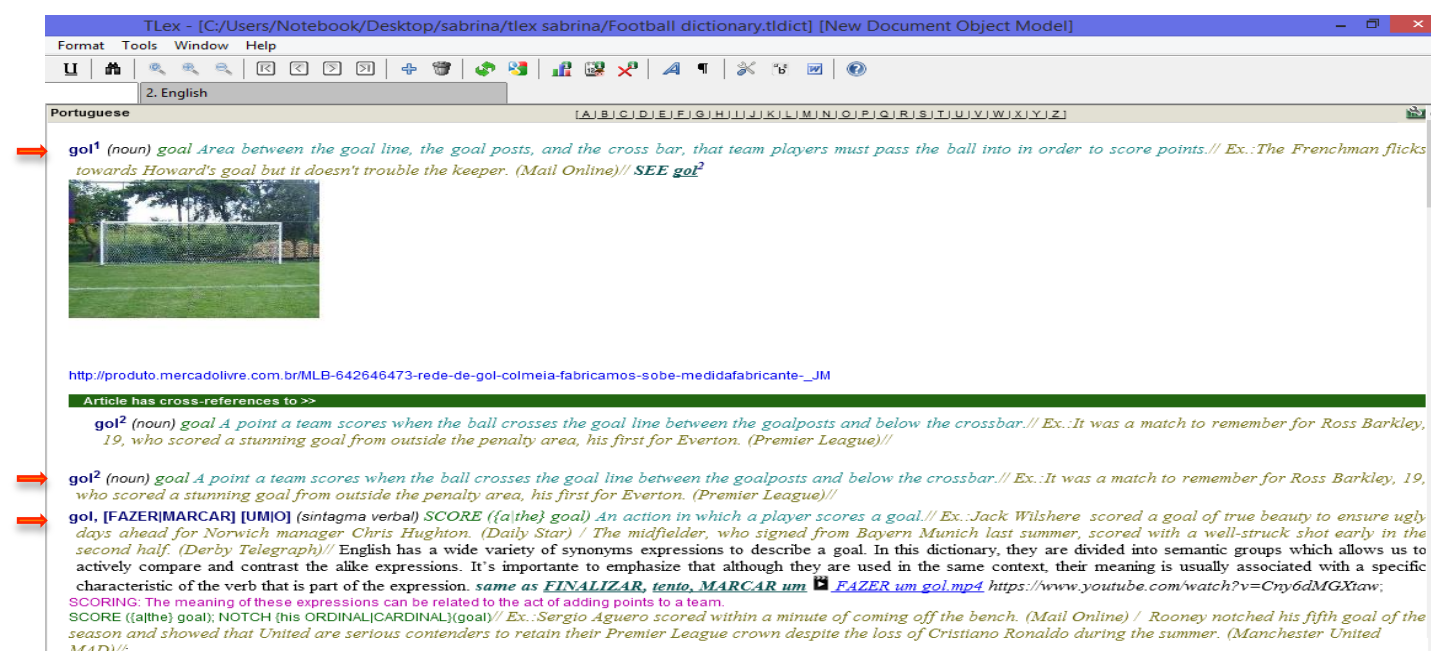

Figura 67: Entrada dos dois verbetes de 'gol' e do verbete 'gol, [FAZER|MARCAR] [um|o]'.

\subsubsection{Categoria gramatical}

O quadro 20 apresenta as cinco categorias gramaticais identificadas entre os termos. A coluna da esquerda mostra as categorias gramaticais em português e a coluna da direita em inglês, com seus respectivos exemplos ${ }^{278}$ :

\begin{tabular}{|l|l|l|l|}
\hline \multicolumn{2}{|c|}{ português } & \multicolumn{2}{c|}{ inglês } \\
\hline adjetivo & chinelinho & adjective & ---- \\
\hline sintagma nominal & carregador de piano & noun phrase & cricket score \\
\hline sintagma verbal & MARCAR um tento & verb phrase & SIT [back|deep] \\
\hline substantivo & gol & noun & challenge \\
\hline verbo & FINALIZAR & verb & SCORE \\
\hline
\end{tabular}

Quadro 20: Categorias gramaticais identificadas entre os termos.

A informação sobre a categoria gramatical aparece em itálico, na cor preta, entre parênteses, e separada da entrada e das outras informações do enunciado

${ }^{278}$ Os exemplos apresentados não são equivalentes tradutórios. 


\section{Capítulo 5}

definitório por espaço. Destacamos, na figura abaixo, a categoria gramatical dos dois verbetes de 'falta' e da CLE 'falta, [FAZER|COMETER] uma':

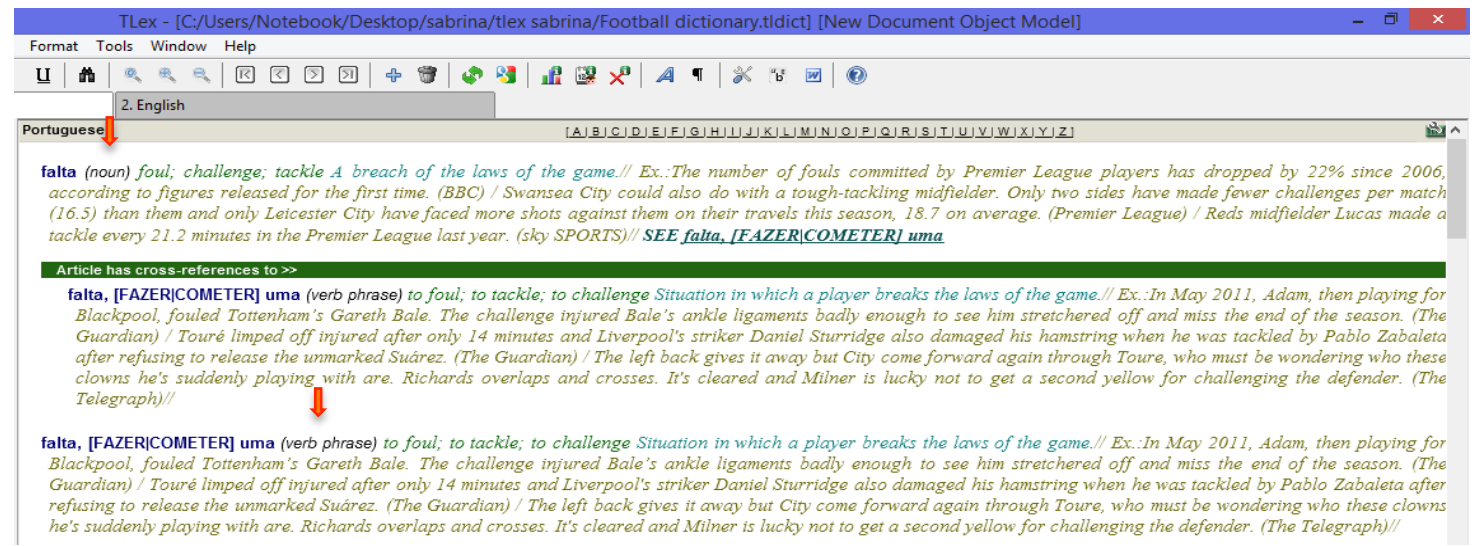

Figura 68: Destaque da categoria gramatical dos dois verbetes de 'falta' e da CLE 'falta,

[FAZER|COMETER] uma'.

\subsubsection{Equivalente(s)}

Como explicado no item 2.3.2, consideramos equivalente um termo ou CLE que funcione no texto de chegada como funciona no texto de partida (TAGNIN, 2007, p. 1). No modelo de dicionário proposto, o equivalente é apresentado após a categoria gramatical, em itálico, na cor verde e separado do elemento que o antecede e do elemento seguinte por espaço. Quando um termo possui mais de um equivalente, os equivalentes são apresentados em conjunto, em ordem de frequência e separados por ponto e vírgula (;). A figura 69 destaca os equivalentes de nutmeg em português:

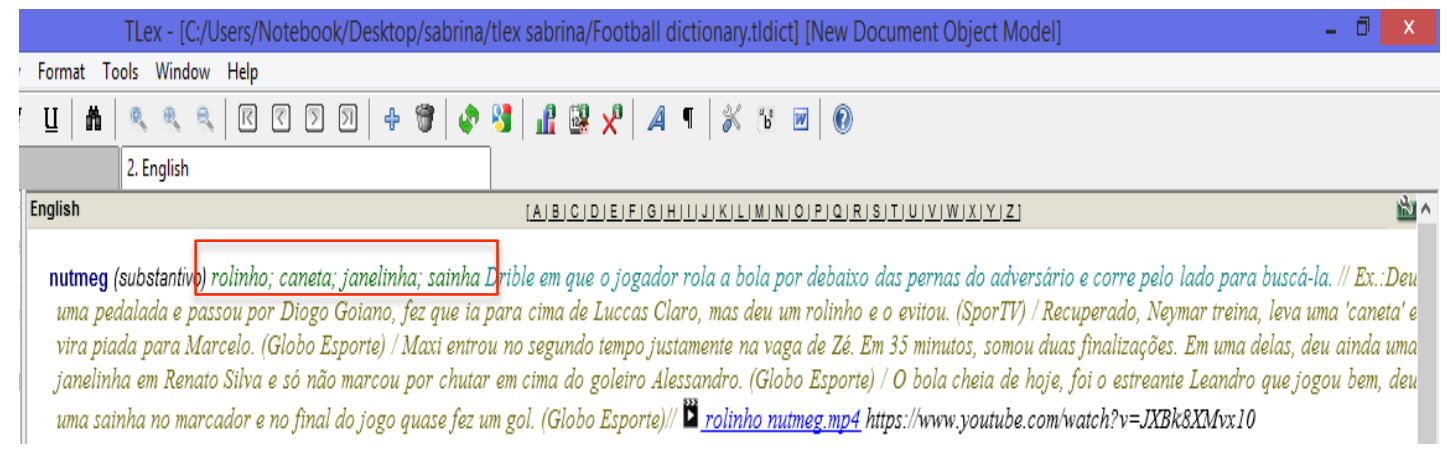

Figura 69: Destaque dos equivalentes de nutmeg em português. 


\section{Capítulo 5}

A formatação e o estilo apresentados acima foram utilizados para os equivalentes de todos os verbetes, com exceção do verbete da CLE 'gol, [FAZER|MARCAR] [um|o]', pois o termo possui 39 CLEs equivalentes em inglês e cada uma dessas CLEs possui um significado específico e evoca um tipo de gol ou modo distinto de fazer o gol (vide item 4.1). Por esse motivo, criamos um estilo e formatação específicos para esse verbete. A figura 70 destaca os equivalentes de 'gol, [FAZER|MARCAR] [um|o]':

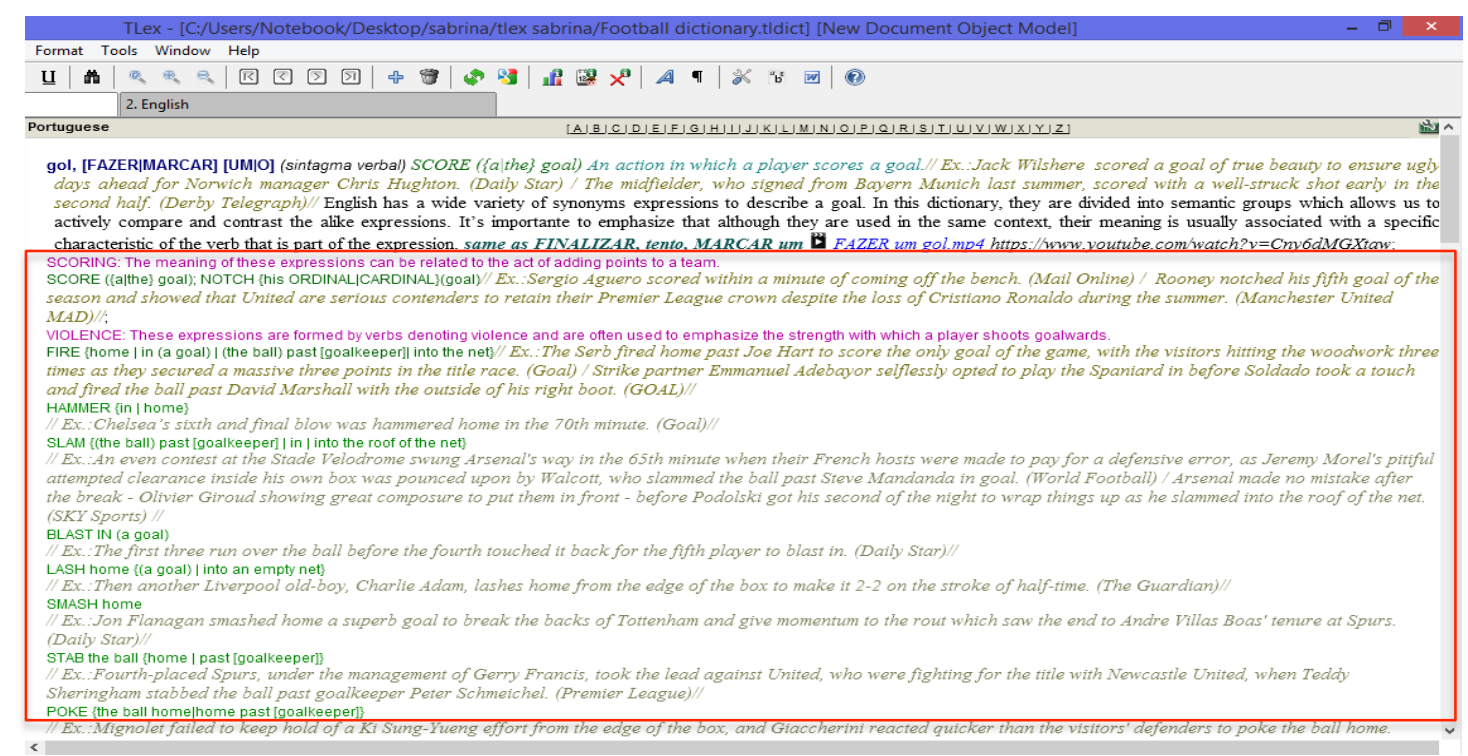

Figura 70: Destaque dos equivalentes de 'gol, [FAZER|MARCAR] [um|o]'.

Como podemos observar, inicialmente o dicionário apresenta SCORE (\{a|the\} goal) como equivalente. No entanto, nas informações enciclopédicas ${ }^{279}$ encontramos uma breve explicação sobre o fato dea língua inglesa possuir diferentes expressões equivalentes para 'gol, [FAZER|MARCAR] [um|o]', e que essas expressões foram agrupadas em campos semânticos com o intuito de evidenciar um melhor contraste de seus significados. Em seguida, o dicionário exibe os grupos semânticos e as expressões que os compõem. Cada grupo semântico é apresentado na cor rosa e em letras maiúsculas, seguido de uma explicação; as expressões que compõem cada grupo são apresentadas na linha abaixo com a mesma formatação dos equivalentes.

\footnotetext{
${ }^{279}$ Item 5.3.2.6.
} 


\section{Capítulo 5}

\subsubsection{Definição}

A parte mais laboriosa da construção do dicionário foi a elaboração das definições. Segundo a norma ISO 1087, definição é "um enunciado que descreve um conceito e que permite distingui-lo de outros conceitos no interior de um sistema de conceitos”. Na teoria, a definição proposta pela norma ISO nos parece bastante clara. No entanto, na prática, ou seja, no momento de construir um enunciado definitório, tivemos certa dificuldade. Para sanar essa dificuldade e responder às inúmeras indagações que surgiam à medida que tentávamos definir um verbete, debruçamo-nos sobre os estudos de definições em Terminologia.

O primeiro passo para a construção das definições do dicionário foi entender a diferença entre 'definição' e 'descrição', ainda um tanto quanto obscura, para, em um segundo momento, esmiuçar o conceito de 'definição' e, posteriormente, adotar uma definição do termo 'definição', dentre as tantas existentes.

Rey (1977, p. 42) distingue com clareza os termos 'definição' e ‘explicação”. Para o autor, a definição explicita todos os traços pertinentes de significado ou todos os traços conceptuais pertinentes, e nada além disso. A descrição, por outro lado, deve conter traços pertinentes e pode conter traços não pertinentes, isto é, pode conter informações extras que vão além dos traços conceptuais essenciais. Com base na explicação de Rey, entendemos que a definição deve conter apenas informação essencial para o entendimento do significado de um termo. Se acrescentarmos mais informações teremos uma descrição, não uma definição. Entendida essa diferença, o próximo passo foi compreender, de forma mais ampla, o conceito 'definição' que, segundo Tebé (1996), é relativamente bem documentado, quer em normas, quer em estudos terminológicos. Para tanto, consultamos os trabalhos de Barros (2004), Sager (1990), Cabré (1993), Rey (1979) e Wüster (1998).

Apresentar um estudo detalhado sobre o entendimento do termo 'definição terminológica' de cada um dos teóricos acima foge do escopo de nossa pesquisa. Contudo, acreditamos que o primeiro passo para construir um enunciado definitório é entender o conceito 'definição' em sua totalidade. Para facilitar a compreensão do termo, compilamos uma tabela com as definições encontradas: 


\section{Capítulo 5}

\begin{tabular}{|c|l|}
\hline teórico & \multicolumn{1}{c|}{ definição } \\
\hline Barros (2004, p. 159) & $\begin{array}{l}\text { "Paráfrase sinonímica que exprime o conceito designado pela unidade } \\
\text { lexical ou terminológica por meio de outras unidades linguísticas". }\end{array}$ \\
\hline Sager (1990) & $\begin{array}{l}\text { Processo de descrever um conceito linguisticamente tendo como base } \\
\text { uma lista de características que transmitem o significado desse conceito. }\end{array}$ \\
\hline Cabré (1993, p. 196) & $\begin{array}{l}\text { "Enunciado que descreve uma noção e que, dentro de um sistema } \\
\text { nocional, permite diferenciá-la de outras noções". }\end{array}$ \\
\hline Rey (1979) & $\begin{array}{l}\text { Junção entre uma definição lexicográfica e uma descrição enciclopédica } \\
\text { com o objetivo de evocar um conceito de uma língua de especialidade. }\end{array}$ \\
\hline Wüster (1985, p. 55) & $\begin{array}{l}\text { "Descrição de um conceito por meio de outros conceitos, usualmente } \\
\text { feita por meio de palavras". }\end{array}$ \\
\hline
\end{tabular}

Embora cada definição apresente sua particularidade, todas têm em comum o fato de que 'definição' descreve um conceito de uma área de especialidade. Esse foi o ponto de partida para elaborar a nossa definição do termo. Somamos a isso o fato de que uma definição explicita somente os traços pertinentes, ou essenciais, de um significado, deixando de lado características não essenciais. Nesse momento, deparamos com o que Finatto (2001, p. 286) aponta como uma das grandes dificuldades da elaboração de uma definição terminológica: selecionar o que é essencial frente ao acessório.

Partimos do princípio de que para selecionar os traços pertinentes é necessário levar em consideração três fatores essenciais: o domínio específico em questão, o perfil do produto terminográfico e o público-alvo. No que se refere ao domínio específico, o futebolês pode ocupar os dois extremos em uma linha que define o grau de especialização de uma língua de especialidade, pois é, ao mesmo tempo parte do cotidiano de muitos brasileiros e ingleses, e obscuro para a parcela da população que não se interessa pelo esporte. Dessa forma, acreditamos que alguns termos, por mais que carreguem características culturais e históricas, são conhecidos por muitas pessoas, até mesmo por aquelas que não demonstram interesse pelo esporte. Tomemos como exemplo o caso do termo 'gol' ou da CLE 'gol, [FAZER|MARCAR] [um|o]'. Cremos que ambos têm seu significado compreendido até mesmo por alguém que não admire, assista ou leia sobre futebol. No entanto, essa realidade não é compartilhada por outros termos como 'bichado', por exemplo, cujo significado é compreendido somente por pessoas que entendem um pouco mais sobre o assunto.

Quanto ao perfil do produto terminográfico, consideramos os seguintes fatores: 


\section{Capítulo 5}

a) a obra terminográfica é digital e poderá, futuramente, ser disponibilizada online, ou seja, não precisamos nos restringir a limitações de espaço, fator bastante comum em obras impressas;

b) o propósito principal da obra é tratar de termos culturalmente marcados, que por natureza apresentam dificuldade na tradução. Por esse motivo, temos como objetivo definir o conceito de um verbete da forma mais clara possível. No entanto, temos que ser cuidadosos para não incluir na definição traços não essenciais, que podem ser incluídos no elemento 'informações enciclopédicas' (item 5.3.2.6).

Elaboramos um modelo de dicionário terminográfico tendo em mente um público-alvo que tenha ao menos um conhecimento básico sobre o tema, uma vez que uma pessoa desinteressada pelo tema ou que não necessite compreender ou escrever sobre futebol não se interessará pela obra. Acreditamos, também, que a mínima necessidade de compreensão ou produção de um texto nesse domínio específico vem acompanhada de um conhecimento mínimo da área. Levamos, ainda, em consideração o fato de que, além de um público de conhecimento médio, especialistas sobre o assunto podem se interessar pela obra e, nesse caso, os dados recolhidos durante a análise dos verbetes e que não foram incluídos na definição por apresentarem informações acessórias não devem ser descartados, mas sim apresentados nas informações enciclopédicas.

Para fechar o entendimento do conceito 'definição', compartilhamos a visão de Finatto $(2001,129)$, para quem o enunciado definitório é "a voz de alguém e a voz de uma área do conhecimento" que deve ser mediada e entendida como reflexo e produto de condições socioculturais, comunicativas e pragmáticas.

Após apresentar diferentes abordagens para o significado de 'definição' em dicionário terminológico, julgamos interessante, para o propósito deste trabalho, apresentar o conceito de definição aqui adotado. Ressaltamos, entretanto, que não temos como objetivo questionar as definições já existentes, mas, por uma questão de linearidade da tese, mostramos, abaixo, nosso entendimento de definição terminológica: 


\section{Capítulo 5}

Enunciado que descreve o conceito de um termo de especialidade por meio de unidades linguísticas e que se limita a oferecer informações essenciais para a compreensão do conceito descrito.

A definição apresentada é resultado da junção de algumas das definições presentes no quadro 21 e tem como objetivo nortear a elaboração das definições do modelo de dicionário construído.

O modo de definição do termo varia de acordo com o domínio e com a característica do termo descrito. No entanto, Barros (2004, p. 165) apresenta uma fórmula que nos pareceu ideal pela Terminologia. A fórmula em questão é composta por duas partes: gênero próximo + diferenças específicas. Essa fórmula identifica o termo como parte de um conjunto e, em seguida, o distingue de outros elementos pertencentes a esse mesmo conjunto. Observemos a definição de diver:

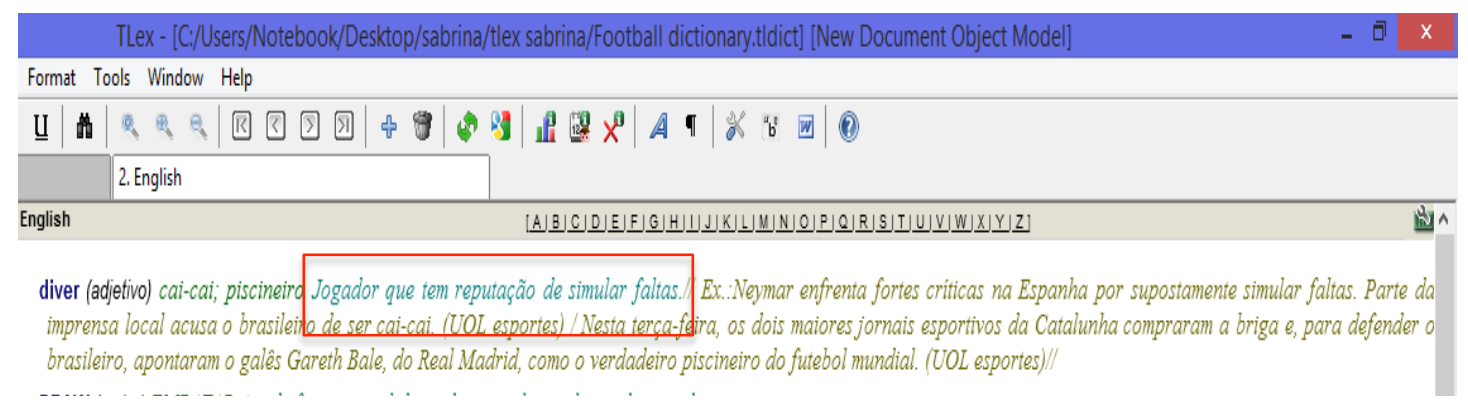

Figura 71: Destaque para a definição de diver.

Primeiramente, identificamos o termo como parte de um grupo, nesse caso, 'jogadores', e, em seguida, o diferenciamos do grupo apresentando suas características específicas: 'que tem reputação de simular faltas'.

Existem diversos tipos de definição, e poderíamos listar todos os modelos encontrados durante a pesquisa. Contudo, entendemos que cada modelo pode ter sua especificidade e aplicabilidade justificadas pela natureza da obra terminográfica. Em nosso dicionário, trabalhamos, sempre que possível, com o modelo de definição por compreensão, que segue aquele apresentado por Barros (2004). Em uma definição por compreensão, as características restritivas são apresentadas com o objetivo de 


\section{Capítulo 5}

diferenciar o conceito descrito dos outros conceitos pertencentes ao mesmo grupo, conferindo-lhe um caráter único. Podemos observar essa dinâmica na definição da figura 71, em que o jogador diver é diferenciado de todos os outros jogadores pelo seu hábito de simular faltas.

Expostos o conceito e o modo de definição adotados, explicamos, brevemente, o procedimento utilizado para a elaboração das definições.

Utilizamos as definições extraídas da web para compilar as definições dos verbetes. Por exemplo, no caso do termo 'rolinho', consideramos as seguintes definições:

a) "este drible é quando o jogador rola a bola por debaixo das pernas de quem o está marcando e corre pelo lado para buscar a bola."

b) "Esse drible tem como característica desmoralizar o adversário e levantar a torcida!"

c) "Jogar a bola entre as pernas do jogador adversário."

d) "O drible feito pelos jogadores que faz a bola passar pelo vão da perna do adversário."

e aplicamos o modelo de definição por compreensão. Primeiramente, diferenciamos 'rolinho' de todos os outros elementos do mesmo grupo ('drible') para, em seguida, apresentar suas características restritivas: "rolar a bola por baixo das pernas do adversário e correr pelo lado para buscá-la". Chegamos à seguinte definição: "Drible em que o jogador rola a bola por baixo das pernas do adversário e corre pelo lado para buscá-la”.

No modelo de dicionário proposto, as definições são separadas do elemento anterior ('equivalente') por ponto e vírgula (;) e do elemento seguinte ('exemplos') por barras duplas (//). São grafadas em verde e aparecem em itálico.

\subsubsection{Exemplo(s)}

Para os teóricos da LC como Tagnin (2005), Berber Sardinha (2004), Bowker e Pearson (2002) e Sinclair (1991), uma das grandes vantagens, senão a maior, de pesquisas em LC é trabalhar com a língua em uso, ou seja, a maneira como a língua é 


\section{Capítulo 5}

efetivamente utilizada por seus usuários. Em se tratando de um modelo de dicionário compilado de acordo com os princípios da LC, é de se esperar que os exemplos nele presentes tenham sido retirados do corpus. Ao selecionar os exemplos, procuramos, sempre que possível, escolher aqueles que contribuíam para a compreensão do significado do termo ou CLE. No entanto, dado o alto grau de especialidade do corpus de estudo, a maior parte dos exemplos não expandia a informação contida na definição. Em um primeiro momento, recorremos ao Google para buscar exemplos mais explicativos. Contudo, após as primeiras buscas constatamos que textos sobre futebol não são de natureza explicativa; são, em sua maioria, narrações de acontecimentos, sejam esses em campo ou nos "bastidores" do futebol. O único gênero textual que se mostrou explicativo foi a crônica futebolística. No entanto, além de não fazer parte de nosso corpus, frequentemente as crônicas utilizam os termos típicos do futebol de forma mais criativa.

Dada a dificuldade de encontrar exemplos que acrescentassem alguma informação à definição elaborada, aceitamos a natureza dos gêneros textuais com os quais trabalhamos e extraímos, quando possível, os exemplos do corpus, salvo em casos em que buscávamos exemplos de um equivalente em inglês que não apresentava ocorrência no corpus. Nesses casos, extraímos os exemplos de textos encontrados no Google e armazenamos os textos em uma pasta para, em momento oportuno, serem inseridos no corpus.

Disponibilizamos até três exemplos para cada verbete, sendo que $80 \%$ dos verbetes apresenta somente um exemplo, os outros $20 \%$ são casos em que a CLE possui um item intercambiável, como, por exemplo, os verbos 'fazer' e 'cometer' na CLE 'falta, [FAZER|COMETER]'. Nesse verbete, apresentamos dois exemplos, um com cada verbo. Observemos a figura 72 : 


\section{Capítulo 5}

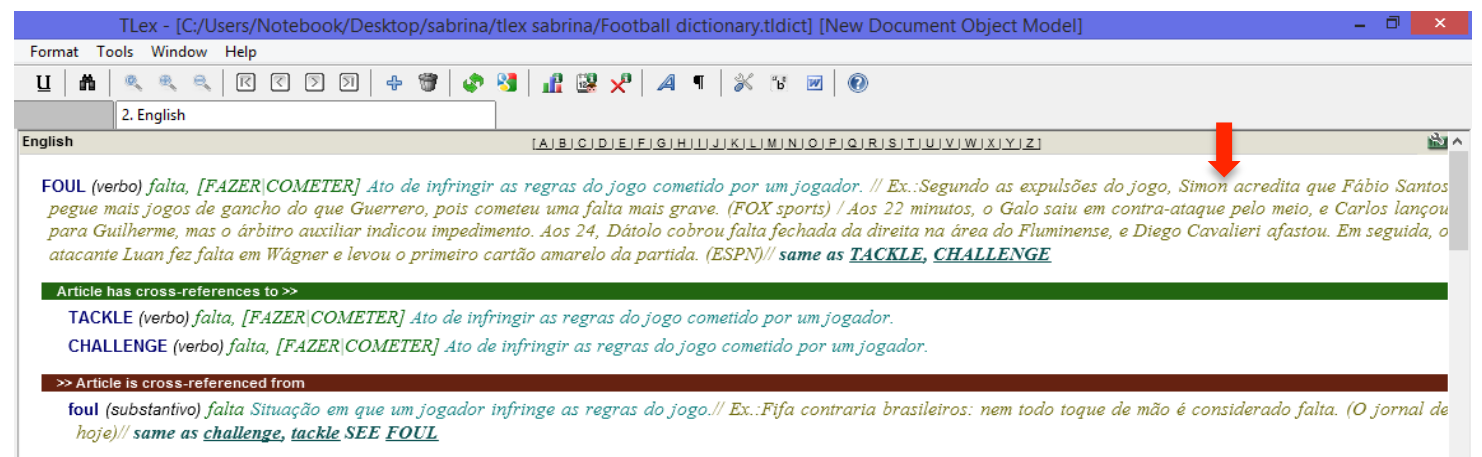

Figura 72: Destaque para os exemplos de 'falta, [FAZER|COMETER]'.

Também disponibilizamos mais de um exemplo no caso de termos com mais de um equivalente na outra língua, caso de nutmeg:

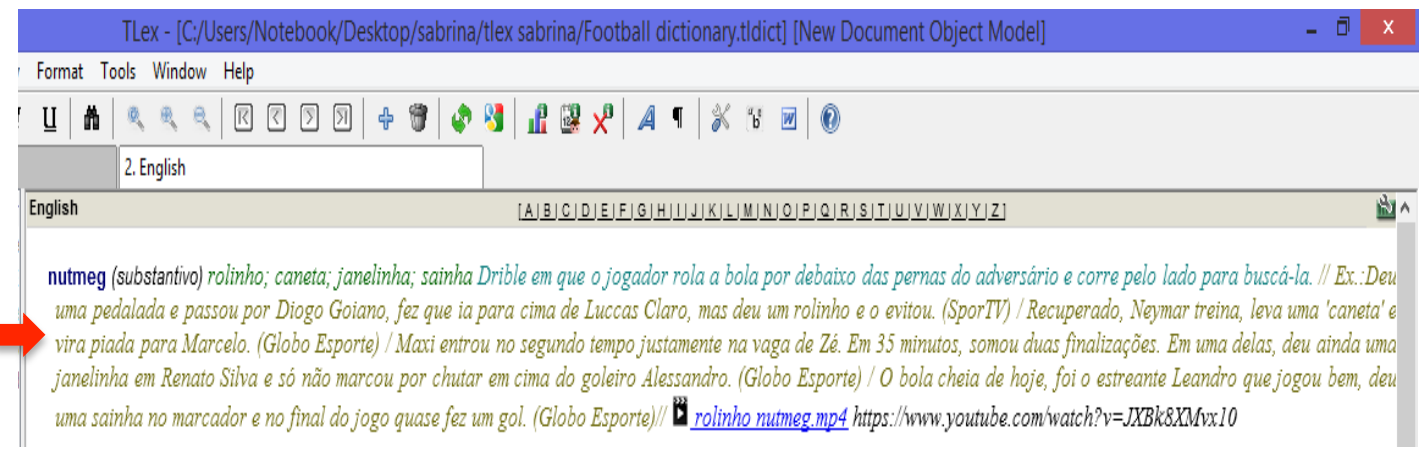

Figura 73: Destaque para os exemplos dos equivalentes de nutmeg em português.

Cada exemplo aparece em itálico, na cor verde musgo, e é separado do elemento anterior e do termo seguinte por barras duplas (//). O símbolo "Ex.:" sempre antecede o primeiro exemplo, e, no caso de mais de um exemplo, utilizamos a barra individual (/) para delimitar cada um.

\subsubsection{Informações enciclopédicas}

O campo 'informações enciclopédicas' contém informações históricas, culturais e dados de cunho mais geral que auxiliam na compreensão do significado de um termo ou que acrescentam informações relevantes à definição.

A figura 74 exemplifica a informação enciclopédica do termo dummy, que tem como equivalente 'drible da vaca' em português: 


\section{Capítulo 5}

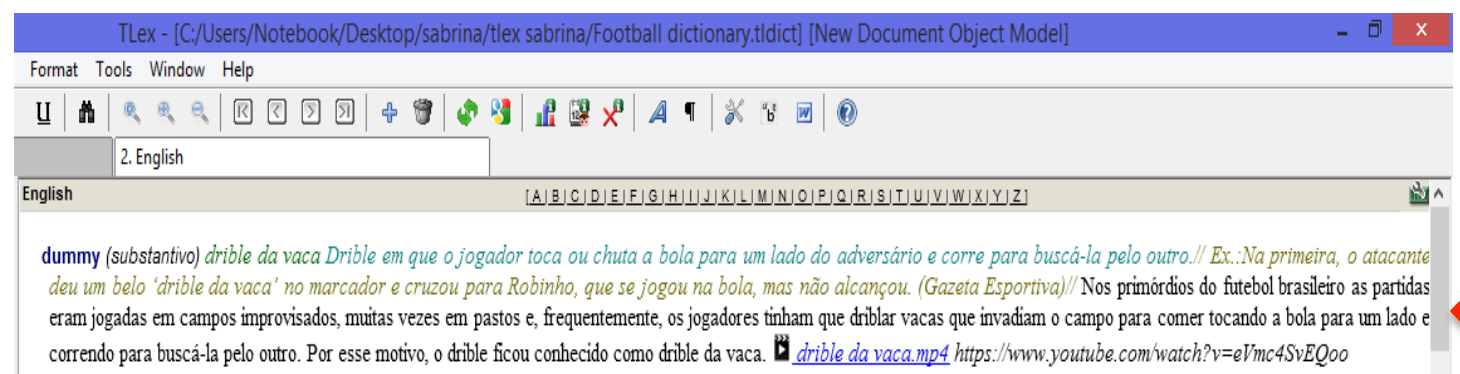

Figura 74: Destaque da informação enciclopédica do termo dummy.

Nesse caso, a informação enciclopédica narra, brevemente, a origem do termo em português.

A figura 75 exemplifica um caso em que a informação enciclopédica auxilia o consulente a compreender a definição:

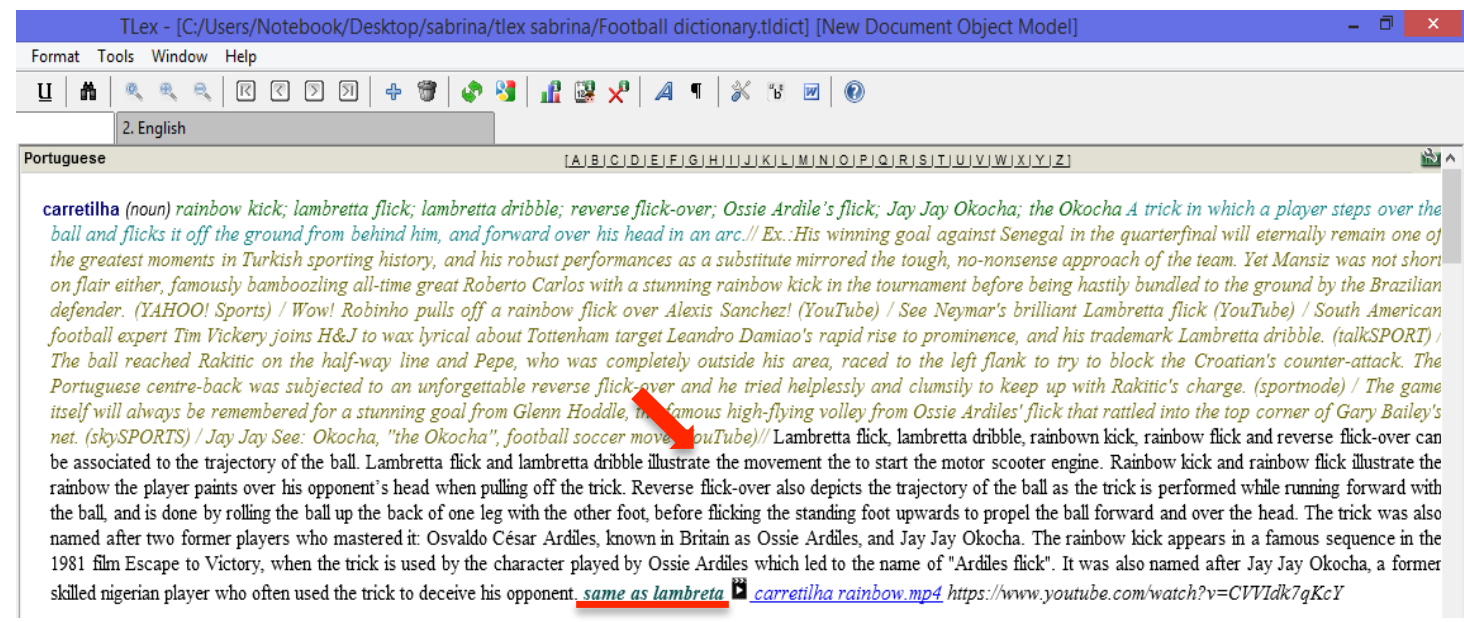

Figura 75: Destaque da informação enciclopédica do termo 'carretilha'.

No caso de 'carretilha', a informação enciclopédica auxilia o consulente a entender a origem dos nomes do drible por meio da descrição do movimento que o jogador faz com o corpo e por meio da descrição da trajetória da bola.

As informações enciclopédicas são grafadas em preto, separadas do elemento anterior por barras duplas (//) e do elemento seguinte por espaço. 


\section{Capítulo 5}

\subsubsection{Remissivas}

O sistema de remissivas estabelece as relações semântico-conceptuais entre os verbetes de uma obra terminográfica, ligando variantes e fornecendo um conhecimento mais amplo e detalhado sobre os termos ou CLEs (BARROS, 2004).

Para Barros (2004), a construção de um sistema de remissivas segundo critérios estabelecidos é fundamental para garantir a uniformidade de uma obra terminográfica.

Adotamos dois tipos de remissivas: 1) 'mesmo que' (same as): utilizada para sinônimos; e 2) 'ver também' (see also): utilizada para ligar um termo (ex.: 'gol) a uma CLE formada pelo mesmo termo (ex.: gol, [FAZER|MARCAR] [um|o]). Uma vez que seguimos os princípios da LC para a análise dos termos e construção do dicionário, no caso de sinônimos utilizamos o termo com o maior número de ocorrências no corpus como a entrada principal; seus sinônimos podem ser acessados pela referência 'mesmo que'.

As remissivas são os últimos elementos grafados no verbete e aparecem em negrito e itálico e na cor verde escura. O software Tlex permite a inclusão de remissivas nos verbetes desde que todos os termos tenham uma entrada. Dessa forma, para remeter o termo 'carretilha' (item mais frequente no corpus) ao termo 'lambreta' (item menos frequente no corpus), criamos uma entrada para 'lambreta'. A figura 76 mostra a referência cruzada entre 'lambreta' e 'carretilha': 


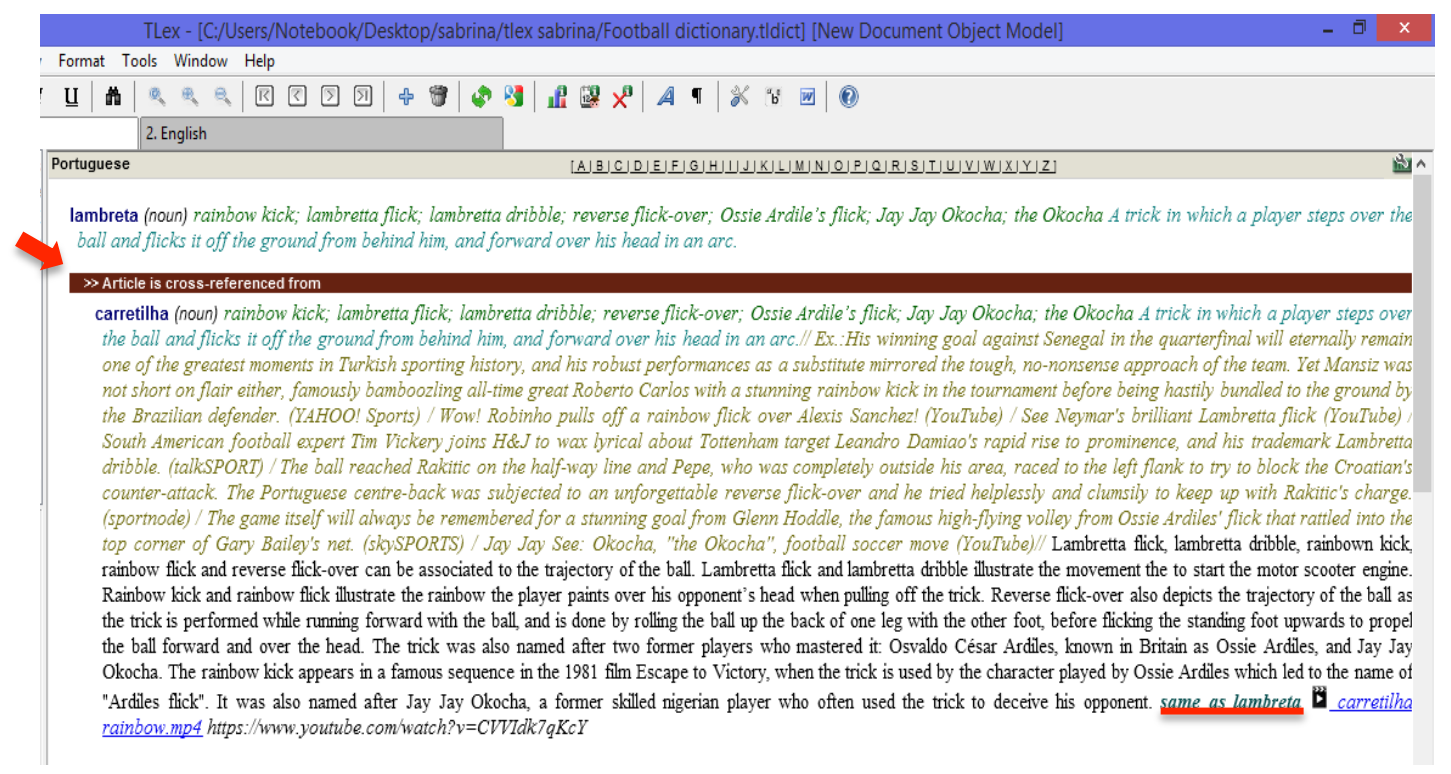

Figura 76: Referência cruzada entre 'lambreta' e 'carretilha'.

Ao final do verbete 'lambreta' encontramos a informação article is crossreferenced from seguido do verbete principal ('carretilha') na linha abaixo, recuado à esquerda. O software adiciona essa informação automaticamente quando o terminológo cruza duas referências.

Se consultarmos 'carretilha', encontraremos ao final do verbete a informação: article has cross references to $>>$ seguido do verbete 'lambreta' na linha de baixo, recuado à direita.

\subsubsection{Vídeo}

Embora em teoria a informação contida na definição deva ser suficiente para que o consulente entenda o significado do termo ou CLE, esse nem sempre é o caso. Em alguns dicionários, tanto de língua geral quanto especializados, os exemplos acrescentam, indiretamente, informações que contribuem para a compreensão do significado do termo. No entanto, como exposto anteriormente, tal fato não ocorreu em nossa pesquisa. Por esse motivo, optamos por adicionar vídeos em alguns verbetes, sobretudo nos verbetes de dribles e jogadas. Acreditamos que um consulente não familiarizado com futebol pode ter o significado de um termo ou CLE esclarecido 


\section{Capítulo 5}

ao assistir a um vídeo que mostre detalhadamente a dinâmica do movimento da bola ou do movimento executado pelo jogador.

Durante a seleção dos vídeos, optamos sempre pelos de caráter mais didático, como, por exemplo, o que mostra um profissional ensinando passo a passo a execução de um drible ou uma compilação de determinado drible.

Infelizmente, por questões óbvias não será possível visualizar os vídeos presentes nos verbetes. Contudo, disponibilizamos os vídeos de dribles presentes no dicionário em um CD anexo. É importante enfatizar que o programa TLex permite a inserção de vídeos e imagens na obra desde que os arquivos estejam salvos no computador em que o software está instalado. O elemento vídeo, quando presente, aparece em forma de link no final do verbete seguido de seu endereço. Para visualizar o vídeo, basta que o consulente clique no ícone:

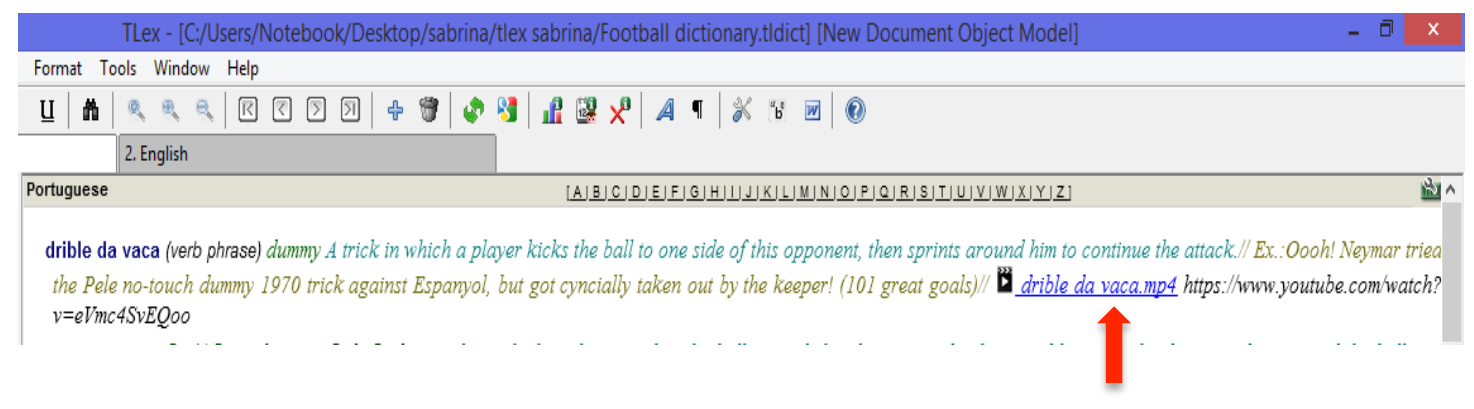

Figura 77: Modo de visualização do elemento 'vídeo' no TLex.

\subsubsection{Imagem}

Acreditamos que a ilustração de alguns termos pode auxiliar o consulente na compreensão dos significados, como, por exemplo, no caso do termo 'gol' quando este se refere à estrutura física. Observemos o verbete 'gol': 


\section{Capítulo 5}

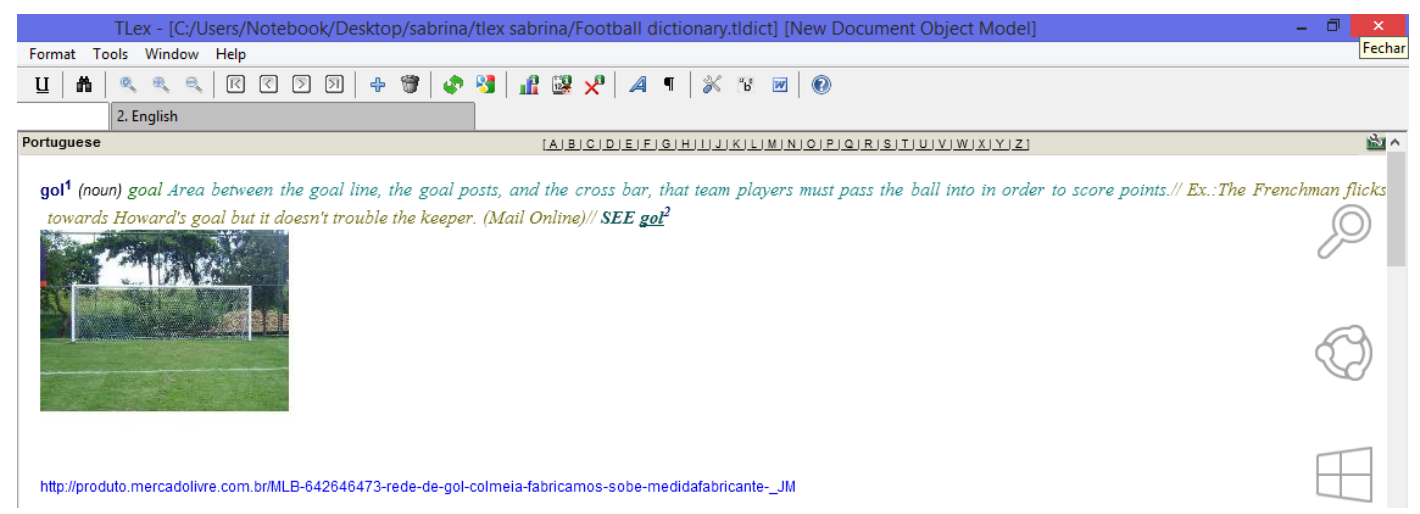

Figura 78: Verbete 'gol'.

Assim como o elemento 'vídeo', o elemento 'figura' é disponibilizado no fim do verbete, seguido do endereço eletrônico do qual a figura foi extraída. 


\section{Considerações finais}

O presente trabalho partiu da hipótese de que os diferentes jeitos de jogar, a história do futebol em cada cultura, a apropriação cultural das regras na Inglaterra e no Brasil e outros fatores de ordem histórico-social contribuíram para a criação do léxico do futebol em português e inglês. Propusemo-nos a observar o léxico do futebol tendo como pano de fundo a história do esporte em cada cultura, pois acreditamos que as terminologias são influenciadas por fatores contextuais. Fatores, esses, que devem ser considerados durante o ato tradutório.

A natureza terminológica do trabalho e o desejo de auxiliar o tradutor deram origem ao objetivo de nossa pesquisa: criar um modelo de glossário de futebol composto por verbetes marcados por diferenças culturais entre o Brasil e a Inglaterra.

Para alcançar os dois objetivos propostos, estabelecemos seis passos: compilar um corpus comparável de futebol no par de línguas português e inglês, composto por textos de campeonatos ingleses e brasileiros; explorar o corpus e fazer um levantamento das palavras-chave mais frequentes; selecionar os termos e combinatórias léxicas especializadas (CLEs) culturalmente marcados; estabelecer possíveis equivalentes para os termos e CLEs; criar definições para os termos e CLEs; e criar um modelo de dicionário composto por termos e CLEs culturamente marcados.

Inicialmente, discutimos os seis passos seguidos para alcançar os objetivos. Em seguida, refletimos sobre a hipótese em que nos baseamos para a execução da pesquisa e apresentamos outras duas hipóteses que surgiram durante a análise. Ao final, tecemos comentários gerais sobre o objetivo principal de nossa tese e apresentamos algumas considerações sobre questões de interdisciplinaridade.

O primeiro passo, compilar o corpus de estudo, demandou mais trabalho do que esperávamos. Ainda no início da pesquisa, tivemos que modificar sua composição, pois, a princípio, trabalharíamos com dois subcorpora: um contemporâneo, formado por textos coletados no período de 2006 a 2010 durante nossa pesquisa de mestrado, e que foi ampliado com textos da Copa das Confederações (2013) e da Copa do Mundo (2014); e outro, histórico, composto por 


\section{Considerações finais}

textos sobre resultados de partidas das fases finais das copas de 1930 a 2014. Essa compilação teve de ser alterada por dois motivos principais: 1) para identificar particularidades do futebol brasileiro e do futebol inglês não precisaríamos somente de um corpus comparável em português e inglês, mas sim de um corpus comparável composto por textos sobre campeonatos brasileiros e campeonatos ingleses; 2) a compilação do corpus histórico mostrou-se muito laboriosa. Não conseguimos acesso aos textos que pretendíamos coletar dentro do recorte proposto. Ademais, quando encontrávamos os textos, estes estavam em formato .pdf e o software conversor não reconhecia os caracteres, fator que dificulta, ou, em nosso caso, impossibilita a compilação do corpus.

Além da composição, tivemos que repensar os campeonatos dos quais coletaríamos os textos, já que, como detalhado anteriormente a configuração dos campeonatos no Brasil e na Inglaterra difere bastante.

A diferença do número de palavras dos textos em inglês e português foi explicada pelo conceito de high e low-context cultures, segundo o qual a quantidade de informação linguística necessária para transmitir o significado varia de acordo com a cultura. O Brasil pertence à categoria de países high-context, caracterizados por deixar grande quantidade de elementos contextuais implícitos. Por esse motivo, informações que estão subentendidas na fala ou, como em nosso caso, em um texto, contribuem de forma efetiva para a transmissão do significado. A Inglaterra, por outro lado, pertence à categoria de países low-context, caracterizados por explicitar os elementos contextuais e debater exaustivamente os assuntos, de modo que não restem dúvidas que deem margem a uma interpretação equivocada. Os textos em português apresentam um relato sucinto, enfatizando os gols e dando pouco destaque para as jogadas, focando, dessa forma, o resultado em detrimento dos meios, até mesmo nas narrações minuto a minuto. Já os textos em inglês descrevem a partida com riqueza de detalhes e quase sempre apresentam, além de um apanhado geral, a descrição dos lances mais importantes, enfatizando, assim, a importância dos meios e do resultado.

A mesma diferença no grau de detalhamento dos resultados de partidas, das descrições de partidas e dos relatos de partidas com comentários de internautas também foi observada nas notícias sobre compra e venda de jogadores e técnicos e nas notícias sobre a situação dos times nos campeonatos. Além das particularidades 


\section{Considerações finais}

dos países de high e low-context, destacamos o interesse e o hábito do torcedor inglês de comentar a partida junto com o narrador, prática que não se mostrou popular no Brasil.

O segundo e o terceiro passos, fazer um levantamento das palavras-chave mais frequentes e selecionar os termos e CLEs culturalmente marcados, foram realizados de forma semiautomática. O levantamento das palavras-chave foi feito automaticamente pelo software WordSmith Tools por meio da comparação com o corpus de referência. Já a seleção dos termos culturalmente marcados, que constituem os estudos de caso, foi feita manualmente por meio da análise da lista de palavraschave e subsequente eliminação de nomes de times e de jogadores, palavras que faziam referência a campeonatos, palavras gramaticais, numerais e advérbios.

Conforme exposto anteriormente, temos ciência de que alguns termos culturalmente marcados não foram abordados em nossa análise. Contudo, acreditamos que tal fato não constitua um ponto negativo, já que nosso objetivo não foi compilar uma obra completa de termos culturalmente marcados, mas sim mostrar a importância de fatores sociais, históricos e culturais na construção de uma terminologia e registrar esses fatores em um modelo de dicionário. Além disso, os resultados finais dependem de uma série de decisões tomadas pelo pesquisador durante o percurso da pesquisa. Assim, os termos selecionados refletem a composição do corpus de estudo, a metodologia de análise e as decisões mais específicas, como, por exemplo, a exclusão de nomes de times e de jogadores.

O quarto passo, estabelecer possíveis equivalentes para os termos e CLEs, demandou mais trabalho e tempo do que o esperado. A princípio acreditávamos que trabalhar com um corpus comparável balanceado asseguraria, de certa forma, a identificação de equivalentes tradutórios na língua de chegada. É fato que a maior parte dos equivalentes foi encontrada por meio da análise do corpus de estudo, tanto por meio da análise das linhas de concordância da tradução prima facie, quanto de um possível colocado do termo em inglês, de um sinônimo do termo em português, de um já candidato a equivalente em inglês, das linhas de concordância das etiquetas gramaticais ou da análise das palavras-chave do subcorpus em inglês. No entanto, conforme detalhado no item 3.5.3, tivemos que utilizar outros dois mecanismos de 


\section{Considerações finais}

busca para identificar alguns equivalentes: pesquisa na internet pelo Google e conversa com especialista.

A pesquisa na internet mostrou-se bastante eficaz tanto para um melhor entendimento do significado dos termos em português, quanto para a busca de seus equivalentes em inglês. Além disso, recorremos ao YouTube durante toda a pesquisa a fim de compreender melhor os dribles. As consultas a especialistas da área também foram produtivas, pois, durante essas conversas, obtivemos informações mais específicas sobre os termos e CLEs significativamente recorrentes no corpus, fator que contribuiu sobremaneira para a identificação de alguns equivalentes. Em suma, apesar de utilizarmos três ferramentas de busca para encontrar equivalentes tradutórios, a busca em nosso corpus provou-se bastante eficaz e foi suficiente para a identificação dos equivalentes da maioria dos termos e CLEs.

A fim de executar o quinto passo, criar definiç̧ões para os termos e CLEs, fizemos pesquisas mais extensas na internet. Acessamos sites esportivos, blogs de fãs de futebol e alguns dicionários on-line; também examinamos crônicas, enciclopédias e todo tipo de fonte que apresentasse definições para os termos e CLEs que estudávamos. Registramos as definições encontradas nas fichas terminológicas e, a partir dessas definições, elaboramos nossa própria definição. Após elaborar as definições, conversávamos, sempre que possível, com pesquisadores de futebol e jornalistas esportivos a fim de validar a definição. Quando não tínhamos um especialista à disposição, conversávamos com familiares, amigos e conhecidos, todos fãs de futebol.

O sexto passo, criar um modelo de dicionário composto pelos verbetes marcados por diferenças culturais entre Brasil e Inglaterra, foi realizado parcialmente. Isto é, criamos um modelo de glossário dentro das limitações de tempo da pesquisa. Esse modelo é composto por nove elementos: entrada, categoria gramatical, equivalente, definição, exemplo, informações enciclopédicas, dois tipos de remissivas - 'mesmo que' e 'ver também' -, vídeo e imagem.

Cremos que o modelo de verbete resultante auxiliará os consulentes que tenham como objetivo ler ou escrever sobre futebol em português ou inglês e, ao mesmo tempo, entender um pouco mais sobre as particularidades do futebol brasileiro e do futebol inglês. Naturalmente, outros elementos, tais como os colocados e as 


\section{Considerações finais}

CLEs mais comuns em que os termos ocorrem, ou, ainda, um indicador de frequência do termo ou CLE podem ser incluídos no verbete; as possibilidades da montagem de um verbete são inúmeras. Em nossa pesquisa selecionamos os elementos que julgamos mais relevantes. Enfim, como exposto anteriormente, um dos grandes desafios da compilação de dicionários baseados em corpus é, diante de todas as informações que o corpus evidencia, selecionar as mais relevantes para compor o verbete, sem deixar que o dicionário perca sua característica de obra lexicográfica ou terminográfica e se transforme em uma enciclopédia.

Nossa hipótese inicial de que os diferentes jeitos de jogar, a história do futebol em cada cultura, a apropriação cultural das regras na Inglaterra e no Brasil e outros fatores de ordem histórico-social contribuíram para a criação do léxico do futebol em português e inglês foi confirmada, como podemos observar detalhadamente nos estudos de caso. Embora o futebol brasileiro esteja passando por uma série de mudanças, a forma-representação do "futebol-arte" ainda prevalece no imaginário do brasileiro. Observamos tal fato em dois níveis. Primeiramente, nas próprias palavraschave do subcorpus em português. Conforme discutido em alguns estudos de caso, como, por exemplo, no 'drible da vaca' e no 'rolinho' e seus sinônimos, a ocorrência dos termos que designam esses dribles em português é mais frequente do que as ocorrências que designam esses mesmos driblem no subcorpus em inglês, embora a frequência dos dribles em partidas não nos pareça muito maior no campeonato brasileiro do que no campeonato inglês ${ }^{280}$. Também observamos o binômio "futebolarte" x "futebol-força" na análise do minicorpus compilado para investigar a hipótese de que o futebol inglês é mais 'pegado' e 'rápido' do que o futebol brasileiro. O futebol brasileiro ainda é associado com palavras como 'drible', 'criatividade', 'espontaneidade', 'habilidade', 'beleza' e 'ginga', ao passo que o futebol inglês é quase que exclusivamente associado com palavras de força e rapidez.

Ainda no que se refere ao binômio "futebol-arte" x "futebol-força", observamos que, embora os pesquisadores de futebol reconheçam que tanto o futebol jogado pelo Brasil quanto o futebol jogado pela Inglaterra apresentem características de um futebol globalizado, já que equipes do mundo inteiro usam modelos

\footnotetext{
${ }^{280}$ Para afirmar tal hipótese, levantada com base em conversas com especialistas, teríamos que realizar um estudo sobre a frequência de dribles nos campeonatos no Brasil e na Inglaterra.
} 


\section{Considerações finais}

semelhantes (SOARES \& LAVISOLO, 2003, p. 140) e os times são compostos por jogadores de diversas nacionalidades, essa imagem de "futebol-arte" está presente até mesmo no imaginário dos pesquisadores, já que esses usam com frequência as palavras mencionadas no parágrafo anterior para se referir ao nosso futebol. Contudo, para que tal hipótese fosse comprovada seria necessário conduzir um estudo com os artigos, livros e teses que abordem o assunto. Nesse caso, a LC poderia ser utilizada a fim de levantar as palavras utilizadas por esses autores para falar sobre o futebol brasileiro analisando o contexto histórico-cultural em que as obras foram produzidas e as colocações e CLEs em que as palavras ocorrem.

Após seguir os seis passos acima descritos e comprovar nossa hipótese, alcançamos o objetivo final de nossa tese: criar um modelo de dicionário de futebol composto por verbetes marcados por diferenças culturais entre Brasil e Inglaterra. $\mathrm{O}$ modelo de dicionário foi criado levando em consideração as particularidades dos dois futebóis e está aberto a alterações. Assim como qualquer obra lexicográfica, um formato final do dicionário só poderá ser estabelecido uma vez que o projeto editorial e o meio de publicação forem definidos.

Ainda que não seja o objetivo do trabalho, a pesquisa nos permitiu realizar algumas reflexões sobre LC, Terminologia e Tradução Técnica. A LC mostrou-se aporte metodológico valiosíssimo para a extração terminológica. Mais do que isso, a LC guiou-nos durante toda a pesquisa, desde a hipótese levantada até as conclusões finais e propiciou o surgimento de novas hipóteses. Por esse motivo, acreditamos que, dependendo da forma como é utilizada e dos objetivos da pesquisa, a LC é muito mais do que um conjunto de práticas metodológicas. No que se refere à Terminologia, constatamos que os fatores culturais, o contexto e a finalidade de uso influenciam de forma direta o funcionamento de uma língua de especialidade.

Last but not least, após todas as leituras concluídas, as reflexões realizadas no percurso de nossa pesquisa e a experiência com a busca de equivalentes tradutórios para termos e CLEs da linguagem do futebol em português e inglês, acreditamos que o debate sobre ser ou não a Tradução Técnica influenciada por condicionantes culturais já foi suficientemente discutido para se concluir que, assim como qualquer outro gênero textual, o texto especializado é culturalmente condicionado. A pergunta que deveria ser feita é: Como estabelecer um conjunto de práticas que auxilie 


\section{Considerações finais}

tradutores e estudiosos da tradução a considerar elementos culturais e históricos na busca de equivalentes tradutórios de diferentes línguas de especialidade?

Acreditamos que os procedimentos metodológicos seguidos em nossa pesquisa podem servir como ponto de partida para futuras pesquisas. Entretanto, adaptações no processo podem fazer-se necessárias conforme o domínio estudado.

Encerramos nossas considerações finais com uma breve reflexão sobre interdisciplinaridade. Para que o objetivo final de nossa pesquisa fosse alcançado, lançamos mão de diferentes abordagens teóricas e metodológicas. Utilizamos a LC como metodologia e aporte teórico para a observação da linguagem; fizemos uso de ferramentas computacionais e métodos estatísticos para analisar o corpus; lançamos mão dos Estudos da Tradução para identificar os equivalentes dos termos e CLEs, bem como para selecionar as informações pertinentes a cada cultura e que deveriam constar no modelo de dicionário proposto; recorremos à Terminologia para entender os princípios que regem o futebolês e para elaborar o modelo de dicionário; cursamos a disciplina "História Social do Futebol: Impulso Lúdico, Composição e Significações", ministrada no Departamento de História da Universidade de São Paulo, para aprender sobre a história do futebol; e recorremos ao conceito formarepresentação, do antropólogo Luiz Henrique de Toledo, para interpretar as diferenças no comportamento dos termos em português e inglês. Enfim, gostaríamos de ressaltar a importância do diálogo entre linguistas em geral, entre eles tradutores, terminológos e linguistas de corpus, com pesquisadores de outras áreas a fim de expandir os horizontes de pesquisas de mestrado e doutorado.

"It was an initiation into the love of learning, of learning how to learn [...] as a matter of interdisciplinary cognition that is, learning to know something by its relation to something else."

(Leonard Bernstein) 


\section{Referências bibliográficas}

AIJMER, Karin; ALTENBERG, Bengt. (eds.) English Corpus Linguistics: studies in honour of Jan Svartvik. London: Longman, 1991, p. 8-29.

ALMEIDA, Gladis M. de B. O percurso da Terminologia: de atividade prática à consolidação de uma disciplina autônoma. TRADTERM, São Paulo, n. 9, p. 221-222, 2003.

ALMEIDA, Lucas G. de; OLIVEIRA, Marcos L. de; SILVA, Cristiano D. da. Uma análise da vantagem de jogar em casa nas duas principais divisões do futebol brasileiro. Revista Brasileira de Educação Física e Esporte, São Paulo, v. 25, n.1, p. 49-54, 2011.

ANCHIMBE, Eric. Blend it like a banana: Representing the ecology in live football commentaries. IN: LAVRIC, Eva; GERHARD, Pisek; SKINNER, Andrew. The Linguistics of Football. Tubingen: Gunter Narr, 2008.

STADLER, Wolfgang. (org.) The Linguistics of Football. Tübingen: Gunter Narr Verlag Tübingen, 2008.

ASENSIO, Roberto M. Specialised translation: a concept in need of revision. Babel, v. 53, n. 1, p. 48-55, 2007.

AZENHA JR., João. Tradução técnica e condicionantes culturais: primeiros passos para um estudo integrado. São Paulo: Humanitas, 1999.

BAAYEN, R. Harald. Lexis, Word Frequencies, and Text Type. IV-V Jornades de corpus linguistics 1996-1997. Proceedings... Barcelona, Institut Universitari de Lingüistica Aplicada, Universitat Pompeu Fabra, 1998, p. 87-102.

BAKER, Mona. Corpus linguistics and translation studies: Implications and applications. IN: BAKER, Mona; FRANCIS, Gill; TOGNINI-BONELLI, Elena. (eds.) Text and Technology: In Honour of John Sinclair. Amsterdam/Philadelphia: John Benjamins, 1993, p. 233-250.

BAKER, Mona. In other words: a coursebook on translation. London/New York: Routledge, 1992. 


\section{Referências bibliográficas}

. Corpora in translation studies: an overview and some suggestions for future research. Target, v. 7, n. 2, p. 223-243, 1995.

- Corpus-based Translation Studies: The Challenges that Lie Ahead. IN: SOMERS, Harold. (ed.) Terminology, LSP and Translation: Studies in Language Engineering in Honour of Juan C. Sager. Amsterdam/Philadelphia: John Benjamins, 1996.

; KAPLAN, Robert E. Translated! A new breed of bilingual dictionaries. Babel, v. 40, n. 1, p. 1-11, 1994.

BAKER, Paul. Using Corpora in Discourse Analysis. London: Continuum, 2006.

. Querying keywords: questions of difference, frequency and sense in keywords analysis. Journal of English Linguistics, v. 32, n. 4, p. 346-359, 2004.

BARBOSA, Maria Aparecida. Dicionário, vocabulário, glossário: concepções. In: ALVES, I. M. (org.). A constituição da normalização terminológica no Brasil. 2 ed. São Paulo: FFLCH/CITRAT, 2001.

BARNBROOK, Geoff; MASON, Oliver; KRISHNAMURTHY, Ramesh. Collocation: applications and implications. London: Palgrave Macmillan, 2013.

BARROS, Lídia A. Curso básico de Terminologia. São Paulo: Edusp, 2004.

BEAUGRANDE, Robert-Alain; DRESSLER, Wolfgang U. Introduction to Text Linguistics. London: Longman, 1981.

BERBER SARDINHA. Lingüística de Corpus: Histórico e problemática. Revista D.E.L.T.A., São Paulo, v. 16, n. 2, p. 323-367, 2000.

. Linguística de corpus. Barueri: Manole, 2004.

BEVILACQUA, Cleci. A fraseología jurídico-ambiental. 1996. Dissertação (Mestrado em Letras)-Universidade Federal do Rio Grande do Sul, Porto Alegre, UFRGS, 1996.

; MACIEL, Anna M. B.; RAMOS, Patrícia C. R.; SCHEEREN, Claúdia; KILLIAN, Cristiane. CLEs da linguagem jurídica: as combinatórias discursivas do texto legislativo brasileiro. IN: ALVAREZ, Maria L. O. (org.) 


\section{Referências bibliográficas}

Tendências atuais na pesquisa descritiva e aplicada em fraseologia e paremiologia. v. 2. Campinas: Pontes Editores, 2012, p. 241-253.

BLAIS, Esther. La phraséologie. Une hypothèse de travail. Terminologies Nouvelles, v. 10, p. 50-56, 1993.

BOUTIN-QUESNEL, Rachel; BÉLANGER Nycole; KERPAN Nada; ROUSSEA, Louis-Jean. Vocabulaire systématique de la terminologie. Québec: Publications du Québec, 1985. [Cahiers de l'Office de la langue française].

BOWKER, Lynne. Exploring the potential of corpora for raising language awareness in student translators. Language Awareness, v. 8, n.3, p. 160-173, 1999.

; PEARSON, Jennifer. Working with specialized language: a practical guide to using corpus. London/New York: Routledge, 2002.

BUGUEÑO MIRANDA, Félix Valentín; FARIAS, Virgínia Sita. Informações discretas e discriminantes no artigo léxico. Cadernos de Tradução, Florianópolis, v. 18, p. 115-135, 2006.

BYRNE, Jody. Technical Translation: Usability Strategies for Translating Technical Documentation. Dordrecht: Springer, 2006.

CABRÉ, Maria T. [1999] La Terminología: representación y comunicación: elementos para una teoria de base comunicativa y otros artículos. Barcelona: IULA, 2005.

; LORENTE, Mercè.; ESTOPÀ, Rosa. Terminología y Fraseología. V Simposio de Terminologia Iberoamericana. Actas..., Colégio de México, Ciudad de México, 1996, p. 67-81.

CARDOSO, Maurício. Futebol na raça. Veja, São Paulo, n.1528, 7 jan. 1998.

CARVALHO, Luciana. A tradução de binômios nos contratos de common law à luz da linguística de corpus. 2007. Dissertação (Mestrado em Letras) -Faculdade de Filosofia, Letras e Ciências Humanas, Universidade de São Paulo, São Paulo, 2007.

CASTELLANI FILHO, Lino. Futebol em mosaico: evolução histórica - evolução técnica e tática. Apostila. 1982.

DAMATTA, Roberto. (org.). Esporte na sociedade: Um ensaio sobre o futebol brasileiro. IN: DAMATTA, Roberto. Universo do Futebol. Rio de Janeiro: Pinakotheke, 1982. 


\section{Referências bibliográficas}

DAMO, Arlei S. Ah! Eu sou gaúcho! O nacional e o regional no futebol brasileiro. Estudos Históricos, Rio de Janeiro, v. 13, n. 23, 1999.

. Do dom a profissão: uma etnografia do futebol de espetáculo a partir da formação de jogadores no Brasil e na França. 2005. 435 f. Tese (Doutorado em Antropologia Social)-Instituto de Filosofia e Ciências Humanas, Universidade Federal do Rio Ggrande do Sul, Porto Alegre, 2005.

DAOLIO, Jocimar. Futebol, cultura e sociedade. Campinas: Editora Autores Associados, 2005.

DAYRELL, Carmen. Corpora no Ensino de Inglês Acadêmico: Padrões LéxicoGramaticais em Abstracts de Pós-graduandos Brasileiros. IN: TAGNIN, Stella E. O; VIANA, Vander. Corpora no Ensino de Línguas Estrangeiras. São Paulo: HUB Editorial, 2011.

DESMET, Isabel. Pour une approche terminologique des sciences sociales et humaines. Les sciences sociales et humaines du travail en portugais et en français. 1996. Tese (Doutorado)-Université Paris-Nord (Paris XIII), Paris, 1996. $2 \mathrm{v}$.

DUBUC, Robert. [1992] Manual práctico de Terminología. Trad. Ilena Cabrera. Providencia: RiL, 1999.

DUNNING, Eric. As ligações sociais e a violência no desporto. IN: ELIAS, Nobert; DUNNING, Eric. A busca da excitação. Lisboa: Difel, 1992, p. 327-354.

ELIAS, Norbert; DUNNING, Eric. A busca da excitação. Lisboa: Difel, 1992.

FILHO, Mário. O negro no futebol brasileiro. Rio de Janeiro: Civilização Brasileira, 1964.

FINATTO, Maria José Bocorny. Definição terminológica: fundamentos teórico-metodológicos para sua descrição e explicação. 2001. Tese (doutorado). Universidade Federal do Rio Grande do Sul, Porto Alegre, 2001.

. B. Exploração terminológica com apoio informatizado: perspectivas, desafios e limites. IN: ISQUERDO, Aparecida N.; ALVES, Ieda M. (org.). As Ciências do Léxico. v. 3. Campo Grande/São Paulo, 2007, p. 447-458.

FRANCO JÚNIOR, Hilário. A Dança dos Deuses - Futebol, Sociedade, Cultura. São Paulo: Companhia das Letras, 2007. 


\section{Referências bibliográficas}

GAUDIN, François. Pour une sociotermiologie Dês prolemes semantiques aux pratiques institutionnelles. Rouen: Publications de l'Université de Rouen, 1993.

GERBER, Regina M. Recursos eletrônicos e pesquisas envolvendo LC. IN: GERBER, Regina M.; VASILÉVSKI, Vera. (orgs.) Um Percurso para pesquisas com base em corpus. Florianópolis: Editora da UFSC, 2007.

GIGLIO, Sérgio S.; SPAGGIARI, Enrico. A produção das ciências humanas sobre futebol no Brasil: um panorama (1990-2009). Revista de História, São Paulo, v. 163, p. 293-350, 2010.

GLEDHILL, Christopher. Collocation and genre analysis. The discourse function of collocation in cancer research abstracts and articles. Zeitschrift für Anglistik und Amerikanistik, v. 1, p. 1-26, 1995.

GOLDBLATT, David. The Ball is Round: A Global History of Soccer. New York: Riverhead Books, 2008.

GOUADEC, Daniel. Nature et traitement des entités phraséologiques. Terminologie et phraséologie. Acteurs et amenageurs: Actes de la deuxième Université d'Automne en Terminologie. Paris: La Maison du Dictionnaire, p. 167-193, 1994.

GRÉCIANO, Gertrud. Vers une modélisation phrasélogique: acquis et projets d'EUROPHRAS. Terminologies Nouvelles, v. 10, p. 16-22, 1993.

GREEN, Geoffrey. Soccer: The World Game. London: Phoenix House Limited, 1953.

GUEDES, Simoni Lahud. Discursos autorizados e rebeldes no futebol brasileiro. Esporte e Sociedade, v.6, n.16. Nov/2010.

HAENSCH, G. Tipologia de las obras lexicográficas e aspectos práticos de la elaboracioón de diccionarios. IN: ETTINGER, S. et al. La lexicografía. De la linguística teórica a la lexicografía practica. Madrid: Gredos, 1982.

HALL, Edward. T. Beyond Culture. New York: Anchor Press/Doubleday, 1976. . The Silent Language. New York: Anchor Press/Doubleday, 1990.

HALLIDAY, Michael. System and function in language. Selected papers, London, p. 101-135, 1978.

HANKS, Patrick. Contextual Dependency and Lexical Sets. International Journal of Corpus Linguistics, v.1, n. 1, p. 75-98, 1996. 
Referências bibliográficas

HAUSMANN, Franz Josef; WIEGAND, Herbert Ernst. Component Parts and Structures of General Monolingual Dictionaries: A survey. IN: HAUSMANN, Franz Josef; REICHMANN, Oskar; WIEGAND, Herbert Ernst; ZGUSTA, Ladislav et al. Wörterbücher, dictionaries, dictionnaires. Ein internationales Handbuch zur Lexikographie. Band 1. Berlin/New York: Walter de Gruyter, 1989, p. 328-360.

HEID, Ulrich. Décrire las collocations: deux approches lexicographiques et leur application dans un outil informatisé. Terminologie et traduction, Bruselas, v. 2, n. 3, p. 523-548, 1992.

. On ways words work together - topics in lexical combinatories. IN: MARTIN, W. [et al.]. Proceedings of the 6th Euralex Inernational Congress on Lexicography (EURALEX 1994), Amsterdam, The Netherlands, 1994, p. 226-257.

. Towards a corpus-based dictionary of German noun-verb collocations. IN: FONTENELLE, T. et.al. (org.) Euralex'98. Proceedings... Université de Liège, 1998, p. 513- 522.

HELAL, Ronaldo; MURAD, Mauricio. Alegria do Povo e Don Diego: um ensaio sociológico sobre o êxtase e a agonia de heróis do futebol. Pesquisa de Campo no 1 - Núcleo de Sociologia do Futebol, Rio de Janeiro, , 1995.

; GORDON, Cesar. A crise do futebol brasileiro: perspectivas para o século XXI. Eco-Pos - Publicação da Pós-Graduação em comunicação e cultura, Rio de Janeiro, UFRJ, n. 1, v. 5, 2002.

HOEY, Michael. Lexical priming and the properties of text. IN: PARTINGTON, Alan; MORLEY, John; HAARMAN, Louann (Eds.). Corpora and Discourse. Bern: Peter Lang, 2004, p. 382-412.

HOFFMANN, L. Llenguatges d'especialitat. Selecció de textos. In: BRUMME, Jenny. (dir.). Llenguatges d' especialitat. Selecció de de textos de Lothar Hoffmann. Barcelona: IULA/UPF, 1998.

HOLANDA, Allan Pinheiro; MENESES, Anelise F. de; MAPURUNGA, Patrícia V. R.; DE LUCA, Marcia L. M. M.; COELHO, Antonio C. D; MENESES, Anelise F. de; MAPURUNGA, Patrícia V. R.; DE LUCA, Marcia L. M. M.; COELHO, Antonio C. D. Determinantes do nível de disclosure em clubes 


\section{Referências bibliográficas}

brasileiros de futebol. Revista de Contabilidade do Mestrado em Ciências Contábeis da UERJ, Rio de Janeiro, v. 17, n. 1, p. 2-17, 2012.

HOLMES, James S. The Name and Nature of Translation Studies. Translated! Papers on Literary Translation and Translation Studies, Amsterdam, p. 67-80, 1988.

HUNSTON, Susan. Corpora in Applied Linguistics. Cambridge: Cambridge University Press, 2002.

KATAN, David. Translating Cultures: an Introduction for Translators, Interpreters and Mediators. Manchester/Northampton: St. Jerome Publishing, 2004.

KENNEDY, Graeme. An introduction to corpus linguistics. London: Longman, 1998. . Phraseology and language pedagogy: Semantic preference associated with English verbs in the British National Corpus. IN: MEUNIER, Fanny; GRANGER, Sylviane. (eds) Phraseology in Foreign Language Learning and Teaching. Amsterdam: John Benjamins, 2008, p. 21-41.

KINGSCOTT, Geoffrey. Technical Translation and Related Disciplines. Perspectives: Studies in Translatology, v. 10, p. 247-255, 2002.

KRIEGER, Maria da G.; FINATTO, Maria J. B. Introdução à Terminologia: teoria e prática. São Paulo: Contexto, 2004.

KROEBER, Alfred L.; KLUCKHOHN, Clyde. Culture: a Critical Review of Concepts and Definitions. Cambridge: Papers of the Peabody Museum, v. XLVII, $\quad$ n. $1, \quad 1952 . \quad$ Disponível em: $<$ http://www.scribd.com/doc/230913406/Kroeber-y-Kluckhohn-1952-Culturea-critical-review-of-concepts-and-definitions\#scribd > Acesso em: 21 ago. 2015.

KÜBLER, Natalie; ASTON, Guy. Using corpora in translation. IN: O'KEEFFE, Anne; McCARTHY, Michael. (eds.) The Routledge handbook of Corpus Linguistics. Abingdon/New York: Routledge, 2010.

LAINÉ, Claude.; PAVEL; Sylvia.; BOILEAU, Monique. La phrasélogie - nouvelle dimension de la recherche terminologique. Travaux du module canadien du RINT. L'Actualité terminologique, Canada, v. 25, n. 3, p. 5-9, 1992.

LAVIOSA, Sara. Corpus-based translation studies: theory, findings, applications. Amsterdam/New York: Rodopi, 2002. 


\section{Referências bibliográficas}

LEECH, Geoffrey. The state of the art in corpus linguistics. N: SVARTVIK, Jan. English Corpus Linguistics. London/New York: Longman, 1991. . Introducing corpus annotation. IN: GARSIDE, Roger; LEECH, Geoffrey; McENERY, Anthony. (eds.) Corpus Annotation. London: Longman, 1997, p. $1-18$.

. Developing linguistic corpora: a guide to good practice. Adding Linguistic Annotation. Lancaster: Lancaster University, 2004. Disponível em: < http://www.ahds.ac.uk/creating/guides/linguistic-corpora/chapter2.htm > Acesso: 2 ago. 2015.

LEITH, Alex. Over the moon, Brian - The Football Language. London: Boxtree, 1998.

L'HOMME, Marie-Claude. Caractérisation des combinaisons lexicales spécialisées par raport aux collocations de langue générale. IN: FONTENELLE, T. et al. Euralex'98. Proceedings... Liège: Université de Liège, 1998, p. 513-522.

; BERTRAND, Claudine. Specialized lexical combinations: should they be described as collocations or in terms of selectional restrictions? Ninth EURALEX International Congress, EURALEX 2000. Proceedings...Stuttgart, Germany, Aug. 8-12, 2000, p. 497-506.

LEONCINI, Marvio P.; SILVA, Márcia T. da. Entendendo o Futebol como um Negócio: um estudo exploratório. Gestão e Produção, São Carlos, v. 12, n. 1, p. 11-23, 2005.

LOY, John W; KENYON, Gerald S; McPHERSON, Barry D. Sport, Culture and Society: a Reader on the Sociology of Sports. London: Macmillan, 1969.

MAIA, Belinda. Terminology and Translation-Bringing Research and Professional Training Together Through Technology. META Simposium - For a Proactive Translatology. Proceedings... Université de Montréal, 2005, p. 7-9.

MANCA, Elena. From phraseology to culture: qualifying adjectives in the language of tourism. IN: RÖMER, Ute; RAINER, Schulze. Patterns, Meaningful Units and Specialized Discourses, Amsterdam/Philadelphia: John Benjamin, 2010, p. $105-122$.

MARPLES, Morris. A History of Football. London: Secker \& Warburg, 1954. 


\section{Referências bibliográficas}

MARTIN, Willy. Remarks on Collocations in sublanguages. Terminologie et traduction,Bruselas, vol. 2, n.3., p. 157-164, 1992.

MATTOS, Cláudia. Cem anos de paixão: uma mitologia carioca no futebol. Rio de Janeiro: Rocco, 1997.

MATUDA, Sabrina. A fraseologia do futebol: um estudo bilingue português-inglês direcionado pelo corpus. 2011. 304 f. Dissertação (Mestrado em Estudos Linguísticos e Literários em Inglês)-Faculdade de Filosofia, Letras e Ciências Humanas da Universidade de São Paulo, São Paulo, 2011.

MÁXIMO, João; PORTO, Luís R. A história ilustrada do futebol brasileiro. São Paulo: Edibras, 1968.

McENERY, Tony; XIAO, Richard; TONO, Yukio. Corpus-based Language Studies: an Advanced Resource Book. London/New York: Routledge, 2006.

; HARDIE, Andrew. Corpus Linguistics: method, theory and practice. Edinburgh: Cambridge University Press, 2012.

MELO, Victor Andrade de. História da história da Educação Física e do esporte no Brasil: panorama, perspectivas e propostas. Revista Eletrônica de História do Brasil, Juiz de Fora, v.1, n.1, 1997. Disponível em: $<$ http://www.boletimef.org/biblioteca/574/ Historia-da-educacao-fisica-e-doesporte-no-Brasil>. Acesso em: 17 fev. 2015.

MUNDAY, Jeremy. Introducing Translation Studies. Theories and applications. London/New York: Routledge, 2001.

OAKES, Michael. Statistics for Corpus Linguistics. Edinburgh: Edinburgh University Press, 1998.

PAIS, Cidmar T. Aspectos de uma tipologia dos universos de discurso. Revista Brasileira de Lingüística, São Paulo, v. 7, p. 43-65, 1984.

PALUMBO, Giuseppe. The use of phraseology for training and research in the translation of LSP texts. IN: MAIA, Belinda; HALLER, Johann; ULRYCH, Marguerita. (eds.) Training the Language Services Provider for the New Millenium. III Encontros de Tradução de Astra-FLUP, Anais... Porto: Faculdade de Letras da Universidade do Porto, 2003, 199-211.

PAVEL, Sylvia. La phraséologie en langue de spécialité. Méthodologie de consignation dans les vocabulaires terminologiques. Terminologies Nouvelles, 
Referências bibliográficas

v.10, p. 67-82, 1993. Disponível em < http://www.termiumplus.gc.ca/didacticiel_tutorial/francais/contributions_sp/1 993 phraseologie_f.htm >. Acesso em: 14 fev 2015.

PESANT, Ghislaine; THIBAULT, Estelle. Terminologie et cooccurrence en langue du droit. Terminologies Nouvelles, v. 10, p. 23-35, 1993.

RAMOS, Graciliano. Alexandre e outros heróis. 32. ed. Rio de Janeiro, São Paulo: Record, 1990.

REBECHI, Rozane Rodrigues. A Tradução da Culinária Brasileria para o Inglês: um Estudo sob o Enfoque da Linguística de Corpus. 2015. Tese (Doutorado em Letras) -Faculdade de Filosofia, Letras e Ciências Humanas, Universidade de São Paulo, São Paulo, 2015.

REY, Alan. Le lexique: images et modèles, du dictionnaire à la lexicologie. Paris: Armand Colin, 1997.

. La terminologie. Noms et notions. Paris: Presses Universitaires de France, 1979.

REY-DEBOVE, Josette. Étude linguistique et sémiotique des dictionnaires français contemporains. La Haye: Mouton, 1972.

RIBOLDI, Ari. Cabeça-de-bagre: termos, expressões e gírias do futebol. Porto Alegre: AGE, 2008

RIVERA DOMINGUEZ, Ligia. El vocabulário popular religioso. La concepción popular del diablo. Cuadermos de Trabajo, Puebla, n. 9. , p. 45-55, 1985.

ROSENFELD, Anatol. Negro, macumba e futebol. São Paulo: Edusp/Perspectiva, 1993.

SAGER, Juan C. A Practical Course in Terminology Processing. Amsterdam/Philadelphia: John Benjamins, 1990.

SANTORINI, B. Part-of-Speech tagging guidelines for the Penn Treebank Project. 1991. Disponível em: http://www.ims.unistuttgart.de/projekte/corplex/TreeTagger/Penn-Treebank-Tagset.pdf $>$. Acesso em 7 mar. 2015.

SAPIR, Edward; IRVINE, Judith T. The Psychology of Culture: A Course of Lectures. Berlin: Mouton de Gruyter, 1994. 


\section{Referências bibliográficas}

SCHAETZEN, Caroline de. Un accès rapide aux collocations. Terminologies Nouvelles, n. 10, p. 103-114, 1993.

SCOTT, Mike. WordSmith Tools version 4, Oxford: Oxford University Press, 2004. ; TRIBBLE, Christopher. Textual patterns: key words and corpus analysis in language education. Amsterdam/Philadelphia: John Benjamins, 2006. . WordSmith Tools version 6. Oxford: Oxford University Press, 2012.

SINCLAIR, John. Naturalness in Language. IN: AARTS, Jan; MEIJS, Willem. (eds.) Corpus Linguistics: Recent developments in the use of computer corpora in English Language Research. Amsterdam: Rodopi, 1984, p. 203-210. . Corpus, Concordance, Collocation. Oxford: Oxford University Press, 1991.

SOARES, Antônio J. A modo de resposta. Estudos Históricos, n. 23, p. 163-173, 1999. Disponível em: <bibliotecadigital. fgv.br/ojs/index.php/reh/article/download/2091/1230>. Acesso em: 28 jul. 2015.

; LOVISOLO, Hugo R. Futebol: a construção histórica do estilo nacional. Revista Brasileira de Ciências do Esporte, São Paulo, n.1, p. 129-143, 2003.

TAGNIN, Stella. E. O. O jeito que a gente diz: combinações consagradas em inglês e português. São Paulo: Disal, 2013.

. O jeito que a gente diz: expressões convencionais e idiomáticas. São Paulo: Disal, 2005.

- A identificação de equivalentes tradutórios em corpora comparáveis. I Congresso Internacional da ABRAPUI. Anais..., Minas Gerais, 2007. Disponível em: < identificação de equivalentes tradutórios em corpora comparáveis. I Congresso Internacional da ABRAPUI. Anais $>$ Acesso: 11 ago. 2015.

TEBÉ, Carles. Bancos de dados terminologicos. Terminometro: La Terminologia en España,número especial, p. 65-68, 1996.

TEIXEIRA, Elisa Duarte. 2008. A linguística de corpus a serviço do tradutor: proposta de um dicionário de culinária voltado para a produção textual. Tese (Doutorado em Estudos Linguísticos e Literários em Inglês)-FFLCH/, USP, São Paulo, 2008. 


\section{Referências bibliográficas}

TEMMERMAN, Rita. Towards a new way of terminology description. The sociocognitive approach. Amsterdam/Philadelphia: John Benjamins, 2000.

TOGNINI-BONELLI, Elena. Corpus linguistics at work. Amsterdam/Philadelphia: John Benjamins Publishing Company, 1991. . Theory and Practice. Birmingham: TWC Trask, 1996. . Corpus Linguistics at work. Amsterdam/Philadelphia: John Benjamins, 2001.

TOLEDO, Luiz Henrique. de. No país do Futebol. São Paulo: Zahar, 2000. . A cidade vista de dentro (e de fora) de uma bola de gude: esportes, jogos e passatempos na metrópole. IN: MAGNANI, José Guilherme Cantor. et. al. (Org.). São Paulo 450 anos: uma viagem por dentro da metrópole. São Paulo: Secretaria Municipal da Cultura, 2005, p. 143-146. . Lógicas no Futebol. São Paulo: Hucitec/Fapesp, 2002.

TRIBBLE, Christopher. Genres, keywords, teaching. Towards a pedagogic account of the language of project proposals. Rethinking language pedagogy from a corpus perspective. BURNARD, Lou; McEnery, Tony. (eds.) Frankfurt: Peter Lang, 2000, p. 74-90.

TROMPENAARS, Fons; HAMPDEN-TURNER, Charles. Riding the Waves of Culture: Understanding Cultural Diversity in Business. London/Santa Rosa: Nicholas Brealey Publishing Limited, 1997.

ULRYCH, M. The impact of multilingual parallel concordancing on translation. Practical Applications in Language Corpora. Proceedings ... Łódź: Łódź University Press, 1997, p. 421-235.

VIANA, Vander V.; TAGNIN, Stella E. O. (org.) Corpora na Tradução. São Paulo: HUB Editorial, 2015.

VILLELA, Jorge L. M. Por uma etnografia da pelada: descrição de um caso. Revista do Núcleo de Sociologia do Futebol. Futebol e Cidadania, n. 05, p. 69-96, 1997.

WELKER, Herbert A. Dicionários: uma pequena introdução à lexicografia. Brasília: Thesaurus, 2004.

WISNIK, José Miguel. The Riddle of Brazilian Soccer: Reflections on the Emancipatory Dimensions of Culture. Review: Literature and Arts of the Americas, issue 73, v. 39, n. 2, p. 198-209, 2006. 


\section{Referências bibliográficas}

. Veneno remédio. São Paulo: Companhia das Letras, 2008.

WITZIG, Richard. The Global Art of Soccer. New Orleans: CusiBoy Publishing, 2006

WRIGHT, Sue E.; WRIGHT, Leland D. Scientific and technical translation. Amsterdam/Philadelphia: John Benjamins, 1993.

WÜSTER, Eugen. Introducción a la teoría general de la terminología y a la lexicografía terminológica. Trad. Maria Teresa Cabré. Barcelona: IULA, 1998.

ZANETTIN, Federico. Translation-driven corpus: corpus resources for descriptive and applied translation studies. Manchester/Kinderhook: St. Jerome, 2012.

ZAVAGLIA, Adriana; AZENHA, João; REICHMANN, Tinka. Cultural markers in LSP translation. IN: BAUMANN, Klaus-Dieter (Hg.). Fach - Translat Kultur: Interdisziplinäre Aspekte der vernetzten Vielfalt. Band 2. Berlin: Frank und Timme, 2011, p. 785-808. 


\section{Anexo 1}

bichado (adjective) crock A player who is injured; usually chronically injured.// Ex.:He's not a crock. Real knew about Bale's back woes and deny he needs surgery as angry agent defends £86m star. (Mail Online)//

cai-cai (noun) diver A player who pretends to have been tripped or impeded by an opposing player.// Ex.:Neymar Back in October, Sky Sports' Revista de La Liga panel discussed whether Neymar is a diver, or victim of unfair challenges.. (bleacher report)// same as piscineiro

caneta (noun) nutmeg A trick in which a player rolls the ball through the opponent's legs.// Ex.:Romelu Lukaku created the second just before half-time with a powerful run leaving Arsenal's defence - and midfield - entirely in his wake. He set up Steven Naismith, who looked suspiciously offside, but nevertheless finished neatly with a nutmeg through the goalkeeper's legs. (The Guardian)// same as rolinho, jalelinha, sainha

\section{carregador de piano (noun phrase)}

1 box-to-box midfielder A player who both defends and attacks, influencing the game at both ends of the pitch.// Ex.:By contrast, Kroos is dynamic and hardworking. He can play at the back of midfield or at the front, in the centre or on the flank. He could almost certainly play as a box-to-box midfielder in a 4-4-2 if he ever were asked to do something so archaic. He is creative without being flash, breaks up play without being violent. He is physically robust without being a monster and astute in possession without over-reaching. (The Guardian)//

carretilha (noun) rainbow kick; lambretta flick; lambretta dribble; reverse flick-over; Ossie Ardile's flick; Jay Jay Okocha; the Okocha A trick in which a player steps over the ball and flicks it off the ground from behind him, and forward over his head in an arc./I Ex.:His winning goal against Senegal in the quarterfinal will eternally remain one of the greatest moments in Turkish sporting history, and his robust performances as a substitute mirrored the tough, no-nonsense approach of the team. Yet Mansiz was not short on flair either, famously bamboozling all-time great Roberto Carlos with a stunning rainbow kick in the tournament before being hastily bundled to the ground by the Brazilian defender. (YAHOO! Sports) / Wow! Robinho pulls off a rainbow flick over Alexis Sanchez! (YouTube) / See Neymar's brilliant Lambretta flick (YouTube) / South American football expert Tim Vickery joins H\&J to wax lyrical about Tottenham target Leandro Damiao's rapid rise to prominence, and his trademark Lambretta dribble. (talkSPORT) / The ball reached Rakitic on the half-way line and Pepe, who was completely outside his area, raced to the left flank to try to block the Croatian's counter-attack. The Portuguese centre-back was subjected to an unforgettable reverse flick-over and he tried helplessly and clumsily to keep up with Rakitic's charge. (sportnode) / The game itself will always be remembered for a stunning goal from Glenn Hoddle, the famous high-flying volley from Ossie Ardiles' flick that rattled into the top corner of Gary Bailey's net. (skySPORTS) / Jay Jay See: Okocha, "the Okocha", football soccer move (YouTube)//Lambretta flick, lambretta dribble, rainbow kick, rainbow flick and reverse flick-over can be associated to the trajectory of the ball. Lambretta flick and 
lambretta dribble illustrate the movement to start the motor scooter engine. Rainbow kick and rainbow flick illustrate the rainbow the player paints over his opponent's head when pulling off the trick. Reverse flick-over also depicts the trajectory of the ball as the trick is performed while running forward with the ball, and is done by rolling the ball up the back of one leg with the other foot, before flicking the standing foot upwards to propel the ball forward and over the head. The trick was also named after two former players who mastered it: Osvaldo César Ardiles, known in Britain as Ossie Ardiles, and Jay Jay Okocha. The rainbow kick appears in a famous sequence in the 1981 film Escape to Victory, when the trick is used by the character played by Ossie Ardiles which led to the name of "Ardiles flick". It was also named after Jay Jay Okocha, a former skilled Nigerian player who often used the trick to deceive his opponent. same as lambreta https://www.youtube.com/watch? $v=C V V I d k 7 q K c Y$

cera, FAZER (verb phrase) time, STALL for Situation in which a player wastes time, dives or exchanges passes with other players without building up a head of steam.// Ex.:The Nou Camp is a cauldron of whistles, as though this is an attempt to stall for time. As though Arsene Wenger's grand plan was "let's all pretend to be hurt until we're allowed into the next round." And here's some cheery news... (The Telegraph)//

chinelinho (noun) sicknote reputation A player who pretends to be injured in order not to play.// Ex.:Gourcuff's new injury scare is just a latest in a long history of physical setbacks for the playaker. With a salary of $£ 80,000$-a-week combined with his sicknote reputation, it would be reasonable to argue that while Gourcuff may want to move to Arsenal, Arsenal wouldn't want to sign him. (101 great goals)//

chocolate (noun) cricket score A victory of a team by a large number of goals// Ex.:Khedira scores Germany's fifth in the first half. An easy shot on target past Cesar. We joke about a cricket score, but sadly, that's the way it's headed. (Mail online)//

clássico (noun) derby A match between two rivals, usually from the same area./I Ex.:Manchester City 4 Manchester United 1: Demolition derby! Aguero strikes twice while Yaya and Nasri rub salt into Moyes' wounds as new boss endures embarrassment at the Etihad (Mail Online)// The origin of the term is somewhat obscure, but it is widely reported that the term originates from the town of Ashbourne, Derbyshire, England where, in the early 12th century, two teams from opposite ends of the town played a rough and tumble game called the Royal Shrovetide Football Match. The match, between the 'uppers' and the 'downers' - townspeople from opposite sides of the river, was played every Shrove Tuesday and Ash Wednesday. The goal of the game was to get a painted leather ball into the opposition's goal by fair means or foul. The goals were three miles apart and were on the sites of mills and a goal was scored when a player stroke the mill wheel three times with the ball. There were few rules and there were no fouls or penalties. Needless to say there were many injuries and intense rivalry. It is believed that there were about 400 players who would all meet in two local pubs and spend a couple of hours drinking before the kick-off. This practice appears to have died out with the advent of organized sport in the late 18th, early 19th centuries. Except in the Derbyshire village of Ashbourne where the match is still played. Nowadays, derbies are heated affairs and violence seems to be a part of the fixture. However the matches they encompass are considered to be the best in the sport. Some derbies are known to go beyond the sport due to their references to wider cultural, religious and political issues. In Britain there are specific terms to refer to some derbies. E.g.: the term "North London derby" is used to refer to a derby between Millwall F.C. and West Ham 
United F.C.. Too see a complete list of English derbies go to: http://en.wikipedia.org/wiki/Local_derbies in the United Kingdom

corte seco (noun phrase) Cruyff turn A trick in which a player, instead of kicking the ball, drags it behind his planted foot with the inside of his crossing foot, turns through 180 degrees, and accelerates away from the defender.// Ex.:The highlight of his first-half performance arrived just four minutes later when, after dropping deep to receive the ball, he pulled off a pretty Cruyff turn in the centre of the pitch, drove forward and found a teammate out wide. (Mail Online)// The trick was named after the famous Dutch player Johann Cruyff and it became famous during the 1974 FIFA World Cup in the Netherlands' match against Sweden. It was soon widely copied by other players around the world and it still remains one of the most commonly used dribbling tricks in the modern game. https://www.youtube.com/watch? $v=M 2 R f L z \operatorname{lgy} c$ c

drible da vaca (noun phrase) dummy A trick in which a player kicks the ball to one side of his opponent, then sprints around him to continue the attack.// Ex.:Oooh! Neymar tried the Pele no-touch dummy 1970 trick against Espanyol, but got cyncially taken out by the keeper! (101 great goals)// https://www.youtube.com/watch?v=eVmc4SvEQoo

elástico (noun) flip(-)flap; elastico; flick-flack A trick in which a player pushes the ball towards his dominant side, then quickly moves the dominant foot around the ball and uses its interior to push the ball to his non-dominant side.// Ex.:Neymar freaked out with his mate Willian after an amazing flip flap he did against Turkey. (Weloba) / Zlatan Ibrahimovic fails to do an elastico, ends up hugging a Hammarby player. (YouTube) / Now at Bradford, the winger pulled off a dazzling bit of skill in their weekend clash with Port Vale. He bamboozled his marker with a flick-flack, a trick which makes opponents think you're going one way before you quickly change direction while they're disoriented. (101 great goals)// The flip(-)flap is claimed to be the property of Roberto Rivelino, a former Brazilian footballer and one of the stars of Brazil's 1970 FIFA World Cup team. However, the player himself says he learned the trick from his friend Sérgio Echi, who played with him in the Corinthians youth team in '64. The flip(-)flap is often described as the most Brazilian of all tricks and used to be performed by high profile players like Romário, Ronaldo and Ronaldinho. https://www.youtube.com/watch? $=$ SMXn5hpxaxE

EMPATAR (verb) EQUALISE; DRAW; TIE. An action in which a player scores a goal and his team reaches the same score as their opponent.// Ex.:Seven minutes is a long time in a Merseyside derby, however. Even after Sturridge equalised with a glancing header from Gerrard's free-kick with a minute of normal time left, there was still time for Suárez to bring another sharp save from Howard and the exciting Deulofeu to test Mignolet again at the other end. (The Guardian) / It meant Liverpool had no option but to field a strong side sporting only three changes from the side that fought back to draw 2-2 with Aston Villa last weekend. (Liverpool Echo) / The Spurs player tied the match 2-2 in the 65th minute with a wonderful 30-yard free-kick that ripped into the Vale top corner at speed. (101 great goals)//

falta (noun) foul; challenge; tackle A breach of the laws of the game.// Ex.:The number of fouls committed by Premier League players has dropped by 22\% since 2006, according to figures released for the first time. (BBC) / Swansea City could also do with a tough-tackling midfielder. Only two sides have made fewer challenges per match (16.5) than them and only Leicester City have faced more shots against them on their travels this season, 18.7 on average. (Premier League) / Reds midfielder Lucas made a tackle every 21.2 minutes in the Premier League last year. (sky SPORTS)// SEE falta, [FAZER|COMETER] uma 
falta, [FAZER|COMETER] uma (verb phrase) to foul; to tackle; to challenge Situation in which a player breaks the laws of the game.// Ex.:In May 2011, Adam, then playing for Blackpool, fouled Tottenham's Gareth Bale. The challenge injured Bale's ankle ligaments badly enough to see him stretchered off and miss the end of the season. (The Guardian) I Touré limped off injured after only 14 minutes and Liverpool's striker Daniel Sturridge also damaged his hamstring when he was tackled by Pablo Zabaleta after refusing to release the unmarked Suárez. (The Guardian) / The left back gives it away but City come forward again through Toure, who must be wondering who these clowns he's suddenly playing with are. Richards overlaps and crosses. It's cleared and Milner is lucky not to get a second yellow for challenging the defender. (The Telegraph)//

FINALIZAR (verb) SCORE (\{a|the\} goal) An action in which a player scores a goal.// Ex.: O atacante, contudo, se redimiu dois minutos depois. Após articulação de Ganso com Léo, Kardec recebeu passe curto na entrada da área e finalizou para as redes. (Gazeta do Povo)// The verb FINALIZAR may also be used in situations where a player shoots goalwards but doesn't score.

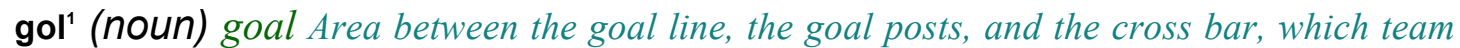
players must pass the ball into in order to score points.// Ex.:The Frenchman flicks towards Howard's goal but it doesn't trouble the keeper. (Mail Online)// SEE gol ${ }^{2}$

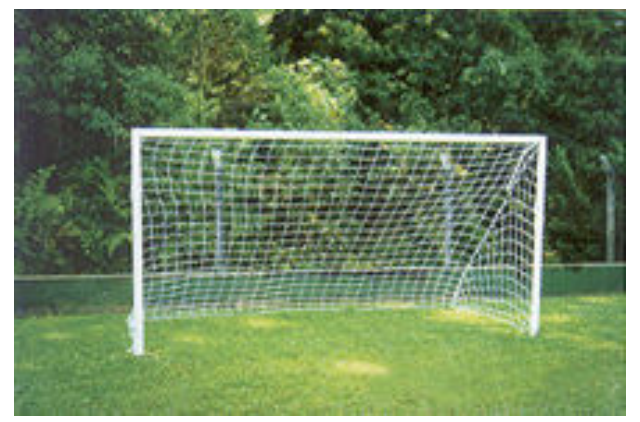

http://produto.mercadolivre.com.br/MLB-642646473-rede-de-gol-colmeiafabricamos-sobe-medidafabricante- JM

$\mathbf{g o l}^{2}$ (noun) goal A point a team scores when the ball crosses the goal line between the goalposts and below the crossbar.// Ex.:It was a match to remember for Ross Barkley, 19, who scored a stunning goal from outside the penalty area, his first for Everton. (Premier League)//

gol, [FAZER|MARCAR] [UM|O] (verb phrase) SCORE (\{a|the\} goal) An action in which a player scores a goal.// Ex.:Jack Wilshere scored a goal of true beauty to ensure ugly days ahead for Norwich manager Chris Hughton. (Daily Star) / The midfielder, who signed from Bayern Munich last summer, scored with a well-struck shot early in the second half. (Derby Telegraph)//English has a wide variety of synonymous expressions to describe a goal. In this dictionary, they are divided into semantic groups which allows us to actively compare and contrast the similar expressions. It is important to emphasize that although they are used in the same context, their meaning is usually associated with a specific characteristic of the verb that is part of the expression. same as FINALIZAR, tento, MARCAR um https://www.youtube.com/watch? $v=$ Cny6dMGXtaw; 
SCORING: The meaning of these expressions can be related to the act of adding points to a team's score.

SCORE ( $\{$ a|the $\}$ goal); NOTCH $\{$ his ORDINAL|CARDINAL $\}$ (goal)

// Ex.:Sergio Aguero scored within a minute of coming off the bench. (Mail Online) / Rooney notched his fifth goal of the season and showed that United are serious contenders to retain their Premier League crown despite the loss of Cristiano Ronaldo during the summer. (Manchester United MAD)//;

VIOLENCE: These expressions are formed by verbs denoting violence and are often used to emphasize the strength with which a player shoots goalwards.

FIRE \{home | in (a goal) | (the ball) past [goalkeeper]| into the net\}

// Ex.:The Serb fired home past Joe Hart to score the only goal of the game, with the visitors hitting the woodwork three times as they secured a massive three points in the title race. (Goal) / Strike partner Emmanuel Adebayor selflessly opted to play the Spaniard in before Soldado took a touch and fired the ball past David Marshall with the outside of his right boot. (GOAL)//

HAMMER \{in | home $\}$

// Ex.:Chelsea's sixth and final blow was hammered home in the 70th minute. (Goal)//

SLAM \{(the ball) past [goalkeeper] | in | into the roof of the net\}

// Ex.:An even contest at the Stade Velodrome swung Arsenal's way in the 65th minute when their French hosts were made to pay for a defensive error, as Jeremy Morel's pitiful attempted clearance inside his own box was pounced upon by Walcott, who slammed the ball past Steve Mandanda in goal. (World Football) / Arsenal made no mistake after the breakOlivier Giroud showing great composure to put them in front - before Podolski got his second of the night to wrap things up as he slammed into the roof of the net. (SKY Sports) II

BLAST IN (a goal)

// Ex.:The first three run over the ball before the fourth touched it back for the fifth player to blast in. (Daily Star)//

LASH home $\{$ (a goal) $\mid$ into an empty net $\}$

// Ex.:Then another Liverpool old-boy, Charlie Adam, lashes home from the edge of the box to make it 2-2 on the stroke of half-time. (The Guardian)//

SMASH home

// Ex.:Jon Flanagan smashed home a superb goal to break the backs of Tottenham and give momentum to the rout which saw the end to Andre Villas Boas' tenure at Spurs. (Daily Star)//

STAB the ball \{home | past [goalkeeper]

// Ex.:Fourth-placed Spurs, under the management of Gerry Francis, took the lead against United, who were fighting for the title with Newcastle United, when Teddy Sheringham stabbed the ball past goalkeeper Peter Schmeichel. (Premier League)//

POKE \{the ball home|home past [goalkeeper]\}

// Ex.:Mignolet failed to keep hold of a Ki Sung-Yueng effort from the edge of the box, and Giaccherini reacted quicker than the visitors' defenders to poke the ball home. (Premier League)//

KNOCK \{the ball \{into the net $\mid$ in | home $\}$ \} / NUMBER goals

// Ex.:It was a terrific stop from Jack Butland just before Sturridge knocked the ball home from close-range. (SKY Sports) / It doesn't stop there, though - as a player Poyet knocked in four goals in 11 games against the Magpies. (Four Four Two) //

THUMP \{home $\mid$ past [goalkeeper]\} 
// Ex.:De Jong let fly in hope from outside the box, and when his effort deflected high into the box, the French international showed great strength and desire to shake off his marker, bring the ball under control and thump past Guzan into the roof of the net. (The Independent)//

CLIP the ball into the net

// Ex.:Nolan struck in the 50th minute when he collected Kevin Davies' cross-cum-shot and clipped the ball into the net. (BBC)//

THUNDER a goal home

// Ex.:And finally, with 15 minutes to go, their luck ran out. Good work from Mekki and Molesley down the left channel saw the ball run to Oyeleke, who thundered the ball home from 22 yards inside the near post. (Get Hampshire)//;

EFFORTLESS ACTIONS: These expressions are formed by verbs that depict actions that are easy to carry out.

SLIDE \{home his ORDINAL (goal) | the ball home\}

// Ex.:Both sides were chasing the win and it looked to be heading Southampton's way in the 88th minute when substitute Leandre Griffit found himself clear of the defence and held his nerve to slide home his second goal for the club. (The Chesterfield Post)//

SWEEP \{home | the ball into the net\}

// Ex.:The tide mostly flowed the same way after the break, although Niclas Jensen might have restored City's interest when he shot wide of an open goal. Soon the Pensioners were in total control when Terry flicked on Hasselbaink's corner for Mario Stanic to sweep into the net. (Chelsea FC)//

DINK in [a goal]

// Ex.:The World Player of the Year dinked in the winner in the 77th minute as Barca desperately poured forward after Andoni Iraola had cancelled out David Villa's early opener with a 49th-minute penalty. (ahram online)//

TUCK home (a goal)

// Ex.:The summer signing volleyed home after 14 minutes, crossed for Frazer Wright to head home before half-time, and tucked home a third from Danny Invincibile's low cross in the second half. (The Telegraph)//

STROKE a shot past [goalkeeper]

// Ex.:The striker controls, edges past Alex down the inside-right channel and into the box, and strokes a sure shot past Cech and into the bottom left-hand corner of the net. Wonderful football - and it came from nothing, after a very slow start indeed by the home side! (The Guardian)//;

SPEED: these expressions are formed by verbs that show the speed with which the footballer shoots goalwards or the speed of the ball.

TAP $\{$ in $\mid$ home $\}$

// Ex.:The Zurich defence were expecting a shot but instead the Argentinian forward squared it for Raul to tap home from six yards. (The Telegraph)

FIZZ [the ball past goalkeeper|a sidefooter at goal]

// Ex.:Stones were under too much self imposed pressure during a distinctly dodgy period of play but turned the game around 10 minutes later; skipper Wes Parker had seen enough and charged down the flank, crossed expertly for McGleish who was well placed to fizz the ball past Borough keeper Erbil Bozkurt to break the deadlock. (Wealdstone F.C.)//

SNATCH [a goal]

// Ex.:But the early pressure soon dissipated and Celtic's task, already tough, grew even more difficult when Braga snatched an away goal in the 21st minute. (SKY Sports)//; 


\section{Anexo 1}

MOVEMENT: This group of expressions is formed by verbs that depict the movement of the ball towards the goal.

SLOT \{home([agoal)]|(theball)into \{an|the\} empty net|past[goalkeeper]| in\}

// Ex.:Robinho, who was the game's outstanding player, then provided one of the assists of the championship so far as he threaded a delightful ball to Elano in the 72nd minute before the midfielder slotted home a second. (SKY SPORTS)

DRILL (the ball) home

// Ex.:After Davies missed a header, Van Persie cushioned a lovely lay-off into Rooney's path and he drilled the ball home low into the corner for his fifth United goal of the season. (Mail Online)//

BURY the ball past [goalkeeper]

// Ex.:For good measure, Fabregas popped in a peach for his second and Arsenal's fifth as he ran up field, picked his spot and buried the ball past Howard. (Click Liverpool)//

HOOK in ([a goal])

// Ex.:When defender Marius Zaliukas hooked in the second shortly after the break, belief they were capable of a sensational result coursed through the home ranks. (Scotsman)//

STEER the ball past [goalkeeper]

// Ex.:His pass picks out the run of Osman who steers the ball past Schwarzer. (Football $U K) / /$

COMPLETION: These expressions are formed by verbs that depict the act of completing an action.

FINISH (off) (a goal)

// Ex.:The much-maligned Cleverley finished off a classy goal and looked sharp in the middle, seizing upon Villa mistakes in a 3-0 Man United win. (Talk Sport)

DELIVER a goal

// Ex.:It's been 25 years since a match between these two teams delivered a goal and it doesn't look like we're going to get one tonight. (The Guardian)//;

HEADER: These expressions describe goals scored by heading the ball into the net. NOD \{home (into an empty goal) | in | into the net\}; // Ex.:Benteke nodded home to set up a thrilling finale. (Mirror)

HEAD (the ball) \{home|past (goalkeeper)|into the (roof of the) net\};

// Ex.:The visitors were then gifted a goal as Guaita only succeeded in punching Gabi's corner onto the head of Garcia who headed into the roof of the net. (Football UK)//

\{HAMMER | POUND\} a header into the net.

// Ex.:The towering forward Jan Koller pounded a header into the net to start the scoring on a counterattack in the fifth minute. (Mail Online)//;

ACHIEVEMENT: These expressions are formed by verbs that emphasize the action of reaching a goal.

NET [a goal]

// Ex.:Liverpool's season is firmly back on track after Yossi Benayoun netted a hat-trick in Saturday's 4-0 Premier League home win over Burnley. Substitute Stefan Maierhofer netted a late consolation for Wolves. (My Liverpool F.C.)

BAG [a goal]

// Ex.:Dave Kitson is finally beginning to find his feet at Stoke as he bagged the winner in a 10 victory over Sunderland at the Britannia Stadium. Drogba was a real menace throughout, 
heading just over from a Jose Bosingwa cross before bagging the all-important goal. (Football 365)//

NICK [a goal]

// Ex.:Birmingham City had the early Premier League leaders begging for the final whistle before Aaron Lennon nicked a winner for Tottenham deep into stoppage time. Lions fans were already leaving the Den when Paul Shaw nicked a consolation goal on 79 minutes but the roar that went up when Tim Cahill (right) made it 3-2 within seconds brought many back. (Tottenham Hot Spur Mad)//;

POSITION: This expression shows the position of the ball after the goal is scored NESTLE $\{$ in $\mid$ into $\}$ the (back of the) net

// Ex.:Not a brilliant penalty-struck low and only a few feet to the left of the centre of the goal, but Julio Cesar went the other way and the ball nestled in the back of the net. (The Guardian)

janelinha (noun) nutmeg A trick in which a player rolls the ball through the opponent's legs.// Ex.:Romelu Lukaku created the second just before half-time with a powerful run leaving Arsenal's defence - and midfield - entirely in his wake. He set up Steven Naismith, who looked suspiciously offside, but nevertheless finished neatly with a nutmeg through the goalkeeper's legs. (The Guardian)// article is cross-referenced from rolinho

lambreta (noun) rainbow kick; lambretta flick; lambretta dribble; reverse flick-over; Ossie Ardile's flick; Jay Jay Okocha; the Okocha A trick in which a player steps over the ball and flicks it off the ground from behind him, and forward over his head in an arc. article is cross-referenced from carretilha

piscineiro (noun) diver A player who pretends to have been tripped or impeded by an opposing player.// Ex.: Neymar Back in October, Sky Sports' Revista de La Liga panel discussed whether Neymar is a diver, or victim of unfair challenges.. (bleacher report)// same as cai-cai

retranca, JOGAR na (verb phrase) [back|deep], SIT Tactics in which a team doesn't attack, only defends and waits for counter-attack opportunities.// Ex.:City seem happy to sit back and allow Hull the ball, which is no surprise given Hull's lack of an attacking threat today. (Mail Online) / The first half started as expected; Tottenham dominating possession looking to thread a pass through the Sheriff defence. However the visitors sat deep and stifled Spurs by giving them no space to create. Tottenham were forced into shooting from distance with Moussa Dembele and Étienne Capoue coming the closest. (90 MIN)//

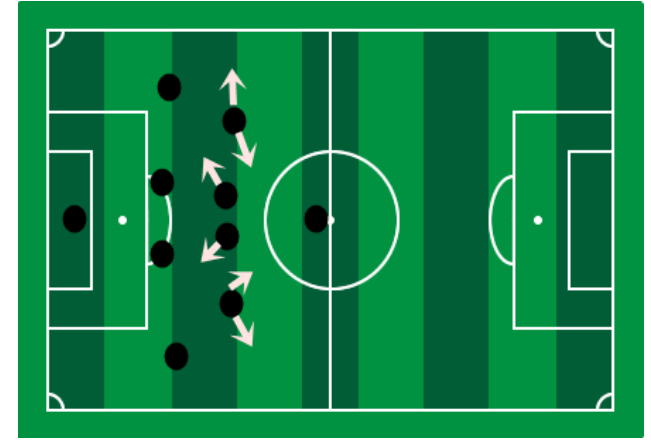

http://canelada.com.br/caneladas-taticas/uma-copa-de-retranca/ 
rolinho (noun) nutmeg; A trick in which a player rolls the ball through the opponent's legs.// Ex.:Romelu Lukaku created the second just before half-time with a powerful run leaving Arsenal's defence - and midfield - entirely in his wake. He set up Steven Naismith, who looked suspiciously offside, but nevertheless finished neatly with a nutmeg through the goalkeeper's legs. The Oxford English Dictionary defines 'nutmeg' as a Victorian slang that means to be tricked or deceived, especially in a manner which makes the victim look foolish. In his book "The Language and Folklore of the World's Greatest Game", Peter Seddon points out that the term 'nutmeg' comes from duplicitous practice in the nutmeg trade. He states: "Nutmegs were such a valuable commodity that unscrupulous exporters were wont to pull a fast one by mixing a helping of wooden replicas into the sacks being shipped to England" and "being nutmegged soon came to imply stupidity on the part of the duped victim and cleverness on the part of the trickster." The term soon started to be used in football, implying that the player whose legs the ball had been played through had been nutmegged. same as sainha, caneta, janelinha https://www.youtube.com/watch? $v=k$-rPdihNnek

sainha (noun) nutmeg A trick in which a player rolls the ball through the opponent's legs.// Ex.:Romelu Lukaku created the second just before half-time with a powerful run leaving Arsenal's defence - and midfield - entirely in his wake. He set up Steven Naismith, who looked suspiciously offside, but nevertheless finished neatly with a nutmeg through the goalkeeper's legs. (The Guardian)// article is cross-referenced from rolinho

técnico (noun) manager; coach Professional who is responsible for running a football club or a national team. The manager may also serve as the coach of the team.// Ex.:After this latest stumble at home, United manager David Moyes presented his own assessment: 'We played well,' he said. (Mail Online) / 'Dinoasaur coach' David Moyes reveals Robin van Persie is fit and ready to go - despite criticism of 'Jurassic' training methods. (The Independent)//In UK the manager of a team has two responsibilities: 1) to run a football club and 2) to coach the team. These responsibilities tend to be divided in most countries, hence the title of manager is almost exclusively used in British football. In Brazil, the professional who coaches the team is the "técnico" and the professional who manages the team is the "dirigente". The term "coach" is sometimes used to emphasize the trainer responsibility of coaching a team, as we can see in the second example. Besides the differences in the responsibilities attributed to these professionals in the UK and in Brazil, we should bear in mind that the structures of football clubs differ significantly in these countries. The majority of football clubs in England are unincorporated associations comprising a group of individuals bound together by the constitution or rules of the club. The clubs have a company status in which their ownership resides with the shareholders and that the shareholders are motivated by profit, hence they are organized like companies and have positions that do not exist in Brazilian clubs. On the other hand, in Brazil teams are organized as non-profit sport associations and their organization may differ from team to team. same as treinador 


\section{Anexo 1}

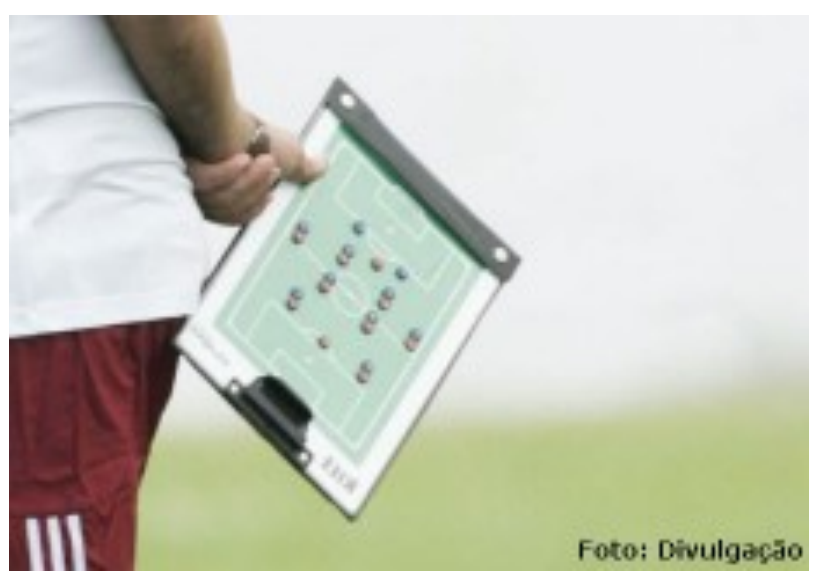

http://www.empregoerenda.com.br/editorias/formacao-profissional/1637-treinadorde-futebol

tento, MARCAR um (verb phrase) SCORE (\{a|the $\}$ goal) An action in which a player scores a goal.// Ex.:Artur, aos $47 \mathrm{~min}$, marcou um tento de cabeça em impedimento. (Radio Maranatha FM)//

treinador (noun) manager; coach Professional who is responsible for running a football club or a national team. The manager may also serve as the coach of the team. 


\section{Anexo 2}

[back|deep], SIT (sintagma verbal) retranca, JOGAR na Sistema de jogo em que o time se fecha na defesa com a maioria dos seus jogadores.// Ex.:O S. Paulo jogou na retranca contra o Santos e segurou o empate. (Gazeta do povo)//

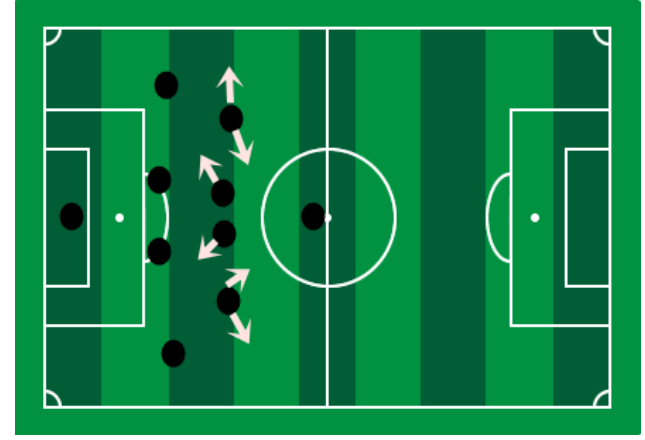

http://canelada.com.br/caneladas-taticas/uma-copa-de-retranca/

BAG [a goal] (sintagma verbal) gol, [FAZER $\mid M A R C A R]$ [UM $\mid O]$; tento, MARCAR um; FINALIZAR Ato de fazer um gol.; esta entrada é referência cruzada de SCORE (\{a|the\} goal)

REALIZAÇÃO: As expressões que compõem essa categoria semântica são formadas por verbos que pertencem à categoria de realização, entendida aqui como consecução, ou seja, o ato de alcançar um objetivo.

expressões que pertencem ao mesmo campo semântico:

NET [a goal]; NICK [a goal];

BLAST IN (a goal) (sintagma verbal) gol, [FAZER $\mid M A R C A R]$ [UM $\mid O]$; tento, MARCAR um; FINALIZAR Ato de fazer um gol.; esta entrada é referência cruzada de SCORE (\{a|the\} goal)

VIOLÊNCIA: O sintagma compõe um grupo de expressões formadas por verbos que transmitem a ideia de ação violenta. Essas expressões frequentemente enfatizam a força com que o jogador chuta ao gol.

expressões que pertencem ao mesmo campo semântico:

FIRE \{home | in (a goal) | (the ball) past [goalkeeper]| into the net\}; HAMMER \{in | home\}; SLAM \{(the ball) past [goalkeeper] | in | into the roof of the net\}; LASH home $\{$ (a goal) $\mid$ into an empty net\}; SMASH home; STAB the ball home $\mid$ past [goalkeeper]\}; POKE \{the ball home|home past [goalkeeper]\}; KNOCK \{the ball \{into the net $\mid$ in $\mid$ home\}\} / NUMBER goals; THUMP \{home | past [goalkeeper]\}; CLIP the ball into the net; THUNDER a goal home;

box-to-box midfielder (sintagma nominal) carregador de piano Jogador, frequentemente um meia ou centroavante, sem muita técnica, que normalmente atua na marcação, mas que também ajuda no ataque.// Ex.: Juvenal troca estrela por 'carregador de piano' e diz que Lucas é só sonho (Globo Esporte)// 
BURY the ball past [goalkeeper] (sintagma verbal) gol, [FAZER $\mid M A R C A R]$ [UM|O]; tento, MARCAR um; FINALIZAR Ato de fazer um gol.; esta entrada é referência cruzada de SCORE (\{a|the\} goal)

MOVIMENTO: As expressões que compõem esse campo semântico são formadas por verbos que descrevem o movimento que a bola faz para dentro do gol.

expressões que pertencem ao mesmo campo semântico:

SLOT \{home([agoal)]|(theball)into \{an|the\} empty net|past[goalkeeper]| in\}; BURY the ball past [goalkeeper]; HOOK in ([a goal]); STEER the ball past [goalkeeper];

CHALLENGE (verbo) falta, [FAZER|COMETER] Ato de infringir as regras do jogo cometido por um jogador. esta entrada é referência cruzada de FOUL

challenge (substantivo) falta Situação em que um jogador infringe as regras do jogo. esta entrada é referência cruzada de foul

CLIP the ball into the net (sintagma verbal) gol, [FAZER $\mid M A R C A R]$ [UM $\mid O]$; tento, MARCAR um; FINALIZAR Ato de fazer um gol.; esta entrada é referência cruzada de SCORE (\{a|the\} goal)

VIOLÊNCIA: O sintagma compõe um grupo de expressões formadas por verbos que transmitem a ideia de ação violenta. Essas expressões frequentemente enfatizam a força com que o jogador chuta ao gol.

expressões que pertencem ao mesmo campo semântico:

FIRE \{home | in (a goal) | (the ball) past [goalkeeper]| into the net\}; HAMMER \{in | home\}; SLAM \{(the ball) past [goalkeeper] | in | into the roof of the net\}; BLAST IN (a goal); LASH home $\{$ (a goal) | into an empty net $\}$; SMASH home; STAB the ball \{home | past [goalkeeper]\}; POKE \{the ball home|home past [goalkeeper]\}; KNOCK \{the ball \{into the net $\mid$ in | home\}\} / NUMBER goals; THUMP \{home | past [goalkeeper]\}; THUNDER a goal home;

cricket score (sintagma nominal) chocolatel/ Ex.:Gol da Alemanha! Chocolate sobre o Brasil vira piada na internetInternautas fizeram de uma partida de video-game uma simulação do fatídico 7 a 1 da Alemanha no Brasil, inspirado no Barcelona x Fluminense, clássico da internet. (FOX Sports)// A origem da expressão é incerta, no entanto, a ideia de que tenha surgido em uma partida do Campeonato Brasileiro, em 1981, em que o Vasco goleou o Internacional por 4 - 0 é compartilhada por muitos. O resultado foi, na época, considerado uma vingança pela derrota da final do Campeonato Brasileiro de 1979, em que o Internacional tinha derrotado o Vasco. Na final de 1981, durante a derrota do Internacional, o narrador Washington Rodrigues teria colocado no ar a música "El bodeguero" do cubano Richard Egües, cujo refrão é "Toma chocolate / Paga lo que debes". Vitória de um time sobre outro com uma grande diferença de gols

crock (substantivo) bichado Jogador que apresenta algum problema fisico; geralmente crônico.// Ex.:A imprensa soltou que Dagoberto, está machucado e que vai continuar no Cruzeiro sendo aquele jogador bichado que jogava no Internacional, mas vim aqui para esclarecer que é o contrario. (Plantão do Futebol)//

Cruyff turn (sintagma nominal) corte seco Drible em que um jogador finge que vai passar ou cruzar a bola, mas, em vez de chutá-la, arrasta a bola por trás do pé que está no chão com a parte de dentro do pé que realizaria o chute.// Ex.:O meia do Cruzeiro deu um 
corte seco no defensor e finalizou com precisão de fora da área, no canto esquerdo do Rodrigo Posso, fazendo 1 a 0 para o Maior de Minas. (Globo Esporte)// https://www.youtube.com/watch? $v=U 1 k 7 D G q R F 5 g$

DELIVER a goal (sintagma verbal) gol, [FAZER $\mid M A R C A R]$ [UM|O]; tento, MARCAR um; FINALIZAR Ato de fazer um gol. ; esta entrada é referência cruzada de SCORE ( $\{a \mid$ the $\}$ goall)

COMPLETUDE: As expressões que compõem essa categoria semântica são formadas por verbos que carregam o sentido de completar, realizar uma tarefa, assim como o verbo "finalizar" em português.

expressões que pertencem ao mesmo campo semântico:

FINISH (off) (a goal);

derby (substantivo) clássico Duelo futebolístico de grande rivalidade realizado, frequentemente, por dois times de um mesmo estado.// Ex.:Fla domina o clássico, faz gol de letra e vence o Flu no Maracanã: 3 a 2 (Globo Esporte)// Clássicos são caracterizados por enfrentamentos entre clubes ao mesmo tempo próximos e diferentes. Próximos na localização geográfica, divididos por bairros, algumas vezes ruas e diferentes devido a origens, discursos e idealizações bastante distintos, fato que, não raramente, pode contribuir para a presença de violência nessas partidas. Alguns clássicos possuem nomes específicos, como, por exemplo, Atletiba, termo utilizado para o clássico entre Atlético Paranaense e Coritiba. O termo, utilizado mais frequentemente para confrontos estaduais, também pode ser utilizado para designar confrontos interestaduais, no entanto esse uso não é frequente. $\mathrm{O}$ termo derby ou dérbi é utilizado, em português, para descrever rivalidades entre times de cidades menores, pois mobilizam toda a cidade, uma vez que, por ser pequena, a cidade possui somente dois times grandes, como é o caso do 'Dérbi Campineiro' ou do 'Dérbi de Ribeirão Preto' entre o Botafogo Futebol Clube e o Comercial Futebol Clube. Para visualizar a lista completa de clássicos brasileiros acesse: http://pt.wikipedia.org/w/index.php?title=Anexo:Clássicos_de_futebol_do_Brasil\&action=ed it\&redlink $=1$

DINK in [a goal] (sintagma verbal) gol, [FAZER $\mid M A R C A R]$ [UM $\mid O]$; tento, MARCAR um; FINALIZAR Ato de fazer um gol.; esta entrada é referência cruzada de SCORE (\{a|the\} goal)

FACILIDADE: O sentido principal das expressões que compõem esse grupo semântico recai sobre a facilidade com que o gol foi feito. Na realidade, a facilidade não caracteriza o gol, mas sim a trajetória da bola, a posição do jogador ou o toque que o jogador dá na bola.

expressões que pertencem ao mesmo campo semântico:

SLIDE \{home his ORDINAL (goal) | the ball home\}; SWEEP \{home $\mid$ the ball into the net\}; TUCK home (a goal); STROKE a shot past [goalkeeper];

diver (substantivo) cai-cai; piscineiro Jogador que tem reputação de simular faltas.// Ex.:Neymar enfrenta fortes críticas na Espanha por supostamente simular faltas. Parte da imprensa local acusa o brasileiro de ser cai-cai. (UOL esportes) / Nesta terça-feira, os dois maiores jornais esportivos da Catalunha compraram a briga e, para defender o brasileiro, apontaram o galês Gareth Bale, do Real Madrid, como o verdadeiro piscineiro do futebol mundial. (UOL esportes)// 
DRAW (verbo) EMPATAR Ato de fazer um gol de modo a igualar o placar da partida. esta entrada é referência cruzada de EQUALISE

DRILL (the ball) home (sintagma verbal) gol, [FAZER $\mid M A R C A R]$ [UM|O]; tento, MARCAR um; FINALIZAR Ato de fazer um gol.; esta entrada é referência cruzada de SCORE (\{a|the\} goal)

MOVIMENTO: As expressões que compõem esse campo semântico são formadas por verbos que descrevem o movimento que a bola faz para dentro do gol.

expressões que pertencem ao mesmo campo semântico:

SLOT \{home([agoal)]|(theball)into \{an|the\} empty net|past[goalkeeper]| in\}; HOOK in ([a goal]); STEER the ball past [goalkeeper];

dummy (substantivo) drible da vaca Drible em que o jogador toca ou chuta a bola para um lado do adversário e corre para buscá-la pelo outro.// Ex.:Na primeira, o atacante deu um belo 'drible da vaca' no marcador e cruzou para Robinho, que se jogou na bola, mas não alcançou. (Gazeta Esportiva)// Nos primórdios do futebol brasileiro as partidas eram jogadas em campos improvisados, muitas vezes em pastos e, frequentemente, os jogadores tinham que driblar vacas que invadiam o campo para comer tocando a bola para um lado e correndo para buscá-la pelo outro. Por esse motivo, o drible ficou conhecido como drible da vaca. https://www.youtube.com/watch?v=eVmc4SvEQoo

elastico (substantivo) elástico Drible em que o jogador, com a bola grudada no pé e parado na frente do marcador, toca duas vezes com o mesmo pé na bola, mudando seu movimento, de forma a enganar seu adversário. esta entrada é referência cruzada de flip()flap

EQUALISE (verbo) EMPATAR Ato de fazer um gol de modo a igualar o placar da partida. // Ex.:O Corinthians empatou com um gol do atacante Didi, após um cruzamento do meia Renaldo pela esquerda. (Folha de S. Paulo)// same as DRAW, TIE

FINISH (off) (a goal) (sintagma verbal) gol, [FAZER $\mid M A R C A R][U M \mid O]$; tento, MARCAR um; FINALIZAR Ato de fazer um gol. ; esta entrada é referência cruzada de SCORE (\{a|the\} goal)

COMPLETUDE: As expressões que compõem essa categoria semântica são formadas por verbos carregam o sentido de completar, realizar uma tarefa, assim como o verbo "finalizar" em português.

expressões que pertencem ao mesmo campo semântico:

DELIVER a goal;

FIRE \{home | in (a goal) | (the ball) past [goalkeeper] into the net (sintagma verbal) gol, [FAZER|MARCAR] [UM|O]; tento, MARCAR um; FINALIZAR Ato de fazer um gol. ; esta entrada é referência cruzada de SCORE (\{a|the\} goal)

VIOLÊNCIA: O sintagma compõe um grupo de expressões formadas por verbos que transmitem a ideia de ação violenta. Essas expressões frequentemente enfatizam a força com que o jogador chuta ao gol.

expressões que pertencem ao mesmo campo semântico:

HAMMER \{in | home\}; SLAM \{(the ball) past [goalkeeper] | in | into the roof of the net $\}$; BLAST IN (a goal); LASH home $\{$ (a goal) $\mid$ into an empty net $\}$; SMASH home; STAB the ball \{home | past [goalkeeper]\}; POKE\{the ball home|home past 
[goalkeeper]\}; KNOCK \{the ball \{into the net $\mid$ in | home\}\} / NUMBER goals; THUMP \{home | past [goalkeeper]\}; CLIP the ball into the net; THUNDER a goal home;

FIZZ [the ball past goalkeeper|a sidefooter at goal] (sintagma verbal) gol, [FAZER|MARCAR] [UM|O]; tento, MARCAR um; FINALIZAR Ato de fazer um gol.; esta entrada é referência cruzada de SCORE (\{a|the\} goal)

VELOCIDADE: As expressões que formam esse grupo são compostas por verbos que enfatizam a velocidade do gol; não somente a velocidade com que o jogador recebe e chuta ao gol, mas também a rapidez dos toques até o momento do gol. expressões que pertencem ao mesmo campo semântico:

TAP $\{$ in|home $\}$; SNATCH [a goal];

flick-flack (noun) elástico Drible em que o jogador, com a bola grudada no pé e parado na frente do marcador, toca duas vezes com o mesmo pé na bola, mudando seu movimento, de forma a enganar seu adversário. esta entrada é referência cruzada de flip(-)flap

flip(-)flap (substantivo) elástico Drible em que o jogador, com a bola grudada no pé e parado na frente do marcador, toca duas vezes com o mesmo pé na bola, mudando seu movimento, de forma a enganar seu adversário.// Ex.:No segundo tempo, a seleção brasileira continuou jogando em alto nível. Com 8 minutos, Willian deu um elástico incrível, passando por dois jogadores adversários e conseguindo criar uma bela jogada. (Esporte Interativo)// Rivelino, ex-futebolista que atuava como meia, é citado como inventor do 'elástico'. No entanto, em uma entrevista, o jogador disse que aprendeu a jogada com Sérgio Echi, seu companheiro no aspirantes do Corinthians que jogou somente onze jogos no time principal. Rivelino diz ter aperfeiçoado a criação de Echi. O drible, considerado um dos mais espetaculares do futebol, exige técnica apurada e habilidade com a bola; permite que o jogador crie uma superioridade perante o rival, pois, ao superar seu defensor, fica em posição vantajosa para continuar a manobra de ataque. São poucos os jogadores que dominam o 'elástico'; Rivelino, Romário, Ronaldinho Gaúcho, Ronaldo Fenômeno e Robinho são sempre citados entre os que executam o drible com perfeição. same as elastico, flick-flack https://www.youtube.com/watch? $v=x r A l C p A j s J w$

FOUL (verbo) falta, [FAZER $\mid$ COMETER] Ato de infringir as regras do jogo cometido por um jogador. // Ex.:Segundo as expulsões do jogo, Simon acredita que Fábio Santos pegue mais jogos de gancho do que Guerrero, pois cometeu uma falta mais grave. (FOX sports) I Aos 22 minutos, o Galo saiu em contra-ataque pelo meio, e Carlos lançou para Guilherme, mas o árbitro auxiliar indicou impedimento. Aos 24, Dátolo cobrou falta fechada da direita na área do Fluminense, e Diego Cavalieri afastou. Em seguida, o atacante Luan fez falta em Wágner e levou o primeiro cartão amarelo da partida. (ESPN)// same as TACKLE, CHALLENGE

foul (substantivo) falta Situação em que um jogador infringe as regras do jogo.// Ex.:Fifa contraria brasileiros: nem todo toque de mão é considerado falta. (O jornal de hoje)// same as challenge, tackle; SEE FOUL

goal' (substantivo) gol Espaço retangular limitado por uma baliza horizontal e duas balizas verticais, às quais se prende uma rede, e demarcado por uma linha paralela à baliza horizontal.// Ex.:O centroavante avançou em direção ao gol do Tigre, demorou a finalizar, ignorou companheiro que o acompanhava e acabou desarmado. (Terra Esportes)// 


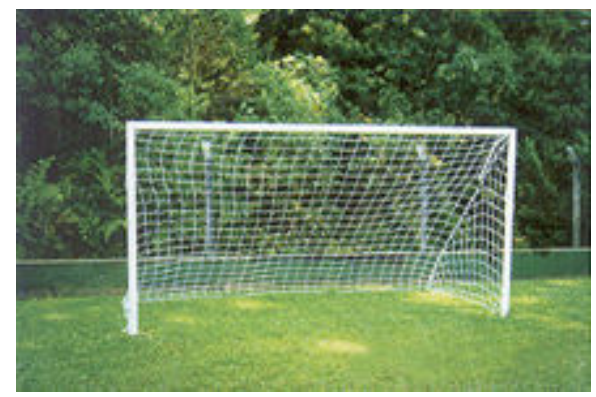

http://produto.mercadolivre.com.br/MLB-642646473-rede-de-gol-colmeiafabricamos-sobe-medidafabricante-_JM

goal $^{2}$ (substantivo) gol Ponto que um time faz quando a bola ultrapassa por completo a linha do gol.// Ex.:Era o $21^{\circ} \mathrm{gol}$ dele na competição. Artilheiro! Mas o Grêmio é o Grêmio. Um ainda garoto Ronaldinho avançou pela esquerda, deixou o marcador e marcou um lindo gol: 1 a 2. (Imortais do Futebol)//

HAMMER \{in I home\} (sintagma verbal) gol, [FAZER|MARCAR] [UM|O]; tento, MARCAR um; FINALIZAR Ato de fazer um gol.; esta entrada é referência cruzada de SCORE (\{a|the\} goal)

VIOLÊNCIA: O sintagma compõe um grupo de expressões formadas por verbos que transmitem a ideia de ação violenta. Essas expressões frequentemente enfatizam a força com que o jogador chuta ao gol.

expressões que pertencem ao mesmo campo semântico:

FIRE \{home | in (a goal) | (the ball) past [goalkeeper]| into the net\}; LAM \{(the ball) past [goalkeeper] | in | into the roof of the net $\}$; BLAST IN (a goal); LASH home \{(a goal) $\mid$ into an empty net\}; SMASH home; STAB the ball \{home | past [goalkeeper]\}; POKE \{the ball home|home past [goalkeeper]\}; KNOCK \{the ball \{into the net $\mid$ in $\mid$ home \} / NUMBER goals; THUMP \{home | past [goalkeeper]\}; CLIP the ball into the net; THUNDER a goal home;

\{HAMMER | POUND\} a header into the net (sintagma verbal) gol, [FAZER|MARCAR] [UM|O]; tento, MARCAR um; FINALIZAR Ato de fazer um gol.; esta entrada é referência cruzada de SCORE (\{a|the\} goal)

GOLS DE CABEÇA: As expressões que compõem essa categoria semântica são formadas por verbos que narram gols de cabeça.

expressões que pertencem ao mesmo campo semântico:

NOD \{home (into an empty goal) $\mid$ in $\mid$ into the net\}; HEAD (the ball) \{home $\mid$ past (goalkeeper)|into the (roof of the) net\};

HEAD (the ball) \{home|past (goalkeeper)|into the (roof of the) net\} (sintagma verbal) gol, [FAZER|MARCAR] [UM|O]; tento, MARCAR um; FINALIZAR Ato de fazer um gol.; esta entrada é referência cruzada de SCORE (\{a|the\} goal)

GOLS DE CABEÇA: As expressões que compõem essa categoria semântica são formadas por verbos que narram gols de cabeça.

expressões que pertencem ao mesmo campo semântico:

NOD \{home (into an empty goal) $\mid$ in $\mid$ into the net $\}$; HAMMER $\mid$ POUND $\}$ a header into the net; 
HOOK in ([a goal]) (sintagma verbal) gol, [FAZER $\mid$ MARCAR] [UM|O]; tento, MARCAR um; FINALIZAR Ato de fazer um gol.; esta entrada é referência cruzada de SCORE (\{althe\} goal)

MOVIMENTO: As expressões que compõem esse campo semântico são formadas por verbos que descrevem o movimento que a bola faz para dentro do gol.

expressões que pertencem ao mesmo campo semântico:

SLOT \{home([agoal)]|(theball)into \{an|the\} empty net|past[goalkeeper]| in\}; DRILL (the ball) home; BURY the ball past [goalkeeper]; STEER the ball past [goalkeeper];

Jay Jay Okocha (sintagma nominal) lambreta; carretilha Drible em que o jogador puxa a bola com um calcanhar e a levanta com o outro, fazendo a bola passar por cima do oponente e dominando-a do outro lado, de modo a dar sequência à partida. esta entrada é referência cruzada de rainbow kick

KNOCK \{the ball \{into the net | in | home\}\} I NUMBER goals (sintagma verbal) gol, [FAZER|MARCAR] [UM|O]; tento, MARCAR um; FINALIZAR Ato de fazer um gol,; esta entrada é referência cruzada de SCORE (\{a|the\} goal)

VIOLÊNCIA: O sintagma compõe um grupo de expressões formadas por verbos que transmitem a ideia de ação violenta. Essas expressões frequentemente enfatizam a força com que o jogador chuta ao gol.

expressões que pertencem ao mesmo campo semântico:

FIRE \{home | in (a goal) | (the ball) past [goalkeeper]| into the net\}; HAMMER \{in | home\}; SLAM \{(the ball) past [goalkeeper] | in | into the roof of the net\}; BLAST IN (a goal); LASH home $\{$ (a goal) | into an empty net $\}$; SMASH home; STAB the ball $\{$ home $\mid$ past [goalkeeper]\}; POKE $\{$ the ball home|home past [goalkeeper]\};; THUMP \{home $\mid$ past [goalkeeper]\}; CLIP the ball into the net; THUNDER a goal home;

lambretta dribble (sintagma nominal) lambreta; carretilha Drible em que o jogador puxa a bola com um calcanhar e a levanta com o outro, fazendo a bola passar por cima do oponente e dominando-a do outro lado, de modo a dar sequência à partida. esta entrada é referência cruzada de rainbow kick

lambretta flick (sintagma nominal) lambreta; carretilha Drible em que o jogador puxa a bola com um calcanhar e a levanta com o outro, fazendo a bola passar por cima do oponente e dominando-a do outro lado, de modo a dar sequência à partida. esta entrada é referência cruzada de rainbow kick

LASH home \{(a goal) | into an empty net\} (sintagma verbal) gol, [FAZER $\mid M A R C A R]$ [UM|O]; tento, MARCAR um; FINALIZAR Ato de fazer um gol.; esta entrada é referência cruzada de SCORE (\{a|the\} goal)

VIOLÊNCIA: O sintagma compõe um grupo de expressões formadas por verbos que transmitem a ideia de ação violenta. Essas expressões frequentemente enfatizam a força com que o jogador chuta ao gol.

expressões que pertencem ao mesmo campo semântico:

FIRE \{home | in (a goal) | (the ball) past [goalkeeper]| into the net\}; HAMMER \{in | home\}; SLAM \{(the ball) past [goalkeeper] | in | into the roof of the net\}; BLAST IN (a goal); SMASH home; STAB the ball \{home | past [goalkeeper]\}; POKE \{the ball home|home past [goalkeeper]\}; KNOCK \{the ball \{into the net $\mid$ in $\mid$ home $\}$ \} / 
NUMBER goals; THUMP \{home | past [goalkeeper]\}; CLIP the ball into the net; THUNDER a goal home;

manager ${ }^{1}$ (substantivo) dirigente Profissional que gerencia um time.// Ex.:Dirigente do Timão diz que renovação com Guerrero está encaminhada. (Lancenet)// A função do "manager" do futebol inglês não existe no futebol brasileiro uma vez que no Brasil os clubes são associações desportivas, não empresas, como na Inglaterra. Por esse motivo, a hierarquia empresarial adotada no futebol inglês não encontra um único correspondente direto no futebol brasileiro.

manager $^{2}$ (substantivo) técnico; treinador Profissional que treina um time.// Ex.:Com a partida se encaminhando para seus minutos finais, o técnico Muricy Ramalho sacou Felipe Anderson e "Patito" Rodríguez, lesionado, para as entradas de Bernardo e João Pedro, respectivamente. (Placar) / Na volta para a etapa complementar, o treinador Muricy Ramalho trocou Giva por André, no Santos. No São Caetano, Martine sacou Pirão, que havia recebido cartão amarelo no primeiro tempo, para a entrada de Rogério. (Placar)// A função do "manager" do futebol inglês não existe no futebol brasileiro, uma vez que no Brasil os clubes são associações desportivas, não empresas, como na Inglaterra. Por esse motivo, a hierarquia empresarial adotada no futebol inglês não encontra um único correspondente direto no futebol brasileiro.

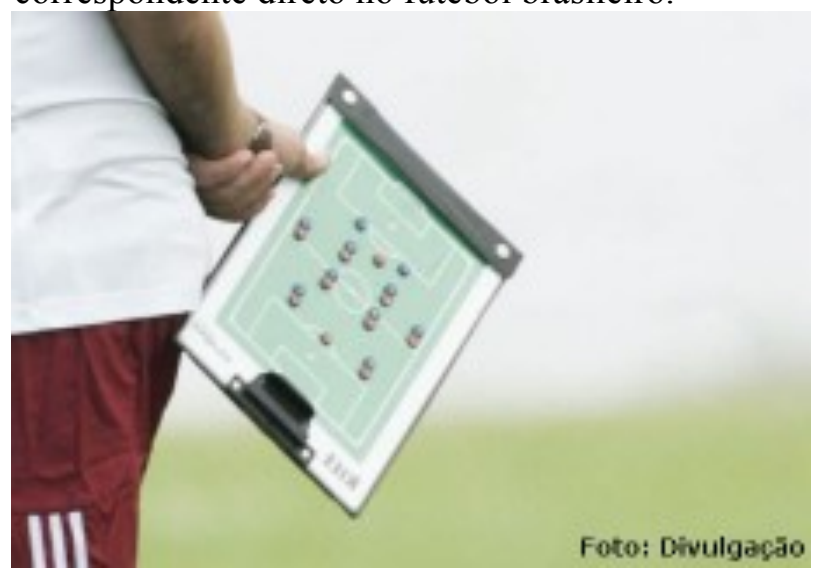

http://www.empregoerenda.com.br/editorias/formacao-profissional/1637-treinadorde-futebol

NESTLE \{in | into\} the (back of the) net (sintagma verbal) gol, [FAZER|MARCAR] $[U M \mid O]$; tento, MARCAR um; FINALIZAR Ato de fazer um gol.; esta entrada é referência cruzada de SCORE (\{a|the\} goal)

POSITION: This expression shows the position of the ball after the goal is scored.

NET [a goal] (sintagma verbal) gol, [FAZER $\mid M A R C A R]$ [UM|O]; tento, MARCAR um; FINALIZAR Ato de fazer um gol; esta entrada é referência cruzada de SCORE (\{a|the\} goal)

REALIZAÇÃO: As expressões que compõem essa categoria semântica são formadas por verbos que pertencem à categoria de realização, entendida aqui como consecução, ou seja, o ato de alcançar um objetivo.

expressões que pertencem ao mesmo campo semântico:

BAG [a goal]; NICK [a goal]; 
NICK [a goal] (sintagma verbal) gol, [FAZER $\mid M A R C A R]$ [UM $\mid O]$; tento, MARCAR um; FINALIZAR Ato de fazer um gol.; esta entrada é referência cruzada de SCORE (\{a|the\} goal)

REALIZAÇÃO: As expressões que compõem essa categoria semântica são formadas por verbos que pertencem à categoria de realização, entendida aqui como consecução, ou seja, o ato de alcançar um objetivo.

expressões que pertencem ao mesmo campo semântico:

NET [a goal]; BAG [a goal];

NOD \{home (into an empty goal) | in | into the net\} (sintagma verbal) gol, [FAZER|MARCAR] [UM|O]; tento, MARCAR um; FINALIZAR Ato de fazer um gol.; esta entrada é referência cruzada de SCORE (\{a|the\} goal)

GOLS DE CABEÇA: As expressões que compõem essa categoria semântica são formadas por verbos que narram gols de cabeça.

expressões que pertencem ao mesmo campo semântico:

HEAD (the ball) \{home|past (goalkeeper)|into the (roof of the) net\}; \{HAMMER POUND $\}$ a header into the net;

NOTCH \{his ORDINAL|CARDINAL\}(goal) (sintagma verbal) gol, [FAZER|MARCAR] [UM|O]; tento, MARCAR um; FINALIZAR Ato de fazer um gol.; esta entrada é referência cruzada de SCORE (\{a|the\} goal)

PONTUAÇÃO: A expressão é utilizada para pontuar os gols e seu significado recai sobre o ato de adicionar gols ao placar de uma partida.

nutmeg (substantivo) rolinho; caneta; janelinha; sainha Drible em que o jogador rola a bola por baixo das pernas do adversário e corre pelo lado para buscá-la.// Ex.:Deu uma pedalada e passou por Diogo Goiano, fez que ia para cima de Luccas Claro, mas deu um rolinho e o evitou. (SporTV) / Recuperado, Neymar treina, leva uma 'caneta' e vira piada para Marcelo. (Globo Esporte) / Maxi entrou no segundo tempo justamente na vaga de Zé. Em 35 minutos, somou duas finalizações. Em uma delas, deu ainda uma janelinha em Renato Silva e só não marcou por chutar em cima do goleiro Alessandro. (Globo Esporte) / O bola cheia de hoje, foi o estreante Leandro que jogou bem, deu uma sainha no marcador e no final do jogo quase fez um gol. (Globo Esporte)/l https://www.youtube.com/watch? $v=J X B k 8 X M v x 10$

Ossie Ardile's flick (sintagma nominal) lambreta; carretilha Drible em que o jogador puxa a bola com um calcanhar e a levanta com o outro, fazendo a bola passar por cima do oponente e dominando-a do outro lado, de modo a dar sequência à partida. esta entrada é referência cruzada de rainbow kick

POKE\{the ball home|home past [goalkeeper]\} (sintagma verbal) gol, [FAZER|MARCAR] [UM|O]; tento, MARCAR um; FINALIZAR Ato de fazer um gol.; esta entrada é referência cruzada de SCORE (\{a|the\} goal)

VIOLÊNCIA: O sintagma compõe um grupo de expressões formadas por verbos que transmitem a ideia de ação violenta. Essas expressões frequentemente enfatizam a força com que o jogador chuta ao gol.

expressões que pertencem ao mesmo campo semântico:

FIRE \{home | in (a goal) | (the ball) past [goalkeeper]| into the net\}; HAMMER \{in | home\}; SLAM \{(the ball) past [goalkeeper] | in | into the roof of the net\}; BLAST IN 
(a goal); LASH home $\{$ (a goal) $\mid$ into an empty net $\}$; SMASH home; STAB the ball \{home | past [goalkeeper]\}; KNOCK \{the ball \{into the net $\mid$ in $\mid$ home $\}$ \} / NUMBER goals; THUMP \{home | past [goalkeeper]\}; CLIP the ball into the net; THUNDER a goal home;

rainbow kick (sintagma nominal) lambreta; carretilha Drible em que o jogador puxa a bola com um calcanhar e a levanta com o outro, fazendo a bola passar por cima do oponente e dominando-a do outro lado, de modo a dar sequência à partida.// Ex.:Que bonito! Cicinho dá uma lambreta e encobre Zizao aos 12 do $1^{\circ}$ tempo. (Globo TV) / Alguém ainda vai quebrá-lo. Eu pensei dez vezes, ia quebrá-lo todo. No lance que ele ia tentar dar a carretilha, eu ia grudá-lo na tela. Uma coisa que eu não admito é falta de respeito, e Neymar estava faltando com respeito. Ele não precisa disso, não precisa fazer graça. Por isso, admiro o Ronaldinho Gaúcho e o Ronaldo Fenômeno. Sempre jogaram o futebol que jogaram sem menosprezar ninguém - declarou Nunes. (Globo Esporte)// No caso de 'carretilha', o nome do drible pode ser associado ao movimento que a linha de pesca faz quando o pescador solta a carretilha e joga a isca na água; no caso de 'lambreta'e no caso de 'lambreta', o nome pode ser associado à pedalada necessária para iniciar o motor do veículo. same as lambretta flick, lambretta dribble, reverse flick-over, Ossie Ardile's flick, Jay Jay Okocha, the Okocha https://www.youtube.com/watch? $=$ CVVIdk7qKcY

reverse flick-over (sintagma nominal) lambreta; carretilha Drible em que o jogador puxa a bola com um calcanhar e a levanta com o outro, fazendo a bola passar por cima do oponente e dominando-a do outro lado, de modo a dar sequência à partida. esta entrada é referência cruzada de rainbow kick

SCORE (\{a|the\} goal) (sintagma verbal) gol, [FAZER $\mid M A R C A R]$ [UM $\mid O]$; tento, MARCAR um; FINALIZAR ato de fazer um goll/ Ex.:O Palmeiras fez um gol aos 43 do $2^{\circ}$ tempo. (Globo Esporte) / Carlinhos Madureira arriscou de longe e marcou um belo gol pelo Paysandu. (Youtube) / No último teste antes da Copa, Brasil vence a Sérvia com gol solitário de Fred, que, caindo, marcou o tento homenageando o Fluminense! (Blog Milton Neves) I Aos 44, Leandro passou para Tiago Real. A bola ainda desviou em Tiago Garça, mas caiu no meia palmeirense, que finalizou e ampliou: 3 a 0 . (Palmeiras Online)// O verbo "finalizar" também pode ser utilizado em situações em que o jogador chuta para o gol, mas não marca. $\mathrm{O}$ inglês possui várias expressões que podem ser utilizadas para descrever um gol, sendo que a mais frequente é SCORE ( $\{\mathrm{a} \mid$ the $\}$ goal. Neste dicionário, dividimos as expressões em categorias semânticas a fim de facilitar o entendimento e comparação. Ressaltamos que, diferentemente do inglês, o português não possui a mesma variedade de expressões. Por esse motivo, embora as expressões possuam particularidades em seus significados em inglês, o equivalente em português não apresenta a mesma distinção. same as NOTCH \{his ORDINAL|CARDINAL\}(goal), FIRE \{home | in (a goal)|(the ball) past [goalkeeper]| into the net\}, HAMMER \{in | home\}, SLAM \{(the ball) past [goalkeeper] | in | into the roof of the net\}, BLAST IN (a goal), LASH home \{(a goal) | into an empty net\}, SMASH home, STAB the ball \{home | past [goalkeeper]\}, POKE\{the ball home|home past [goalkeeper]\}, KNOCK \{the ball \{into the net $\mid$ in $\mid$ home\}\} / NUMBER goals, THUMP \{home | past [goalkeeper]\}, CLIP the ball into the net, THUNDER a goal home, SLIDE \{home his ORDINAL (goal)| the ball home\}, SWEEP \{home | the ball into the net\}, DINK in [a goal], TUCK home (a goal), STROKE a shot past [goalkeeper], TAP \{in|home\}, FIZZ [the ball past goalkeeper|a sidefooter at goal], SNATCH [a goal], SLOT \{home([agoal)]|(theball)into\{an|the\} empty net|past/goalkeeper]| in\}, DRILL (the ball) home, BURY the ball past [goalkeeper], HOOK in ([a goal]), STEER the ball past [goalkeeper], FINISH (off) (a goal), DELIVER a goal, NOD \{home (into an empty goal)| in | into the net\}, HEAD (the ball) \{home|past (goalkeeper)|into the (roof of the) net\}, 
\{HAMMER | POUND\} a header into the net, NET [a goal], BAG [a goal], NICK [a goal], NESTLE \{in | into\} the (back of the) net https://www.youtube.com/watch? $v=N F H S Y$ $\underline{U C q Y 8}$

sicknote reputation (sintagma nominal) chinelinho Jogador que simula contusões e que faz o possivel para não jogar.// Ex.: Mais uma vez, nós santistas queremos agradecer ao São Paulo por ter comprado esta mala do Ganso. Estão vendo? Não jogou nada no São Paulo e já está começando a mesma palhaçada que fazia no Santos. Acredite no que estou falando, daqui a pouco vai pro Departamento Médico de novo. Esse é o verdadeiro chinelinho. Chupa Sãopaulinada, vocês queriam o cara? Agora aguenta. (Lancenet)//

SLAM \{(the ball) past [goalkeeper] | in | into the roof of the net\} (sintagma verbal) gol, [FAZER|MARCAR] [UM|O]; tento, MARCAR um; FINALIZAR Ato de fazer um gol.; esta entrada é referência cruzada de SCORE (\{a|the\} goal)

VIOLÊNCIA: O sintagma compõe um grupo de expressões formadas por verbos que transmitem a ideia de ação violenta. Essas expressões frequentemente enfatizam a força com que o jogador chuta ao gol.

expressões que pertencem ao mesmo campo semântico:

FIRE \{home | in (a goal) | (the ball) past [goalkeeper]| into the net\}; HAMMER \{in | home $\}$; BLAST IN (a goal); LASH home \{(a goal)| into an empty net\}; SMASH home; STAB the ball \{home | past [goalkeeper]\}; POKE \{the ball home|home past [goalkeeper]\}; KNOCK \{the ball \{into the net | in | home\}\} / NUMBER goals; THUMP \{home | past [goalkeeper]\}; CLIP the ball into the net; THUNDER a goal home;

SLIDE \{home his ORDINAL (goal) | the ball home\} (sintagma verbal) gol, [FAZER|MARCAR] [UM|O]; tento, MARCAR um; FINALIZAR Ato de fazer um gol.; esta entrada é referência cruzada de SCORE (\{a|the\} goal)

FACILIDADE: O sentido principal das expressões que compõem esse grupo semântico recai sobre a facilidade com que o gol foi feito. Na realidade, a facilidade não caracteriza o gol, mas sim a trajetória da bola, a posição do jogador ou o toque que o jogador dá na bola.

expressões que pertencem ao mesmo campo semântico:

SWEEP \{home $\mid$ the ball into the net\}; DINK in [a goal]; TUCK home (a goal); STROKE a shot past [goalkeeper];

SLOT \{home([agoal)]|(theball)into\{an|the\} empty net|past[goalkeeper]| in\} (sintagma verbal) gol, [FAZER|MARCAR] [UM|O]; tento, MARCAR um; FINALIZAR Ato de fazer um gol.; esta entrada é referência cruzada de SCORE (\{a|the\} goal)

MOVIMENTO: As expressões que compõem esse campo semântico são formadas por verbos que descrevem o movimento que a bola faz para dentro do gol.

expressões que pertencem ao mesmo campo semântico:

DRILL (the ball) home; BURY the ball past [goalkeeper]; HOOK in ([a goal]); STEER the ball past [goalkeeper];

SMASH home (sintagma verbal) gol, [FAZER|MARCAR] [UM|O]; tento, MARCAR um; FINALIZAR Ato de fazer um gol.; esta entrada é referência cruzada de SCORE (\{a|the\} goal) 
VIOLÊNCIA: O sintagma compõe um grupo de expressões formadas por verbos que transmitem a ideia de ação violenta. Essas expressões frequentemente enfatizam a força com que o jogador chuta ao gol.

expressões que pertencem ao mesmo campo semântico:

FIRE \{home | in (a goal) | (the ball) past [goalkeeper]| into the net\}; HAMMER \{in | home\}; SLAM \{(the ball) past [goalkeeper] | in | into the roof of the net\}; BLAST IN (a goal); LASH home $\{($ a goal) $\mid$ into an empty net $\}$; STAB the ball home | past [goalkeeper]\}; POKE \{the ball home|home past [goalkeeper]\}; KNOCK the ball \{into the net $\mid$ in $\mid$ home $\}$ \} / NUMBER goals; THUMP \{home | past [goalkeeper]\}; CLIP the ball into the net; THUNDER a goal home;

SNATCH [a goal] (sintagma verbal) gol, [FAZER $\mid$ MARCAR] [UM|O]; tento, MARCAR um; FINALIZAR Ato de fazer um gol.;

VELOCIDADE: As expressões que formam esse grupo são compostas por verbos que enfatizam a velocidade do gol; não somente a velocidade com que o jogador recebe e chuta ao gol, mas também a rapidez dos toques até o momento do gol.

expressões que pertencem ao mesmo campo semântico:

TAP \{in|home\}; FIZZ [the ball past goalkeeper|a sidefooter at goal];

STAB the ball \{home I past [goalkeeper]\} (sintagma verbal) gol, [FAZER $\mid M A R C A R]$ $[U M \mid O]$; tento, MARCAR um; FINALIZAR Ato de fazer um gol.; esta entrada é referência cruzada de SCORE (\{a|the\} goal)

VIOLÊNCIA: O sintagma compõe um grupo de expressões formadas por verbos que transmitem a ideia de ação violenta. Essas expressões frequentemente enfatizam a força com que o jogador chuta ao gol.

expressões que pertencem ao mesmo campo semântico:

FIRE \{home | in (a goal) | (the ball) past [goalkeeper]| into the net\}; HAMMER \{in | home\}; SLAM \{(the ball) past [goalkeeper] | in | into the roof of the net\}; BLAST IN (a goal); LASH home $\{$ (a goal) $\mid$ into an empty net $\}$; SMASH home; POKE \{the ball home|home past [goalkeeper]\}; KNOCK \{the ball \{into the net $\mid$ in $\mid$ home $\}$ / NUMBER goals; THUMP \{home | past [goalkeeper]\}; CLIP the ball into the net; THUNDER a goal home;

STEER the ball past [goalkeeper] (sintagma verbal) gol, [FAZER $\mid M A R C A R]$ [UM $\mid O]$; tento, MARCAR um; FINALIZAR Ato de fazer um gol.; esta entrada é referência cruzada de SCORE (\{a|the\} goal)

MOVIMENTO: As expressões que compõem esse campo semântico são formadas por verbos que descrevem o movimento que a bola faz para dentro do gol.

expressões que pertencem ao mesmo campo semântico:

SLOT \{home([agoal)]|(theball)into \{an|the\} empty net|past[goalkeeper]| in\}; DRILL (the ball) home; BURY the ball past [goalkeeper]; HOOK in ([a goal]);

STROKE a shot past [goalkeeper] (sintagma verbal) gol, [FAZER $\mid M A R C A R]$ [UM $\mid O]$; tento, MARCAR um; FINALIZAR Ato de fazer um gol.; esta entrada é referência cruzada de SCORE (\{a|the\} goal)

FACILIDADE: O sentido principal das expressões que compõem esse grupo semântico recai sobre a facilidade com que o gol foi feito. Na realidade, a facilidade 
não caracteriza o gol, mas sim a trajetória da bola, a posição do jogador ou o toque que o jogador dá na bola.

expressões que pertencem ao mesmo campo semântico:

SLIDE \{home his ORDINAL (goal) | the ball home\}; SWEEP \{home $\mid$ the ball into the net\}; DINK in [a goal]; TUCK home (a goal);

SWEEP \{home | the ball into the net\} (sintagma verbal) gol, [FAZER $\mid M A R C A R]$ $[U M \mid O]$; tento, MARCAR um; FINALIZAR Ato de fazer um gol.; esta entrada é referência cruzada de SCORE (\{a|the\} goal)

FACILIDADE: O sentido principal das expressões que compõem esse grupo semântico recai sobre a facilidade com que o gol foi feito. Na realidade, a facilidade não caracteriza o gol, mas sim a trajetória da bola, a posição do jogador ou o toque que o jogador dá na bola.

expressões que pertencem ao mesmo campo semântico:

SLIDE \{home his ORDINAL (goal) | the ball home\}; DINK in [a goal]; TUCK home (a goal); STROKE a shot past [goalkeeper];

TACKLE (verbo) falta, [FAZER|COMETER] Ato de infringir as regras do jogo cometido por um jogador. esta entrada é referência cruzada de FOUL

tackle (substantivo) falta Situação em que um jogador infringe as regras do jogo. esta entrada é referência cruzada de foul

TAP \{in|home\} (sintagma verbal) gol, [FAZER|MARCAR] [UM|O]; tento, MARCAR um; FINALIZAR Ato de fazer um gol.; esta entrada é referência cruzada de SCORE (\{a|the\} goal)

VELOCIDADE: As expressões que formam esse grupo são compostas por verbos que enfatizam a velocidade do gol; não somente a velocidade com que o jogador recebe e chuta ao gol, mas também a rapidez dos toques até o momento do gol. expressões que pertencem ao mesmo campo semântico:

FIZZ [the ball past goalkeeper|a sidefooter at goal]; SNATCH [a goal];

The Matthews move (sintagma nominal) Movimento em que o jogador dá um toque na bola ligeiramente para a esquerda com o interior do pé direito. Se o defensor se move nessa direção, o jogador usa o exterior do pé direito para apertar a bola no lado direito do defensor, saltando por ele e continuando pelo lado.// Ex.:My dad made me watch old Betamax video tapes that focused on skill and technique. It involved a Dutch coach called Wiel Coerver. He was in charge of Feyenoord in the 1970s and he created the Coerver coaching technique. In terms of dribbling, it focused on misdirection - so the defender moved one way and you could go the other. It's things like the Matthews move, the Rivelino move and the Maradona move - I used to practise it all in the front garden. (FourFourTwo)// Embora seja executado por jogadores brasileiros, "The Matthews move" não possui um equivalente em português. Quando o movimento é realizado, jornalistas esportivos normalmente utilizam os termos "ginga, "drible" e "corte" para descrevê-lo. Em inglês o termo homenageia o jogador Stanley Matthews, futebolista inglês, que executava o drible com perfeição. https://www.youtube.com/watch? $v=0 Y y S w 0 p n E W E$

the Okocha (substantivo) lambreta; carretilha Drible em que o jogador puxa a bola com um calcanhar e a levanta com o outro, fazendo a bola passar por cima do oponente $e$ 
dominando-a do outro lado, de modo a dar sequência à partida. esta entrada é referência cruzada de rainbow kick

THUMP \{home I past [goalkeeper]\} (sintagma verbal) gol, [FAZER $\mid M A R C A R][U M \mid O]$; tento, MARCAR um; FINALIZAR Ato de fazer um gol,; esta entrada é referência cruzada de SCORE (\{a|the\} goal)

VIOLÊNCIA: O sintagma compõe um grupo de expressões formadas por verbos que transmitem a ideia de ação violenta. Essas expressões frequentemente enfatizam a força com que o jogador chuta ao gol.

expressões que pertencem ao mesmo campo semântico:

FIRE \{home | in (a goal) | (the ball) past [goalkeeper]| into the net\}; HAMMER \{in | home\}; SLAM \{(the ball) past [goalkeeper] | in | into the roof of the net\}; BLAST IN (a goal); LASH home $\{$ (a goal) $\mid$ into an empty net $\}$; SMASH home; STAB the ball \{home | past [goalkeeper]\}; POKE \{the ball home|home past [goalkeeper]\}; KNOCK \{the ball \{into the net $\mid$ in $\mid$ home $\}\}$ / NUMBER goals; CLIP the ball into the net; THUNDER a goal home;

THUNDER a goal home (sintagma verbal) gol, [FAZER $\mid M A R C A R]$ [UM $\mid O]$; tento, MARCAR um; FINALIZAR Ato de fazer um gol.; esta entrada é referência cruzada de SCORE (\{a|the $\}$ goal)

VIOLÊNCIA: O sintagma compõe um grupo de expressões formadas por verbos que transmitem a ideia de ação violenta. Essas expressões frequentemente enfatizam a força com que o jogador chuta ao gol.

expressões que pertencem ao mesmo campo semântico:

FIRE \{home | in (a goal) | (the ball) past [goalkeeper]| into the net\}; HAMMER \{in | home\}; SLAM \{(the ball) past [goalkeeper] | in | into the roof of the net\}; BLAST IN (a goal); LASH home $\{$ (a goal) $\mid$ into an empty net $\}$; SMASH home; STAB the ball \{home | past [goalkeeper]\}; POKE \{the ball home|home past [goalkeeper]\}; KNOCK \{the ball \{into the net $\mid$ in | home\}\} / NUMBER goals; THUMP \{home | past [goalkeeper]\}; CLIP the ball into the net;

TIE (verbo) EMPATAR Ato de fazer um gol de modo a igualar o placar da partida. esta entrada é referência cruzada de EQUALISE

time, STALL for (sintagma verbal) cera, FAZER Situação em que um jogador retarda a reposição da bola, simula contusões ou troca passes estéreis a fim de passar o tempo.// Ex.:Visivelmente exaustos, os chilenos tentaram ganhar tempo, fazendo cera para forçar a decisão nos pênaltis. A torcida percebeu e soltou gritos de "timinho!" (Terra esportes)//

TUCK home (a goal) (sintagma verbal) gol, [FAZER $\mid M A R C A R]$ [UM $\mid O]$; tento, MARCAR um; FINALIZAR Ato de fazer um gol.; esta entrada é referência cruzada de SCORE (\{a|the\} goal)

FACILIDADE: O sentido principal das expressões que compõem esse grupo semântico recai sobre a facilidade com que o gol foi feito. Na realidade, a facilidade não caracteriza o gol, mas sim a trajetória da bola, a posição do jogador ou o toque que o jogador dá na bola.

expressões que pertencem ao mesmo campo semântico:

SLIDE \{home his ORDINAL (goal) $\mid$ the ball home\}; SWEEP \{home $\mid$ the ball into the net ; DINK in [a goal]; STROKE a shot past [goalkeeper] 